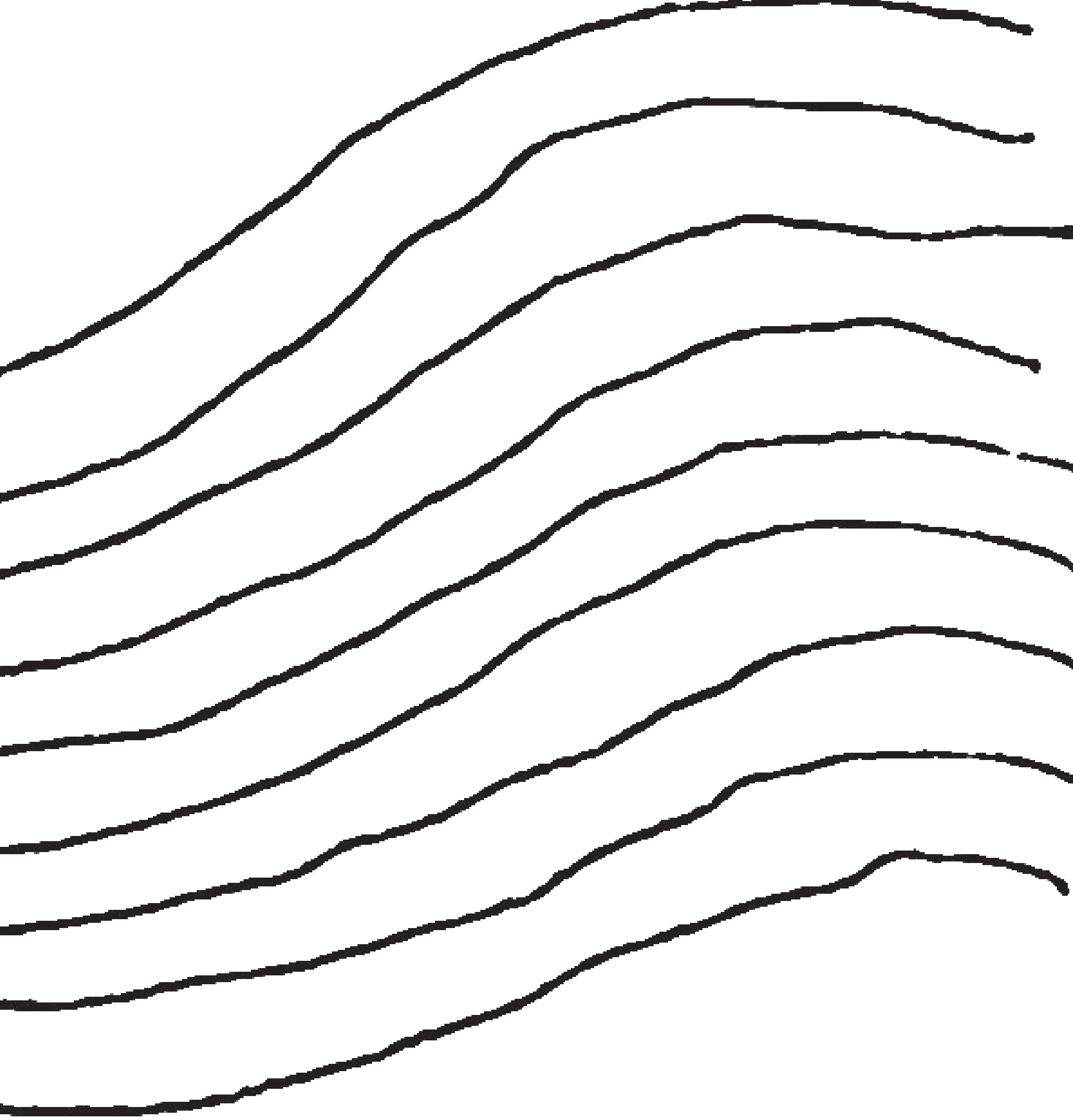

\title{
A conservação da arquitetura moderna: as fachadas do Edifício Coman
}

\author{
Valéria A. C. Bonfim
}

Dissertação de Mestrado

Faculdade de Arquitetura e Urbanismo da Universidade de São Paulo - FAUUSP 
UNIVERSIDADE DE SÃO PAULO

FACULDADE DE ARQUITETURA E URBANISMO

VALERIA APARECIDA COSTA BONFIM

\section{A CONSERVAÇÃO DA ARQUITETURA MODERNA: AS FACHADAS DO EDIFÍCIO COPAN}





\section{A CONSERVAÇÃO DA ARQUITETURA MODERNA: AS FACHADAS DO EDIFÍCIO COPAN}

Dissertação apresentada à Faculdade de Arquitetura e Urbanismo da Universidade de São Paulo para a obtenção do título de Mestre em Tecnologia da Arquitetura.

Área de concentração: Tecnologia da Arquitetura

Orientadora: Prof. ${ }^{a}$ Dr. ${ }^{a}$ Fabiana Lopes de Oliveira

Exemplar revisado e alterado em relação à versão original, sob responsabilidade do autor e anuência do orientador.

A versão original, em formato digital, ficará arquivada na Biblioteca da Faculdade.

São Paulo 08 de maio de 2019. 
Autorizo a reprodução e divulgação total ou parcial deste trabalho, por qualquer meio convencional ou eletrônico, para fins de estudo e pesquisa, desde que citada a fonte.

Catalogação na Publicação

Serviço Técnico de Biblioteca

Faculdade de Arquitetura e Urbanismo da Universidade de São Paulo

Bonfim, Valéria

A conservação da arquitetura moderna: as fachadas do Edifício Copan / Valéria Bonfim; orientadora Fabiana Oliveira. - São Paulo, 2019.

$333 \mathrm{p}$.

Dissertação (Mestrado) - Faculdade de Arquitetura e Urbanismo da Universidade de São Paulo. Área de concentração: Tecnologia da Arquitetura.

1. Plano de Conservação. 2. Manutenção. 3. Arquitetura Moderna. 4. Edifício Copan. I. Oliveira, Fabiana, orient. II. Título. 


\section{AGRADECIMENTOS}

À minha orientadora Prof.a. Dra ${ }^{a}$. Fabiana Lopes de Oliveira pela dedicação e paciência, que teve ao longo da trajetória, sempre tentado extrair o melhor do meu potencial.

Ao Affonso Celso Prazeres de Oliveira que abriu as portas do Copan, do precioso acervo do condomínio e que compartilhou comigo as histórias, as experiências e o amor pelo edifício. Sem sua inestimável ajuda o caminho teria sido bem mais árduo.

Agradeço aos colaboradores do Copan, em especial a Sergio Ambrosio de Souza, pelas inestimáveis ajudas e incentivos, ao Ezequiel Segg sempre muito atento nas aventuras em altura, ao Ronaldo Cordeiro e ao Benício, companheiros de levantamentos, guias na viga de transição e caçadores de pastilhas. E aos inúmeros colaboradores sempre todos muito solícitos e gentis.

Ao Walter Galvão que, como meu professor durante a graduação, me incentivou no caminho acadêmico e me iniciou no conhecimento sobre o Copan.

À Marianna Tonini primeira companheira de pesquisas no Copan.

À colega de mestrado Camilla Meneses na ajuda para a medição dos brises.

À estudante de arquitetura Danielle Freitas do Vale que muito prestativamente redesenhou uma planta importante do Copan.

Aos senhores Pedro Cordeiro e Joel Maziero que muito me apresentaram sobre os tijolos de Ribeirão Pires, provável berço dos tijolos do Copan. Ao Sr. Marcílio Duarte do Centro de Documentação Histórica da cidade de Ribeirão Pires, que mui gentilmente recebeu-me no museu da cidade e colou-me em contato com os senhores anteriormente mencionados.

Aos meus pais, familiares e amigos pela compreensão e incentivo ao longo desta trajetória.

Ao "meu amigo" Hemingway que nas horas difíceis falava ao meu ouvido: "guenta mão!" 



\section{RESUMO}

A arquitetura erigida pelo Movimento Moderno - inovadora tanto em suas formas quanto em seus materiais - envelheceu sem a aplicação dos conceitos de conservação tão em voga atualmente e, por isso, observa-se um grande número de exemplares em processo de degradação, necessitando intervenção imediata. Dentre eles está o Edifício Copan, reconhecido social e oficialmente como patrimônio arquitetônico, foi projetado por Oscar Niemeyer no início da década de 1950 e tombado pelo CONPRESP - Conselho Municipal de Preservação do Patrimônio Histórico, Cultural e Ambiental da Cidade de São Paulo em 2012. Ao longo dos anos suas icônicas fachadas sofreram com ações das intempéries e ausência de manutenção, sendo necessário restaurá-las, pois apresentavam um avançado estado de degradação. Neste contexto destaca-se a importância de um planejamento que contemple ações de manutenção preventiva, pela ótica da conservação do patrimônio, de modo a minorar a deterioração natural de seus elementos e componentes, mitigando a necessidade de substituições. Assim sendo, são propostos neste trabalho, dois instrumentos de proteção para as fachadas do Copan: o Plano de Conservação e o Manual de Uso, Operação e Manutenção. O primeiro apresenta os valores culturais atribuídos ao patrimônio, a hierarquização dos elementos representativos e as políticas, apontando o que deve ser conservado. Enquanto que o manual descreve as ações de manutenção, a periodicidade e os registros das ações realizadas, mostrando como preservar. A metodologia aplicada consiste na revisão da bibliografia internacional e nacional relacionada ao tema e no levantamento e análise de informações técnicas do Edifício COPAN, tendo como resultado a documentação das transformações projetuais e durante a construção, das características arquitetônicas por meio da realização do as built, dos componentes originais e dos especificados para a restauração. Conclui-se que a maior problemática da conservação do patrimônio moderno é pelo fato do mesmo ser entendido de forma diferente dos edifícios seculares, pois o curto distanciamento temporal conduz a uma propensão de intervenções corretivas que não seguem os princípios da restauração e os valores no âmbito do patrimônio histórico. Espera-se que os instrumentos propostos sejam exigências documentais no âmbito do patrimônio histórico e arquitetônico, visando também a conscientização sobre a importância da manutenção preventiva e da prevalência da conservação sobre a restauração na arquitetura moderna.

Palavras chaves: plano de conservação; manutenção; arquitetura moderna; revestimento de fachada; patrimônio arquitetônico; Edifício Copan. 


\section{ABSTRACT}

The architecture built by the Modern Movement - innovative both in shape and materials - aged without the application of the preservation concepts so in vogue today and, thus, a large number of examples are observed in degradation, requiring immediate intervention. Among these is the Copan building, which is socially and officially recognized as an architectural heritage, designed by Oscar Niemeyer in the beginning of the 1950s and made into a listed building by CONPRESP - Municipal Council for the Preservation of Historical, Cultural and Environmental Heritage of the City of São Paulo in 2012. During the years its iconic facades suffered from the actions of bad weather and the lack of maintenance, requiring their restoration, because they showed advanced state of degradation. In this context, emphasis is laid on the importance of planning that contemplates preventive maintenance action, from the perspective of the conservation of the patrimony, in order to mitigate the natural deterioration of its elements and components, mitigating the need for replacements. Therefore, this work proposes two instruments of protection for the facades of Copan: Conservation Plan and the Use, Operation and Maintenance Manual. The first presents the cultural values attributed to the patrimony, the hierarchization of the representative elements and the policies, highlighting what should be conserved. While the manual describes the maintenance actions, periodicity and records of actions performed, showing how to preserve. The methodology applied consists of the international and national bibliography related to the subject and of the survey and analysis of technical information of the Copan Building, which results in the documentation of the design transformations, and during construction, the architectural features through the execution of as built, of the original components and the specifications for restoration. It is concluded that the major problem of the conservation of modern heritage is the fact that it is considered different from secular buildings, because the short temporal distance leads to a propensity for corrective interventions that are not according to the principles of restoration and values within the scope of historical heritage. It is expected that the instruments proposed become documental requirements in the scope of historical and architectural heritage, also aimed at raising awareness regarding the importance of preventive maintenance and the prevalence of preservation over restoration in modern architecture.

Keywords: conservation plan; maintenance; modern architecture; façade cladding; architectural heritage; Copan Building. 


\section{LISTA DE FIGURAS}

Figura 1- Planta do desenvolvimento histórico da Carnegie Library ....................................39

Figura 2 - Elevação Oeste J. C. Walker - 1880 ............................................................................ 39

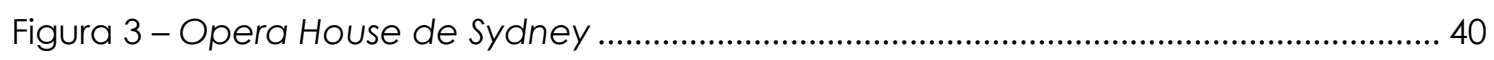

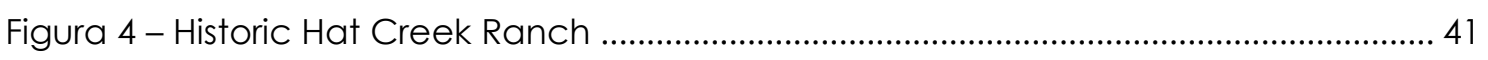

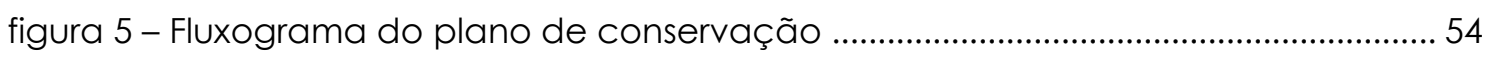

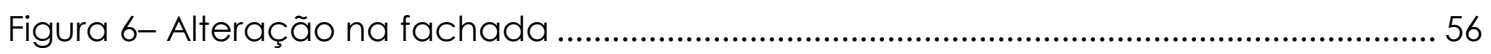

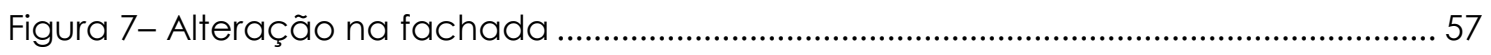

figura 8 - recuperação do desempenho por ações de manutenção ................................. 61

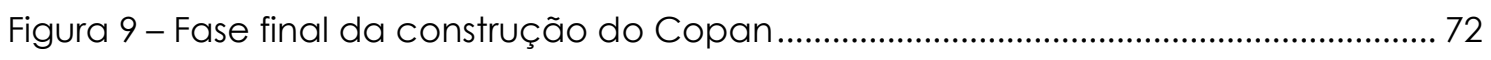

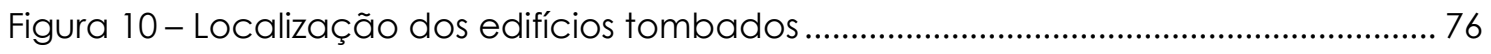

Figura 11 - Planta do térreo com Hotel e Edifício Residencial .............................................. 80

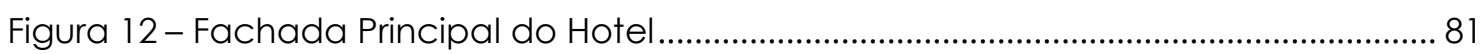

Figura 13 - Vista Parcial da Fachada Frontal com a Rampa sem os pilares ..................... 81

Figura 14 - Vista Parcial da Fachada Frontal sem os brises.................................................. 82

Figura 15- Detalhe da planta do térreo do projeto de 1952 com a rampa helicoidal .. 83

Figura 16 - Detalhe da fachada do projeto de 1952 com a rampa helicoidal ................ 84

Figura 17 - Detalhe da planta do terraço com o restaurante e o cinema .......................... 84

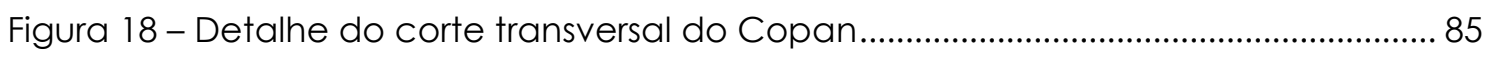

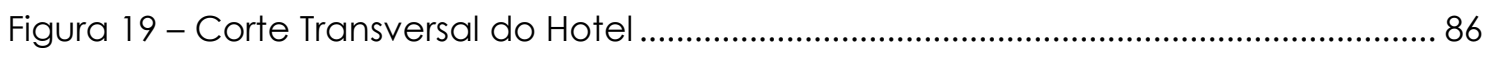

Figura 20 - Trecho da planta do pavimento tipo dos Blocos E e F (projeto de 1952) ..... 88

Figura 21 - Planta do Bloco E (projeto modificativo de 1972) ................................................ 89

Figura 22 - Planta do Bloco F (projeto modificativo de 1972) ............................................... 89

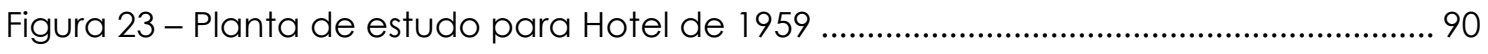

Figura 24 - Trecho da planta do pavimento tipo correspondente ao Bloco B ................ 91

Figura 25- Planta promocional do empreendimento - apartamentos do Bloco B ......... 91

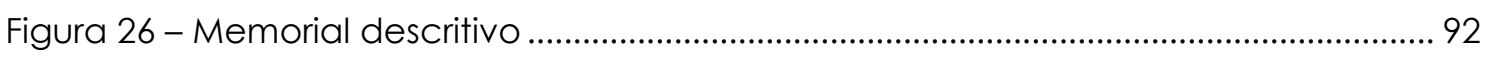

Figura 27 - Corte do projeto de prefeitura de 1952 ............................................................... 95

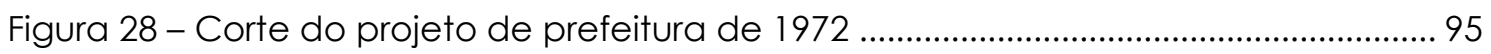

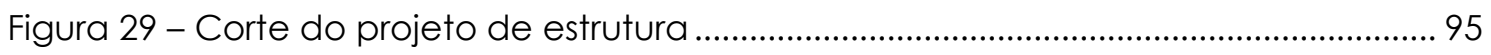

Figura 30 - As built da fachada sudoeste e noroeste .............................................................. 96

Figura 31 - As built da fachada sudoeste e noroeste ............................................................... 97

Figuras 32 e 33 - Fotografia da fachada posterior do Bloco F ao B..................................... 98 
Figura 34 - Fotografia da Configuração Formal da Fachada Posterior.....

Figuras 35 e 36 - Detalhe dos elementos horizontais revestidos com pastilhas brancas 100

Figura 37 - As Built Parcial da Fachada Posterior (Blocos F e E) ......................................... 100

Figura 38 - Vista parcial da fachada posterior (Bloco B) ...................................................... 101

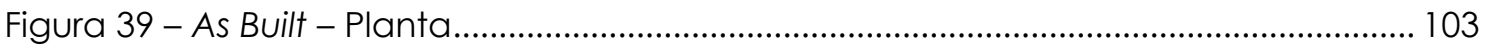

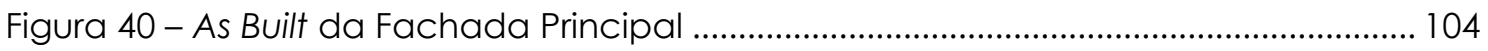

Figura 41 - As Built da Fachada Nororeste e Sudoeste ............................................................ 105

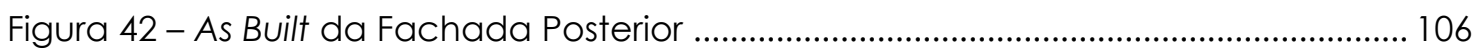

Figura 43 - As Built da Fachada Posterior, Planta e Fachada Principal dos Corpos 1 e 2

Figura 44 - As Built da Fachada Posterior, Planta e Fachada Principal dos Corpos 3 e 4 108

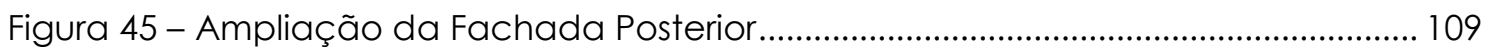

Figura 46 - Capa do encarte da Companhia Pan-América - Hotéis e Turismo.............. 111

Figura 47 - Detalhe de Forma para os Tubulões ............................................................. 112

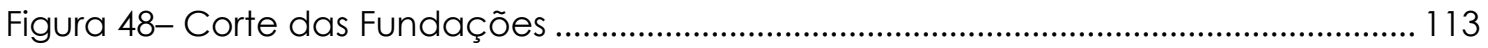

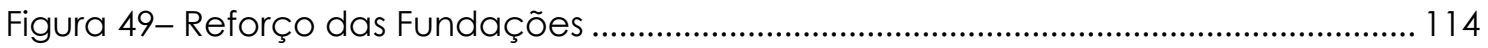

Figura 50 - Junta de Dilatação entre o Corpos 2 e 3 ............................................................... 115

Figura 51 - Armaduras da Viga de Transição ......................................................................... 116

Figura 52 - Tabela de Resumo dos Aços do Projeto de Estrutura do Copan .................... 117

Figura 53 - Tabela de Resumo dos Aços do Projeto de Estrutura do Copan .................... 117

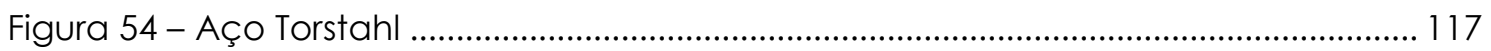

Figura 55-Laje e contrapiso da Torre dos Elevadores do Bloco B ..................................... 119

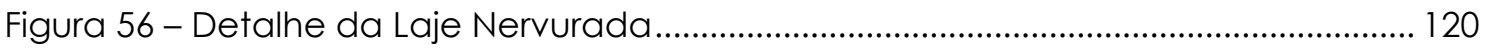

Figura 57 - Detalhe da Laje Nervurada e Forro de Estuque ............................................... 120

Figura 58 - Alvenaria interna de vedação com blocos cerâmicos ..................................... 121

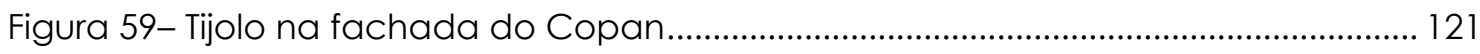

Figura 60 - Tijolos retirados das fachadas do Copan ............................................................ 122

Figura 61 - Comparativo dos tijolos do Edifício Copan com as informações de Ribeirão

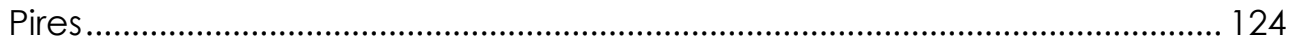

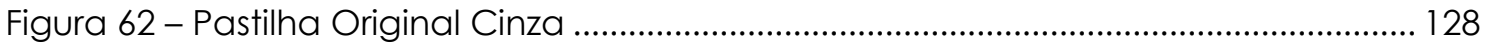

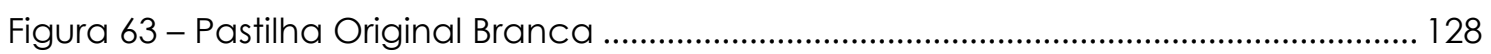

Figura 64-Subsistema de revestimento de argamassa do Copan ................................... 129 
Figura 65 - Degradação da fachada publicada em 1991 pelo jornal Folha de São Paulo

Figura 66 - Fachada Noroeste sem as pastilhas

Figura 67 - Mapa de Danos das Fachadas Noroeste, Sudoeste e Torre dos Elevadores do Bloco B

Figura 68 - Desplacamento de pastilha (fachada posterior)

Figura 69- Descolamento de pastilha (torre dos elevadores do Bloco B)

Figura 70 - Gancho metálico exposto 138

Figura 71 - Desplacamento de pastilha 138

Figura 72 - Concreto desagregando e desplacamento de pastilhas - torre dos elevadores do Bloco B.

Figura 73 - Descolamento de pastilhas e armadura exposta - fachada posterior....... 138

Figura 74 - Planta de Localização das amostras .................................................................... 140

Figura 75 - Formas de Ruptura

Figura 76 - Corpos de prova após ruptura do ensaio de resistência de aderência à tração da camada original de emboço

Figura 77 - Esquema dos painéis para o ensaio para determinação da resistência de aderência à tração do emboço original.

Figura 78- Juntas de movimentação

Figura 79 - Detalhe 01 da junta de movimentação e Detalhe 02 do friso 154

Figura 80 - Detalhe 01 da junta de movimentação e Detalhe 02 do friso 154

Figura 81 - Fachada Noroeste durante a remoção do revestimento.

Figura 82 - Corte dos brises.

Figura 83 - Projeto de revestimento de fachada - frisos

Figura 84 - Procedimento para execução dos frisos.

Figura 85 - Realização do Ensaio de Avaliação de Dureza Superficial do Concreto Endurecido na Viga de Transição do Bloco F.....

Figura 86 - Realização do Ensaio de Avaliação de Dureza Superficial do Concreto Endurecido no Lado Interno da Viga de Transição.

Figura 87 - Realização do Ensaio de Avaliação de Dureza Superficial do Concreto Endurecido no Lado Interno da Viga de Transição.

Figura 88 - Torre dos Elevadores do Bloco B em fevereiro de 2018 


\section{LISTA DE TABELAS}

Tabela 1-Reconstituição do traço de argamassa de emboço

Tabela 2 - Limite de Resistência de Aderência à Tração (Ra)

Tabela 3 - Determinação de resistência à tração

Tabela 4 - Determinação de resistência à tração da camada original de emboço

Tabela 5 - Resultado do Ensaio de Concreto Endurecido - Avaliação da Dureza Superficial pelo Esclerômetro de Reflexão

Tabela 6 - Ensaio de reconstituição de traço de argamassa de reboco....... 165

Tabela 7 - Ensaio de reconstituição de traço de argamassa de assentamento

Tabela 8 - Resultados dos Ensaios de Resistência à Tração da Face A da Torre dos Elevadores do Bloco B

Tabela 9 - Resultados dos Ensaios de Resistência à Tração da Face B da Torre dos Elevadores do Bloco B

Tabela 10 - Resultados dos Ensaios de Resistência à Tração da Face D da Torre dos Elevadores do Bloco B

Tabela 11 - Resultados dos Ensaios de Resistência à Tração da Face F da Torre dos Elevadores do Bloco B

Tabela 12 - Resultados dos Ensaios de Resistência à Tração da Face G da Torre dos Elevadores do Bloco B

Tabela 13 - Resultados dos Ensaios de Resistência à Tração da Fachada Sudoeste

Tabela 14 - Resultados dos Ensaios de Resistência à Tração da Fachada Noroeste.

Tabela 15 - Resultados dos Ensaios de Resistência à Tração da Face D da Torre dos Elevadores do Bloco B 


\section{LISTA DE QUADROS}

Quadro 1 - comparativo das metodologias para elaboração de plano de conservação

Quadro 2 - definições e conceitos

Quadro 3 - estrutura do manual de uso, operação e manutenção 68

Quadro 4 - Relação de Folhas do Projeto Legal .79

Quadro 5 - Comparativo entre as quatro alterações de projeto .93 


\section{SUMÁRIO}

CAPÍTULO 1 - INTRODUÇÃO

1.1. INTRODUÇÃO

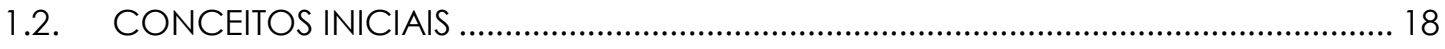

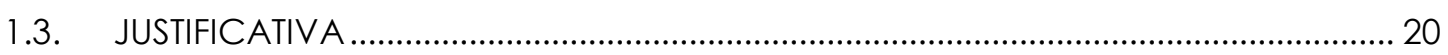

1.4. OBJETIVOS

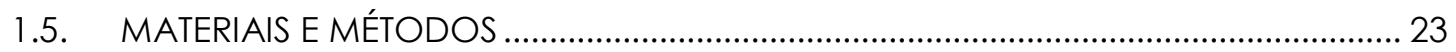

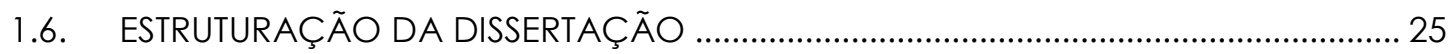

CAPÍTULO 2 - CONSERVAÇÃO DO PATRIMÔNIO ARQUITETÔNICO ..................................... 27

2.1. PATRIMÔNIO — A IMPORTÂNCIA DA CONSERVAÇÃO ……................................ 27

2.2. PRESERVAÇÃO DA ARQUITETURA: PLANO DE CONSERVAÇÃO — CONTEXTO INTERNACIONAL E NACIONAL

2.3. DIRETRIZES PARA ELABORAÇÃO DE UM PLANO DE CONSERVAÇÃO ................... 48

2.4. MANUTENÇÃO COMO ELEMENTO DE PRESERVAÇÃO ............................................58

2.5. A IMPORTÂNCIA DO MANUAL DE USO, OPERAÇÃO E MANUTENÇÃO PARA EDIFICAÇÕES

2.6. DIRETRIZES PARA ELABORAÇÃO DO MANUAL DE USO, OPERAÇÃO E MANUTENÇÃO

CAPÍTULO 3 - OBJETO DE ESTUDO: EDIFÍCIO COPAN

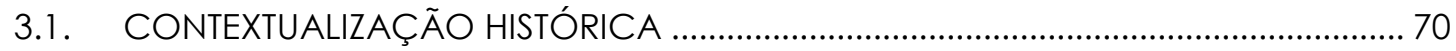

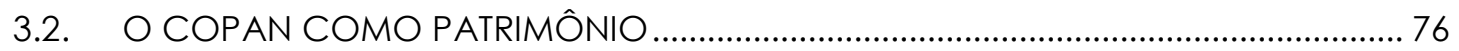

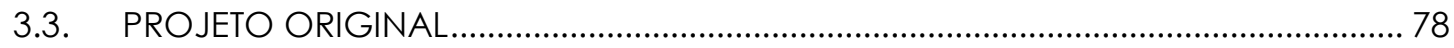


3.4. FACHADAS - CONFRONTO ENTRE OS PROJETOS E ELABORAÇÃO DO AS BUILT 94 MATERIAIS E TÉCNICAS CONSTRUTIVAS ORIGINAIS DO EDIFÍCIO

3.5.1. FUNDAÇÕES

3.5.2. ESTRUTURA

3.5.3. VEDAÇÕES VERTICAIS

3.5.4. REVESTIMENTO EXTERNO ORIGINAL

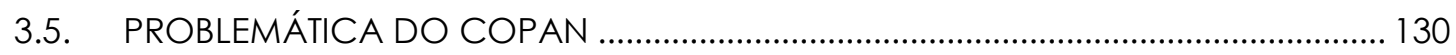

3.6. DIAGNÓSTICO DAS CONDIÇÕES DAS FACHADAS ............................................. 134

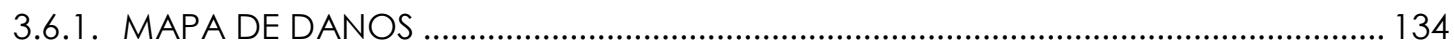

3.6.2. RECONSTITUIÇÃO DE TRAÇO DE ARGAMASSA DE EMBOÇO .............................. 139

3.6.3. ENSAIO DE DETERMINAÇÃO DE RESISTÊNCIA DE ADERÊNCIA À TRAÇÃO ......... 142

3.6.4. SUBSÍDIOS PARA ELABORAÇÃO DO PROJETO EXECUTIVO DO REVESTIMENTO DE FACHADA 145

3.6.5. ENSAIO PARA DETERMINAÇÃO DA RESISTÊNCIA DE ADERÊNCIA À TRAÇÃO DA CAMADA ORIGINAL DE EMBOÇO 146

3.6.6. ENSAIO PARA DETERMINAÇÃO DA RESISTÊNCIA DE ADERÊNCIA À TRAÇÃO DO ACABAMENTO DECORATIVO (PASTILHAS) 148

3.6.7. PROJETO EXECUTIVO DO REVESTIMENTO DE FACHADA 152

3.7. ATIVIDADES TÉCNICAS REALIZADAS NA PESQUISA 160

3.8.1. ENSAIO PARA AVALIAÇÃO DA DUREZA SUPERFICIAL DO CONCRETO ENDURECIDO PELO USO DO ESCLERÔMETRO DE REFLEXÃO

3.8.2. RECONSTITUIÇÃO DO TRAÇO DA ARGAMASSA DE REBOCO E ASSENTAMENTO DAS PASTILHAS 
CAPÍTULO 4 - CONCLUSÕES

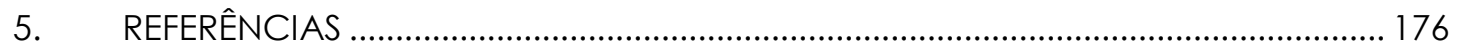

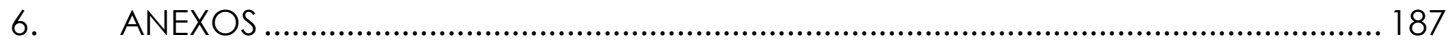

I. RESULTADOS DOS ENSAIOS DE RESISTÊNCIA À TRAÇÃO ................................................ 187

II. RESULTADOS DOS ENSAIOS DE RESISTÊNCIA À TRAÇÃO .............................................. 192

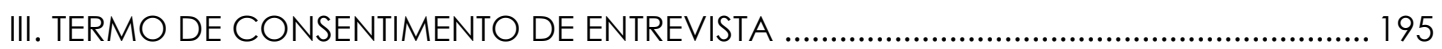




\section{CAPÍTULO 1 - INTRODUÇÃO}

\subsection{INTRODUÇÃO}

Projetado pelo arquiteto Oscar Niemeyer no início da década de 1950, O Edifício Copan, que entrou para o Guinness Book - O Livro dos Recordes como maior prédio residencial da América Latina (SCHOLZ, 2013), há anos começou a apresentar problemas decorrentes da idade da edificação, além das consequências da falta de manutenção durante longo período. Suas enormes fachadas são revestidas, em sua maioria, por pastilhas de porcelana nas cores branca e cinza, que com o passar do tempo começaram a se desprender, como causa das manifestações patológicas e do avançado estágio de degradação das fachadas.

O Edifício Copan é um patrimônio' arquitetônico reconhecido pela sociedade e por órgão governamental. É um exemplar de arquitetura do Movimento Moderno, que teve suas icônicas fachadas degradadas pelas ações do tempo e ausência de manutenção, mas que atualmente está em processo de reconstrução, que, como definido na Carta de Burra (ICOMOS, 2013), pressupõe voltar a um estágio anterior conhecido com a inclusão de novos elementos. E após décadas perdendo o acabamento decorativo que desplacou das fachadas, colocando em risco a integridade física das pessoas que caminhavam na calçada do edifício, optou-se pela proteção do Copan com telas e bandejas e remoção das pastilhas originais das fachadas sudoeste e noroeste para o tratamento da base, recomposição da camada de emboço, execução de frisos e juntas de movimentação e o assentamento de novas pastilhas, similares às originais.

O reconhecimento oficial do Copan como patrimônio ocorreu em dezembro de 2012, quando foi tombado pelo CONPRESP - Conselho Municipal de Preservação do Patrimônio Histórico, Cultural e Ambiental da Cidade de São Paulo (SÃO PAULO, 2012), que traz em sua resolução as considerações quanto ao valor histórico, arquitetônico, urbanístico e

1 De acordo com Lemos (1981) o segmento de maior abrangência no patrimônio é expresso pelo termo "patrimônio cultural" e, dentro deste estão: o patrimônio ambiental; os bens intangíveis (técnicas e saberes) e os tangíveis (bens materiais), que englobam objetos, artefatos e construção. 
paisagístico, ficando preservadas suas características arquitetônicas externas e ambientes internos que constituem as áreas comuns.

Em outubro de 2013 iniciou-se uma avaliação das condições de integridade dos elementos estruturais, elementos de vedação e do revestimento de porcelana das fachadas pela empresa Falcão Baver, por meio de inspeções visuais e ensaios. Os dados obtidos nesse levantamento forneceram subsídios para a elaboração do projeto de revestimento de fachada, que data do primeiro semestre de 2015, mesmo ano em que se iniciou o processo de reconstrução das fachadas sudoeste e noroeste, mas que desde o final de 2016 se encontra paralisado por questões administrativas junto ao órgão de preservação.

Após a reconstrução dos elementos mais representativos do Edifício Copan, suas fachadas, é fundamental que haja, por parte do condomínio e de seus gestores, a adoção de uma política de preservação para esse subsistema com a sistematização dos procedimentos de manutenção preventiva, evitando a deterioração do subsistema e a necessidade de novas intervenções que, além dos altos custos agregados, podem comprometer os aspectos simbólicos representativos de uma época.

O presente trabalho consiste na documentação dos dados relevantes à conservação e na proposição de instrumentos voltados a proteção das fachadas do Edifício Copan. Este estudo não se restringiu apenas à compilação das informações adquiridas por meio de relatórios técnicos, ensaios e projeto executivo de revestimento de fachada, realizados anteriormente ao início desta pesquisa, mas busca complementar estas informações ao longo de todo seu desenvolvimento. Informações que foram adquiridas por meio da contextualização histórica do edifício, do acompanhamento da obra, da realização de novos ensaios complementares, do desenvolvimento do as built, da documentação das diferentes fases do projeto original, da caracterização dos materiais e componentes utilizados na construção e da análise crítica de todos os dados levantados. Deste modo, com uma esta visão mais abrangente deste patrimônio, coletaram-se subsídios para o desenvolvimento 
dos instrumentos de conservação de suas fachadas: o plano de conservação e o manual de uso, operação e manutenção. Esta ação resultou em um acervo documental que extrapola sua utilização no Copan e torna-se importante fonte de informações acerca dos materiais e técnicas construtivas do período de sua construção, contribuindo assim, com outras ações de intervenção no patrimônio de arquitetura moderna brasileira.

\subsection{CONCEITOS INICIAIS}

Cabe para este estudo esclarecer alguns conceitos utilizados ao longo do texto, hierarquizados por alguns autores de forma distintas, como por exemplo Pinheiro (2009), onde relata que na esfera do patrimônio cultural o termo "preservar" é mais abrangente que o termo "conservar", pois "[...] abarca toda e qualquer ação que visa defender, resguardar e proteger os referenciais de uma cultura, dentre elas a de conservar os suportes físicos desse universo buscando garantir sua longevidade por meio das manutenções preventiva e corretiva". Já para Kühl (2008), no campo do patrimônio arquitetônico "conservação" e "restauração" são os termos mais adequados e não devem ser confundidos com reforma, reabilitação e retrofit, que são intervenções voltadas para edifícios antigos genéricos, que não tem valor patrimonial.

Diante das diferentes abordagens dos conceitos encontrados, sentiu-se a necessidade de definir os termos que serão empregados neste trabalho. Adotou-se o que prescreve a Carta de Burra, de 1979, (ICOMOS, 2013) documento base para a conservação de patrimônio reconhecida e aceita mundialmente, que foi baseada no conhecimento do Australia ICOMOS² Members e, fornece orientação para a conservação e gestão de locais de significado cultural. Nela são encontradas as definições conceituais voltadas ao patrimônio e que serão empregadas, são elas:

a) conservação como sendo o processo de cuidar de um lugar para manter seu significado cultural podendo implicar, ou não, na preservação, na restauração e na manutenção;

\footnotetext{
${ }^{2}$ ICOMOS - International Council on Monument and Sites.
} 
b) manutenção como sendo o cuidado de proteção contínua de um lugar e sua configuração, e, diferentemente do reparo, não envolve a restauração ou reconstrução;

c) preservação como sendo a proteção, a manutenção do estado existente retardando a deterioração;

d) restauração como sendo a retomada para um estado anterior conhecido, removendo acréscimos ou reunindo elementos existentes sem a introdução de novos materiais; e a

e) reconstrução, que visa voltar o lugar a um estágio anterior conhecido, mas com o acréscimo de novos elementos (ICOMOS, 2013).

\subsection{JUSTIFICATIVA}

A importância da preservação do patrimônio edificado tem ganhado força nos últimos anos e não somente no que concerne a edificações antigas e de notório valor histórico, mas também os exemplares de arquitetura do Movimento Moderno que, muitas vezes, por estarem cronologicamente mais próximos aos nossos dias, não têm sua importância reconhecida de imediato. Todavia, a curta distância de tempo que nos separa não diminui seu valor cultural e histórico e, tampouco, a necessidade de manutenção para a conservação de suas características arquitetônicas, conforme postulado na Carta de Madrid (ICOMOS, 2011), que aponta a obrigação da conservação do patrimônio arquitetônico do século XX com a mesma importância da conservação de edificações de épocas passadas.

A preservação da arquitetura do Movimento Moderno se apresenta com inúmeros desafios. Conforme aponta Carvalho (2005), no que concerne à materialidade pode-se observar a fragilidade e a vulnerabilidade tanto de seus materiais quanto de seus sistemas construtivos, o desconhecimento acerca dos processos de degradação dos materiais utilizados na época, a perda da função original, além da desatualização das instalações. A proximidade com os dias atuais e o grande número de 
exemplares produzidos no período tornam ainda mais árdua a tarefa de identificar quais têm atributos a serem preservados.

No âmbito do patrimônio arquitetônico, os bens tombados têm necessidade de manutenção potencializada, tanto pela degradação ou fim da vida útil dos subsistemas, devido à idade da edificação, como pelos valores histórico e arquitetônico significativos, que justamente levaram à proteção da obra por órgãos de patrimônio. No século XIX, os teóricos da preservação, especialmente os ingleses John Ruskin e William Morris, demonstraram preocupações acerca dos efeitos prejudiciais que as restaurações poderiam exercer sobre a autenticidade das edificações. Eles, portanto, preconizavam a manutenção preventiva como forma de minimizar os reparos prejudiciais (STANIFORTH, 2013). No entanto, a cultura de manutenção permanente, assim como a cultura da prevalência da conservação sobre a restauração, não faz parte de nossa tradição (IPHAN, 2005). Essa prática leva a um avançado estágio de deterioração, sendo necessária, muitas vezes, a substituição de alguns elementos e componentes. Quanto a isso, de acordo com Aguiar (2017) os revestimentos produzidos industrialmente com frequência têm sua linha de produção interrompida, dificultando ainda mais sua substituição, e muitas vezes não há mais como substituí-los, exceto pela produção artesanal, o que gera custos elevados (MACDONALD, 2013).

Nesse contexto, a prevenção por meio de ações rotineiras de manutenção é a melhor maneira de preservação do patrimônio arquitetônico e, para a sistematização dos procedimentos, dois instrumentos se apresentam com grande relevância: o Manual de Uso, Operação e Manutenção e o Plano de Conservação.

O Manual de Uso, Operação e Manutenção apresenta as informações que concernem às ações periódicas de manutenção, com vistas ao bom desempenho da edificação e o prolongamento de sua vida útil (SANTOS e SCHIMITT, 2003). Vieira (2015) destaca que mesmo as edificações mais antigas, anteriores à NBR 5674/2012, devem desenvolver seus programas de manutenção objetivando a preservação de suas características originais, mesmo perante a necessidade de reformas ou desejo de modernização de 
usuários em busca de inovações tecnológicas. O Manual de Uso, Operação e Manutenção sistematiza os procedimentos e a periodicidade das ações de manutenção preventiva apontando como preservar, mitigando, assim, a degradação da edificação e, consequentemente, a necessidade de grandes intervenções corretivas, com altos custos agregados. As diretrizes para a elaboração desse documento são encontradas na NBR 14037/2011, e podem ser para o edifício como um todo ou para partes dele.

Já o Plano de Conservação é um documento que estabelece o que é significativo na edificação e quais as políticas apropriadas para manter esses significados ao longo do tempo (KERR, 2013). É projetado para conservar o valor cultural de um bem, apontando políticas sustentáveis de conservação (JONKER, s/d). O Plano de Conservação é, portanto, o instrumento que diz o que e por que preservar, enquanto fornece diretrizes e estratégias de conservação.

Ambos os documentos se complementam: um fornecendo subsídios técnicos para ações de manutenção, visando preservar o desempenho e estender a vida útil da edificação, enquanto o outro fornece suporte no que concerne às questões inerentes ao patrimônio histórico e arquitetônico. Esse argumento é corroborado por Tinoco (2013), quando diz que ao dissociar ações de manutenção dos projetos de conservação, contribui-se para a perda de valores significativos e autenticidade do bem.

O patrimônio arquitetônico necessita de ações que permeiem as duas esferas - a técnica e a teórica, sendo necessária uma visão holística que aborde os diferentes aspectos relacionados em prol da preservação de sua materialidade e da conservação de seus aspectos culturais e simbólicos. Neste trabalho, procura-se contribuir para a preservação das fachadas sudoeste e noroeste do Edifício Copan ao sistematizar os procedimentos de manutenção preventiva descritos no Manual de Uso, Operação e Manutenção e a conservação dos aspectos culturais e históricos do edifício por meio de políticas e estratégias definidas no Plano de Conservação. 


\subsection{OBJETIVOS}

Este trabalho tem como objetivo a elaboração de um Manual de Uso, Operação e Manutenção para as fachadas sudoeste e noroeste do Edifício Copan, que estão em processo de reconstrução, e um Plano de Conservação para todas as fachadas do edifício, que são salvaguardadas pelo órgão de preservação do patrimônio local.

Com esses dois instrumentos pretende-se auxiliar a gestão do Edifício Copan em duas vertentes distintas: uma voltada à manutenção preventiva, abordando aspectos técnicos necessários para a preservação do subsistema de revestimento externo, de modo a prolongar sua vida útil e mitigar a degradação de seus elementos e componentes, e a outra voltada à conservação das características e significância do patrimônio arquitetônico, que devem ser mantidas para as gerações futuras.

\subsection{MATERIAIS E MÉTODOS}

Para cumprir o objetivo proposto, a metodologia aplicada na pesquisa foi estruturada em três etapas distintas. São elas:

I - Revisão bibliográfica e levantamento das informações acerca das características técnicas das fachadas e dos elementos que as compõem.

Nessa etapa do trabalho foi realizada a revisão da bibliografia internacional e nacional a partir de livros, teses, dissertações, artigos, normas técnicas e manuais, abrangendo questões dos campos da história e da tecnologia acerca dos temas relacionados:

a) ao patrimônio histórico e arquitetônico e à arquitetura moderna, abordando as formas de intervenção no patrimônio moderno;

b) à manutenção pontuando sua importância para preservação do desempenho, prolongamento da vida útil do subsistema de revestimento cerâmico e conservação das características culturais; 
c) ao estudo dos materiais, por meio da análise de ensaios, fichas técnicas e normas técnicas, visando ao conhecimento técnico dos componentes que compõem o sistema de revestimento das fachadas do Copan;

d) aos exemplos de intervenções em patrimônio arquitetônico, de programas de conservação preventiva, as produções de manuais de uso, operação e manutenção e planos de conservação, para a obtenção de informações necessárias para a elaboração do Manual de Uso, Operação e Manutenção e do Plano de Conservação para as fachadas do Edifício Copan.

No que concerne ao levantamento das informações foi realizada a análise dos relatórios técnicos, do mapa de danos, das manifestações patológicas e condições físicas das fachadas do Copan, assim como a coleta de dados sobre o contexto histórico e urbano da cidade de São Paulo, da concepção do projeto à ocupação do Edifício Copan.

II - Análise dos projetos originais (de arquitetura, de estrutura e de prefeitura) que contam com 1.206 pranchas digitalizadas. Análise do projeto executivo de revestimento de fachada (com emissão inicial em 13/01/2015 e última revisão em 10/05/2016, que contém 15 pranchas e um memorial descritivo. Pesquisa e análise do acervo do condomínio, encartes originais da construtora com cronograma e detalhamento do andamento das obras, memorial descritivo original, fotografias antigas encontradas em jornais e revistas mostrando as manifestações patológicas e a cronologia das imagens levantadas. Acompanhamento da obra de reconstrução das fachadas, para a compreensão das características técnicas do subsistema de revestimento cerâmico das fachadas e o confronto das atividades realizadas no canteiro com o que havia sido especificado no projeto de revestimento de fachada, articulando teoria e prática. Elaboração do as built para a comparação das informações do projeto original com o que foi construído.

III - Elaboração do Manual de Uso, Operação e Manutenção e do Plano de Conservação, embasados no conhecimento obtido nas etapas 
realizadas anteriormente. O Manual de Uso, Operação e Manutenção apresenta parâmetros técnicos para ações de manutenção preventiva, por meio de roteiro com explicitação das atividades e periodicidade de cada ação, fichas de manutenção e inspeção para o registro e documentação de todas as atividades realizadas nas fachadas. O Manual de Uso, Operação e Manutenção é o instrumento que fornece parâmetros técnicos para estabelecer ações de manutenção preventiva, com o objetivo de contribuir para a conservação, durabilidade e prolongamento da vida útil do subsistema de revestimento cerâmico que está sendo reconstruído, ao mesmo tempo que apresenta a sistematização para a documentação dos registros realizados, formando um banco de dados para as fachadas do edifício. Ao lado disso, o Plano de Conservação, específico para as fachadas tombadas, apresenta a significância do patrimônio, as diretrizes de conservação e as políticas apropriadas.

\subsection{ESTRUTURAÇÃO DA DISSERTAÇÃO}

O presente trabalho está estruturado em cinco capítulos, incluindo este de introdução e dois apêndices.

O capítulo 2 apresenta a fundamentação teórica obtida por meio da revisão da bibliografia relativa ao Plano de Conservação, abordando os contextos internacional e nacional sobre o tema e diretrizes para $\circ$ desenvolvimento do Plano de Conservação. Apresenta também o referencial teórico e normativo relativo à manutenção preventiva como elemento de preservação, para manter o desempenho e estender a vida útil do subsistema de revestimento cerâmico do edifício, a importância e os preceitos para a elaboração de manual de manutenção para edificações.

O capítulo 3 é referente ao estudo de caso, o Edifício Copan, e nele se apresenta uma breve contextualização histórica, sua importância enquanto patrimônio arquitetônico, a análise do projeto original e dos materiais especificados em projeto, os materiais e as técnicas construtivas utilizadas na construção do edifício, a caracterização arquitetônica e a problemática do Copan. Apresenta-se, também, o levantamento técnico realizado para subsidiar a elaboração do projeto de revestimento das 
fachadas, os ensaios realizados (reconstituição de traço de argamassa de emboço, aderência à tração) e, por fim, as atividades técnicas desempenhadas durante a pesquisa (avaliação de dureza superficial pelo esclerômetro de reflexão, reconstituição de traço de argamassa de reboco e de assentamento das pastilhas, acompanhamento da obra para remoção das partes soltas, documentação dos elementos de vedação, as built e 0 confronto dos projetos originais com o projeto de revestimento de fachada). Todo esse material objetiva apresentar não apenas um panorama geral das condições físicas das fachadas do edifício, mas desenvolver um acervo documental sobre as técnicas projetuais e construtivas do Edifício Copan e, que representam uma época.

No capítulo 4 são apresentadas as conclusões do trabalho e, na sequência, as referências bibliográficas e os anexos. Separados do corpo da dissertação estão dois apêndices, que são o produto final do trabalho.

O Apêndice A apresenta O Plano de Conservação para as fachadas do Edifício Copan.

O Apêndice B refere-se à proposta do presente trabalho, ou seja, - Manual de Uso, Operação e Manutenção para as fachadas sudoeste e noroeste do Edifício Copan. 


\section{CAPÍTULO 2 - CONSERVAÇÃO DO PATRIMÔNIO ARQUITETÔNICO}

\subsection{PATRIMÔNIO - A IMPORTÂNCIA DA CONSERVAÇÃO}

No que tange ao patrimônio arquitetônico aspectos importantes entram em pauta: a conservação, a preservação e a manutenção. A conservação trata de aspectos intangíveis, como os valores e os significados culturais do patrimônio para a sociedade. Esses valores são expressos por meio de uma materialidade que tende a se deteriorar com o tempo; logo, para que esses valores sejam preservados, é necessário a manutenção do tangível, do material. Todavia, a manutenção de patrimônio arquitetônico deve ser embasada em rigor técnico, sob a ótica da conservação, a fim de proteger os valores e os significados que fizeram do edifício um patrimônio arquitetônico. Sem esses cuidados, a manutenção poderia até ser prejudicial, comprometendo a identidade do patrimônio.

A conservação pode incluir os processos de: retenção ou reintrodução de um uso; retenção de associações e significados; manutenção, preservação, restauração, reconstrução, adaptação e interpretação. Geralmente, incluirá uma combinação de mais de um desses elementos. A manutenção é fundamental para a conservação, pois é de importância cultural e necessária para manter o significado do patrimônio (ICOMOS, 2013).

Para Fitch (1981), a conservação é um viés mais amplo da preservação do patrimônio, e ele a define como "a intervenção física na própria matéria de um edifício para assegurar sua integridade estrutural ou estética" e que, por meio de diagnose e terapias adequadas, é possível reparar a matéria danificada e estender a vida útil do edifício.

A conservação do patrimônio arquitetônico tem sido alvo de crescente interesse nos últimos anos. Todavia, esse não é um assunto recente, já estava presente desde Vitruvius (séc. I a.C.), mas suas bases teóricas ganharam força no século XIX, com o desenvolvimento de políticas conservacionistas na Áustria, França, Alemanha, Holanda e Bélgica. A partir da 
década de 1970 essas abordagens passaram a figurar igualmente nos Estados Unidos (CARVALHO, 2015), não se limitando a procedimentos e métodos analíticos rigorosos, mas incluindo também a conexão da sociedade com o cuidado do patrimônio (VAN BALEN, 2008).

No campo disciplinar da conservação os documentos e normativas apontam a prevenção, como medida de preservação do patrimônio. Mas apesar de as cartas patrimoniais preconizarem ações preventivas a fim de evitar a deterioração do bem, isso nem sempre ocorrev e apenas no final do século XX a conservação preventiva passou a ser difundida como estratégia que conhece e trata as causas da deterioração, objetivando diminuir a necessidade de grandes intervenções de restauro (AGUIAR et al., 2017).

O conceito de conservação preventiva tem sua origem filosófica no século XIX, quando teóricos conservacionistas, entre eles John Ruskin e William Morris, começaram a discutir sobre os efeitos potencialmente prejudiciais que as restaurações poderiam ter nas edificações, colocando em risco a autenticidade do patrimônio. Diante disto, a manutenção preventiva passou a ser apresentada como forma de mitigar a degradação e a necessidade de intervenções de restauro (STANIFORTH, 2013). O conceito de conservação preventiva e sua implementação para a conservação do patrimônio arquitetônico passou por uma rápida evolução, baseando-se em reflexões teóricas (VAN BALEN, 2008).

A partir da década de 1990 há um desdobramento do conceito em "conservação preventiva" e "conservação curativa", fundamentada em abordagens distintas. De um lado, analisando os fatores de risco e desenvolvimento de políticas de preservação para mitigar ou evitar os danos, por outro lado, o reconhecimento dos tipos de degradação que requerem tratamentos curativos. Ambas as abordagens metodológicas, frequentemente combinadas, baseiam-se na antecipação os danos, por meio de uma reflexão teórica e aperfeiçoamento prático para que as intervenções possibilitem a longevidade do patrimônio (GUICHEN, 1999). 
Os teóricos contemporâneos da conservação traçam um paralelo com a medicina ao postular que a prevenção é melhor que a cura e, atualmente, o que se observa é uma vertente voltada à prevenção e não mais à correção dos danos ou à restauração, como era observado no passado. Pois a abordagem corretiva é potencialmente perigosa para a herança cultural, uma vez que a extensão dos danos possa ser de tal magnitude que não seja mais possível preservar a matéria como testemunho de uma época.

Van Balen (2011) propõe diferentes níveis de prevenção: a prevenção primária, que evita as causas dos efeitos indesejados (degradação); a prevenção secundária, que concerne aos meios de monitoramento que permitem a detecção precoce dos sintomas causados por efeitos indesejáveis; e, por último, a prevenção terciária, que se refere aos meios que previnem a propagação dos efeitos indesejados ou a geração de novos efeitos colaterais.

Essas reflexões teóricas surgem a partir das cartas patrimoniais que são documentos desenvolvidos por órgãos de preservação nos âmbitos nacional e internacional e apresentam diretrizes de conservação do patrimônio.

"As cartas patrimoniais são fruto da discussão de um determinado momento. Antes de tudo, não têm a pretensão de ser um sistema teórico desenvolvido de maneira extensa e com absoluto rigor, nem de expor toda a fundamentação teórica do período. As cartas são documentos concisos e sintetizam os pontos a respeito dos quais foi possivel obter consenso, oferecendo indicações de caráter geral. Seu caráter, portanto, é indicativo ou, no máximo, prescritivo. Obviamente, cartas internacionais, como a de Veneza, não podem ter caráter normativo, pois suas indicações devem ser reinterpretadas e aprofundadas para as diversas realidades culturais de cada país, e ser, ou não, absorvidas em suas propostas legislativas [...]" (KÜHL, 2010).

A primeira carta patrimonial foi a de Atenas, de 1931, e postula o levantamento de informações acerca do patrimônio, com a elaboração de um inventário e métodos de conservação desses monumentos. Apresenta, 
ainda, diretrizes para a reconstituição da materialidade do patrimônio e menciona a necessidade de "adoção de um sistema de manutenção regular e permanente, apropriada para assegurar a preservação dos edifícios". As recomendações nela contidas tiveram, como afirma Kühl (2010), grande repercussão internacional e forneceram as bases para a Carta de Veneza.

A Carta de Veneza, de 1964, apresenta entre as suas recomendações duas de extrema relevância para o desenvolvimento deste trabalho, são elas: "Para a conservação dos monumentos é essencial que estes sejam sujeitos a operações regulares de manutenção;" e "quando as técnicas tradicionais se revelarem inadequadas, a consolidação de um monumento pode ser efetuada pelo emprego de qualquer técnica moderna para a conservação e construção, cuja eficácia tenha sido demonstrada cientificamente e garantida através da experiência de uso" (ICOMOS, 1964). Esta carta permanece como documento-base, apresentando ações indicativas de conservação e registrando a manutenção como fator essencial à conservação do bem de significado cultural.

A Carta de Burra, de 1979, fornece orientação para a conservação e gestão de locais de significado cultural, ou seja, valores estéticos, históricos científicos ou sociais de um bem para as gerações passadas, presentes ou futuras. Enfatiza a conservação como os cuidados para a preservação das características de valor cultural, por meio de medidas de segurança, destinação futura e manutenção (ICOMOS, 2013).

A Carta do ICOMOS3, de 2003, oferece recomendações para investigação e diagnóstico, por meio da compreensão das características estruturais e dos materiais, para posteriormente propor terapias que devem ser dirigidas às causas e não aos sintomas. O documento enfatiza a necessidade do resguardo da integridade dos componentes, enquanto produto da tecnologia de construção específica do seu tempo. A importância das investigações e diagnósticos, antes das intervenções, para coletar informações sobre a estrutura, os materiais e as manifestações patológicas, a fim de identificar as causas dos danos e a extensão da degradação. Entre as

\footnotetext{
${ }^{3}$ ICOMOS - International Council on Monument and Sites.
} 
técnicas tradicionais e inovadores devem ser adotadas as mais compatíveis com os valores do patrimônio, respeitando os requisitos de segurança e durabilidade. Sempre que possivel, as medidas adotadas para as intervenções devem ser reversíveis, permitindo a aprimoração futura advindas de novos conhecimentos e, quando não forem completamente reversíveis, que ao menos não limitem intervenções posteriores. Para evitar efeitos colaterais indesejados é fundamental estabelecer as características e a compatibilidade dos materiais novos com os existentes. A remoção e/ou alteração do material histórico e dos elementos arquitetônicos devem ser evitadas. Durante e após a intervenção devem ser realizadas ações de verificação e de monitoramento e, estas devem ser documentadas e guardadas como parte da história do patrimônio. O documento enfatiza ainda que as intervenções devem ser mínimas, proporcionais aos objetivos de segurança estrutural e durabilidade, mas com a menor interferência possível aos valores do patrimônio (ICOMOS, 2003).

Carta de Madrid, de 2011, apresenta as diretrizes para conservação de patrimônio arquitetônico do século XX, deixando explicito em seu texto que é dever da sociedade conservar o patrimônio de arquitetura moderna, com os mesmos cuidados atribuídos ao patrimônio de épocas passadas. Processo que se inicia com a identificação, a avaliação e a compreensão do seu significado cultural, tendo sempre em mente que os materiais constituem um testemunho do seu tempo, lugar e uso. Posteriormente o desenvolvimento de uma metodologia de planejamento de conservação e políticas que visem resguardar a autenticidade e a integridade do bem, por meio de plano de manutenção preventiva, com inspeções periódicas devidamente documentadas. A investigação dos aspectos técnicos do patrimônio é fundamental para o desenvolvimento de métodos de conservação, devendo cada caso ser analisado individualmente para atender às diferentes tipologias. O patrimônio vivo, muitas vezes, requer mudanças para adequação ao uso cotidiano, mas estas mudanças devem ser geridas de forma a minimizar o impacto no significado cultural, na autenticidade e na integridade do bem, e quando houver a necessidade de substituição de materiais, estes devem ser semelhantes aos originais, mas distinguíveis (ICOMOS, 2011). 
Todas as cartas patrimoniais mencionadas anteriormente apresentam dois pontos em comum: o primeiro diz respeito ao conhecimento do patrimônio, seus materiais e suas técnicas para que sejam propostas medidas adequadas de conservação e o segundo trata da importância da manutenção preventiva na conservação do patrimônio arquitetônico, que mesmo tendo sido amplamente discutido e recomendada pelos teóricos, na prática nem sempre é realizada.

As reflexões teóricas tiveram início a partir da necessidade de preservação de patrimônio histórico, que até pouco tempo era limitado aos edifícios antigos, mas no final do século XX inicia-se um processo de reconhecimento da arquitetura do Movimento Moderno como patrimônio cultural (OKSMAN, 2011) e os conceitos de preservação utilizados para edifícios históricos passam a pautar a preservação de exemplares de arquitetura moderna, tendo inclusive uma das cartas patrimoniais, a de Madrid, dedicada a este período específico.

A arquitetura produzida pelo Movimento Moderno ganha força em escala global após a Primeira Guerra Mundial. Com as premissas de uso racional de materiais modernos, ela rompe com as tradições históricas e o uso de ornamentos em prol de funcionalidade e de processos industriais na sua produção, tornando-se, assim, símbolo do progresso técnico, político e social de uma época (AGUIAR et al., 2017).

A preservação da arquitetura do Movimento Moderno se apresenta com inúmeros desafios, conforme aponta Carvalho (2005). No que concerne à materialidade pode-se observar a fragilidade e a vulnerabilidade tanto de seus materiais quanto de seus sistemas construtivos, o desconhecimento acerca dos processos de degradação dos materiais utilizados, a perda da função original, além da desatualização das instalações. A proximidade com os dias atuais não permite o distanciamento histórico necessário para atribuição de valor e o grande número de exemplares produzidos no período torna ainda mais árdua a tarefa de identificar quais têm atributos a serem preservados. Ainda segundo Carvalho (2005), os debates sobre a aplicação dos princípios de conservação para os edifícios do Movimento Moderno e o desenvolvimento de estratégias foram impulsionados 
pela observação de problemas similares nos edifícios antigos e nos edifícios modernos.

Para salvo (2007), o mesmo rigor metodológico e científico utilizado para a conservação de edifícios antigos deve ser aplicado aos exemplares de arquitetura moderna. Frequentemente, os edifícios genéricos de época recente são demolidos ou totalmente modificados e os de interesse histórico e cultural são preservados, mas não sem transformações substanciais e manutenções substitutivas.

A partir da década de 1980, um crescente interesse dos profissionais voltados à preservação do patrimônio moderno produziu discussões e fóruns internacionais, com o objetivo de traçar estratégias para a realização de inventários, metodologia de avaliação, preservação e conservação dos exemplares significativos da arquitetura moderna. Em 1985, uma reunião de especialistas, promovida pelo International Council on Monument and Sites (ICOMOS), ocorreu em Paris e a partir de então o Conselho da Europa passa a promover uma série de encontros de especialistas em arquitetura do Movimento Moderno, com destaque para o encontro "Patrimônio Arquitetônico do Século XX", realizado em Viena em 1989, no qual foram estabelecidas recomendações aos governos dos Estadosmembros quanto à preparação de inventários, critérios de seleção, avaliação do estado de conservação e disseminação das informações nas esferas educacionais e políticas. Em 1990 foi elaborada em Barcelona uma proposta política para a preservação do patrimônio moderno, que resultou na recomendação $R$ (91) do Conselho da Europa, que traz em seu texto as seguintes recomendações: 1) identificação do patrimônio do século $X X ; 2)$ proteção dos exemplares mais significativos; 3 ) gerenciamento e conservação desse patrimônio; 4) conscientização das instâncias políticas e do público em geral; e 5) estabelecimento de cooperação em nível europeu (CARVALHO, 2005).

O interesse historiográfico da arquitetura moderna, aliado à tomada de consciência do avançado estágio de degradação de alguns de seus ícones, motivou o desenvolvimento de pesquisas voltadas tanto para questões históricas quanto para a identificação das soluções técnicas 
construtivas, objetivando a proteção e a salvaguarda do patrimônio moderno (CARVALHO, 2005). É nesse contexto que em 1990 é criado o DOMOCOMO International Working Party for Documentation and Conservtion of Buildings, Sites and Neighbourhoods of the Modern Movement, uma organização não governamental que buscou se manter pouco burocrática, agregando países de diferentes partes do mundo e assumindo as discussões voltadas à preservação do Movimento Moderno.

As primeiras ações de preservação da arquitetura do Movimento Moderno tiveram início na Europa, em épocas distintas para diferentes países. De acordo com Carvalho (2005), o primeiro país a definir instrumentos para a seleção, identificação e proteção de exemplares de arquitetura do Movimento Moderno foi a França. O Théâtre de Champs-Élysées foi declarado monumento de interesse histórico e arquitetônico em 1957. Posteriormente, o decreto de 1961 possibilitou a inscrição de exemplares de arquitetura moderna no Inventário Suplementar de Monumentos Históricos, iniciando-se assim o processo legal de proteção do patrimônio moderno. Na Alemanha, a preservação do patrimônio moderno ocorre de forma delicada, haja vista as questões históricas associadas à Segunda Guerra Mundial e às relações da população com as manifestações culturais.

Em 1958 é declarado o interesse em preservar o Weissenhofsiedlung ${ }^{4}$, de Stuttgart, em 1977 iniciam-se os esforços para a reconstrução de seu estado original e, em 1981, fica estabelecida uma comissão para a sua restauração. Na Inglaterra o Movimento Moderno tem seu período mais expressivo de 1945 a 1975 e o reconhecimento oficial do patrimônio teve seu início em 1970. Na Itália, a preservação da arquitetura moderna utiliza as mesmas bases conceituais do restauro de edifícios antigos.

A conservação do patrimônio se faz, portanto, por ações sistemáticas de cuidados, de manutenção preventiva, evitando a deterioração e assim utilizando ações minimamente invasivas que podem pôr em risco a identidade do bem cultural. Nesse sentido, o Plano de Conservação se apresenta como um importante instrumento na preservação do patrimônio

\footnotetext{
${ }^{4}$ Exposição de protótipos habitacionais desenvolvidos pelos grandes mestres do modernismo durante o período de 1927 a 1932.
} 
arquitetônico, pois, sendo um documento abrangente, ajuda a relacionar diversas possibilidades, propiciando decisões mais pertinentes na resolução dos conflitos inerentes a cada caso. O Plano de Conservação tem um caráter dinâmico, tal como o bem que está sendo preservado, e por essa razão necessita de revisões para que eventuais problemas sejam analisados de modo sistêmico e holístico.

Estando a conservação voltada para aspectos culturais e a preservação para a proteção do estado atual, mitigando a deterioração, ambas estão intrinsecamente relacionadas com a manutenção, que deve ser pautada a partir de uma abordagem preventiva com rigor teórico e metodológico tanto para edifícios de épocas passadas quanto para exemplares de arquitetura do Movimento Moderno. E tanto as cartas patrimoniais quanto os teóricos da conservação apontam a importância do conhecimento acerca dos mecanismos de degradação para a proposição de ações adequadas de manutenção para conservar os valores culturais e preservar as características arquitetônicas do patrimônio.

\subsection{PRESERVAÇÃO DA ARQUITETURA: PLANO DE CONSERVAÇÃO - CONTEXTO INTERNACIONAL E NACIONAL}

O Plano de Conservação é um documento que estabelece o que é significativo em um lugar e as políticas apropriadas para permitir que os significados sejam mantidos ao longo do tempo. Relaciona as ações de conservação propostas aos recursos disponíveis, abordando todos os dados relevantes em um sistema de prioridades. Sua elaboração deve ser feita com os problemas de implementação sempre em mente e de maneira que sua leitura seja clara, sem jargões profissionais, de modo preciso, inequívoco, relevante e passível de realização (KERR, 2013).

Para a instituição inglesa Heritage Lottery Fund o Plano de Conservação é um documento que ajuda a entender por que o patrimônio é valorizado e por quem. A partir de uma visão geral estabelece políticas que auxiliam na tomada de decisões para os cuidados com o edifício, garantindo o uso e os valores culturais (Heritage Lottery Fund, s/d). 
Para ○ Heritage Branch, órgão governamental canadense, o Plano de Conservação é elaborado para atender às necessidades inerentes ao patrimônio, apresentando políticas que equilibrem o uso e a significância do lugar, fornecendo subsídios para a tomada de decisões sobre um edifício histórico. Deve estar intrinsecamente ligado aos valores patrimoniais do lugar, bem como aos valores sociais, ambientais e econômicos, de modo a mitigar efeitos negativos oriundos da ambiguidade de interpretação, fornecendo diretrizes para o uso sustentável, ações de manutenção, reparos, alterações e gestão do patrimônio, visando sua longevidade (Heritage Branch, s/d).

Para a Fundação Casa de Rui Barbosa, no Brasil, o Plano de Conservação contribui para a preservação, pois aborda aspectos técnicos, culturais e orçamentários para a implantação das ações necessárias (Fundação Casa de Rui Barbosa, s/d).

Essas abordagens, apesar de distintas e elaboradas para realidades diferentes, apresentam pontos convergentes, que são a essência do Plano de Conservação. Destacam-se a preservação das características materiais, a retenção dos valores culturais e os recursos disponíveis para a elaboração e implementação das políticas de conservação.

O Plano de Conservação se apresenta, portanto, como instrumento aliado à preservação do patrimônio histórico, uma vez que a documentação fornece subsídios para entender não apenas a significância do local, enquanto patrimônio, mas permite levantar sistematicamente a materialidade do bem e seu comportamento no decorrer do tempo. Desse modo, possibilita a proposição de meios adequados de preservação para a retenção de seus valores culturais e sua autenticidade, por estar embasado em conhecimento acerca de suas características. Um Plano de Conservação é, portanto, indissociável dos conceitos de preservação, conservação e manutenção.

As preocupações voltadas à conservação do patrimônio estão presentes na sociedade desde Vitruvius, conforme citado anteriormente. Entretanto, a fim de mostrar a evolução dos processos voltados à conservação, que culminaram em diretrizes estabelecidas por instituições 
governamentais para a elaboração de planos de conservação, serão apresentadas três localidades distintas: Reino Unido, Canadá e Austrália, cujas metodologias serviram de parâmetros para o desenvolvimento do presente trabalho.

No Reino Unido as primeiras iniciativas voltadas à conservação do patrimônio histórico, surgem em 1882, com uma legislação protetiva dos edifícios e sítios de valores culturais e históricos, a Ancient Monuments Protection Act, que cria uma categoria destinada aos cuidados com o patrimônio e cujos custos com a manutenção deveriam ser previamente aprovados pelo Tesouro de Sua Majestade, ao mesmo tempo que previa punição a qualquer pessoa que cometesse atos danosos aos edifícios históricos (UNESCO, s/d). Mais tarde as instituições inglesas de caráter nacional, o National Trust e o English Heritage, inspiraram instituições na Escócia, no País de Gales e na Irlanda do Norte.

O National Trust, uma associação sem fins lucrativos constituída em 1894 e aprovada pelo Parlamento em 1907, detém a propriedade de mais de 350 construções e sítios históricos, que the proporcionam rendimentos com atividades comerciais, anvidades de associações, colaboração de voluntários, além de receber doações e heranças. O English Heritage, criado em 1983, é um órgão oficial de orientação ao governo com vistas a incentivar a valorização e a conservação, para futuras gerações, do patrimônio erigido pelo homem, de modo a incutir na população o cuidado e a apreciação de seu patrimônio histórico. O sistema de loterias do Reino Unido, The National Lottery, dedica um percentual de sua arrecadação para diversas esferas culturais, entre elas a preservação do patrimônio. Há uma listagem desenvolvida por órgãos que administram os procedimentos de preservação, cujos bens incluídos ficam habilitados a receber recursos financeiros para essa finalidade. Esses mesmos órgãos fornecem suporte para a valorização dos bens listados. Todavia, os bens que forem descaracterizados, ou abandonados, são retirados da lista e perdem direito à verba da instituição nacional (LEFÈVRE, 2017).

No Reino Unido, a partir da Carta de Burra, da Conferência de Nara e da implementação do Heritage Lottery Fund, ambos de 1994, o Plano 
de Conservação passou a ser um documento indispensável aos recursos públicos voltados à preservação, principalmente após o restauro, como forma de exigência na comprovação de garantias à integridade e à autenticidade do patrimônio (TINOCO, 2013).

Inúmeros são os planos de conservação desenvolvidos no Reino Unido e, como exemplo, cita-se a Dunfermline Carnegie Library, um edifício situado na cidade de Dunfermline, na Escócia. O edifício, que abriga uma biblioteca, conta com três fases principais de construção (figura 1). A primeira fase da biblioteca foi completada em 1883, cujo projeto é atribuído a J. C. Walker. A ampliação e a alteração, projetadas por J. Shearer, foram interrompidas pela Primeira Guerra Mundial e concluídas apenas em 1922. A fase final da ampliação data de 1993, sob a responsabilidade do arquiteto L. Dunkerley.

O Plano de Conservação para este edifício, elaborado em 2012, foi uma atualização de um relatório anterior, produzido em 2007, ambos assinados pela Simpson \& Brown Architects. Ele foi desenvolvido com o intuito de auxiliar na construção de uma extensão que fornecesse um novo museu e uma galeria de arte, projetados por Richard Murphy Architects. O Plano de Conservação elaborado para a biblioteca aborda questões relacionadas ao entendimento do lugar, sua história e transformações ao longo do tempo. A avaliação de sua significância aborda aspectos históricos, arquitetônicos, arqueológicos, estéticos, paisagísticos, ecológicos e sociais. Trata das questões voltadas ao entendimento do tecido existente, do uso, da manutenção, do gerenciamento das informações e propõe políticas de conservação relacionando os diversos aspectos levantados. Na Figura 2 observam-se as ampliações e as alterações da edificação ao longo de sua história e, desse modo, é possível entender os processos que dão ao bem cultural sua forma atual (SIMPSON \& BROWN ARCHITECTS, 2012). 


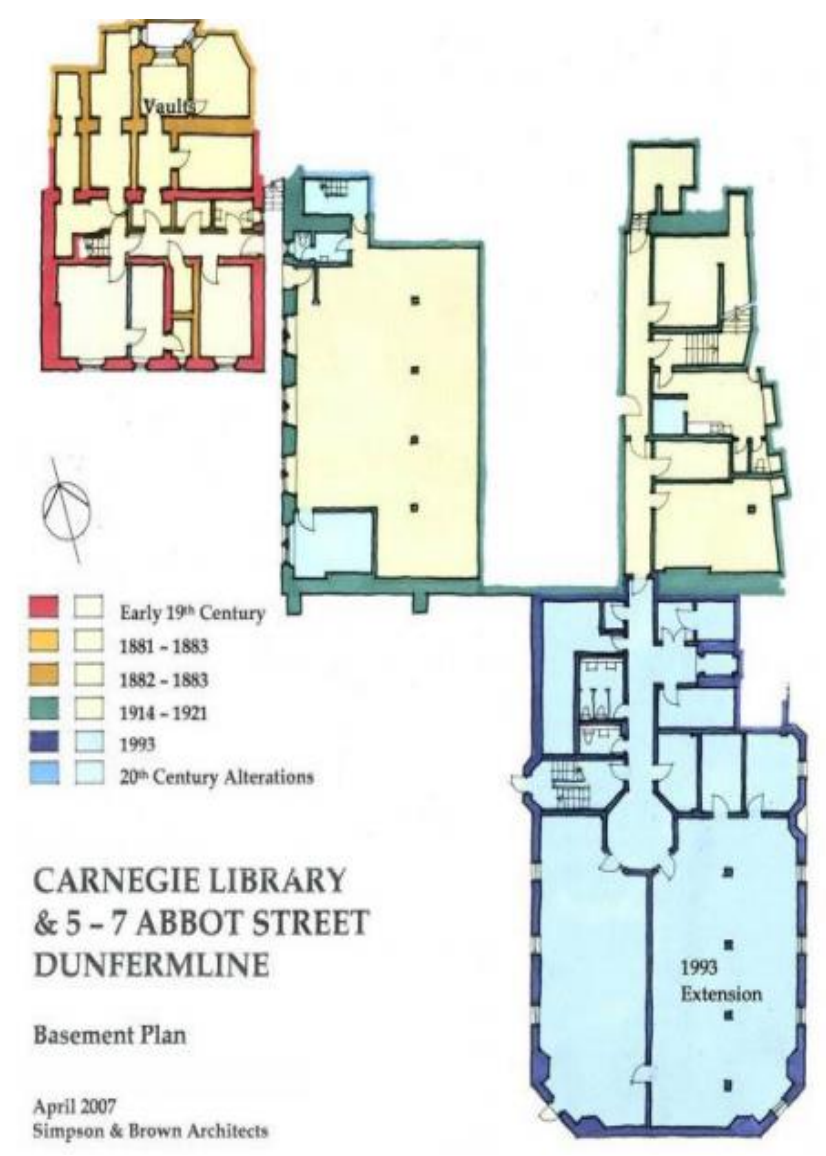

Figura 1- Planta do desenvolvimento histórico da Carnegie Library

Fonte: Simpson \& Brown Architects, 2007.

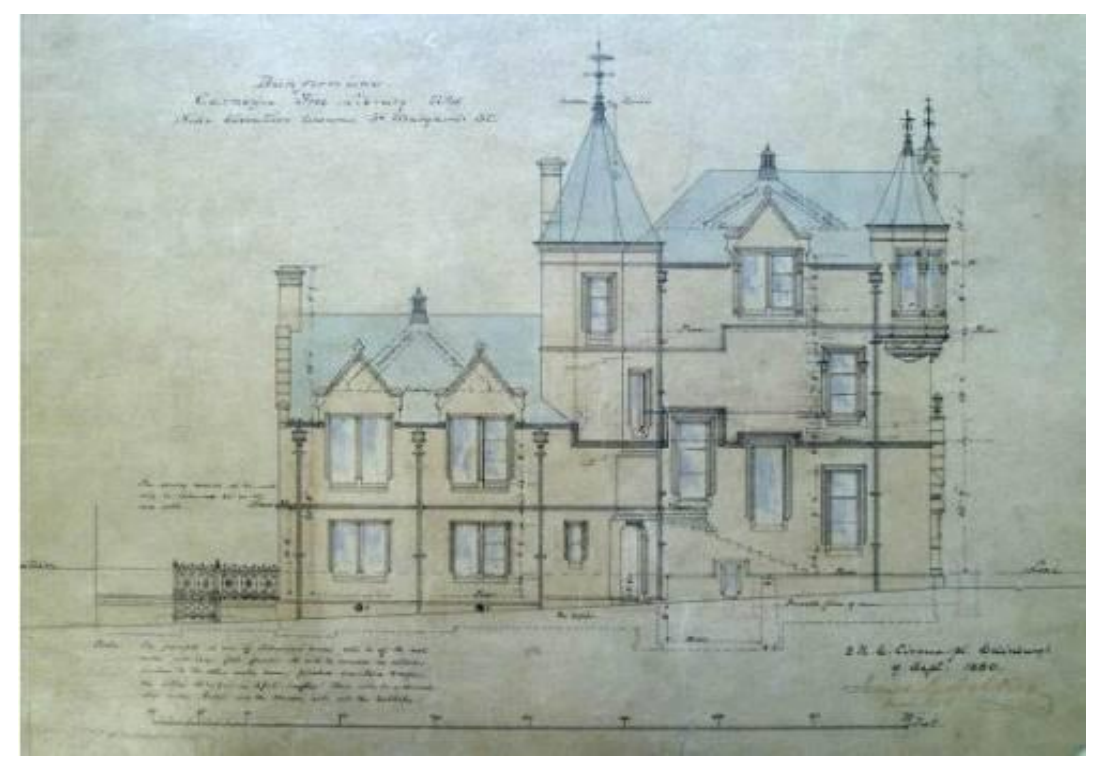

Figura 2 - Elevação Oeste J. C. Walker - 1880

Fonte: Simpson \& Brown Architects. 
Na Austrália, o Plano de Conservação elaborado para a Opera House de Sydney (figura 3) em 1993, que se encontra atualmente em sua quarta edição (KERR, 2003), tem sido um exemplo metodológico que inspira outros planos em diversas partes do mundo. Esse plano aborda, em ordem cronológica, a história não só do teatro, mas do sítio no qual foi construído, de modo a entender a edificação e sua relação com o entorno como um todo. Aborda os diferentes níveis de significância e as políticas de conservação oferecem cuidados atuais e futuros, incorporando princípios de flexibilidade necessários para a melhoria funcional e desenvolvimento futuro do edifício e seu entorno, embasados em tratamento progressivo para as diferentes partes, mas retendo os conceitos de Utzon, o arquiteto criador do projeto da Opera House de Sydney (KERR, 2003).

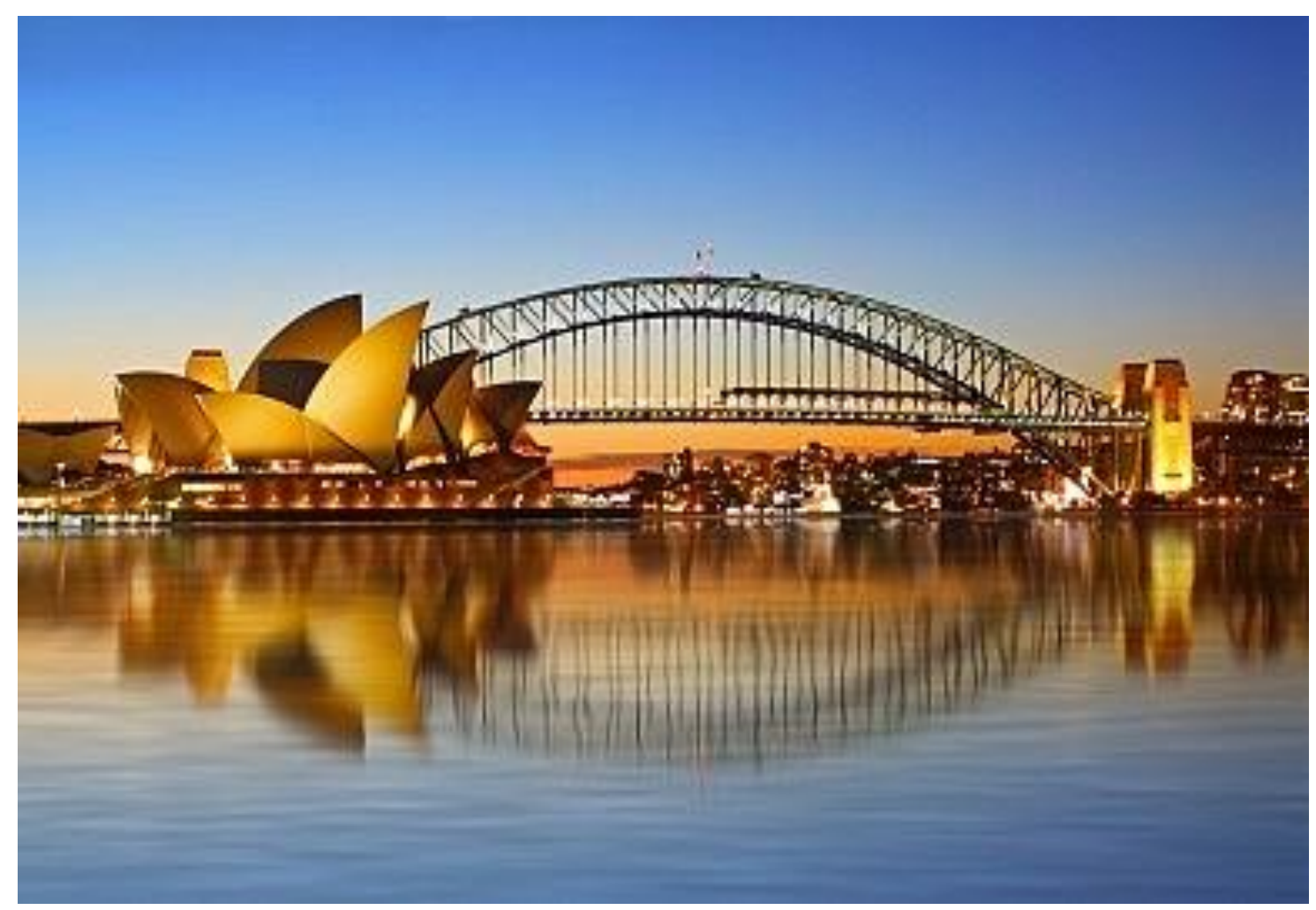

Figura 3 - Opera House de Sydney

Fonte: www.thediplomat.com.

Países como Portugal, Espanha e Itália adotaram planos de conservação como política de preservação preventiva (AGUIAR et al., 2017). O British Columbia Heritage Branch, no Canadá, promove a cultura de conservação do patrimônio, enfatizando que, mesmo que a maioria dos 
recursos patrimoniais seja de propriedade privada, todos podem compartilhar a administração responsável e o orgulho cultural associado a eles. Em seu website disponibilizam uma vasta documentação voltada à preservação do patrimônio, que vai desde exemplos de planos de conservação até guias de como executá-los (British Columbia, 2013).

O Plano de Conservação para o Historic Hat Creek Ranch (figura 4), desenvolvido pelo British Columbia Heritage Branch, foi elaborado por James Burton, Birmingham \& Wood Architects and Planners, em 2013, com o objetivo de propor um planejamento para usos futuros das propriedades históricas da província de Colúmbia Britânica, no Canadá. A intenção é que sirva de guia para proprietários e gestores de sítios históricos, de modo a garantir que o significado, enquanto patrimônio, seja mantido pelas comunidades locais. Ao motivar a cooperação e a confiança entre a esfera administrativa e a comunitária, oferece orientações acerca da mitigação do impacto causado pelas eventuais mudanças.

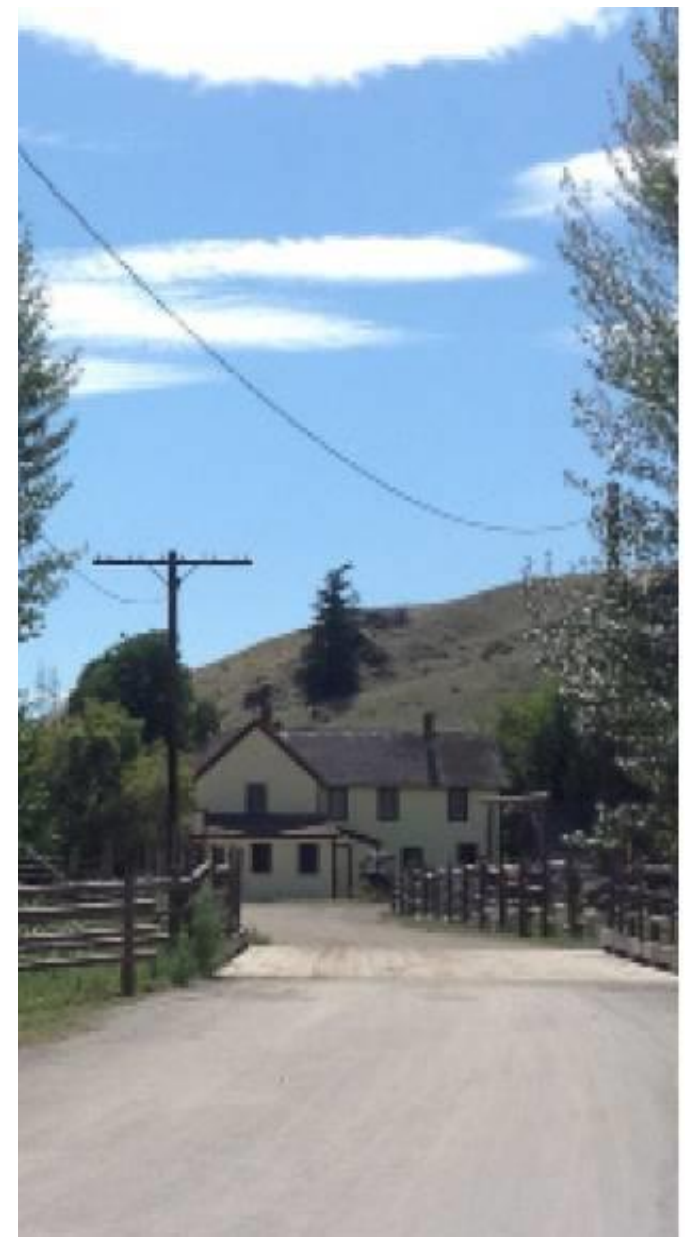

Figura 4 - Historic Hat Creek Ranch

Fonte: BC Heritage Branch.
O Hat Creek Ranch, administrado pelo British Columbia Heritage Branch, está listado no registro nacional de locais históricos e incluído na relação dos bens históricos por seus valores naturais, arqueológicos, históricos, culturais, científicos, estéticos e sociais. Oferece aos seus visitantes uma experiência de como era a vida nos primeiros anos da província, com uma gama de técnicas construtivas de edifícios originais encontradas no local, além dos aspectos ecológicos de fauna e flora selvagens.

Em seu Plano de Conservação para o entendimento do local são abordados a evolução 
cronológica, seus aspectos históricos, a declaração de significados, a visão da comunidade, o potencial de usos futuros, a avaliação de impactos futuros e as políticas de conservação. Aponta ainda as opções de usos futuros, como museu, parada de estrada e centro cultural comunitário. Por meio de uma análise na qual confronta as receitas geradas e os investimentos necessários aponta também, em ordem hierárquica, as melhores opções para usos futuros (British Columbia, 2013).

Os três exemplos de planos de conservação apresentados anteriormente, apesar de serem de continentes distintos e para patrimônios de temáticas diferentes, fornecem diretrizes similares, baseadas em premissas metodológicas que apontam a necessidade de entendimento do local, do seu desenvolvimento cronológico e das relações históricas e sociais com a comunidade. Pois é a partir do entendimento do lugar e dos valores a eles atribuídos pela sociedade que é possível identificar suas significâncias. No que tange aos aspectos técnicos e construtivos, o diagnóstico é necessário para o conhecimento acerca do seu estado físico e/ou de degradação e fundamental para a proposição de medidas de manutenção rotineira, visando reter as características e os atributos que fazem do edifício um bem a ser preservado para a posteridade.

No Brasil, o primeiro registro de preocupação visando à proteção de monumentos históricos data de 1742, quando Dom André de Melo e Castro, Conde de Galveias, Vice-Rei do Estado do Brasil de 1735 a 1749, ao tomar conhecimento das intenções do governador de Pernambuco acerca das construções erigidas pelos holandeses, escreve-lhe uma carta demonstrando a percepção da complexidade que envolve o problema de proteção a monumentos históricos.

"[...], mas ainda me lastima mais que, com ela, se arruinará também uma memória que mudamente estava recomendando à posteridade as ilustres e famosas ações que obraram os Portugueses na Restauração dessa Capitania, de que se seguiu livrarse do jugo fábricas em que se incluem as estimáveis circunstâncias (referidas) [...] são livros que falam, sem que seja necessário lê-los [...]" (IPHAN, 1980). 
A primeira referência legislativa protetiva do patrimônio nacional aparece na Constituição de 1934. Todavia, esta outorgava somente à União e aos estados a proteção das belezas naturais e monumentos de valor histórico e artístico. Aos municípios não cabiam tais atribuições. Na Constituição de 1937, no entanto, os municípios passam a figurar, também, como responsáveis à proteção de bens culturais (SILVA, 2012). Abaixo é apresentada parte do texto do Decreto-Lei $n^{\circ}$ 25/37 que define o que é patrimônio nacional e em que circunstâncias são assim chancelados.

"Art. $1^{\circ}$ Constitui o patrimônio histórico e artístico nacional o conjunto dos bens móveis e imóveis existentes no país e cuja conservação seja de interesse público, quer por sua vinculação a fatos memoráveis da história do Brasil, quer por seu excepcional valor arqueológico ou etnográfico, bibliográfico ou artístico."

"§ $1^{\circ}$ Os bens a que se refere o presente artigo só serão considerados parte integrante do patrimônio histórico e artístico nacional depois de inscritos separada ou agrupadamente num dos quatro Livros do Tombo, de que trata o art. $4^{\circ}$ desta lei."

Há no Brasil três esferas de proteção do patrimônio artístico e nacional: federal, estadual e municipal. A regulamentação pelo Decreto-Lei $n^{\circ}$ 25/37, que institui o tombamento como instrumento jurídico de proteção, é efetivada com a inscrição do bem em um dos livros do tombo existentes. "[...] se tombar é inscrever, registrar, inventariar, cadastrar, tombamento é a operação material da inscrição do bem, móvel ou imóvel, no livro público respectivo. Tombamento é também o ato administrativo que concretiza a determinação do poder público no livro do tombo" (CRETELLA, apud SILVA, 2012).

O tombamento como instituto jurídico protetor do patrimônio cultural impõe limitações quanto ao exercício e ao direito de propriedade, postulando em seu texto a restrição à alienabilidade e à vizinhança, veto à modificação do bem, institui a obrigação do proprietário em conservá-lo e, quando este não dispuser de recursos para tal, deverá comunicar o poder público da necessidade de obras e ações de conservação, sendo tal omissão 
passível de punição com multa (SILVA, 2012). No Brasil é muito comum o tombamento como prática de conservação. Todavia, este assegura um impedimento legal à demolição, mas não à preservação efetiva da edificação, tampouco sua reintegração social e cultural (LEFÈVRE, 2017).

O interesse público da preservação de bens culturais por meio do tombamento está fundamentado na Constituição Federal, na qual estabelece as bases dos direitos culturais como um direito coletivo à preservação do patrimônio cultural para fruição pela sociedade brasileira. Nesse contexto o tombamento se apresenta com um instrumento jurídico que objetiva impor a preservação de materiais públicos ou privados, aos quais são atribuídos valores culturais (IPHAN, 2005). A Constituição de 1988 traz em seu texto o termo "patrimônio cultural brasileiro" e especifica quais bens culturais abriga, conforme o artigo 216 abaixo:

"Art. 216. Constituem patrimônio cultural brasileiro os bens de natureza material e imaterial, tomados individualmente ou em conjunto, portadores de referência à identidade, à ação, à memória dos diferentes grupos formadores da sociedade brasileira, nos quais se incluem:

I - as formas de expressão;

II - os modos de criar, fazer e viver;

III - as criações científicas, artísticas e tecnológicas;

IV-as obras, objetos, documentos, edificações e demais espaços destinados às manifestações artístico-culturais;

V - os conjuntos urbanos e sítios de valor histórico, paisagístico, artístico, arqueológico, paleontológico, ecológico e científico" (BRASIL, 1988).

Para além das garantias legais, há ainda programas de fomento à conservação do patrimônio cultural. A linha evolutiva dos programas governamentais de conservação do patrimônio cultural construído tem início com o Programa Integrado de Reconstrução das Cidades Históricas do Nordeste do Brasil, de 1973, passando pelo Programa Monumenta/BID, de 2000, e o PAC das Cidades Históricas, de 2009. Todavia, as políticas públicas 
privilegiam ações que muitas vezes contribuem para a perda de valores significativos de autenticidade e integridade de monumentos e conjuntos históricos, ao dissociar ações periódicas de manutenção dos projetos de conservação (TINOCO, 2013).

As culturas de manutenção permanente, assim como a cultura da prevalência da conservação sobre a restauração, não fazem parte de nossa tradição (IPHAN, 1980). Monumentos que foram contemplados com o financiamento do restauro pelo Programa das Cidades Históricas, durante as décadas de 1980 e 1990, sofreram mais tarde novos processos de restauro por não terem passado por ações de manutenção com vistas à preservação. Essa prática de ausência sistemática de manutenção até a deterioração do bem, levando novamente ao restauro, é lesiva não só financeiramente, mas também fisicamente, pondo em risco a integridade dos materiais que 0 compõem, assim como a significância da edificação e/ou do lugar.

Nesse sentido, o Banco Nacional de Desenvolvimento Econômico e Social - BNDES, ainda que de forma incipiente, passou a solicitar aos proponentes a apoio financeiro para projetos culturais os seguintes elementos complementares para análise das propostas: apresentação de um plano de custeio com indicação das fontes de receitas previstas para a manutenção da utilização principal do bem; apresentação de plano de manutenção (física) do monumento, por prazo de no mínimo três anos após o restauro, com indicação de fontes de receitas previstas; apresentação de um plano de segurança (antifurto, anti-incêndio etc.); definição de no mínimo uma ação de caráter cultural complementar ao restauro que objetive 0 incremento turístico local, o incremento da sustentabilidade financeira do monumento, a geração de emprego e renda; capacitação de mão de obra, ou educação patrimonial (CHAGAS, apud TINOCO, 2013).

O Centro de Estudos Avançados da Conservação Integrada CECl vem desenvolvendo planos de conservação desde 1997, visando garantir os valores culturais do patrimônio por meio da conservação e do restauro de edifícios, principalmente no Nordeste do Brasil. Sua produção abrange ações técnicas, políticas e econômicas, traçando diretrizes capazes de acompanhar as mudanças e transformações da edificação, por um prazo 
mínimo de vinte anos. Os modelos por eles desenvolvidos tiveram como base as premissas estabelecidas no Plano de Conservação da Opera House de Sydney, elaborado por James Kerr (2013). São eles: conhecimento do lugar; avaliação da significância; estudos dos impactos potenciais e propostas das políticas de conservação.

O Museu Casa de Rui Barbosa consiste em uma fundação de desenvolvimento cultural, de pesquisa e de ensino, com vistas a preservar a obra e aspectos da vida de Rui Barbosa. A construção data de 1850 e seu acervo conta com, aproximadamente, mil e duzentas peças de mobiliário, decoração e mais de 37 mil livros. A elaboração do Plano de Conservação teve início em 1997 e surgiu da necessidade de reduzir as intervenções restauradoras e valorizar a ampliação das possibilidades de preservação. A partir de então, a identificação das necessidades da instituição se fez necessárias para a definição das estratégias de conservação. A etapa do diagnóstico utilizou como base a metodologia do "The Conservation Assessment: A proposed model for evaluating Museum Environmental Management Needs", elaborado pelo Getty Conservation Institute, compreendendo a elaboração de diagnósticos de conservação, a elaboração de projetos executivos e as intervenções necessárias para sua implementação, a elaboração de um plano de manutenção como instrumento preventivo de riscos de deterioração futura e, também, o treinamento da equipe de manutenção (Fundação Casa de Rui Barbosa, s/d).

Mais recentemente foi desenvolvido o estudo para um Plano de Conservação Preventiva para o Pavilhão Arthur Neiva, publicado em 2017 e realizado com o apoio financeiro da Getty Foundation, como parte integrante da iniciativa internacional Keepping it Modern, lançada em 2014, cujo objetivo é apoiar a conservação de edifícios de arquitetura moderna ao redor do mundo. Essa iniciativa busca entender as causas de deterioração para então implementar ações de conservação, por meio de planos de conservação que orientem políticas de manutenção e preservação a longo prazo. Para poderem se tornar efetivos, os planos de conservação devem ser embasados em investigações aprofundadas das condições estruturais do edifício por meio 
de testes e análises de materiais modernos e o desenvolvimento de protocolos de conservação fundamentados em pesquisas (AGUIAR et al., 2017).

Diante disso, observa-se que não bastam ações legais que respaldem a não demolição do bem, ou o restauro sistemático do patrimônio cultural, se estas ações não estivem atreladas às ações de conservação preventiva e manutenção rotineira. Todavia, tais ações devem estar expressas de forma documental e inteligível para os gestores responsáveis pelo patrimônio. Essas ações, portanto, devem estar embasadas em um Plano de Conservação estruturado em uma metodologia sistêmica de cuidados. O Plano de Conservação, por si só, não dá conta da preservação do bem. Ele é, antes, um instrumento fundamental para tal ação, mas há que estar associado a uma gestão efetiva do patrimônio cultural e histórico. 


\subsection{DIRETRIZES PARA ELABORAÇÃO DE UM PLANO DE CONSERVAÇÃO}

Se a partir da década de 1980 as discussões acerca de métodos de preservação de patrimônio ganharam destaque, foi no início da década seguinte que a metodologia desenvolvida pelo arquiteto australiano James Semple Kerr, autor do Plano de Conservação da Opera House de Sydney, passou a ser difundia entre os interessados em conservação do patrimônio.

Kerr já se dedicava a pesquisas acerca do tema desde a década de 1980, quando publicou a $1^{a}$ edição do "The Conservation Plan - A Guide to the Preparation of Conservation Plans for Places of European Cultural Significance", que teve sua $7^{a}$ edição publicada em 2013 (TINOCO, 2013). Este trabalho se tornou um guia para planos de conservação, sendo amplamente utilizado por profissionais e instituições voltadas à preservação do patrimônio histórico de diferentes partes do mundo.

A instituição canadense Heritage Branch e a inglesa Heritage Loterry Fund disponibilizam guias para elaboração de planos de conservação inspirados na metodologia desenvolvida pelo arquiteto australiano James Semple Kerr. Todavia, esses guias apresentam pequenas particularidades para se adaptar às necessidades institucionais e às realidades locais.

Enquanto o Heritage Branch e o Heritage Lottery Fund dividem suas metodologias em quatro etapas distintas, Kerr usa dois estágios: o primeiro para o levantamento das informações e o segundo para o desenvolvimento de políticas de conservação, conforme pode ser observado no Quadro 1. 


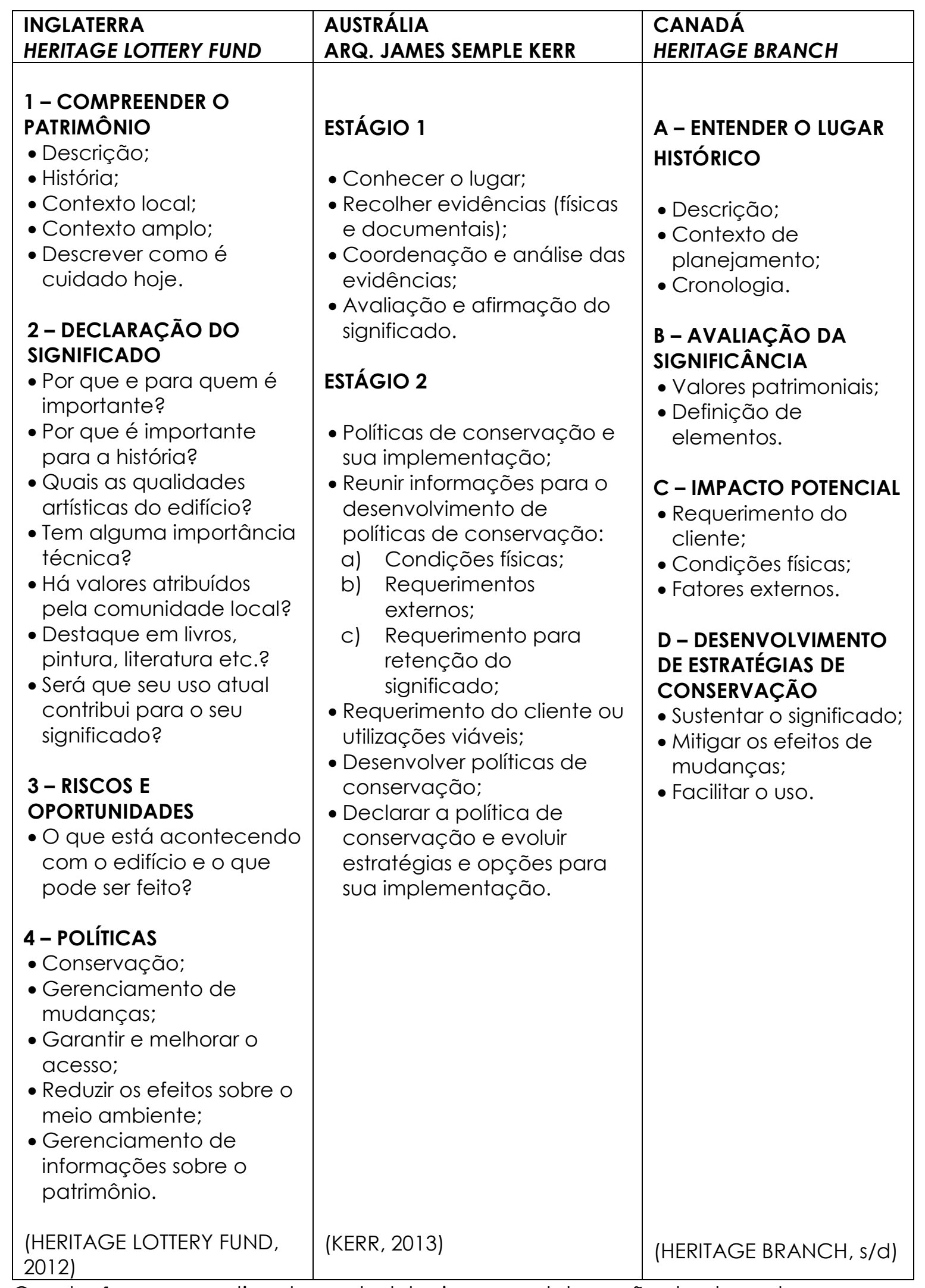

Quadro 1 - comparativo das metodologias para elaboração de plano de conservação

Fonte: elaboração da autora. 
As três metologias têm início pelo conhecimento do local, que nada mais é que a identificação dos atributos e valores imputados ao lugar pela sociedade. No entanto, enquanto o Heritage Branch e o Heritage Lottery Fund postulam a descrição do local e uma contextualização histórica, Kerr aborda esses mesmos dados por um viés mais investigativo ao propor o recolhimento e, posteriormente, o confronto das informações físicas e documentais para a reconstrução da história do local. Pois, para ele, apesar de precisas, muitas vezes as informações documentais são incompletas enquanto registro hitórico, sendo necessário um exame detalhado de sua história interpretado à luz do inventário em desenvolvimento.

O Heritage Lottery Fund aborda um aspecto importante, que é a descrição de como o patrimônio é cuidado no momento, enquanto Kerr aborda apenas a política de gestão para a implementação do Plano de Conservação.

As três metodologias tratam da avaliação, afirmação e declaração de significado, que de acordo com o Heritage Lotttery Fund é a parte mais importante do plano, pois nessa etapa é identificado por que e para quem o patrimônio é importante. São estabelecidos alguns critérios para ajudar a identificar o significado cultural do edifício, como os aspectos estéticos, históricos, científicos e sociais.

A instituição inglesa elenca a importância histórica e a associação com personagens ou eventos importantes; as qualidades artísticas do edifício; a importância técnica; se houve ou não alteração de valores ao longo do tempo e se tem sido destaque em filmes, livros, pinturas ou outro meio de expressão cultural.

O Heritage Branch propõe a compreensão de como o patrimônio é valorizado atualmente, indo além dos valores estéticos e históricos, mas identificando, também, os aspectos culturais e sociais. A identificação dos elementos de caráter definidor, que pode ser para o edifício como um todo ou para uma área específica, deve apresentar descrição detalhada, de modo que a conservação possa ser claramente relacionada aos elementos relevantes. 
E, para Kerr, a avaliação do significado cultural deve ser feita por meio de respostas obtidas a partir de determinados questionamentos: Qual a importância do lugar enquanto evidência? Qual o nível de significância nas ligações associativas com pessoas e eventos ligados ao lugar? Quais são as qualidades formais ou estéticas? Mas, embora a declaração de significância constate, em termos gerais, a natureza e o nível de significado do lugar, a avaliação de elementos individuais fornece a flexibilidade necessária para a gestão de mudanças futuras. Com isso, a hierarquização do nível de significância - como exemplo, excepcional; considerável; de pouco importância; significância potencial - ajudará a identificar o que pode ou não ser modificado.

O item riscos e oportunidades postulado pelo Heritage Lottery Fund diz respeito à vulnerabilidade do patrimônio perante as ameaças potenciais, mas também se refere às oportunidades para melhoria das condições do lugar e benefícios para a sociedade. A abordagem proposta é a de confronto do que precisa ser feito para cuidar e como essas mesmas ações poderiam pô-lo em risco; como exemplo, medidas de segurança que podem influenciar na acessibilidade do patrimônio: se mais acessível pode ficar vulnerável ao vandalismo e se menos acessível pode afastar o público.

E o impacto potencial abordado pelo Heritage Branch vai além dos aspectos físicos da preservação ou restauração, mas deve mitigar eventuais consequências negativas das intervenções no patrimônio.

Para Kerr o segundo estágio é voltado para o desenvolvimento de políticas de conservação e sua implementação. Por meio de requisitos de retenção de significância, requisitos e recursos dos clientes e os usos viáveis, analisados sob um olhar crítico, de modo a não permitir que o valor patrimonial seja posto em risco por solicitações incompatíveis com o significado do lugar. A avaliação da condição física e da integridade do patrimônio pode auxiliar nas decisões sobre a viabilidade, ou não, de conservação. Com base na análise do grau de deterioração do local pode-se determinar se a reconstrução é, ou não, justificada e até que ponto, sempre levando em consideração os requisitos externos que incluem as 
determinações governamentais, pois estas afetam diretamente 0 desenvolvimento das políticas de conservação.

O processo de síntese das informações coletadas inicialmente deve abordar os significados retidos ou revelados, a identificação dos usos viáveis e compatíveis, o atendimento aos requisitos legais, a atenção aos recursos disponíveis e a antecipação de oportunidades e ameaças.

Já no quesito declaração de políticas de conservação, Kerr postula que é um documento flexível que varia de acordo com a situação em determinado local, período e recursos disponíveis, devendo seu conteúdo ser adaptado para atender às circunstâncias apresentadas. A abrangência das políticas de conservação pode ser alcançada por meio de categorizações:

Bases de abordagem - abordagem filosófica para a retenção, o reforço ou a revelação dos valores formais, espaciais, as qualidades significativas e as utilizações viáveis, compatíveis e apropriadas.

Controle de mudança - age sobre o desenvolvimento, orientando as mudanças viáveis e compatíveis com a retenção de significância.

Prestação de serviço e retenção de caráter - aborda as formas menos destrutivas de atualização de subsistemas (elétrico, hidráulico, comunicações etc.), a retenção ou recuperação de significância.

Elementos específicos - aborda o tratamento das partes e/ou dos conteúdos específicos do lugar, como equipamentos, móveis, fachadas e telhados.

Cuidado com a construção - orienta acerca da renovação dos materiais ou a mitigação de sua deterioração, por meio de ações adequadas de manutenção, recuperação, reconstrução, consolidação, remoção de trabalhos ou acréscimos prejudiciais e o início de processos com ações protetivas.

Configuração - políticas que reforcem os aspectos significativos da configuração, incluindo relação entre espaços, paisagens, localização e o 
design de novos elementos, tanto permanentes quanto temporários, além da remoção ou atenuação de elementos visuais e não visuais, como poluição sonora e olfativa.

Gestão - políticas para estrutura de gestão e práticas que promovam a execução eficiente das políticas apresentadas acima, de modo a deixar clara a necessidade de planejamento e gerenciamento por uma única entidade, ou ao menos por uma estrutura coordenada de gestão, com responsabilidades e procedimentos bem definidos; um conselho formado por especialistas; manutenção adequada visando reduzir a deterioração e os riscos com incêndio, vandalismo e roubo; controle de elementos efêmeros, como murais, painéis, obras de arte, exposições etc.; documentação dos elementos que afetaram o lugar e o motivo pelos quais foram realizados, como forma de registro para decisões futuras e revisões periódicas das políticas propostas.

As estratégias estabelecem o modo pelo qual as políticas de conservação devem ser implementadas, abrangendo as opções, a sequência e o tempo das ações propostas. A sequência trata da ordem que deve ser tomada, levando em consideração aspectos técnicos da conservação, bem como o tempo que estabelece quando as ações devem ser realizadas. Essas ações estão, muitas vezes, atreladas à disponibilidade de recursos. A estratégia deve recomendar o fornecimento de um manual de manutenção especificando as rotinas de inspeções e os procedimentos necessários para reparos.

As políticas normalmente são sucintas, definidas e adequadas à adoção formal, enquanto as estratégias são mais detalhadas, como se formassem um guia, especificando como e quando implementar determinadas ações. Uma vez adotadas, as políticas só devem ser alteradas por meio de um processo formal. As estratégias, no entanto, podem ser desenvolvidas para abranger uma variedade de opções e mudanças de circunstâncias, mas, quando necessário, elas podem, posteriormente, ser adaptadas com maior facilidade para atender às circunstâncias imprevistas. A complexidade das estratégias está intrinsecamente relacionada com a complexidade do lugar e de seus componentes. Para maior facilidade de 
entendimento, tanto as políticas quanto as estratégias devem ser redigidas de forma simples e inequívoca.

Os três autores abordam aspectos similares para o levantamento das informações, para a determinação de significado e para os impactos potenciais. Entretanto, no que concerne ao desenvolvimento das políticas de conservação, tanto a instituição canadense quanto a inglesa são mais sucintas e não oferecerem muitos parâmetros para o seu desenvolvimento. Diante disso, este trabalho utilizará a metodologia desenvolvida pelo arquiteto australiano, pois, para dar conta da complexidade inerente às fachadas do Edifício Copan, é necessário o estabelecimento de políticas em bases criteriosas e bem definidas.

A partir da análise da metodologia preconizada por Kerr foi desenvolvida a estrutura para o Plano de Conservação para as fachadas do Copan, conforme apresentado na figura 5.

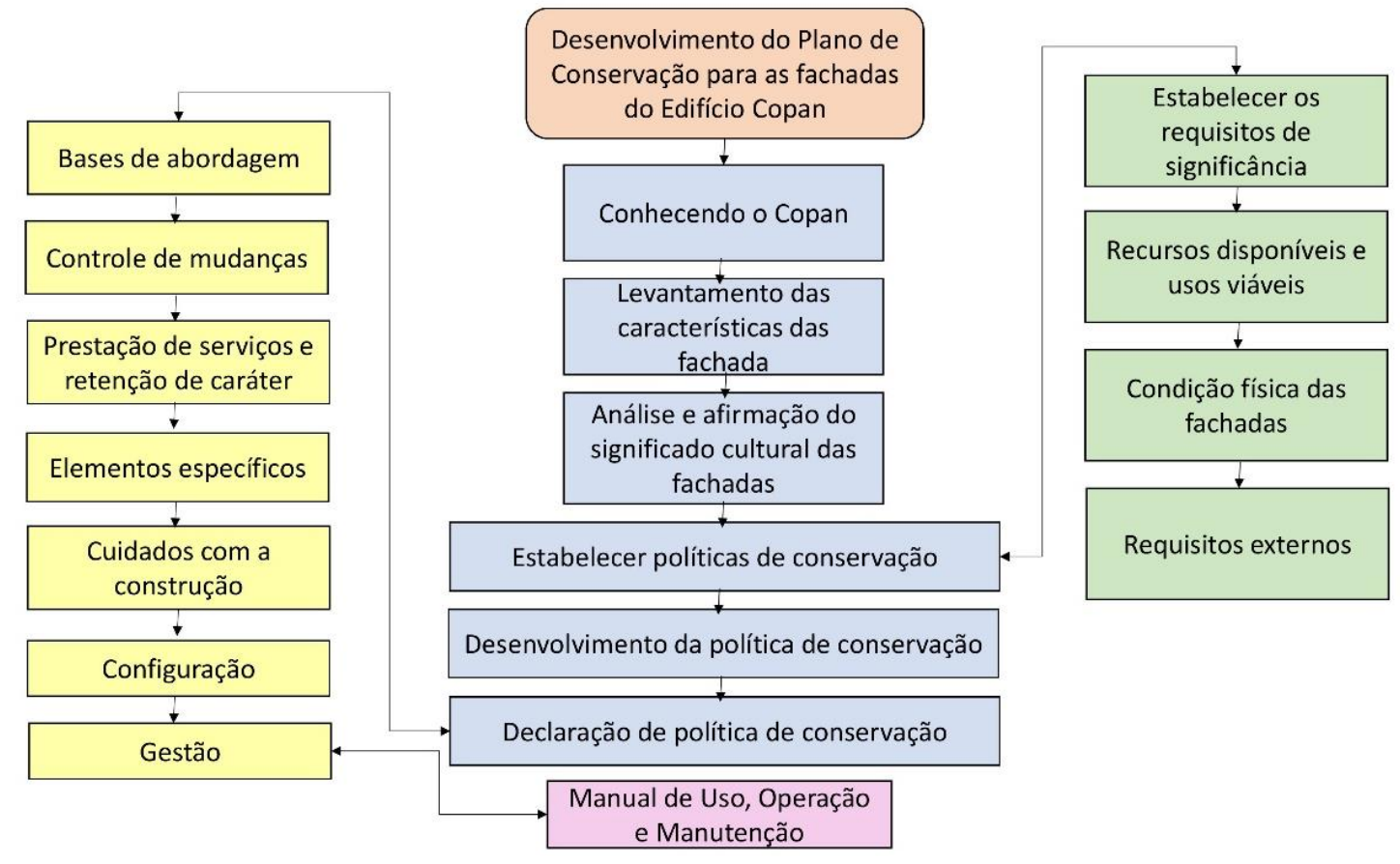

Figura 5 - fluxograma do plano de conservação

Fonte: elaboração da autora.

Conhecendo o Copan- o levantamento histórico permite identificar os valores atribuídos pela sociedade à edificação, o que servirá de 
base para o desenvolvimento de políticas de conservação dos valores culturais.

Levantamento das características das fachadas - por meio da análise de evidências, tanto físicas quanto documentais, é possível reconstruir a história das alterações, dos usos e das transformações pela ação do homem ou por agentes naturais, de modo a ter uma compreensão mais ampla do seu desenvolvimento ao longo dos anos.

Análise dos processos de degradação - permite estabelecer as relações entre os diversos agentes de degradação envolvidos que culminaram no estágio atual, além de mapear o contexto das transformações.

Avaliação e afirmação do significado cultural das fachadas essa etapa consiste em compreender por que as fachadas têm importância para a sociedade, se pelo valor estético, arquitetônico, por ser representativo de um momento de desenvolvimento da sociedade que o construiu, enfim, entender o que é significativo nas fachadas para a sociedade por meio da hierarquização da significância.

Estabelecer políticas de conservação - a partir dos dados coletados anteriormente serão propostas políticas adequadas para 0 desenvolvimento futuro sem prejudicar o seu valor cultural; essa etapa engloba:

a) Estabelecer requisitos de significância - os níveis de importância identificados na etapa de avaliação e afirmação do significado das fachadas permite estabelecer políticas para preservar o que é importante para a manutenção da significância, como, por exemplo, os brises.

b) Recursos disponíveis e usos viáveis - aborda a disponibilidade financeira e as necessidades de alteração, levando-se em conta as solicitações de mudança advindas dos usuários, sob uma ótica crítica e analítica, sem permitir o comprometimento do valor patrimonial; como exemplo disso a Figura 6, em que, ao acrescentar um caixilho para fazer 0 
fechamento acima do cobogó, o usuário em questão comprometeu toda a lógica arquitetônica demarcada pelas linhas vermelhas.

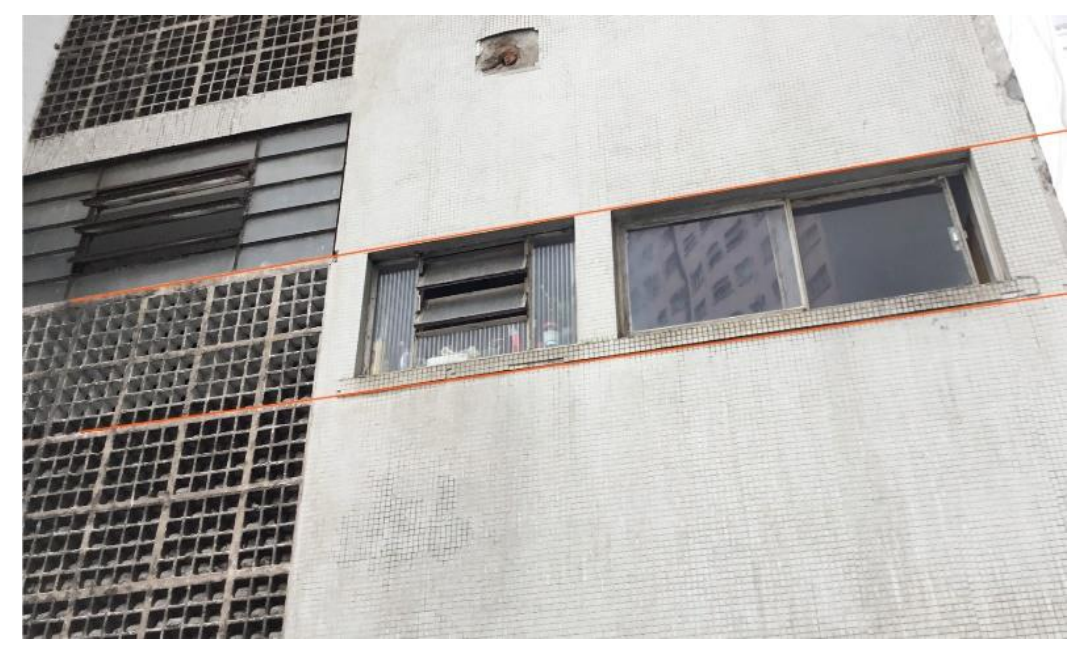

Figura 6- Alteração na fachada

Fonte: Acervo da autora.

c) Condição física das fachadas - por meio da análise do estado atual da estrutura e da integridade das fachadas, será possível avaliar o nível de deterioração e se é justificável, ou não, uma eventual reconstrução, como por exemplo, as alterações nos elementos vazados tipo cobogó da fachada posterior.

d) Requisitos externos - são as determinações governamentais de cunho administrativo e jurídico que incidem sobre as fachadas do Copan, como a resolução de tombamento do CONPRESP.

Desenvolvimento da política de conservação - compreende a sintetização das informações levantadas, abordando os significados, os recursos disponíveis, os usos viáveis, o atendimento aos requisitos externos e a antecipação de eventuais problemas e/ou oportunidades.

Declaração da políitica de conservação - a política de conservação tem um caráter flexível, variando de acordo com as circunstâncias, sendo necessária sua atualização para atender eventuais 
demandas; como exemplo, na ocasião de alteração dos recursos disponíveis, há que se fazer uma revisão de modo a se adequar ao novo panorama. A política de conservação é um conjunto de políticas específicas, abordando diferentes aspectos:

\section{Bases de abordagens - são}

políticas gerais com uma visão para o local sob um viés reflexivo que possibilita reter, reforçar ou revelar elementos significativos e utilizações viáveis.

\section{Controle de mudanças - são} políticas que direcionam 0 desenvolvimento abordando a viabilidade de mudança, suprimindo acréscimos prejudiciais, como o caso do caixilho acima do cobogó, preservando a Figura 7-Alteração na fachada linguagem formal e o valor patrimonial, conforme figura 7 .

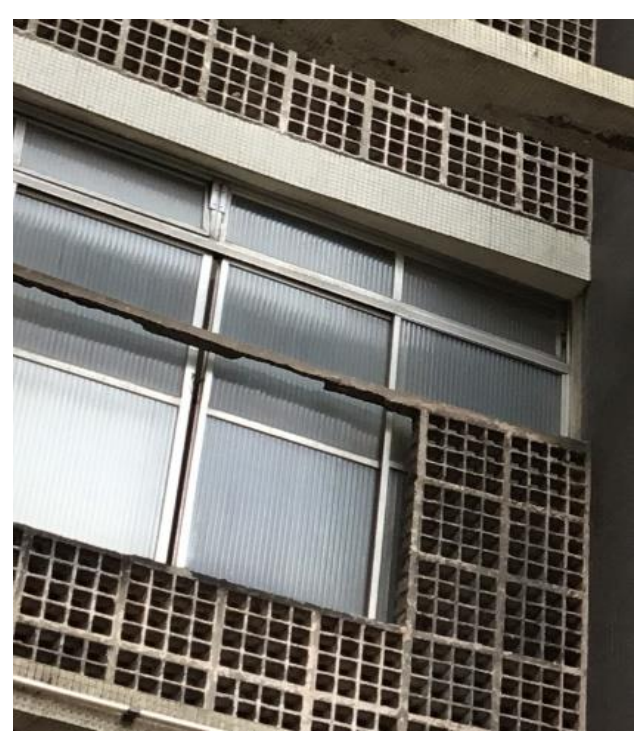

Fonte: Acervo da autora.

Prestação de serviços e retenção de caráter - política que estabelece parâmetros para minimizar eventuais danos causados por mudanças inevitáveis, como a atualização de sistemas elétricos e hidráulicos.

Elementos específicos - são políticas que atuam sobre elementos específicos relacionados com a significância do lugar, como os brises do Copan.

Cuidados com a construção - são políticas que orientam ações de manutenção, reparos, limpeza, substituição ou remoção de elementos, prevenindo o aparecimento de danos.

Configuração - são políticas que reforçam os aspectos significativos da configuração formal, como as relações espaciais e paisagísticas, mitigando elementos intrusivos visuais ou não. 
Gestão - permite a execução de todas as outras políticas e deve expressar a necessidade de planejamento e gerenciamento por uma única entidade, por meio de procedimentos bem definidos elaborados por especialista, documentando os agentes que afetam o lugar, e manutenção preventiva visando à preservação do patrimônio.

\subsection{MANUTENÇÃO COMO ELEMENTO DE PRESERVAÇÃO}

As ações adequadas de manutenção são essenciais para o bom desempenho das edificações, prolongando, assim, sua vida útil. Todavia, no que concerne à complexidade inerente ao patrimônio arquitetônico, tais ações devem ser programadas e executadas de modo a respeitar a historicidade e a significância do bem, a fim de manter não apenas os aspectos físicos e estruturais, mas também as características arquitetônicas e valores culturais que fizeram de tal edifício um bem a ser preservado como um testemunho de uma época passada para as gerações futuras.

Há uma sutileza entre os diferentes conceitos apresentados ao longo do trabalho, cabendo, portanto, uma breve definição, conforme o Quadro 2.

\begin{tabular}{|c|c|}
\hline Conservação & $\begin{array}{l}\text { É o processo de cuidar de um lugar para manter seu significado } \\
\text { cultural podendo implicar, ou não, a preservação, a restauração e a } \\
\text { manutenção (ICOMOS, 2013). }\end{array}$ \\
\hline Preservação & $\begin{array}{l}\text { É a proteção, a manutenção do estado existente retardando a } \\
\text { deterioração (ICOMOS, 2013). }\end{array}$ \\
\hline Desempenho & Comportamento em uso (NBR15575/2013). \\
\hline Durabilidade & $\begin{array}{l}\text { Capacidade da edificação e/ou seus subsistemas em desempenhar } \\
\text { as funções para as quais foi projetada, durante um período de } \\
\text { tempo e em um patamar de desempenho requerido durante sua } \\
\text { vida útil, sob condições de uso específicas, com a realização de } \\
\text { manutenções periódicas visando à recuperação parcial da perda } \\
\text { de desempenho advinda da degradação (NBR15575/2013). }\end{array}$ \\
\hline
\end{tabular}




\begin{tabular}{|c|c|}
\hline Vida útil & $\begin{array}{l}\text { É o período de tempo no qual os edifícios e/ou seus subsistemas se } \\
\text { encontram em condições de atender às funções para as quais } \\
\text { foram projetados, atendendo aos níveis de desempenho previstos } \\
\text { em norma, sempre considerando ações adequadas e rotineiras de } \\
\text { manutenção especificadas no Manual de Uso, Operação e } \\
\text { Manutenção (NBR15575/2013). }\end{array}$ \\
\hline $\begin{array}{l}\text { Vida útil } \\
\text { projeto (VUP) }\end{array}$ & $\begin{array}{l}\text { Designa um período de tempo estimado para o qual um subsistema } \\
\text { é projetado, de modo a atender aos requisitos de desempenho } \\
\text { prescritos em norma, atendendo às especificações do Manual de } \\
\text { Uso, Operação e Manutenção quanto à periodicidade das ações } \\
\text { de manutenção (NBR15575/2013). }\end{array}$ \\
\hline $\begin{array}{l}\text { Manutenção } \\
\text { rotineira }\end{array}$ & $\begin{array}{l}\text { É caracterizada por um fluxo constante de serviços, padronizados e } \\
\text { cíclicos, citando-se, por exemplo, limpeza geral e lavagem de áreas } \\
\text { comuns (NBR 5674/2012). }\end{array}$ \\
\hline $\begin{array}{l}\text { Manutenção } \\
\text { preventiva }\end{array}$ & $\begin{array}{l}\text { Caracterizada por serviços cuja realização seja programada com } \\
\text { antecedência, priorizando as solicitações dos usuários, estimativas } \\
\text { da durabilidade esperada dos sistemas, elementos ou componentes } \\
\text { das edificações em uso, gravidade e urgência, e relatórios de } \\
\text { verificações periódicas sobre o seu estado de degradação (NBR } \\
5674 / 2012 \text { ). }\end{array}$ \\
\hline $\begin{array}{l}\text { Manutenção } \\
\text { corretiva }\end{array}$ & $\begin{array}{l}\text { Caracterizada por serviços que demandam ações ou intervenção } \\
\text { imediata a fim de permitir a continuidade do uso dos sistemas, } \\
\text { elementos ou componentes das edificações, ou evitar graves riscos } \\
\text { ou prejuízos pessoais e/ou patrimoniais aos seus usuários ou } \\
\text { proprietários (NBR 5674/2012). }\end{array}$ \\
\hline
\end{tabular}

Quadro 2 - definições e conceitos

Fonte: elaboração da autora.

Diferentemente de edifícios genéricos, nos quais a garantia do desempenho não precisa, necessariamente, estar atrelada à preservação dos materiais e componentes originais do projeto, o patrimônio arquitetônico requer uma abordagem específica para seus cuidados. Enquanto seus valores 
culturais são assegurados pela conservação, sua materialidade é preservada por meio de cuidados constantes que objetivam reduzir os desgastes e degradações dos elementos originais ao longo dos anos. Pois estes mesmos elementos são testemunhos de uma cultura produtiva e industrial, à qual pertence o edifício histórico. Diante disso, a manutenção se apresenta como parte integrante da preservação do patrimônio.

Para Simonson (1990), a chave para uma preservação bemsucedida é um bom plano de manutenção, pois sem um planejamento a manutenção pode até mesmo ser prejudicial ao realizar reparos indiscriminados, destruindo ou comprometendo a integridade do tecido original, ou, ainda, atuar de forma a "melhorar" o que pode ter sido construído com defeitos ou eliminar todos os sinais de desgaste inerentes às intempéries, tornando o edifício bem conservado, mas apagando assim o caráter testemunhal da historicidade do patrimônio.

A importância da manutenção de edifícios supera o pensamento que limita o processo de construção ao momento em que este entra em uso. Há um valor social intrínseco às edificações devido ao seu caráter enquanto suporte físico para o desenvolvimento das atividades humanas. Os edifícios são construídos para atender seus usuários por muitos anos e, ao longo de sua vida útil, deve apresentar condições satisfatórias de desempenho. Por meio da implantação de um programa de manutenção embasado em abordagens e procedimentos técnicos programados e organizados, é possível salvaguardar tanto a qualidade de vida e a segurança dos usuários, quanto os níveis de desempenho ao longo de sua vida útil e, desse modo, ajudar na preservação material e na conservação dos valores culturais do patrimônio.

Ao longo da vida útil há uma tendência natural de envelhecimento dos materiais e componentes e, com isso, a perda de desempenho de um subsistema e/ou da edificação. Apenas por meio das ações de manutenção é possível retardar a perda e até mesmo recuperar parcialmente o desempenho. 
A Figura 8 mostra as curvas com a perda de desempenho, inerente à degradação, e sua recuperação parcial quando das ações de manutenção desde a entrega, prolongando assim a vida útil da edificação.

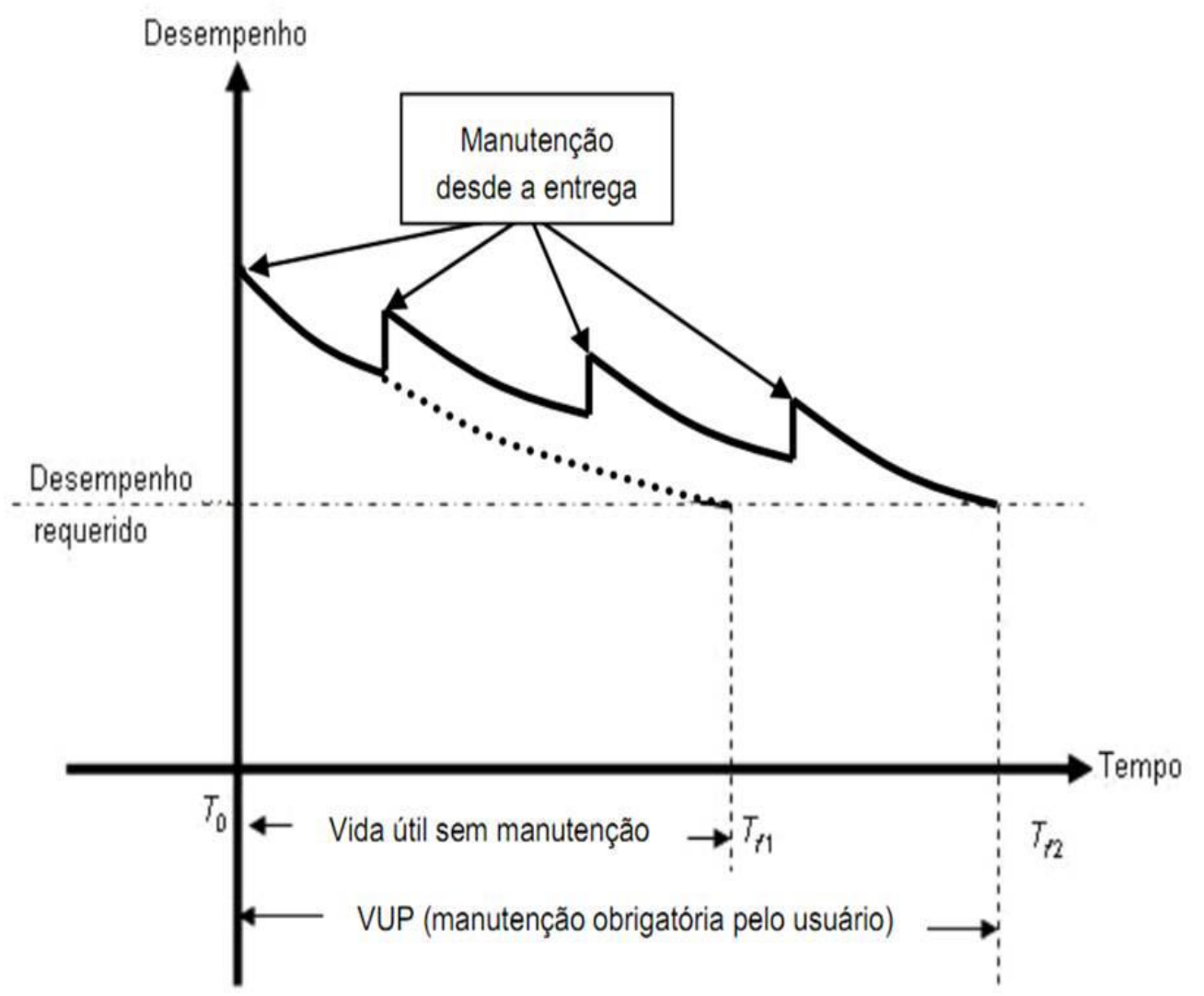

figura 8 - recuperação do desempenho por ações de manutenção

Fonte: ABNT/NBR 15575, 2013.

"[...] é inviável, sob o ponto de vista econômico, e inaceitável, sob o ponto de vista ambiental, considerar as edificações como produtos descartáveis, passiveis da simples substituição por novas construções quando os requisitos de desempenho atingem níveis inferiores àqueles exigidos pela ABNT NBR 15575 (Partes 1 a 6). Isto exige que a manutenção das edificações seja levada em conta tão logo elas sejam colocadas em uso" (ABNT/NBR 5674, 2012).

Em que pese a norma abordar a importância da manutenção preventiva, não deixa de ser curioso o fato de esta vir em seu texto após a manutenção corretiva. Pois, seguindo uma linha lógica e racional de 
planejamento da manutenção, as ações preventivas visam, justamente, mitigar a necessidade de intervenções corretivas.

Ainda que a NBR15575/2013 e a NBR5674/2012 abordem a importância da manutenção logo após a construção, essas recomendações se aplicam, também, para edifícios antigos e fundamentam a sua necessidade logo após um processo de restauro de um patrimônio arquitetônico.

No que concerne à preservação de edifícios históricos, o aspecto mais negligenciado é o da manutenção. Decisões econômicas priorizam ações em curto prazo, ao invés de metas de manutenção de longo prazo, muitas vezes por não identificar os benefícios das ações rotineiras de inspeção e prevenção, que num primeiro momento podem parecer improdutivas. Como essa abordagem promove a deterioração do edifício, fazendo com que este necessite de um reparo dispendioso para recuperar sua aparência histórica, e, desse modo, somente diante da onerosa necessidade de grande intervenção ou restauração, a importância da manutenção preventiva vem à tona (SIMONSON, 1990).

E se para as normas brasileiras a manutenção ajuda a prolongar a vida útil e prevenir a perda de desempenho, para Van Balen (2017) e Pinheiro (2009) as ações preventivas de manutenção ajudam a preservar a autenticidade do patrimônio, na medida em que mitigam a proliferação e o aumento dos danos devido às ações de manutenção e intervenções pontuais, quando necessário. Pois conforme destacam Küppel et al. (2005), a manutenção preventiva em patrimônio cultural diminui a necessidade de grandes ações de restauro, enquanto Van Balen (2015) alerta que, quanto maiores as intervenções, maiores são os riscos de alteração das características do patrimônio. A manutenção preventiva se antecipa, portanto, aos danos inerentes ao desgaste dos materiais causados seja por intempéries ou pela ação do homem, enquanto a manutenção corretiva, mais invasiva, atua de modo a recuperar a integridade física dos materiais e componentes.

Conclui-se que a manutenção é essencial para assegurar o desempenho e prolongar a vida útil dos diferentes tipos de edifícios. E no que 
concerne aos edifícios de valores culturais, arquitetônicos e históricos ela contempla outra importância, que é a da preservação dos materiais e componentes de uma época, que fazem parte da identidade de um bem, cujo valor associado não se restringe aos aspectos financeiros e de sustentabilidade, mas de preservação da história e da cultura de uma época. 


\subsection{A IMPORTÂNCIA DO MANUAL DE USO, OPERAÇÃO E MANUTENÇÃO PARA EDIFICAÇÕES}

A eficácia da manutenção enquanto instrumento de preservação do patrimônio arquitetônico é indissociável de um planejamento sistemático e rigoroso. Nesse contexto se faz necessária uma abordagem fundamentada em procedimentos organizados em um sistema de gestão da manutenção, seguindo uma lógica de controle de qualidade e custo, dentre os quais devem ser levadas em consideração questões como a preservação das características originais da edificação e a prevenção de perda de desempenho. Destaca-se, portanto, a importância da elaboração de Manual de Uso, Operação e Manutenção para a sistematização dos procedimentos, com a descrição das atividades e a periodicidade da realização de cada ação.

O Manual de Uso, Operação e Manutenção se mostra com importância fundamental ao contribuir para a redução dos custos pósocupação, pois fornece as informações necessárias acerca do uso e das ações periódicas de manutenção, objetivando o bom desempenho da edificação ao longo de sua vida útil, sem os altos custos inerentes às ações de manutenção corretiva. O manual, portanto, destaca-se como um elemento de ligação entre as fases do processo produtivo dos edifícios, definindo as responsabilidades dos usuários, dos gestores e dos construtores (SANTOS, 2003).

A obrigatoriedade da entrega do Manual de Uso, Operação e Manutenção por parte dos construtores só entrou em vigor após a vigência do Código de Defesa do Consumidor em 1990 (SANTOS, 2003). Vieira (2015) destaca que mesmo as edificações mais antigas, anteriores à NBR 5674/2012, devem desenvolver seus programas de manutenção objetivando a preservação de suas características originais, mesmo perante as necessidades de reformas ou desejo de modernização de usuários em busca de inovações tecnológicas.

Para Michelin (2005), a finalidade do Manual de Uso, Operação e Manutenção pode ser entendida como a melhora do desempenho da 
edificação e, para tal, este deve conter um roteiro para as inspeções regulares a serem realizadas no edifício, objetivando a antecipação das ações de manutenção antes do surgimento de possíveis problemas.

Simonson (1990) aborda a questão usando o termo "plano de manutenção" e postula que um plano efetivo de manutenção tem que contemplar um sistema de inspeção, horários de trabalho, documentação da construção, relatórios, suporte de referência dos materiais, sistema de contabilidade de custos e um programa de treinamento para os profissionais envolvidos, além de incluir meios de avaliar as atividades de manutenção para identificar pontos fortes e fracos, de modo a promover ajustes no plano quando necessário.

O Manual de Uso, Operação e Manutenção destaca-se, portanto, como um instrumento de extrema relevância, ao fornecer aos responsáveis informações necessárias para preservar o desempenho estabelecido em projeto ao longo da vida útil da edificação, permitindo que esta atenda às funções para as quais foi projetada, de modo a garantir os requisitos dos usuários e a preservação de suas características originais. Todavia, no que concerne à questão de patrimônio arquitetônico essa importância ganha ênfase, pois os bens tombados têm sua necessidade de manutenção potencializada, tanto pela degradação ou fim da vida útil de subsistemas, devido à idade da edificação, como pelos valores histórico e arquitetônico significativos que, justamente, levaram à proteção da obra por órgãos de patrimônio. Nesse contexto, no âmbito da preservação do patrimônio o Manual de Uso, Operação e Manutenção deve estar associado a um Plano de Conservação, cujas ações de manutenção preconizadas no documento devem levar em consideração as características dos sistemas e dos materiais que compõem o edifício enquanto patrimônio a ser preservado. 


\subsection{DIRETRIZES PARA ELABORAÇÃO DO MANUAL DE USO, OPERAÇÃO E MANUTENÇÃO}

As fachadas noroeste e sudoeste do Edifício Copan estão em processo de reconstrução, que conforme a definição da Carta de Burra (ICOMOS, 2013) é a ação que busca voltar o edifício a um estágio anterior conhecido, mas com o acréscimo de novos elementos. Houve a remoção total dos acabamentos decorativos (pastilhas) e foi necessária a reconstrução parcial do revestimento de argamassa, sobre o qual será colocado novo acabamento decorativo, delimitados por panos de assentamento com frisos e juntas de movimentação seladas, que não existiam originalmente. Diante desta intervenção e da necessidade em assegurar o desempenho do subsistema e vida útil dos materiais e componentes, é importante que seja elaborado um Manual de Uso, Operação e Manutenção para as referidas fachadas, com um roteiro de ações de manutenção e periodicidade bem definidos, mitigando a degradação natural e a consequente necessidade de grandes e onerosas intervenções de restauro e eventuais riscos de perda das características arquitetônicas.

A NBR14037/2014 estabelece os requisitos mínimos para a elaboração dos conteúdos a serem apresentados no Manual de Uso, Operação e Manutenção da edificação. Nele devem constar as características técnicas da edificação, os procedimentos recomendáveis e obrigatórios para preservação, uso e manutenção, assim com as condições de utilização, a fim de prevenir eventuais danos causados por usos inadequados. O manual deve ter linguagem simples e ser apresentado de forma didática organizada, com nível de detalhamento compatível com a complexidade da edificação. Deve abordar alguns pontos específicos como: memorial descritivo; relação dos fornecedores; operação e limpeza; programa de manutenção preventiva; registros de manutenção; inspeções; documentação técnica e atualização do manual quando da realização de toda e qualquer alteração.

Simonson (1990) destaca a importância da manutenção para edifícios históricos, aspecto que muitas vezes é negligenciado e que só vem à 
tona quando da necessidade de restauro. A autora enfatiza a necessidade de um plano de manutenção preventiva sistematizado em ações bem definidas de inspeção, manutenção preventiva, manutenção corretiva, registros das ações realizadas e relatórios para a documentação do que foi realizado na edificação, formando um histórico das ações. O sucesso de um plano de manutenção requer informações completas sobre o edifício, seu sistema construtivo, seus subsistemas, materiais e componentes, bem como os seus processos de deterioração, permitindo a identificação do problema, estabelecendo suas causas e prescrevendo os tratamentos adequados.

As premissas postuladas pela NBR14037/2014 são similares às expostas por Simonson (1990), mas enquanto a primeira foi desenvolvida para edifícios novos, mas que serve como referência para edifícios antigos, a segunda trata o tema sob $\circ$ viés do edifícios históricos, apontanto a importância da manutenção para a preservação do patrimônio arquitetônico.

A estrutura do Manual de Uso, Operação e Manutenção das fachadas sudoeste e noroeste do Edifício Copan foi desenvolvida a partir das diretrizes normativas da NBR1 4037/2014 e da NBR5674/2012, como também de guias desenvolvidos pela Câmara Brasileira da Indústria da Construção (CBIC) e pelo Sindicato da Indústria da Construção Civil (SINDUSCON), de Novo Hamburgo, sob a luz da problemática do patrimônio arquitetônico.

O Manual de Uso, Operação e Manutenção para as fachadas sudoeste e noroeste do Edifício Copan foi estruturado da seguinte forma:

\begin{tabular}{|l|l|}
\hline Introdução & $\begin{array}{l}\text { São abordadas as orientações para a utilização do manual e os } \\
\text { procedimentos para a realização das inspeções, das ações de } \\
\text { manutenção e dos registros das referidas ações por meio de fichas } \\
\text { de manutenção e inspeção, tratando de como essas devem ser } \\
\text { arquivadas para formação de registro de fácil rastreabilidade das } \\
\text { ações executadas, além das definições dos termos utilizados no } \\
\text { documento. }\end{array}$ \\
\hline
\end{tabular}




\begin{tabular}{|c|c|}
\hline $\begin{array}{l}\text { Memorial } \\
\text { descritivo }\end{array}$ & $\begin{array}{l}\text { Uma breve descrição do edifício e suas características } \\
\text { arquitetônicas, ilustrado com peças gráficas para facilitar a } \\
\text { compreesão de sua geometria pelos agentes envolvidos nas } \\
\text { ações de manutenção preventiva descritas no manual. }\end{array}$ \\
\hline $\begin{array}{l}\text { Caracterização } \\
\text { do subsistema } \\
\text { de } \\
\text { revestimento } \\
\text { externo }\end{array}$ & $\begin{array}{l}\text { Descrição do subsitema de revestimento externo, dos materiais e } \\
\text { componentes originais e dos utilizados na obra de recuperação } \\
\text { do subsistema. }\end{array}$ \\
\hline $\begin{array}{l}\text { Programa de } \\
\text { manutenção } \\
\text { preventiva }\end{array}$ & $\begin{array}{l}\text { Apresenta um roteiro de ações de manutenção preventiva, com } \\
\text { a sistematização dos procedimentos de inspeção, manutenção, } \\
\text { a elaboração dos relatórios das ações realizadas e a } \\
\text { documentação por meio de registro das fichas utilizadas no } \\
\text { processo de manutenção. }\end{array}$ \\
\hline Fichas & $\begin{array}{l}\text { Modelo das fichas de inspeção, manutenção e relatórios } \\
\text { específicos para cada fachada. }\end{array}$ \\
\hline $\begin{array}{l}\text { Relação dos } \\
\text { fornecedores e } \\
\text { projetistas }\end{array}$ & $\begin{array}{l}\text { Apresenta os contatos dos fornecedores e projetistas dos materiais } \\
\text { e componentes especificados no projeto de revestimento de } \\
\text { fachada. }\end{array}$ \\
\hline Referências & $\begin{array}{l}\text { Aponta as referências normativas e bibliográficas utilizadas no } \\
\text { documento. }\end{array}$ \\
\hline $\begin{array}{l}\text { Atualização e } \\
\text { revisões do } \\
\text { manual }\end{array}$ & $\begin{array}{l}\text { Expõe a ficha de registro das atualizaçõe e revisões com a } \\
\text { identificação dos responsáveis por tais ações. }\end{array}$ \\
\hline
\end{tabular}

Quadro 3 - estrutura do manual de uso, operação e manutenção

fonte: elaboração da autora.

O programa de manutenção está estruturado no roteiro de ações de manutenção, que contém o desempenho e a vida útil de projeto 
(VUP) requeridos em norma, com as especificações de atividades, descrevendo alguns processos de deterioração que podem ocorrer antes das ações de manutenção, ou as condições aceitáveis que devem ser mantidas. Está organizado a partir de check-list apontando a periodicidade e as atividades a serem realizadas nos elementos e componentes, a fim de assegurar o desempenho do subsistema de revestimento externo.

A manutenção preventiva tem início a partir das ações de inspeção, indicadas no roteiro de ações de manutenção, que visa avaliar as condições e identificar os problemas, sendo necessário entender a natureza dos elementos e componentes do subsistema, bem como seu processo de deterioração, para identificar as causas e, então, propor um tratamento adequado.

O relatório gerado a partir da inspeção descreve as condições físicas dos materiais a partir das verificações in loco, os métodos utilizados para o levantamento das informações, as datas e os responsáveis pelas ações, e aponta a necessidade ou não de investigação mais aprofundada das causas de alguns sintomas para a proposição de ações de manutenção corretiva. Esses relatórios servem não apenas para ações imediatas, mas funcionam como um registro do desempenho do subsistema ao longo de determinado período.

A documentação por meio das fichas e relatórios das ações de inspeção e manutenção realizadas permite identificar e mapear as atividades e os agentes envolvidos ao longo dos anos. A lista com a relação dos projetistas e fornecedores de materiais possibilita um contato ágil com os envolvidos.

Diante disso, o Manual de Uso, Operação e Manutenção se apresenta não apenas com um caráter prescritivo, apontando a periodicidade e os procedimentos, mas, também, como um banco de dados sobre o subsistema que se retroalimenta a cada ação realizada. Forma, assim, um registro técnico que poderá ser consultado para a tomada de decisões futuras. 


\section{CAPÍTULO 3 - OBJETO DE ESTUDO: EDIFÍCIO COPAN}

\subsection{CONTEXTUALIZAÇÃO HISTÓRICA}

O icônico Edifício Copan é um símbolo de São Paulo, sendo frequentemente apresentado na mídia como marco arquitetônico da cidade. Sua grandiosidade reflete o pensamento de uma época de crescimento e expansão tanto populacional quanto econômica, o que gerou a necessidade de novos materiais e técnicas construtivas para atender às demandas de uma cidade ávida por desenvolvimento. Sua história nos mostra as transformações formais durante a concepção projetual e a programática durante a construção. Acompanhando o ritmo frenético da cidade e alinhado com as premissas de revitalização do centro de São Paulo, vêm sofrendo transformações físicas e sociais ao longo do tempo. Diante disso, faz-se necessária uma breve contextualização histórica sobre o edifício.

O déficit habitacional, que remontava ao início do século XIX, e o interesse da iniciativa privada em produzir habitação a preço de custo, coligados à expansão econômica advinda dos acordos do pós-guerra entre as nações aliadas, produziram um boom imobiliário em São Paulo no início da década de 1950 (SAMPAIO, 2002), alinhado com o cenário internacional. Nesse panorama promissor, Octavio Orozimbo Roxo Loureiro, fundador de um banco especializado em negócios imobiliários e investimentos - o Banco Nacional Imobiliário (BNI) -, surge com a ideia de lançar um grande complexo hoteleiro em comemoração ao IV Centenário da Cidade de São Paulo. Ao grande hotel estaria acoplado um conjunto de instalações de interesse turístico (LEMOS, 2014). O BNI, em parceria com a rede hoteleira norteamericana Intercontinental Hotels Corporation, interessada em participar do incremento turístico do pós-guerra tanto no Rio de Janeiro quanto em São Paulo, constituíram a Companhia Pan-América - Hotéis e Turismo - COPAN. Inspirados em experiências norte-americanas, visavam ao desenvolvimento turístico da cidade (LEAL, 2003). O estudo arquitetônico inicial para o complexo foi realizado pela Holabird, Root and Burgee, uma firma especializada em projetos hoteleiros de alta categoria, com o programa distribuído em volumes prismáticos, dispostos em forma de zigue-zague, 
acompanhando a irregularidade do terreno. Essa versão inicial foi publicada em 21 de setembro de 1951 no jornal Folha da Manhã. Após duas semanas, o mesmo jornal publica outra reportagem trazendo uma fotomontagem da maquete, já inserida no contexto urbano de sua implantação. O autor do novo projeto, o arquiteto Oscar Niemeyer, apresentou ao prefeito Armando Arruda Pereira, juntamente com os técnicos norte-americanos do projeto inicial, o novo projeto, cuja geometria sinuosa lhe é característica, para discutir as implicações que o projeto teria na capital.

O projeto do complexo hoteleiro idealizado por Niemeyer para o empreendimento da Companhia Pan-América - Hotéis e Turismo - COPAN, formada a partir da parceria entre o BNI e a Internacional Hotel Corporation, subsidiária da Pan-American Airways, apresenta dois blocos distintos. O edifício destinado aos apartamentos residenciais, em forma de $S$, e, no alinhamento da Avenida Ipiranga e o edifício, edifício de planta retangular, destinado ao hotel, cujo desenvolvimento do projeto continuaria sob responsabilidade dos norte-americanos, especialistas no assunto. Todavia, no projeto de prefeitura consta como autor do projeto o arquiteto Henrique E. Mindlin.

O arquiteto Oscar Niemeyer tinha escritório no Rio de Janeiro e notório medo de aviões, o que dificultava suas vindas a São Paulo. Com a necessidade de agilizar os processos relativos aos projetos em andamento na capital paulista, em 1951 Niemeyer abre um escritório satélite na cidade de São Paulo, capitaneado pelo arquiteto Carlos Lemos, que assina os projetos de prefeitura por meio de procuração. Mais tarde, com o avançar das obras da construção de Brasília, Niemeyer encarregou Lemos de dar andamento ao projeto do Copan.

A construção teve início em 1952, mas devido a questões políticas e econômicas as obras passaram por períodos de paralização, tendo sido concluídas apenas em 1971, após modificações significativas do projeto original. Muitas mudanças ocorreram nesse ínterim: a rede hoteleira norteamericana já havia deixado a parceria e sucessivas construtoras haviam assumido a obra do Copan desde então. Em 1957 o Banco Bradesco comprou a Companhia Nacional de Indústria e Construção (CNI), empresa que havia 
atuado no início da construção e, depois disso, esse banco privado conclui a obra da Avenida Ipiranga em 1971-1972 (LEMOS, 2014).

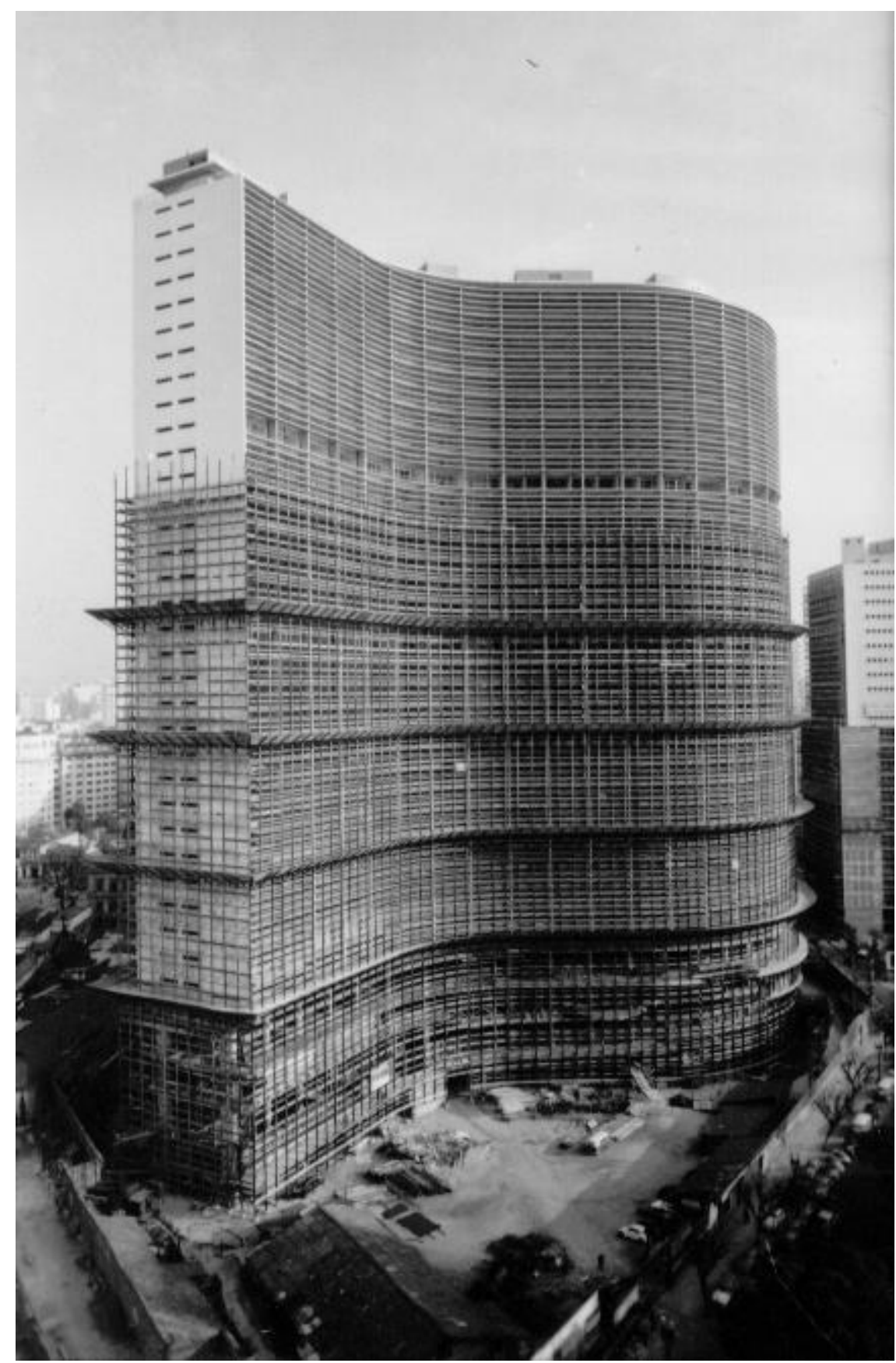

Figura 9 - Fase final da construção do Copan

Fonte: Acervo do Condomínio Copan.

O edifício destinado ao hotel também nunca foi concluído; em seu lugar foi construída uma agência bancária projetada por Carlos Lemos, 
que após muitas conversas conseguiu dissuadir o banqueiro da ideia de um edifício neoclássico para manter a volumetria proposta inicialmente por Niemeyer (LEAL, 2003).

Se durante as décadas de 1940 e 1950 a situação econômica teve reflexos positivos no mercado imobiliário paulista, nas décadas seguintes a região central da cidade de São Paulo viveu de fato um processo de degradação, em parte causado pela diminuição dos investimentos no local. Durante os anos 1970 e 1980 o processo de deterioração da região levou à decadência dos edifícios, tendo alguns sido abandonados e outros transformados em cortiços. Somente a partir de 1990, com o incentivo da prefeitura e a criação de programas de revitalização do centro paulistano é que esse cenário começou a ser alterado (GALVÃO, 2007). E o reflexo do que acontecia na região central de São Paulo também foi sentido naquele que havia sido projetado para ser o Rockefeller Center da cidade.

A questão da decadência do Copan na década de 1980 e início da década 1990 é frequentemente encontrada na mídia impressa. Reportagens da época relatam o drama de moradores ao ficarem vários dias sem água por conta de uma bomba quebrada e 15 dias sem o fornecimento de energia por causa de curto-circuito. A falta de manutenção ao longo dos anos era motivo de preocupação não só dos moradores, mas de empresas concessionárias, como a Eletropaulo. E quando as pessoas do entorno viam fumaça na cobertura do Copan, advinda da queima de lixo pelo incinerador, era motivo de temor. Além dos problemas relacionados às instalações, de ausência de manutenção, o edifício era conhecido, também, por abrigar traficantes de prostitutas, o que comprometia sua imagem.

Mas a partir de 1993, quando o atual síndico - Sr. Affonso Celso Prazeres de Oliveira - assume a administração do condomínio, observa-se uma preocupação em resgatar o Copan de outrora. Para atender às exigências do Corpo de Bombeiros uma série de reformas foram feitas, para a criação de rotas de fuga e troca de extintores e hidrantes. Para-raios foram instalados, as instalações elétricas foram substituídas, assim como as bombas hidráulicas e os elevadores. O incinerador de lixo foi desativado e o reservatório de 
combustível no subsolo foi extinto, entre tantas outras obras que vêm sendo realizadas até os dias de hoje.

No que concerne à manutenção das fachadas, o síndico concedeu à autora uma entrevista - com termo de consentimento assinado (em anexo) -, realizada nas dependências do condomínio no dia 9 de fevereiro de 2018 e fez um relato das ações efetuadas.

Ações de recolocação e substituição pontual das pastilhas ocorreram no início da década de 1990, que teve início com a aquisição do estoque remanescente das pastilhas produzidas para o edifício. Segundo o síndico do Copan: "Entre 1994 e 1995 [...] foram comprados dois caminhões de pastilhas brancas, por volta de $2.000 \mathrm{~m}^{2}$ e aproximadamente $200 \mathrm{~m}^{2}$ de pastilhas cinza. As pastilhas brancas foram utilizadas para reparos no acesso da garagem [...] houve o descolamento maciço da área, quando estávamos trabalhando, colocando uma antena de celular para ter sinal da galeria e, quando começamos a trabalhar para fazer a fixação, essa massa de pastilhas veio abaixo. Ela não estava estufada, por incrível que pareça, não apresentava nada, mas só o fato de usar a furadeira com martelete, aquilo começou a despencar [...] e a substituição parcial dos brises [...] uma faixa de 20 a $25 \mathrm{~cm}$, que era a parte mais deteriorada, que é o que sofria mais ação do tempo e sofre ainda hoje [...] não foi possível fazer todos os andares, pois não havia pastilhas suficientes [...]. Em relação às pastilhas cinza [...] pouco ou quase nada foi feito. Foram recuperadas algumas áreas, especialmente as áreas do terraço [...] nós tivemos que impermeabilizar o piso do terraço, nós fizemos a amarração junto à grade até o corpo do prédio, mais ou menos 20 cm. A marca está lá ainda hoje [...]".

Suas enormes fachadas são revestidas na maior parte por pastilhas de porcelana nas cores branca e cinza, incluindo parcialmente os marcantes brises, que possuem revestimento cerâmico na face superior e pintura branca na superfície inferior. Com o passar dos anos elas começaram a desplacar e cair nas calçadas, pondo em risco os pedestres que por ali transitavam. De acordo com relatos de moradores, era muito comum as pastilhas começarem a cair quando chovia ou ventava (CARDILLI, 2009), e em 
2009 um pedaço maior que se desprendeu causou a morte de um cachorro. A partir desse acontecimento foi necessária a colocação de uma rede de proteção em volta do edifício e de bandejas na fachada frontal, para evitar que o material que estava se soltando caísse nos transeuntes. Depois disso, uma série de providências começou a ser tomada com o objetivo de restaurar as fachadas do edifício.

Em 2012 a Resolução no 33/92 do Conselho Municipal de Preservação do Patrimônio Histórico, Cultural e Ambiental da Cidade de São Paulo (CONPRESP), considerando os valores históricos, arquitetônicos, urbanísticos e paisagísticos formados por um conjunto de edifícios, entre eles $O$ Copan, tomba suas fachadas e áreas comuns.

Em 2014 uma empresa especializada é contratada para fazer um levantamento das condições físicas das fachadas do edifício, por meio de uma série de ensaios técnicos que serão abordados mais adiante.

Em 2015 uma empresa especializada em projeto de revestimento de fachada é contratada para desenvolver um projeto para as fachadas do Copan.

Em 2016 tem início a obra de remoção das partes soltas (pastilhas e camada de emboço) das fachadas sudoeste e noroeste. E no final de 2016 as obras foram paralisadas.

Atualmente as fachadas sudoeste e noroeste, que tiveram seu revestimento de argamassa reconstruído, estão ainda sem o acabamento decorativo (as pastilhas), pois ainda não há um consenso entre o condomínio e o órgão de preservação do patrimônio. 


\subsection{O COPAN COMO PATRIMÔNIO}

O Edifício Copan foi tombado pelo CONPRESP - Conselho Municipal de Preservação do Patrimônio Histórico, Cultural e Ambiental da Cidade de São Paulo por meio da Resolução n 19 de 2012. Nesta resolução foi tombado um conjunto de seis edifícios de arquitetura modernista da chamada "mancha de São Paulo moderna", pela relevância de seus valores históricos, arquitetônicos e paisagísticos, são eles: 1- Copan; 2- Prédio dos Gabinetes dos desembargadores do Direito Público, Tribunal de Justiça de São Paulo - Antigo São Paulo Hilton Hotel; 3- Banco Brasileiro de Descontos Bradesco; Jaçatuba; 4- Jaçatuba; 5- Bratke, Gilbratar e Major e 6- Renata Sampaio Ferreira, conforme figura 10.

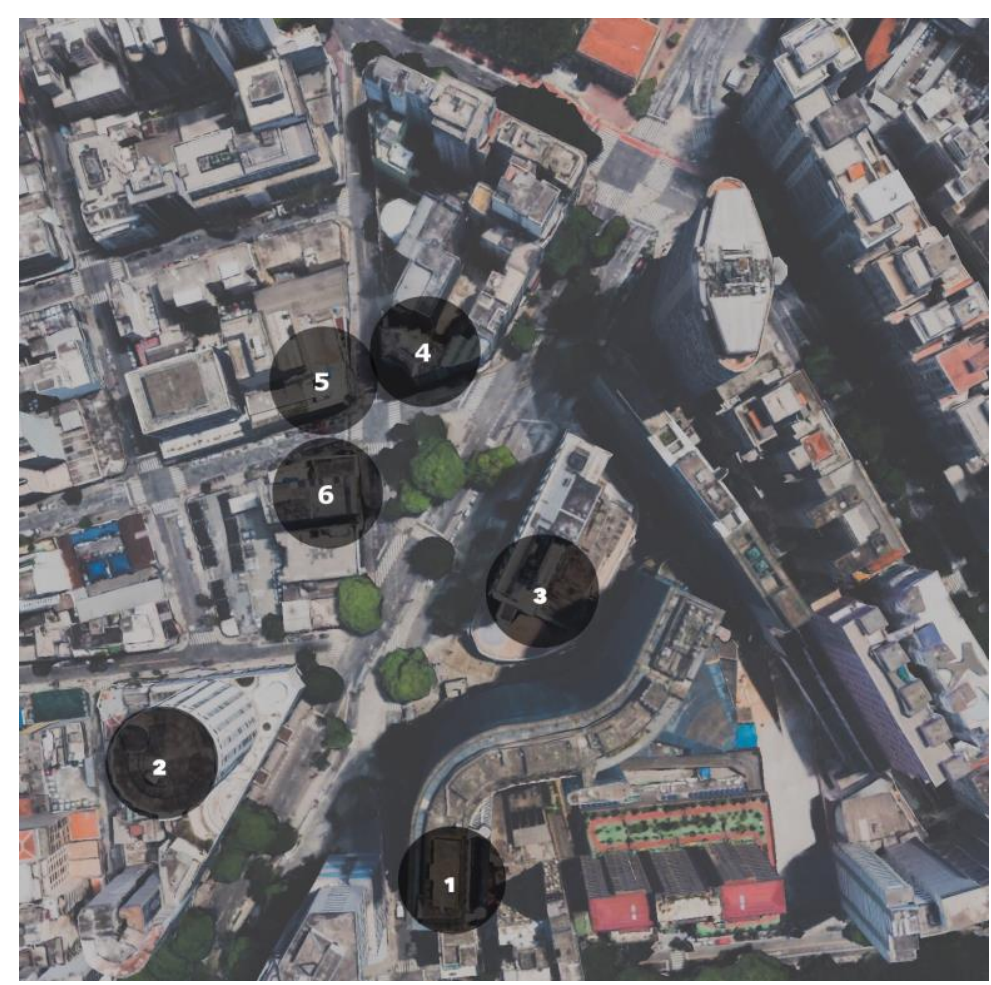

Figura 10 - Localização dos edifícios tombados

Fonte: Google Eath adaptado pela autora.

O documento apresenta em seu texto as seguintes observações: "CONSIDERANDO que estes edifícios participam da listagem do 
Anexo I da Resolução n44/92 de Abertura do Processo de Tombamento dos imóveis enquadrados na Zona de Uso Z8.200;

CONSIDERANDO, ainda, a unidade histórica, arquitetônica e paisagística, configurada pelo conjunto urbano formado pelos edifícios; e

CONSIDERANDO que é atribuição do CONPRESP a definição da área de entorno dos bens tombados, a ser controlado por sistemas de ordenações espaciais adequadas, incluindo o estabelecimento e a divulgação dos critérios para análise e aprovação de intervenções físicas nessas áreas; e

CONSIDERANDO o contido no Processo Administrativo $n^{\circ} 2012-$ $0.051 .849-3$

RESOLVE:

Artigo $1^{\circ}$-TOMBAR o seguinte conjunto de Edifícios Modernos:

1) EDIFÍCIO COPAN

\section{$[\ldots]$}

Artigo $2^{\circ}-$ Nos edifícios tombados, relacionados no Artigo $1^{\circ}$, ficam preservados os seguintes elementos que constituem sua arquitetura:

a) Características arquitetônicas externas.

b) Ambientes e elementos internos que constituem as áreas comuns. [...]" (SÃO PAULO, 2013).

Portanto, de acordo com a referida resolução, o Edifício Copan, inserido em um conjunto arquitetônico, passa a ter suas fachadas e áreas comuns preservadas pelo órgão de proteção patrimonial municipal, o que corrobora a importância deste trabalho ao propor um Manual de Uso, Operação e Manutenção como parte integrante de um Plano de Conservação para suas icônicas fachadas. 


\subsection{PROJETO ORIGINAL}

O projeto de Oscar Niemeyer, com a colaboração de Carlos Lemos, gerou mais de mil pranchas. O síndico do condomínio, Sr. Affonso Celso Prazeres de Oliveira, recebeu em 2002 as pranchas originais que pertenciam ao Banco Bradesco, responsável pelo término das obras do Edifício Copan. Devido à sua importância histórica e necessidade de cuidados especiais, o conjunto que compõe o projeto original foi doado à FAU-USP no ano de 2003 (GALVÃO, 2008). Atualmente 1.206 pranchas encontram-se digitalizadas. Entre os desenhos estão os projetos de arquitetura, os projetos para aprovação na Prefeitura do Município de São Paulo, projeto de estrutura, projeto de instalações elétricas, instalações hidráulicas, além de peças gráficas complementares utilizadas na ocasião da promoção das vendas das unidades. Mas, apesar do grande número de pranchas, há indícios de que havia outras que não chegaram até os nossos dias.

O projeto de prefeitura apresenta quatro modificações, totalizando 48 pranchas, que foram analisadas e confrontadas com o projeto de estrutura e com o que se encontra in loco. O Quadro 4 mostra as datas de protocolo e de aprovação dos projetos, seus respectivos processos e alvarás e relação de folhas em cada um deles. 


\begin{tabular}{|c|c|c|c|}
\hline PROJETO DE MAIO 1952 & PROJETO DE 1952-1953 & PROJETO DE 1958-1961 & PROJETO DE 1966-1972 \\
\hline Processo 81482/51 & $\begin{array}{l}\text { Processo 181.056/52 } \\
\text { Alvará 63.864/53 } \\
\text { Aprovação:03/02/1953 }\end{array}$ & $\begin{array}{l}\text { Substituição de } \\
\text { plantas do processo } \\
181.056 / 52 \\
\text { Alvará } 173.932 \\
\text { Aprovação: } \\
06 / 09 / 1961\end{array}$ & $\begin{array}{l}\text { Substituição de } \\
\text { plantas processo } \\
216.039 / 58 \\
\text { Alvará 173.932 } \\
\text { Aprovação: } \\
\text { 16/08/1972 }\end{array}$ \\
\hline $\begin{array}{l}\text { Folha } 1 \text { - } 2^{\circ} \text { Subsolo } \\
\text { Folha } 2 \text { - } 1^{\circ} \text { Subsolo } \\
\text { Folha } 3 \text { - Térreo } \\
\text { Folha } 4 \text { - } 1^{\circ} \text { Sobreloja } \\
\text { - Girau } \\
\text { Folha } 5 \text { - Sobreloja } \\
\text { Folha } 6 \text { - Andares } \\
\text { normais } \\
\text { Folha } 7 \text { - Corte } \\
\text { Folha } 8 \text { - Fachada e } \\
\text { Corte } \\
\text { Folha } 9 \text { - Fachada } \\
\text { Folha } 10 \text { - Situação }\end{array}$ & $\begin{array}{l}\text { Folha } 1 \text { - Situação } \\
\text { Folha } 2 \text { - } 1^{\circ} \text { Subsolo } \\
\text { Folha } 3 \text { - 2 Subsolo } \\
\text { Folha } 4 \text { - Térreo } \\
\text { Folha } 5 \text { - Sobreloja } \\
\text { Folha } 6 \text { - Foyer } \\
\text { Folha } 7 \text { - Terraço } \\
\text { Folha } 8 \text { - Andar tipo } \\
\text { Folha } 9 \text { - Cobertura } \\
\text { Folha } 10 \text { - Corte } \\
\text { transversal } \\
\text { Folha } 11 \text { - Corte } \\
\text { longitudinal } \\
\text { Folha } 12 \text { - Fachada }\end{array}$ & $\begin{array}{l}\text { Folha } 1 \text { - Situação } \\
\text { Folha } 2 \text { - } 1^{\circ} \text { Subsolo } \\
\text { Folha } 3 \text { - } 2 \text { } \text { Subsolo } \\
\text { Folha } 4 \text { - Térreo } \\
\text { Folha } 5 \text { - Sobreloja } \\
\text { Folha } 6 \text { - Foyer } \\
\text { Folha } 7 \text { - Terraço } \\
\text { Folha } 8 \text { - Andar tipo } \\
\text { Folha } 9 \text { - Cobertura } \\
\text { Folha } 10 \text { - Corte } \\
\text { transversal } \\
\text { Folha } 11 \text { - Corte } \\
\text { longitudinal } \\
\text { Folha } 12 \text { - Fachada }\end{array}$ & $\begin{array}{l}\text { Folha } 1 \text { - Situação } \\
\text { Folha } 2 \text { - } 1^{\circ} \text { Subsolo } \\
\text { Folha } 3 \text { - } 2^{\circ} \text { Subsolo } \\
\text { Folha } 4 \text { - Térreo } \\
\text { Folha } 5 \text { - Foyer } \\
\text { Folha } 6 \text { - Terraço } \\
\text { Folha } 7 \text { - Cobertura } \\
\text { do Terraço } \\
\text { Folha } 8 \text { - Corte } \\
\text { transversal } \\
\text { Folha } 9 \text { - Corte } \\
\text { longitudinal } \\
\text { Folha } 10 \text { - Fachada } \\
\text { Folha } 11 \text { - Sobre Loja } \\
\text { Folha } 12 \text { - Andar tipo } \\
\text { do } 1^{a} \text { ao } 12^{\circ} \\
\text { Folha } 13 \text { - Andar tipo } \\
\text { do } 13^{\circ} \text { ao } 32^{\circ} \\
\text { Folha } 14 \text { - Cobertura }\end{array}$ \\
\hline
\end{tabular}

Quadro 4 - Relação de Folhas do Projeto Legal

Fonte: Elaboração da autora.

O primeiro processo, de número 81.482, protocolado em 5 de maio de 1952, no qual constam o projeto do hotel, de autoria do arquiteto Henrique Mindlin, e o projeto do edifício de apartamentos residenciais de Niemeyer, as pranchas de prefeitura referentes ao hotel apresentam carimbo de aprovação com data de 24 de julho de 1953. No carimbo dos desenhos dos apartamentos residenciais Oscar Niemeyer aparece como autor do projeto, mas este foi assinado por procuração pelo engenheiro João Domingos de Toledo Piza. 
Esse imponente conjunto arquitetônico, apresentado à prefeitura, foi chamado pela imprensa da época de "maciço turístico", uma espécie de Rockefeller Center de São Paulo. Ele seria implantado em um terreno de 10.572,80 $\mathrm{m}^{2}$, na Avenida Ipiranga com a Rua Araújo, composto por dois blocos independentes, sendo um deles um hotel, com:

- 1 boate; 1 restaurante; 2 subsolos com 500 vagas de garagem; térreo com 84 lojas; girau com 84 lojas, sobreloja com 11 lojas, piscina e, do $1^{\circ}$ ao $30^{\circ}$ pavimento, 1.560 apartamentos.

O outro bloco era destinado a um edifício de apartamentos residenciais, com:

- 2 subsolos com garagens; teatro para 500 pessoas; cinema para 3.500 lugares; térreo com 84 lojas; terraço jardim; restaurante e 960 apartamentos distribuídos ao longo de 30 andares, totalizando $107 \mathrm{~m}$ de altura, $8 \mathrm{~m}$ mais baixo que o máximo permitido pelo Decreto-Lei 41/40.

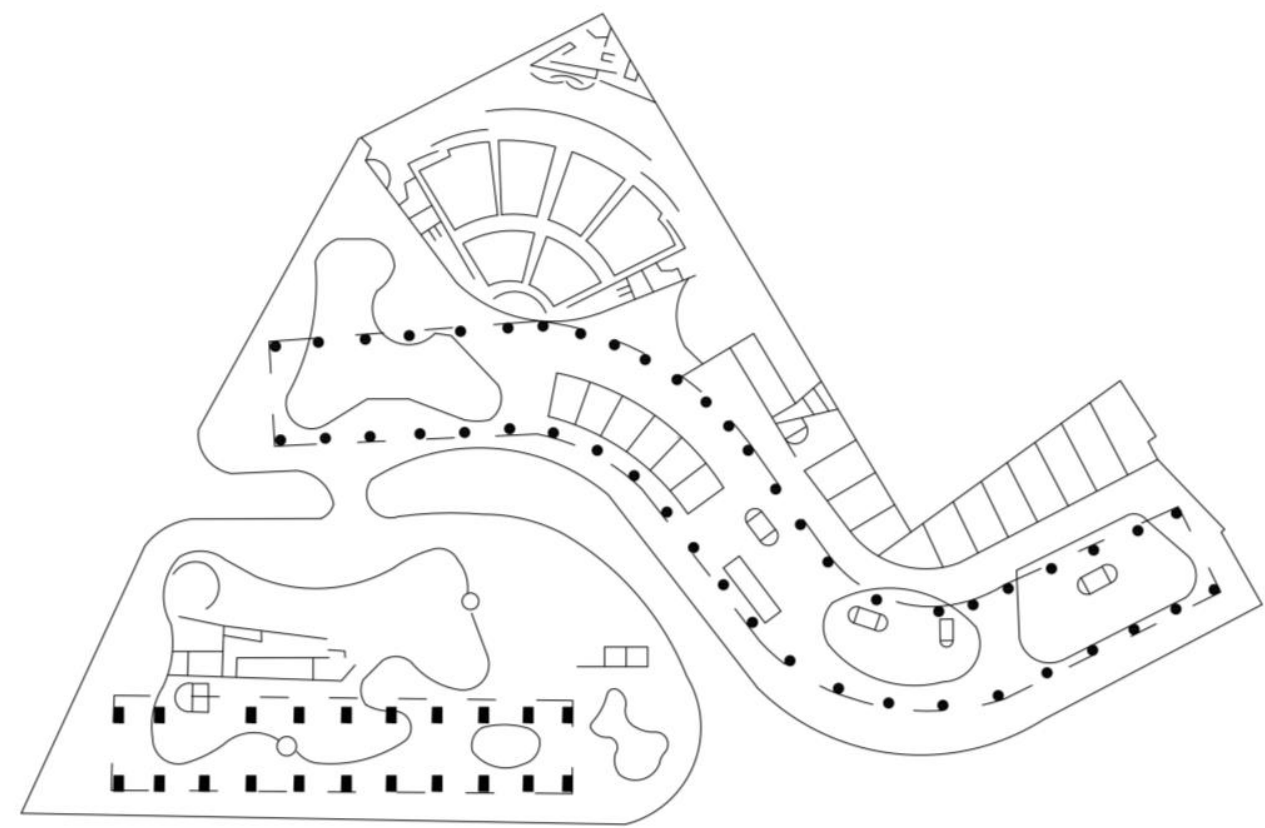

Figura 11 - Planta do térreo com Hotel e Edifício Residencial

Fonte: Acervo da Prefeitura de São Paulo (1952) redesenhado por Daniella Freitas do Valle. 
Nesse projeto também constam as fachadas do hotel (figural2), a rampa de acesso ao terraço sem os pilares (figura 13) e a fachada do Copan ainda sem os brises (figura 14).

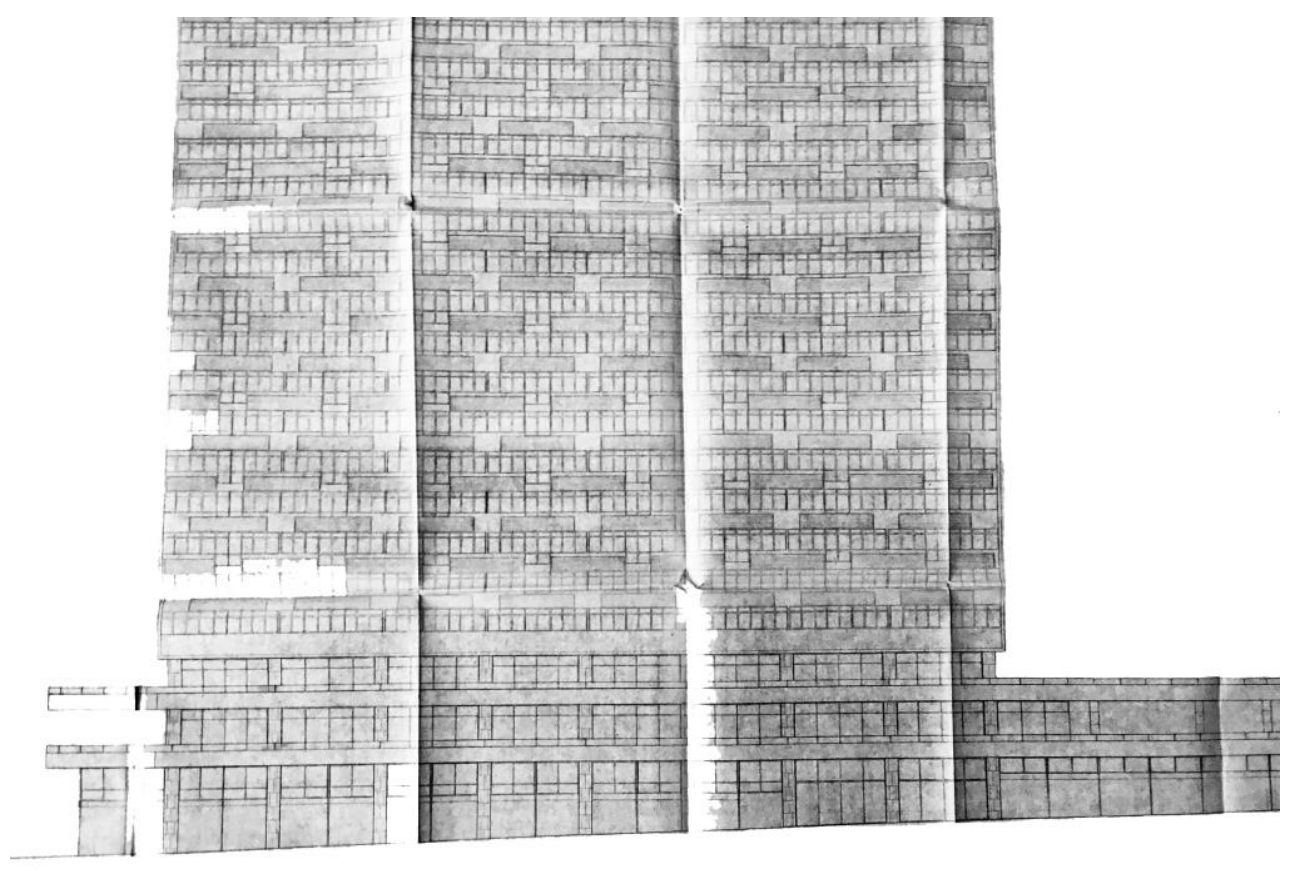

Figura 12 - Fachada Principal do Hotel

Fonte: Acervo da Prefeitura de São Paulo.

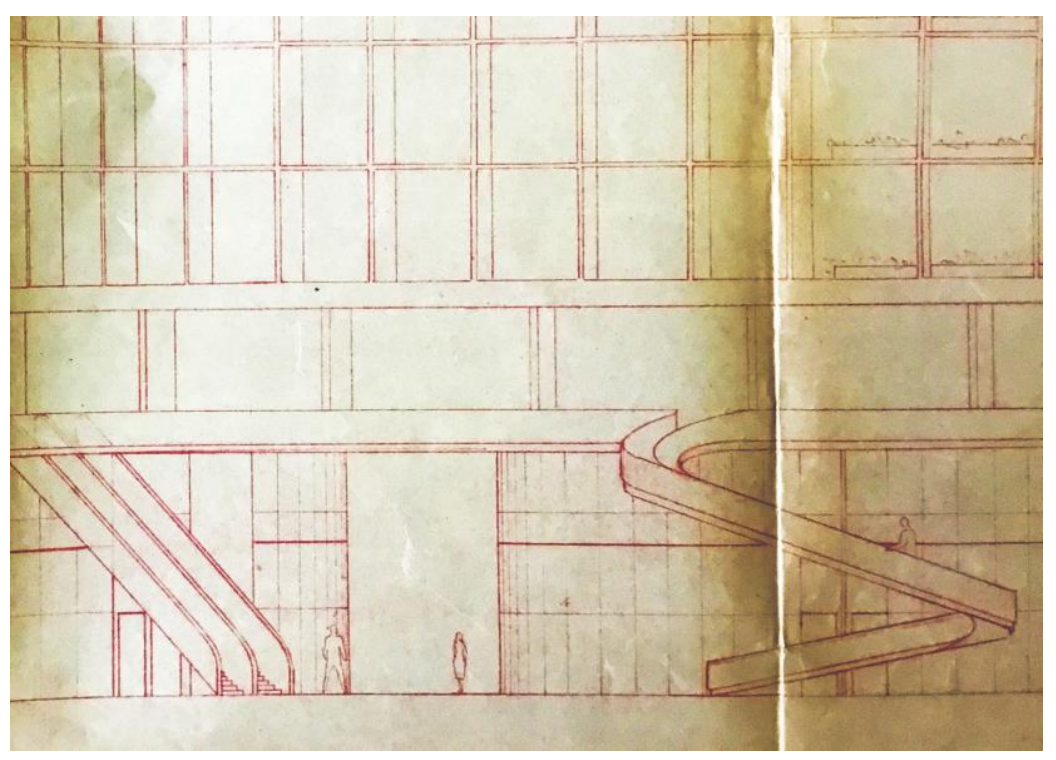

Figura 13 - Vista Parcial da Fachada Frontal com a Rampa sem os pilares

Fonte: Acervo da Prefeitura de São Paulo. 


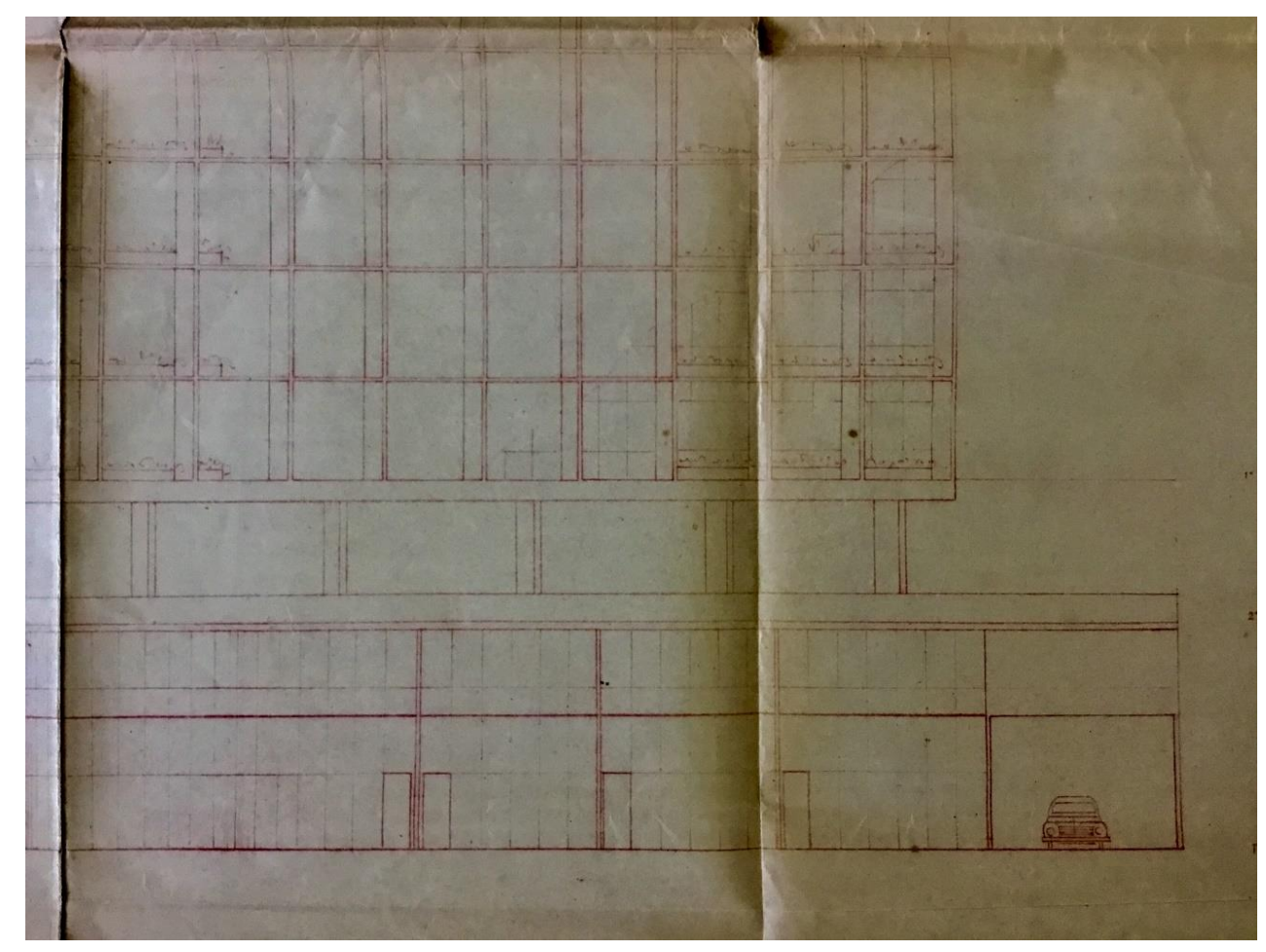

Figura 14 - Vista Parcial da Fachada Frontal sem os brises

Fonte: Acervo da Prefeitura de São Paulo.

No segundo processo, de número 181.056, protocolado em 19 de dezembro de 1952 e aprovado em 3 de fevereiro de 1953, o projeto apresenta apenas o edifício de apartamentos residenciais e a indicação do terreno pertencente ao hotel. De acordo com um despacho, a separação em novo processo ocorreu devido a um empecilho causado por ação judicial de despejo contra uma garagem, que ocupava o terreno do hotel. O mesmo despacho diz ser conveniente a separação dos projetos, uma vez que, de acordo com a legislação vigente, o hotel estaria isento do pagamento de emolumentos.

Talvez essa separação em processos diferentes tenha sido realizada para facilitar o atendimento das exigências legais da prefeitura, hipótese levantada a partir da análise de um despacho que consta do projeto anterior e que faz uma série de exigências ao bloco de apartamentos, enquanto a única ressalva em relação ao hotel era o recuo frontal. 
Nessa fase o projeto contemplava um terraço jardim acessado por meio de uma rampa helicoidal e escadas rolantes, de onde se acessaria, por meio de outra rampa, o foyer do cinema, mas nada disso foi executado. De acordo com Lemos (2014), Niemeyer não havia previsto qualquer tipo de pilar para sustentar a rampa e, quando o engenheiro Oswaldo de Moura Abreu indagou se os pilares ficariam situados por dentro ou por fora da rampa, causou verdadeiro furor no escritório. Carlos Lemos foi até o Rio de Janeiro conversar com o calculista de Niemeyer, Joaquim Cardoso, que havia feito uma rampa parecida em uma residência projetada pelo arquiteto. Todavia, a resposta do engenheiro foi de que a rampa idealizada por Niemeyer para o Copan, sem os pilares, era inexequível, pois tinha duas voltas e meia subindo mais de 8 metros. E, apesar de no projeto de maio de 1952 não constar os pilares, o que se observa no projeto de prefeitura de novembro de 1952 é a demarcação de dois pilares na rampa (figuras 15 e 16), confrontando as informações de que o arquiteto não os havia previsto em seu projeto.

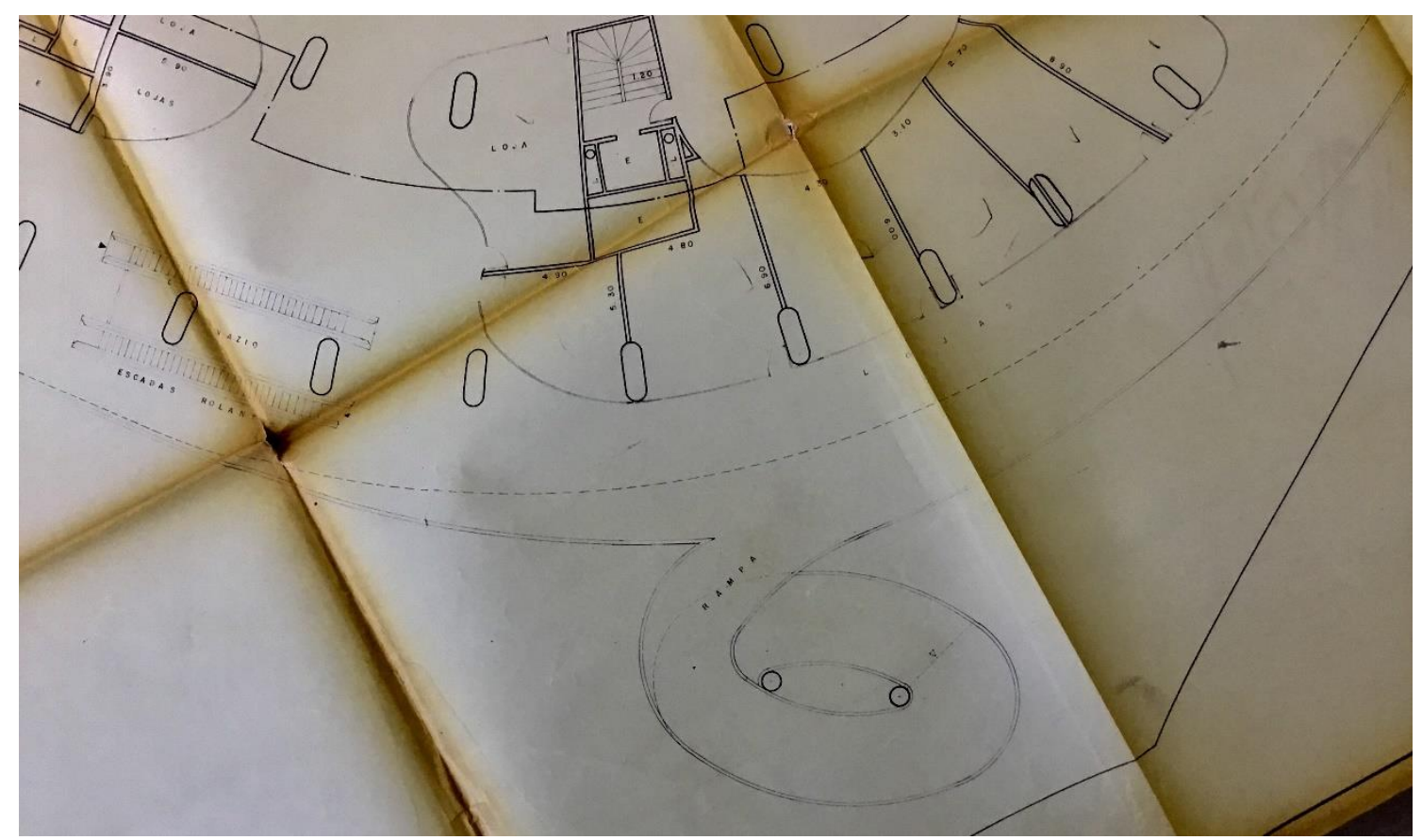

Figura 15- Detalhe da planta do térreo do projeto de 1952 com a rampa helicoidal Fonte: Acervo do Arquivo Municipal. 


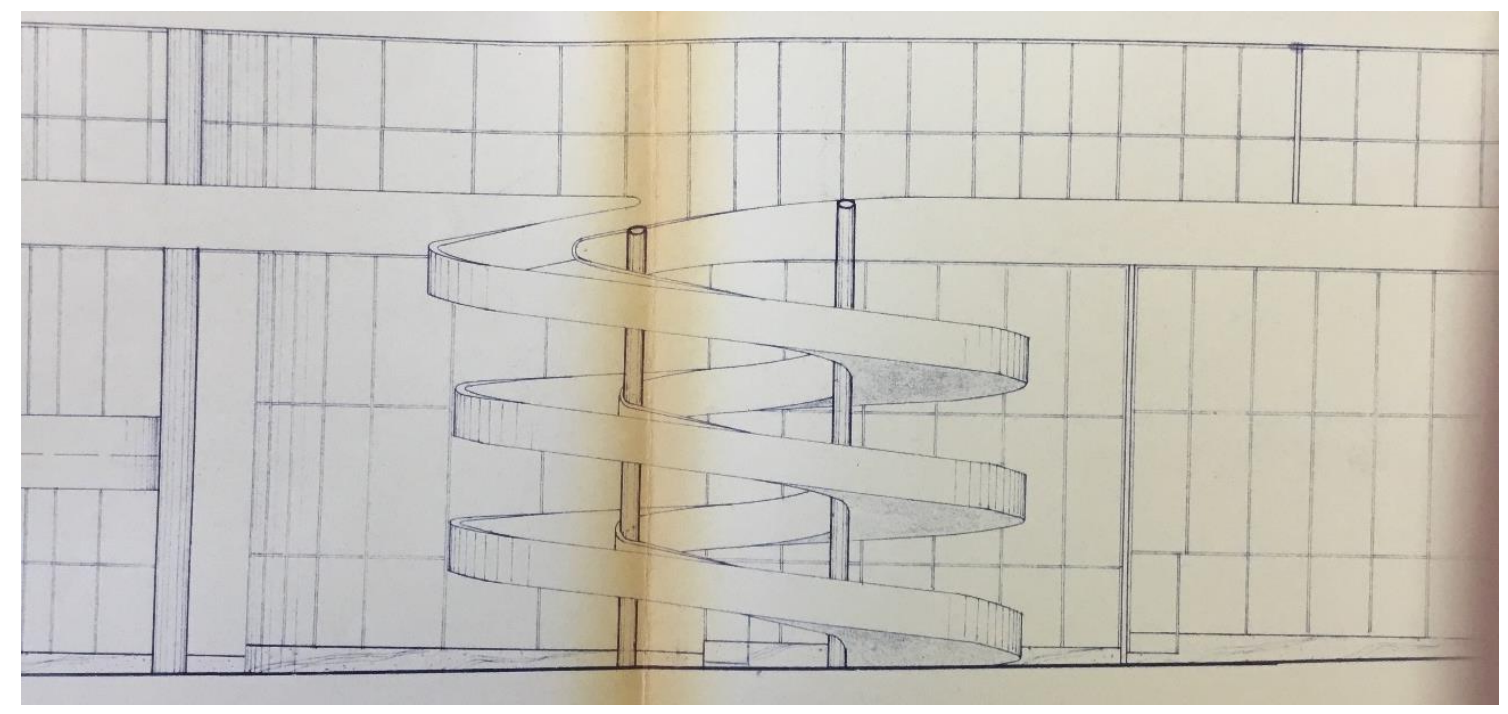

Figura 16 - Detalhe da fachada do projeto de 1952 com a rampa helicoidal Fonte: Acervo do Arquivo Municipal.

O terraço contemplaria um restaurante, lojas, piso com junta de grama, bilheteria e rampas de acesso ao foyer do cinema. Na Figura 17 é possível observar o restaurante com seu formato circular e um trecho do cinema. No corte (figura 18) é possível ver o teatro no $2^{\circ}$ subsolo, o cinema logo acima e a forma do teto que conversa com o teto do salão de festas do hotel (figura 19).

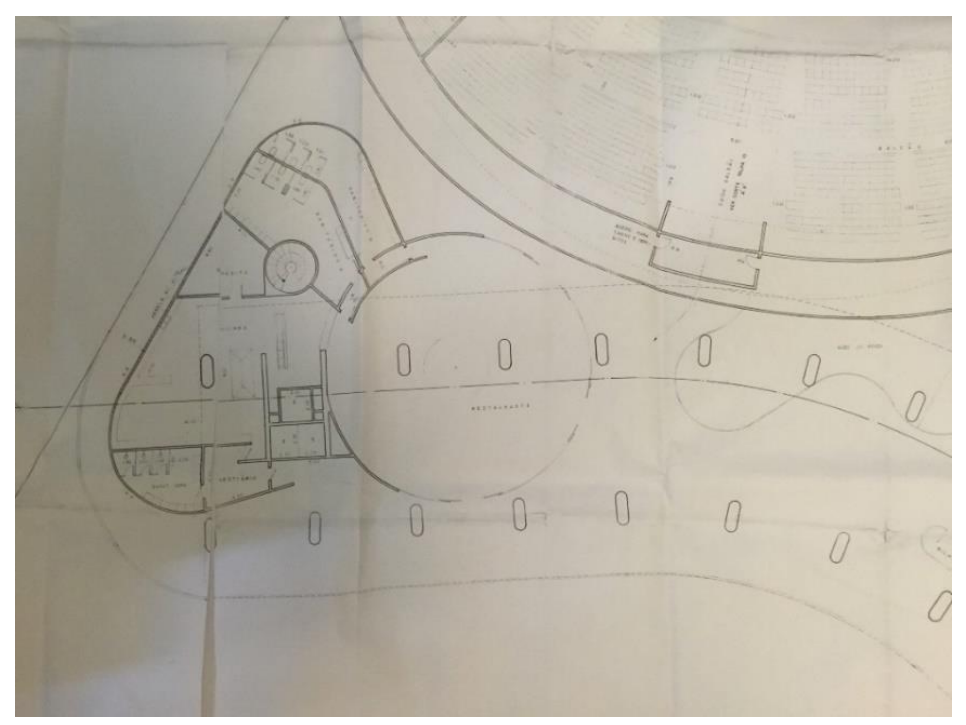

Figura 17 - Detalhe da planta do terraço com o restaurante e o cinema Fonte: Acervo do Arquivo Municipal. 


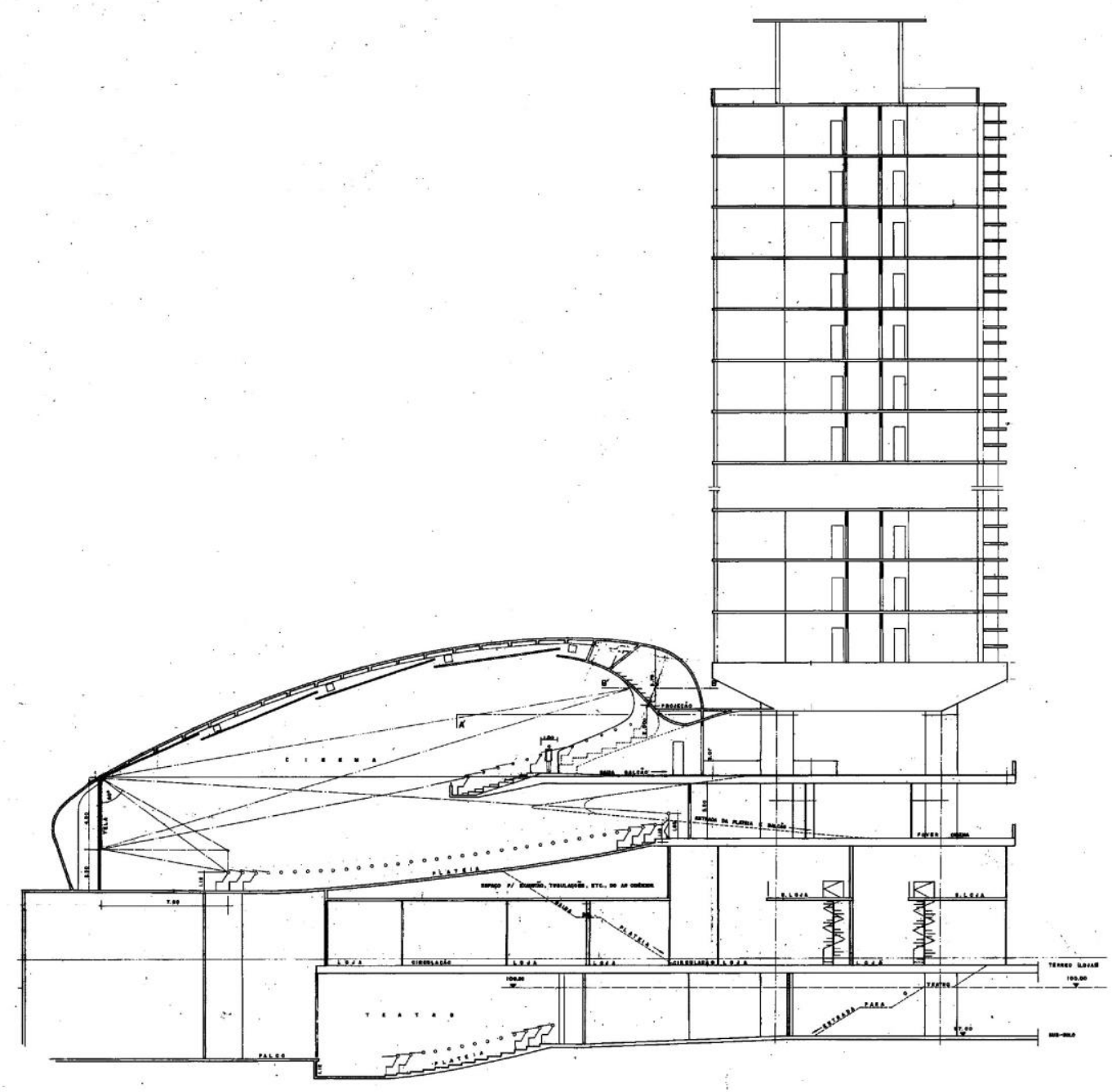

Figura 18 - Detalhe do corte transversal do Copan

Fonte: Acervo do Arquivo Municipal. 


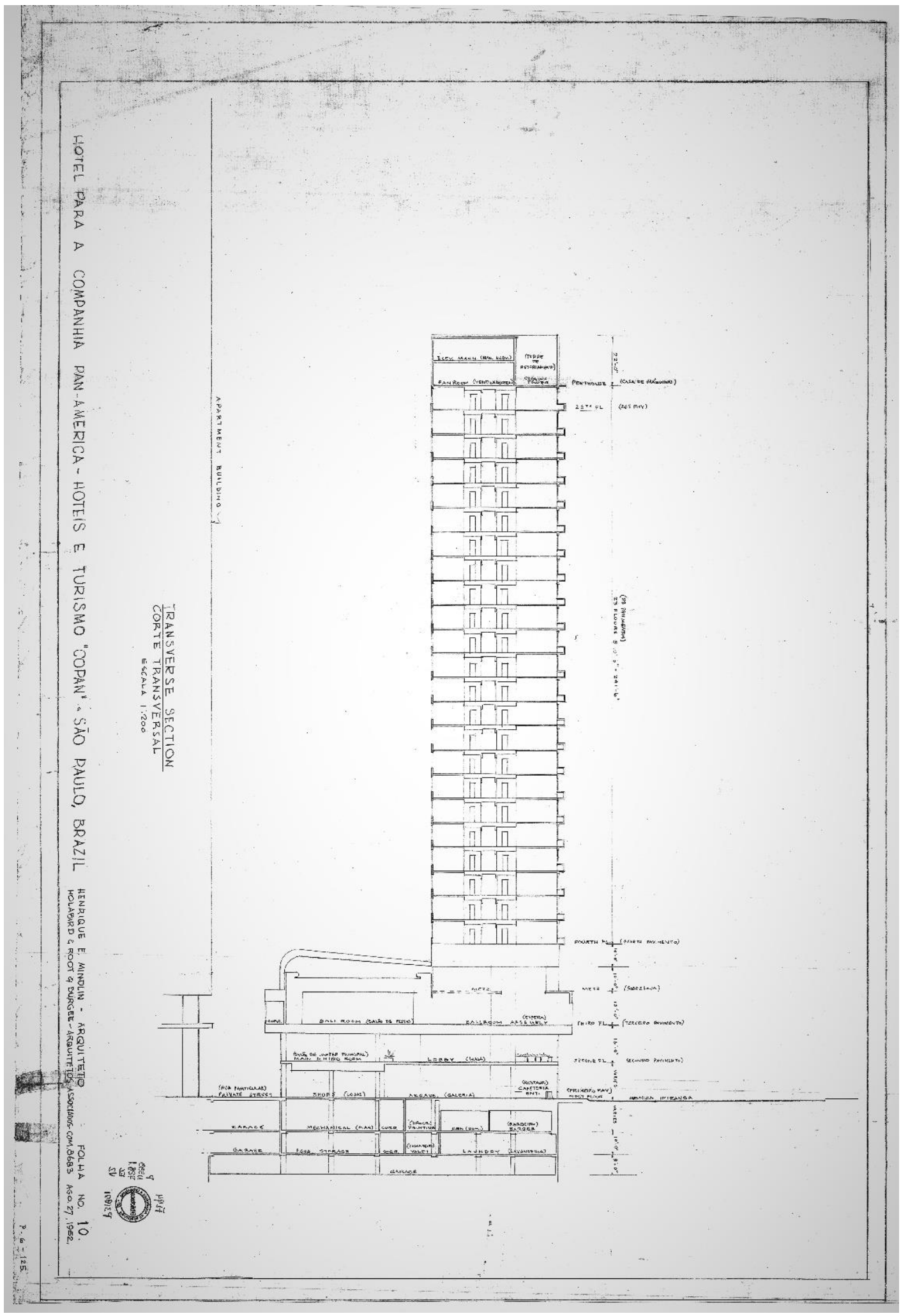

Figura 19 - Corte Transversal do Hotel

Fonte: Acervo do Condomínio Copan. 
Uma prancha produzida pelo escritório norte-americano Holabird, Root and Burgee, com data de 27 de agosto de 1952, posterior, portanto, ao projeto de prefeitura, apresenta um corte do hotel com a localização do edifício de apartamentos residenciais e os gabaritos definidos por Niemeyer (figura 18). Este desenho conta com os termos em inglês, o nome do referido escritório e o nome de Henrique Mindlin como arquiteto. Indicando a associação entre o arquiteto brasileiro e a empresa norte-americana.

Na terceira fase do projeto consta, no carimbo, a seguinte informação: "substituição de plantas - proc. 181.056/52 - Alv.63.864/53". Com solicitação feita em 1958 e aprovada em 16 de setembro de 1961, portanto após o Bradesco assumir as obras. Nos documentos da prefeitura consta como proprietário a Companhia Pan-América - Hotéis e Turismo.

As modificações não implicaram aumento de área ou alteração do pé-direito aprovado. As alterações em relação ao projeto anterior estavam restritas ao foyer e ao terraço. O cinema teve sua disposição e metragens alteradas, bem como o restaurante, o bar, a copa e os sanitários, enquanto no foyer foram acrescentados mais 8 lojas e as outras foram remanejadas. A localização da escada rolante foi também alterada.

E na quarta fase as pranchas apresentam o carimbo de projeto modificativo, aprovado em 16 de agosto de 1972 com as informações: "Substituição de Plantas - proc. 216.039/58 - Alv. 173.932/61". Anexado ao processo da prefeitura consta uma solicitação, com data de 26 de maio de 1966, com o seguinte texto: "A Companhia Pan-América de Empreendimentos Gerais 'COPAN', com sede nesta capital, à Avenida Ipiranga, $n^{\circ} 200$, desejando substituir a planta aprovada pelo alvará $n^{\circ} 173.932 / 61$ processo $n^{\circ} 216.039 / 58$, vem respeitosamente requerer a $\vee$. Excia. a expedição de alvará de substituição de planta uma vez aprovadas as plantas e memoriais anexos, esclarecendo que das modificações introduzidas não decorrerá acréscimo de área da construção." 
A troca do nome da COPAN é um indicativo do fim da associação com a empresa norte-americana e com as premissas hoteleiras estabelecidas no início do projeto.

Quando O Bradesco assume as obras do Copan, em 1957, através da $\mathrm{CNI}$, ele promove uma série de mudanças no programa inicial, o que desagradou muito Niemeyer, de acordo com Lemos (2014), e entre as alterações estão: a remoção do teatro, a transformação do terraço em um espaço para escritórios e a transformação dos apartamentos maiores de 4 dormitórios e varanda dos Bloco E e F (figura 20), de difícil venda, em unidades menores e mais lucrativas, com apartamentos de 1 dormitório e kitchenettes (figuras 21 e 22), passando de 896 para os atuais 1.160 apartamentos residenciais.

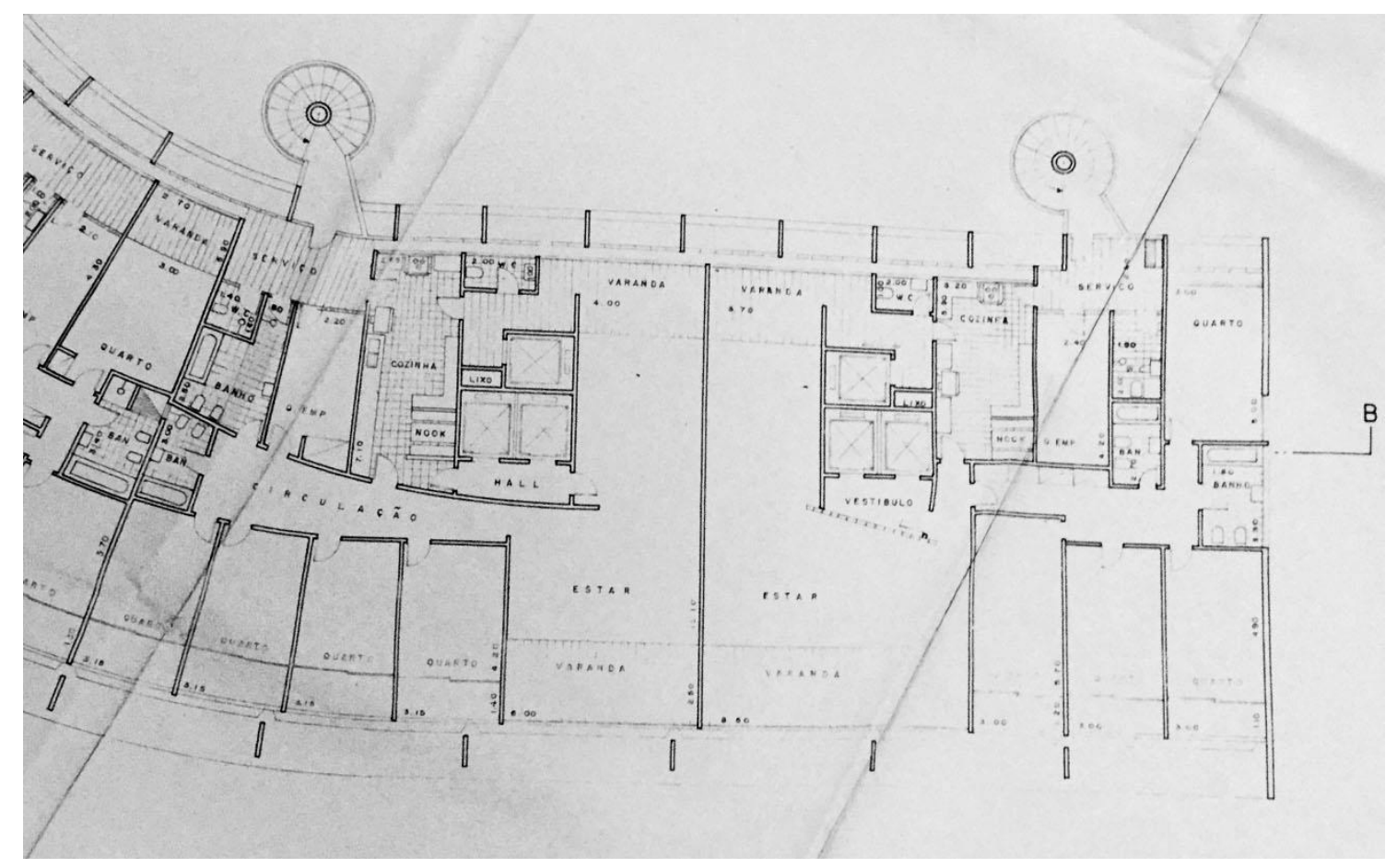

Figura 20 - Trecho da planta do pavimento tipo dos Blocos E e F (projeto de 1952) Fonte: Acervo do Arquivo Municipal. 


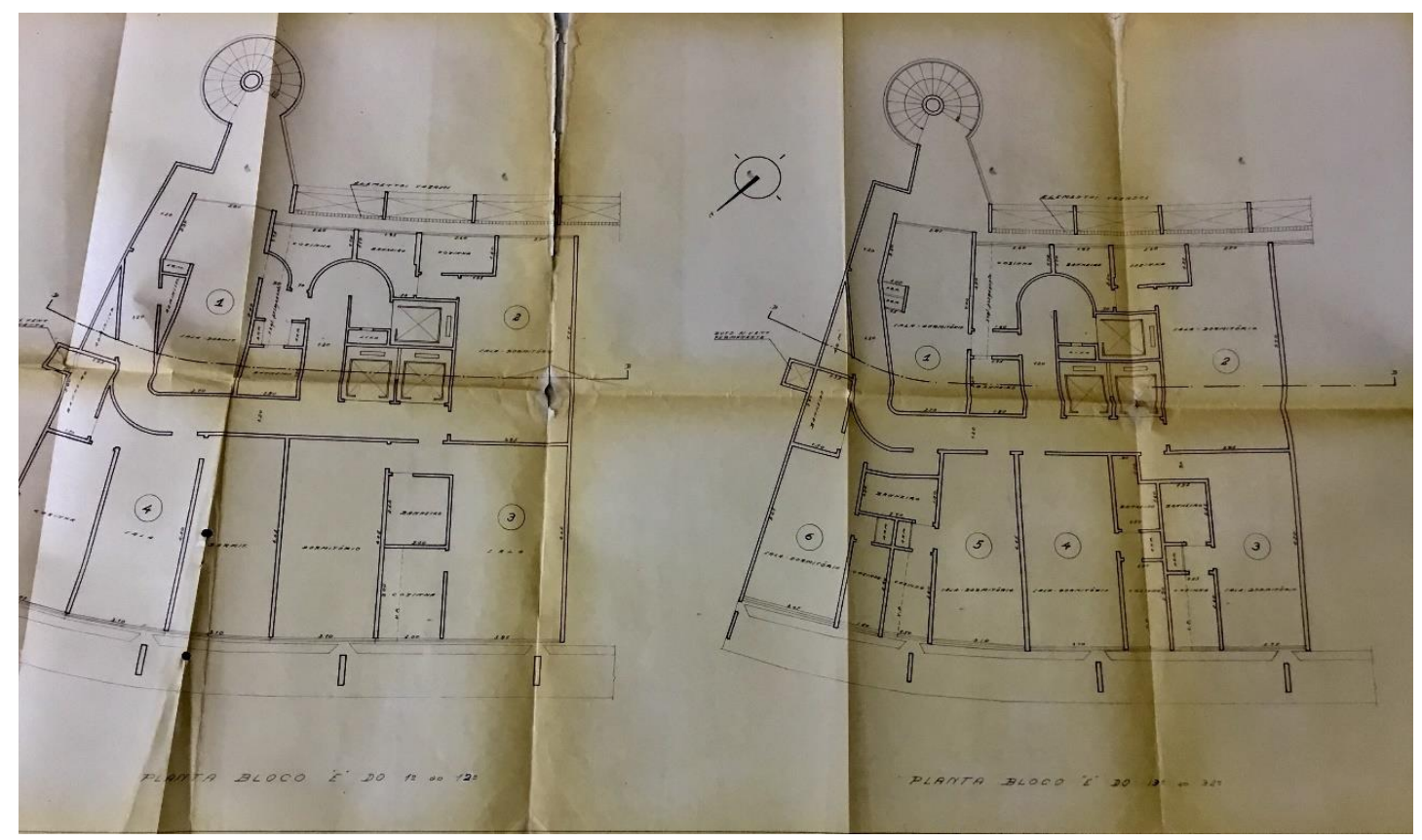

Figura 21 - Planta do Bloco E (projeto modificativo de 1972)

Fonte: Acervo do Arquivo Municipal.

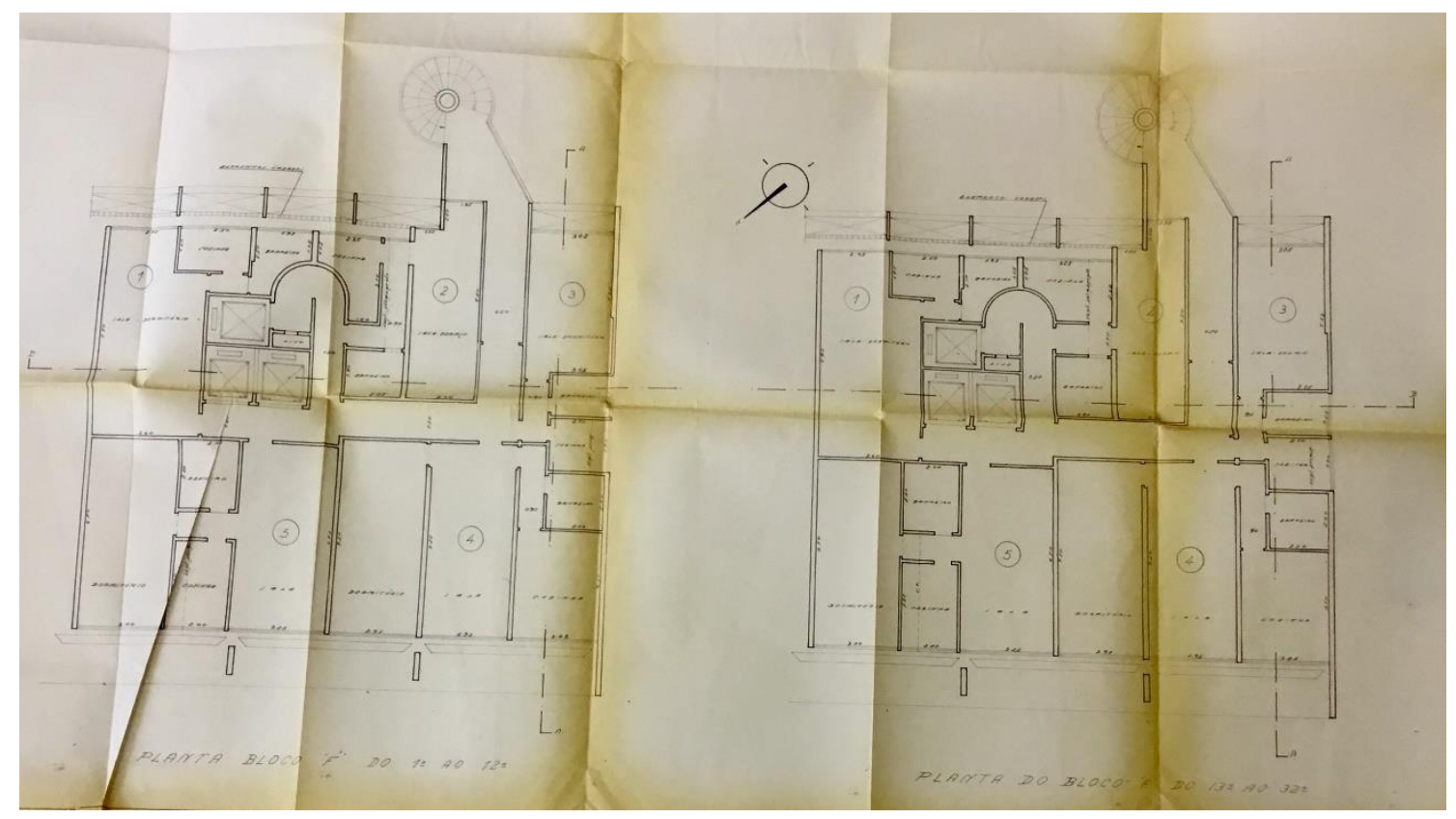

Figura 22 - Planta do Bloco F (projeto modificativo de 1972)

Fonte: Acervo do Arquivo Municipal. 
Observa-se que a última alteração projetual acrescentou duas folhas, sendo elas a cobertura do terraço e a divisão na folha de andar tipo de $1^{\circ}$ ao $12^{\circ}$ e do $13^{\circ}$ ao $32^{\circ}$. Nesse último projeto, vemos o terraço dar lugar a um ambiente de escritórios, a subdivisão dos apartamentos maiores em apartamentos pequenos, a retirada do teatro, do restaurante, do bar, das escadas rolantes e da rampa helicoidal, que foi substituída pela escada de concreto, projetada por Carlos Lemos, que se encontra hoje no local.

Entre as pranchas digitalizadas encontra-se uma que data de 3 de agosto de 1959, cujo título é "Pavimento tipo - estudo para hotel" (figura 23), na qual há a demarcação apenas do Bloco $B$ inserido no corpo do edifício, embora nos documentos que se encontram na prefeitura não há qualquer alusão do edifício ter sido concebido como hotel.

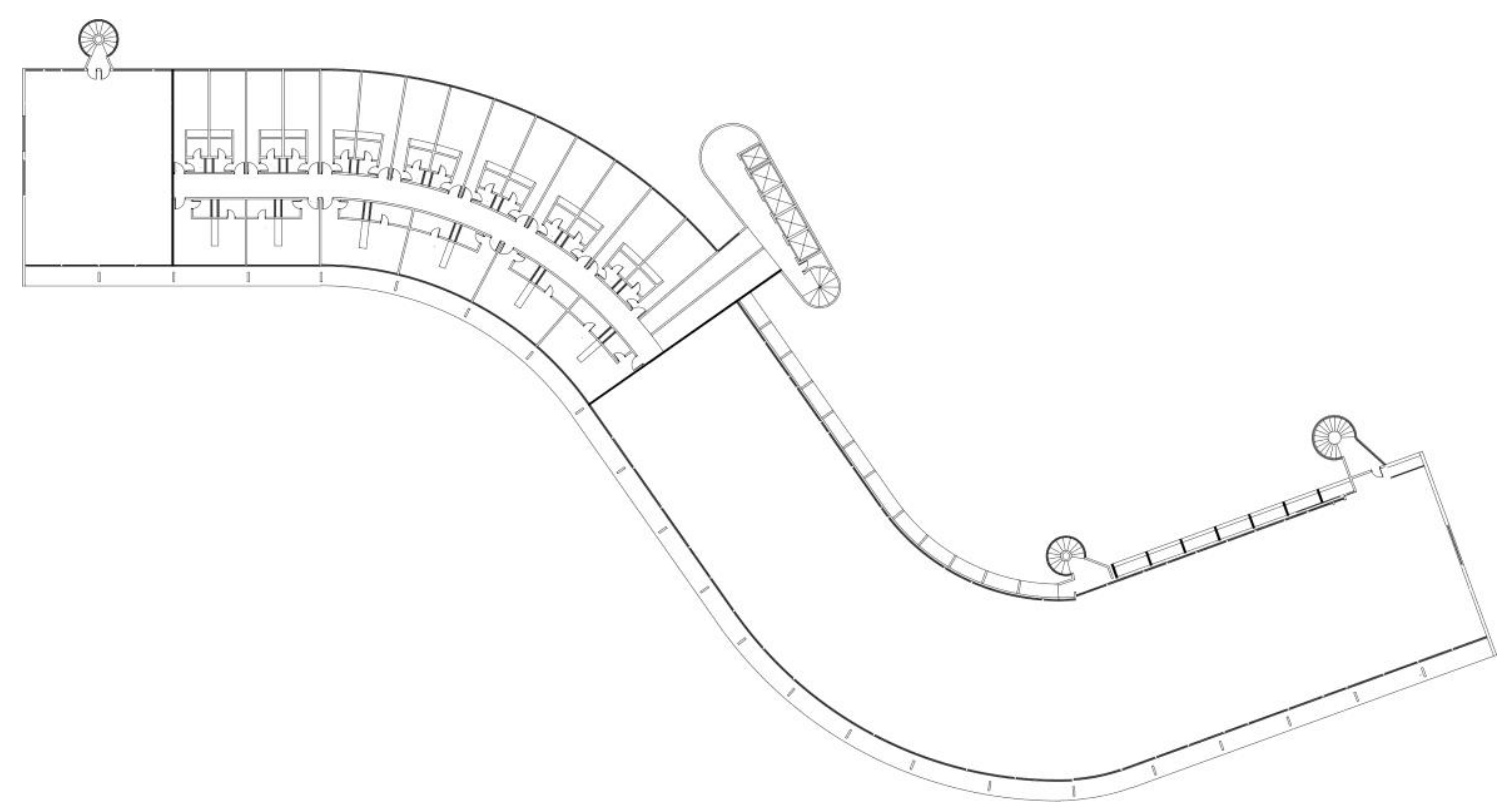

Figura 23 - Planta de estudo para Hotel de 1959

Fonte: Acervo do Condomínio Copan redesenhado pela autora.

Na planta de prefeitura do pavimento tipo do projeto de 1952, nos apartamentos do Bloco B não consta nenhuma referência ao ambiente da cozinha (figura 24), e sim A.C ("ante-câmara"), o que poderia corroborar a ideia de que esse bloco seria destinado ao hotel. Todavia, a nomenclatura foi 
apenas um artifício para contornar as recomendações do código de obras vigente, que preconizava área mínima para cozinha de $7 \mathrm{~m}^{2}$, enquanto o novo código em análise permitia área de $3 \mathrm{~m}^{2}$, ainda assim muito acima do $1,5 \mathrm{~m}^{2}$ projetado para as kitchenettes. Já no encarte de vendas (figura 25) do empreendimento, as mesmas plantas aparecem com o termo "kitch" nos locais onde foram construídas as cozinhas, indicando ao futuro comprador a função do ambiente.

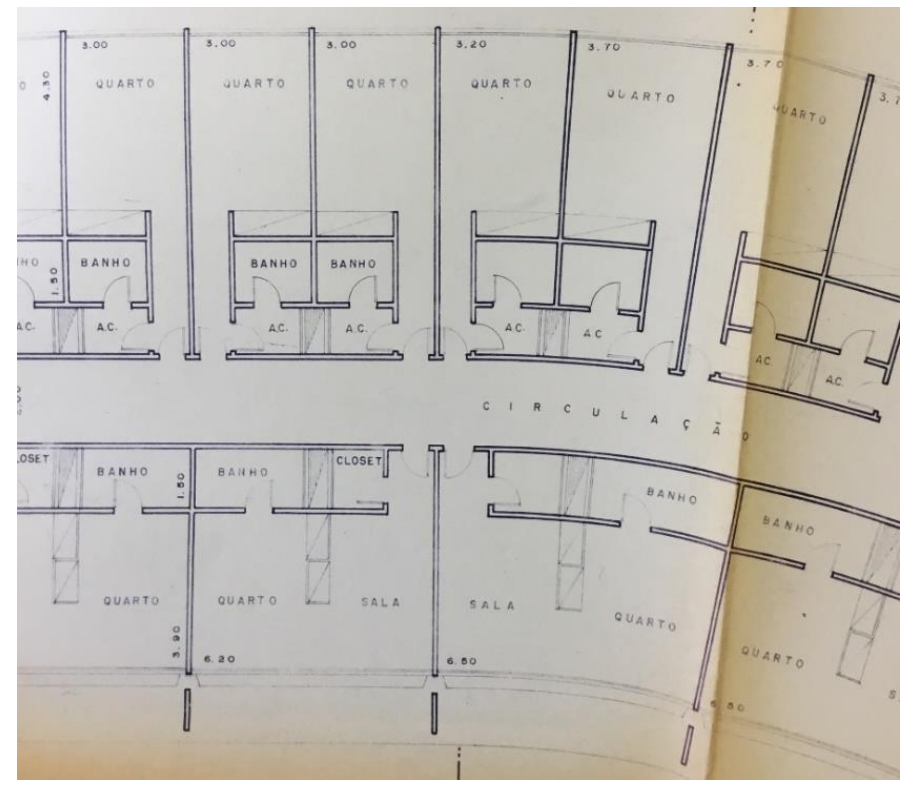

Figura 24 - Trecho da planta do pavimento tipo correspondente ao Bloco B

Fonte: Acervo do Arquivo Municipal.

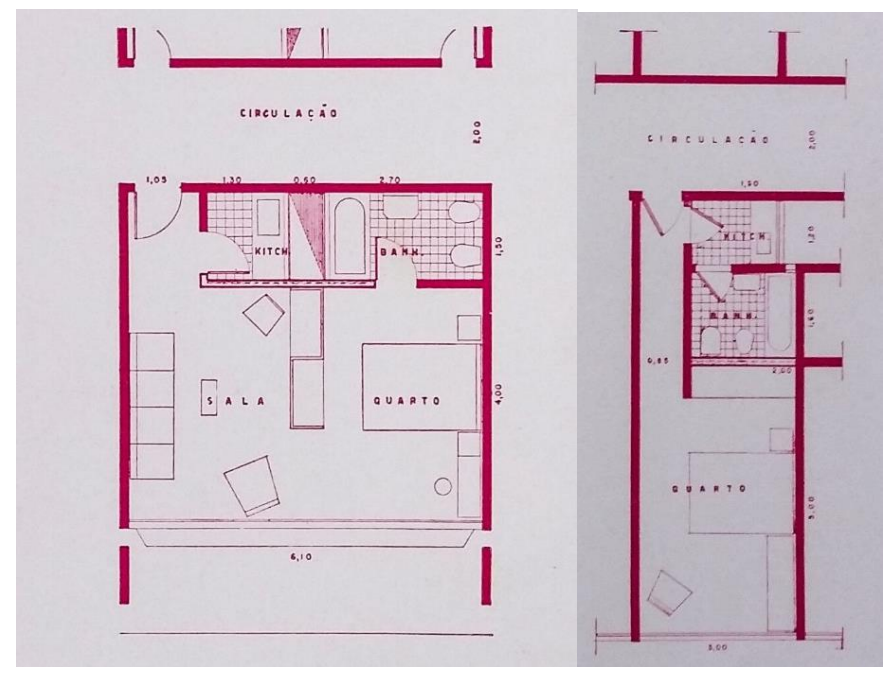

Figura 25- Planta promocional do empreendimento - apartamentos do Bloco B Fonte: Acervo do Condomínio Copan. 
Se os desenhos suscitam alguma dúvida quanto às funções dos apartamentos do Bloco $B$, não há qualquer registro no processo legal de que o Edifício Copan abrigasse um programa hoteleiro, mas o contrário. Os documentos (de maio de 1952) mostram que estavam sendo projetados dois edifícios distintos, cada um deles para abrigar uma função específica. E essa distinção fica muito clara no título do documento apresentado à prefeitura em 1952 junto com o projeto, cujo título é: "Memorial descritivo do edifício de apartamentos que faz parte do Maciço Turístico da Companhia Pan-América de Hotéis e Turismo" (figura 26). Conclui-se, portanto, que o Edifício Copan não foi projetado para abrigar a função hoteleira, mesmo porque não havia no seu programa ambientes que dessem suporte a tal função. E que os desenhos que porventura tenham sugerido isso tinham o objetivo de contornar a legislação. Os desenhos que surgiram mais tarde não passaram de um estudo de banco analisando, provavelmente, o que seria mais lucrativo.

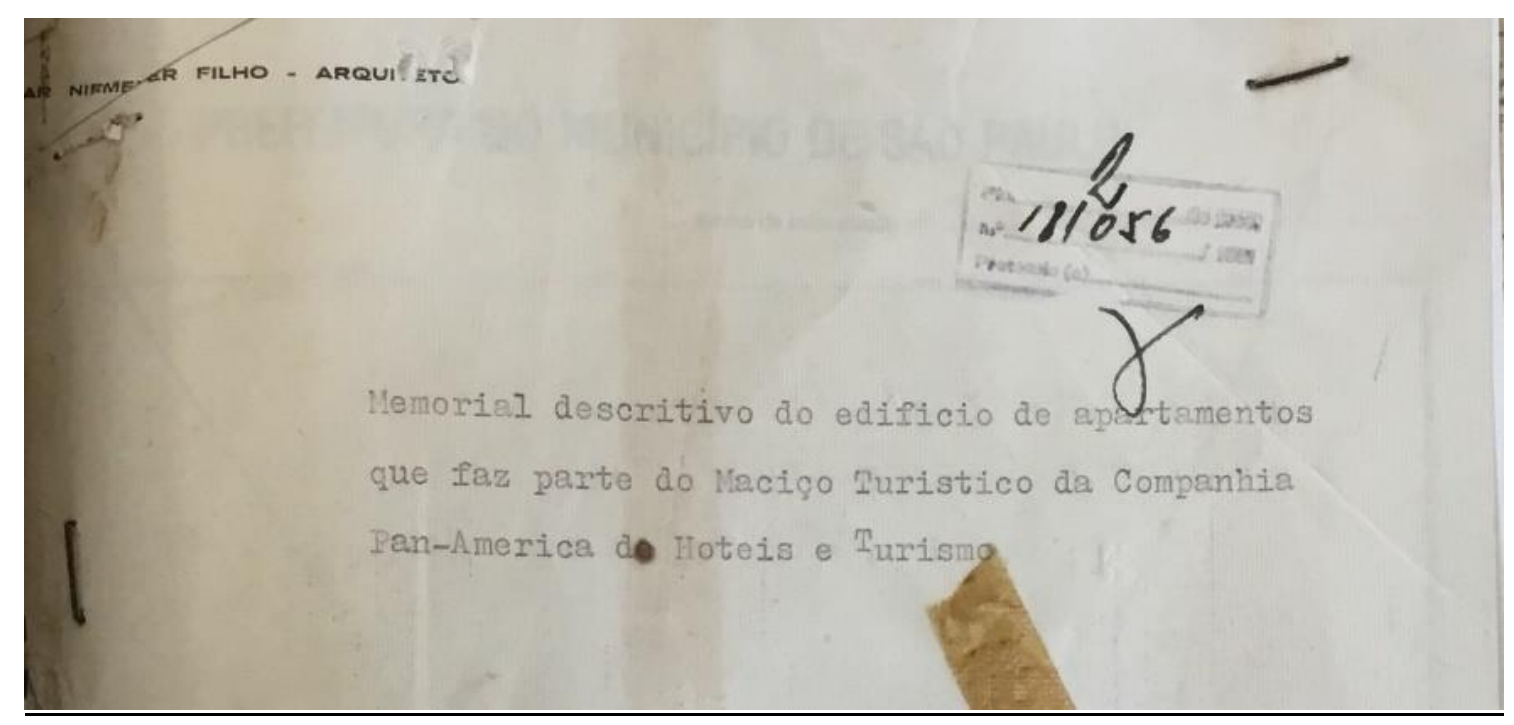

Figura 26 - Memorial descritivo

Fonte: Acervo do Arquivo Municipal.

No Quadro 5 é possível fazer um comparativo das alterações projetuais sofridas ao longo dos anos. 


\begin{tabular}{|l|c|c|c|c|}
\hline Programa & 1952 & $1952-1953$ & $1958-1961$ & $1966-1972$ \\
\hline Subsolo com garagem & 2 & 2 & 2 & 2 \\
\hline Lojas no térreo & 84 & 78 & 86 & 69 \\
\hline Lojas na sobreloja & 47 & 34 & 34 & - \\
\hline Terraço jardim & Sim & Sim & Sim & Não \\
\hline Restaurante & 1 & 1 & 1 & - \\
\hline Bar & 1 & 1 & 1 & 3 \\
\hline Salas para escritório & - & - & - & 32 \\
\hline Andares & 30 & 32 & 32 & 1.160 \\
\hline Apartamentos & 960 & 896 & 896 & Sim \\
\hline Brises & Não & Sim & Sim & Não \\
\hline Rampa helicoidal & Sim & Sim & Sim & 1.214 \\
\hline Cinema (lugares) & 3.500 & 1.628 & 638 & - \\
\hline & 500 & 638 & & \\
\hline
\end{tabular}

Quadro 5 - Comparativo entre as quatro alterações de projeto Fonte: Elaboração da autora. 


\subsection{FACHADAS - CONFRONTO ENTRE OS PROJETOS E ELABORAÇÃO DO AS BUILT}

Em que pese o acervo arquitetônico contar com um grande número de pranchas, poucas são as peças gráficas referentes às fachadas. No projeto de prefeitura é possível encontrar apenas a fachada principal, e no projeto de arquitetura há um amplo detalhamento do embasamento da fachada principal e noroeste do edifício, que compreende o térreo, a sobreloja, o foyer e o terraço.

As fachadas sudoeste, noroeste e posterior não constam das pranchas remanescentes. Entretanto, o nível de detalhes executados indica a existência de um projeto que deu suporte à construção, mas que não chegou até os nossos dias.

Foram analisadas as 1.206 pranchas digitalizadas, das quais 291 são do projeto de arquitetura; 24 pranchas dos projetos de prefeitura pertencentes ao acervo da administração do condomínio e 38 pranchas de projeto legal que foram encontradas no Arquivo Municipal, da prefeitura.

A análise das peças gráficas permitiu confrontar as informações dos projetos de arquitetura com o projeto de estrutura e ambos com o que foi construído. Foi realizado um levantamento in loco com medição pelo uso de trena dos elementos arquitetônico e estruturais, os elementos de vedação alvenaria e cobogó, os brises e os caixilhos das fachadas sudoeste, noroeste, posterior e principal para a elaboração do as built. Esse levantamento permite confrontar graficamente o que foi construído com os projetos originais, além de servir como documentação do que é encontrado no local.

O as built realizado trata apenas das fachadas e as divisões internas dos apartamentos, que aparecem nas plantas, estão de acordo com o projeto de prefeitura.

O que se observa é que o projeto de estrutura se baseou no projeto de prefeitura, mas que foram necessárias alterações que não foram compatibilizadas pela arquitetura. 
As dimensões externas definidas pela arquitetura, assim como os raios das curvas do "S" foram obedecidas pela estrutura. A arquitetura propunha $3.15 \mathrm{~m}$ de piso a piso e $2.80 \mathrm{~m}$ de pé direito, no projeto de 1952 , mas no projeto de 1972 o piso a piso aparece com $3.03 \mathrm{~m}$, enquanto no projeto de estrutura o intervalo entre as lajes é de $3.15 \mathrm{~m}$. In loco aferiu-se que o piso a piso foi executado conforme a estrutura, enquanto internamente o pé-direito permaneceu conforme o projeto de arquitetura.
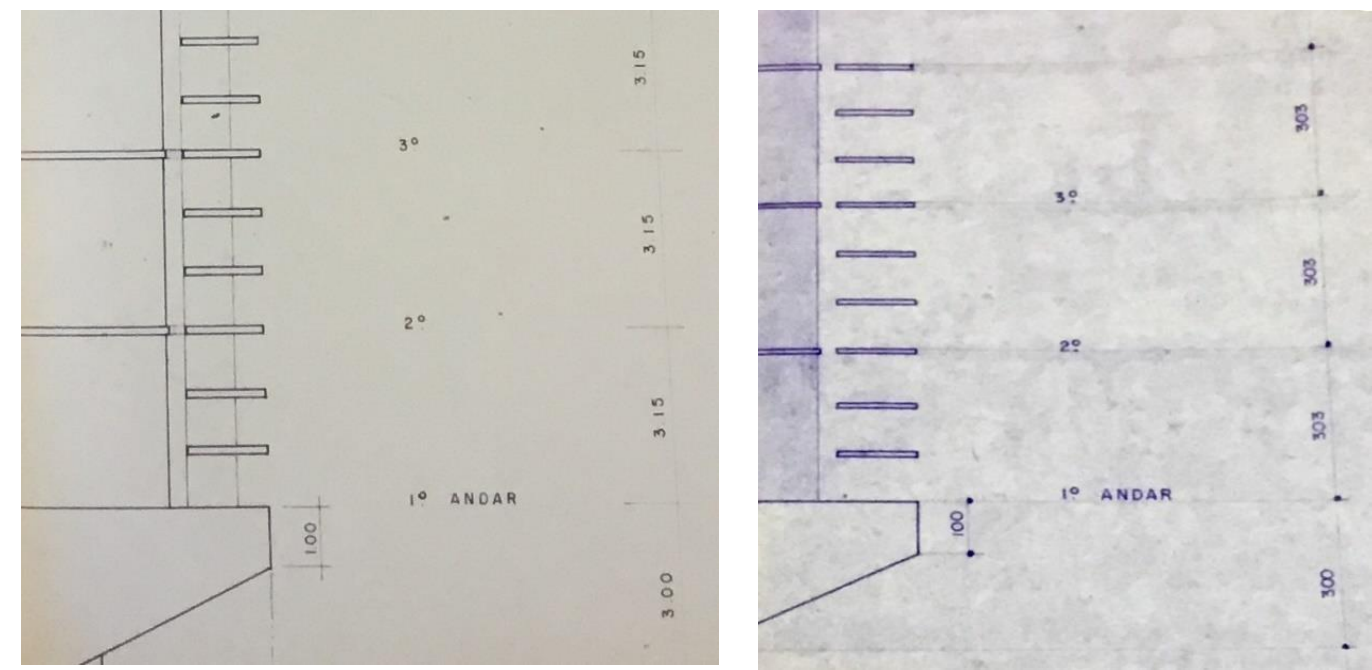

Figura 27 - Corte do projeto de Figura 28 - Corte do projeto de prefeitura de 1952 prefeitura de 1972

Fonte: Acervo do Arquivo Municipal. Fonte: Acervo do Condomínio Copan.

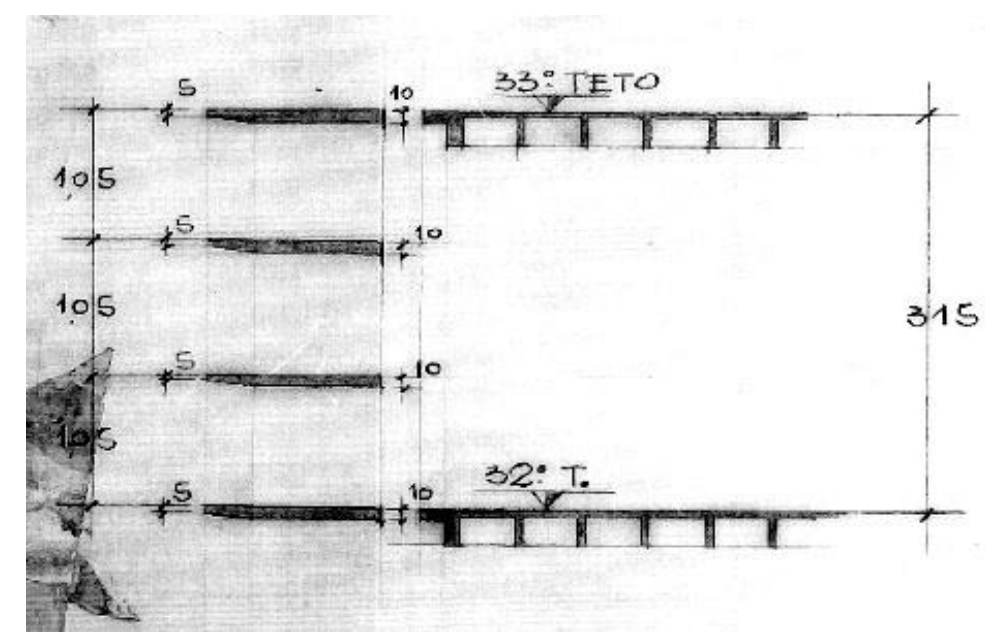

Figura 29 - Corte do projeto de estrutura

Fonte: Acervo do Condomínio Copan. 
A fachada principal é composta de brises de concreto armado, revestidos nas faces laterais e superior em pastilha de porcelana na cor branca e pintura branca na parte inferior. Os brises ficam afastados da laje dos andares $30 \mathrm{~cm}$, na qual são engastados por meio de elementos metálicos fixados nos pilares de concreto armado, revestidos de pastilhas cinzas, conforme pode ser observado na figura 30 .

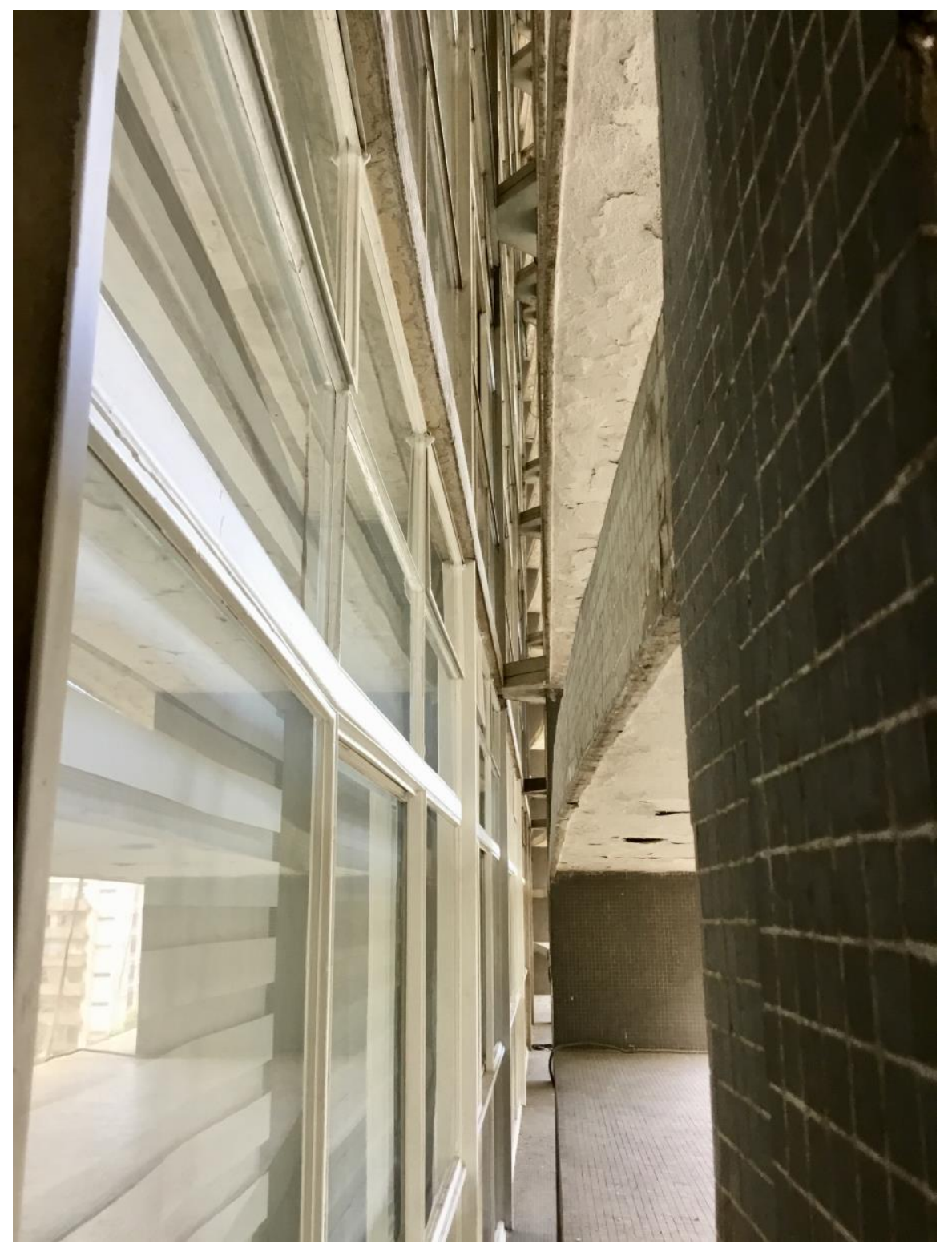

Figura 30 - As built da fachada sudoeste e noroeste

Fonte: Acervo da autora. 
A partir da medição in loco da distância dos pilares da fachada principal, foi possível observar que o executado está de acordo com o projeto de estrutura e não com o de arquitetura.

As fachadas sudoeste e noroeste (figura 31) constam com 18,15m de largura tanto no projeto de arquitetura quanto no de estrutura, e ambas foram executadas conforme projeto.

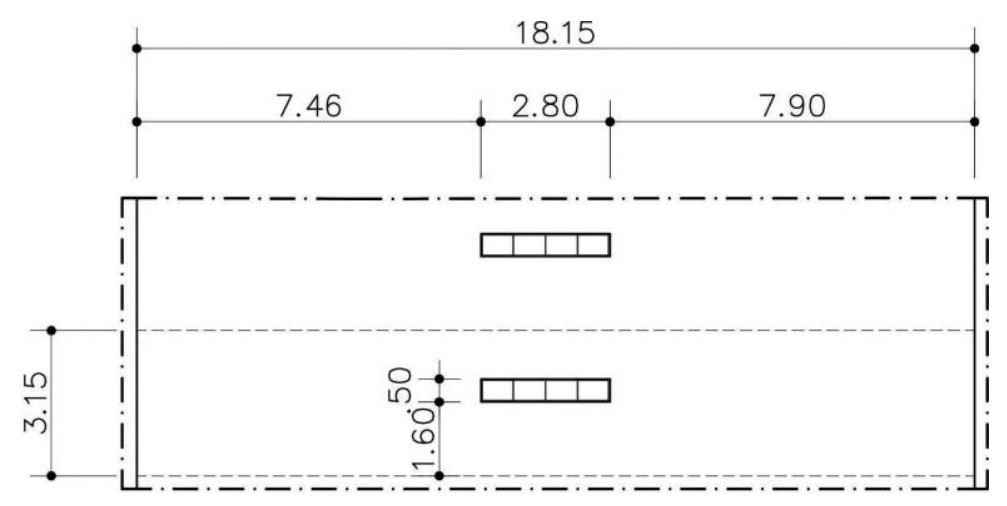

FACHADA SUDOESTE

$\begin{array}{lllll}0 \quad 5 \quad 10 \quad 20 & 30 \\ \text { ESCALA GRÁFICA }(\mathrm{m})\end{array}$

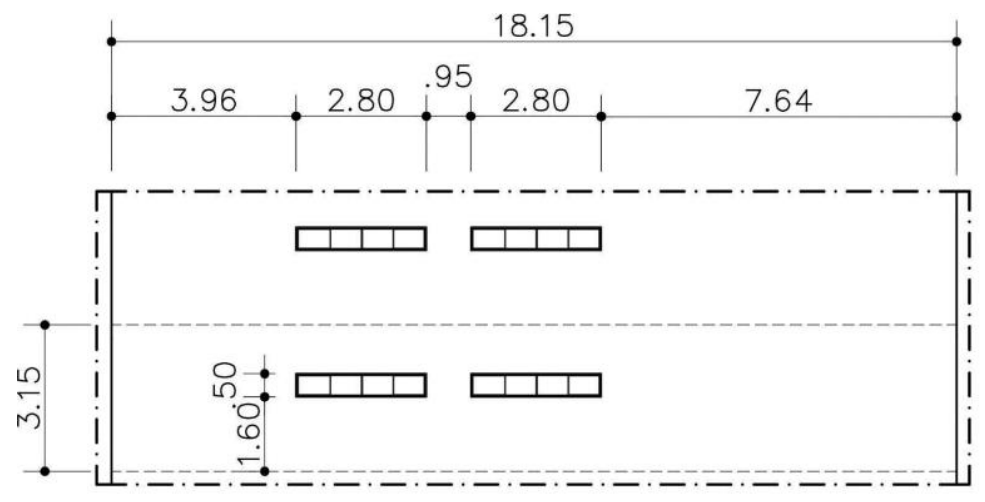

FACHADA NOROESTE

$\overbrace{\text { ESCALA GRÁFICA }(\mathrm{m})}^{5 \quad 10 \quad 20 \quad 30}$

Figura 31 - As built da fachada sudoeste e noroeste

Fonte: Elaboração da autora.

A fachada posterior (figuras 32 e 33) é, talvez, a mais complexa do Copan. Tem uma sutileza de detalhes que a princípio passam despercebidos a um olhar desatento, dispersado por tantas modificações que 
foram realizadas pelos moradores ao longo dos anos. Não há registro de projeto para essa fachada, mas sua complexidade e nível de detalhamento são indicativos de que houve um projeto minucioso muito bem elaborado, fornecendo subsídios à execução.

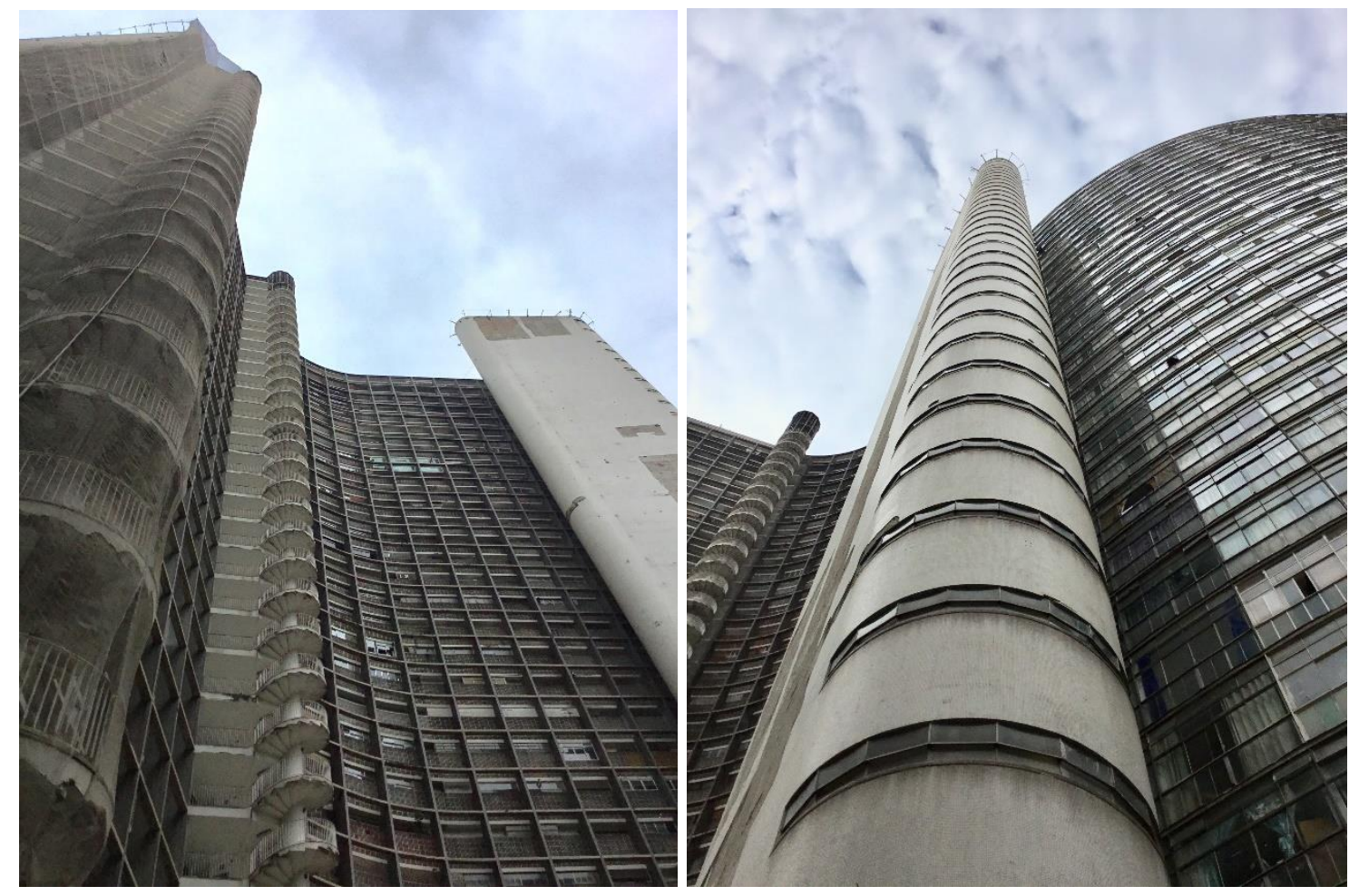

Figuras 32 e 33 - Fotografia da fachada posterior do Bloco F ao B

Fonte: Acervo da autora.

Dos Blocos C ao F o limite o corpo do "S" é marcado por viga revestida em pastilhas brancas, encimada por cobogó cinza, com $2.10 \mathrm{~m}$ de altura. Avançando $1.17 \mathrm{~m}$ para além do limite dos apartamentos estão os elementos estruturais: pilares e vigas. As vigas revestidas com pastilhas brancas obedecem a um intervalo de $3.15 \mathrm{~m}$, coincidindo com a laje de cada pavimento. Os pilares revestidos em pastilhas cinzam afloram da viga de transição faceando os elementos verticais (figura 34). E o que se observa são os elementos horizontais na cor branca e os elementos verticais na cor cinza, com uma única exceção para a lateral da empena da faceada sudoeste, o primeiro elemento vertical, que tem a face externa revestida de pastilhas 
brancas. Essas linhas brancas externas formadas pela viga de transição, a viga da cobertura e a empena emolduram o edifício (figuras 35 e 36).

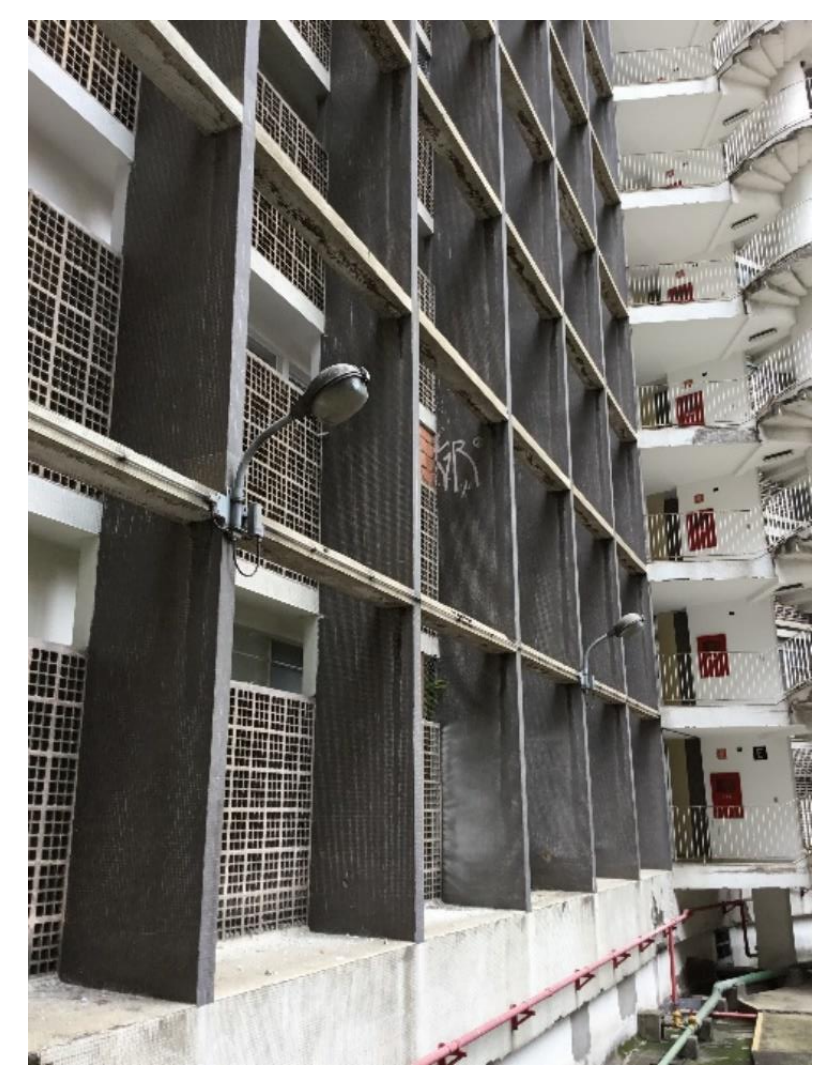

Figura 34 - Fotografia da Configuração Formal da Fachada Posterior Fonte: Acervo da autora.
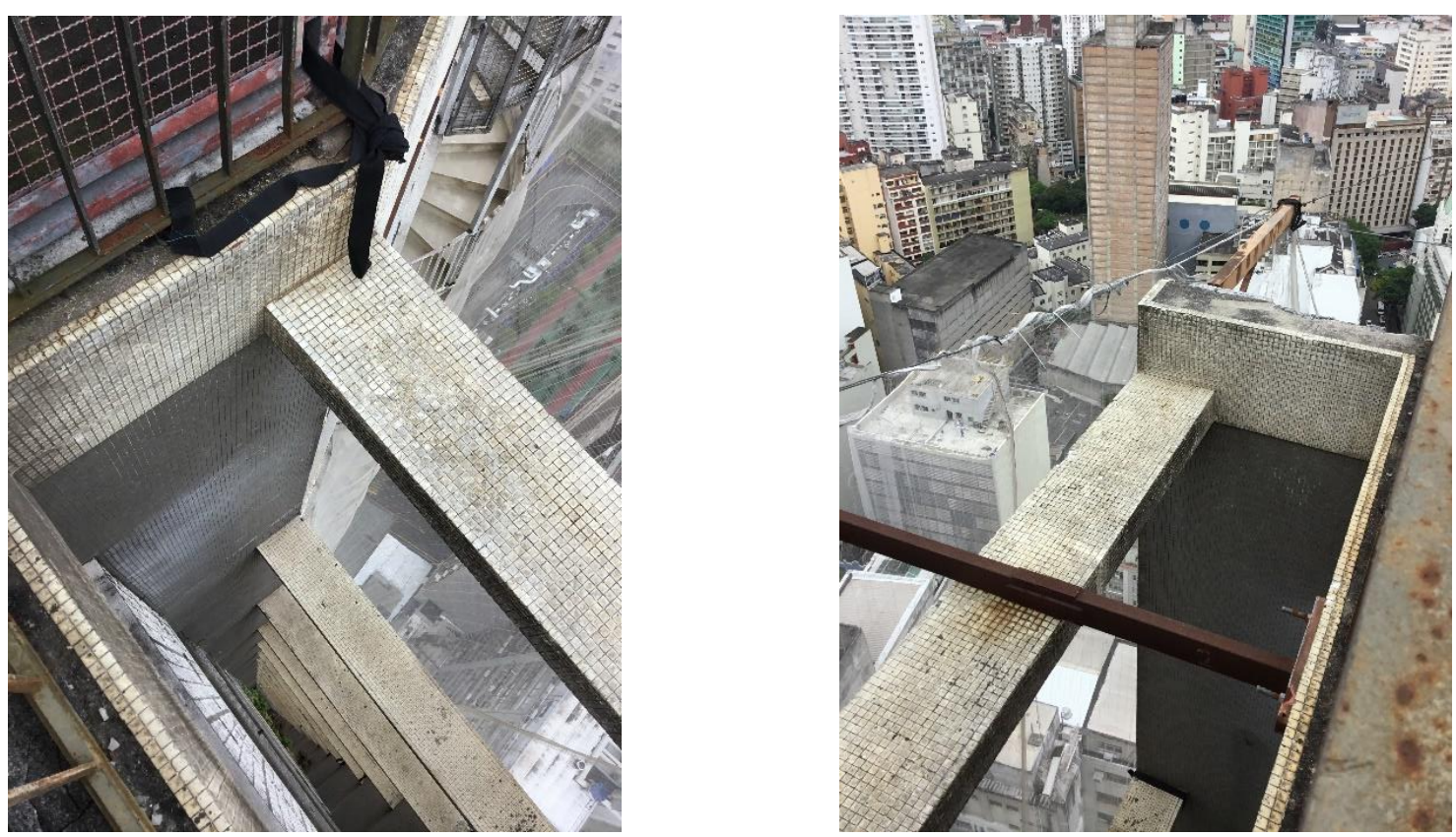
Figuras 35 e 36 - Detalhe dos elementos horizontais revestidos com pastilhas brancas

Fonte: Acervo da autora.

No projeto de arquitetura os apartamentos do Bloco $\mathrm{C}$ ao $\mathrm{F}$ foram projetados com uma pequena varanda, com $50 \mathrm{~cm}$ de profundidade, com um fechamento em cobogó com 2.10m de altura. Essa solução arquitetônica resolvia a estética dessa fachada que é composta por janelas de diferentes dimensões e formatos, possibilitando um padrão de fechamento e, ao mesmo tempo, permitindo iluminação e ventilação natural. A parte superior das janelas e portas ficava na mesma altura do cobogó, portanto, ocultas por ele, e com isso a fachada de programa complexo adquiriu uniformidade (figura 37).

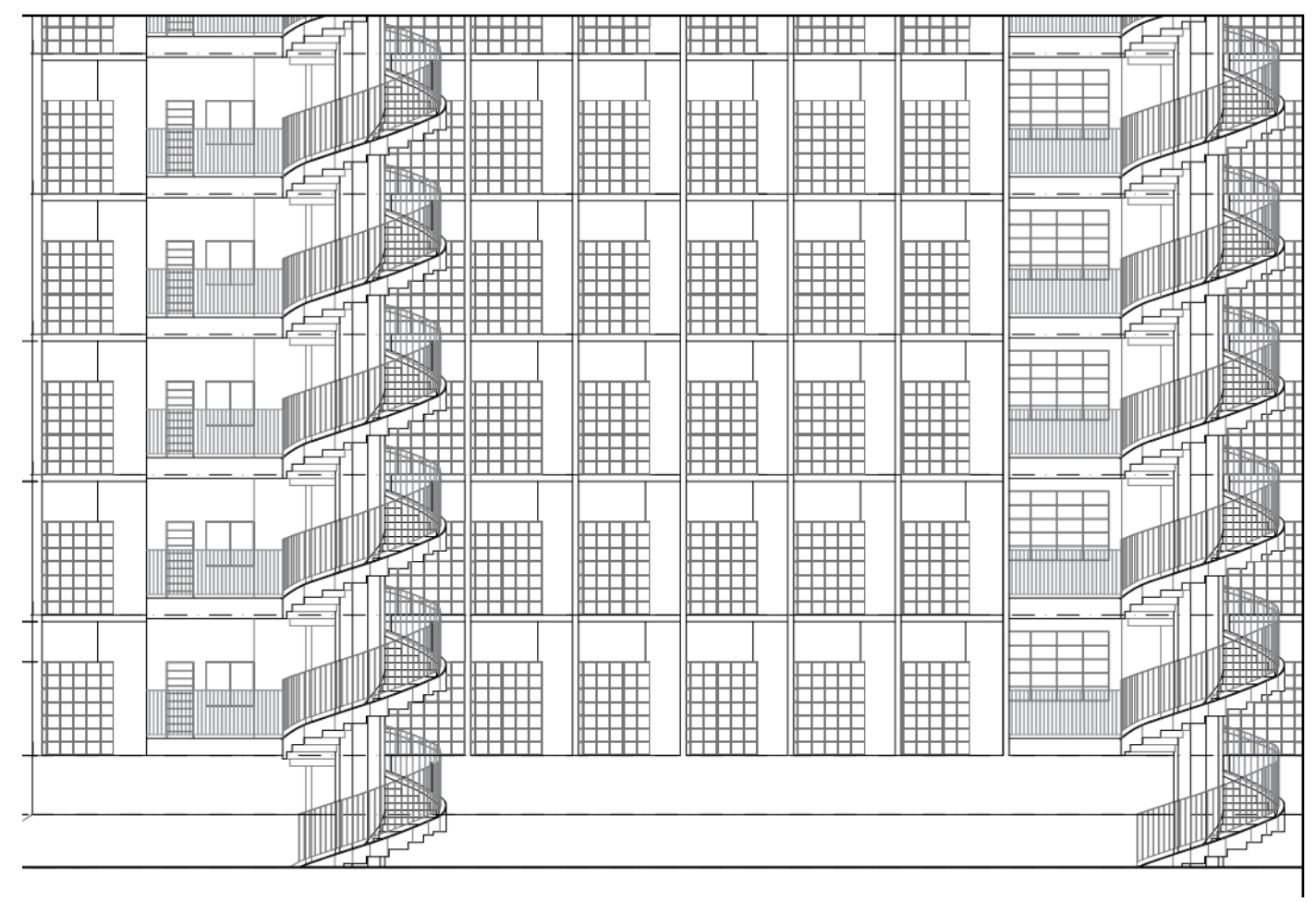

Figura 37 - As Built Parcial da Fachada Posterior (Blocos F e E)

Fonte: Elaboração da autora.

Deslocado do corpo do edifício estão as três escadas helicoidais de emergência: Bloco A, Bloco E e Bloco F, com um pilar central de $\varnothing 1.10 \mathrm{~m}$ em torno do qual estão dispostos 18 degraus a cada pavimento. 
A torre dos elevadores do Bloco B é um elemento à parte do edifício. É toda revestida com pastilha branca e suas dimensões externas estão de acordo com o projeto original.

No Bloco B as 14 kitchenettes que estão voltadas para a fachada posterior obedecem à distribuição do projeto de estrutura e não o de arquitetura. A laje fica marcada na fachada, enquanto a parede divisória dos apartamentos fica recuada e é arrematada por um montante metálico do caixilho, dando a sensação de continuidade (figura 38). As linhas horizontais dos caixilhos coincidem com as alturas dos brises da fachada principal.

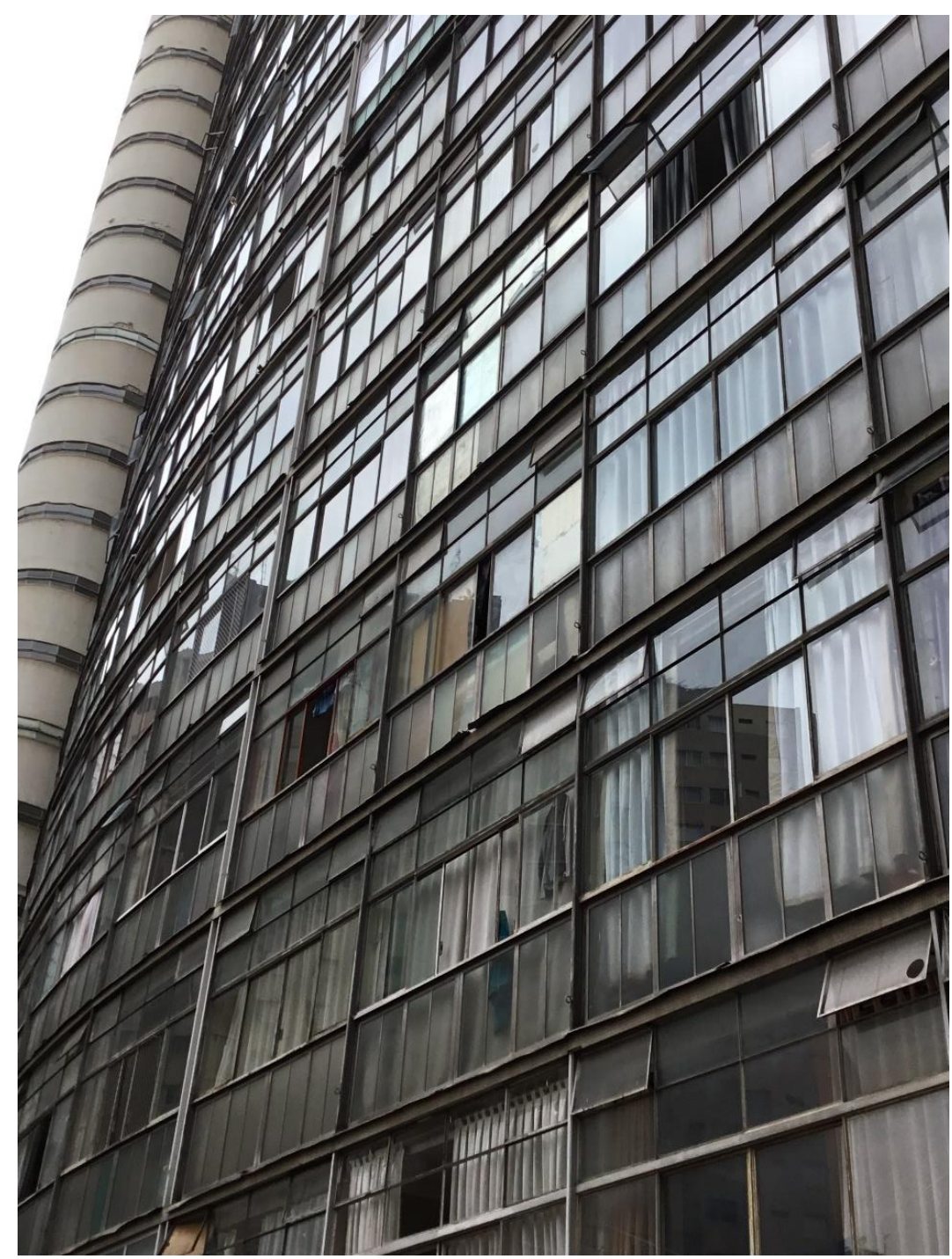

Figura 38 - Vista parcial da fachada posterior (Bloco B)

Fonte: Acervo da autora. 
As fachadas sudoeste e noroeste obedecem tanto ao projeto de estrutura quanto ao de arquitetura. A sudoeste conta com uma janela dividida por um montante no eixo da alvenaria que separa dois ambientes. Já a fachada noroeste tem duas janelas de mesma configuração para quarto e banheiro.

No início da década de 1990, para a aprovação do projeto de Corpo de Bombeiros, o edifício precisou fazer algumas adequações, entre elas a substituição da parte inferior dos caixilhos de piso ao teto por elementos de alumínio e vidro de segurança do tipo aramado. Foram colocadas chapas de zinco abaixo dos caixilhos do Bloco $B$ e porta para saída de emergência dos Blocos C e D, também por solicitação do Corpo de Bombeiros.

Há pouca documentação das fachadas do Copan em cada uma das quatro fases de projeto legal só há desenho da fachada principal. Por ter suas fachadas tombadas, viu-se a necessidade de realizar o as built delas, que seguem nas figuras 39 a 45 . 


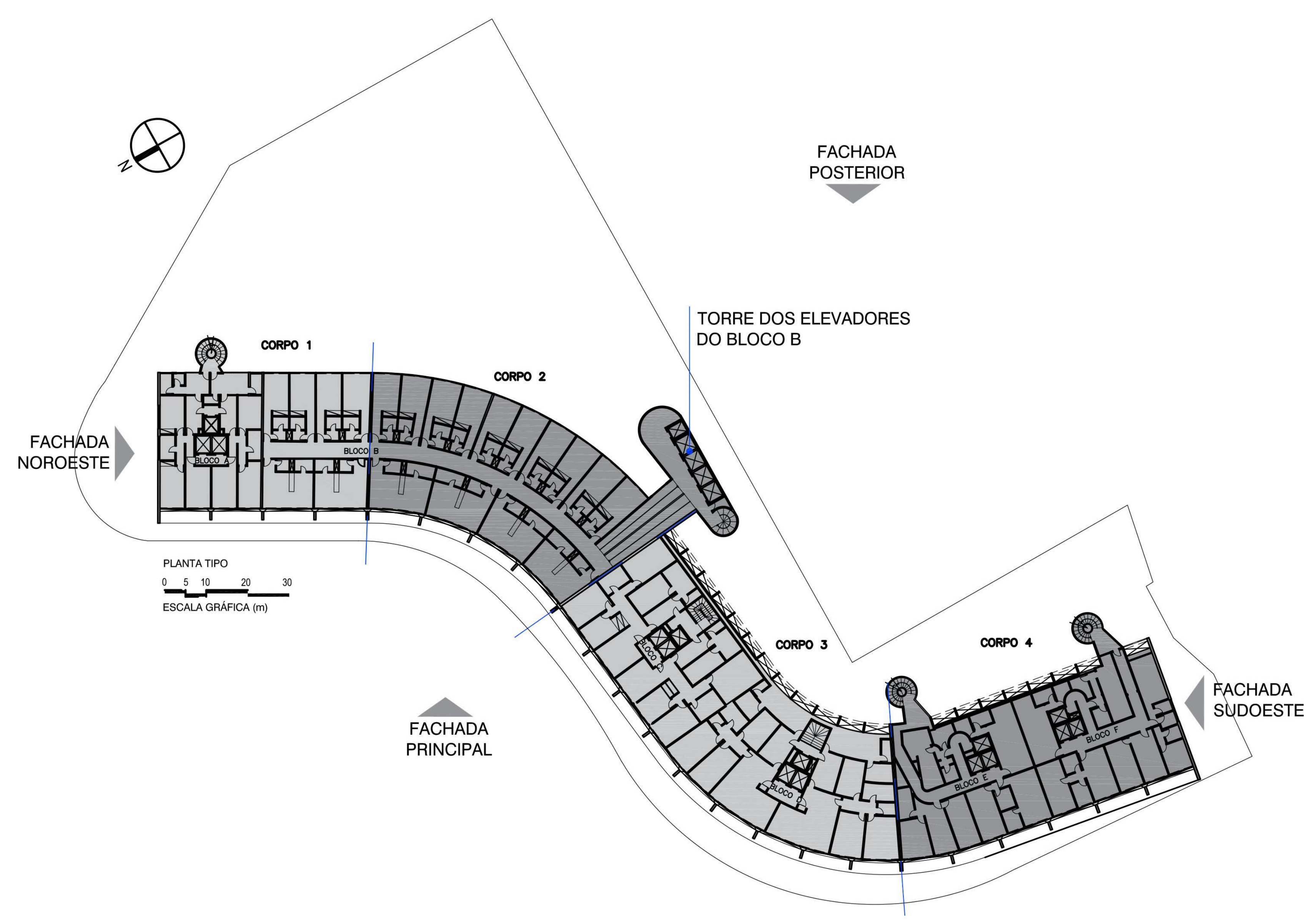




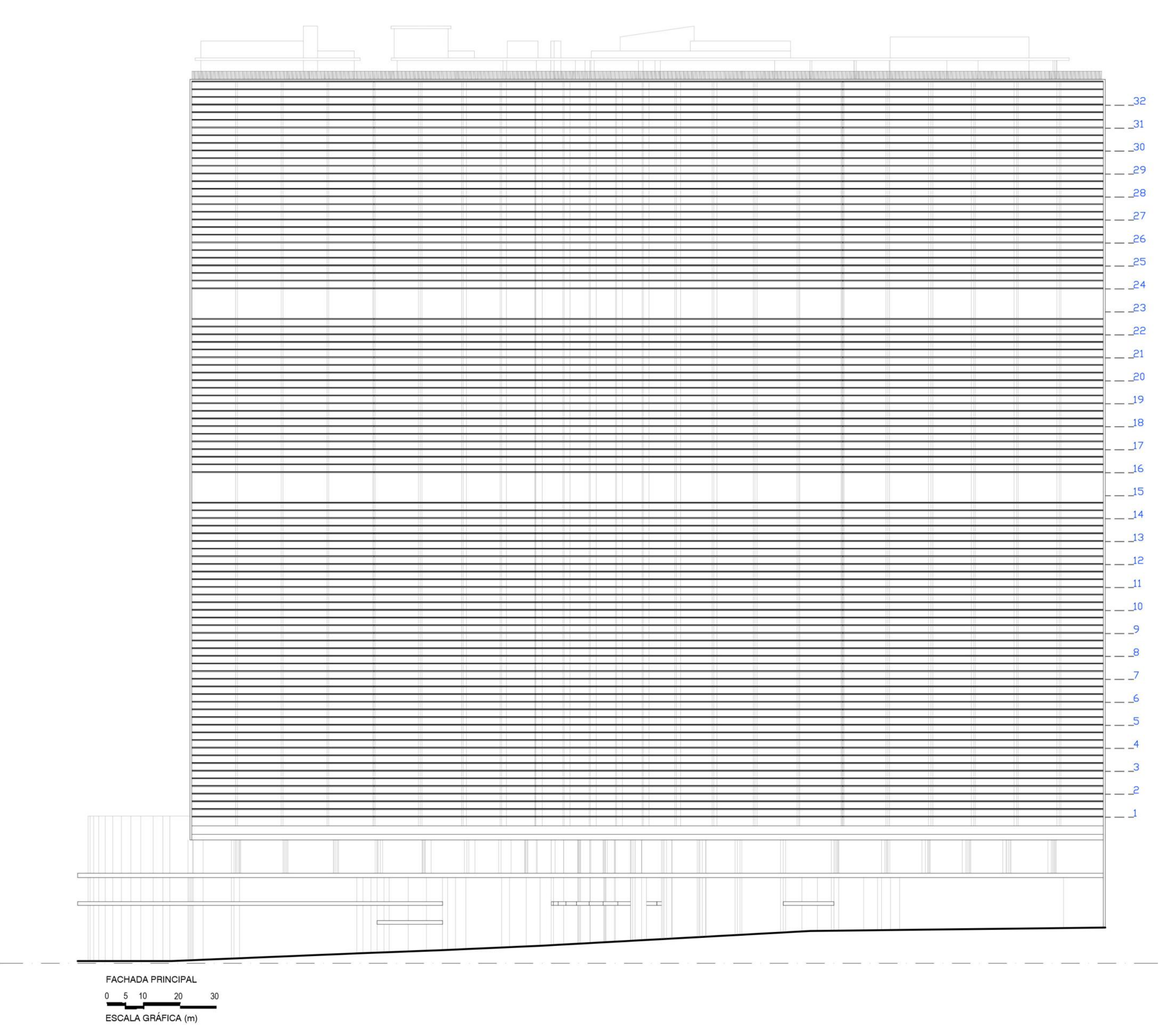

Figura 40 - As Built da Fachada Principal Fonte: Elaboração da autora 


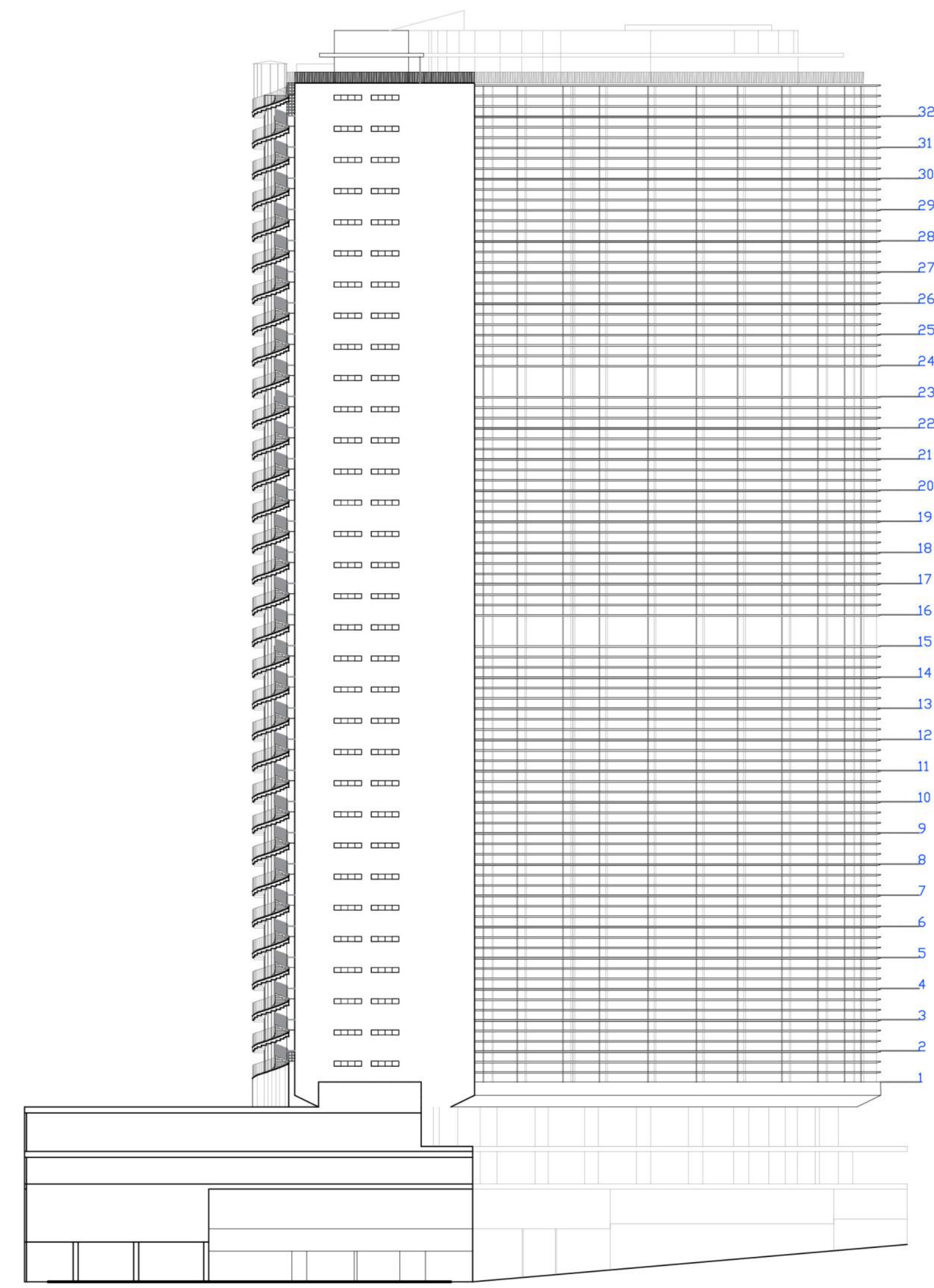

FACHADA NOROESTE

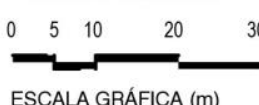

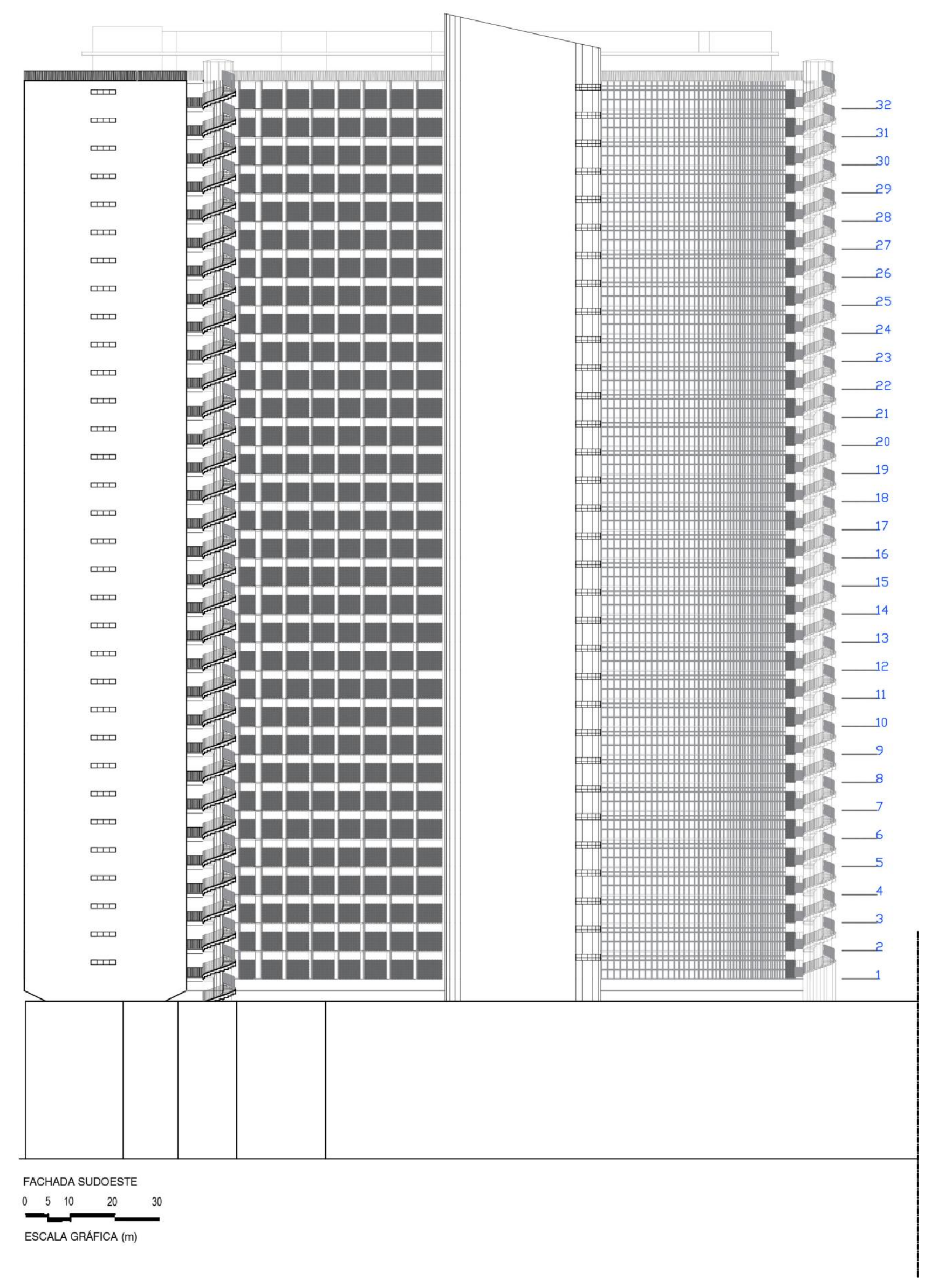




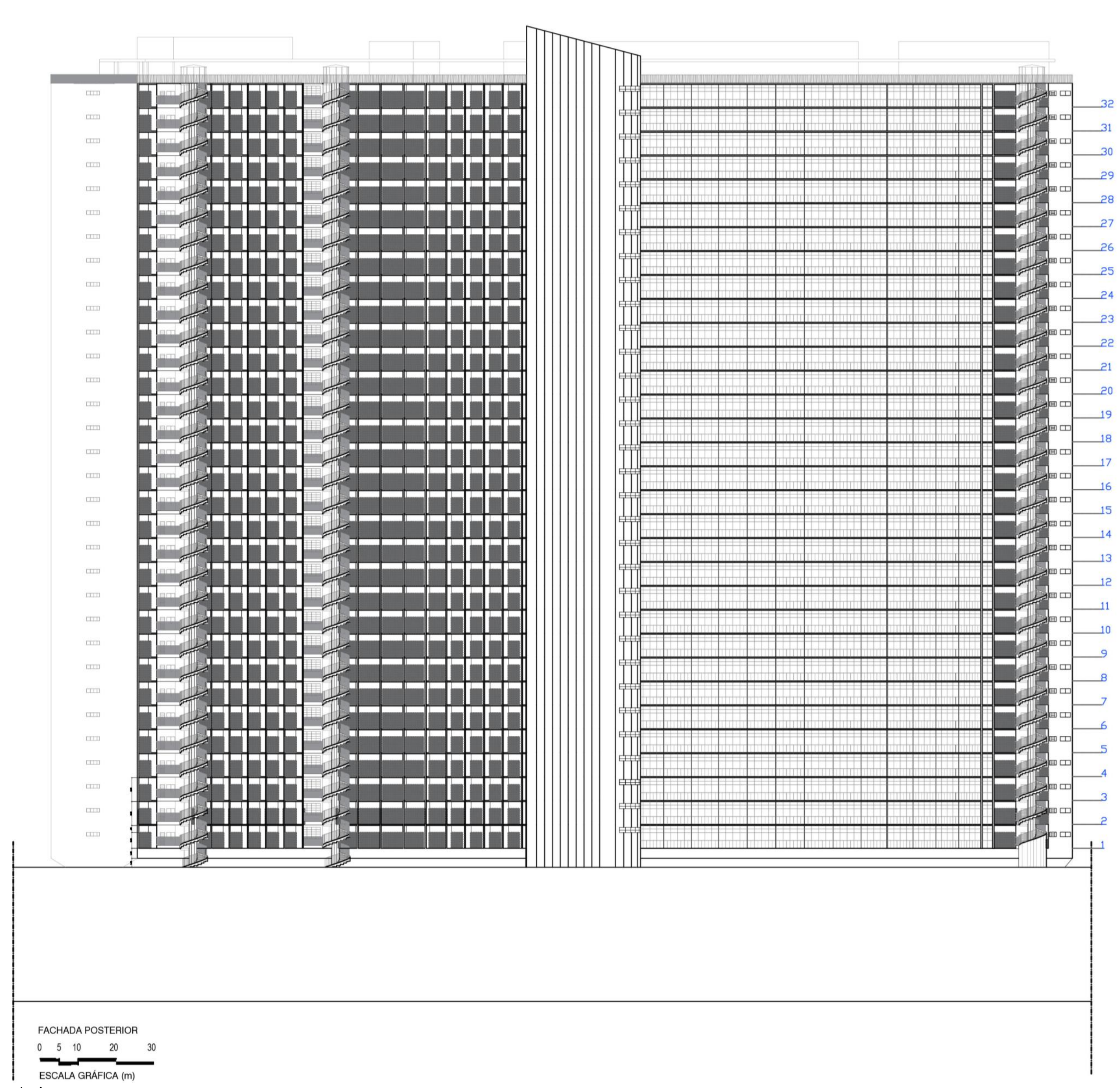

Figura 42 - As Built da Fachada Posterior

Fonte: Elaboração da autora. 


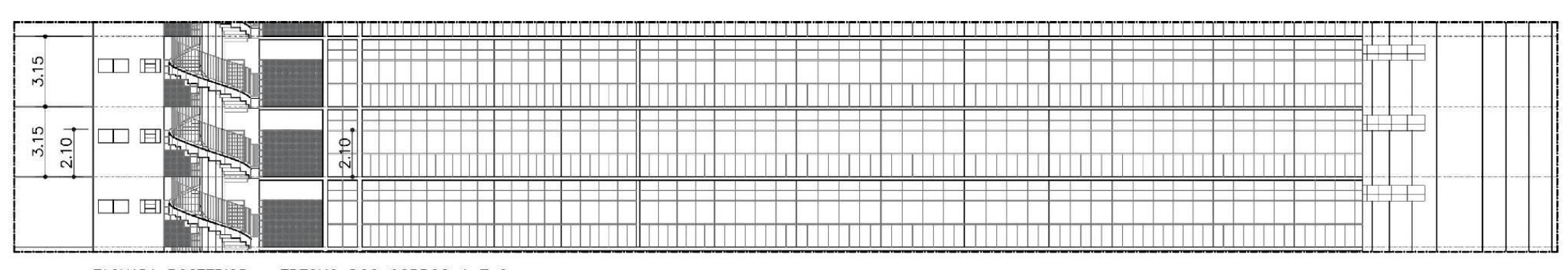

FACHADA POSTERIOR - TRECHO DOS CORPOS 1 E 2
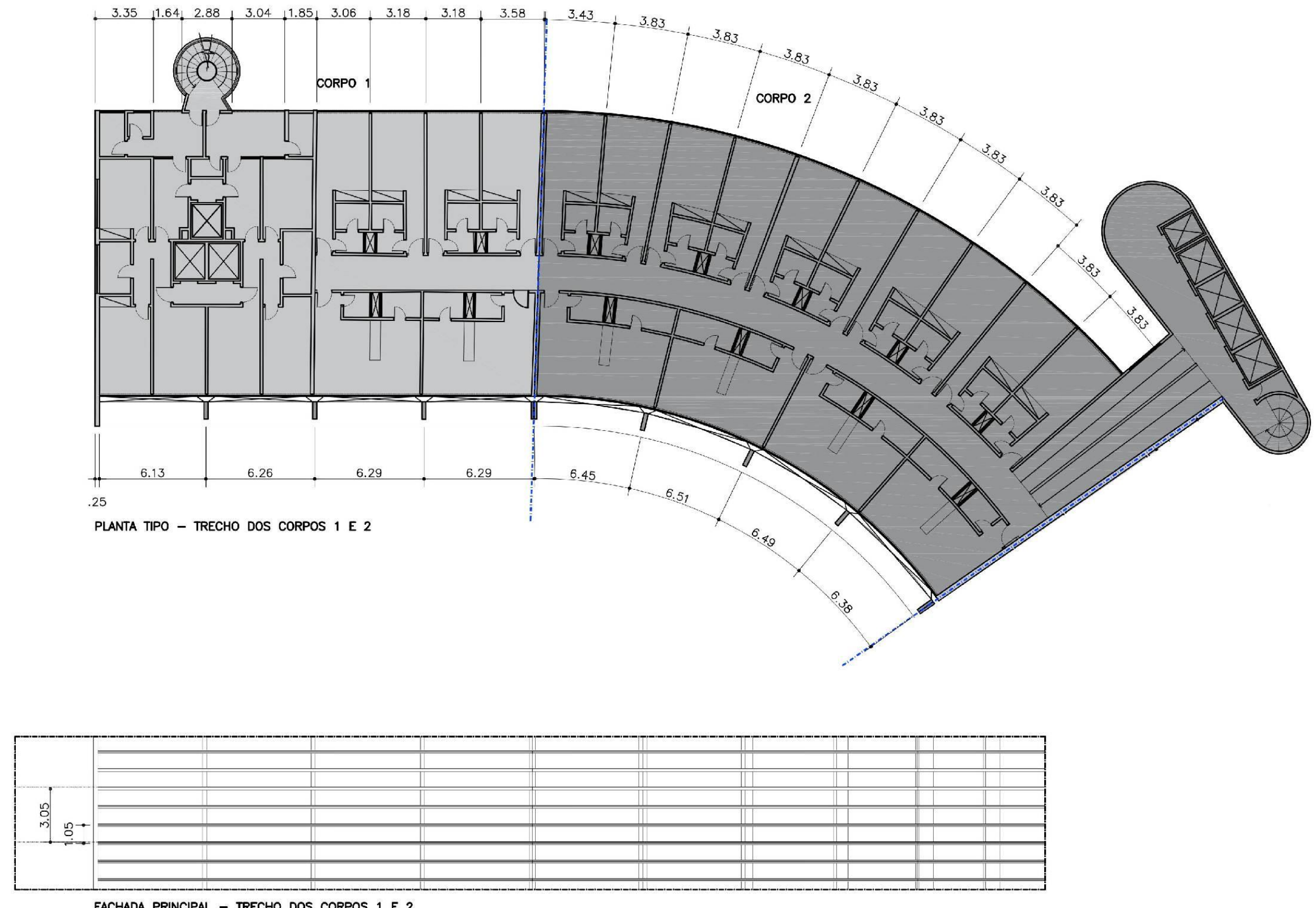

POMOA PPICPA - TRECHO DOS CORPOS 1 E 2

Figura 43 - As Built da Fachada Posterior, Planta e Fachada Principal dos Corpos 1 e 2

Fonte: Elaboração da autora. 


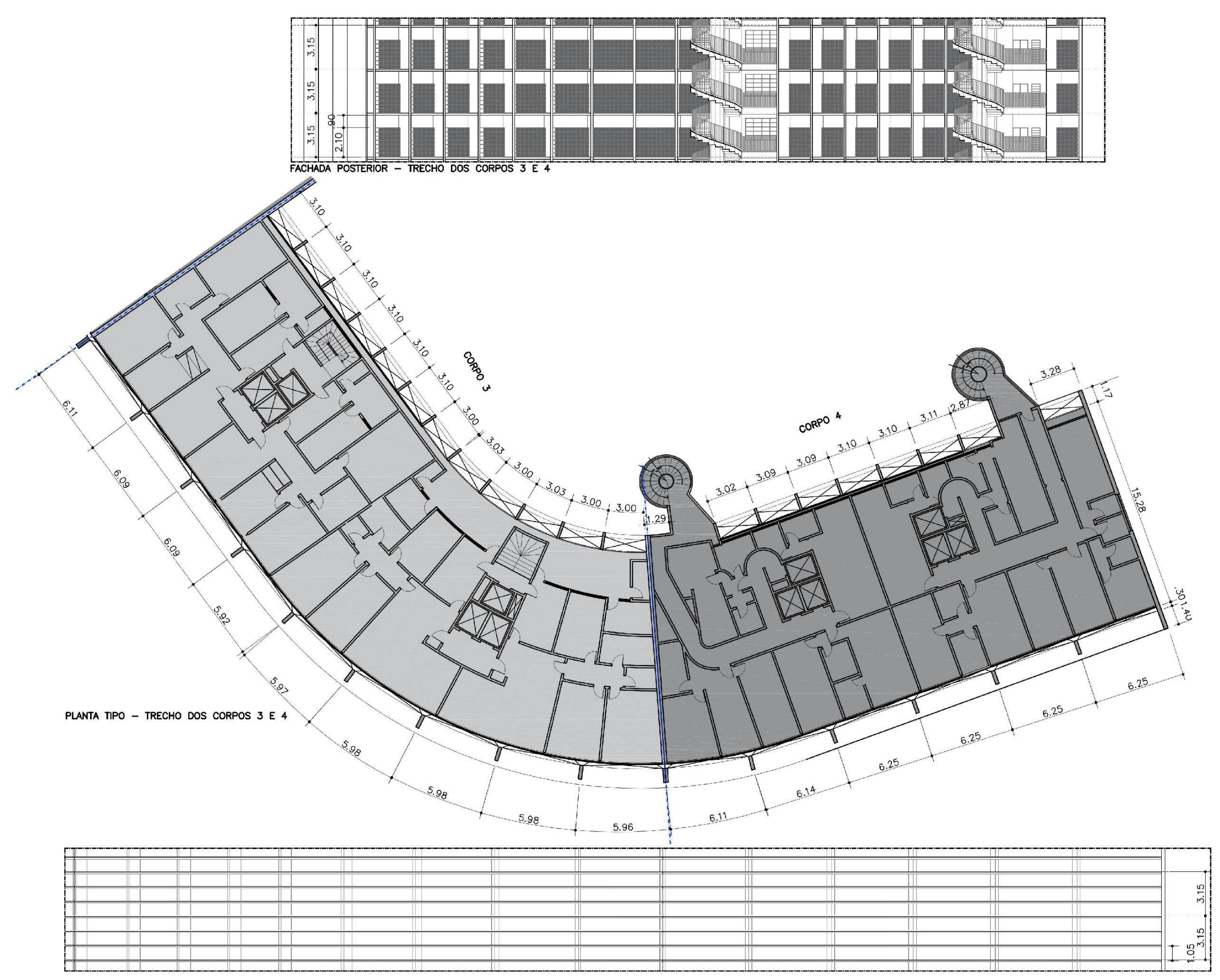

FACHADA PRINCIPAL - TRECHO DOS CORPOS 3 E 4

Figura 44 - As Built da Fachada Posterior, Planta e Fachada Principal dos Corpos 3 e 4

Fonte: Elaboração da autora. 


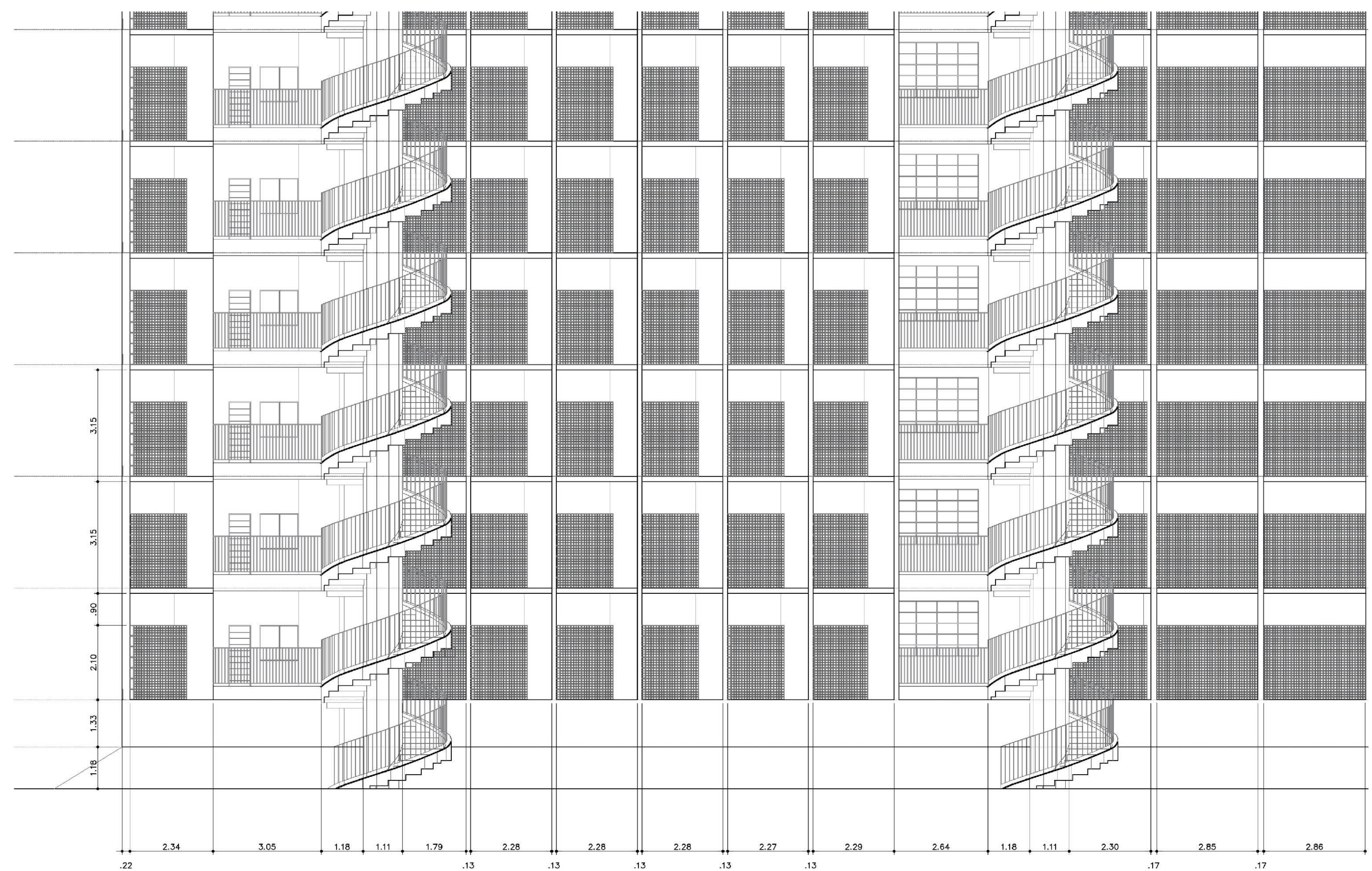

FACHADA POSTERIOR - TRECHO DOS CORPOS 3 E 4

Figura 45 - Ampliação da Fachada Posterior

Fonte: Elaboração da autora. 


\section{5 . \\ MATERIAIS E TÉCNICAS CONSTRUTIVAS ORIGINAIS DO EDIFÍCIO}

Aqui serão abordados aspectos relativos aos materiais e técnicas construtivas empregadas na construção do Edifício Copan, com o objetivo de formar um acervo documental do desenvolvimento técnico da época, embasado nos documentos oficiais, peças gráficas, ensaios e observação in loco.

memorial descritivo do edifício fornece algumas informações importantes. Todavia, documentos deste tipo costumavam ser produzidos anterior a construção e não eram atualizados. Ao lado disso o longo período de tempo da construção, assim como as alterações projetuais mencionadas anteriormente, fazem com que as informações nele encontradas sejam observadas com ressalvas, sendo necessário o confronto com outras informações para a averiguação se o que foi especificado em projeto foi realmente construído.

No acervo do Condomínio Copan foi encontrado um encarte da Companhia Pan-América - Hotéis e Turismo (figura 46) que traz um balancete das contas da construção, com a descriminação dos materiais comprados no período de 1951 a 1956.

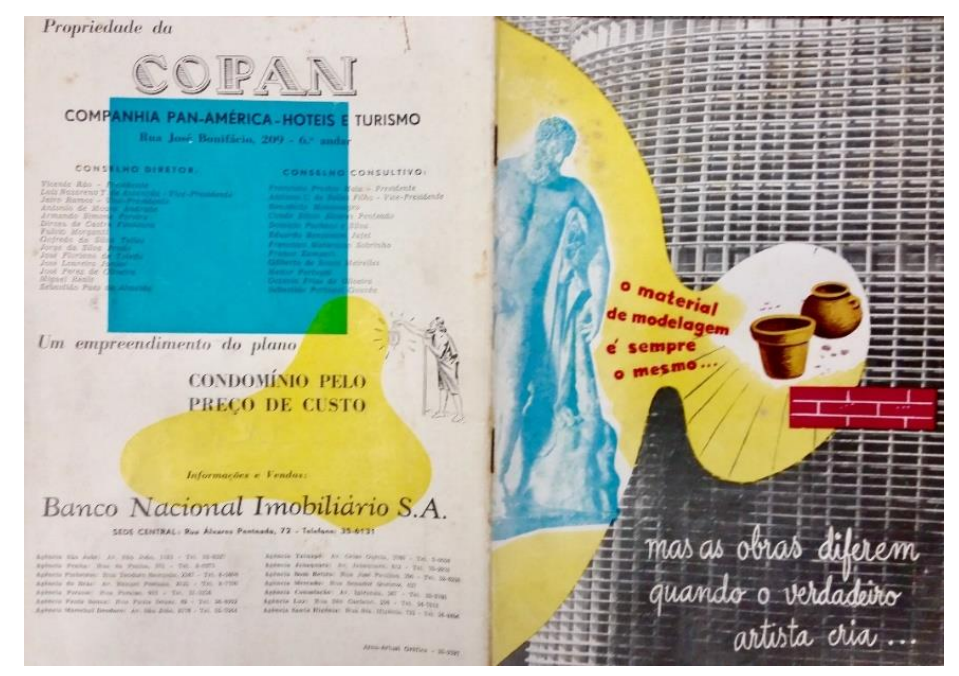

Figura 46 - Capa do encarte da Companhia Pan-América - Hotéis e Turismo Fonte: Acervo do Condomínio Copan. 


\subsubsection{FUNDAÇÕES}

O memorial descritivo de 1952 não especifica os tipos de fundações a ser utilizadas, diz apenas: "Fundações - as fundações serão diretas ou indiretas, dependendo dos estudos das camadas sub-jacentes do terreno."

No projeto de fundações, elaborado pelo escritório técnico Oswaldo de Moura Abreu, Waldemir Tietz e Nelson de Barros Camargo, com data de 1954, é possível ver as formas para os tubulões, onde constam altura mínima do bloco de $1,30 \mathrm{~m}$ e do topo do bloco até o baldrame do $2^{\circ}$ subsolo consta 5,03 de profundidade, conforme Figura 47.

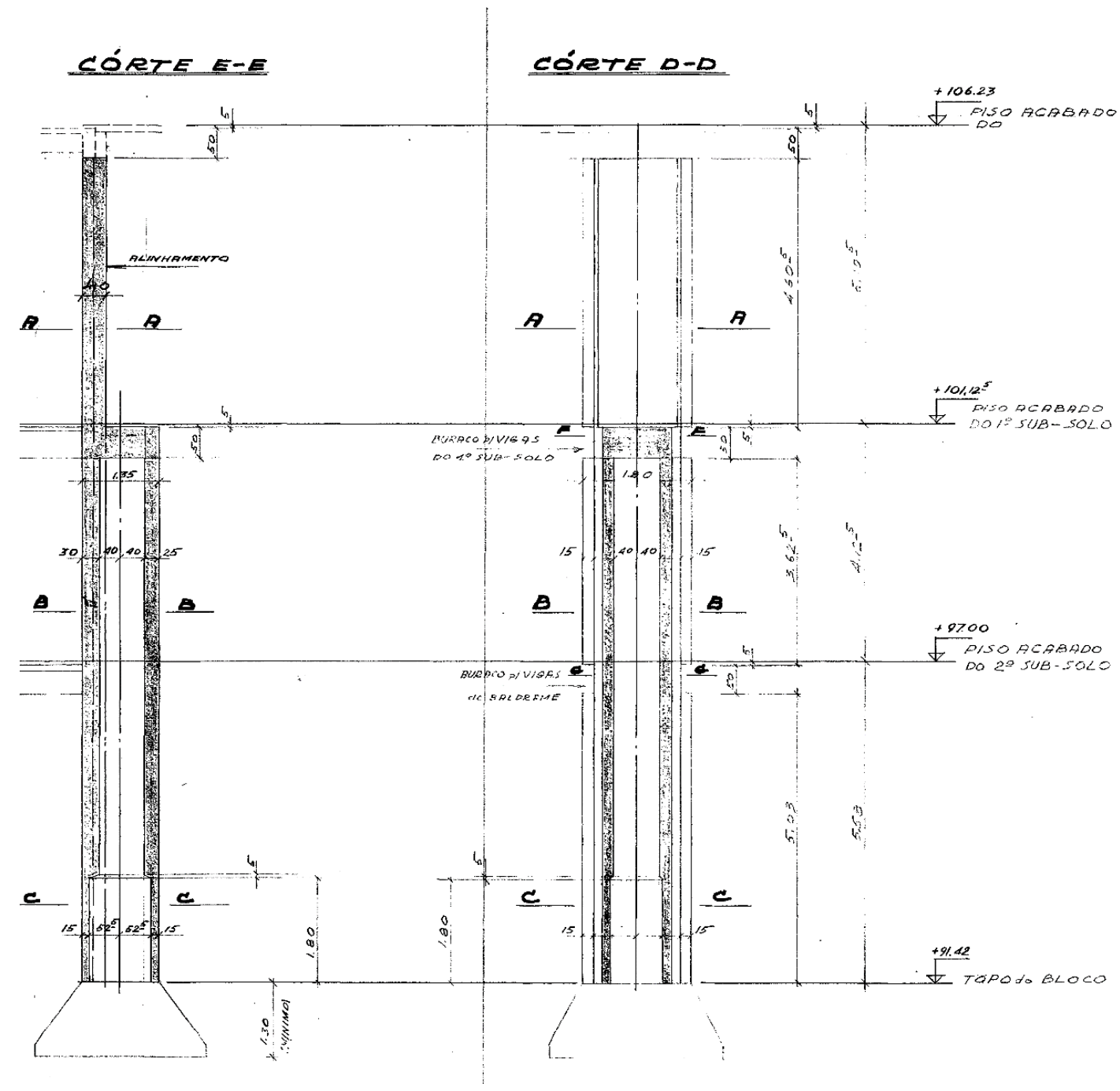

Figura 47 - Detalhe de Forma para os Tubulões

Fonte: Acervo do Condomínio Copan. 
De acordo com Galvão (2007), no final da década de 1950 os corpos 1 e 2 começaram a recalcar, devido ao tipo de fundação incompatível com o terreno arenoso. Houve uma prévia compactação do solo, realizado por meio de estacas de concreto armado com $8 \mathrm{~m}$ de comprimento, enterradas a $6 \mathrm{~m}$ de profundidade e com espaçamento de $1 \mathrm{~m}$ e posteriormente as fundações diretas e seus caixões pneumáticos foram posicionadas (BRANCO, 2013 apud VARGAS, 1975). Todavia não há registros das soluções adotadas, sendo incerta a localização exata das referidas estacas. Na figura 48 são representados os tubulões, as fundações diretas e as estacas de compactação.

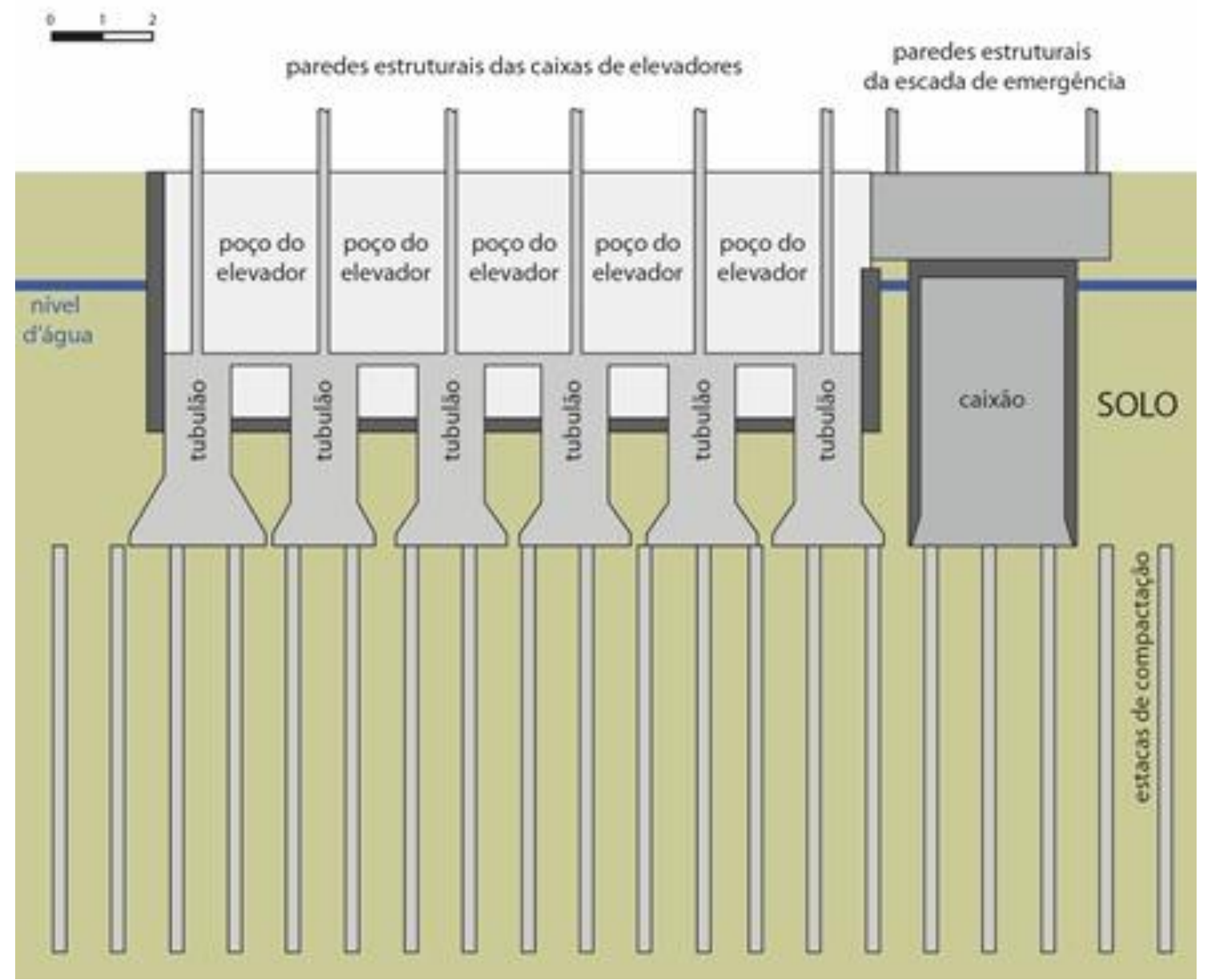

Figura 48- Corte das Fundações

Fonte: Marcel Branco, 2013. 
Embora o problema do recalque tenha sido estudado por técnicos do Laboratório Nacional de Engenharia Civil de Lisboa e pelos engenheiros do IPT (Instituto de Pesquisas Tecnológicas), tendo à frente o engenheiro Milton Vargas, teve a solução apresentada, segundo Lemos (2014) por Tadeusz Starzynski, que havia trabalhado durante 16 anos nas obras do Copan.

Desenvolvida pelo escritório técnico Franco da Rocha, a solução consistia em aumentar a área das sapatas (figura 49), que seriam empurradas para baixo por meio de macacos hidráulicos, compactando o solo arenoso abaixo. E, em 1960, já na fase de acabamento do Bloco B, o mais afetado, cujo desaprumo foi na ordem de $30 \mathrm{~cm}$, não havia sinais do avanço do recalque e desde 1958 o IPT vem monitorando o afundamento (LEMOS, 2014).

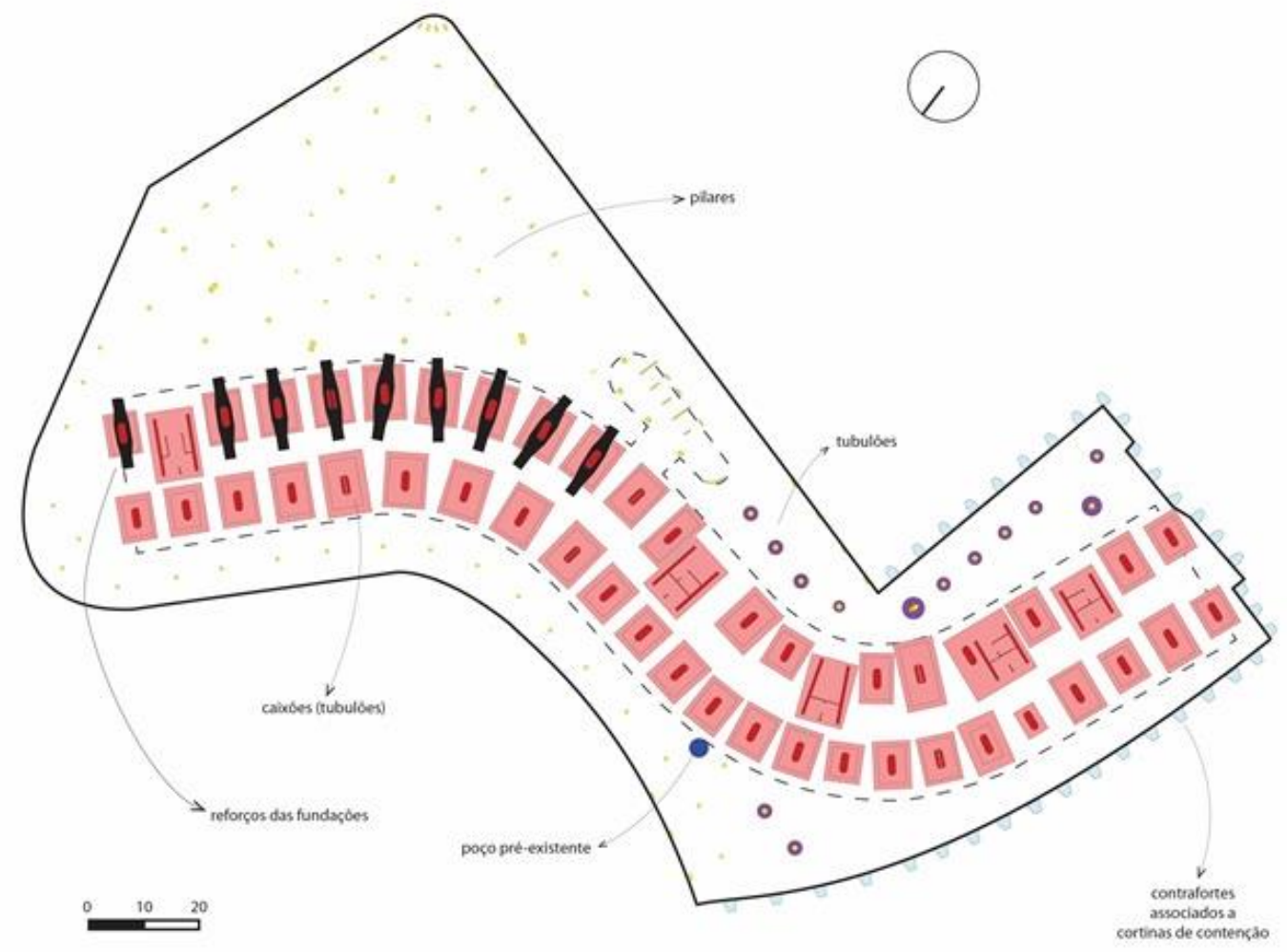

Figura 49- Reforço das Fundações

Fonte: Marcel Branco, 2013. 
Ao longo dos anos que se seguiram, muitas obras foram realizadas no entorno e, entre elas, duas linhas de Metrô. A partir da análise dos relatórios o IPT, Branco (2013) verificou que em duas situações a velocidade de sedimentação sofreu um aumento, sendo uma delas em 1975 e a outra em 2006, datas que coincidem com as Linhas Vermelha e Amarela do Metrô, respectivamente, localizadas muito próximas ao edifício.

Atualmente é possível verificar um avançado desnível no piso do $2^{\circ}$ subsolo do corpo 2 e uma significativa abertura da junta de dilatação entre os corpos 2 e 3 na cobertura, conforme Figura 50.

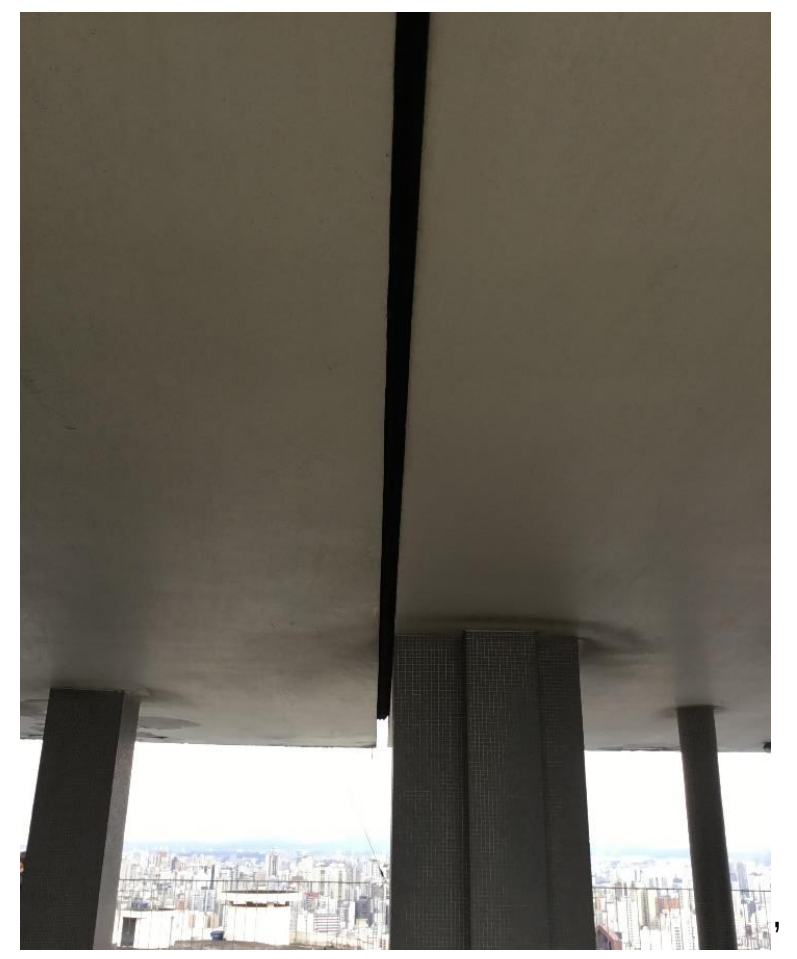

Figura 50 - Junta de Dilatação entre o Corpos 2 e 3

Fonte: Acervo da autora. 


\subsubsection{ESTRUTURA}

A estrutura do Copan foi concebida em concreto armado, como tantas outras obras de Niemeyer. Na Figura 51 é possível visualizar as armaduras da viga de transição antes da concretagem.

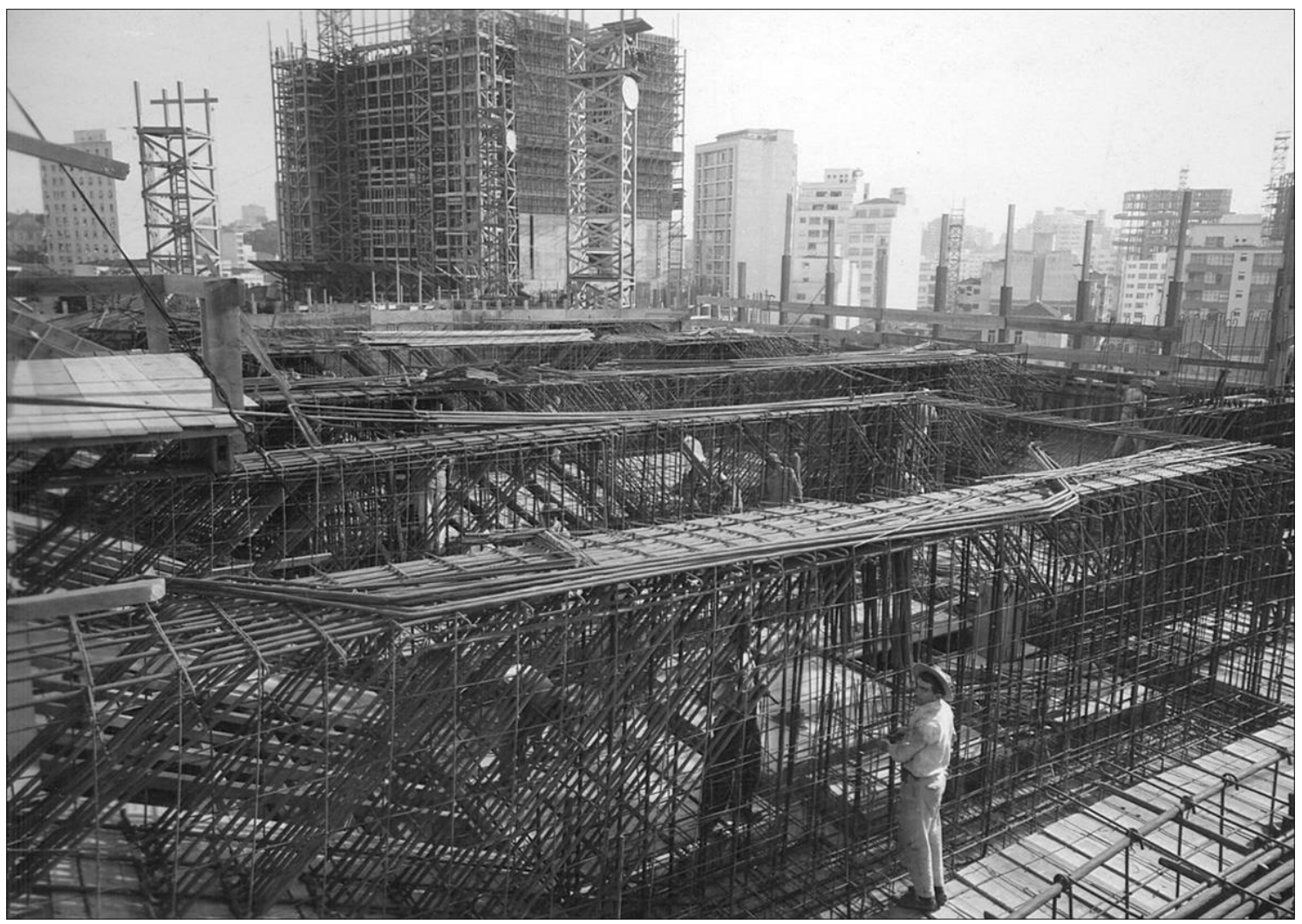

Figura 51 - Armaduras da Viga de Transição

Fonte: Acervo do Condomínio Copan.

No projeto de estrutura do Copan são encontradas as seguintes especificações: 37 CA; Aço Torcido; Aço Torstahl e Aço Comum5 (figuras 52 e 53). O número 37 representa o limite de ruptura em $\mathrm{kgf} / \mathrm{mm}^{2}$. Atualmente este aço corresponde, aproximadamente, ao atual CA-25, com suas barras lisas. $O$ aço torcido consistia em uma barra com duas nervuras longitudinais, que, a

\footnotetext{
${ }^{5} \mathrm{Na}$ prancha de 1954, "armadura das vigas do piso do térreo", elaborada pelo escritório técnico Oswaldo de Mouro Abreu, Waldemir Tietz e Nelson de Barros Camargo, consta tabela de resumo dos aços com os termos: 37 CA e Aço Torcido. Já na prancha de 1964, "fôrmas do forro falso e armação do mesmo", desenvolvida pelo escritório técnico Franco da Rocha, os termos utilizados nas tabelas de resumo das barras são: Aço Torstahl CA-T 50 e Aço Comum.
} 
partir da torção a frio, formavam duas linhas espiraladas (figura 54). Comercialmente era conhecido como aço Torstahl, de patente austríaca.

\begin{tabular}{|c|c|c|}
\hline \multicolumn{3}{|c|}{ ACO TORCIDO } \\
\hline$R$ & $5 U$ & 10 \\
\hline$\phi$ & MTS & KGS. \\
\hline $5 / 16$ & 7,30 & 3. - \\
\hline $3 / 8$ & 21.40 & $12 .-$ \\
\hline $1 / 2$ & 173.10 & $172 .-$ \\
\hline $5 / 8$ & 43,55 & $67^{5}$ \\
\hline $3 / 4$ & 177.20 & 396.- \\
\hline $7 / 8$ & 32.00 & $97-$ \\
\hline & TOTAL: & 7475 \\
\hline
\end{tabular}

\begin{tabular}{|c|c|c|}
\hline \multicolumn{3}{|c|}{$37 \mathrm{C} . \Delta$} \\
\hline$\frac{k}{b}$ & 5 UT & $\frac{0 .}{k \sigma_{5}}$ \\
\hline $3 / 16$ & 80.80 & 6. \\
\hline $1 / 4$ & 106.50 & 51. \\
\hline $5 / 6$ & $1 / 20.10$ & 16.5 \\
\hline $3 / 3$ & 13.20 & 7.5 \\
\hline $1 / 2$ & 35.85 & 35.5 \\
\hline & TOTA & 146.5 \\
\hline
\end{tabular}

Figura 52 - Tabela de Resumo dos Aços do Projeto de Estrutura do Copan Fonte: Acervo do Condomínio Copan.
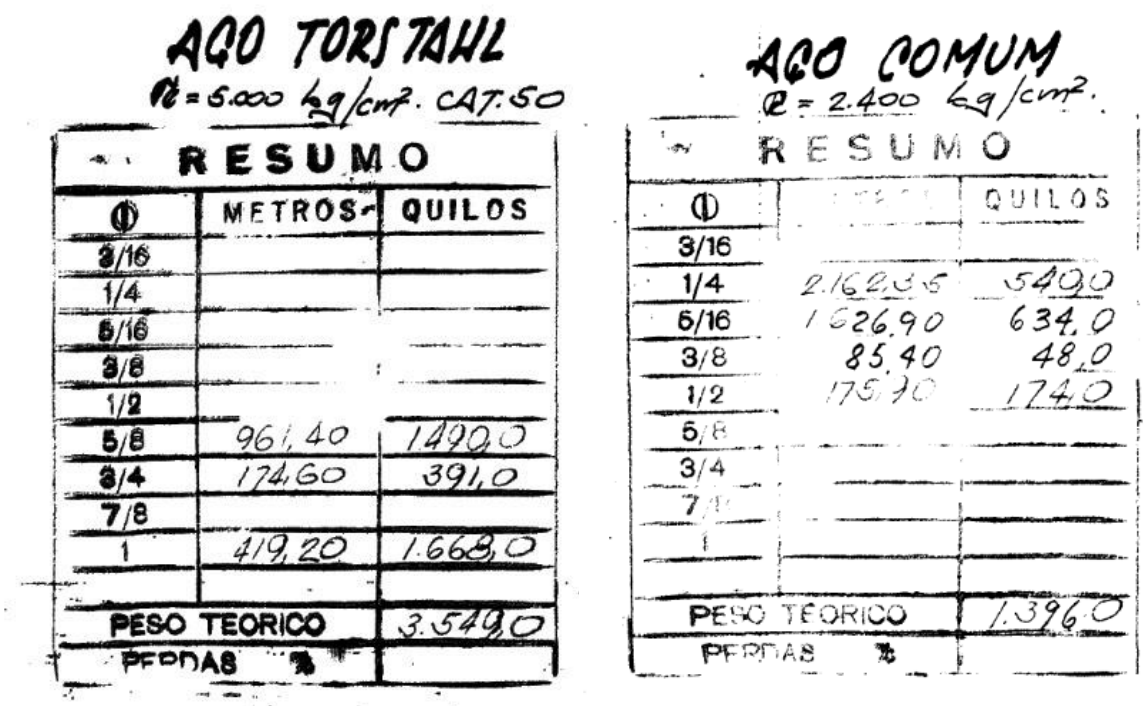

Figura 53 - Tabela de Resumo dos Aços do Projeto de Estrutura do Copan Fonte: Acervo do Condomínio Copan.

\section{TORSTAHL}

Figura 54 - Aço Torstahl

Fonte: Revista Técnica das Construções, 1965. 
Ao longo dos anos o aço sofreu transformação tanto no processo de produção quanto na nomenclatura e, se anteriormente o nome estava associado ao limite de ruptura, hoje está relacionado com a tensão de escoamento.

O encruamento, endurecimento por deformação plástica, a frio, ocorre a uma temperatura abaixo de $720^{\circ} \mathrm{C}$, promove $\mathrm{o}$ aumento da resistência mecânica e da dureza, mas, ao mesmo tempo, diminui a resistência à corrosão e da ductilidade, bem como maior dificuldade de solda. Enquanto no tratamento a quente, ou seja, processo com temperatura acima de $720^{\circ} \mathrm{C}$, o aço apresenta melhor trabalhabilidade, possibilidade de solda e não perde suas propriedades mecânicas quando aquecido, seu limite de escoamento é resistente a incêndios moderados, uma vez que perde resistência com temperaturas acima de $1.150^{\circ} \mathrm{C}$ (PINHEIRO et al., 2003).

A NB-1, vigente em 1960, recomendava o dobramento a frio do aço 37CA, para as barras das armaduras e, havendo a necessidade de ser feito a quente, este não poderia ser excessivo, a fim de não prejudicar as qualidades do material, e as barras de aço CA-T 40 e CA-T 50 deveriam sempre ser dobradas a frio (ABNT/NB-1, 1960). Essa recomendação demonstra os cuidados para que o aço não perdesse suas propriedades mecânicas durante o aquecimento.

Atualmente as barras de aço lisas não são mais utilizadas no concreto armado, devido às suas características inconvenientes de aderência.

Por meio de furos efetuados na laje da torre dos elevadores do Bloco B, abertos para passagem de tubulações, foi possível verificar as espessuras da laje e do contrapiso. A espessura da laje é de aproximadamente $6 \mathrm{~cm}$, delimitada pelos agregados graúdos do concreto, 0 contrapiso com coloração mais clara e a forma de madeira deixada no caixão perdido, conforme Figura 55. 


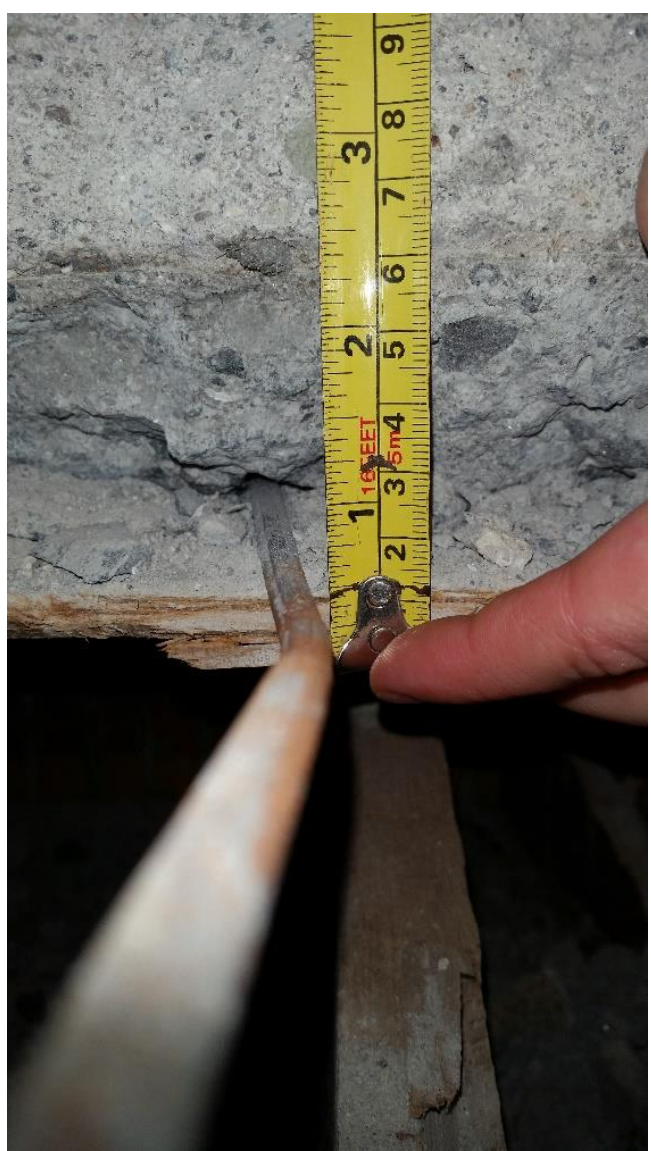

Figura 55-Laje e contrapiso da Torre dos Elevadores do Bloco B Fonte: Acervo da autora.

As lajes dos andares são do tipo nervuradas e na Figura 56 observa-se um trecho do projeto de armadura de laje e nervura do $33^{\circ}$ teto corpo 3, no qual são apresentas as dimensões e espaçamento das nervuras, espessura da laje e a especificação das barras de aço. Em inspeção feita in loco no teto de apartamento do Bloco D, também no corpo 3, foi possivel aferir a largura da nervura (figura 57), que corresponde com o projeto. As formas de madeiras ainda se encontram nas nervuras e na parte inferior destas há um forro de estuque com fibras naturais. 


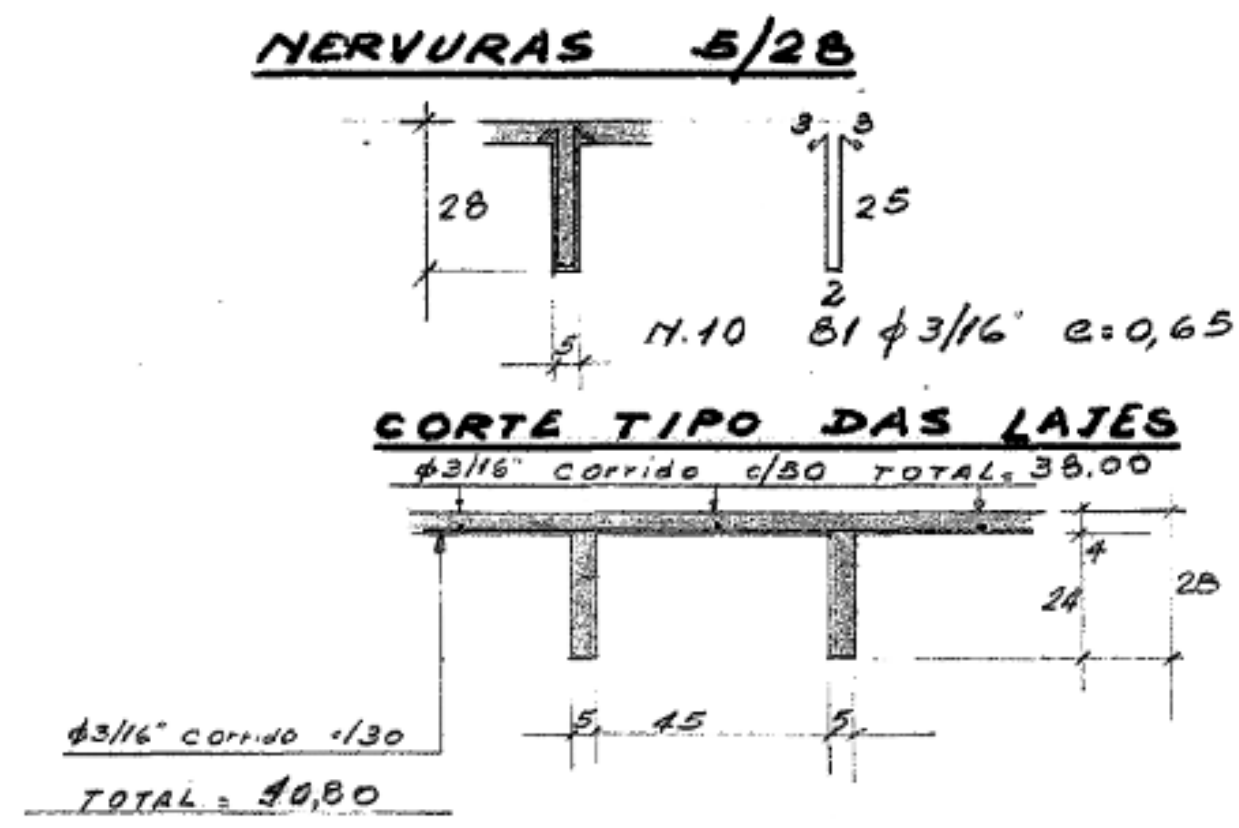

Figura 56 - Detalhe da Laje Nervurada

Fonte: Acervo do Condomínio Copan.

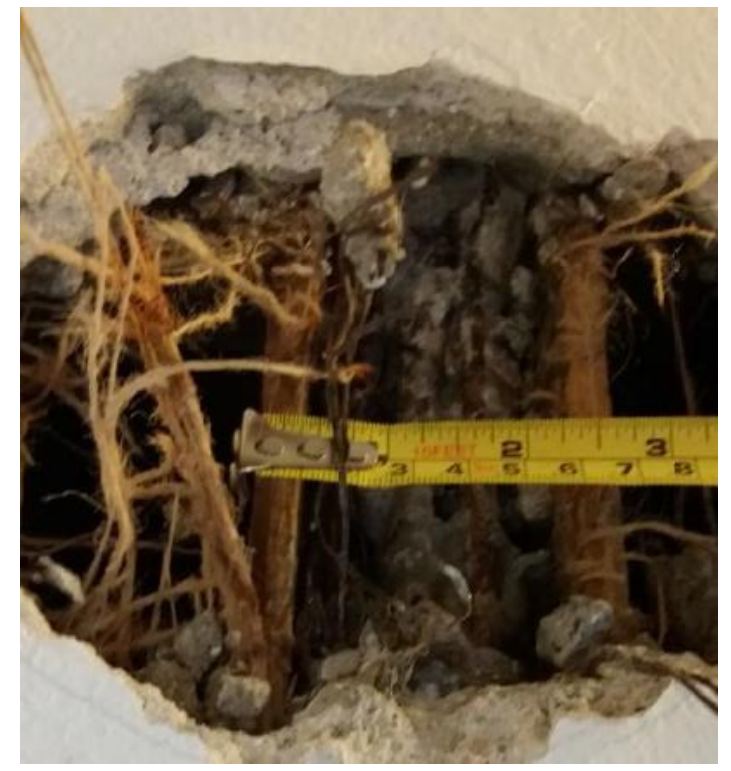

Figura 57 - Detalhe da Laje Nervurada e Forro de Estuque Fonte: Acervo da autora. 
A partir da análise do projeto de estrutura foi possível identificar os tipos de aço especificados que eram utilizados na ocasião da construção, bem como suas propriedades mecânicas e, por meio dos levantamentos feitos in loco, foi possível a comparação do projeto com o executado e, desse modo, auxiliar na documentação das características técnicas do edifício.

\subsubsection{VEDAÇÕES VERTICAIS}

O memorial descritivo do projeto de 1952 especifica para as vedações "tijolos furados e comuns". Em apartamento do Bloco B, com face para a fachada posterior, foi encontrada alvenaria de vedação construída com bloco cerâmico de 6 furos (figura 58) e nas alvenarias externas foram encontrados tijolos cerâmicos maciços (figura 59), corroborando a informação encontrada no memorial descritivo e na discriminação dos materiais que constavam no encarte da companhia.

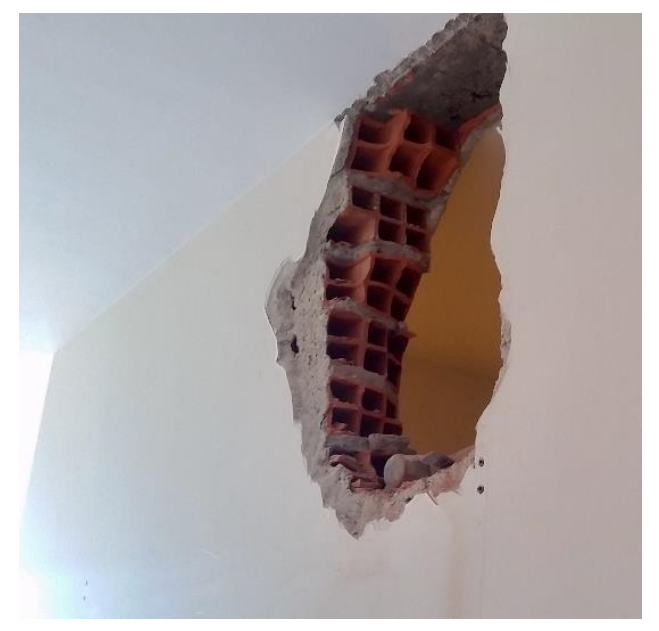

Figura 58 - Alvenaria interna de vedação com blocos cerâmicos

Fonte: Acervo da autora.

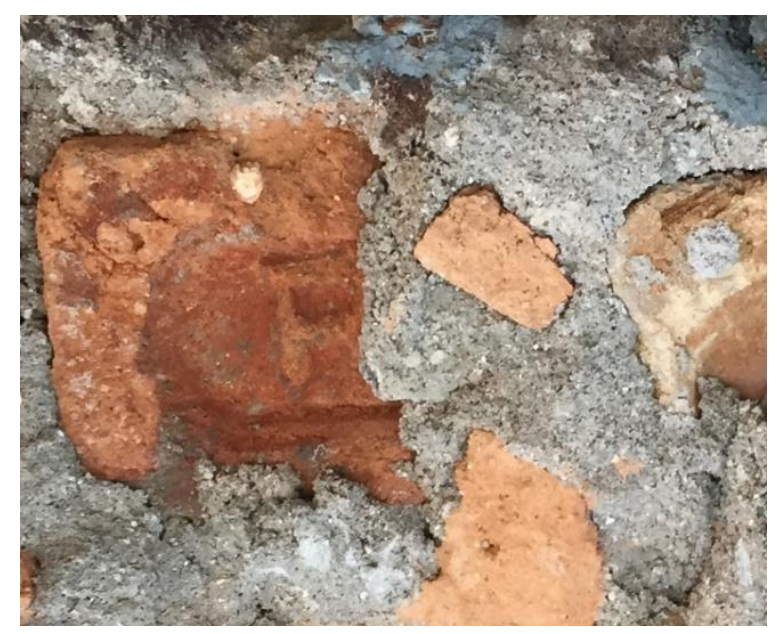

Figura 59- Tijolo na fachada do Copan

Fonte: Acervo Marianna Tonini.

Durante as obras de recuperação das fachadas foi possível retirar, sem causar danos ao subsistema de vedação do edifício, quatro exemplares íntegros de tijolos (figuras 60). As amostras, medindo 21,5 × 10,5 ×5 
$\mathrm{cm}$, contêm as marcas das respectivas olarias, o que suscitou questionamentos acerca de local e métodos produtivos.

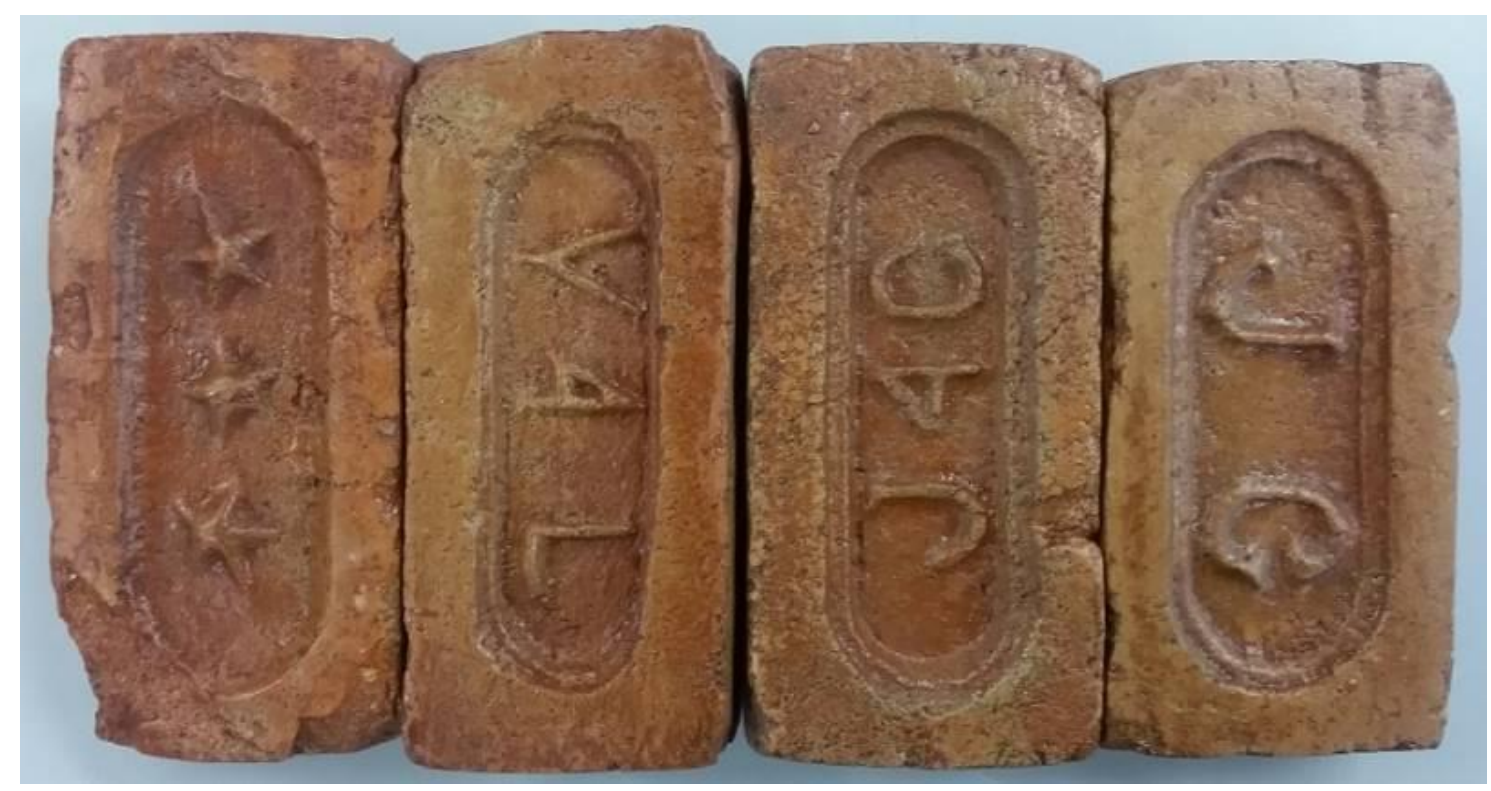

Figura 60 - Tijolos retirados das fachadas do Copan

Fonte: Acervo da autora.

Deu-se início a uma pesquisa com o objetivo de rastrear a origem dos tijolos utilizados no Edifício Copan. Durante o período da construção era comum o processo de produção dos tijolos maciços cerâmicos de maneira artesanal, sendo fabricados por olarias informais, portanto sem registro. $\bigcirc$ levantamento da informação acerca de local e métodos de produção dos tijolos é uma importante forma de documentação material do processo de construção e, após uma longa busca, houve a indicação do Professor Lúcio Gomes Machado de que alguma informação relevante seria encontrada em Ribeirão Pires, município a 33 km do centro de São Paulo.

A região de Ribeirão Pires foi um importante polo de produção de tijolos e devido à proximidade com a ferrovia, tinha sua produção facilmente escoada para a capital. De acordo com Del Corto (2006) entre as décadas de 30 e 50 Ribeirão Pires ficou conhecida como a cidade das olarias. 
O museu da cidade conta com um grande acervo material, embora sem catalogação ou informações complementares no que concerne aos tijolos. De todo modo, funcionários e diretor muito solícitos intermediaram o contato com dois senhores integrantes da Associação de Preservação e Memória da Cidade - o Sr. Joel Maziero (descendente de oleiros), que guarda um arquivo pessoal com os nomes das olarias e uma ficha catalográfica com as imagens dos tijolos produzidos por uma boa parte delas, e o Sr. Pedro Manuel Cordeiro, profundo conhecedor dos processos de produção. Ambos relataram um pouco da história da cidade e sua produção oleira, e, ao analisarem as imagens dos tijolos do Copan, reconheceram três dos tijolos como tendo sido produzidos em Ribeirão Pires.

O tijolo com a marca de três estrelas (figura 61) pôde ser encontrado no catálogo do Sr. Joel Maziero, o com a marca J4C foi atribuído à olaria José Machado da Cunha, e O V4L como sendo produzido por Vincenzo Laurito. O sobrenome Laurito é encontrado em Simões (2008), de acordo com o autor Josefina Pandofi Laurito era coproprietária de uma olaria e chegara na cidade 1885.

O sistema de marcação utilizado na época obedecia ao seguinte critério: a primeira marca era a inicial do prenome do dono da olaria; a marca do meio, regra geral, um numeral, indicando o número da fileira na qual o tijolo foi produzido, e a terceira marca era a inicial do sobrenome da família. A impressão do número no tijolo permitia eventual rastreamento caso algum lote apresentasse problemas. A Figura 60 apresenta os tijolos tirados do Copan, os nomes das olarias de Ribeirão Pires atribuídos a eles e o catálogo parcial do Sr. Maziero. 


\section{TIJOLOS DO COPAN}
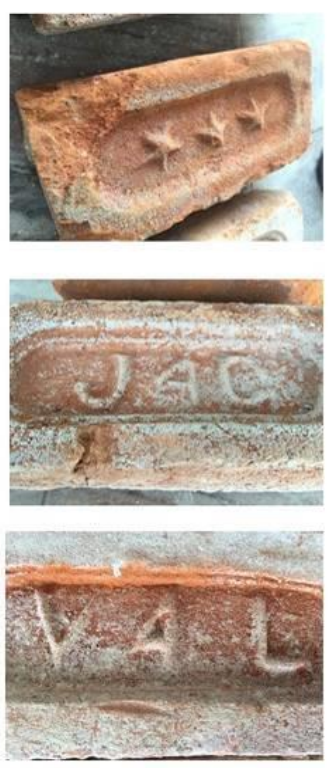

NOMES DAS OLARIAS

DE RIBEIRÃO PIRES

\section{Olaria Três Estrelas}

José Machado da Cunha

Vincenzo Laurito
CATÁLOGO SR. JOEL MAZIERO
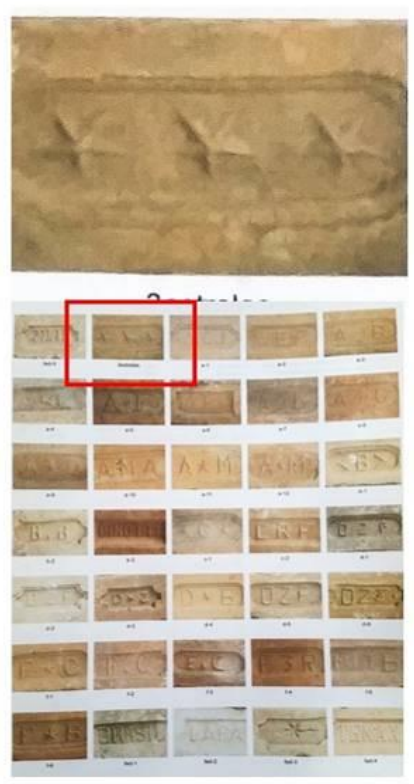

Figura 61 - Comparativo dos tijolos do Edifício Copan com as informações de Ribeirão Pires

Fonte: Acervo da autora.

O processo de produção dos tijolos tinha início com o carroceiro, que no final da tarde ia até o barreiro, local onde havia grande quantidade de barro de boa qualidade, para extrair o material. Carregava o barro em uma carroça e o levava para o picador, responsável pelo preparo da matériaprima. Em um local quadrado eram colocadas camadas de barro entremeadas com camadas de terra, formando um "sanduíche". Depois o picador recolhia essa mistura com uma pá e a jogava dentro da pipa. A pipa era um equipamento circular feito de madeira, que ficava apoiado no chão. Na parte superior, disposto horizontalmente, tinha um tronco de árvore, a manjara, que era atrelado a um burro ou cavalo que ficava andando em volta da pipa, girando o eixo que promovia a mistura do material.

Conforme o barro era misturado, na parte inferior da pipa saía a pasta pronta. O pipeiro então pegava o barro, colocava-o em um carrinho de mão com duas rodas e base plana, e o levava até o terreiro. O terreiro era um 
local plano, sem cobertura, onde ficavam dispostas várias linhas de bancadas para a produção dos tijolos. O pipeiro distribuía o barro no chão, próximo a cada bancada. Na bancada trabalhava o batedor, o responsável pela moldagem dos tijolos. O batedor untava a fôrma de madeira com areia fina para desmoldar os tijolos com facilidade. Em seguida pegava uma pelota de barro e a arremessava para dentro da fôrma. Com o impulso, o barro que era jogado preenchia toda a fôrma. O batedor pegava então um instrumento em forma de arco, com um arame na parte inferior, e passava na face superior da fôrma para tirar o excesso de barro, deixando a superfície plana. Depois disso dava quatro batidas com a fôrma na bancada, uma de cada lado, para que o tijolo descolasse e fosse desenformado.

O lançador, o responsável por enfileirar os tijolos, pegava o tijolo com duas paletas de madeira, para não marcar o tijolo que ainda estava mole, e colocava o tijolo enfileirado no terreiro, deixando sempre um intervalo entre um tijolo e outro. À medida que iam batendo os tijolos, eles iam avançando no terreiro, de modo que a produção ia ficando enfileirada, até que ficassem um pouco mais rígidos e pudessem então ser empilhados. Posteriormente os tijolos eram emparedados, ou seja, eram dispostos de forma organizada, cruzando as camadas, sempre com um espaço entre eles. Assim eram deixados no terreiro por alguns dias, dependendo da condição climática, para que pudessem secar. Por cima das pilhas de tijolos eram colocadas telhas para evitar que uma eventual chuva estragasse a produção. Depois que os tijolos estavam secos eram levados para o forno. O forno geralmente tinha duas bocas de fogo e os tijolos eram dispostos formando um túnel, para homogeneizar a queima, sempre deixando um espaço entre eles. Na parte superior e na entrada do forno era colocada uma camada de barro para selar o forno e não deixar que o calor escapasse. O processo de queima era comandado pelo foguista, responsável por manter o fogo inicialmente lento, para dar uma aquecida no forno, depois vinha o fogo pesado e, por último, o fogo de manutenção. Esse processo de queima levava até três dias. Terminada a queima, dava-se início ao processo de resfriamento dos tijolos para poder desenfornar. Por último, os tijolos eram transportados até a estação de trem, carregados e despachados para Santos, São Paulo e região. 
A produção dos tijolos começava por volta das 4 horas da manhã e ia até as 10 ou 11 horas. Nesse horário cada batedor já tinha produzido, em média, 1.500 tijolos. Até às 15 horas os tijolos secos, da produção de dias anteriores, eram enfornados para queima.

Não há comprovação cabal de que os tijolos do Edifício Copan vieram de fato de Ribeirão Pires, mas há fortes evidências de que isso tenha ocorrido. Todavia, o conhecimento acerca da produção do componente nos ajuda a valorizar ainda mais a história e configura-se como importante fonte de documentação dos processos produtivos dos componentes empregados na construção. 


\subsubsection{REVESTIMENTO EXTERNO ORIGINAL}

Até meados da década de 1940 as fachadas dos edifícios altos eram frequentemente revestidas com pedra natural no térreo e sobreloja e, a partir do $1^{\circ}$ pavimento era utilizado o revestimento de "pedra fingida"6, que consiste em uma argamassa cimentícia com adição de agregados que the conferia a aparência de revestimento pétreo (CUNHA, 2017). Este paradigma só foi rompido em 1947, quando o Edifício Altino Arantes, sede do Banco do Estado de São Paulo, teve suas fachadas acima da sobreloja revestidas com pastilhas de porcelana (REVISTA ACRÓPOLE, 1947), componente que até então era utilizado nos pisos dos edifícios ecléticos (COELHO, 2003).

Diante do advento das pastilhas como revestimento de fachada, a pedra fingida caiv em desuso por ser um processo muito artesanal e que requeria uma mão de obra especializada e com custos elevados de aplicação e manutenção, enquanto que as pastilhas apresentavam vantagens de instalação e manutenção em relação à pedra fingida. $O$ impacto do uso das pastilhas na construção civil da época foi tão intenso, que edifícios projetados para serem revestidos com pedra fingida, tiveram 0 acabamento decorativo modificado durante a execução para pastilhas de porcelana, como o caso do edifício do INSS e do edifício Sede do Banco do Brasil, inaugurados respectivamente em 1952 e 1955 (CUNHA, 2016). Mas foi a partir da década de 1950 que o revestimento de pedra fingida foi praticamente abondado para dar lugar às pastilhas de porcelana como revestimento de inúmeros edifícios modernos, entre eles o Copan.

As pastilhas de porcelana ganharam força como revestimento padronizado e moderno e chegaram junto com a industrialização brasileira, que de acordo com Coelho (2003), na década de 1950 estavam em atividade no estado de São Paulo as seguintes empresas: Indústria Paulista de Porcelanas Argilex S/A; Cerâmica Jatobá S/A; Vidrotil; Mosaico Cristais Veneza S/A; Indústrias Reunidas Vidrobrás Ltda.; C. Pugliese \& Cia. Ltda.; Dema; Lompi e Atlas.

\footnotetext{
${ }^{6}$ Termo utilizado por CUNHA (2016), mas também conhecida como: argamassa raspada, massa lavada, cimento penteado, argamassa de pó de pedra, cirex, entre outros.
} 
No memorial descritivo do projeto de 1952 e no projeto modificativo, aprovado em 1972, foram especificadas pastilhas de porcelana, enquanto no encarte da Companhia Pan-América - Hotéis e Turismo o memorial descritivo especifica para os revestimentos externos "pastilhas de porcelana e de vidro, tipo Argilex ou semelhante", tendo sido utilizados as de porcelana, nas cores branca e cinza, nas medidas $1.9 \times 1.9 \mathrm{~cm}$, conforme Figuras 62 e 63.

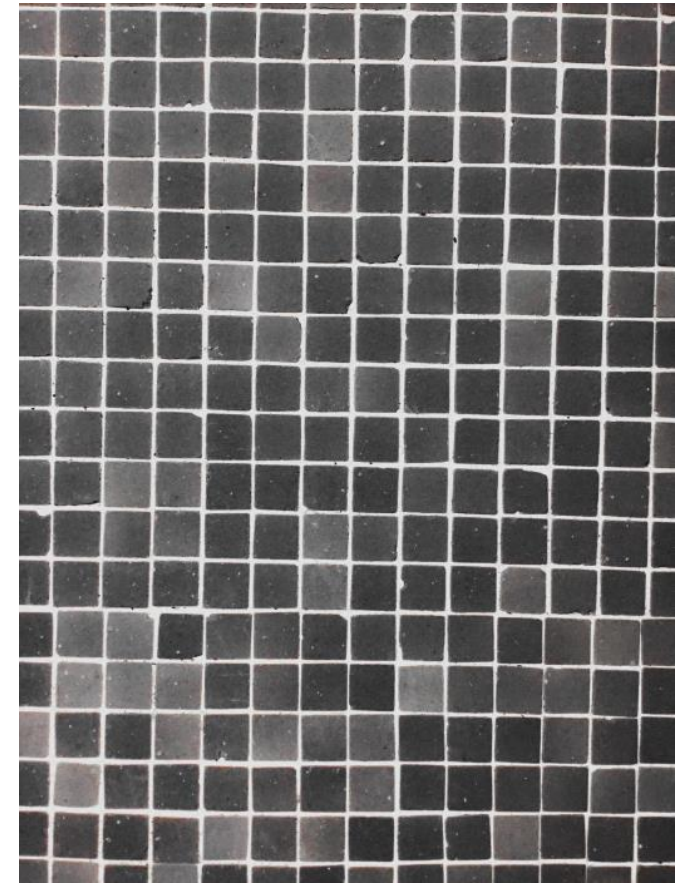

Figura 62 - Pastilha Original Cinza Fonte: Acervo da autora.

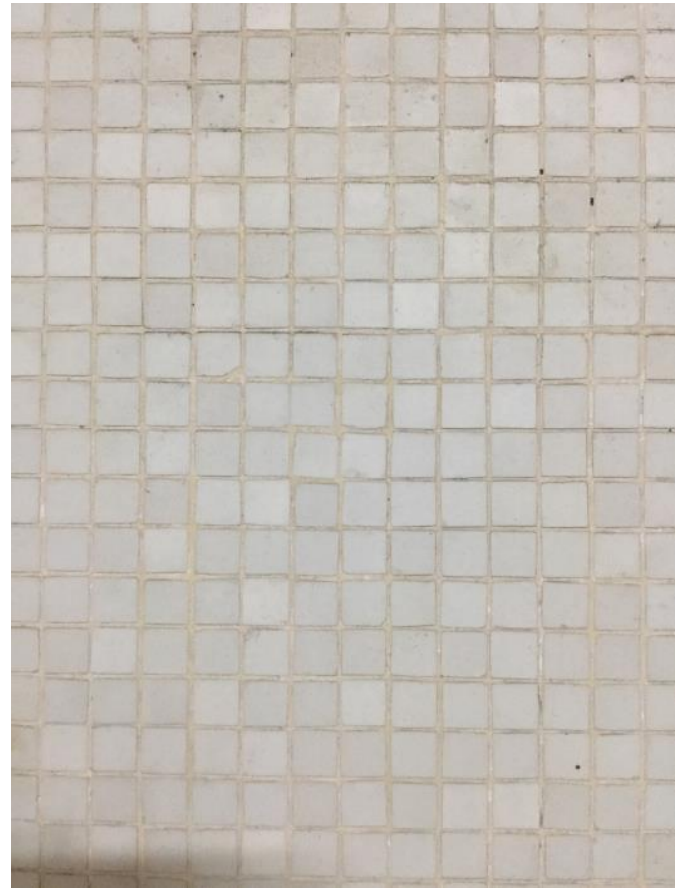

Figura 63 - Pastilha Original Branca Fonte: Acervo da autora.

O subsistema original é formado por revestimento em duas camadas: emboço e reboco, sobre o qual é assentado o acabamento decorativo, as pastilhas de porcelana. O emboço é aplicado sobre alvenaria e estrutura de concreto, o reboco é aplicado sobre o primeiro e serve de suporte para o assentamento das pastilhas. Na Figura 64 é possível observar as camadas de argamassa que compõem esse subsistema. 


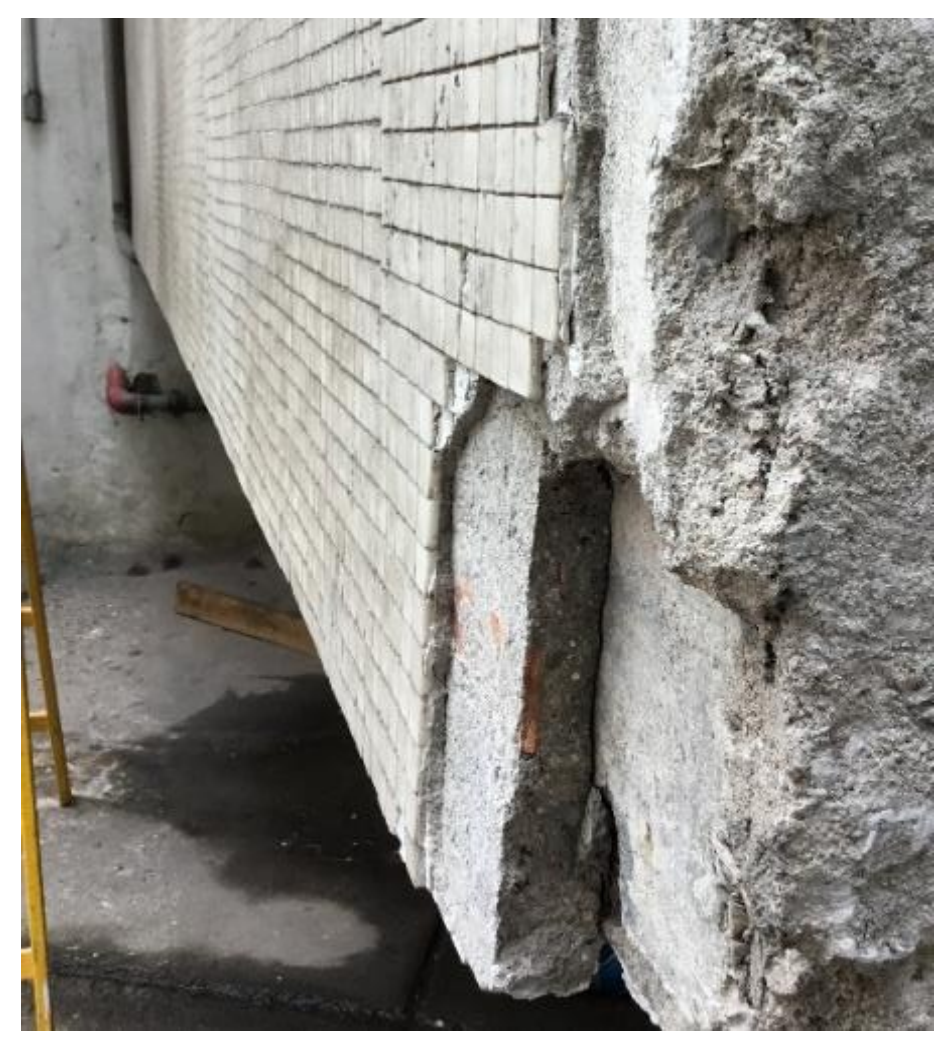

Figura 64- Subsistema de revestimento de argamassa do Copan Fonte: Acervo da autora. 


\subsection{PROBLEMÁTICA DO COPAN}

O Copan é um edifício emblemático, que após as alterações projetuais e consequentes transformações sofridas durante a fase inicial da obra, se estabeleceu como ponto de grande interesse da sociedade paulistana da época. Com o passar dos anos veio uma época de decadência e, após um período de recuperação, a longa fase de reconhecimento institucional enquanto patrimônio arquitetônico. A problemática do Copan acompanha de perto sua grandiosidade, tudo nele é gigantesco, até mesmo os problemas. Devido à ausência de manutenção por décadas, suas fachadas - que Ihe conferem sua característica mais marcante - foram sofrendo um processo de degradação decorrente da ausência de manutenção e envelhecimento dos materiais e componentes. Posteriormente iniciou-se um processo de reconstrução das fachadas sudoeste e noroeste, bem como a remoção de algumas partes soltas do revestimento externo da torre dos elevadores do Bloco B, mas atualmente as obras se encontram paralisadas, as referidas fachadas sem o acabamento decorativo e fachada principal protegida com telas e bandejas na parte inferior.

Embora a construção só tenha sido concluída em 1972, com auto de vistoria expedido em 21 de fevereiro de 1974, o edifício começou a ser parcialmente ocupado a partir do seu primeiro habite-se, que data de 26 de maio de 1966. E com seus 52 anos de ocupação, o Edifício Copan atinge o tempo mínimo estabelecido pela NBR15575/2013 para a vida útil de projeto (VUP) da estrutura. Em que pese o edifício ser muito anterior à norma e esta não ser retroativa, é nela que se encontram parâmetros nacionais para mensurar o desempenho das edificações e de suas partes, dando início a uma reflexão acerca de conceitos como sustentabilidade, vida útil, durabilidade, atualização de sistemas e, principalmente, a conservação do patrimônio arquitetônico, que requer uma vida útil superior que a estabelecida pela norma.

Ao longo de seus 52 anos o subsistema de revestimento externo passou a se deteriorar e o desplacamento do acabamento decorativo que reveste suas fachadas - as pastilhas de porcelana - tornou-se frequente. Em 
imagem publicada em 1991 (figura 65), a fachada noroeste aparece com uma grande área de desplacamento nos primeiros andares. Com o passar dos anos o problema foi se agravando até chegar ao ponto de pôr em risco a segurança dos transeuntes, sendo necessária a colocação de telas de proteção para evitar acidentes.

As manifestações patológicas nas fachadas do Copan não se resumem ao desplacamento de pastilhas, nelas são encontradas:

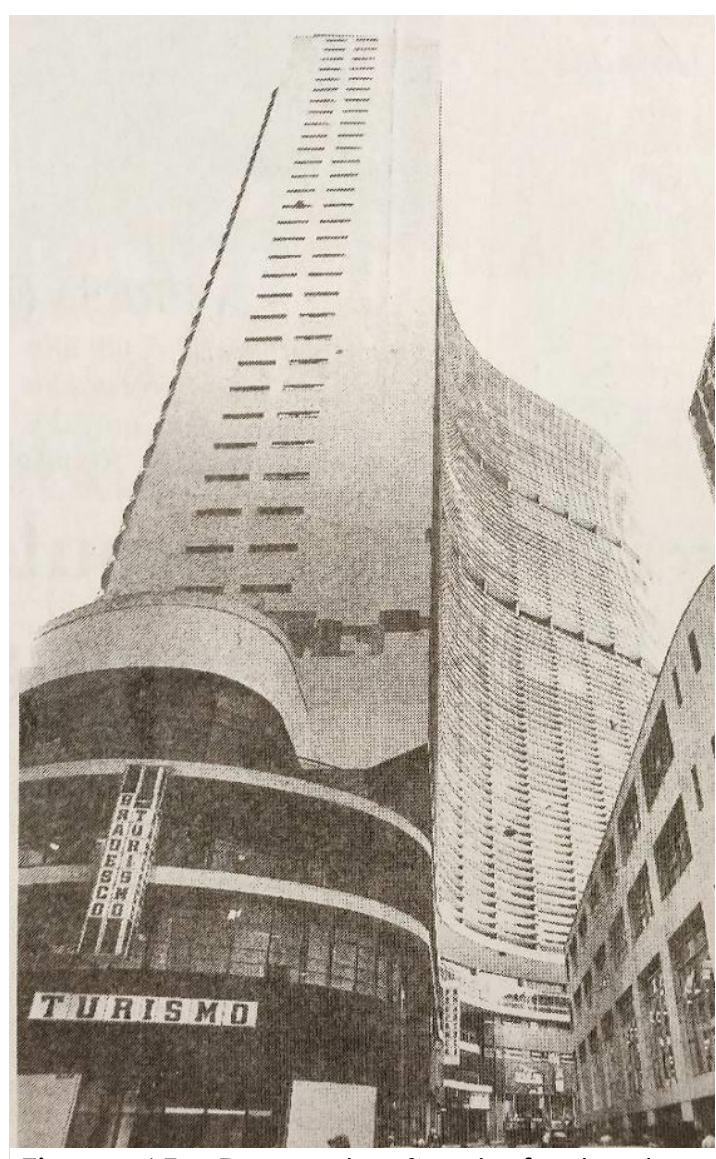

Figura 65 - Degradação da fachada publicada em 1991 pelo jornal Folha de São Paulo

Fonte: Acervo do Edifício Copan.
- descolamento do acabamento decorativo e do revestimento de argamassa;

- fissuras;

- concreto desagregado;

- armadura exposta;

- corrosão de armaduras;

- lacuna dos rejuntes;

- colonização biológica;

- sujidade.

Ante as manifestações patológicas existentes há a necessidade de tratamento para sanar as causas e reestabelecer o desempenho do subsistema de revestimento externo. Todavia, é

nesse ponto que se encontra toda a problemática associada às fachadas do edifício, pois é um patrimônio arquitetônico, reconhecido pela sociedade e salvaguardado pelo órgão de proteção, e as ações, frequentemente utilizadas para recuperação de edifícios genéricos, que substituem os materiais e componentes alterando as características originais, não se aplicam para o 
Copan. Pois tanto a sua estética quanto os seus elementos são testemunhos de uma época a serem preservados, não cabendo, portanto, a sua substituição indiscriminada.

E se por um lado os elementos do subsistema de revestimento externo devem ser preservados como testemunho histórico, por outro o avançado estágio de degradação muitas vezes impossibilita a sua recuperação, uma vez que o desempenho perdido não pode ser recuperado, sendo inevitável a substituição.

E sendo inevitável a substituição, preocupações com as características estéticas originais devem pautar a escolha dos novos elementos, na tentativa de reconstruir de acordo com um estágio anteriormente conhecido e que atenda aos requisitos de desempenho estabelecidos em norma, levando em consideração a durabilidade e vida útil desses elementos. Uma vez que os aspectos patrimoniais e os altos custos envolvidos não permitem substituições sucessivas, destaca-se a importância da manutenção preventiva para mitigar a degradação natural dos materiais e componentes, e também das políticas de conservação, a fim de resguardar as características do patrimônio.

As pastilhas produzidas na época da construção do Copan (1952-1972), já não se encontram mais em linha comercial, sendo necessária uma produção especial para atender às demandas de material e formato, implicando custos elevados e disponibilidade de empresas capazes de tal fabricação.

Após longo período sem ações de manutenção as fachadas do Copan atingiram um avançado estágio de deterioração, comprometendo o desempenho do subsistema de revestimento externo e a aparência patrimonial do edifício. E com o objetivo de sanar a problemática e resgatar a aparência estética das fachadas foi realizado, entre 2013 e 2014, um diagnóstico das manifestações patológicas das fachadas do Copan e, em 2015, foi desenvolvido um projeto executivo de revestimento, no qual foram 
especificados os materiais e componentes a serem utilizados para reconstrução das fachadas.

Em 2015 foi iniciada a obra para a remoção total das pastilhas (segundo recomendações do diagnóstico realizado) e das partes sem aderência da camada de emboço das fachadas sudoeste, noroeste e da torre dos elevadores do Bloco B. Na sequência foi realizado o revestimento de argamassa de camada única, com argamassa industrializada, nas fachadas sudoeste e noroeste (figura 66). No final de 2016 houve a paralização da obra e até o término deste trabalho (fevereiro de 2019) não há definição de quando serão retomadas as atividades nas fachadas.

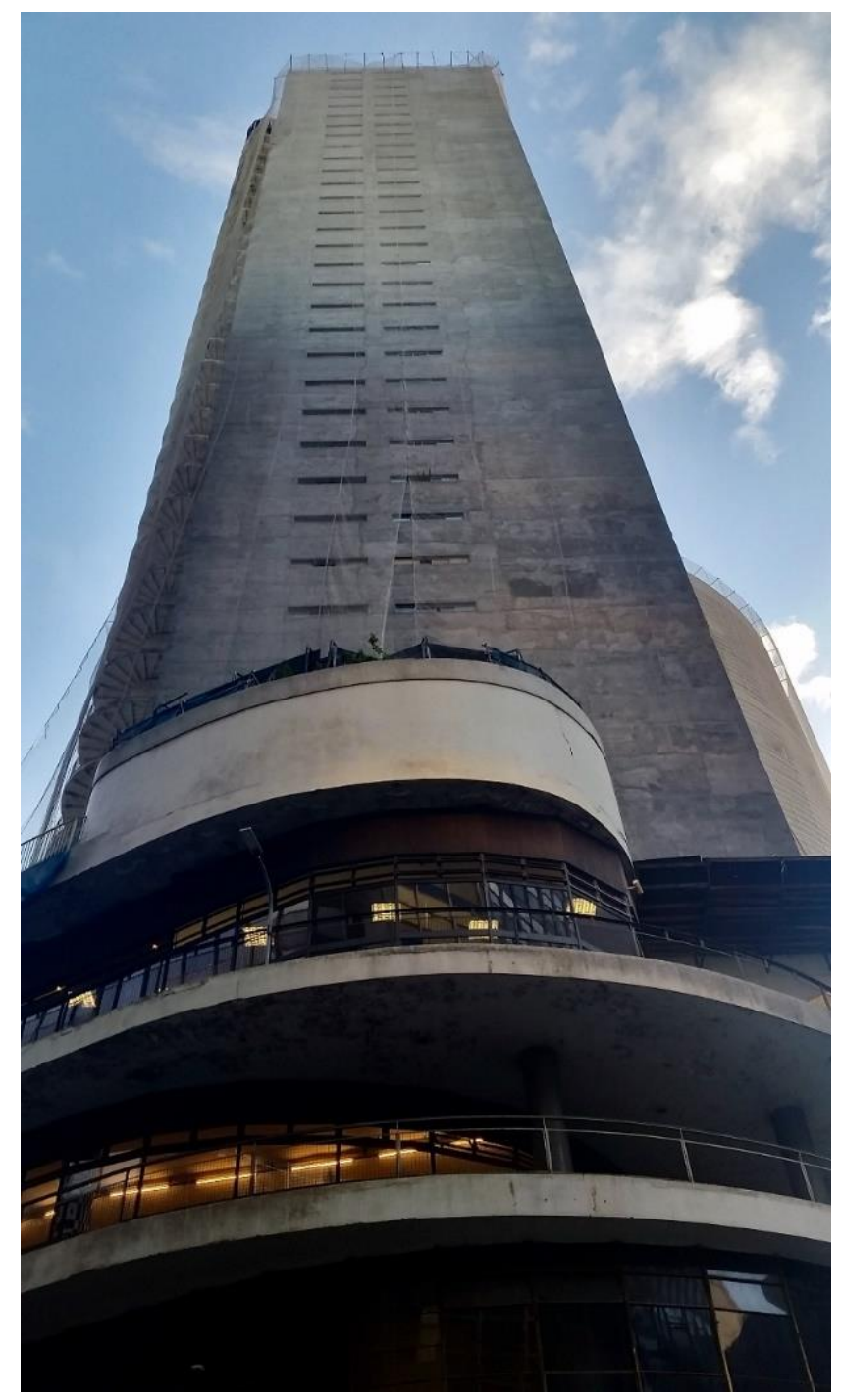

Figura 66 - Fachada Noroeste sem as pastilhas

Fonte: Acervo da autora. 


\subsection{DIAGNÓSTICO DAS CONDIÇÕES DAS FACHADAS}

Para ações efetivas de preservação do Copan, enquanto patrimônio de arquitetura moderna, faz-se necessário um processo de documentação e caracterização dos materiais e componentes, bem como das técnicas empregadas na construção. Essa caracterização se dá por meio de análises dos projetos originais, inspeções visuais e ensaios. E a partir desse conhecimento é possível compreender o comportamento do subsistema de revestimento e as causas das diversas manifestações patológicas encontras nas fachadas do Copan. O conhecimento acerca das causas de degradação e a caracterização técnica do edifício torna-se um elemento norteador para tomada de decisões e especificações, tanto dos materiais e técnicas quanto da periodicidade e ações de manutenção, visando manter o desempenho e vida útil do sistema de fachadas.

Com o objetivo de obter o diagnóstico das manifestações patológicas do subsistema de revestimento externo, a administração do Condomínio Copan contratou o Centro de Controle Falcão Baver, durante o período de 28 de outubro de 2013 a 30 de janeiro de 2014, para realizar inspeções técnicas nas fachadas do Edifício Copan. Em que pese esse levantamento ter sido anterior ao início desta pesquisa de mestrado, os dados levantados são importantes enquanto documentação do edifício.

\subsubsection{MAPA DE DANOS}

Para as fachadas sudoeste, noroeste e da torre dos elevadores do Bloco B a inspeção foi realizada por equipe especializada, utilizando técnica de rapel. Para essas três últimas fachadas foi elaborado um mapa de danos, figura 66, que identifica e representa graficamente as manifestações patológicas existentes na ocasião. Segundo Tinoco (2009), "O mapa de danos sintetiza o resultado das investigações sobre as alterações estruturais e funcionais nos materiais, nas técnicas, nos sistemas e nos comportamentos construtivos", sendo, portanto, um importante instrumento para a compreensão da extensão dos danos causados pela degradação do subsistema. 

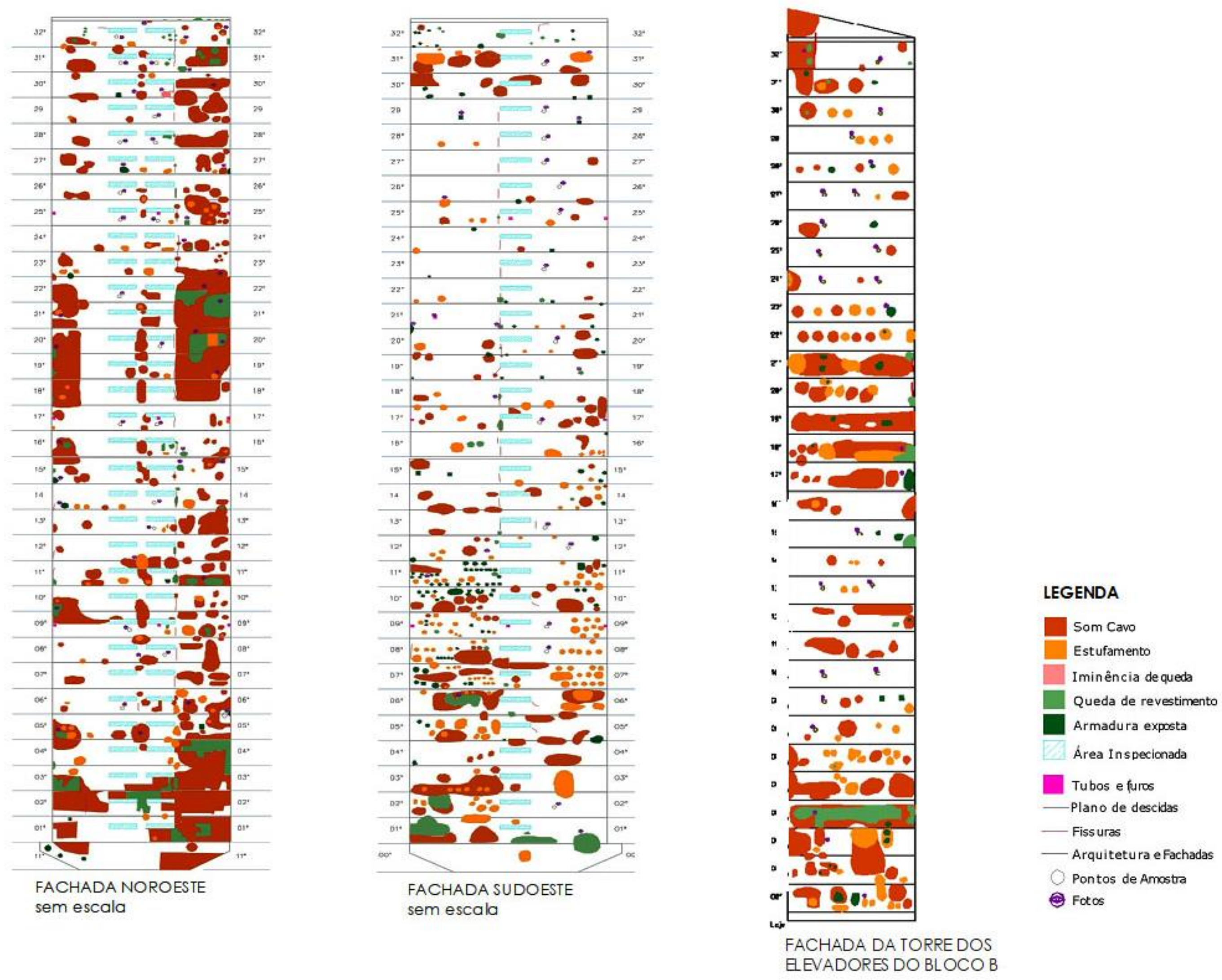

Figura 67 - Mapa de Danos das Fachadas Noroeste, Sudoeste e Torre dos Elevadores do Bloco B

Fonte: Falcão Baver. 
A inspeção da fachada frontal (brises) se deu por amostragem, por dentro de 19 apartamentos, visualizando-se as manifestações patológicas através dos caixilhos. Na fachada posterior a inspeção também foi visual, a partir das escadas externas utilizando-se binóculo.

As figuras a seguir ilustram algumas das manifestações patológicas representadas no mapa de danos.

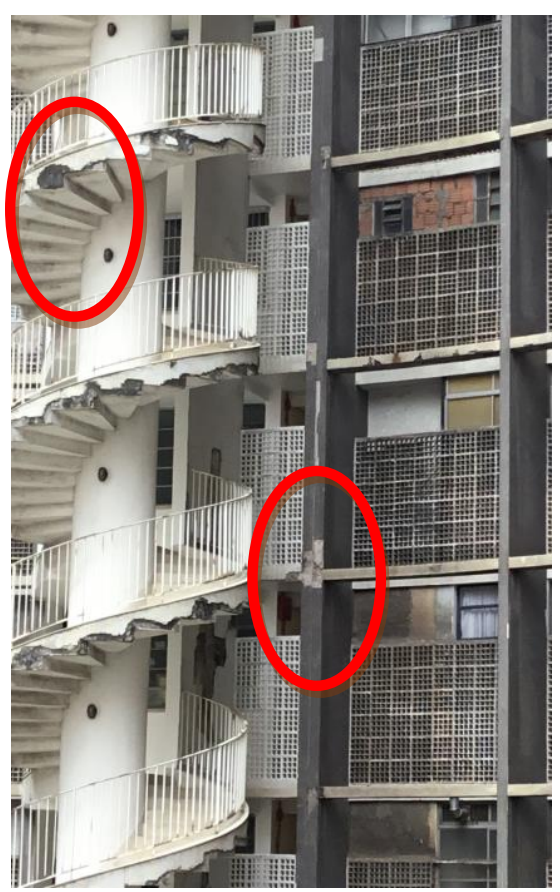

Figura 68 - Desplacamento de pastilha (fachada posterior)

Fonte: Acervo da autora.

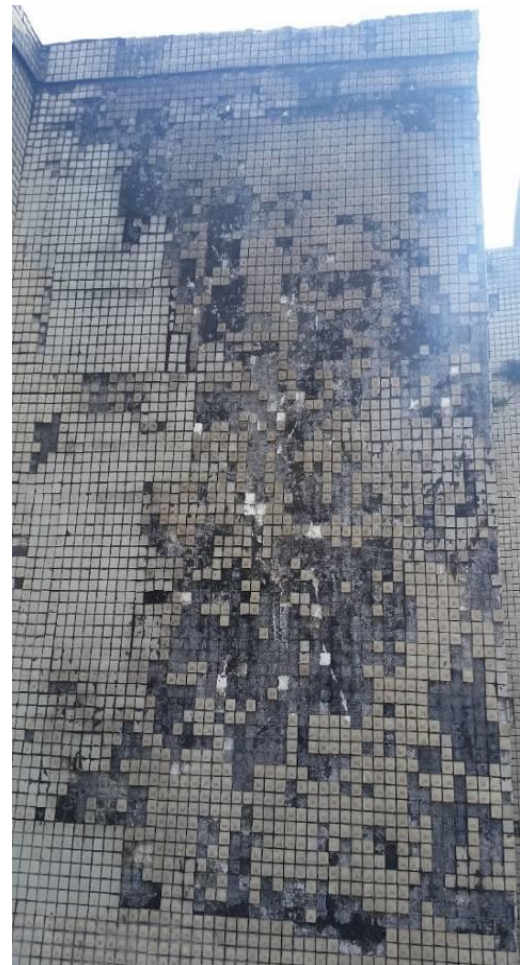

Figura 69- Descolamento de pastilha (torre dos elevadores do Bloco B)

Fonte: Acervo da autora. 


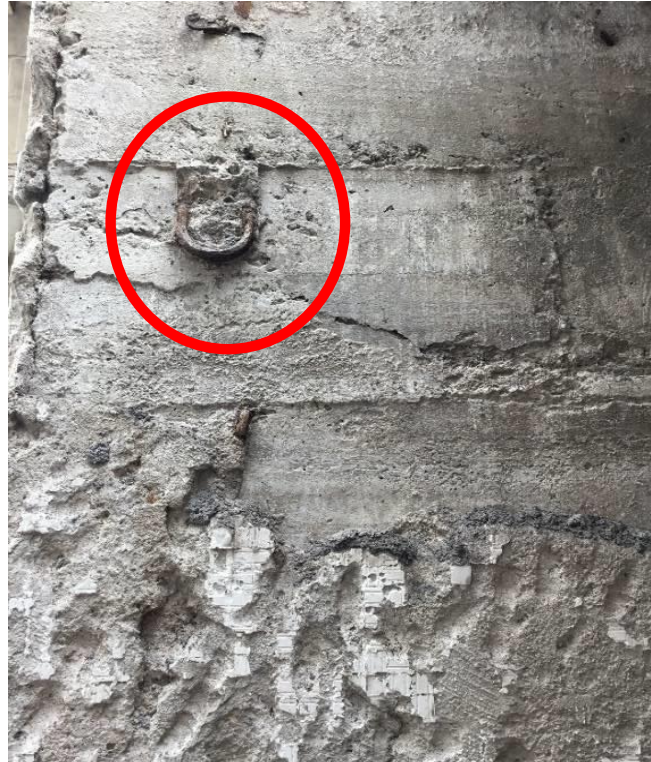

Figura 70 - Gancho metálico exposto

Fonte: Acervo da autora.

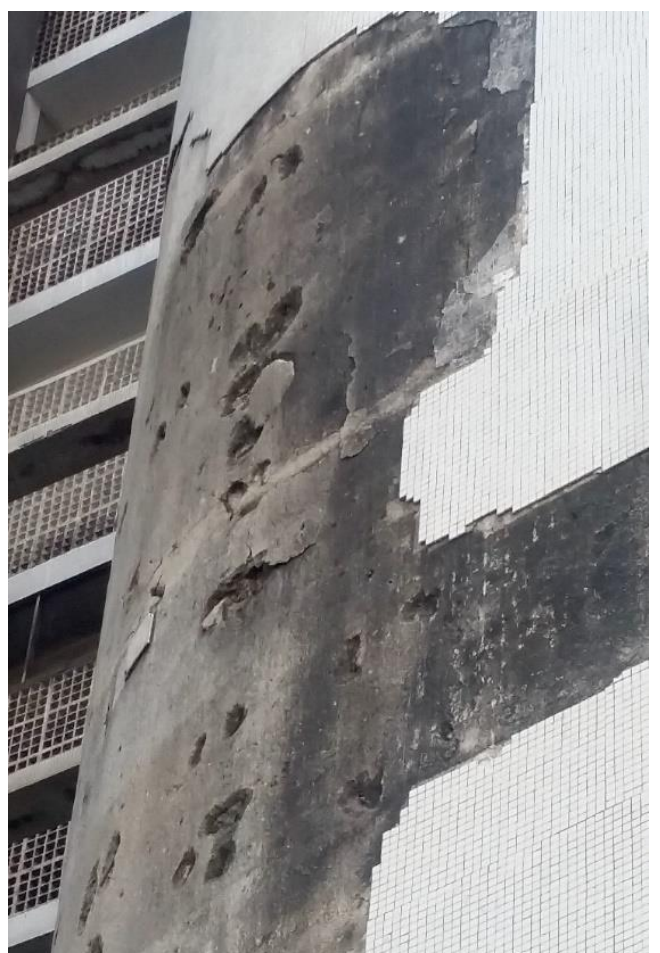

Figura 72 - Concreto desagregando e desplacamento de pastilhas - torre dos elevadores do Bloco B

Fonte: Acervo da autora.

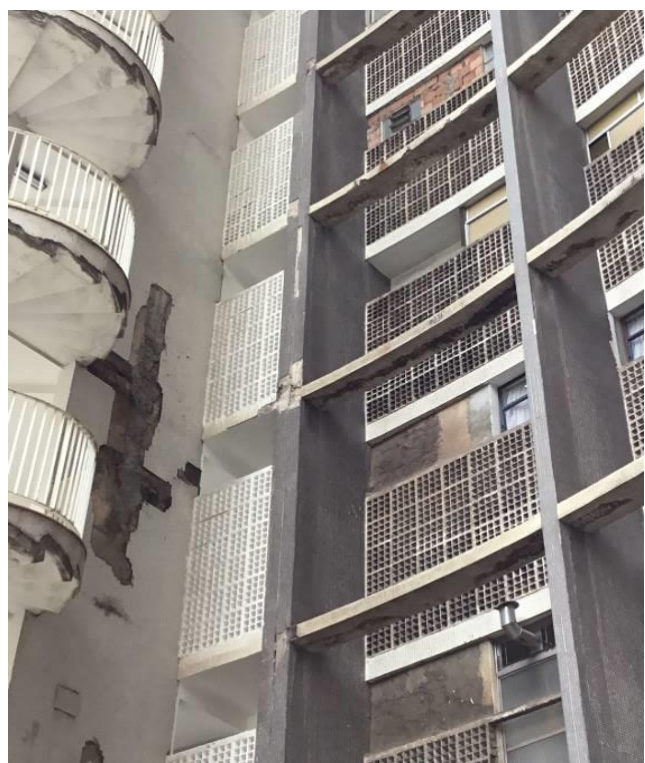

Figura 71 - Desplacamento de pastilha

Fonte: Acervo da autora.

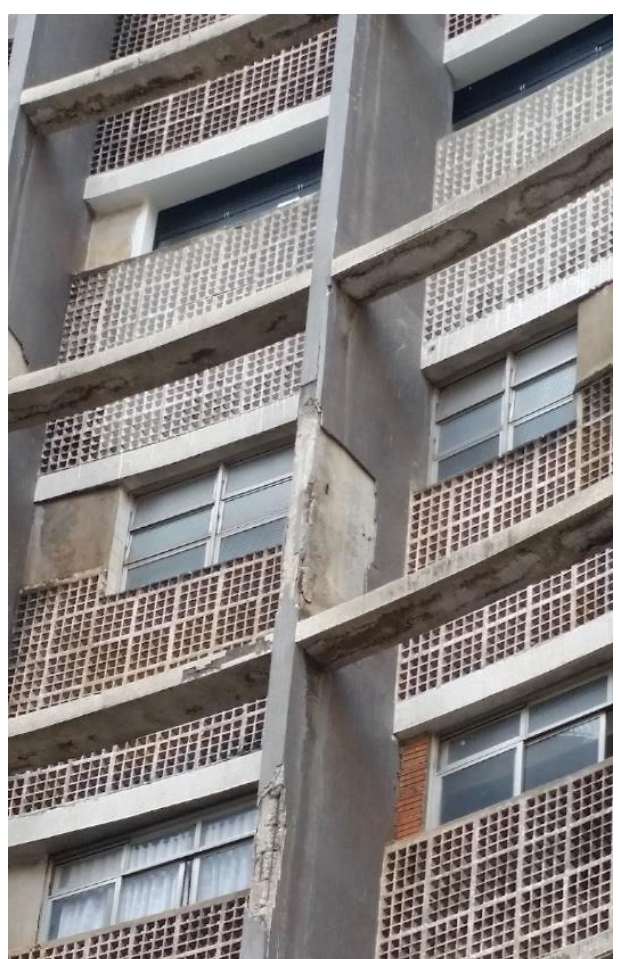

Figura 73 - Descolamento de pastilhas e armadura exposta fachada posterior

Fonte: Acervo da autora. 
Com o objetivo de obter um diagnóstico das manifestações patológicas do subsistema de revestimento externo original, a administração do condomínio contratou empresa especializada para a realização de inspeções e ensaios em suas fachadas, entre eles o ensaio de reconstituição de traço da argamassa de emboço e o ensaio de determinação de resistência de aderência à tração.

\subsubsection{RECONSTITUIÇÃO DE TRAÇO DE ARGAMASSA DE EMBOÇO}

A reconstituição do traço de argamassa nos fornece informações acerca das proporções dos materiais empregados na dosagem, aglomerantes e agregados, expressos em massa ou volume, e é obtida por meio de ensaios realizados em laboratórios.

Para a reconstituição do traço da argamassa de emboço foram coletadas amostras das fachadas do Edifício Copan em dezembro de 2013. As metodologias utilizadas nos ensaios foram:

- Argamassa - Reconstituição de Traço; Agregado para Concreto;

- Reconstituição de Traço em Argamassa - atualização do método IPT (Instituto de Pesquisas Tecnológicas);

- Argamassa para Concreto Determinação de Sais, Cloretos e Sulfatos.

As metodologias baseiam-se no princípio de que, ao ser atacada por ácido clorídrico, a argamassa gera duas frações, sendo uma insolúvel e a outra solúvel. O ensaio de reconstituição de traço de argamassa é baseado em análise química quantitativa, que é composta por quatro etapas distintas e nas quais são identificadas e determinadas as proporções de cimento, cal, areia e água utilizadas na sua composição, sendo possível a reconstituição do traço por meio de uma relação entre agregados e aglomerantes. A partir dos dados obtidos com os resultados é possível criar uma fonte documental, com 
o registro dos elementos e suas respectivas proporções, utilizados na argamassa de emboço, que compõem o subsistema de revestimento externo das fachadas do Edifício Copan.

Para a realização dos ensaios foram coletadas 7 amostras, sendo: 1 amostra da fachada sudoeste; 1 amostra da fachada noroeste; e outras 5 da torre dos elevadores do Bloco B, localizada na fachada posterior, que foi subdivida em sete partes, designadas A, B, C, D, E, F e G. Todas as amostras foram numeradas e chamadas de AM. Na Figura 73 é possível identificar suas respectivas localizações.

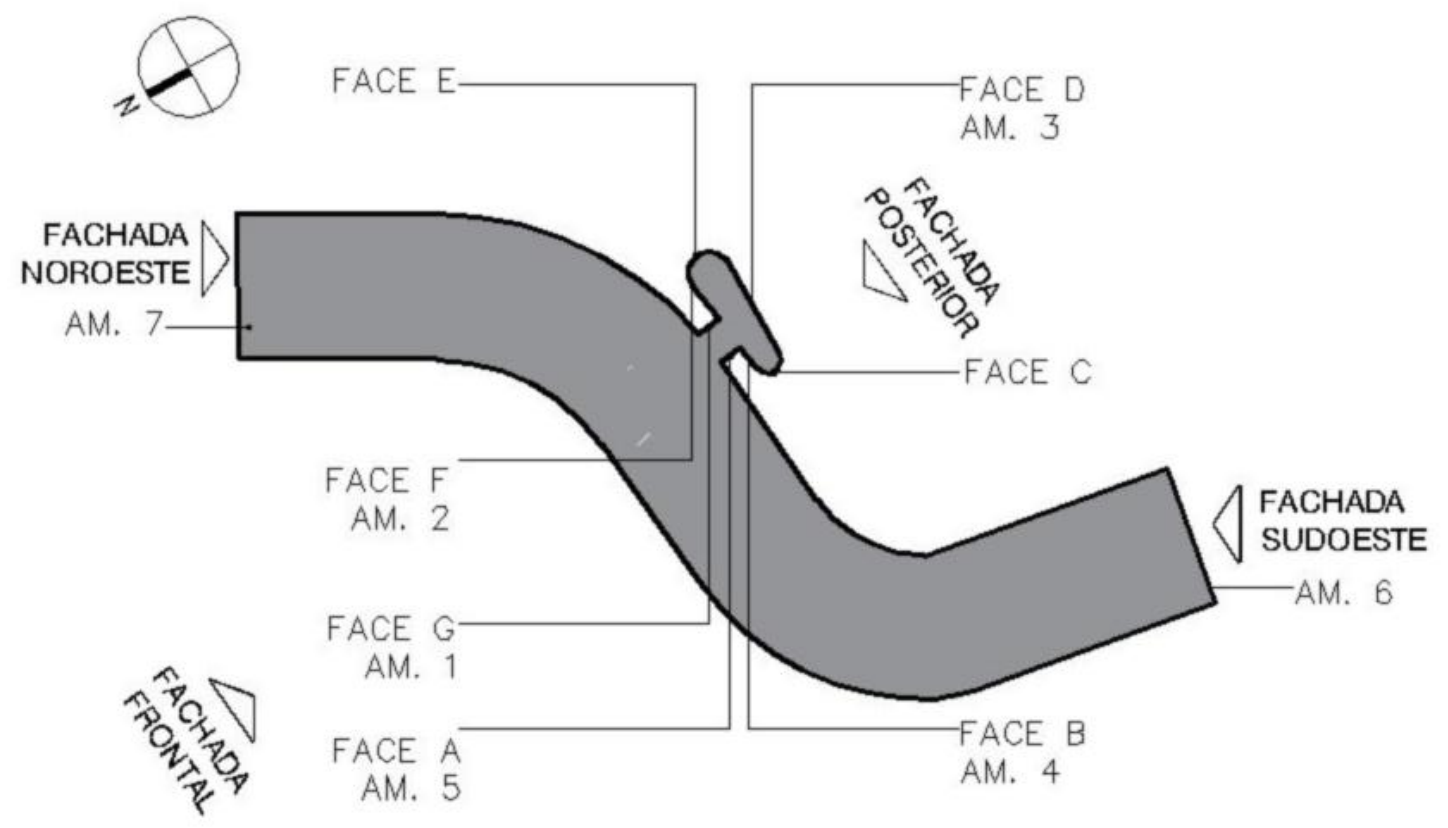

Figura 74 - Planta de Localização das amostras

Fonte: Elaboração da autora.

Os sulfatos são potencialmente prejudicais ao cimento, pois a reação química com produtos da hidratação do cimento pode gerar substâncias expansíveis, promovendo fissuras, aumento da permeabilidade e o ingresso de soluções agressivas, levando à desagregação da argamassa (SOUZA, 2016). 
Os resultados obtidos indicam a presença de sulfato solúvel, variando de 0,04 a 0,34\%, ou seja, dentro do limite estabelecido pela NBR $11578 / 91$ - Cimento Portland composto - Especificação, que é de 4,0\%. Indicam, também, a presença de óxido e cálcio e dióxido de silício superiores na proporção de 3:1, sendo então um indicativo da presença de cal na composição da argamassa de emboço.

A cal é um aglomerante utilizado para melhorar a trabalhabilidade da argamassa, diminuir a absorção de água e o índice de vazios, porém provoca diminuição da resistência à compressão e à tração. Os resultados apresentam um percentual de cal nas 7 amostras variando de 9,66\% a 15,33\% e variação entre o volume de cal e agregado, possivelmente fruto da produção artesanal da argamassa virada no canteiro da obra durante a construção. A Tabela 1 apresenta os resultados obtidos com as amostras ensaiadas.

\begin{tabular}{|l|c|l|l|l|l|l|l|l|}
\hline PARÂMEtroS & UNID. & $\begin{array}{l}\text { AM. } \\
\mathbf{1}\end{array}$ & AM. 2 & AM. 3 & AM. 4 & AM. $\mathbf{~ A M . ~}$ & AM. 7 \\
\hline Sulfatos solúveis & $\%$ & 0,04 & 0,34 & 0,33 & 0,13 & 0,16 & 0,29 & 0,06 \\
\hline $\begin{array}{l}\text { Cloretos solúveis para } \\
\text { concreto simples }\end{array}$ & $\%$ & 0,003 & 0,003 & 0,004 & 0,001 & 0,009 & 0,010 & 0,003 \\
\hline $\begin{array}{l}\text { Cloretos solúveis para } \\
\text { concreto armado }\end{array}$ & $\%$ & 0,003 & 0,003 & 0,004 & 0,001 & 0,009 & 0,010 & 0,003 \\
\hline $\begin{array}{l}\text { Cloretos solúveis para } \\
\text { concreto protendido }\end{array}$ & $\%$ & 0,003 & 0,003 & 0,004 & 0,001 & 0,009 & 0,010 & 0,003 \\
\hline Dióxido de silício & $\%$ & 3,00 & 4,01 & 3,99 & 3,29 & 2,53 & 3,03 & 2,98 \\
\hline Óxido de cálcio & $\%$ & 10,89 & 14,57 & 10,89 & 9,53 & 10,61 & 11,70 & 9,80 \\
\hline Resíduo insolúvel & $\%$ & 72,19 & 60,39 & 67,84 & 72,79 & 72,58 & 68,80 & 73,32 \\
\hline Umidade & $\%$ & 0,34 & 0,88 & 1,21 & 0,87 & 0,37 & 0,91 & 0,94 \\
\hline Agregados & $\%$ & 72,19 & 60,39 & 67,84 & 72,79 & 72,58 & 68,80 & 73,32 \\
\hline Cimento & $\%$ & 18,15 & 24,28 & 18,15 & 15,88 & 17,68 & 19,50 & 16,33 \\
\hline Cal & $\%$ & 9,66 & 15,33 & 14,01 & 11,33 & 9,74 & 11,70 & 10,35 \\
\hline Traço- cimento & $\mathrm{m} / \mathrm{m}$ & 1,00 & 1,00 & 1,00 & 1,00 & 1,00 & 1,00 & 1,00 \\
\hline Traço- cal & $\mathrm{m} / \mathrm{m}$ & 0,53 & 0,63 & 0,77 & 0,71 & 0,55 & 0,60 & 0,63 \\
\hline Traço- agregados & $\mathrm{m} / \mathrm{m}$ & 3,98 & 2,49 & 3,74 & 4,58 & 4,11 & 3,53 & 4,49 \\
\hline
\end{tabular}

Tabela 1-Reconstituição do traço de argamassa de emboço

Fonte: Falcão Baver, 2014 - adaptado pela autora. 


\subsubsection{ENSAIO DE DETERMINAÇÃO DE RESISTÊNCIA DE ADERÊNCIA À TRAÇÃO}

Os ensaios de determinação de resistência de aderência à tração foram realizados em regiões íntegras das fachadas noroeste, sudoeste e da torre dos elevadores do Bloco B, de forma a verificar a aderência da pastilha de porcelana até o substrato, tendo como base a NBR 13528/2010 Revestimento de paredes de argamassas inorgânicas - Determinação da Resistência de Aderência à Tração, que prescreve os métodos de ensaio, recomenda o registro das formas de rupturas dos corpos de prova, conforme Figura 75 e seus respectivos percentuais. De acordo com a NBR 13749/2-013 Revestimentos de paredes de argamassas inorgânicas - Especificação, o revestimento deve ser aceito se, para cada grupo de 12 corpos de prova, pelo menos 8 valores forem iguais ou superiores aos indicados na Tabela 2, que indica a resistência de aderência à tração superior a $0,30 \mathrm{Mpa}$, para acabamento externo em revestimento cerâmico.

\begin{tabular}{|c|c|l|c|}
\hline \multicolumn{2}{|c|}{ Local } & \multicolumn{1}{c|}{ Acabamento } & $\begin{array}{c}\text { Ra } \\
\text { (MPa) }\end{array}$ \\
\hline \multirow{3}{*}{ Parede } & \multirow{2}{*}{ Interna } & Pintura ou base para reboco & $\geq 0,20$ \\
\cline { 3 - 4 } & & Cerâmica ou laminado & $\geq 0,30$ \\
\cline { 2 - 4 } & \multirow{2}{*}{ Externa } & Pintura ou base para reboco & $\geq 0,30$ \\
\cline { 3 - 4 } & & Cerâmica & $\geq 0,30$ \\
\hline \multicolumn{2}{|c|}{ Teto } & & $\geq 0,20$ \\
\hline
\end{tabular}

Tabela 2 - Limite de Resistência de Aderência à Tração (Ra)

Fonte: ABNT/NBR 13749, 2013. 

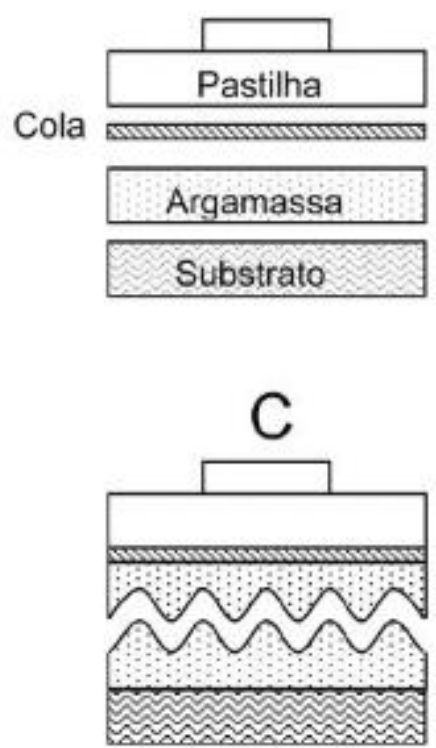

Ruptura na argamassa

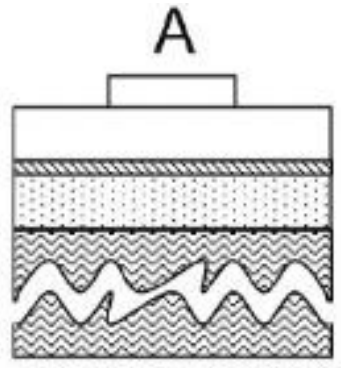

Ruptura no substrato
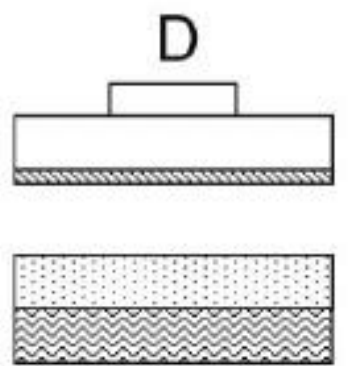

Ruptura na interface argamassa/cola
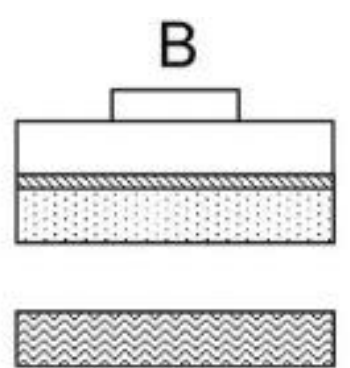

Ruptura na interface substrato/argamassa
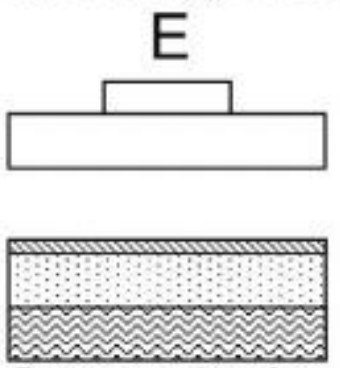

Ruptura na interface cola/pastilha

Figura 75 - Formas de Ruptura

Fonte: ABNT/NBR 135289, 2010.

Foram ensaiados 84 corpos de prova, conforme a Tabela 3.

Dentre os $84^{7}$ corpos de prova ensaiados, 55 não atenderam ao limite mínimo de resistência de aderência à tração, estabelecido atualmente pela ABNT/NBR 13749 para revestimentos novos, representando uma porcentagem de $65,47 \%$ de amostras reprovadas. Das amostras reprovadas, 18 sofreram ruptura na região do substrato, representando 32,73\%, e 37 amostras romperam na região da argamassa de emboço, representando 67,27\%. 0 relatório apontou como prováveis causas para as amostras que romperam na região do substrato (alvenaria) a possibilidade de estarem relacionadas com adoção de material deficiente, porosidade demasiada nos tijolos cerâmicos ou na argamassa de assentamento, irregularidades superficiais, existência de vazios entre os elementos da alvenaria, regiões com focos anômalos, deterioração do material e/ou má execução do substrato.

\footnotetext{
${ }^{7}$ A ABNT/NBR 13528:2010 preconiza que cada ensaio seja composto de 12 corpos de prova de mesmas características. Dos 7 pontos ensaiados nenhum apresenta o número estabelecido pela norma, devido à dificuldade de ancoragem do equipamento nas faces curvas da torre dos elevadores. Todavia, o número total de corpos de prova é 84 , perfazendo a quantidade necessária para 7 ensaios.
} 


\begin{tabular}{|l|c|c|c|}
\hline LOCALIZAÇÃO & $\begin{array}{c}\text { QUANT. CORPOS DE } \\
\text { PROVA }\end{array}$ & $<\mathbf{0 , 3 0 ~} \mathbf{~ P P a}$ & $>\mathbf{0 , 3 0 ~} \mathbf{~ P a}$ \\
\hline Face A & 8 & 4 & 4 \\
\hline Face B & 10 & 6 & 4 \\
\hline Face D & 17 & 11 & 6 \\
\hline Face F & 8 & 6 & 2 \\
\hline Face G & 9 & 8 & 1 \\
\hline Fachada Sudoeste & 14 & 10 & 4 \\
\hline Fachada Noroeste & 18 & 10 & 8 \\
\hline $\begin{array}{l}\text { Total de Corpos de } \\
\text { Prova }\end{array}$ & $\mathbf{8 4}$ & $\mathbf{5 5}$ & $\mathbf{2 9}$ \\
\hline
\end{tabular}

Tabela 3 - Determinação de resistência à tração

Fonte: Falcão Baver, 2014 - adaptado pela autora.

Com base nos resultados obtidos com o ensaio de determinação de resistência de aderência à tração (tabelas 8 a 14 em anexo) e a porcentagem de amostras reprovadas, o relatório técnico apontou para a necessidade de remoção total da argamassa de emboço e do revestimento de pastilhas das fachadas.

Com base nos resultados dos ensaios realizados, o relatório técnico recomendou a remoção total da argamassa de emboço e a elaboração de um projeto de revestimento de fachada.

Seguindo as recomendações do relatório técnico, a administração do condomínio contratou uma empresa especializada para o desenvolvimento do projeto de revestimento de fachadas. 


\subsubsection{SUBSÍDIOS PARA ELABORAÇÃO DO PROJETO EXECUTIVO DO REVESTIMENTO DE FACHADA}

Em 2015 a empresa contratada para o desenvolvimento do projeto de revestimento de fachadas recebeu toda a documentação sobre o diagnóstico das condições do subsistema de revestimento externo das fachadas do Edifício Copan e a análise dos seus resultados pautou as decisões projetuais para a reconstrução deste subsistema.

Após análise dos resultados dos ensaios de determinação de resistência à tração verificou-se que das 84 amostras ensaiadas 55 apresentaram valores $<0,30 \mathrm{MPa}$. Todavia, das amostras reprovadas 15 apresentaram valores superiores a 0,20MPa e, destas, 4 amostras com 0,29MPa e uma com 0,28MPa, indicando valores razoáveis para um revestimento com quase 50 anos na época.

Entre as amostras reprovadas, 21 romperam na argamassa de assentamento das pastilhas. A hipótese levantada era a de que na ocasião da construção era comum o assentamento das pastilhas de porcelana com pasta de cal como camada de ligação entre o emboço e as pastilhas. Essa camada porosa sofre com ações do tempo, principalmente por meio da penetração de água das chuvas pelos rejuntes, o que paulatinamente pode levar à redução de aderência dessa camada (ARCO, 2015).

Por meio dos resultados do ensaio de reconstituição de traço da argamassa de emboço, observou-se que esta possuía grande quantidade de cimento, variando entre $16 \%$ a $24 \%$, dosagem que costuma produzir argamassas com boa aderência e durabilidade.

Diante dos dados analisados passou-se a cogitar a possibilidade da não remoção total da camada de emboço (ação recomendada no relatório técnico da Falcão Baver), o que diminuiria significativamente a geração de resíduos, os impactos ambientais e principalmente os custos. Os requisitos para que a camada original de emboço não fosse totalmente demolida foram: apresentar boa aderência com o substrato e resistência 
superficial, que permitisse o assentamento de nova camada de acabamento decorativo (pastilhas).

Vale salientar que, na época da construção do edifício, não haviam referências normativas para determinação dos valores de resistência de aderência à tração. E tampouco os valores requeridos hoje para construções novas seriam atingidos em uma construção com quase meio século na ocasião dos ensaios. Todavia, as referências normativas servem como parâmetro para a análise dos resultados, vistos sempre com a ressalva do avanço cronológico e a degradação natural do subsistema de revestimento externo.

\subsubsection{ENSAIO PARA DETERMINAÇÃO DA RESISTÊNCIA DE ADERÊNCIA À TRAÇÃO DA CAMADA ORIGINAL DE EMBOÇO}

Esse ensaio foi realizado na torre dos elevadores de Bloco B, em local onde foram identificadas as piores condições de desagregação da camada de emboço original. O preparo da superfície consistiu apenas em hidrojateamento para limpeza e remoção de partes soltas. Com o objetivo de verificar a resistência de aderência com a base utilizou-se o método preconizado na NBR 13528:2010, onde o corte dos corpos de prova chega até o substrato e todas as camadas são tracionadas. Os critérios para avaliação desses resultados são descritos na NBR13749:2013, na qual figura que para cada 12 corpos de prova 8 devem apresentar resistência de aderência superior a 0,30MPa. Os resultados obtidos estão apresentados na Tabela 4 


\begin{tabular}{|c|c|c|c|}
\hline $\begin{array}{l}\text { CORPO DE } \\
\text { PROVA N }\end{array}$ & SUBSTRATO & TENSÃO (MPa) & $\begin{array}{c}\text { FORMA DE } \\
\text { RUPTURA }\end{array}$ \\
\hline 01 & Alvenaria & 0,17 & Substrato \\
\hline 02 & Alvenaria & 0,40 & Substrato \\
\hline 03 & Alvenaria & 0,32 & Substrato \\
\hline 04 & Alvenaria & 0,35 & Substrato \\
\hline 05 & Alvenaria & 0,49 & Substrato \\
\hline 06 & Alvenaria & 0,10 & Substrato \\
\hline 07 & Alvenaria & 0,16 & Substrato \\
\hline 08 & Alvenaria & 0,18 & Substrato \\
\hline 09 & Alvenaria & 0,29 & Substrato \\
\hline 10 & Alvenaria & 0,29 & Substrato \\
\hline 11 & Alvenaria & 0,19 & Substrato \\
\hline 12 & Alvenaria & 0,37 & Substrato \\
\hline
\end{tabular}

Tabela 4 - Determinação de resistência à tração da camada original de emboço Fonte: ARCO, 2015 - adaptado pela autora.

Os resultados obtidos mostram que dos 12 pontos ensaiados 5 apresentaram valores superiores a 0,30 MPa, 2 apresentaram valores de 0,29 MPa e apenas um valor com 0,10 MPa. Ou seja, dos valores reprovados, 2 estão muito próximos do estabelecido atualmente pela norma e apenas 1 valor muito baixo. Considerando a idade do edifício, esses resultados apresentaram valores razoáveis, indicando que havia a possibilidade da não demolição total da camada original de emboço. Observou-se ainda que a ruptura do revestimento ocorreu na interface argamassa/substrato, da alvenaria de vedação composta por tijolos maciços cerâmicos ou na sua argamassa de assentamento (figura 76), indicando que mesmo que a camada de emboço fosse totalmente demolida, e fosse empregada uma argamassa com maior potencial de aderência, os resultados não seriam maiores, tendo em vista que a limitação da resistência se encontra na camada superficial da alvenaria. Logo, se a camada de emboço original não seria demolida, seria necessário reforçá-la a fim de melhorar sua resistência superficial, e diante disso foi realizado outro ensaio. 

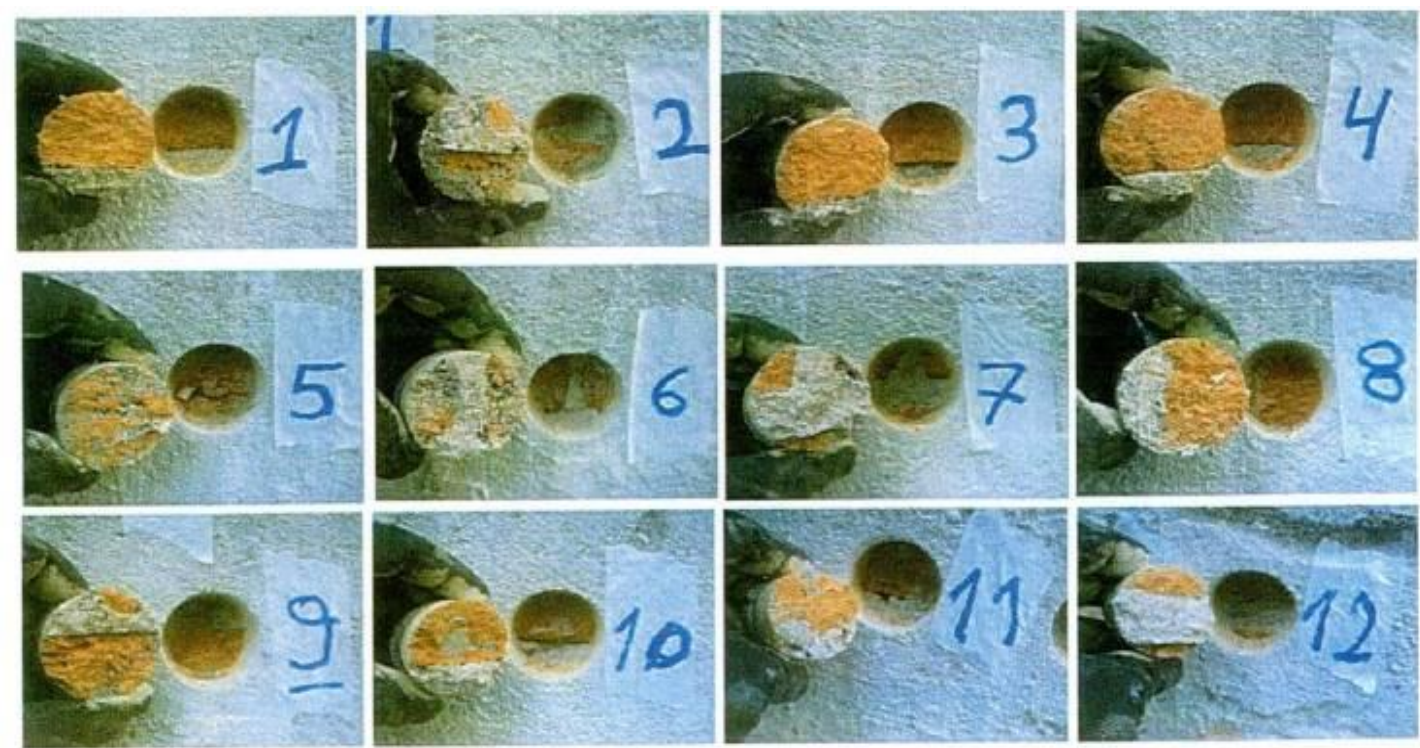

Figura 76 - Corpos de prova após ruptura do ensaio de resistência de aderência à tração da camada original de emboço

Fonte: ARCO, 2015.

\subsubsection{ENSAIO PARA DETERMINAÇÃO DA RESISTÊNCIA DE ADERÊNCIA À TRAÇÃO DO ACABAMENTO DECORATIVO (PASTILHAS)}

Foram realizados ensaios na torre dos elevadores do Bloco B, a fim de verificar a resistência de aderência à tração do acabamento decorativo (pastilhas) no emboço original, com a aplicação de produto para tratamento desta superfície por meio de aglutinação de partículas. Com o objetivo de verificar a resistência superficial do emboço e a aderência da argamassa colante, os ensaios realizados foram modificados em relação ao preconizado na NBR 13528:2010, no qual o corte das amostras não chegou até a base do emboço, justamente para avaliar a resistência da superfície e o conjunto pastilhas/argamassa colante.

O preparo da área consistiv em remoção das pastilhas originais, limpeza superficial da camada de emboço com remoção das partes soltas e hidrojateamento para remoção de sujidades. Foram delimitados quatro painéis de ensaios, dos quais três receberam aplicação de produtos para 
aglomeração superficial da argamassa de emboço, de diferentes fabricantes, a fim de verificar possível aumento da resistência superficial, e um deles não recebeu aplicação de produto, para servir de referência. Em cada painel foram aplicados dois tipos de pastilhas, de vidro e de porcelana, com três argamassas colantes, de diferentes fabricantes. Para cada combinação foram ensaiados 3 corpos de prova, totalizando 18 corpos de prova por painel.

As condições de preparo dos painéis e os tipos de argamassa utilizados estão descritas a seguir:

Painel 1 - imprimação com selador acrílico à base de metil metacrilato.

Painel 2 - imprimação com endurecedor à base de silicatos.

Painel 3 - resina à base de dispersão aquosa de copolímero estireno acrílico.

Painel 4 - não foi aplicado nenhum produto para que pudesse ser utilizado como referência na identificação dos resultados da ação dos produtos aplicados nos outros quadros.

Argamassa colante 1 - composta de cimento, agregados minerais de granulometria balanceada, aditivos químicos especiais não tóxicos e polímeros. Contém impermeabilizantes, biocida (fungicida/algicida).

Argamassa colante 2 - à base de cimento branco, agregados minerais, calcário dolomítico, pigmentos inorgânicos, aditivos e polímeros, do tipo AC III.

Argamassa colante 3 - à base de cimento especial, agregados selecionados e aditivos químicos não tóxicos, do tipo AC III. 

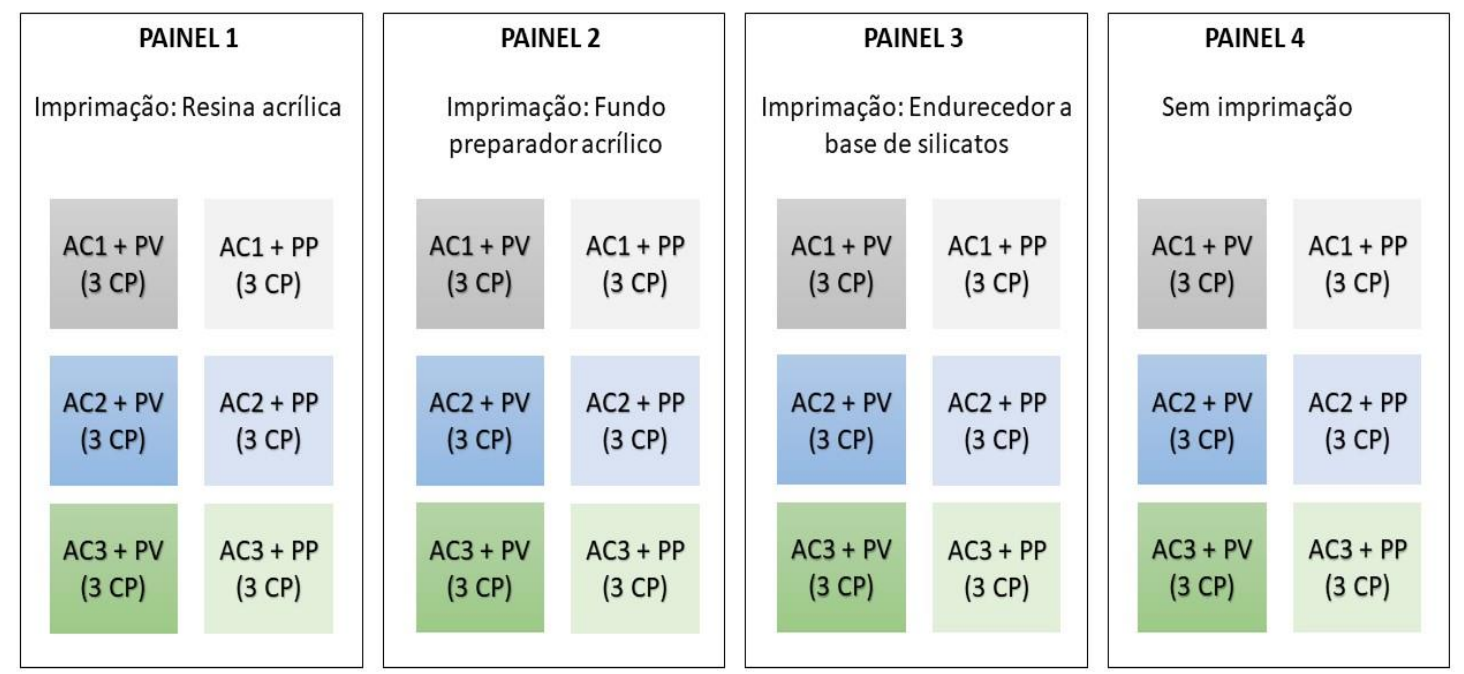

Legenda: AC - Argamassa Colante; PV - Pastilha de Vidro; PP - Pastilha de Porcelana; CP-Corpo de Prova

Figura 77 - Esquema dos painéis para o ensaio para determinação da resistência de aderência à tração do emboço original

Fonte: Acervo da autora.

Foram analisados dois tipos de ruptura: base, quando ocorreu na superfície da camada de emboço, e colante, quando se deu na argamassa colante.

No Painel 1 a média da resistência foi de 0,60MPa, sendo 0,56MPa na base e 0,63MPa na argamassa colante. Sendo que 9 romperam na base e outros 9 romperam na argamassa colante.

No Painel 2 a média de resistência foi de 0,66MPa, sendo 0,65MPa na base e 0,67MPa na argamassa colante. Tendo 9 rupturas na base e 9 na argamassa colante.

No Painel 3 a média de resistência foi de 0,68MPa, sendo 0,67MPa na base e 0,68MPa na argamassa colante. Das 18 amostras 6 romperam na base e 12 na argamassa colante.

E por fim, no Painel 4, sem o tratamento superficial da camada de emboço, apresentou-se média de resistência de 0,45MPa, sendo 0,47MPa 
na base e 0,46MPa na argamassa colante, sendo que das 18 amostras apenas 3 apresentaram valores inferiores a 0,30MPa e apenas 1 rompeu na argamassa colante.

Os resultados mostraram que com o tratamento superficial da camada de emboço houve uma melhora da resistência de aderência. Dado confirmado pela quantidade de ruptura na base do Painel 4, sem tratamento superficial.

O tratamento superficial da camada de emboço do Painel 3 foi o que apresentou melhor desempenho, uma vez que não apenas foi o painel com maior resistência de aderência à tração, mas também o que apresentou o menor número de ruptura na base.

Todas as argamassas empregadas apresentaram desempenho adequado, sendo os melhores resultados obtidos com argamassa 3, depois a argamassa 2 e por último a argamassa 1.

No que concerne às pastilhas, tanto as de vidro quanto as de porcelana apresentaram comportamento semelhante em relação à resistência de aderência, quando observados os valores em que a ruptura ocorreu na interface da argamassa colante com a pastilha, sendo possível a utilização de qualquer um dos dois tipos. Uma redução de aderência foi observada nas pastilhas que possuíam algum tipo de tela no tardoz das placas, sendo recomendadas placas de pastilhas sem esse elemento na parte posterior.

De posse dos resultados obtidos com os ensaios, que estão na Tabela 15 em anexo, a empresa responsável pela elaboração do projeto de revestimento de fachadas concluiu acerca da viabilidade da recuperação das fachadas, atingindo um desempenho adequado do revestimento sem a demolição total da camada de emboço, pois o tratamento superficial aumentou a resistência de aderência da camada de revestimento. 


\subsubsection{PROJETO EXECUTIVO DO REVESTIMENTO DE FACHADA}

A campanha de ensaios de resistência à tração com o uso de diferentes produtos para tratamento da base, argamassa e pastilhas, forneceu subsídios para a especificação dos materiais a serem empregados nas fachadas do Copan. A ARCO Assessoria em Racionalização Construtiva foi contratada para desenvolver o projeto de revestimento de fachada que foi emitido em 13 de janeiro de 2015, com revisões parciais em 10 de maio de 2015, após os ensaios realizados no dia 6 de março de 2015 e a última revisão de 11 de maio de 2016, após a emissão do memorial descritivo que data de 17 de janeiro de 2016.

O projeto de revestimento de fachadas é composto de 15 pranchas, que apresentam as fachadas noroeste e sudoeste na íntegra, as fachadas frontal e posterior parcialmente e um extenso detalhamento técnico construtivo dos frisos, juntas e métodos de execução.

De acordo com a NBR 13755/2017 - Revestimentos Cerâmicos de Fachadas e Paredes Externas com Utilização de Argamassa Colante - Projeto, Execução, Inspeção e Aceitação - Procedimento, as juntas de movimentação devem ser utilizadas em revestimento nas regiões com a possibilidade de movimentação entre dois elementos da base, como, por exemplo, alvenaria e fundo de viga. São utilizadas para dividir os painéis de revestimento e outros menores, minimizando as tensões advindas da movimentação estrutural, contrações e expansões térmicas entre outras. As juntas de movimentação com corte parcial do emboço ou sem corte são previstas nas seguintes situações:

"- união da alvenaria de vedação com as vigas de borda dos pavimentos-tipo de estruturas convencionais reticuladas de concreto moldadas in loco [...]

- diedros verticais internos e externos sobre base homogênea quando qualquer um dos panos tiver extensão superior a $6 \mathrm{~m}$ 
- Interfaces entre as placas cerâmicas e elementos construtivos diferentes, como esquadrias e elementos arquitetônicos (cornijas, molduras, sancas etc.)

- Interfaces entre panos de placas cerâmicas de tamanhos e cores distintos, como, por exemplo, a união de pastilhas com placas de porcelanato" (ABNT/NBR 13755/2017).

Originalmente, não havia juntas de movimentação nas fachadas do Edifício Copan, nem concebidas em projeto nem executadas in loco. Porém, no projeto de revestimento de fachada, podem ser observados os detalhes construtivos de frisos e juntas de dilatação da camada de revestimento, a fim de garantir desempenho técnico adequado. Os maiores panos de revestimento têm área de $23,78 \mathrm{~m}^{2}$.

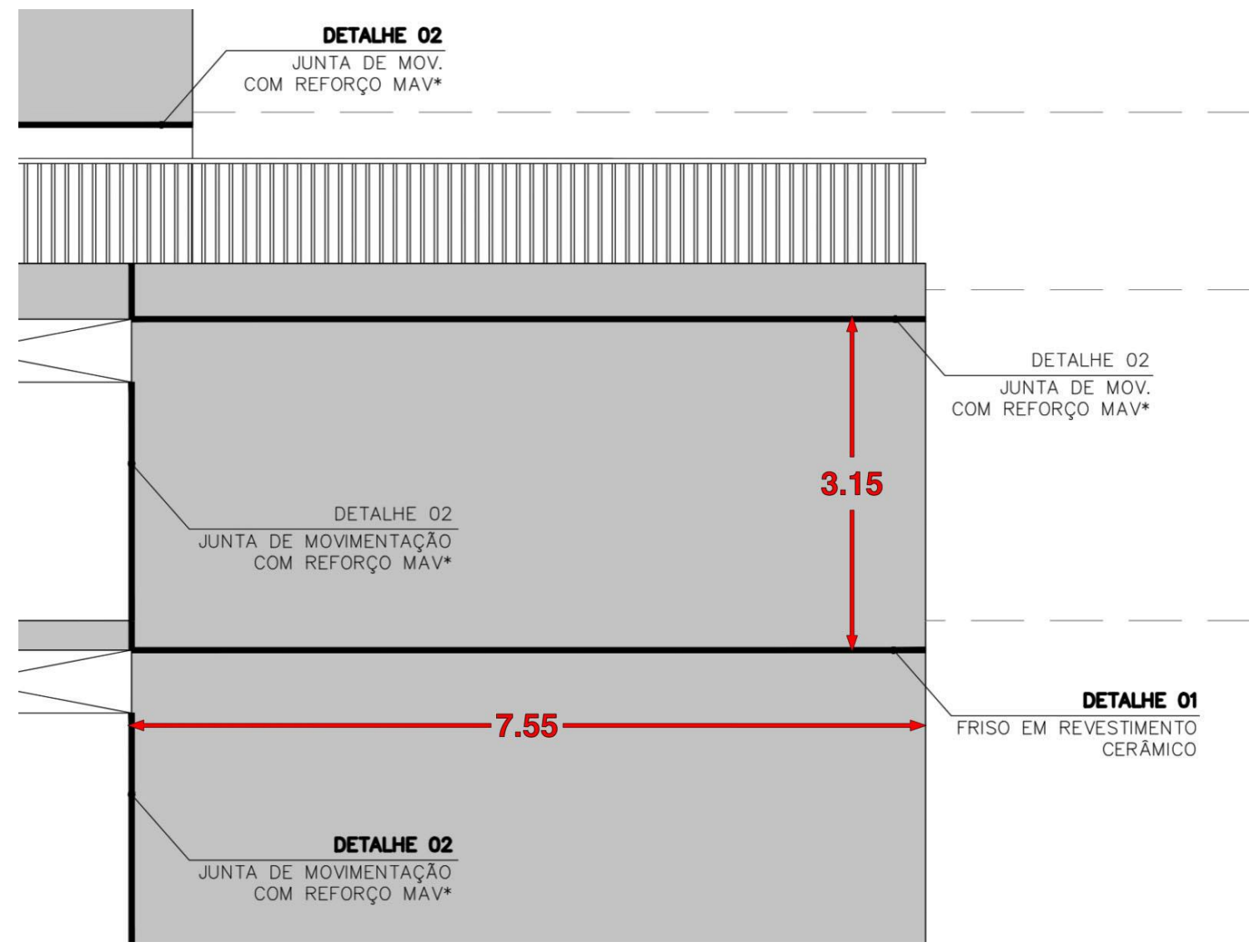

Figura 78- Juntas de movimentação

Fonte: ARCO, 2015. 


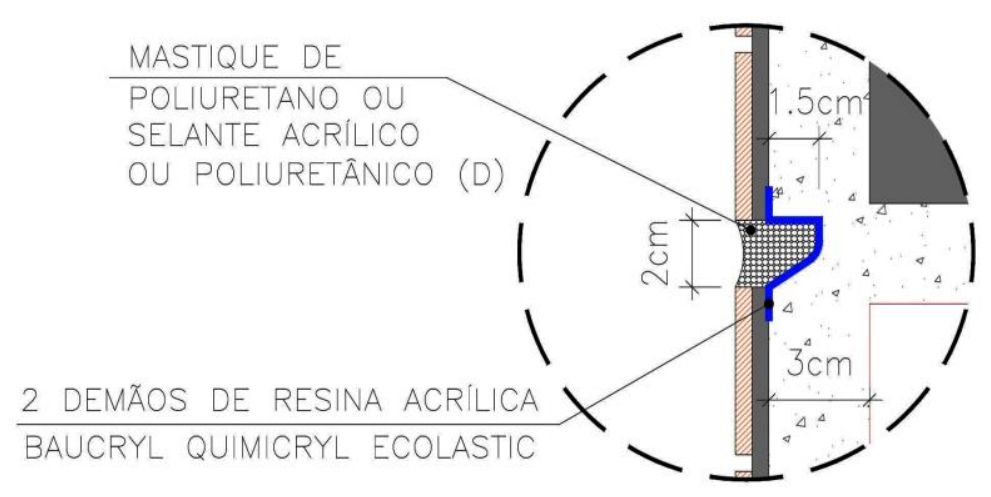

Figura 79 - Detalhe 01 da junta de movimentação e Detalhe 02 do friso Fonte: ARCO, 2015.

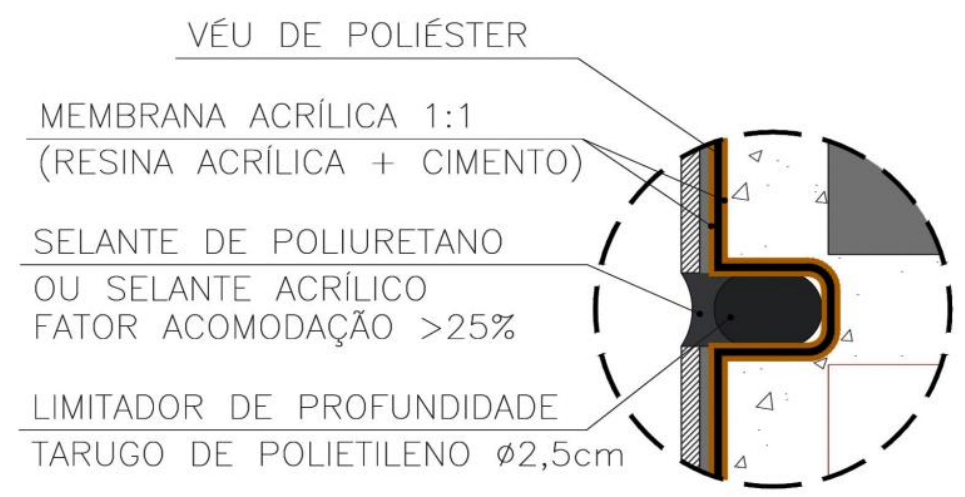

Figura 80 - Detalhe 01 da junta de movimentação e Detalhe 02 do friso Fonte: ARCO, 2015.

As Figuras 79 e 80 correspondem ao trecho do projeto de revestimento de fachadas, apresentado na Figura 78. A fotografia foi tomada em 9 de junho de 2016, durante o acompanhamento da obra de remoção do revestimento de argamassa de emboço desagregada. Na parte inferior do caixilho é possível observar a vedação em alvenaria de tijolos cerâmicos maciços e na lateral direita a interface entre a alvenaria e a empena de concreto, delimitando o pano de revestimento que mede $3,15 \times 7,55 \mathrm{~m}$. 


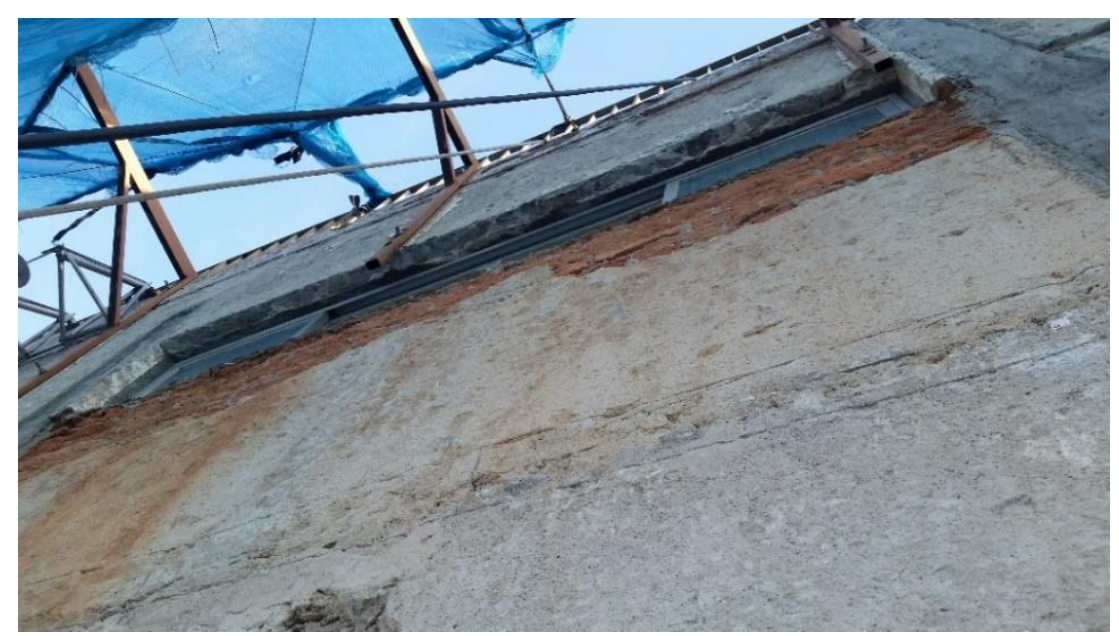

Figura 81 - Fachada Noroeste durante a remoção do revestimento Fonte: Acervo da autora.

O memorial descritivo do projeto traz especificações técnicas quanto à execução dos serviços para a recuperação do revestimento das fachadas do Copan. O preparo da base que receberá o revestimento das fachadas contará com remoção de sujidades, irregularidades, incrustações metálica, como pregos, fios e barras de tirantes de forma, preenchimento de furos, remoção de excesso de argamassas. Os elementos metálicos deverão ser cortados rente à superfície e tratados com pintura anticorrosiva à base de cromato de zinco. Sobre a alvenaria utilizar chapisco tradicional no traço 1:3 a 1:4, dependendo da areia utilizada, de modo a formar uma camada rugosa, aderente e resistente e, sobre a estrutura (pilares e viga) utilizar chapisco industrializado; o emboço será executado com argamassa industrializada para fachadas, onde para cada saco de $20 \mathrm{~kg}$ deverão ser acrescentados $400 \mathrm{~g}$ de resina acrílica, com desempeno grosso para o recebimento do revestimento cerâmico. As juntas de dilatação deverão ser posicionadas em todo o perímetro do edifício, no alinhamento inferior da viga, e sua execução deverá ser realizada por meio de um corte em toda a espessura do emboço, obedecendo à posição descriminada no projeto.

O friso deverá ser posicionado em todo o perímetro do edifício, também, no alinhamento da viga, com profundidade mínima de $1,5 \mathrm{~cm}$ ou $50 \%$ da camada de emboço, reduzindo assim sua espessura, mas mantendo 
um fundo de argamassa na posição determinada em projeto. A fim de garantir a estanqueidade será executado um reforço com resina acrílica e cimento na proporção 1:1 em toda a profundidade da junta, de modo a formar uma faixa de $10 \mathrm{~cm}$. Uma tela de poliéster deverá ser aplicada, com a primeira demão ainda úmida, deixando espaço para a colocação do limitador de junta e do mástique. Na sequência, mais 3 ou 4 demãos da mistura, aplicadas com intervalo de 3 horas entre elas, para o completo preenchimento da tela, promovendo a estanqueidade do sistema. Após a colocação das pastilhas será aplicado o limitador de junta de polietileno expandido, preenchendo $70 \%$ da junta com o selante acrílico ou de poliuretano. Para o revestimento em pastilhas das paredes externas das fachadas deverá ser utilizada argamassa colante para o assentamento das placas cerâmicas (ARCO, 2015).

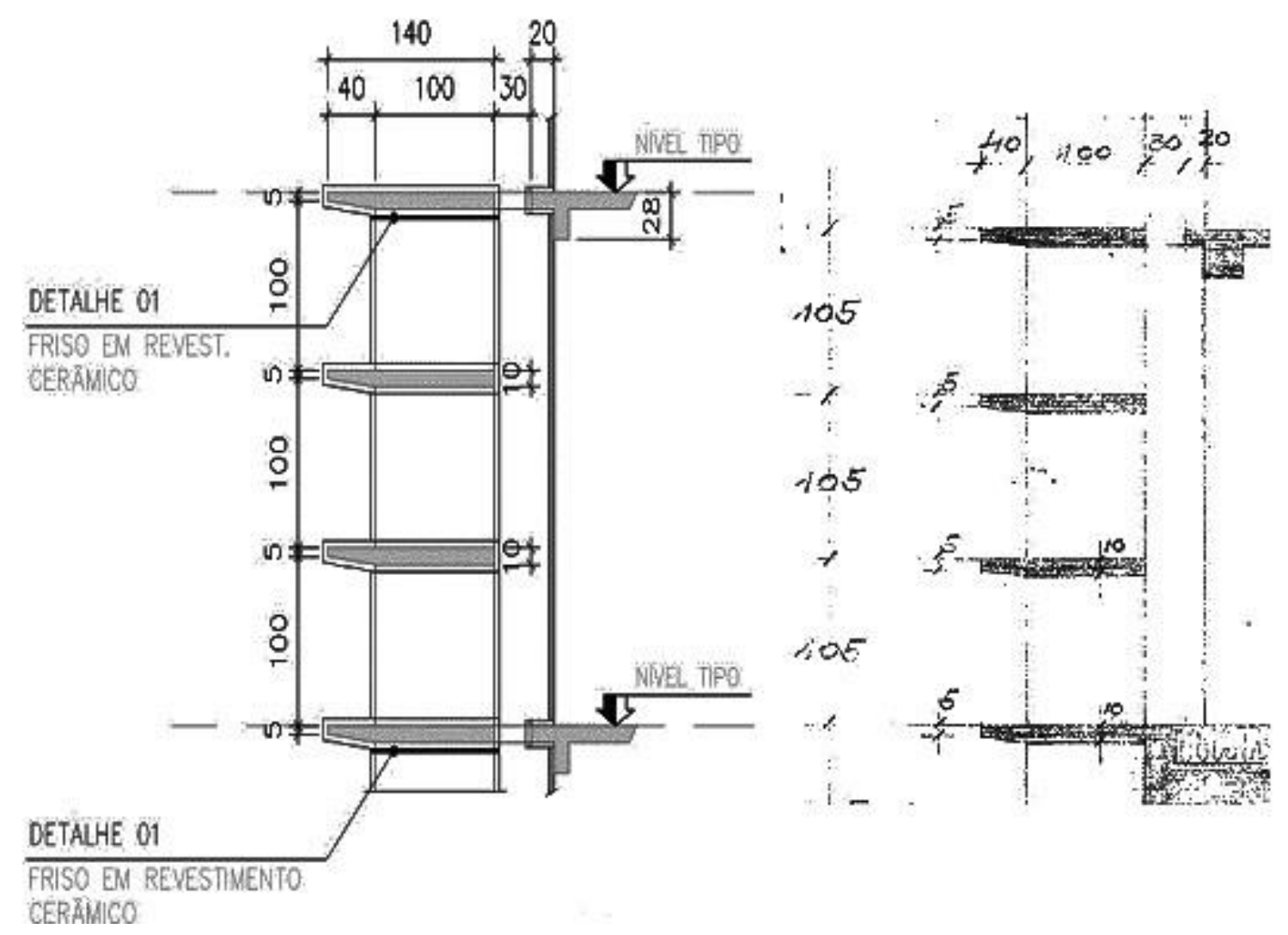

Figura 82 - Corte dos brises

Fontes: ARCO, 2015 e Acervo do Condomínio Copan. 
Na Figura 82 observa-se, à esquerda, o corte do projeto de revestimento de fachadas, e, à direita, o mesmo corte do projeto estrutural original. No projeto original não estava previsto friso, enquanto no segundo há a indicação de friso no revestimento cerâmico.

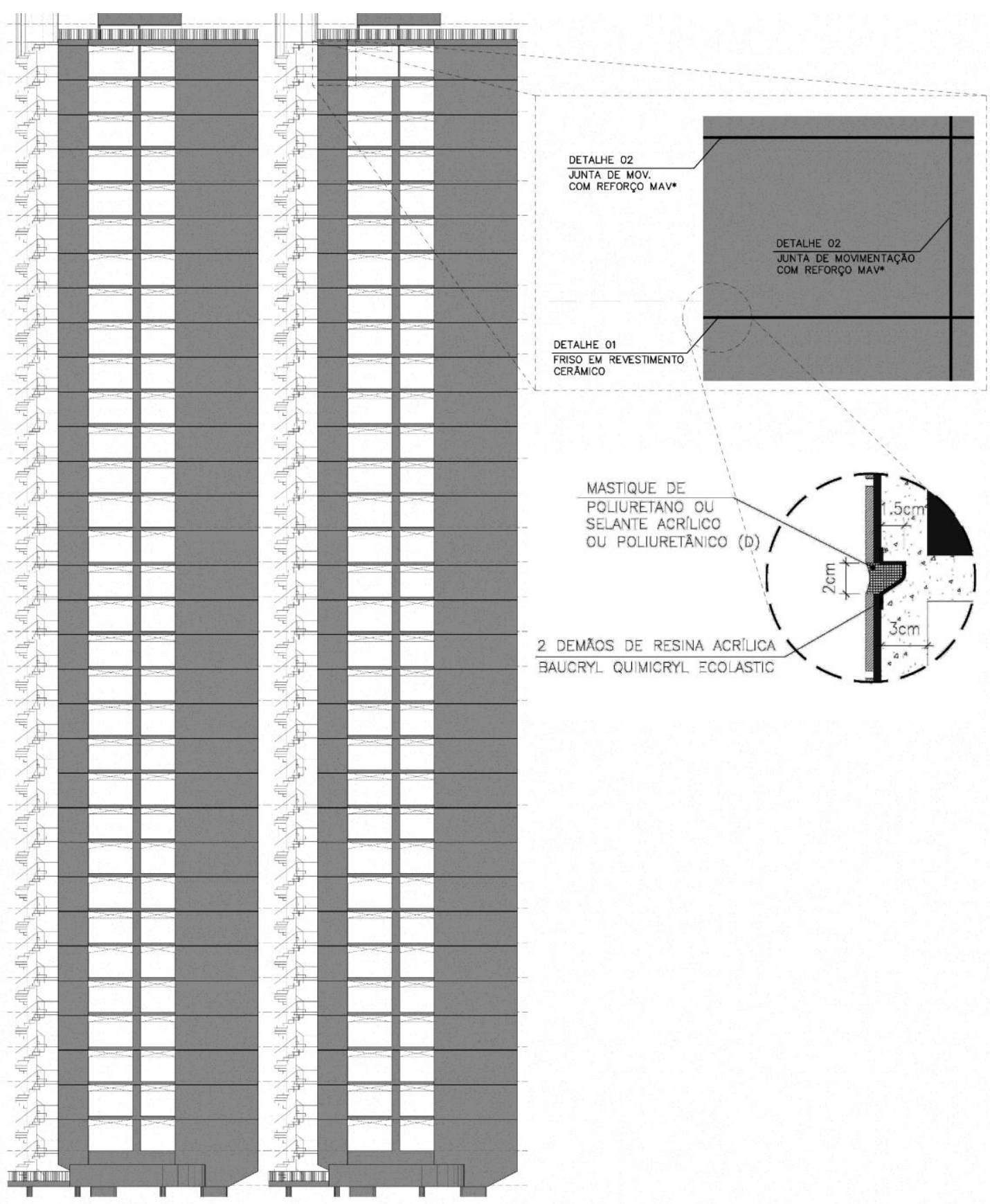

Figura 83 - Projeto de revestimento de fachada - frisos

Fonte: ARCO, 2015. 
A Figura 83 mostra o projeto de revestimento para a fachada sudoeste. À esquerda observa-se a vista total, acima, à direita, uma ampliação, e, abaixo, o detalhe do friso preenchido no revestimento cerâmico, com mástique de poliuretano ou selante acrílico de poliuretano aplicado sobre o fundo preparado com duas demãos de resina acrílica.

A Figura 84 mostra o detalhamento do projeto de execução de fachada apresentando o processo de execução dos frisos. Inicia-se com um corte de $6 \mathrm{~cm}$ na camada de emboço, depois os materiais soltos são removidos, em seguida aplicação de chapisco industrializado, preenchimento do friso com argamassa fresca aditivada com resina acrílica e, com ela ainda fresca, execução da frisagem, após a cura aplicação de duas demãos de resina acrílica avançando $10 \mathrm{~cm}$ além do friso, tanto para cima quanto para baixo, adiante aplicar as pastilhas, proceder com a limpeza do local e aplicar o selante, e por fim, posteriormente, a limpeza final.
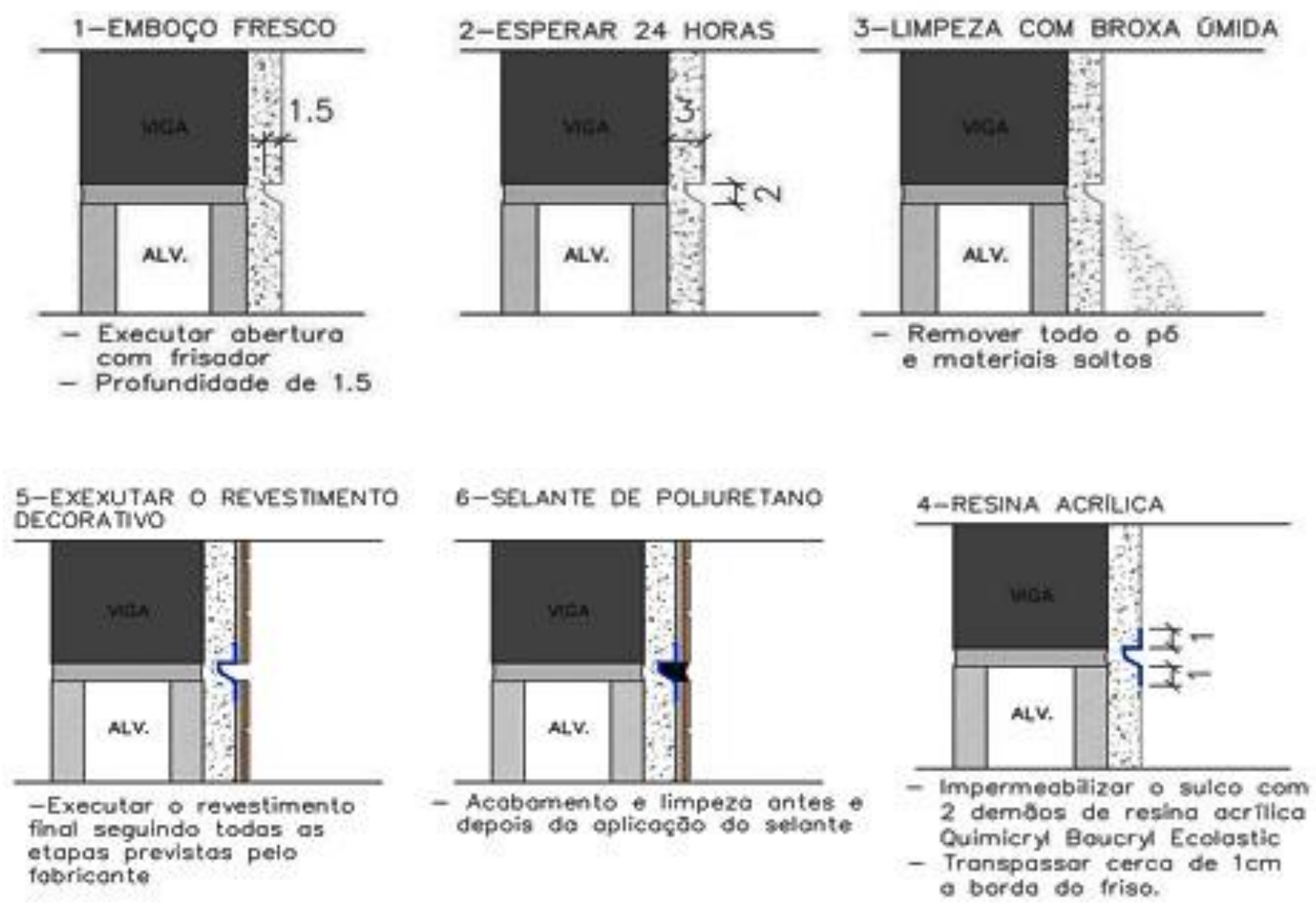

Figura 84 - Procedimento para execução dos frisos

Fonte: ARCO, 2015. 
A planta dos brises encontrados no projeto de revestimento de fachadas coincide com a planta das formas para o elemento. De modo geral, o projeto de revestimento de fachada coincide com o projeto original, conforme já mencionado, mas não há no projeto de arquitetura elevações dos trechos das fachadas desenvolvidas para o projeto de revestimento. Todavia, nos cortes e no projeto de estrutura consegue-se confrontar as informações. 


\subsection{ATIVIDADES TÉCNICAS REALIZADAS NA PESQUISA}

As atividades técnicas realizadas por esta pesquisadora tiveram início no segundo semestre de 2016 com o acompanhamento das obras para remoção das partes soltas das fachadas sudoeste, noroeste e torre dos elevadores do Bloco B, que se deu concomitantemente à análise dos projetos originais, do projeto executivo de revestimento de fachada e dos dados encontrados no relatório técnico, produzido a partir da análise das condições físicas das fachadas, que havia sido elaborado em 2014, portanto, anterior ao início desta pesquisa.

O objetivo das atividades realizadas é o de desenvolver um repertório técnico acerca das características do objeto de estudo, registrando os materiais e componentes utilizados na construção, suas fragilidades perante os agentes de degradação, as manifestações patológicas inerentes ao subsistema de revestimento externo, tal como executado, bem como as formas de tratamento propostas. E a partir da compilação desses dados promover a documentação dos aspectos construtivos do edifício, atividade que se justificaria por ser realizada em exemplar construído em uma época de intensa verticalização na cidade de São Paulo e, ao registrar suas caraterísticas técnicas, estaria, também, lançando luz sobre aspectos comuns a outros edifícios do mesmo período. Não obstante, o objeto de estudo em questão é um patrimônio arquitetônico e a compilação dos dados levantados propicia, não apenas o conhecimento acerca dos materiais e técnicas construtivas utilizados em uma época, mas, principalmente, configura-se em um banco de dados relevante e importante para tomada de decisões em intervenções futuras, visando à preservação do bem.

Diante disso deu-se início a ensaios complementares, cujo objetivo principal é o de promover a documentação das características técnicas do edifício. O Copan foi construído com estrutura de concreto moldado in loco e, apesar de haver projeto de estrutura de concreto, não há registro quanto à resistência do concreto especificado. E para não realizar um ensaio destrutivo com extração de um corpo de provas, optou-se pela realização de um ensaio de avaliação da dureza superficial do concreto 
endurecido pelo uso do esclerômetro de reflexão, pois os resultados apresentariam parâmetros de sua resistência superficial, suficientes para a documentação. Posteriormente foram realizados ensaios de reconstituição de argamassa e reboco e de assentamento das pastilhas. E, de posse das informações advindas das análises dos projetos e dos ensaios realizados, tanto durante a pesquisa quanto os efetuados anteriormente, foi possível realizar a documentação das características técnicas da estrutura, das alvenarias de vedação, que dão suporte ao revestimento de argamassa e o acabamento decorativo.

\subsubsection{ENSAIO PARA AVALIAÇÃO DA DUREZA SUPERFICIAL DO CONCRETO ENDURECIDO PELO USO DO ESCLERÔMETRO DE REFLEXÃO}

Em 21 de maio de 2018 foi realizado um ensaio para avaliação da dureza superficial do concreto endurecido pelo uso do esclerométrico de reflexão, um método não destrutivo que mede a dureza superficial do concreto, com diretrizes estabelecidas pela NBR 7584/2012 - Concreto endurecido - avaliação de dureza superficial pelo esclerômetro de reflexão Método de ensaio. Foram ensaiados 10 pontos da estrutura de concreto (pilares, vigas e empenas), que estavam sem o revestimento e argamassa de emboço, utilizando-se um esclerômetro de recuo Schimidt tipo (N) N34 164500 FB-4504, com energia de percussão de 2,25 N.m.

Como já mencionado, com seus 52 anos de ocupação, o Edifício Copan atinge o tempo mínimo estabelecido pela NBR15575/2013 para a vida útil de projeto (VUP) da estrutura, situado em uma classe de agressividade ambiental moderada, adequada à zona urbana.

Os ensaios foram realizados em 10 pontos distintos, sendo 4 pontos no lado externo da viga de transição, 2 pontos na torre dos elevadores do Bloco B e 4 pontos na parte interna da viga de transição do edifício. Sendo que do lado externo o Ponto 1 foi aferido em viga de transição da fachada noroeste, o Ponto 2, em pilar da torre dos elevadores do Bloco B na altura do $2^{a}$ andar, o Ponto 3 na viga da referida torre, o Ponto 4 na viga de transição 
do entre os Blocos C e D, o Ponto 5 no pilar do bloco D, na altura do $1^{\circ}$ andar. E na parte interna da viga de transição, o Ponto 6 no bloco E, o Ponto 7 no Bloco F, o Ponto 8 no Bloco E, o Ponto 9 no Bloco $\mathrm{C}$ e, por fim o Ponto 10 no Bloco B.

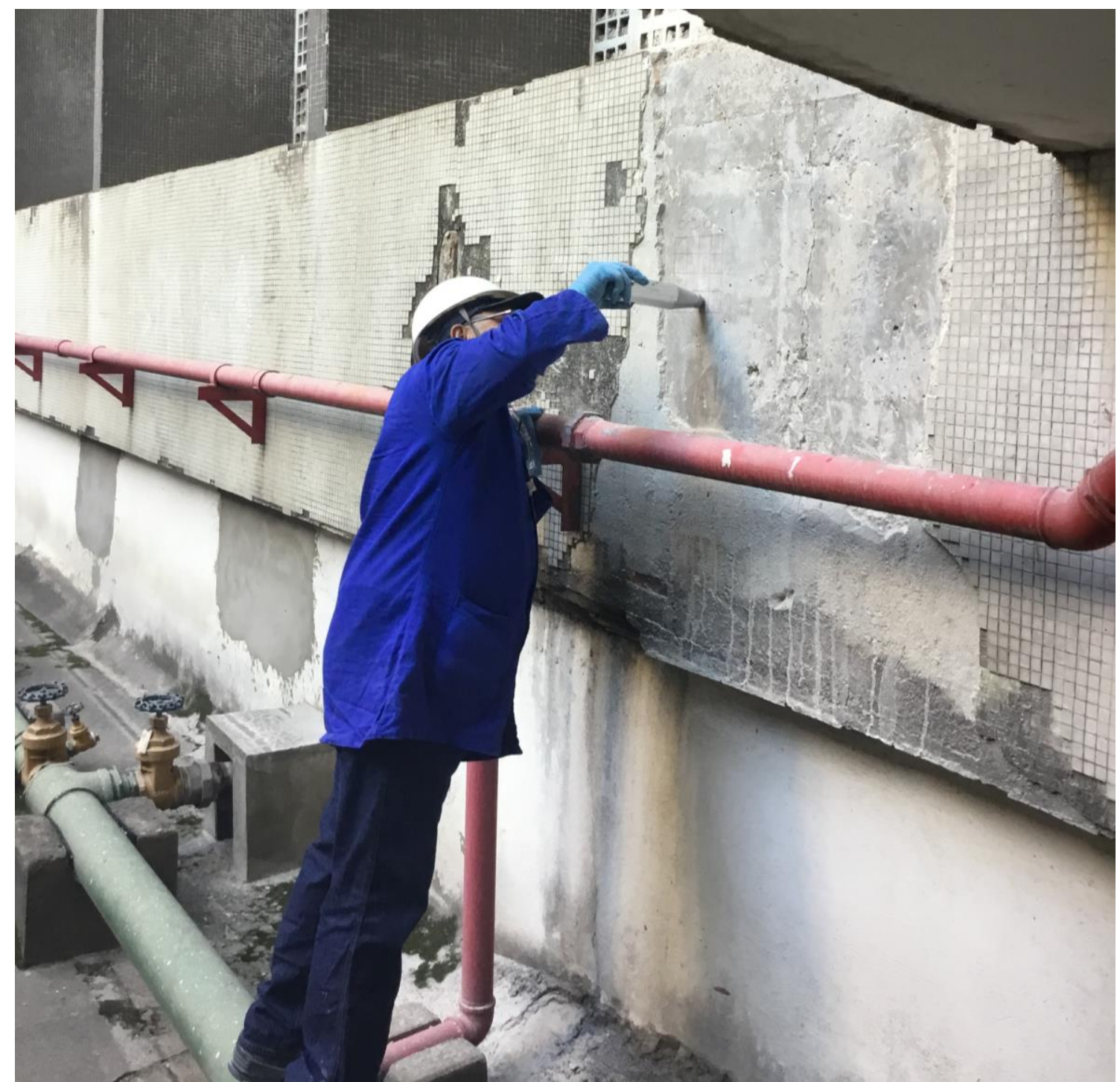

Figura 85 - Realização do Ensaio de Avaliação de Dureza Superficial do Concreto Endurecido na Viga de Transição do Bloco F

Fonte: Acervo da autora.

Os pontos ensaiados foram escolhidos com o objetivo de analisar ao menos um ponto de cada bloco e um número representativo de pontos no lado interno da viga, de modo que se pudesse comparar eventual alteração na dureza superficial em função da carbonatação do concreto, uma vez que 
do lado externo o edifício teve suas fachadas revestidas de pastilhas, mas alguns pontos já se encontravam sem o revestimento há anos, enquanto do lado interno o concreto nunca recebeu qualquer tipo de cobertura, mas por outro lado é um ambiente fechado, sem contato direto com os efeitos do dióxido de carbono.

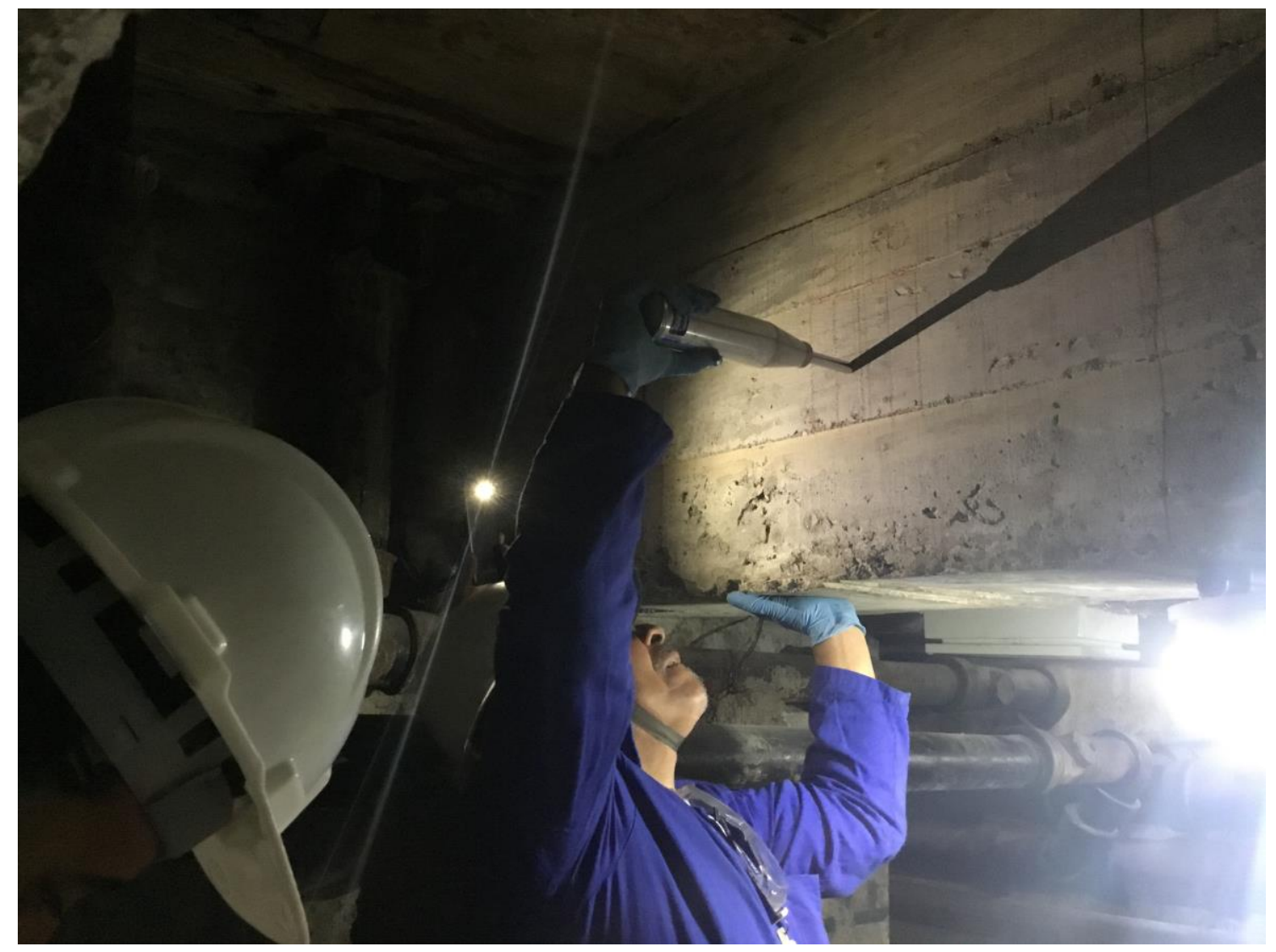

Figura 86 - Realização do Ensaio de Avaliação de Dureza Superficial do Concreto Endurecido no Lado Interno da Viga de Transição

Fonte: Acervo da autora.

Atualmente encontra-se na NBR 12655/2015 a determinação da resistência mínima à compressão, de $20 \mathrm{MPa}$. Todavia, a norma é posterior à construção do edifício e nos fornece apenas um parâmetro comparativo. Os resultados obtidos no ensaio de avaliação de dureza superficial do concreto endurecido podem ser observados na Tabela 5 e apresentam valores médios de resistência à compressão de 49,6 MPa. 


\begin{tabular}{|c|c|c|c|c|c|}
\hline PONTOS & $\begin{array}{c}\text { POSIÇĀO } \\
\text { DO } \\
\text { APARELHO }\end{array}$ & $\begin{array}{c}\text { ÍNDICE } \\
\text { ESCLROMÉTRICO } \\
\text { MÉDIO }\end{array}$ & $\begin{array}{c}\text { COEFICIENTE } \\
\text { DE } \\
\text { CORREÇÃO } \\
\text { DO APARELHO } \\
\text { (\%) }\end{array}$ & $\begin{array}{c}\text { ÍNDICE } \\
\text { ESCLEROMÉTRICO } \\
\text { EFETIVO }\end{array}$ & $\begin{array}{c}\text { RESISTÊNCIA À } \\
\text { COMPRESSÃO }\end{array}$ \\
\hline 1 & 0 & 48,63 & 1,0000 & 48,63 & $48,9 \mathrm{MPa}$ \\
\hline 2 & 0 & 48,38 & 1,0000 & 48,38 & $48,5 \mathrm{MPa}$ \\
\hline 3 & 0 & 43,50 & 1,0000 & 43,50 & $41,4 \mathrm{MPa}$ \\
\hline 4 & 0 & 48,13 & 1,0000 & 48,13 & $48,2 \mathrm{MPa}$ \\
\hline 5 & 0 & 51,38 & 1,0000 & 51,38 & $52,9 \mathrm{MPa}$ \\
\hline 6 & 0 & 51,88 & 1,0000 & 51,88 & $53,6 \mathrm{MPa}$ \\
\hline 7 & 0 & 47,75 & 1,0000 & 47,75 & $47,6 \mathrm{MPa}$ \\
\hline 8 & 0 & 49,75 & 1,0000 & 49,75 & $50,5 \mathrm{MPa}$ \\
\hline 9 & 0 & 50,88 & 1,0000 & 50,88 & $52,2 \mathrm{MPa}$ \\
\hline 10 & 0 & 49,50 & 1,0000 & 49,50 & $50,2 \mathrm{MPa}$ \\
\hline
\end{tabular}

Tabela 5 - Resultado do Ensaio de Concreto Endurecido - Avaliação da Dureza Superficial pelo Esclerômetro de Reflexão

Fonte: Falcão Baver, 2018 - adaptado pela autora.

De posse dos resultados, observou-se que a resistência superficial do concreto apresentou valores relativamente homogêneos, sendo o Ponto 3 , aferido na viga da torre dos elevadores do Bloco B, com o valor mais baixo e o com resultado mais alto foi o do Ponto 6, na viga de transição do lado externo.

Nos projetos originais não foram encontradas as especificações do concreto utilizado na estrutura do edifício e o resultado do ensaio forneceu um parâmetro da resistência superficial do concreto do Copan, não sendo um indicativo absoluto, podendo sofrer interferência, por exemplo, da carbonatação do concreto, que aumenta sua resistência superficial. Não foi realizado a extração de corpo de prova para ensaio de resistência à compressão axial, pois além de ser um ensaio destrutivo, como o Copan é um patrimônio tombado seria necessária autorização do órgão de proteção e, sem uma demanda para o aumento de carga na estrutura, não haveria a necessidade de tal abordagem apenas para documentação. 


\subsubsection{RECONSTITUIÇÃO DO TRAÇO DA ARGAMASSA DE REBOCO E ASSENTAMENTO DAS PASTILHAS}

Durante o desenvolvimento da pesquisa de mestrado, observouse a necessidade de ensaiar as argamassas de reboco e de assentamento das pastilhas, que compõem o subsistema de revestimento externo, a fim de documentar a composição e o traço das camadas originais. A camada de emboço já havia sido ensaiada em 2014, anterior ao início desta pesquisa.

Para a realização do ensaio de reconstituição de traço de argamassa de reboco, realizado no período de 07/06/2018 a 11/06/2018. Uma amostra de aproximadamente $500 \mathrm{~g}$ foi coletada da viga de transição, da fachada posterior entre os Blocos D e F. O ensaio realizado no laboratório químico da Falcão Baver, cujo método utilizado foi uma adaptação do Método de Análises Químicas adotados no IPT teve todas as etapas acompanhadas por esta pesquisadora.

\begin{tabular}{|c|c|}
\hline Parâmetros & Unidade (\%) \\
\hline Agregados & 59,21 \\
\hline Cimento & 2,75 \\
\hline Cal & 38,04 \\
\hline Dióxido de Silício & 0,55 \\
\hline Óxido de Cálcio & 17,10 \\
\hline Resíduo insolúvel & 59,21 \\
\hline Umidade & 0,13 \\
\hline
\end{tabular}

Tabela 6 - Ensaio de reconstituição de traço de argamassa de reboco

Fonte: Falcão Baver, 2018 - Adaptado da autora

O resultado apresenta um traço em volume de: 1 de cimento, 13,83 de cal e 21,53 agregados, sugerindo uma argamassa plástica e com boa trabalhabilidade.

Não foram encontradas especificações de traço de argamassa no projeto original, nem no memorial descritivo, para que pudessem servir de 
comparação, mas o Manual Técnico do Departamento de Obras Públicas, de 1976, nas páginas 191-192, faz referência ao assentamento e rejuntamento de pastilhas com cimento branco e caulim no traço 2:1.

A camada de assentamento das pastilhas do Copan é constituída de argamassa branca e lisa, bem diferente da argamassa de reboco que the serve de base, conforme pode ser observado na figura 87.

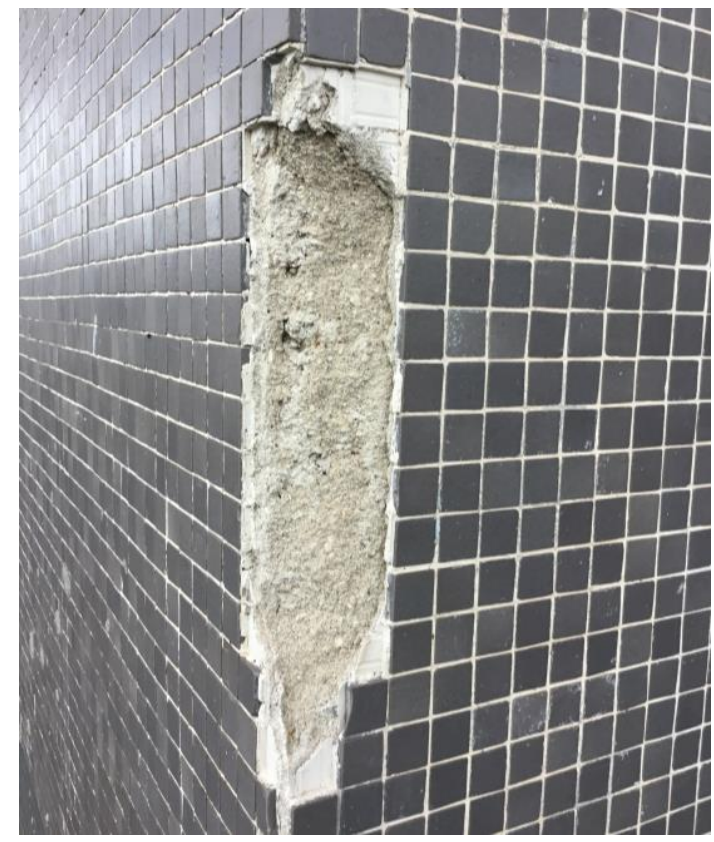

Figura 87 - Realização do Ensaio de Avaliação de Dureza Superficial do Concreto Endurecido no Lado Interno da Viga de Transição

Fonte: Acervo da autora.

A reconstituição de traço de argamassa de assentamento das pastilhas foi realizada entre o período de 23/10/18 a 07/02/19. A amostra coletada estava localizada na viga de transição da fachada posterior entre os blocos D e E. 


\begin{tabular}{|c|c|}
\hline Parâmetros & Unidade (\%) \\
\hline Agregados & 32,08 \\
\hline Cimento & 15,70 \\
\hline Cal & 52,22 \\
\hline Dióxido de Silício & 3,14 \\
\hline Óxido de Cálcio & 26,70 \\
\hline Resíduo insolúvel & 32,08 \\
\hline Umidade & 3,49 \\
\hline
\end{tabular}

Tabela 7 - Ensaio de reconstituição de traço de argamassa de assentamento Fonte: Falcão Baver, 2018 - Adaptado da autora

O resultado apresenta traço de 1: cimento, 3,33 de cal e 2,04 de agregados, indicando argamassa com boa trabalhabilidade.

\subsubsection{ACOMPANHAMENTO DAS OBRAS PARA REMOÇÃO DAS PARTES SOLTAS}

As obras para a retirada do material solto nas fachadas do Edifício Copan tiveram início em setembro de 2015 e foram acompanhadas semanalmente durante o segundo semestre de 2016 até sua paralização. Durantes as visitas foram coletadas dados acerca das características do sistema de revestimento de fachada, como por exemplo os tijolos, verificação das manifestações patológicas, confronto das informações coletadas in loco com o projeto original, a comparação dos materiais utilizados na obra com o projeto executivo de revestimento de fachada e registro fotográfico. 


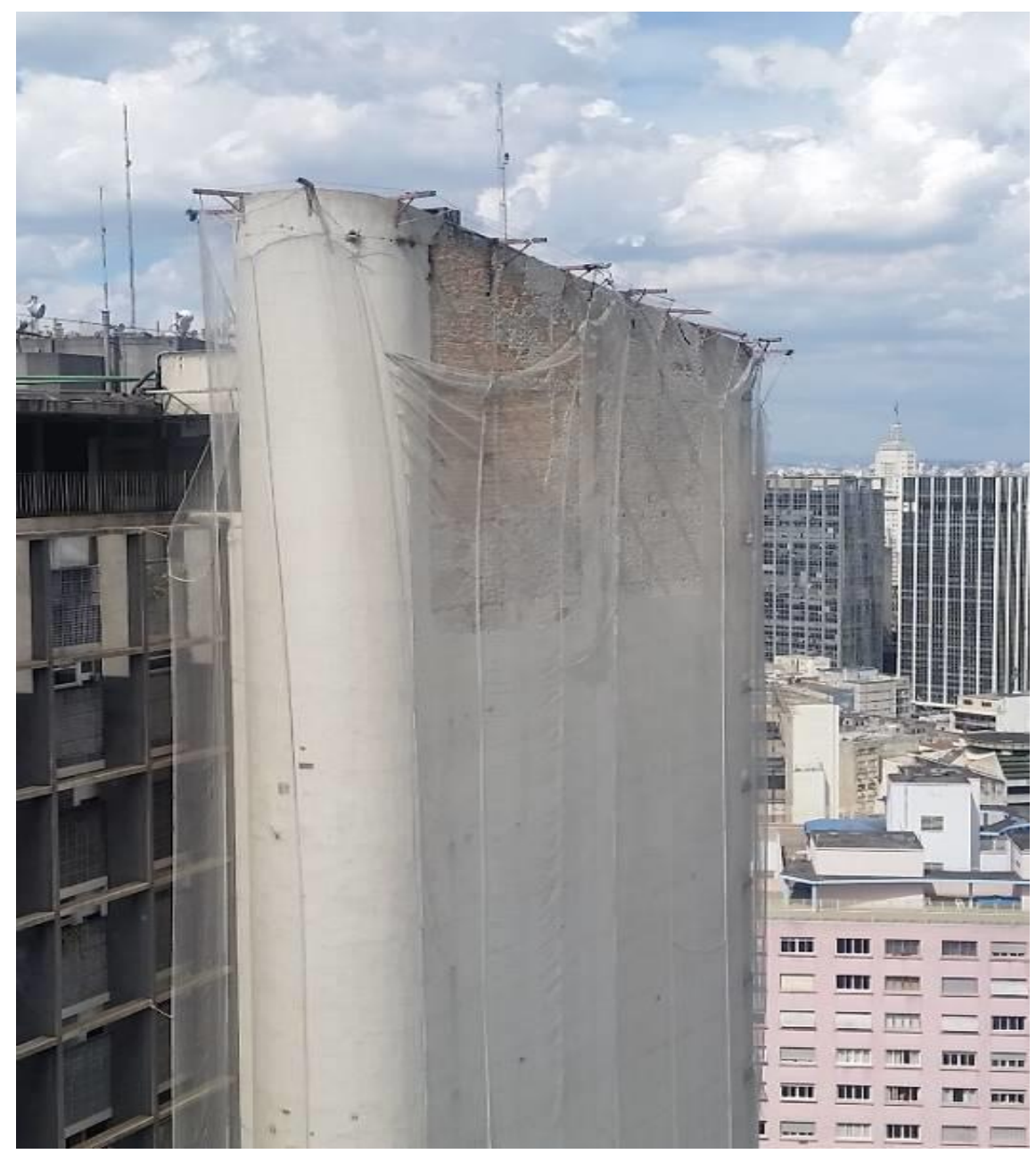

Figura 88- Torre dos Elevadores do Bloco B em fevereiro de 2018 Fonte: Acervo da autora.

As atividades foram iniciadas pelos andares superiores, por meio de balancim elétrico, com o uso de marteletes elétricos para a remoção do revestimento. Conforme descreve Tonini (2016), a experiência dos funcionários durante o processo de retirada validava a necessidade ou não de retirar a argamassa de emboço que se encontrava frágil ou que apresentava "som cavo"- ao acompanhar a obra, a pesquisadora relatou que em algumas regiões a argamassa de emboço saía com facilidade e em outras apresentava estar bem aderida à base.

As fachadas noroeste e sudoeste tiverem suas pastilhas e camadas não aderidas retiradas, bem como a execução da nova camada de emboço, mas nas fachadas da torre dos elevadores do Bloco B (figura 88) 
a retirada das pastilhas foi interrompida pela paralização da obra devido a questões relacionadas à autorização do projeto junto ao órgão de preservação do patrimônio. Sendo assim, as fachadas laterais ficaram sem o revestimento cerâmico e a torre dos elevadores, com a remoção parcial do emboço, o que permite maior exposição às intempéries e possibilidade de avanço da degradação tanto da estrutura como da vedação e do emboço remanescentes. 


\section{CAPÍTULO 4 - CONCLUSÕES}

Embora o Edifício Copan se configure como registro construtivo de uma época, reconhecido social e legalmente como patrimônio de arquitetura moderna, suas fachadas alcançaram um avançado estágio de degradação, colocando em risco a segurança dos transeuntes e do patrimônio arquitetônico. Diante disto, verificou-se a necessidade de desenvolvimento de instrumentos que auxiliassem em sua conservação. Nesse cenário entrou em pauta o objetivo deste trabalho: o desenvolvimento de um Manual de Uso, Operação e Manutenção e um Plano de Conservação para suas icônicas fachadas, como instrumentos complementares à salvaguarda do bem tombado. De um lado, o Manual para atender as demandas de preservação da materialidade e do outro o Plano de Conservação que abrange os aspectos culturais necessários à retenção do seu significado enquanto patrimônio moderno.

O crescente reconhecimento e a necessidade de preservar edifícios de arquitetura moderna trouxeram à tona os desafios envolvidos tanto na identificação do que deve ser preservado quanto nos processos para resguardar o bem, destacando a importância de ações sistematizadas de manutenção preventiva que ajudem a mitigar a degradação e, consequentemente, a necessidade de intervenções de restauro, que podem comprometer a identidade do patrimônio.

Para dar suporte ao objetivo deste trabalho se fez necessário um extenso levantamento e documentação dos materiais e técnicas utilizados, bem como das transformações projetuais ocorridas ao longo da construção. A importância dos dados levantados está não apenas no subsídio para o desenvolvimento dos instrumentos de preservação, mas como fonte documental que poderá auxiliar tanto outros pesquisadores, que pretendam desenvolver trabalhos sobre o tema, quanto profissionais e gestores que eventualmente venham a intervir no edifício.

Foi encontrado um vasto referencial teórico sobre conservação e manutenção separadamente, mas nenhum que unisse os princípios dos 
cuidados inerentes ao patrimônio com os parâmetros técnicos necessários à manutenção dos mesmos. E para a salvaguarda do patrimônio é imprescindível saber o que e como conservar.

Durante a revisão da bibliografia foi encontrado um extenso material internacional, com guias e diretrizes de preservação do patrimônio, mas pouco material nacional. Nos órgãos de preservação nacional também não foram achados modelos de plano de conservação ou de manual de manutenção que pudessem ter sido exigidos em projetos de restauração, a fim de servir de referência. Se instrumentos de preservação, similares aos propostos neste trabalho, fossem requisitados pelos órgãos responsáveis, estes poderiam auxiliar os gestores e proprietários a cuidar do bem tombado. Pois, na esfera popular há a ideia de que o patrimônio tombado é intocável e ações simples de cuidados corriqueiros e preventivos não são realizadas, permitindo o avanço da deterioração para que posteriormente seja restaurado. Porém, conservar não é restaurar. O restauro só acontece por falta de manutenção e pela ação do tempo.

A análise do desenvolvimento projetual durante a construção e do registro documental mostrou que o Copan não havia sido projetado para ser um hotel, mas sim edifício residencial. Auxiliou na compreensão da geometria construída, que por vezes parece sem nexo, como por exemplo ambientes aparentemente sem função, no espaço que atualmente abriga uma galeria de arte, mas que nos projetos iniciais pertenciam à área técnica destinados aos dutos de ventilação do teatro, que nunca foi construído. Também, assim como os azulejos, assentados em lugar que nunca funcionou como área molhável, mas que é resquício do projeto original que previa um restaurante - nunca executado -, pois o terraço para o qual havia sido projetado foi transformado e vendido como escritórios na fase final da construção.

Muitas informações sobre o projeto original foram encontradas, mais de 1000 pranchas remanescentes das obras estão digitalizadas, mas percebe-se que faltam desenhos, como por exemplo, os projetos da fachada posterior. A administração do condomínio conta com um grande acervo 
gráfico e documental da história do Copan e no arquivo municipal foi possível complementar as informações coletadas de outras fontes. Entretanto, o que se observou é que muitas informações gráficas e documentais do patrimônio estão segregadas, dificultando e retardando o seu levantamento.

Este arcabouço documental subsidiou o desenvolvimento dos instrumentos de preservação e se configurou não apenas como registro técnico do edifício, mas, em uma perspectiva mais audaciosa, lançou luz sobre os materiais e componentes que eram empregados na época da verticalização paulistana, podendo servir de ponto de partida para estudos de outros edifícios do mesmo período. Tornando o presente trabalho uma fonte de informações que podem contribuir para intervenções no patrimônio moderno.

O custo de uma restauração é elevado e os desafios encontrados são inúmeros. No caso do Copan, o desplacamento de pastilhas ao longo de décadas fez com que um significativo percentual de revestimento fosse perdido e, como o acabamento decorativo original não está mais em linha de produção, foram encontradas dificuldades para a reposição nas áreas faltantes. A fabricação de pastilhas similares às originais é possível, porém o custo é mais elevado dos que os produtos em linha comercial. Também de custo mais elevado seria o reaproveitamento das pastilhas originais, ou seja, retirada (ou aproveitamento das peças soltas), restauração e recolocação, porém além do parâmetro econômico, não haveria quantidade suficiente para cobrir toda a área de fachada necessária. O poder público faz exigências quanto à semelhança das características do componente, mas proceder a execução tal qual requerida resulta em um valor elevado para a receita de um condomínio residencial. Mas, manter a memória arquitetônica do bem tombado também é essencial. Se não há a conservação preventiva, a cada restauro o prédio perde um pouco do que é original.

O levantamento das condições físicas das fachadas é necessário para a compreensão das causas e da extensão dos danos, mas as indicações de procedimentos devem estar restritas às soluções de projeto. O diagnóstico 
realizado no Copan recomendou, por exemplo, a demolição total da argamassa de emboço, mas foram os questionamentos apontados durante a elaboração do projeto executivo de revestimento de fachadas, por meio de análise dos dados levantados e a realização de novos ensaios, que comprovaram não ser necessária tal ação, minimizando os impactos das intervenções no patrimônio, da geração de resíduos com a demolição e custos. A análise crítica que é intrínseca ao processo projetual permite adotar soluções para o reestabelecimento do desempenho e respeito ao patrimônio, sendo imprescindível um projeto para a realização de intervenções de restauro.

As argamassas de reboco e de assentamento das pastilhas do Copan são compostas de cimento, cal e areia em traços distintos, conforme apontam os resultados dos ensaios de reconstituição de traço. O reboco apresenta uma coloração mais acinzentada, indicando o uso de cimento cinza, mas a argamassa utilizada para o assentamento e rejunte das pastilhas é branca, fina e lisa. No memorial descritivo e nos balancetes de obra, encontrados no acervo do condomínio, foi possível verificar a especificação e a compra de cimento branco, corroborando com o resultado do ensaio e descartando a hipótese de assentamento das pastilhas com pasta de cal, técnica muito comum na época. Apesar de, ao longo dos anos, as fachadas sofrerem com o desplacamento do acabamento decorativo, sugerindo perda de aderência, durante a obra foram observados diversos pontos com boa aderência com a base, sendo necessário o uso de martelete para retirá-las (seria necessária tal ação?).

O ensaio de reconstituição de traço de argamassa caracterizou e documentou as propriedades destas camadas, o que é de suma importância na escolha das novas argamassas, que devem ter módulos de elasticidade similar às existentes que serão preservadas, a fim de evitar o surgimento de novas manifestações patológicas. Pois conforme preconizado na Carta do ICOMOS (2003) para evitar efeitos colaterais indesejados é fundamental estabelecer as características dos materiais e componentes existentes e a compatibilidade destes materiais com os novos. 
Este trabalho abordou a problemática da preservação do Copan sob dois vieses distintos: o teórico e o técnico. O primeiro fundamentou a importância do reconhecimento e do resguardo das significâncias culturais, enquanto testemunho construtivo de uma época, cujo legado permite às gerações futuras estabelecer relações com o passado recente no qual o patrimônio de arquitetura moderna foi produzido, apontando o que deve ser preservado. E o segundo, utilizou as informações adquiridas por meio de análises técnicas, caracterização dos materiais tanto originais quanto dos propostos, para propor ações de preservação adequadas. A união dos aspectos teóricos e técnicos propiciou uma abordagem mais abrangente em relação à complexidade que envolve a preservação do Copan.

O instrumento proposto para auxiliar na preservação da materialidade é o Manual de Uso, Operação e Manutenção, apresentado no Apêndice $B$ desta dissertação, que conta com roteiro de inspeções e ações de manutenção preventiva, programadas de acordo com os materiais e componentes propostos no projeto executivo de revestimento de fachada e parcialmente executado, tendo a periodicidade de cada ação embasada nas referências normativas vigentes. Por meio das ações propostas no manual pretende-se mitigar a degradação natural do subsistema, evitando ou retardando grandes e onerosas intervenções de restauro, cujos riscos inerentes podem comprometer a integridade do edifício enquanto patrimônio.

Com o Plano de Conservação, Apêndice A deste trabalho, objetiva-se deixar clara a importância da retenção dos valores de significância cultural, ao mesmo tempo que descreve quais são os elementos que os contêm, bem como a descrição das políticas de conservação, que irão auxiliar os gestores na tomada de decisões para resguardar o bem tombado.

Devido ao tempo limitado, este trabalho ficou restrito à elaboração do Plano de Conservação para todas as fachadas e o manual para as fachadas sudoeste e noroeste, que estão em processo de 
restauração, mas ambos instrumentos podem ser ampliados e abarcar outros subsistemas e, até o edifício como um todo em trabalhos futuros. Assim como, a metodologia de caracterização dos elementos e componentes podem ser ampliados para outros edifícios do mesmo estilo e época a fim de formar um banco de dados de informações para conservadores de arquitetura moderna.

Por fim, entre os desafios da conservação do patrimônio moderno estão o reconhecimento dos valores arquitetônicos e históricos, a importância da manutenção preventiva, a fim de retardar a degradação natural e assim evitar a necessidade de restauros sucessivos e substituições dos elementos e componentes originais, mas quando estas ações forem necessárias, que sejam fundamentadas no mesmo rigor técnico e metodológico aplicados ao patrimônio secular e não realizadas de modo indiscriminado, em prejuízo da memória arquitetônica moderna. Deste modo, os instrumentos de preservação propostos neste trabalho: o Plano de Conservação e Manual de Uso, Operação e Manutenção, podem auxiliar os gestores a preservar o patrimônio e retardar a necessidade de intervenções de restauro. E a exemplo de órgãos de preservação de outras partes do mundo, deveriam ser adotados aqui no Brasil, a fim de incentivar a cultura de que é melhor conservar do que restaurar. 


\section{REFERÊNCIAS}

AGUIAR, Barbara Cortizo de (org.). Arquitetura Moderna e sua Preservação Estudos para o Plano de Conservação Preventiva do Pavilhão Arthur Neiva. Rio de Janeiro: In-Fólio, 2017.

BRITISH COLUMBIA HERITAGE BRANCH. Conservation Management Plan for Historic Hat Creek Ranch - A guide to future land use planning, management and operations. Vancouver, 2013. Disponível em:

https://www2.gov.bc.ca/assets/gov/british-columbians-our-governments/ourhistory/historic-

places/documents/heritage/conservation_management_plan_hat_creek.pdf $+\& c d=1 \& h l=p t-B R \& c t=c l n k \& g l=b r>$. Acesso em: 21 nov. 2017.

BRANCO, M.; Oliveira, F. Análise dos Recalques das Fundações do Edifício Copan, São Paulo, Brasil. Journal of Engineering Technology (JET), v. 2, p. 100105, 2013.

CARDILLI, Juliana. Após a morte de cachorro, Copan interdita área externa para evitar acidentes. Disponível em:

<http://gl globo.com/Noticias/SaoPaulo/0,,MUL1417294-5605,00APOS+MORTE+DE+CACHORRO+COPAN+INTERDITA+AREA+EXTERNA+PARA+EV ITAR+ACIDENTES.html>. Acesso em: 7 jul. 2016.

CUNHA, Fernanda Craveiro. Revestimento de pedra fingida: protagonista invisível do centro de São Paulo. Dissertação de (Mestrado em Habitação, Planejamento e Tecnologia) - Instituto de Pesquisas Tecnológicas do Estado de São Paulo. São Paulo, 2016.

Revestimento de Pedra Fingida no Centro de São Paulo. Revista

Restauro. Disponível em: < http://web.revistarestauro.com.br/revestimento-depedra-fingida-no-centro-de-sao-paulo/> acesso em: 17 de out 2018. 
COELHO, I. R. P. A Produção de Painéis em Mosaico no Período Pós-Guerra em São Paulo: Industrialização e Modernidade Versus Tradição Artesanal. In: DOCOMOMO BRASIL, 5., 2003, São Carlos. Anais eletrônicos. São Carlos: Docomomo, 2003. Disponível em: <http://www.docomomo.org.br/seminario 5 pdfs/062R.pdf>. Acesso em: 30 mar. 2018.

CARVALHO, Cláudia S. R. Preservação da Arquitetura Moderna: Edifícios de Escritórios Construídos no Rio de Janeiro entre 1930 e 1960. Tese de doutorado. São Paulo, 2005. Faculdade de Arquitetura e Urbanismo da Universidade de São Paulo.

Conservação preventiva de edifícios e sítio históricos: pesquisa e prática. In: Revista CPC, São Paulo, n. 18, p. 141-153, dez. 2014-abr. 2015.

Disponível em: < https://www.revistas.usp.br/cpc/article/download/88655/92657>. Acesso em: 7 ago. 2017.

DEL CORTO, Américo. Reminiscências Ribeirão Pires que vi e vivi. Ribeirão Pires, 2006.

EDIFÍCIO SEDE - BANCO DO ESTADO DE SÃO PAULO - S/A. Revista Acrópole, São Paulo, n.1 16, Ano 10, dezembro, p. 195-208,1947. Disponível em: <http://www.acropole.fau.usp.br/edicao/116>. Acesso em: 29 nov. 2018.

ICOMOS. Carta de Atenas.1933. Disponível em: < http://portal.iphan.gov.br/uploads/ckfinder/arquivos/Carta\%20de\%20Atenas \%201933.pdf>. Acesso em: 14 abr. 2017.

Carta de Veneza: Carta internacional sobre a conservação e o restauro de monumentos e dos sítios. 1964. Disponível em: < http://portal.iphan.gov.br/uploads/ckfinder/arquivos/Carta\%20de\%20Veneza \%201964.pdf >. Acesso em: 14 abr. 2017. 
The Burra Charter - The Australia ICOMOS Charter for Places of

Cultural Significance. 2013. Disponível em: <

http://portal.iphan.gov.br/uploads/ckfinder/arquivos/The-Burra-Charter-2013Adopted-31_10_2013.pdf >. Acesso em: 17 abr. 2017.

Carta do ICOMOS: Princípios para a análise, conservação e restauro estrutural do patrimônio arquitetônico. 2003. Disponível em: <https://5cidade.files.wordpress.com/2008/03/carta-do-icomos2003_principios.pdf >. Acesso em: 14 abr. 2017.

Carta de Madrid: Critérios para a conservação do patrimônio arquitetônico do século XX. 2011. Disponível em: < http://www.icomosisc20c.org/pdf/MDversionportugese.pdf>. Acesso em: 26 mar. 2019.

FITCH, James M. Preservação do Patrimônio Arquitetônico. São Paulo, FAUUSP, 1981.

FUNDAÇÃO CASA DE RUI BARBOSA. O projeto de conservação preventiva do Museu Casa de Rui Barbosa. Rio de Janeiro, s/d. Disponível em: < http://www.casaruibarbosa.gov.br/dados/DOC/artigos/aj/FCRB_ClaudiaCarvalho_Projeto_de_conservacao_preventiva_do_museu_Ca sa_de_Rui_Barbosa.pdf>. Acesso em: 9 maio 2017.

GUICHEN, Gael de. 1 Preventive conservation: a mere fad or far-reaching change? Museum International (201), 51: 4-6. Jan. 1999 Disponível em: < http://unesdoc.unesco.org/images/001 1/001 149/1 14933e.pdf>. Acesso em: 25 set 2018.

HERITAGE BRANCH. Conservation Plans. British Columbia, s/d. Disponível em: <https://www.for.gov.bc.ca/ftp/heritage/external/!publish/web/Conservation _Planning_Methodology.pdf>. Acesso em: 3 ago. 2017.

GALVÃO, Walter J.F.; ORNSTEIN, Sheila Walbe. Análise da Funcionalidade dos Apartamentos do Edifício COPAN/SP. In: $7^{\circ}$ SEMINÁRIO INTERNACIONAL ESPAÇO SUSTENTÁVEL: INOVAÇÕES EM EDIFÍCIOS E CIDADES, NUTAU Núcleo 
de Pesquisa em Tecnologia da Arquitetura e Urbanismo da Universidade de São Paulo, 2008.

. COPAN/SP: A trajetória de um mega empreendimento, da concepção ao uso. 2007. Dissertação (Mestrado em Tecnologia da Arquitetura) - Faculdade de Arquitetura e Urbanismo, Universidade de São Paulo, São Paulo, 2007.

IPHAN. Proteção e Revitalização do Patrimônio Cultural no Brasil: Uma Trajetória. Secretaria do Patrimônio Histórico e Artístico Nacional, n 31 . Brasília, 1980. Disponível em: < http://portal.iphan.gov.br/uploads/ckfinder/arquivos/Protecao_revitalizacao_ patrimonio_cultural(1).pdf>. Acesso em: 3 nov. 2017. . KLÜPPEL, G. P.; SANTANA, M. C. (org.) Manual de Conservação Preventiva para Edificações. Bento Gonçalves, RS, 2005. Disponível em: < http://ipurb.bentogoncalves.rs.gov.br/uploads/downloads/IPHAN_Manual_de _conservao_preventiva.pdf >. Acesso em: 7 jun. 2016.

\section{LEAL, Daniela V. Oscar Niemeyer e o mercado imobiliário de São Paulo na} década de 1950: o escritório satélite sob direção do arquiteto Carlos Lemos e os edifícios encomendados pelo Banco Nacional Imobiliário. Campinas, 2003. Dissertação de mestrado. Instituto de Filosofia e Ciências Humanas, Universidade Estadual de Campinas.

LEMOS, Carlos A. C. A história do Edifício Copan. Trilogia do Copan; vol.1. São Paulo: Imprensa Oficial do Estado de São Paulo, 2014.

O que é Patrimônio Histórico. São Paulo: Brasiliense, 1981.

JONKER, Berdine: Conservation planning Methodology - Developing Policies for the conservation of historic places. British Columbia Heritage Branch, Canada. Disponível em: <https://www.for.gov.bc.ca/ $\mathrm{ftp} /$ heritage/external/!publish/web/Conservation_Planning_Methodology.pdf>. Acesso em: 24 nov. 2017. 
KERR, James S. Conservation Plan - A guide to the preparation of conservation plans for places of European cultural significance. 7.ed. Sydney: New South Wales Government - Department of the Environment and Heritage, 2013.

A Plan for the Conservation of the Sydney Opera House and its Site. 3.ed. Sydney: Sydney Opera House Trust, 2003. Disponível em:< http://www.environment.gov.au/system/files/pages/59ca36d1-4581-4d7d83d7-04b124d801bl/files/soh-conservationplan.pdf>. Acesso em: 17 nov. 2017.

KÜHL, Beatriz Mugayar. Notas sobre a Carta de Veneza. Anais do Museu Paulista: História e Cultura Material, São Paulo, v. 18, n. 2, p. 287-320, dez. 2010. Preservação do Patrimônio Arquitetônico da Industrialização. São Paulo: Ateliê Editorial, 2008.

LEFÈVRE, José Eduardo de Assis. Questões Contemporâneas de Preservação. In: SALCEDO, R. F. B.; BENINCASA, V. (org.). Questões Contemporâneas Patrimônio Arquitetônico e Urbano. 1.ed. São Paulo: Canal 6, 2017. P.13-26.

MACDONALD, SUSan. Modern Matters - Breaking the barriers to conserving modern heritage. In: Conservation perspectives (The Getty Conservation Institute), v. 28, n. 1, Spring 2013.

MICHELIN, L. A. C. Manual de operação, uso e manutenção das edificações residenciais multifamiliares: coleta e avaliação de exemplares de empresas de Caxias do Sul - RS. Trabalho de Conclusão de Curso (Mestrado Profissionalizante em Engenharia) - UFRGS, Porto Alegre, 2005.

OKSMAN, Silvio. Preservação do patrimônio arquitetônico moderno: a FAU de Vilanova Artigas. Dissertação (Mestrado em Projeto, Espaço e Cultura) Faculdade de Arquitetura e Urbanismo, Universidade de São Paulo, São Paulo, 2011. 
PINHEIRO, Marcos José de Araújo (coord.). Metodologia e Tecnologia na Área de Manutenção e Conservação de Bens Edificados - O Caso do Núcleo Arquitetônico Histórico de Manguinhos. Rio de Janeiro: Fiocruz, Casa de Oswaldo Cruz, 2009. Disponível em:

<https://wWw.arca.fiocruz.br/bitstream/icict/20103/2/LMTAMCBE001\%20\%281\% 29.pdf>. Acesso em: 23 dez. 2017.

PINHEIRO, Libânio M.; MUZARDO, Cassiane D.; SANTOS, Sandro P. Estruturas de Concreto - Aço para armaduras. Disponível em:

http://www.fec.unicamp.br/ almeida/ec702/EESC/Acos.pdf>. Acesso em: 20 jul. 2016.

SALVO, Simona. Restauro e 'Restauros' das Obras Arquitetônicas do Século 20: Intervenções em Arranha-céus em Confronto. Revista CPC, São Paulo, n. 4, p.139-157, maio-out. 2007. Disponível em: <www.revistas.usp.br/cpc/article/viewFile/15610/17184>. Acesso em: 18 jul. 2016.

SAMPAIO, Maria Ruth do Amaral. (org.) A Promoção Privada de Habitação Econômica e a Arquitetura Moderna 1930-1964. Rima: São Carlos, 2002

SANTOS, Adriana O.; SCHMITT, Carin M. Manuais de Operação, Uso e Manutenção de Edificações: Estudo exploratório sobre seu conteúdo frente às diretrizes da NBR 14.037/98 e expectativas dos usuários no Rio Grande do Sul e Alagoas. In: IV Encontro Tecnológico da Engenharia Civil e Arquitetura, 2003.

SCHOLZ, Cley. Prédios de São Paulo: Copan. O Estado de São Paulo, São Paulo, 2 de dezembro de 2013. Disponível em: < http://acervo.estadao.com.br/noticias/acervo,predios-de-sao- paulocopan,9408, 0.htm>. Acesso em: 3 maios 2016.

SÃO PAULO (Município) Secretaria Municipal de Cultura - Conselho Municipal de Preservação do Patrimônio Histórico, Cultural e Ambiental da Cidade de São Paulo. Resolução $n^{\circ}$ 19, de 18 de dezembro de 2012. Disponível em: < http://www.prefeitura.sp.gov.br/cidade/upload/1912res_1374185859.pdf >. 
Acesso em: 24 fev.2017.

SIMÕES, Antonio. Etapas Evolutivas de Ribeirão Pires. Ed. Do autor. Ribeirão Pires, 2008.

Diário Oficial da Cidade de São Paulo de 06 de dezembro de 2017 (São Paulo, 2017).

SILVA, Fernando Fernandez da. As Cidades Brasileiras e o Patrimônio Cultural da Humanidade. 2.ed. São Paulo: Edusp, 2012.

SIMONSON, Kaye Ellen. Maintaining Historic Buildings: An Annotated Bibliography. 1990. NPS Reading List. Washington, D.C.: U.S. Dept. of the Interior, National Park Service, Preservation Assistance Division. Disponível em: <https://ia800303.us.archive.org/33/items/maintaininghisto00simo/maintaining histo00simo.pdf>. Acesso em: 23 dez. 2017.

SIMPSON \& BROWN ARCHITECTS, Dunfermline Carnegie Library - Conservation Management Plan. Edinburgh, 2012. Disponível em:< http://www.simpsonandbrown.co.uk/files/image/HeritageConsultancy/12-0619_CarnegieLibrary_ConservationManagementPlan_LowRes.pdf $>$. Acesso em: 3 dez. 2017.

SOUZA. Diego Jesus de. Capacidade de Adições Minerais em Mitigar o Ataque por Sulfato de Sódio e Magnésio em Argamassas de Cimento Portland. Dissertação (Mestrado em Engenharia da Construção Civil) Universidade Federal do Paraná, Curitiba, 2016.

STANIFORTH, Sarah (ed.). Historical perspectives on preventive conservation. Los Angeles: The Getty Conservation Institute, 2013.

TINOCO, Jorge E. L. Plano de Conservação do Ensino à Prática, da Academia aos Canteiros de Obra. Textos para discussão, V. 55. Centro de Estudos Avançados da Conservação Integrada, Olinda, 2013. Disponível em: < file://C:/Users/Val\%C3\%A9ria/Downloads/texto\%20discussao\%2055\%20plano\% 
20de\%20conservacao\%201\%20(1).pdf >. Acesso em: 5 maio 2016.

TONINI, Marianna Brito. Arquitetura Moderna e Preservação do Patrimônio: Um Estudo sobre o Edifício Copan. Trabalho Final de Graduação. São Paulo, 2016. Faculdade de Arquitetura e Urbanismo da Universidade de São Paulo.

UNESCO. Ancient Monuments Portection Act, 1882. Disponível em: < http://www.unesco.org/culture/natlaws/media/pdf/gb/uk_act_1882_orof.pdf >. Acesso em: 23 nov. 2017.

VAN BALEN, Koenraad. Preventive conservation of historic buildings. In Restoration of Buildings and Monuments Materials science, Conservation of architectural heritage, Sustainable construction. PRECOMOS UNESCOS Chair. 2015. Disponível em: < http://www.changes-project.eu/wpcontent/uploads/2016/01/RBM-2015_Preventive-Conservation-of-historicbuildings.pdf $>$. Acesso em: 24 nov. 2017.

Preventive conservation and maintenance of architectural heritage as means of preservation of the spirit of place.In: 16th ICOMOS General Assembly and International Symposium: 'Finding the spirit of place - between the tangible and the intangible', 29 sept - 4 oct 2008, Quebec, Canada. Disponível em :<https://www.icomos.org/quebec2008/cd/toindex/77_pdf/77oKQk-292.pdf>. Acesso em 20 nov. 2017.

VIERA, Flavia do N. Proposta de Elaboração de Plano de Manutenção para Edificaçōes a Partir da Obrigatoriedade Legal da Inspeção Predial no Contexto Urbano das Cidades. Dissertação de mestrado. Rio de Janeiro, 2015. Faculdade Federal do Rio de Janeiro.

\section{NORMAS TÉCNICAS}

ASSOCIAÇÃO BRASILEIRA DE NORMAS TÉCNICAS. NBR 15575: Edificações Habitacionais - Desempenho. Partes 1-6. Rio de Janeiro: ABNT, 2013.

.NBR 5674: Manutenção de Edifícios - Requisitos Para o Sistema de 
Gestão da Manutenção. Rio de Janeiro: ABNT, 2012.

.NBR 14037: Diretrizes para elaboração de manuais de uso, operação e manutenção das edificações - Requisitos para elaboração e apresentação dos conteúdos. Rio de Janeiro: ABNT, 2014.

.NBR 7584: Concreto endurecido - avaliação de dureza superficial pelo esclerômetro de reflexão - Método de ensaio. Rio de Janeiro: ABNT, 2012.

.NBR 12655: Concreto de cimento Portland - Preparo, controle, recebimento e aceitação - Procedimento. Rio de Janeiro: ABNT, 2015.

.NBR 13528: Revestimento de paredes e tetos de argamassas inorgânicas - Determinação da Resistência de Aderência à Tração. Rio de Janeiro: ABNT, 2010.

.NBR 13749: Revestimentos de paredes e tetos de argamassas inorgânicas - Especificação. Rio de Janeiro: ABNT, 2013.

.NBR 11578: Cimento Portland. Rio de Janeiro: ABNT, 1991.

.NBR 13755: Revestimento cerâmicos de fachadas e paredes externas com utilização de argamassa colante - Projeto, execução, inspeção e aceitação - Procedimento. Rio de Janeiro: ABNT 2017.

\section{DOCUMENTOS CONSULTADOS}

Memorial Descritivo de especificação técnica dos serviços de recuperação do revestimento de Fachada do Edifício Copan, elaborado pela empresa "ARCO Assessoria em Racionalização Construtiva", emitido em 17 de janeiro de 2016. Acervo do Edifício Copan.

Parecer Técnico Sobre Ensaios de Aderência, realizado pela empresa "ARCO Assessoria em Racionalização Construtiva", datado de 7 de abril de 2015. 
Acervo do Edifício Copan.

Projeto de revestimento para as fachadas do Edifício Copan, desenvolvidos pela empresa "ARCO Assessoria em Racionalização Construtiva". Emissão inicial de 13 de janeiro de 2015 e última revisão em 10 de maio de 2016. Acervo do Edifício Copan.

Relatório de Ensaio Complementar - Concreto Endurecido: Avaliação da dureza superficial, realizado pela empresa "Falcão Baver - Centro Tecnológico de Controle da Qualidade" e emitido em 8 de julho de 2016. Acervo do Edifício Copan.

Relatório Técnico elaborado pela empresa "Falcão Baver - Centro Tecnológico de Controle da Qualidade", emitido em 30 de janeiro de 2014. Acervo do Edifício Copan.

\section{SITES CONSULTADOS}

Heritage Lottery fund

https://www.hlf.org.uk/

English Heritage

http://www.english-heritage.org.uk/

Simpson \& Brown Architects

https://www.simpsonandbrown.co.uk/

Sydney Opera House

https://www.sydneyoperahouse.com/

British Columbia Heritage Branch

https://www2.gov.bc.ca/

Fundação Casa de Rui Barbosa - Plano de Conservação Preventiva http://www.casaruibarbosa.gov.br/conservacaopreventiva/

IPHAN - Instituto do Patrimônio Histórico e Artístico Nacional http://portal.iphan.gov.br/

ICOMOS - International Council on Monument and Sites http://www.icomos.pt 
COMPRESP - Conselho Municipal de Preservação do Patrimônio Histórico, Cultural e Ambiental da cidade de São Paulo.

http://www.prefeitura.sp.gov.br/cidade/secretarias/cultura/conpresp/

CECl - Centro de Estudos Avançados de Conservação Integrada

http://www.ceci-br.org/ceci/index.php

PRECOM ${ }^{3} O S$

https://set.kuleuven.be/rlicc/research/precomos

SINDUSCON - Sindicato das Indústrias da Construção e do Mobiliário de Novo Hamburgo

http://www.sinduscon-nh.org.br/

CBIC - Câmara Brasileira da Indústria de Construção

http://cbic.org.br 


\section{ANEXOS}

I. RESULTADOS DOS ENSAIOS DE RESISTÊNCIA À TRAÇÃO

\begin{tabular}{|c|c|c|c|}
\hline C.P. $\mathrm{n}^{\circ}$ & Pavimento & Tensão (MPa) & Forma de Ruptura (\%) \\
\hline C.P. 1 & $30^{\circ}$ & 0,21 & $\begin{array}{c}50 \% \text { Argama ssa } \\
50 \% \text { Argamassa Colante }\end{array}$ \\
\hline C.P. 2 & $27^{\circ}$ & 0,26 & $\begin{array}{c}90 \% \text { Argamassa / Argamassa Colante } \\
10 \% \text { Argama ssa Colante / Pastilha }\end{array}$ \\
\hline C.P. 3 & $25^{\circ}$ & 0,51 & $100 \%$ Sub strato \\
\hline C.P. 4 & $20^{\circ}$ & 0,32 & $100 \%$ Sub strato \\
\hline C.P. 5 & $16^{\circ}$ & 0,40 & $100 \%$ Sub strato \\
\hline C.P. 6 & $15^{\circ}$ & 0,06 & $100 \%$ Argamassa / Argamassa Colante \\
\hline C.P. 7 & $13^{\circ}$ & 0,41 & $\begin{array}{r}90 \% \text { Argamassa / Argamassa Colante } \\
5 \% \text { Argamassa Colante / Pastilha } \\
5 \% \text { Pastilha / Cola }\end{array}$ \\
\hline C.P. 8 & $12^{\circ}$ & 0,07 & $100 \%$ Argama ssa \\
\hline
\end{tabular}

Tabela 8- Resultados dos Ensaios de Resistência à Tração da Face A da Torre dos Elevadores do Bloco B

Fonte: Falcão Baver, 2014. 


\begin{tabular}{|c|c|c|c|}
\hline C.P. $n^{\circ}$ & Pavimento & Tensão (MPa) & Forma de Ruptura (\%) \\
\hline C.P. 1 & $33^{\circ}$ & 0,06 & $100 \%$ Substrato / Argamassa \\
\hline C.P. 2 & $32^{\circ}$ & 0,18 & $100 \%$ Argamassa / Argama ssa Colante \\
\hline C.P. 3 & $31^{\circ}$ & 0,03 & $\begin{array}{l}50 \% \text { Substrato } \\
50 \% \text { Argamassa }\end{array}$ \\
\hline C.P. 4 & $29^{\circ}$ & 0,37 & $100 \%$ Argamassa / Argama ssa Colante \\
\hline C.P. 5 & $27^{\circ}$ & 0,37 & $\begin{array}{c}\text { 10\% Argamassa } \\
80 \% \text { Argamassa / Argama ssa Colante } \\
10 \% \text { Argamassa Colante / Pastilha }\end{array}$ \\
\hline C.P. 6 & $25^{\circ}$ & 0,04 & $100 \%$ Substrato / Argamassa \\
\hline C.P. 7 & $24^{\circ}$ & 0,30 & $\begin{array}{l}50 \% \text { Substrato } \\
50 \% \text { Argamassa }\end{array}$ \\
\hline C.P. 8 & $22^{\circ}$ & 0,30 & $100 \%$ Argamassa / Argamassa Colante \\
\hline C.P. 9 & $13^{\circ}$ & 0,29 & $100 \%$ Substrato \\
\hline C.P. 10 & $9^{\circ}$ & 0,19 & $\begin{array}{c}\text { 95\% Argamassa } \\
\text { 5\% Argama ssa / Argamassa Colante }\end{array}$ \\
\hline
\end{tabular}

Tabela 9- Resultados dos Ensaios de Resistência à Tração da Face B da Torre dos Elevadores do Bloco B

Fonte: Falcão Baver, 2014. 


\begin{tabular}{|c|c|c|c|}
\hline C.P. $\mathbf{n}^{\circ}$ & Pavimento & Tensão (MPa) & Forma de Ruptura (\%) \\
\hline C.P. 1 & $32^{\circ}$ & 0,02 & $100 \%$ Argamassa \\
\hline C.P. 2 & $30^{\circ}$ & 0,38 & $\begin{array}{c}50 \% \text { Argamassa } \\
50 \% \text { Argamassa Colante }\end{array}$ \\
\hline C.P. 3 & $29^{\circ}$ & 0,34 & $100 \%$ Argamassa / Argamassa Colante \\
\hline C.P. 4 & $27^{\circ}$ & $>0,31$ & $100 \%$ Substrato \\
\hline C.P. 5 & $27^{\circ}$ & 0,15 & $100 \%$ Argamassa / Argamassa Colante \\
\hline C.P. 6 & $26^{\circ}$ & $>0,23$ & $100 \%$ Substrato \\
\hline C.P. 7 & $25^{\circ}$ & $>0,13$ & $100 \%$ Substrato \\
\hline C.P. 8 & $25^{\circ}$ & 0,14 & $100 \%$ Argamassa \\
\hline C.P. 9 & $24^{\circ}$ & 0,34 & $10 \%$ Substrato \\
\hline C.P. 10 & $24^{\circ}$ & $>0,33$ & $100 \%$ Substrato \\
\hline C.P. 11 & $15^{\circ}$ & 0,33 & $100 \%$ Argamassa / Argamassa Colante \\
\hline C.P. 12 & $13^{\circ}$ & 0,04 & $100 \%$ Argamassa / Argamassa Colante \\
\hline C.P. 13 & $13^{\circ}$ & 0,05 & $100 \%$ Argamassa / Argamassa Colante \\
\hline C.P. 14 & $10^{\circ}$ & 0,04 & 50\% Argamassa \\
\hline C.P. 15 & $10^{\circ}$ & 0,47 & 50\% Argamassa Colante \\
\hline C.P. 16 & $9^{\circ}$ & $>0,11$ & $100 \%$ Argamassa / Argamassa Colante \\
\hline C.P. 17 & $8^{\circ}$ & 0,18 & $100 \%$ Argamassa / Argamassa Colante \\
\hline
\end{tabular}

Tabela 10- Resultados dos Ensaios de Resistência à Tração da Face D da Torre dos Elevadores do Bloco B

Fonte: Falcão Baver, 2014.

\begin{tabular}{|c|c|c|c|}
\hline C.P. $\mathrm{n}^{\circ}$ & Pavimento & Tensão (MPa) & Forma de Ruptura (\%) \\
\hline C.P. 1 & $33^{\circ}$ & 0,17 & $\begin{array}{l}50 \% \text { Substrato } \\
50 \% \text { Argamassa }\end{array}$ \\
\hline C.P. 2 & $32^{\circ}$ & $>0,20$ & $100 \%$ Substrato \\
\hline C.P. 3 & $31^{\circ}$ & 0,17 & $\begin{array}{l}50 \% \text { Substrato } \\
50 \% \text { Argamassa }\end{array}$ \\
\hline C.P. 4 & $28^{\circ}$ & 0,31 & $100 \%$ Argamassa / Argamassa Colante \\
\hline C.P. 5 & $24^{\circ}$ & 0,07 & $\begin{array}{c}40 \% \text { Argamassa / Argamassa Colante } \\
60 \% \text { Pastilha / Cola }\end{array}$ \\
\hline C.P. 6 & $22^{\circ}$ & $>0,29$ & $100 \%$ Substrato \\
\hline C.P. 7 & $18^{\circ}$ & 0,42 & $\begin{array}{c}80 \% \text { Argamassa } \\
20 \% \text { Argamassa / Argamassa Colante }\end{array}$ \\
\hline C.P. 8 & $10^{\circ}$ & 0,16 & $\begin{array}{c}60 \% \text { Argamassa / Argamassa Colante } \\
40 \% \text { Pastilha / Cola }\end{array}$ \\
\hline
\end{tabular}

Tabela 11-Resultados dos Ensaios de Resistência à Tração da Face $\mathrm{F}$ da Torre dos Elevadores do Bloco B

Fonte: Falcão Baver, 2014. 


\begin{tabular}{|c|c|c|c|}
\hline C.P. ${ }^{\circ}$ & Pavimento & Tensão (MPa) & Forma de Ruptura (\%) \\
\hline C.P. 1 & $31^{\circ}$ & 0,09 & $100 \%$ Argamassa \\
\hline C.P. 2 & $29^{\circ}$ & 0,51 & $100 \%$ Argamassa / Argamassa Colante \\
\hline C.P. 3 & $26^{\circ}$ & 0,09 & $100 \%$ Argamassa / Argamassa Colante \\
\hline C.P. 4 & $22^{\circ}$ & 0,12 & $100 \%$ Argamassa / Argamassa Colante \\
\hline C.P. 5 & $18^{\circ}$ & 0,29 & $100 \%$ Argamassa \\
\hline C.P. 6 & $17^{\circ}$ & 0,06 & $100 \%$ Argamassa / Argamassa Colante \\
\hline C.P. 7 & $15^{\circ}$ & 0,10 & $100 \%$ Argamassa / Argamassa Colante \\
\hline C.P. 8 & $13^{\circ}$ & $>0,21$ & $100 \%$ Substrato \\
\hline C.P. 9 & $11^{\circ}$ & 0,11 & $100 \%$ Argamassa / Argamassa Colante \\
\hline
\end{tabular}

Tabela 12-Resultados dos Ensaios de Resistência à Tração da Face $G$ da Torre dos Elevadores do Bloco B

Fonte: Falcão Baver, 2014.

\begin{tabular}{|c|c|c|c|}
\hline C.P. $\mathrm{n}^{\circ}$ & Pavimento & Tensão (MPa) & Forma de Ruptura (\%) \\
\hline C.P. 1 & $31^{\circ}$ & 0,06 & $100 \%$ Argamassa \\
\hline C.P. 2 & $29^{\circ}$ & 0,44 & $\begin{array}{c}10 \% \text { Argam assa Colante / Pastilha } \\
90 \% \text { Cola / Dispositivo }\end{array}$ \\
\hline C.P. 3 & $28^{\circ}$ & 0,66 & $100 \%$ Argamassa / Argamassa Colante \\
\hline C.P. 4 & $27^{\circ}$ & 0,18 & $100 \%$ Argamassa / Argamassa Colante \\
\hline C.P. 5 & $26^{\circ}$ & $>0,24$ & $100 \%$ Substrato \\
\hline C.P. 6 & $25^{\circ}$ & 0,23 & $\begin{array}{l}\text { 85\% Argamassa / Argamassa Colante } \\
15 \% \text { Argam assa Colante / Pastilha }\end{array}$ \\
\hline C.P. 7 & $23^{\circ}$ & 0,24 & $100 \%$ Argamassa / Argamassa Colante \\
\hline C.P. 8 & $20^{\circ}$ & 0,17 & $\begin{array}{c}\text { 65\% Argamassa / Argamassa Colante } \\
35 \% \text { Pastilha / Cola }\end{array}$ \\
\hline C.P. 9 & $17^{\circ}$ & 0,16 & $100 \%$ Argamassa / Argamassa Colante \\
\hline C.P. 10 & $13^{\circ}$ & $>0,32$ & $100 \%$ Substrato \\
\hline C.P. 11 & $12^{\circ}$ & $>0,29$ & $100 \%$ Substrato \\
\hline C.P. 12 & $9^{\circ}$ & $>0,28$ & $100 \%$ Substrato \\
\hline C.P. 13 & $8^{\circ}$ & $>0,39$ & $100 \%$ Substrato \\
\hline C.P. 14 & $2^{\circ}$ & 0,29 & $100 \%$ Argamassa \\
\hline
\end{tabular}

Tabela 13- Resultados dos Ensaios de Resistência à Tração da Fachada Sudoeste

Fonte: Falcão Baver, 2014. 


\begin{tabular}{|c|c|c|c|}
\hline C.P. $n^{0}$ & Pavimento & Tensão (MPa) & Forma de Ruptura (\%) \\
\hline C.P. 1 & $32^{\circ}$ & 0,13 & $\begin{array}{l}90 \% \text { Substrato } \\
10 \% \text { Argamassa }\end{array}$ \\
\hline C.P. 2 & $31^{\circ}$ & $>0,36$ & $100 \%$ Substrato \\
\hline C.P. 3 & $31^{\circ}$ & $>0,18$ & $100 \%$ Substrato \\
\hline C.P. 4 & $29^{\circ}$ & 0,08 & 100\% Argamassa / Argamassa Colante \\
\hline C.P. 5 & $28^{\circ}$ & $>0,33$ & $100 \%$ Substrato \\
\hline C.P. 6 & $28^{\circ}$ & 0,24 & $\begin{array}{l}30 \% \text { Substrato } \\
70 \% \text { Argamassa }\end{array}$ \\
\hline C.P. 7 & $26^{\circ}$ & 0,33 & 100\% Argamassa / Argamassa Colante \\
\hline C.P. 8 & $25^{\circ}$ & $>0,24$ & $100 \%$ Substrato \\
\hline C.P. 9 & $25^{\circ}$ & $>0,32$ & $100 \%$ Substrato \\
\hline C.P. 10 & $22^{\circ}$ & 0,12 & $100 \%$ Argamassa \\
\hline C.P. 11 & $20^{\circ}$ & 0,11 & $100 \%$ Argamassa \\
\hline C.P. 12 & $17^{\circ}$ & 0,21 & $100 \%$ Argamassa \\
\hline C.P. 13 & $17^{\circ}$ & 0,10 & $100 \%$ Argamassa \\
\hline C.P. 14 & $14^{\circ}$ & 0,50 & $100 \%$ Argamassa \\
\hline C.P. 15 & $13^{\circ}$ & 0,15 & $100 \%$ Argamassa / Argamassa Colante \\
\hline C.P. 16 & $9^{\circ}$ & 0,43 & $\begin{array}{l}50 \% \text { Substrato } \\
50 \% \text { Argamassa }\end{array}$ \\
\hline C.P. 17 & $8^{\circ}$ & 0,36 & $100 \%$ Argamassa / Argamassa Colante \\
\hline C.P. 18 & $6^{\circ}$ & 0,41 & $\begin{array}{c}95 \% \text { Argamassa / Argamassa Colante } \\
5 \% \text { Pastilha / Cola }\end{array}$ \\
\hline
\end{tabular}

Tabela 14- Resultados dos Ensaios de Resistência à Tração da Fachada Noroeste

Fonte: Falcão Baver, 2014. 
II. RESULTADOS DOS ENSAIOS DE RESISTÊNCIA À TRAÇÃO

\begin{tabular}{|c|c|c|c|c|}
\hline ARGAMASSA & $\begin{array}{l}\text { TRATAMENTO } \\
\text { DA BASE }\end{array}$ & PASTILHA & $\begin{array}{l}\text { TIPO DE } \\
\text { RUPTURA }\end{array}$ & $\begin{array}{l}\text { VALOR } \\
\text { (MPa) }\end{array}$ \\
\hline Argamassa 1 & Painel 1 & Vidro & Base & 0,83 \\
\hline Argamassa 1 & Painel 1 & Vidro & Base & 0,60 \\
\hline Argamassa 1 & Painel 1 & Vidro & Base & 0,40 \\
\hline Argamassa 1 & Painel 1 & Porcelana & Colante & 0,62 \\
\hline Argamassa 1 & Painel 1 & Porcelana & Base & 0,47 \\
\hline Argamassa 1 & Painel 1 & Porcelana & Base & 0,60 \\
\hline Argamassa 3 & Painel 1 & Vidro & Colante & 0,35 \\
\hline Argamassa 3 & Painel 1 & Vidro & Colante & 0,81 \\
\hline Argamassa 3 & Painel 1 & Vidro & Colante & 0,64 \\
\hline Argamassa 3 & Painel 1 & Porcelana & Colante & 0,66 \\
\hline Argamassa 3 & Painel 1 & Porcelana & Colante & 0,70 \\
\hline Argamassa 3 & Painel 1 & Porcelana & Colante & 0,70 \\
\hline Argamassa 2 & Painel 1 & Vidro & Colante & 0,63 \\
\hline Argamassa 2 & Painel 1 & Vidro & Colante & 0,60 \\
\hline Argamassa 2 & Painel 1 & Vidro & Base & 0,46 \\
\hline Argamassa 2 & Painel 1 & Porcelana & Base & 0,44 \\
\hline Argamassa 2 & Painel 1 & Porcelana & Base & 0,63 \\
\hline Argamassa 2 & Painel 1 & Porcelana & Base & 0,67 \\
\hline Argamassa 3 & Painel 2 & Vidro/tela tardoz & Colante & 0,98 \\
\hline Argamassa 3 & Painel 2 & Vidro/tela tardoz & Colante & 0,35 \\
\hline Argamassa 3 & Painel 2 & Vidro/tela tardoz & Colante & 0,96 \\
\hline Argamassa 3 & Painel 2 & Porcelana & Base & 0,39 \\
\hline Argamassa 3 & Painel 2 & Porcelana & Colante & 0,71 \\
\hline Argamassa 3 & Painel 2 & Porcelana & Base & 0,67 \\
\hline Argamassa 2 & Painel 2 & Vidro/tela tardoz & Colante & 0,65 \\
\hline Argamassa 2 & Painel 2 & Vidro/tela tardoz & Base & 0,75 \\
\hline Argamassa 2 & Painel 2 & Vidro/tela tardoz & Colante & 0,88 \\
\hline Argamassa 2 & Painel 2 & Porcelana/tela tardoz & Base & 0,97 \\
\hline
\end{tabular}




\begin{tabular}{|c|c|c|c|c|}
\hline Argamassa 2 & Painel 2 & Porcelana/tela tardoz & Base & 0,76 \\
\hline Argamassa 2 & Painel 2 & Porcelana/tela tardoz & Base & 0,82 \\
\hline Argamassa 1 & Painel 2 & Vidro & Base & 0,47 \\
\hline Argamassa 1 & Painel 2 & Vidro & Colante & 0,79 \\
\hline Argamassa 1 & Painel 2 & Vidro & Base & 0,49 \\
\hline Argamassa 1 & Painel 2 & Porcelana & Base & 0,55 \\
\hline Argamassa 1 & Painel 2 & Porcelana & Colante & 0,29 \\
\hline Argamassa 1 & Painel 2 & Porcelana & Colante & 0,47 \\
\hline Argamassa 2 & Painel 3 & Vidro & Colante & 0,44 \\
\hline Argamassa 2 & Painel 3 & Vidro/tela tardoz & Colante & 0,71 \\
\hline Argamassa 2 & Painel 3 & Vidro & Colante & 0,54 \\
\hline Argamassa 2 & Painel 3 & Porcelana & Base & 0,97 \\
\hline Argamassa 2 & Painel 3 & Porcelana & Base & 0,76 \\
\hline Argamassa 2 & Painel 3 & Porcelana & Base & 0,61 \\
\hline Argamassa 1 & Painel 3 & Vidro & Base & 0,54 \\
\hline Argamassa 1 & Painel 3 & Vidro & Base & 0,48 \\
\hline Argamassa 1 & Painel 3 & Vidro & Base & 0,73 \\
\hline Argamassa 1 & Painel 3 & Porcelana & Base & 0,42 \\
\hline Argamassa 1 & Painel 3 & Porcelana & Base & 0,70 \\
\hline Argamassa 1 & Painel 3 & Porcelana & Base & 0,34 \\
\hline Argamassa 3 & Painel 3 & Vidro/tela tardoz & Base & 0,68 \\
\hline Argamassa 3 & Painel 3 & Vidro/tela tardoz & Colante & 0,72 \\
\hline Argamassa 3 & Painel 3 & Vidro/tela tardoz & Colante & 1,02 \\
\hline Argamassa 3 & Painel 3 & Vidro & Base & 0,92 \\
\hline Argamassa 3 & Painel 3 & Porcelana & Colante & 0,70 \\
\hline Argamassa 3 & Painel 3 & Porcelana & Base & 0,94 \\
\hline Argamassa 2 & Painel 4 & Vidro & Base & 0,67 \\
\hline Argamassa 2 & Painel 4 & Vidro & Base & 0,40 \\
\hline Argamassa 2 & Painel 4 & Vidro & Colante & 0,46 \\
\hline Argamassa 2 & Painel 4 & Porcelana & Base & 0,16 \\
\hline
\end{tabular}




\begin{tabular}{|l|c|c|c|c|}
\hline Argamassa 2 & Painel 4 & Porcelana & Base & 0,20 \\
\hline Argamassa 2 & Painel 4 & Porcelana & Base & 0,34 \\
\hline Argamassa 1 & Painel 4 & Vidro & Base & 0,36 \\
\hline Argamassa 1 & Painel 4 & Vidro & Base & 0,45 \\
\hline Argamassa 1 & Painel 4 & Vidro & Base & 0,20 \\
\hline Argamassa 1 & Painel 4 & Porcelana & Base & 0,68 \\
\hline Argamassa 1 & Painel 4 & Porcelana & Base & 0,64 \\
\hline Argamassa 1 & Painel 4 & Porcelana & Base & 0,84 \\
\hline Argamassa 3 & Painel 4 & Vidro & Base & 0,40 \\
\hline Argamassa 3 & Painel 4 & Vidro & Base & 0,57 \\
\hline Argamassa 3 & Painel 4 & Vidro & Base & 0,64 \\
\hline Argamassa 3 & Painel 4 & Porcelana & Base & 0,36 \\
\hline Argamassa 3 & Painel 4 & Porcelana & Base & 0,41 \\
\hline Argamassa 3 & Painel 4 & Porcelana & Base & 0,30 \\
\hline
\end{tabular}

Tabela 15- Resultados dos Ensaios de Resistência à Tração da Face D da Torre dos Elevadores de Bloco B

Fonte: ARCO, 2015 - adaptado pela autora. 
III. TERMO DE CONSENTIMENTO DE ENTREVISTA

\section{TERMO DE CONSENTIMENTO LIVRE E ESCLARECIDO}

Eu Affonso Celso Prazeres de Oliveira, como síndico do Condomínio Copan, concordo em conceder uma entrevista, para o estudo que tem como pesquisadora responsável a aluna de mestrado Valeria Aparecida Costa Bonfim, do programa de pós-graduação da Faculdade Arquitetura e Urbanismo da Universidade de São Paulo, $n^{\circ}$. USP 5522078, que pode ser contatada pelo e-mail valeriabonfim@usp.br e pelo telefone (11)98886-7047. Tenho ciência de que o estudo tem em vista realizar a entrevista a fim de registrar os relatos acerca das manutenções realizadas nas fachadas durante a minha gestão. Minha participação consistirá em conceder uma entrevista que será gravada e transcrita. Entendo que esse estudo possui finalidade de pesquisa acadêmica, que os dados obtidos não serão divulgados, a não ser com prévia autorização. A aluna providenciará uma cópia da transcrição da entrevista para meu conhecimento. Além disso, sei que posso abandonar minha participação na pesquisa quando quiser e que não receberei nenhum pagamento por esta participação.

São Paulo, 09 de fevereiro de 2018.

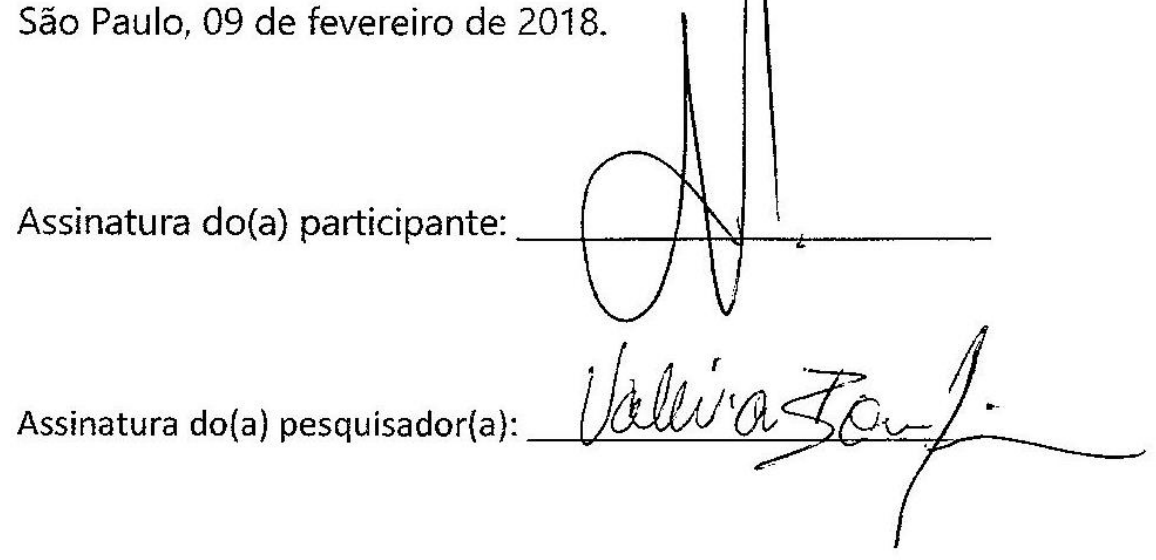




\section{EDIFÍCIO COPAN}

Plano de Conservação

Fachadas

(Apêndice A)

Versão 1

2019 
Este Plano de Conservação é parte integrante da Dissertação de Mestrado intitulada: A conservação da arquitetura moderna: as fachadas do Edifício Copan, apresentada à Faculdade de Arquitetura e Urbanismo da Universidade de São Paulo.

Autora: Valéria A. C. Bonfim

Orientadora: Prof ${ }^{a}$. Dr ${ }^{a}$. Fabiana Lopes de Oliveira 


\section{SUMÁRIO}

1. INTRODUÇÃO

1.1. TERMINOLOGIA 3

1.2. O EDIFÍCIO - (PEÇAS GRÁFICAS) 4

2. CONHECENDO O COPAN 11

2.1. CONTEXTUALIZAÇÃO HISTÓRICA 11

$\begin{array}{ll}\text { 2.2. CRACTERÍSTICAS DAS FACHADA } & 17\end{array}$

2.3. ANÁLISE DE EVIDÊNCIAS 22

2.4. COMPLEMENTO METÁLICO DA ESCADA HELICOIDAL 22

2.5. AVALIAÇÃO DO SIGNIFICADO CULTURAL 29

3. DECLARAÇÃO DE SIGNIFICANCIA 44

3.1. NIVEIS DE SIGNIFICÂNCIA 46

4. POLÍTICAS DE CONSERVAÇÃO 50

4.1. CONFIGURAÇÃO GERAL 50

4.2. EMBASAMENTO 51

4.3. FACHADAS 54

4.4. PRESTAÇÃO DE SERVIÇOS E RETENÇÃO DAS CARACTERÍSTICAS

4.5. CUIDADOS COM A CONSTRUÇÃO 56

4.6. CONTROLE DE MUDANÇA 57

$\begin{array}{lll}\text { 4.7. GESTÃO } & 58\end{array}$

5. CONSIDERAÇÕES FINAIS 59

$\begin{array}{ll}\text { 6. REFERÊNCIAS } & 60\end{array}$

7. ANEXO I - TERMO DE CONSENTIMENTO LIVRE E ESCLARECIDO 62 



\section{INTRODUÇÃO}

O Edifício Copan, símbolo da arquitetura modernista brasileira e ícone da cidade de São Paulo, foi projetado pelo arquiteto Oscar Niemeyer em coautoria com o arquiteto Carlos Lemos para ser um ponto focal na região central da cidade, que passava por um intenso processo de verticalização. Para comemorar o IV centenário da capital paulista e promover o turismo local foi projetado um complexo com dois edifícios: um destinado a um hotel, que não chegou a ser construído, e o outro para apartamentos residenciais com sua emblemática forma sinuosa, ambos fruto de uma parceria entre a empresa brasileira BNI (Banco Nacional Imobiliário) e a americana Intercontinental Hotels Corporation.

O complexo contemplaria galeria comercial, teatro, cinema, boates, restaurantes, piscina para atender hóspedes e moradores, além de garagem subterrânea. Foi chamado pela imprensa da época de "maciço turístico" e por seus empreendedores de Rockfeller Center de São Paulo.

Começou a ser construído no início da década de 1950 e, ao longo dos vinte anos de construção, alterações significativas foram realizadas em relação ao projeto original, entre elas: a não execução do edifício hoteleiro, que seria construído pelos parceiros americanos; a exclusão do teatro; a transformação do terraço em área para escritórios; as modificações no cinema e as transformações nos apartamentos dos Blocos E e F.

Apesar das modificações, o edifício curvilíneo surgiu na paisagem urbana e passou a ser reconhecido como símbolo da cidade pelos paulistanos, parte pela sua estética, parte pela notoriedade do seu criador. Mas com o passar dos anos, intempéries e ausência de manutenção suas marcantes fachadas se degradaram, colocando em risco tanto as pessoas que transitam no entorno quanto o desempenho do subsistema e sua memória enquanto testemunho arquitetônico de uma época, sendo necessárias intervenções de restauro.

Diante disto, destaca-se a importância em reconhecer o que deve ser conservado e de que modo. Pois o patrimônio arquitetônico do Movimento 
Moderno, do qual o Copan faz parte, nem sempre tem sua importância reconhecida de imediato, por estar cronologicamente próximo aos dias atuais. A falta deste reconhecimento pode colocar em risco sua memória ao se realizar, por exemplo, substituições, acréscimos ou supressão de elementos e componentes de forma indiscriminada. Sendo assim com objetivo de estabelecer diretrizes que auxiliem na proteção das fachadas do Copan, foi desenvolvido este Plano de Conservação, cujas políticas pretendem nortear os gestores, frente à complexidade inerente ao patrimônio. Este plano não tem a pretensão de fazer um relato definitivo da história do edifício, nem catalogar cada parte de seus elementos e componentes, mas sim analisar com brevidade os valores significativos do lugar e estabelecer políticas para conservá-los no presente e futuro.

Para atender eventuais demandas, o plano incorpora princípios de flexibilidade e tolerância às mudanças advindas, por exemplo, de solicitações dos usuários ou necessidade de atualização de sistemas, atendendo às requisições dos usos contemporâneos e o desenvolvimento futuro do edifício, sob a luz da conservação do patrimônio.

O Plano de Conservação deve ser associado a outro instrumento de preservação, o Manual de Uso, Operação e Manutenção, no qual são apresentadas as ações de manutenção, a periodicidade e as fichas de registro das atividades realizadas. A associação destes dois instrumentos tem o objetivo de abordar a conservação do patrimônio de uma forma mais abrangente, apontando o que é significativo e deve ser conservado e quais as ações necessárias para preservar a matéria retendo seu significado cultural. 


\subsection{TERMINOLOGIA}

Alguns termos utilizados neste documento são utilizados conforme definição da Carta de Burra. Descreve-se a definição de todos os termos importantes para a interpretação correta do plano de conservação.

Adaptação Alteração de um lugar para se adequar ao uso existente ou proposto

Associação Conexões existentes entre as pessoas e os lugares

Conservação Todos os processos de cuidar de um lugar, a fim de manter seu significado cultural.

Lugar Área geograficamente definida, podendo incluir elementos, objetos, espaços e pontos de vista.

Manutenção Cuidado de proteção contínua, a fim de retardar a deterioração.

Preservação É a proteção, a manutenção do estado existente retardando a deterioração.

Reconstrução Significa retornar um lugar para um estado anterior conhecido e distingue-se da restauração pela introdução de novos materiais.

Restauração Significa retornar um lugar para um estado anterior conhecido, por meio da remoção de acréscimos sem a introdução de novos materiais.

Significância Engloba valores atribuídos pelas pessoas, como estético, cultural histórico, científico, social ov espiritual, que são incorporados no tecido do lugar. 
Tecido Todo o material físico do lugar incluindo elementos, acessórios, conteúdos e objetos.

Uso Que respeita o significado cultural de um lugar. Tal uso compatível envolve o mínimo ou nenhum impacto no significado cultural.

\subsection{O EDIFÍCIO - (PEÇAS GRÁFICAS)}

O terreno no qual o Edifício Copan está implantado é limitado pela Avenida Ipiranga, pela Rua Araújo e pela rua particular Vila Normanda, na qual há uma passagem de pedestres para a Avenida São Luís, na região da República em São Paulo.

A icônica fachada principal - a dos brises - está voltada para a Avenida Ipiranga e um trecho na Rua Araújo. A fachada sudoeste está voltada para a Rua Araújo, a fachada noroeste faceia a rua particular da Vila Normanda e a fachada posterior, está voltada para outros lotes que dão frente para a Rua da Consolação. 


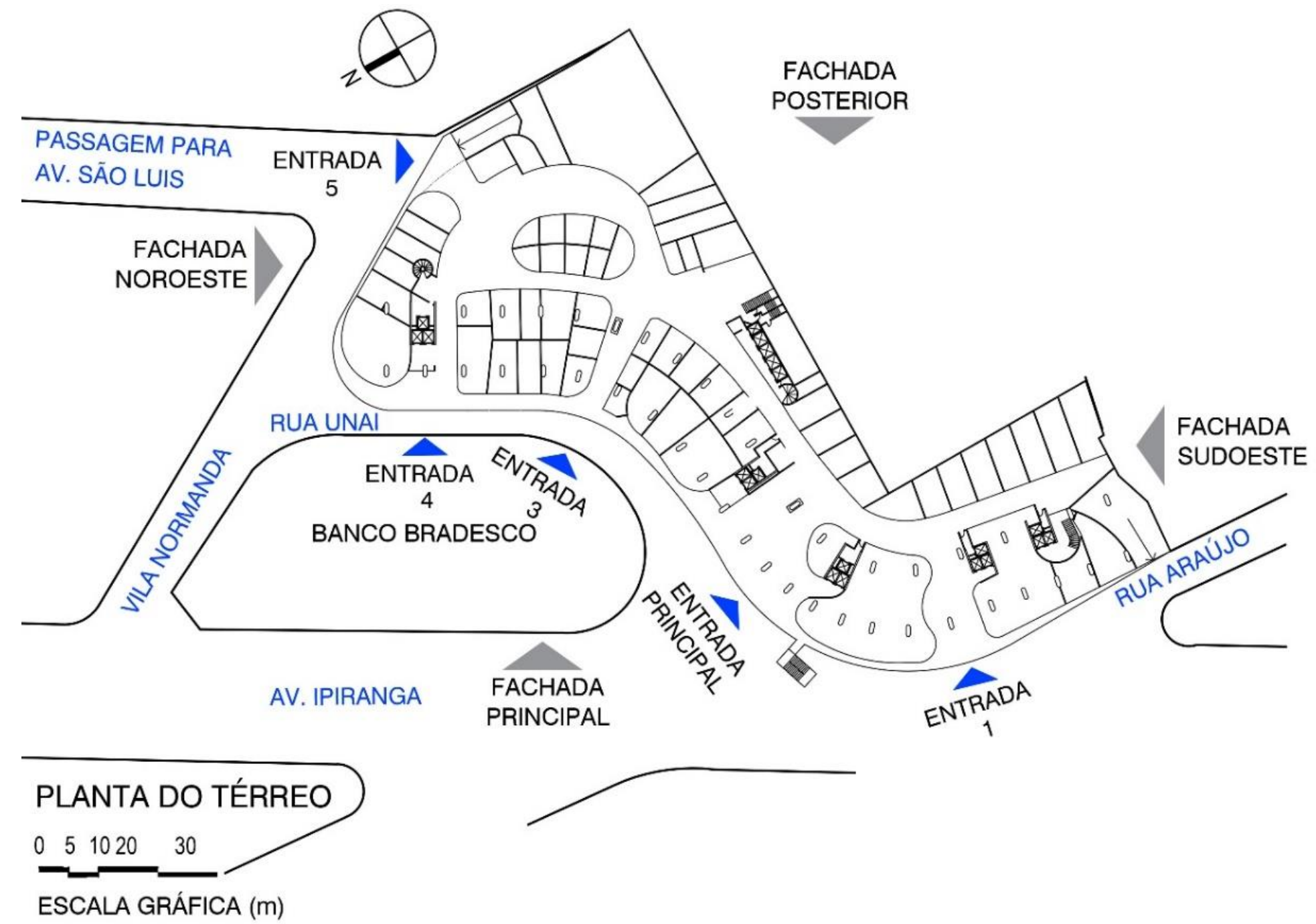




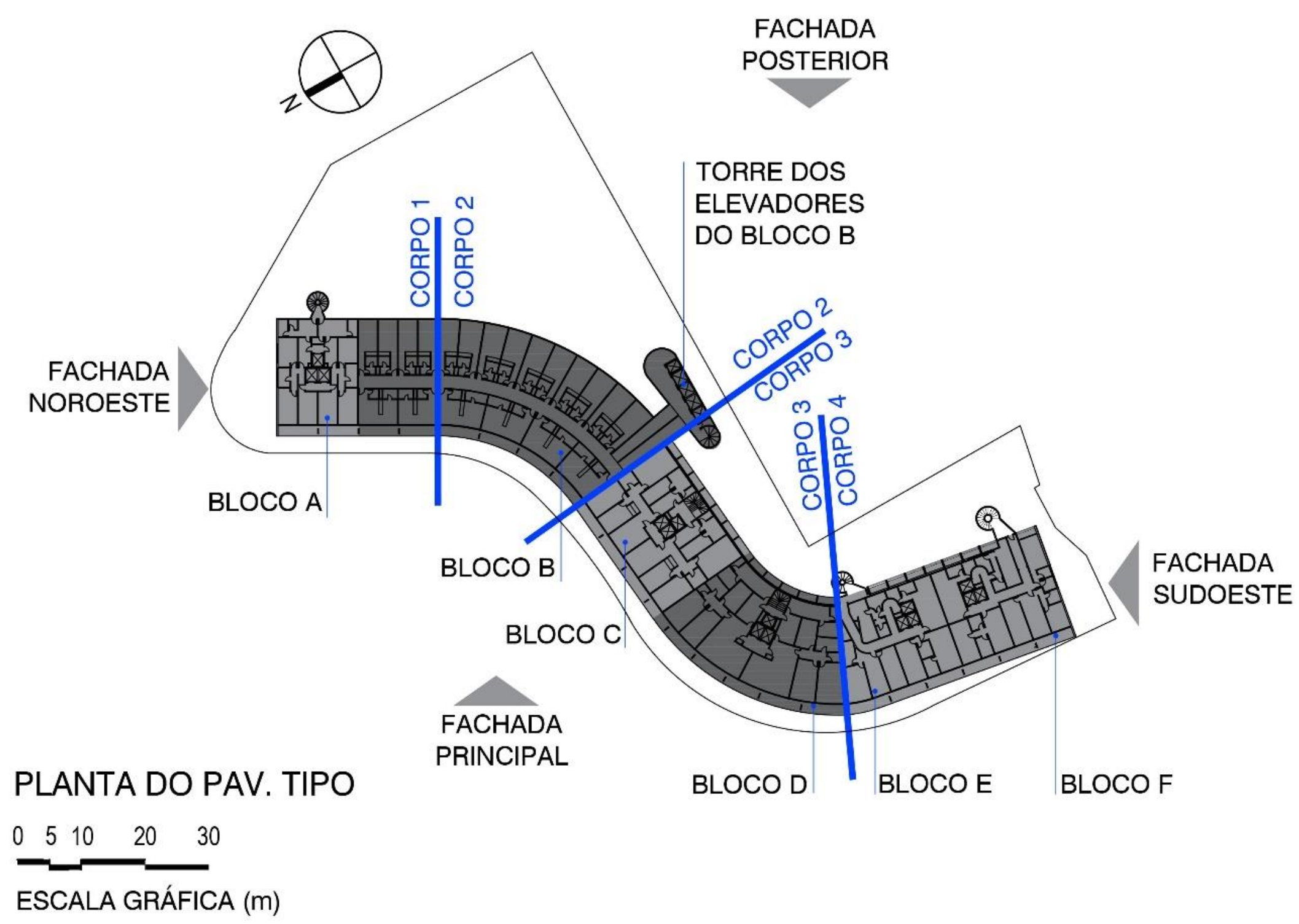

Figura 2 - Planta do pavimento tipo

Fonte: Elaboração da autora. 


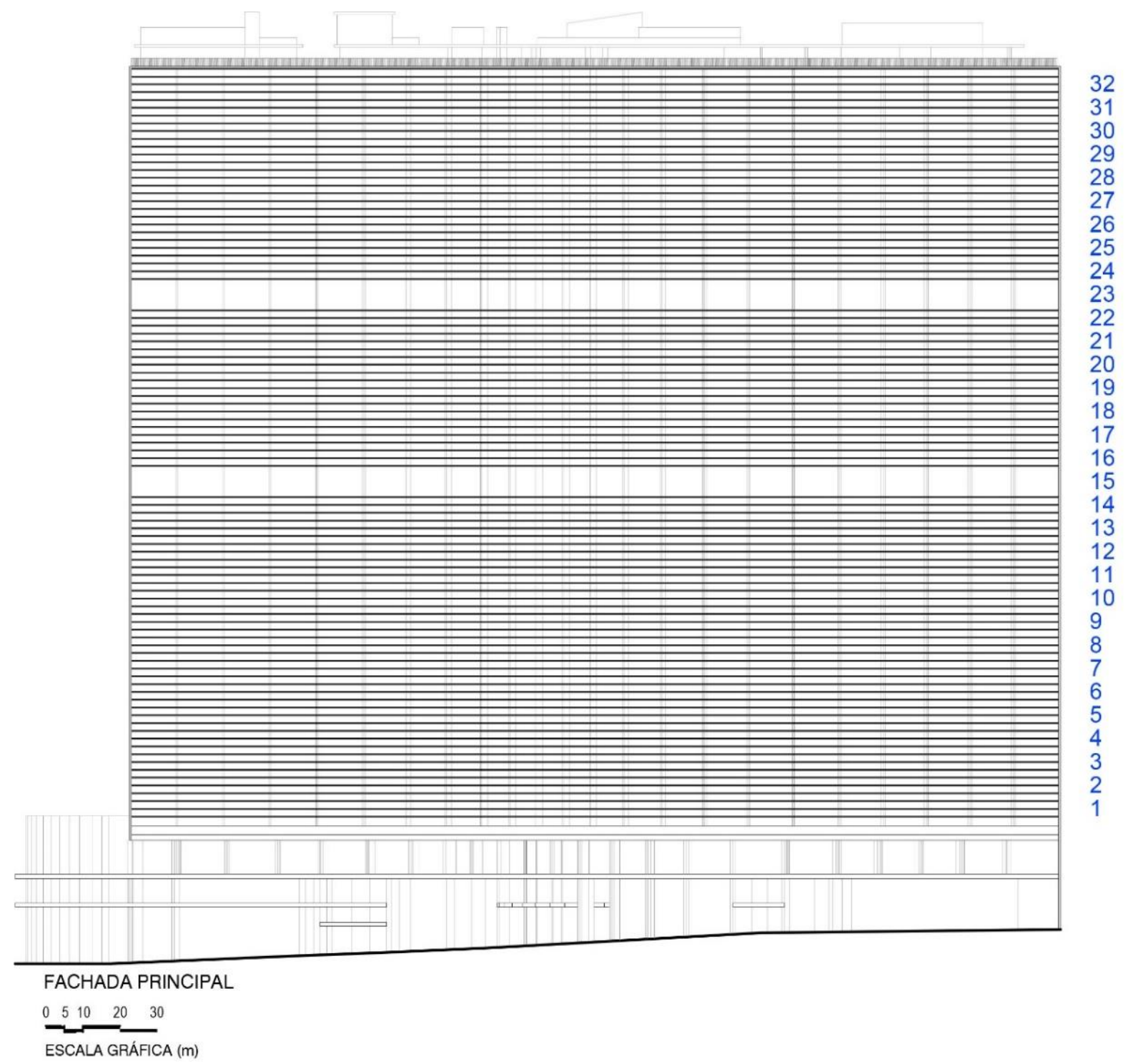

Figura 3 -Elevação da Fachada GRA P Fonte: Elaboração da autora. 


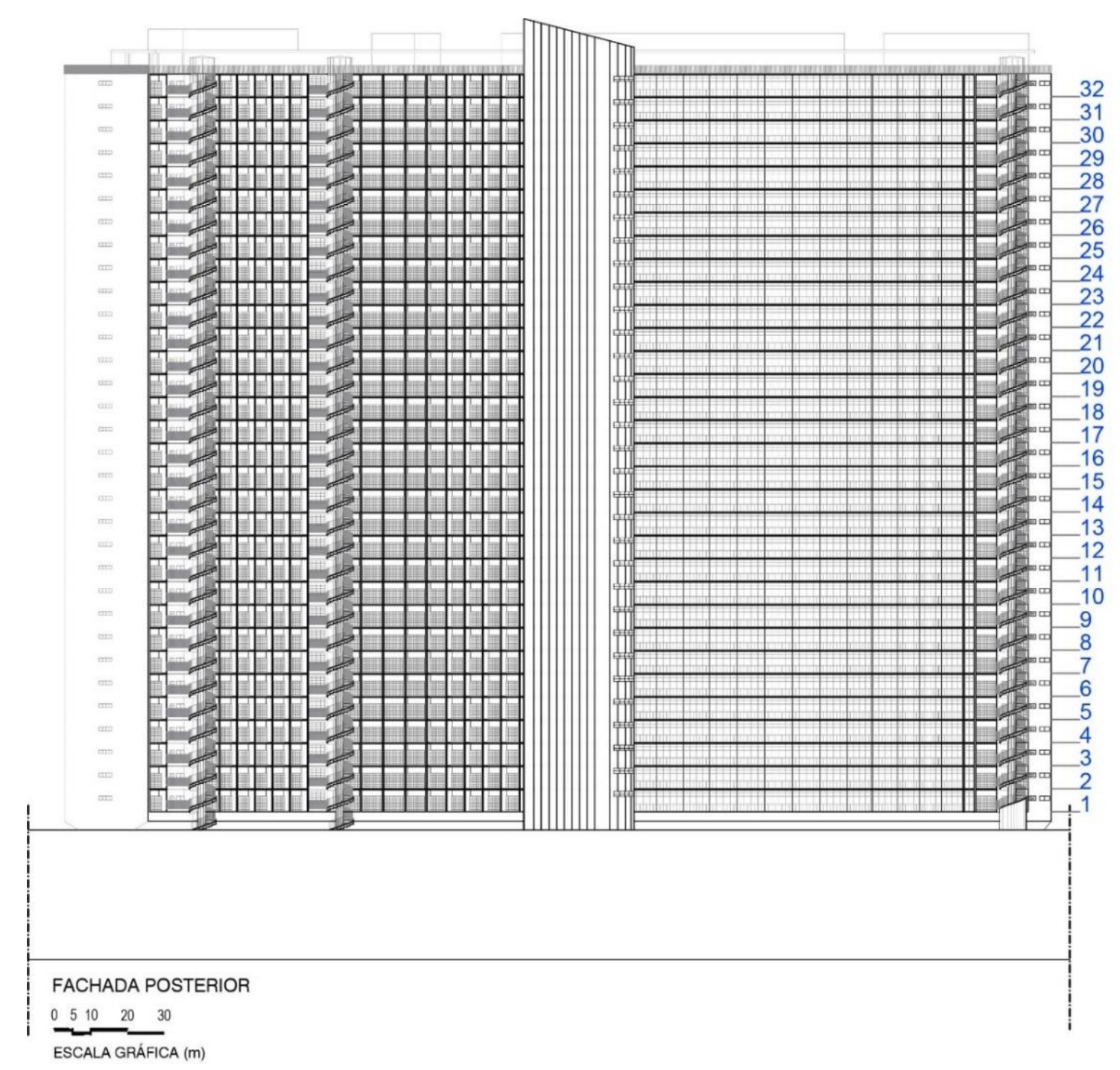

Figura 4 - Elevação da Fachada Posterior Fonte: Elaboração da autora. 


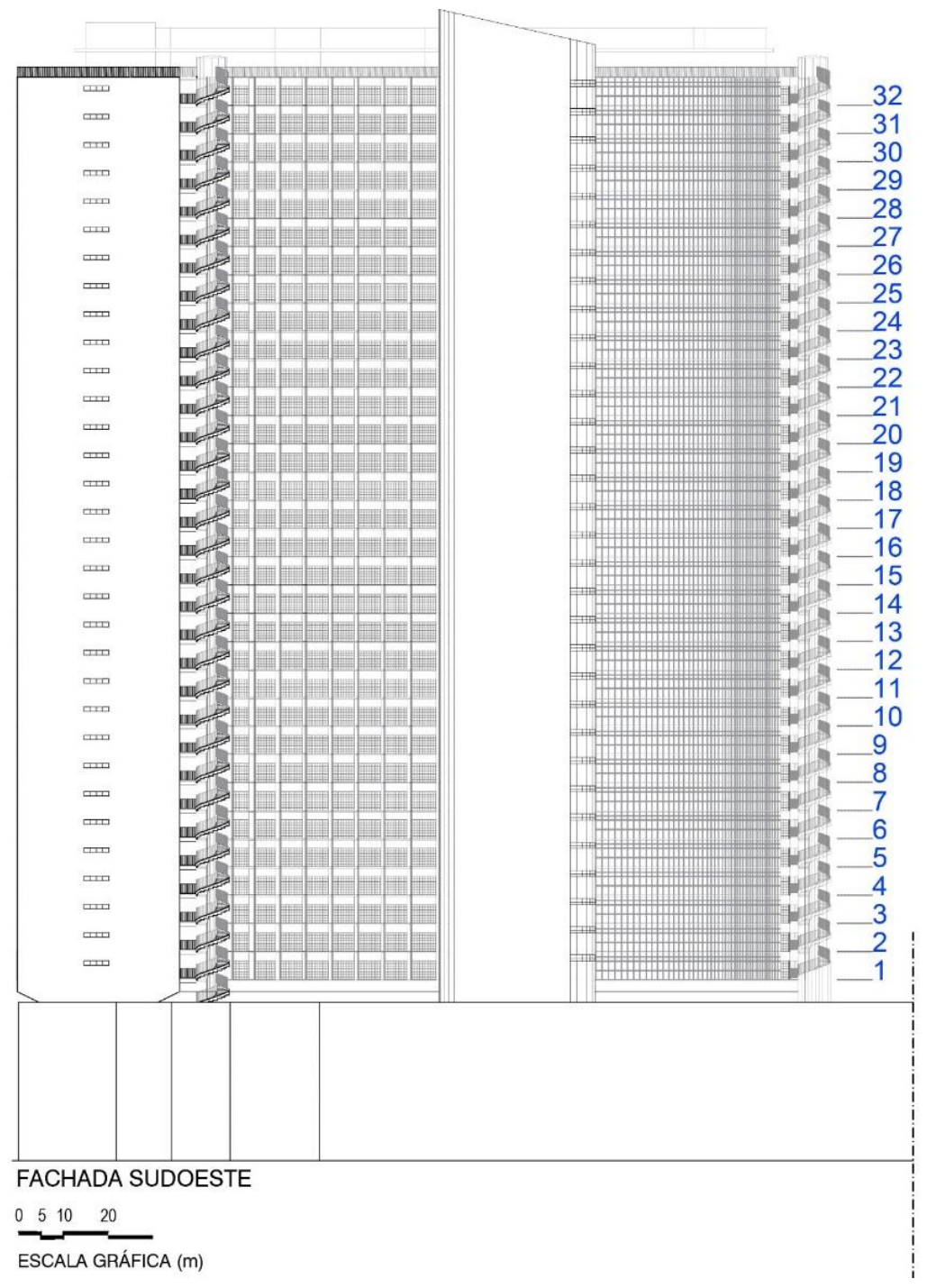

Figura 5 - Elevação da Fachada Sudoeste Fonte: Elaboração da autora. 


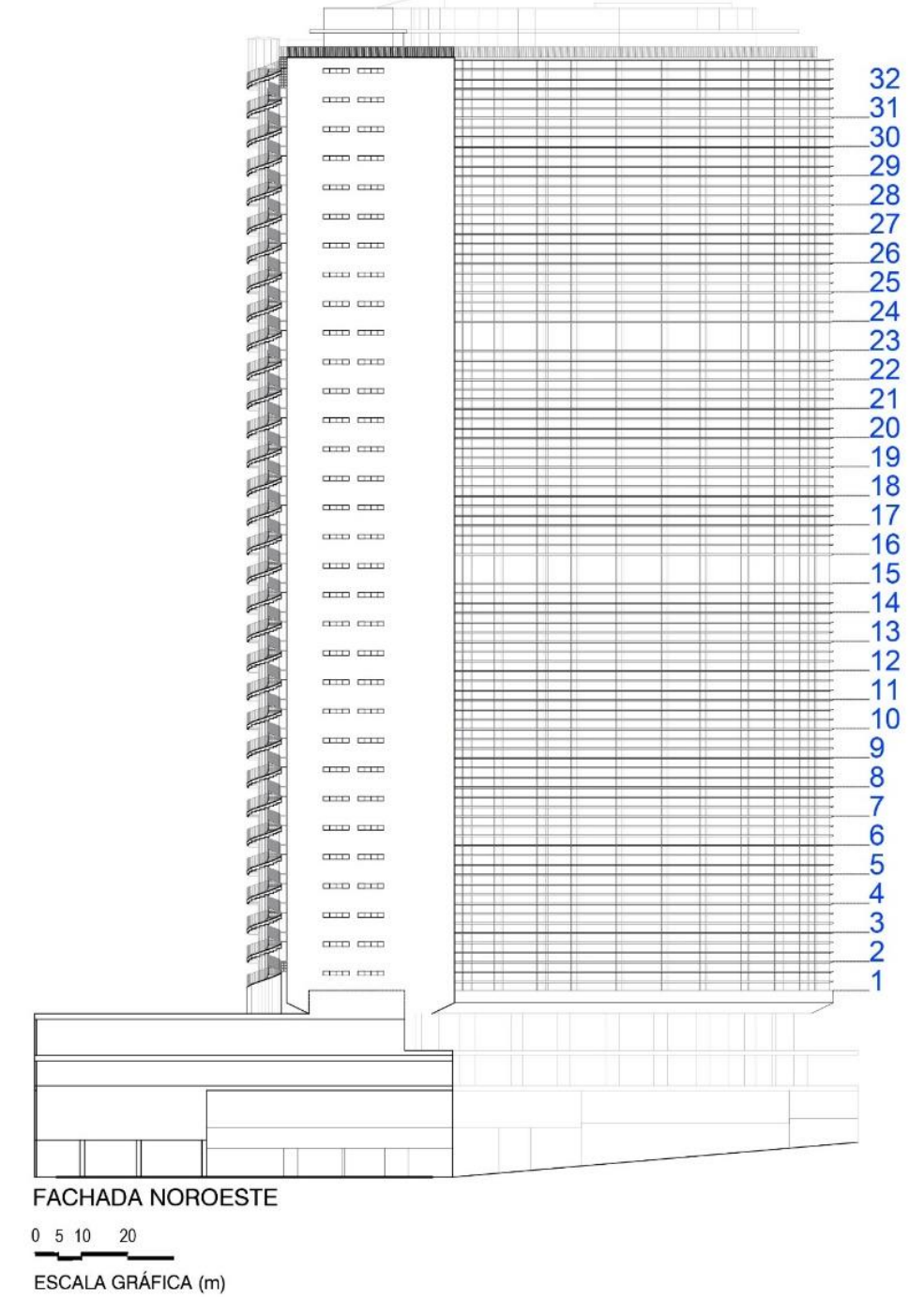

Figura 6 - Elevação da Fachada Noroeste Fonte: Elaboração da autora. 


\section{CONHECENDO O COPAN}

\subsection{CONTEXTUALIZAÇÃO HISTÓRICA}

1951 Octavio Orozimbo Roxo Loureiro fundador do Banco Nacional Imobiliário (BNI), tem a ideia de lançar um grande complexo hoteleiro implantado em conjunto com instalações de interesse turístico, visando as comemorações do IV Centenário de São Paulo. Em viagem a Chicago com seu amigo o arquiteto Henrique Mindlin, foram buscara auxilio técnico de empresa especializada em hotéis de alta classe, a Hollabird, Root and Burgee, cujos estudos iniciais seriam apresentados ao emissário de uma rede hoteleira americana a Intercontinental Hotels Corporation, subsidiária da Pan American Airways e dona de hotéis de grande porte na América latina.

\begin{tabular}{|c|c|}
\hline Junho & $\begin{array}{l}\text { Formalização da Conpanhia Pan-América de Hotéis e Turismo } \\
\text { - COPAN, associação entre a empresa de Roxo Loureiro e a } \\
\text { empresa hoteleira americana. }\end{array}$ \\
\hline Setembro & $\begin{array}{l}\text { Apresentação do estudo para o grande hotel a ser construído } \\
\text { na Av. Ipiranga, que seria o maior da América do Sul, com } 500 \\
\text { apartamentos, piscina, cinema, teatro, salões de arte e lojas, } \\
\text { idealizado para ser o Rockfeller Center de São Paulo. A } \\
\text { reportagem no jornal Folha da Manhã, apresenta fotografia } \\
\text { da maquete do complexo com } 3 \text { lâminas dispostas em } \\
\text { ziguezague (figura } 7 \text { ). Projeto idealizado pela empresa } \\
\text { americana. }\end{array}$ \\
\hline 1951 & $\begin{array}{l}\text { Niemeyer visita o Prefeito Armando Arruda Sampaio, } \\
\text { acompanhada por Roxo Loureiro e os técnicos americanos } \\
\text { para apresentar seu } \circ \text { projeto para } \bigcirc \text { Copan. A }\end{array}$ \\
\hline
\end{tabular}


fotomontagem publicada no jornal Diário da Manhã mostra o Copan com sua forma sinuosa, mas sem os brises.

\begin{tabular}{l}
1951 É protocolado na prefeitura o processo $n^{\circ}$ 081.482/51, o \\
primeiro projeto do complexo hoteleiro contendo o edifício \\
residencial, com sua característica forma sinuosa, tendo \\
como autor do projeto o arquiteto Oscar Niemeyer e, o \\
edifício hoteleiro, faceando a avenida Ipiranga, projetado \\
pelo arquiteto Henrique Mindlin, em parceria com o escritório \\
americano Hollabird, Root and Burgee. \\
\hline $1952 \quad$ É protocolado na prefeitura o processo n¹81.056/52 no qual \\
consta apenas o projeto do edifício residencial. A separação \\
dos projetos se deu pelo fato do hotel ser isento de \\
emolumentos.
\end{tabular}

1952 Início da construção do edifício residencial.

1952/1954 Fundações e concretagem das primeiras lajes do subsolo.

1954 Paralização das obras, por conta de intervenção judicial no BNI.

1956 Retomada das obras;

Conclusão da concretagem da viga de transição;

São responsáveis pelas obras as construtoras: A. Salfati \& $M$. Buchignani Ltda.; Ferreira \& Barreto S.A; a São Paulo S.A e a CNI (Companhia Nacional de Indústria e Construção).

1957 O Bradesco assume como novo promotor imobiliário.

1958 Início do monitoramento dos recalques das fundações pelo IPT; 
Protocolamento de projeto na prefeitura com modificações sem aumento de área.

1961 A CNI assume as obras do Copan.

1965 Entrega das primeiras loja e cinema.

$1966 \quad 1^{\circ}$ habite-se;

Protocolamento do projeto modificativo, onde são feitas as seguintes alterações: o teatro é retirado; o terraço é fechado e transformado em escritório e os apartamentos maiores concentrados nos Blocos $E$ e $F$ são retalhados em apartamentos de um dormitório e kitchenettes.

$1971 \quad 1^{\circ}$ assembleia condominial.

1972 Conclusão das obras.

1974 Último habite-se.

Década Período de decadência do Copan, frequentemente aparece

de 1980 na mídia como antro de prostitutas e traficantes; curtocircuito por falta de manutenção na rede elétrica, que deixou o edifício por vários dias sem energia elétrica; falta de água por dias devido à quebra de equipamentos, entre outros problemas.

1993 Assume a atual administração do Copan tendo como síndico Sr. Affonso Celso Prazeres de Oliveira.

A partir da Foram realizadas diversas atualizações de sistemas elétricos, década hidráulicos e de telecomunicações. Bom como substituição de 1990 da impermeabilização, modernização do centro de medição, desativação do incinerador e do tanque de 
combustível que o abastecia, localizado no subsolo, além de ações de manutenções rotineiras realizadas por uma equipe local bem treinada.

2009 Cachorro morre devido à queda de pastilha.

2012 Copan é tombado pelo CONPRESP.

2013 Levantamento das condições físicas e mapa de danos das fachadas realizados pela Falcão Baver.

2014 Projeto executivo de revestimento de fachada desenvolvido pela ARCO.

2015 Início das obras para remoção das partes soltas e posterior reconstrução das fachadas sudoeste, noroeste e torre dos elevadores do Bloco B.

2016 Paralização das obras.

Atualmente existe uma grande procura por apartamentos no Copan, que voltou a atrair a atenção dos paulistanos a partir da década de 1990, bem como pessoas de todos os cantos do mundo que o procuram, seja pela sua localização, sua arquitetura, por ser uma obra de Niemeyer, reconhecido mundialmente por suas formas curvilíneas ou pela segurança e comodidade interna. O fato é que as ações para valorização do edifício surtiram efeito e as pessoas passaram a procurá-lo cada vez mais. Intensificando os valores culturais atribuídos pela sociedade. 


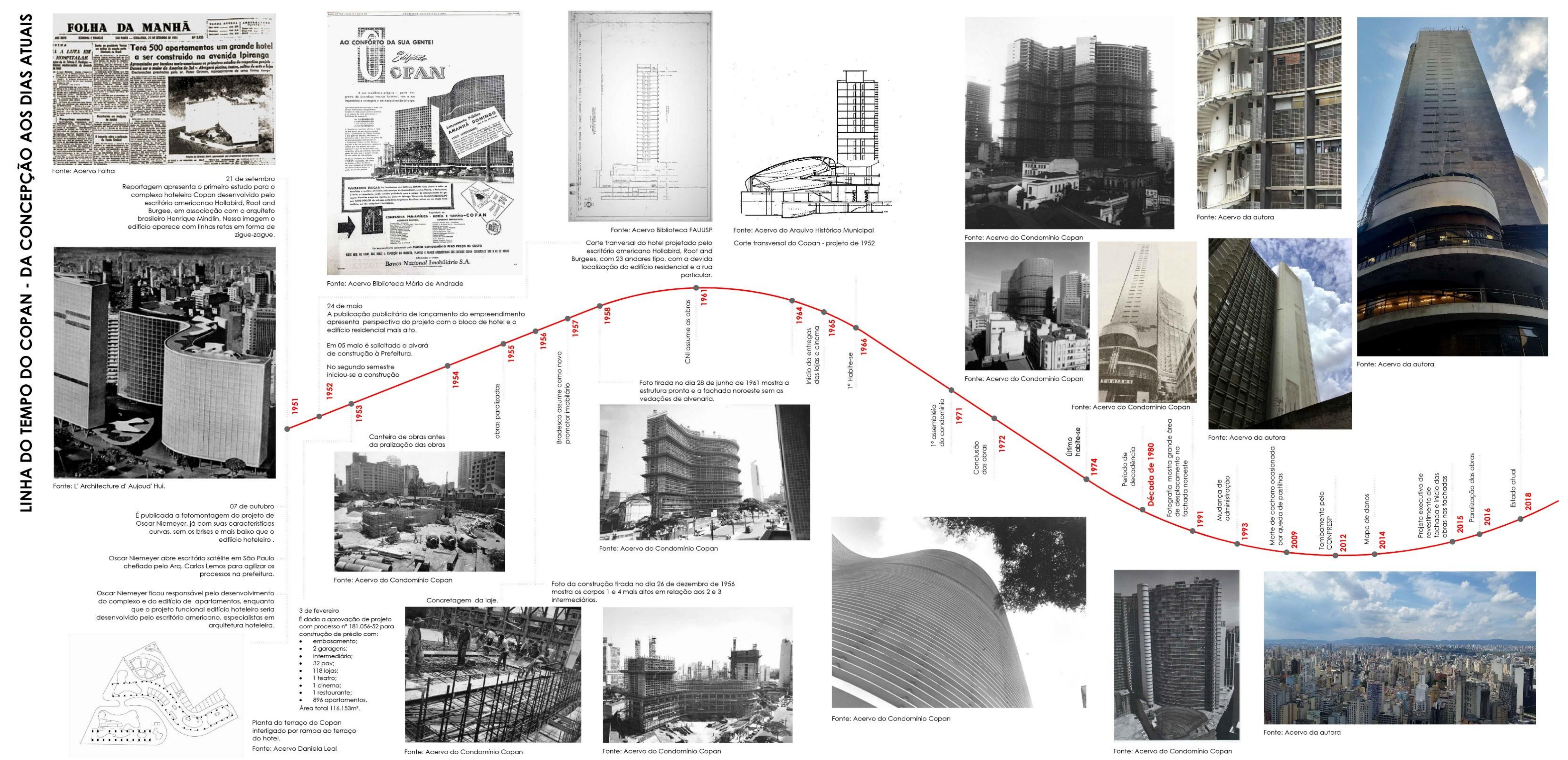




\subsection{CRACTERÍSTICAS DAS FACHADA}

\subsubsection{FACHADA PRINCIPAL}

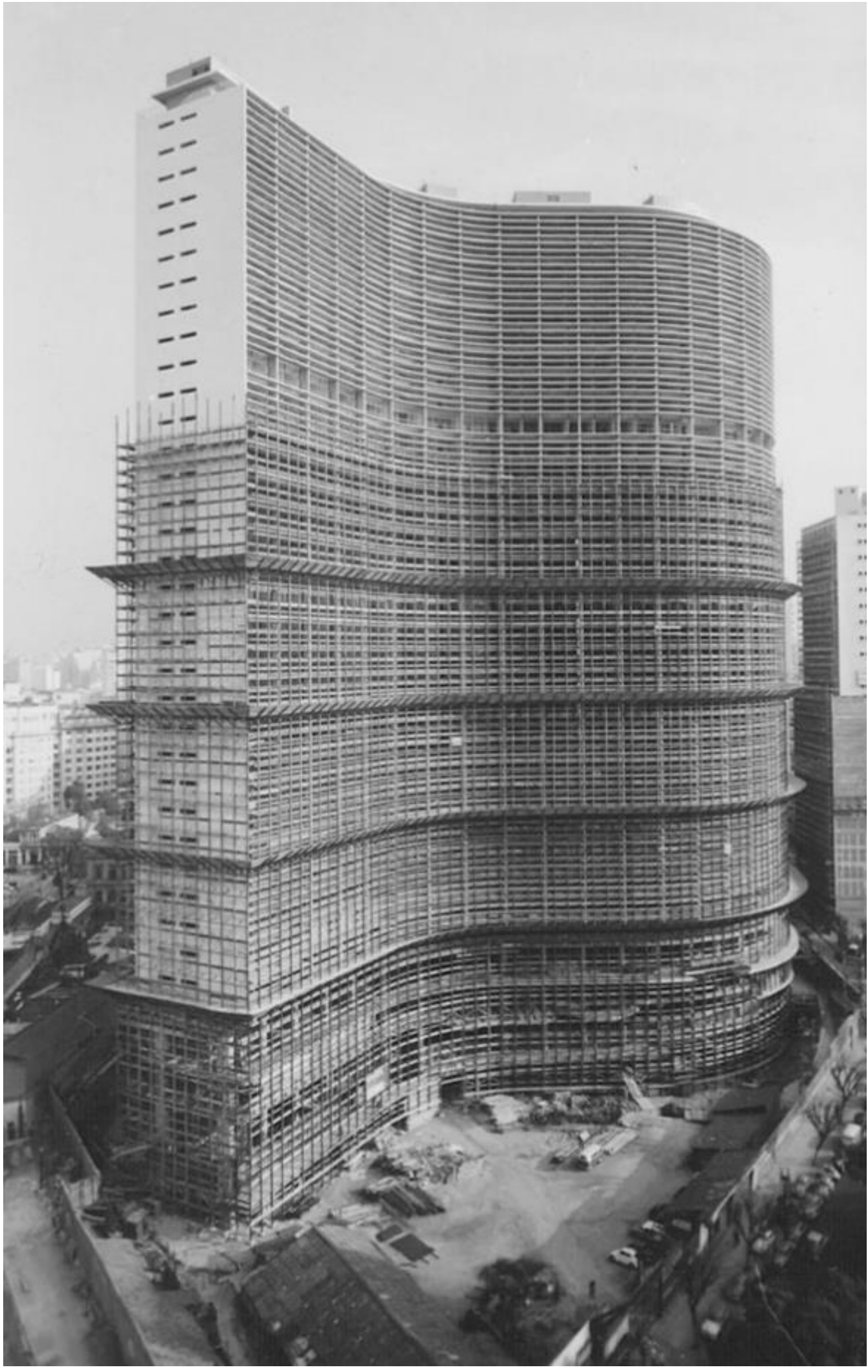

Figura 8 Fachada Principal Fonte: 
A fachada principal é marcada por 92 brises de concreto armado revestidos de pastilhas de porcelana na cor branca, nas laterais e face superior e pintura branca na parte inferior. Os brises estão estruturados em 25 pilares revestidos de pastilhas de porcelana na cor cinza, que se ligam às lajes dos pavimentos por meio de elementos metálicos e, nas extremidades, os brises são engastados nas empenas laterais.
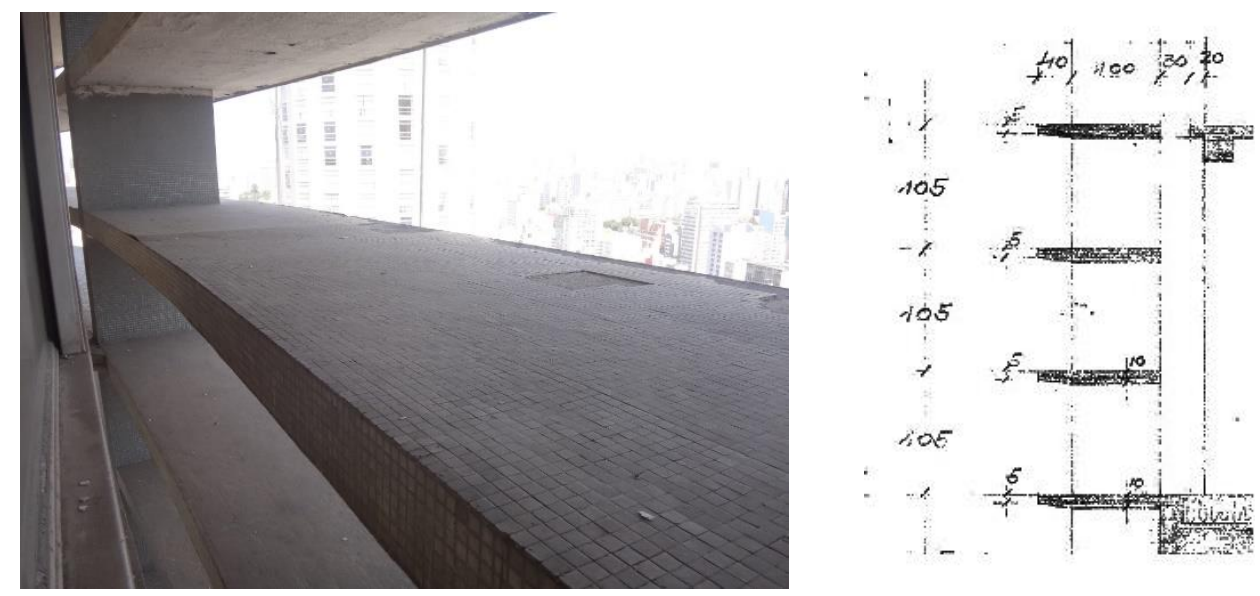

Figura 9 e 10 - Brises

Fonte: Acervo de Fabiana L. de Oliveira figura 9 e figura 10 Acervo do Condomínio Copan 


\subsubsection{FACHADA POSTERIOR}

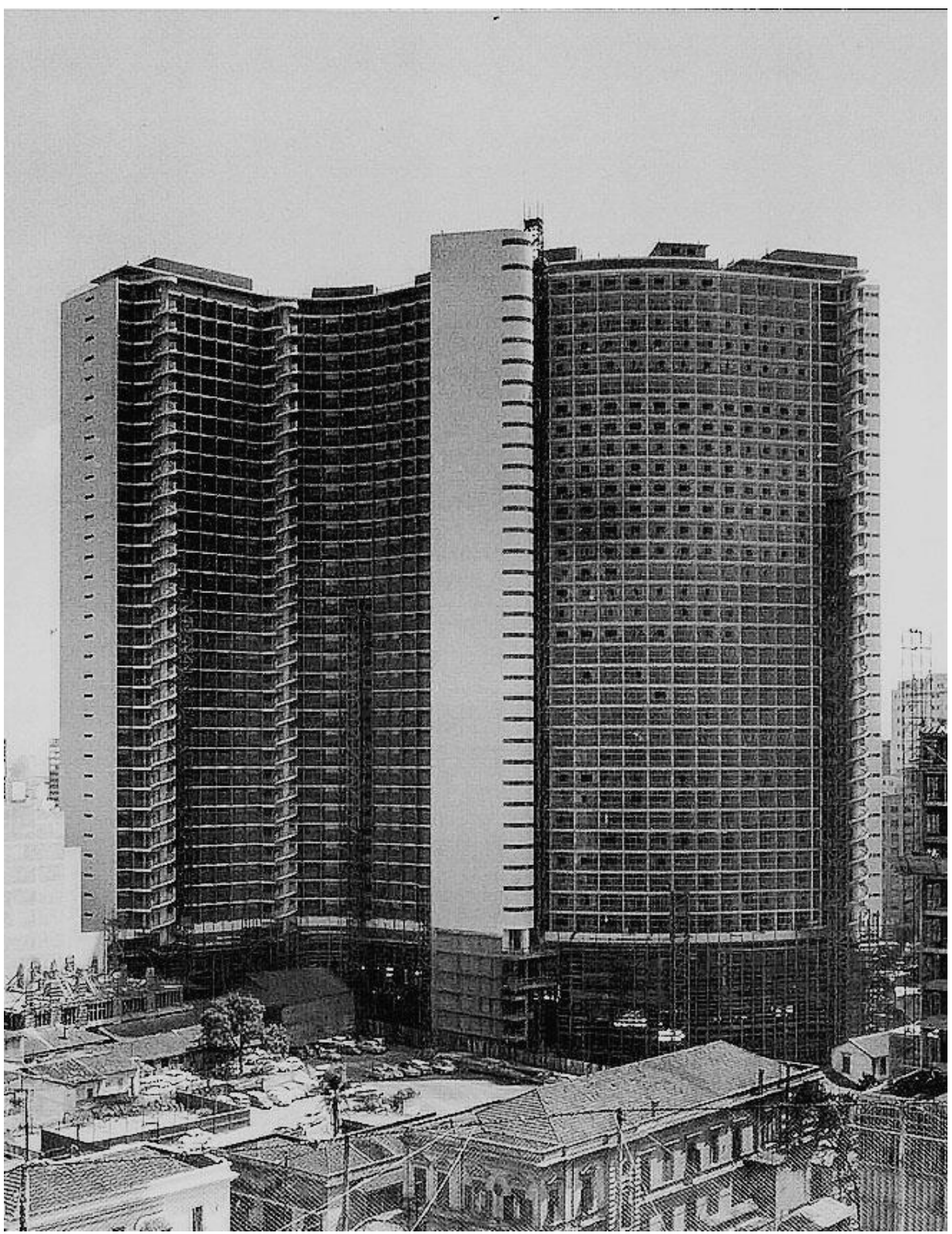

Figura 11 - Fachada Posterior Fonte: Acervo do Condomínio Copan. 

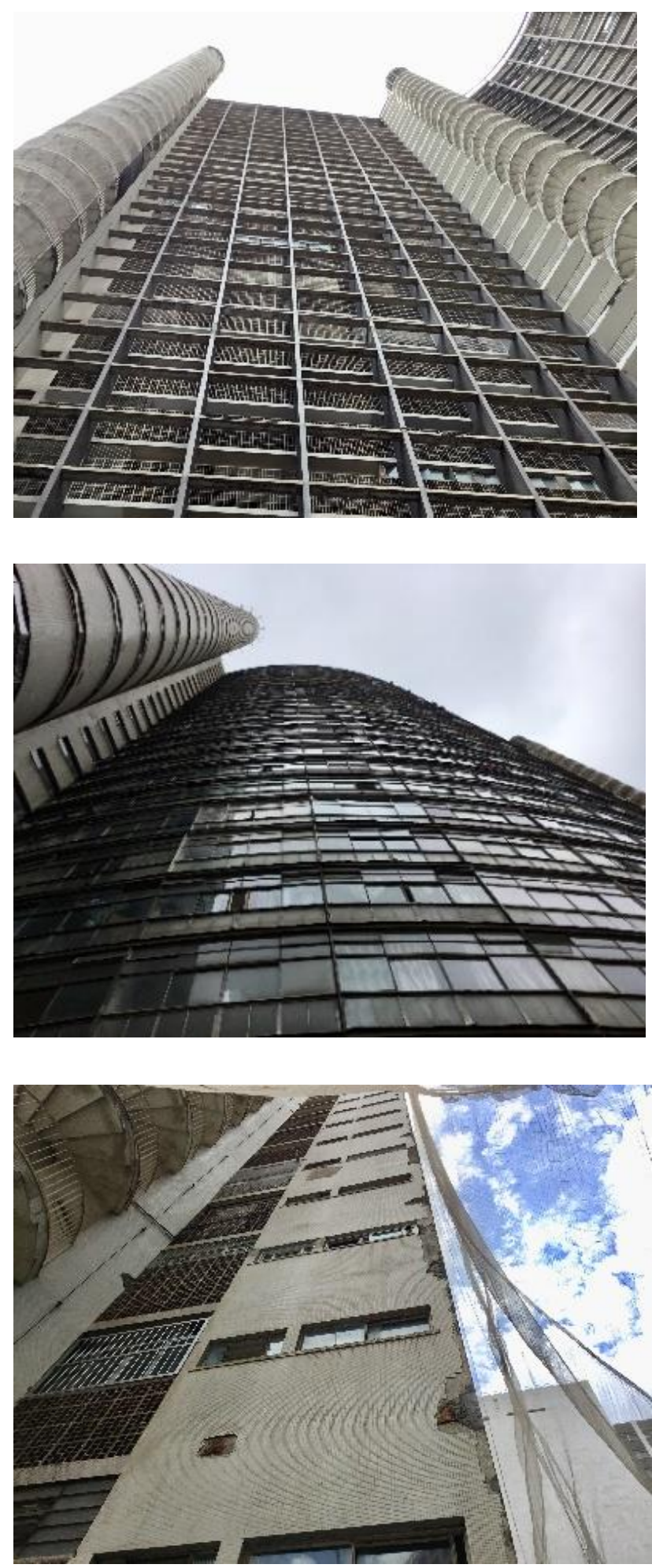

Figura 12, 13 e 14- Fachada Posterior Fonte: Acervo da autora.
A fachada

posterior é a mais complexa e com o maior número de elementos. Do Bloco C ao Bloco $F$ apresenta estrutura externa de concreto armado, formado por pilares revestidos de pastilhas de porcelana cinza e vigas com pastilhas brancas. Os apartamentos possuem fechamento com elementos vazados até a altura de 2,10m dando uma uniformidade ao conjunto. As lajes do Bloco B marcam a fachada horizontalmente vedadas com caixilharia do piso ao teto. No Bloco $A$ os caixilhos metálicos e elementos vazados demarcam a vedações revestidas de pastilhas brancas. 


\subsection{3.}

\section{FACHADA SUDOESTE E NOROESTE}

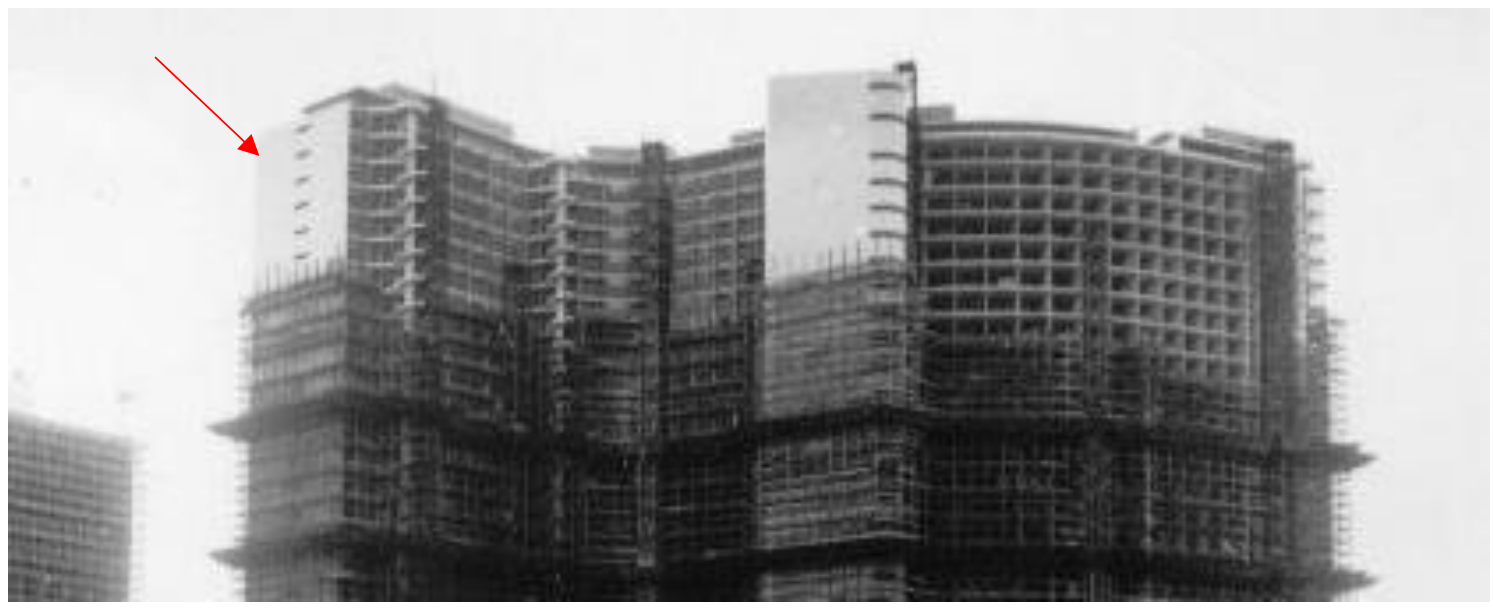

Figura 15 - Fachada Sudoeste

Fonte: Acervo do Condomínio Copan

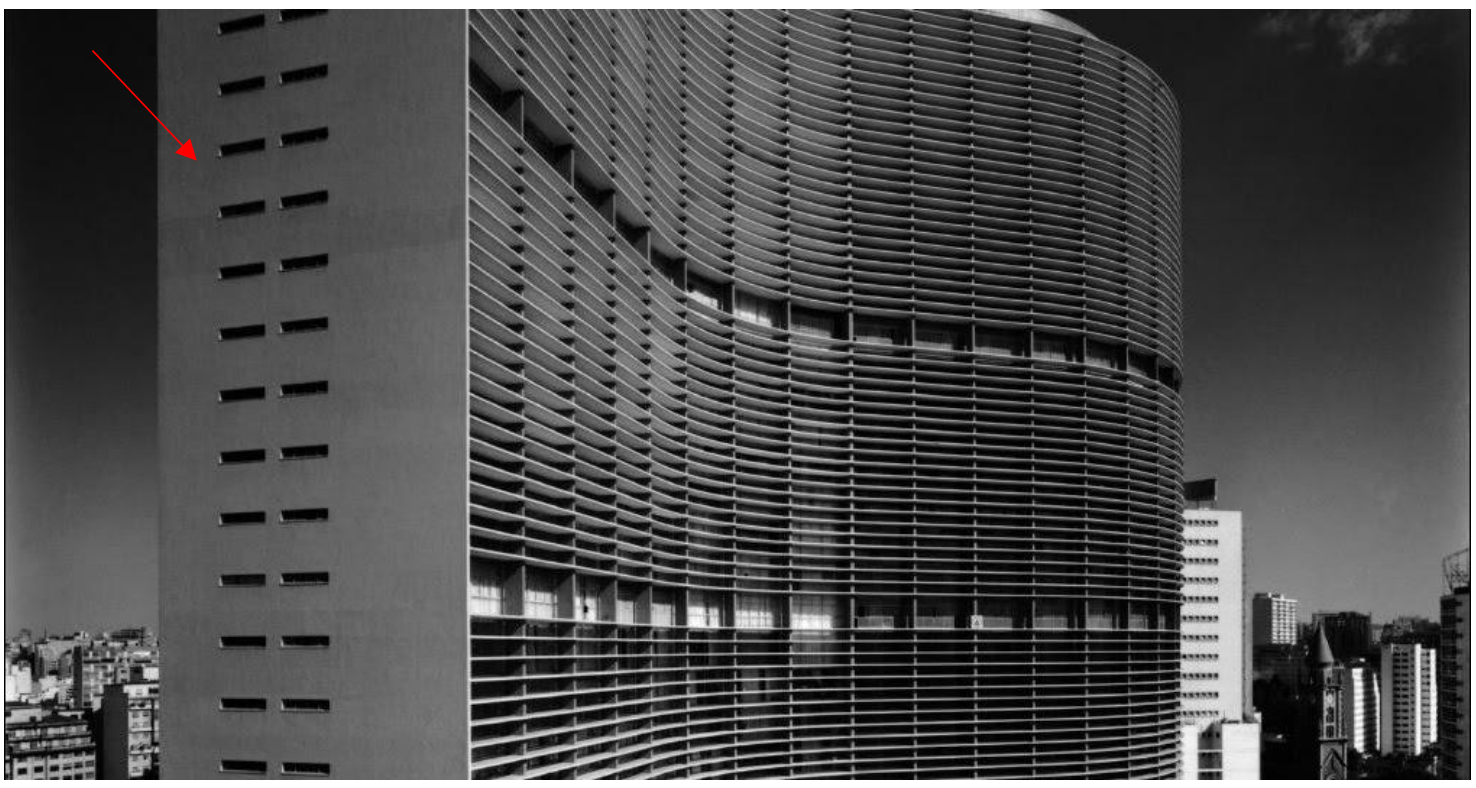

Figura 16 - Fachada Noroeste

Fonte: Acervo Instituto Moreira Salles.

A fachada sudoeste fica voltada para a Rua Araújo, sua empena é revestida de pastilha de porcelana na cor branca, com um caixilho metálico da mesma cor por andar.

A fachada noroeste, voltada para a Rua Vila Normanda também é revestida de pastilha de porcelana na cor branca, mas conta com dois caixilhos metálicos por andar: um para atender um banheiro e outro, de mesma dimensão e formato, para atender um dormitório. 


\subsection{ANÁLISE DE EVIDÊNCIAS}

Durante a etapa de recolhimento de evidências físicas e documentais foram observadas algumas características que não constam nos projetos originais remanescentes, como exemplo, o lance metálico das escadas helicoidais de emergências dos Blocos A, E e F para acessar a cobertura; as portas das saídas de emergência dos Blocos C e D; o fechamento da viga de transição; os módulos de alumínio na parte inferior dos caixilhos do Bloco B e as chapas metálicas entre a laje e os caixilhos do Bloco B.

Essas alterações configuram-se como um registro histórico do desenvolvimento e dos usos do lugar, que interpretados à luz do inventário de informações permite estabelecer uma compreensão das mudanças e a relação com a situação atual.

\subsection{COMPLEMENTO METÁLICO DA ESCADA HELICOIDAL}

As três escadas helicoidais dos Blocos A, E e F de concreto armado foram construídas até a laje do $32^{\circ}$ andar e para acessar a cobertura havia uma escada marinheiro. O complemento metálico foi acrescentado posteriormente à construção do Copan, para facilitar o acesso da equipe de manutenção.

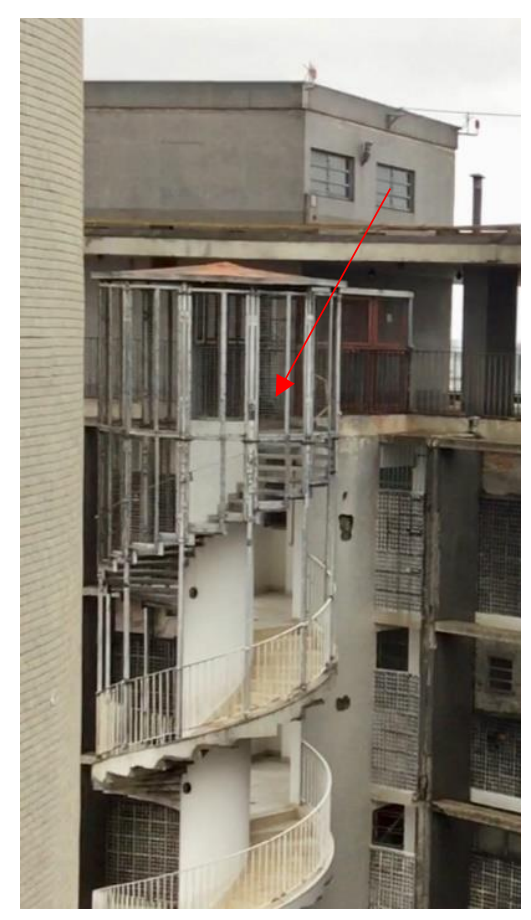

Figura 17 - Complemento da Escada Helicoidal

Fonte: Acervo da autora.

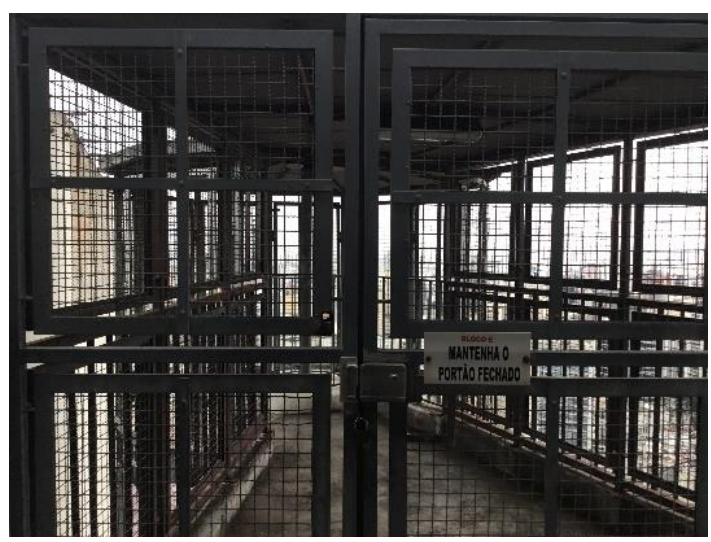

Figura 18 - Complemento da Escada Helicoidal Fonte: Acervo da autora. 


\subsubsection{SAÍDAS DE EMERGÊNCIA DOS BLOCOS C E D}

No início da década de 1990, o Condomínio teve que fazer algumas adequações para atender às exigências de saída de emergência, requerida pelo Corpo de Bombeiros. Sendo necessário a criação de duas portas: uma para o Bloco $\mathrm{C}$ e outra para o Bloco D. Ambas saem na cobertura do terraço, por onde é possível acessar outra escada que dá acesso à galeria do térreo pelo Bloco $\mathrm{F}$.

No Bloco C a saída de emergência fica acima da viga de transição, mas no Bloco D o nível não permitiu a mesma solução, sendo necessário um recorte na viga de transição para acomodar a rota de fuga.

Vale salientar que nas versões iniciais do projeto de Oscar Niemeyer não haveria esse piso e que as rotas de fuga chegariam no terraço jardim de onde seria possível acessar o térreo. Todavia, com as alterações projetuais exigidas pelo Bradesco, as rotas de fuga foram interrompidas sendo necessárias adaptações, para tentar atender às necessidades.

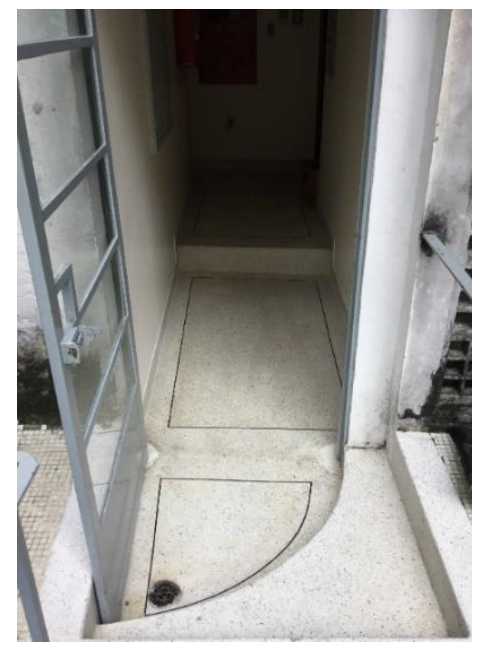

Figura 19 - Recorte na Viga de Transição para Saída de Emergência do Bloco C Fonte: acervo da autora

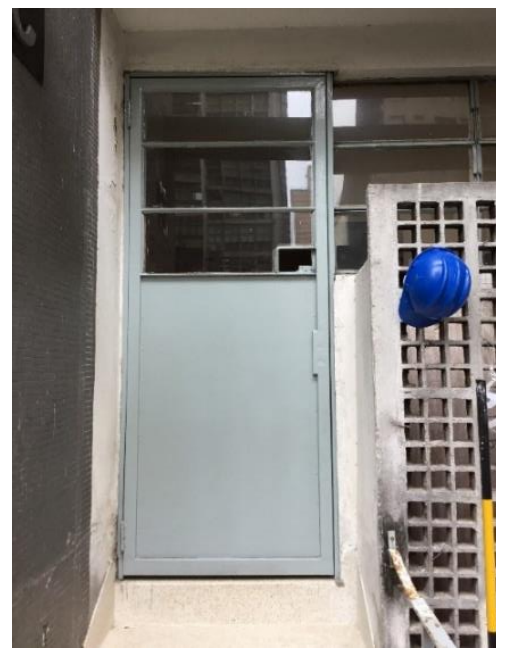

Figura 20 - Saída de Emergência do Bloco D Fonte: acervo da autora

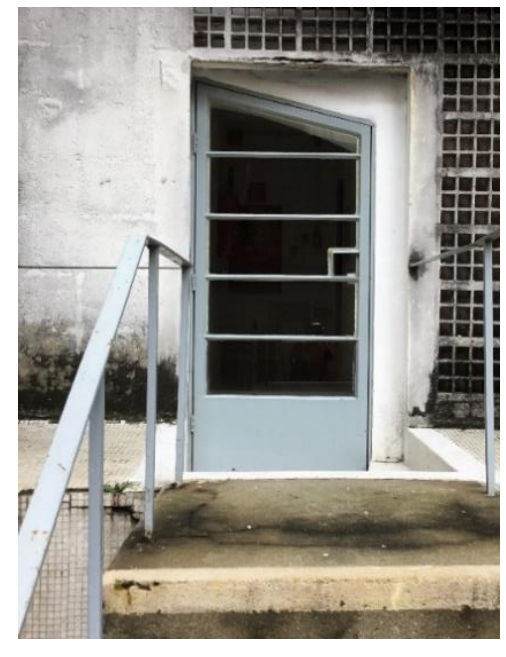

Figura 21 - Saída de Emergência do Bloco C Fonte: acervo da autora 


\subsubsection{COMPLEMENTO DA ESCADA DO BLOCO A}

Na ocasião dos ajustes exigidos pelo Corpo de Bombeiros, a escada de emergência do Bloco A que inicialmente chegava na cobertura do terraço, foi fechada, descendo direto até a garagem. Essa solução foi necessária, tendo em vista o estreitamento que existe entre o corpo do edifício e a cobertura do cinema.

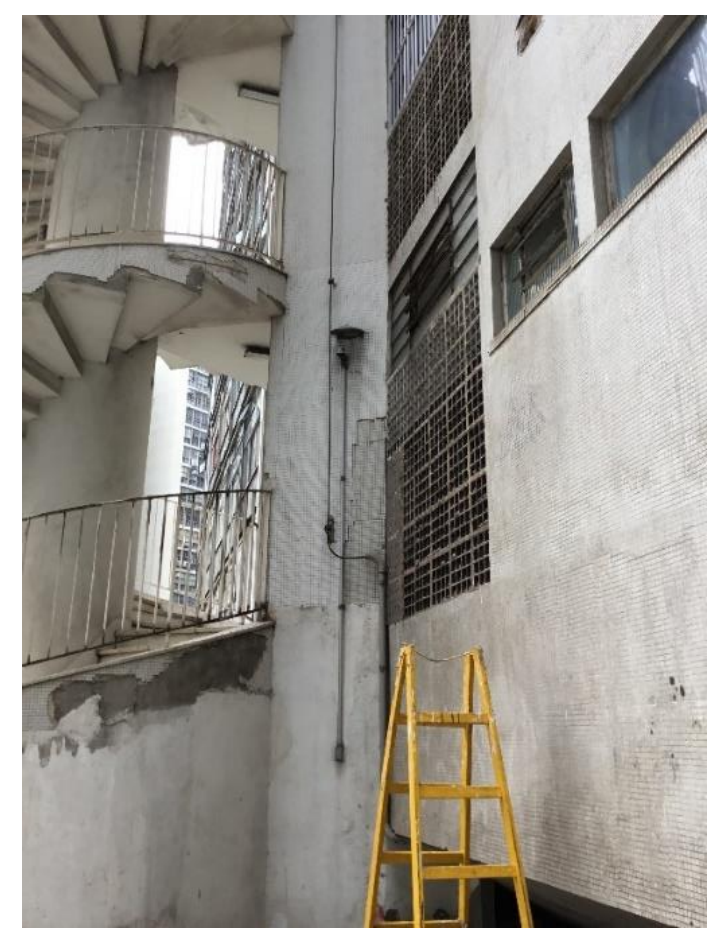

Figura 22 - Fechamento da Saída da Escada do Bloco A na Cobertura do Terraço Fonte: acervo da autora.

\subsubsection{FECHAMENTO DA VIGA DE TRANSIÇÃO NA FACHADA POSTERIOR}

Na tentativa de abrigar parte da tubulação hidráulica que ficava aparente, foi feito um fechamento em alvenaria na base da viga de transição.

Ainda é possível observar o revestimento de pastilha em sua face inclinada, bem como o detalhe construtivo da pingadeira, a fim de evitar 0 escorrimento da água das chuvas.

Na figura 23 é possível observar na parte inferior esquerda 0 fechamento da viga de transição, que é interrompido um pouco antes da escada helicoidal. 


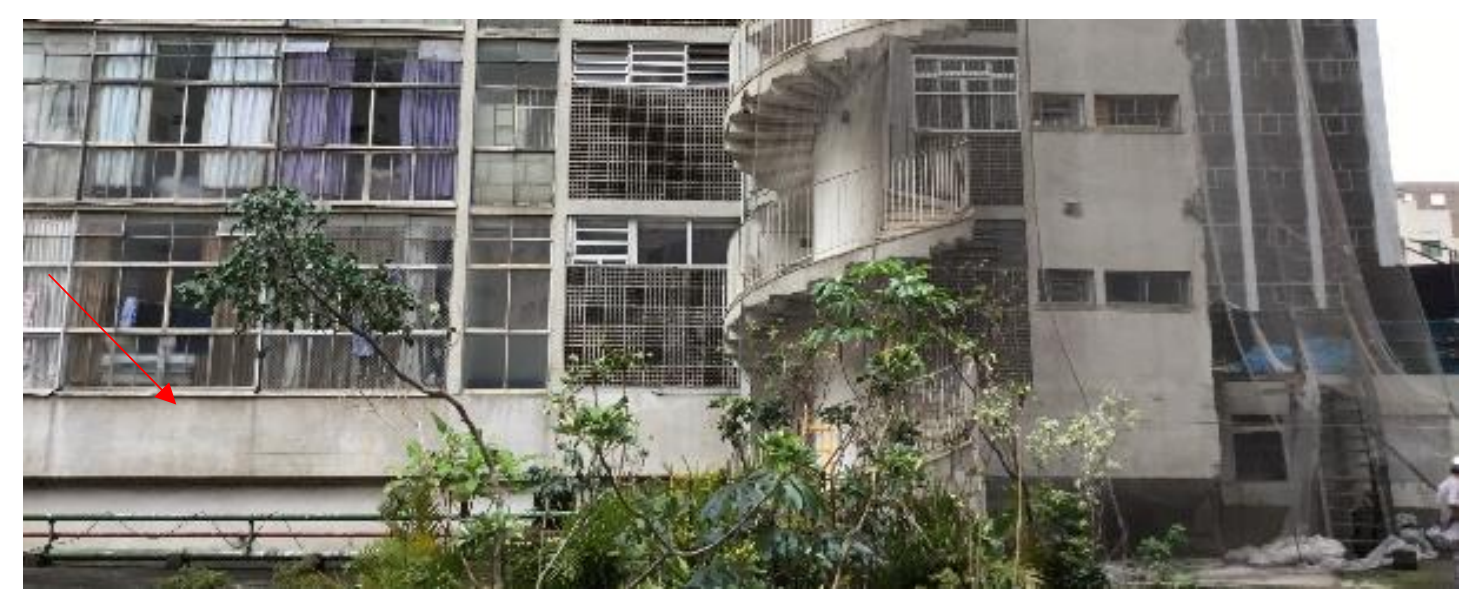

Figura 23 - Fechamento da viga de transição Fonte: acervo da autora
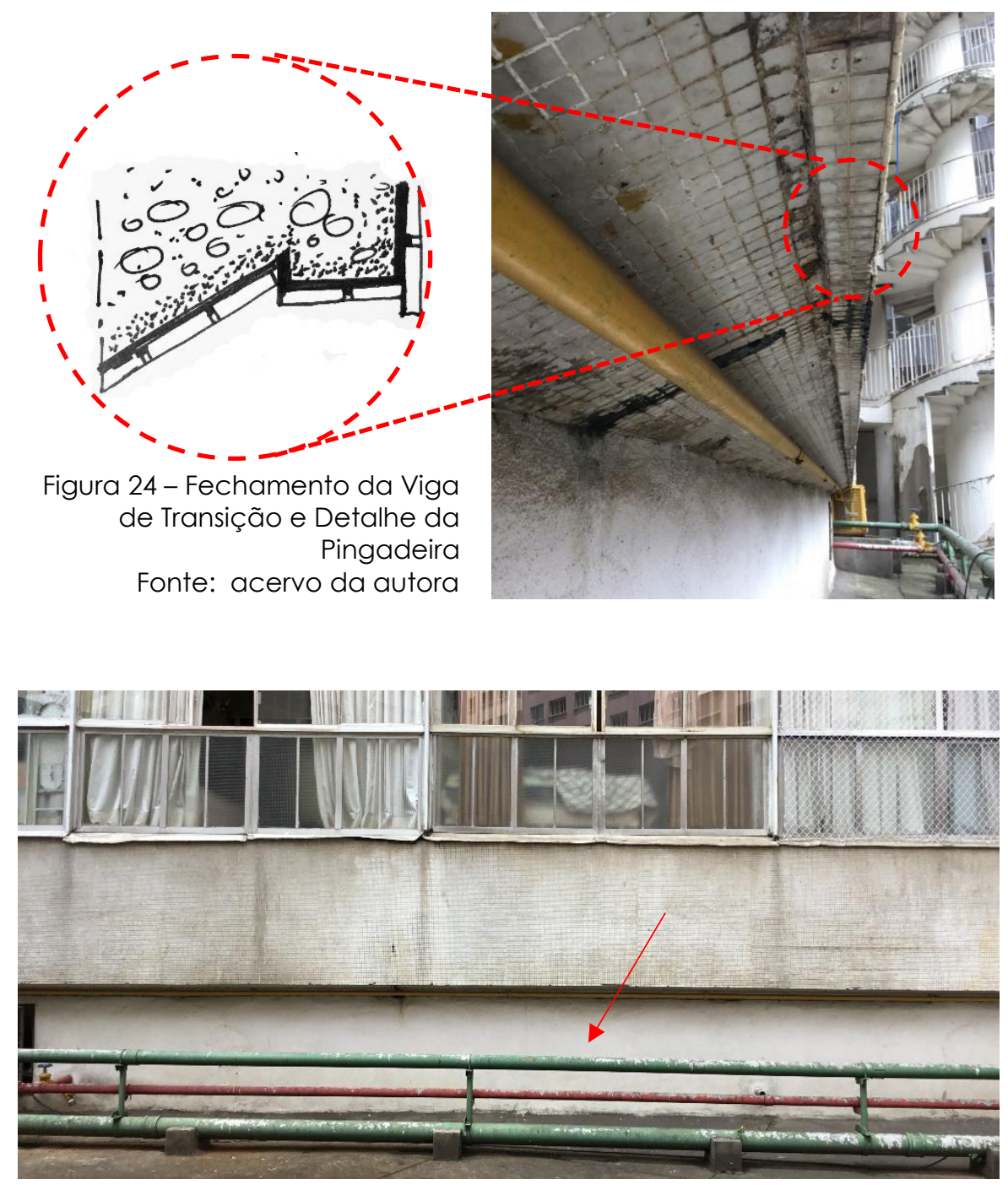

Figura 25 - Fechamento da Viga de Transição Fonte: acervo da autora 


\subsubsection{CAIXILHOS E MÓdULOS DE ALUMÍNIO NO BLOCO B}

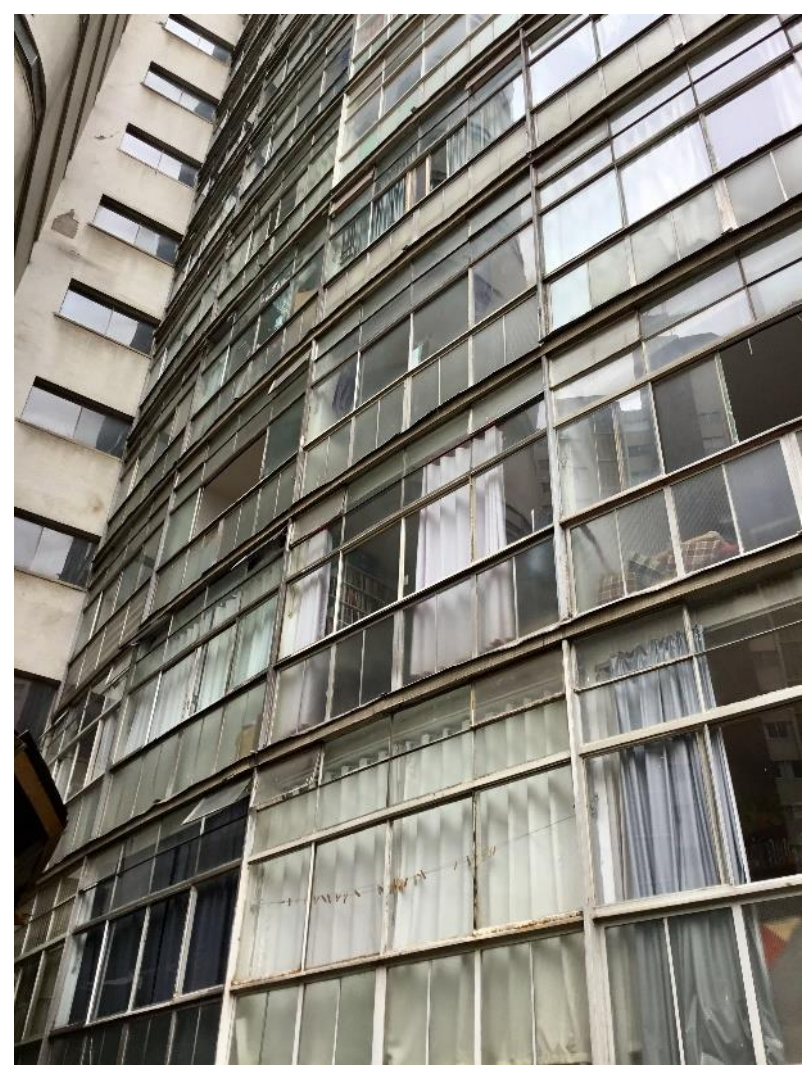

Figura 26 - Fachada Posterior - Bloco B Fonte: Acervo da autora

Ainda como solicitação do Corpo de Bombeiros, o Condomínio teve que fazer adequações nos caixilhos do Bloco B, a fim de evitar que durante um eventual incêndio o fogo de um andar não passasse para outro, sendo realizada a substituição da parte inferior dos caixilhos metálicos, por módulos de alumínio com vidro aramado. E chapa metálica na interface base do caixilho e laje.

Figura 27 - Detalhe do Caixilho, do Vidro e da Chapa metálica Fonte: Acervo da autora

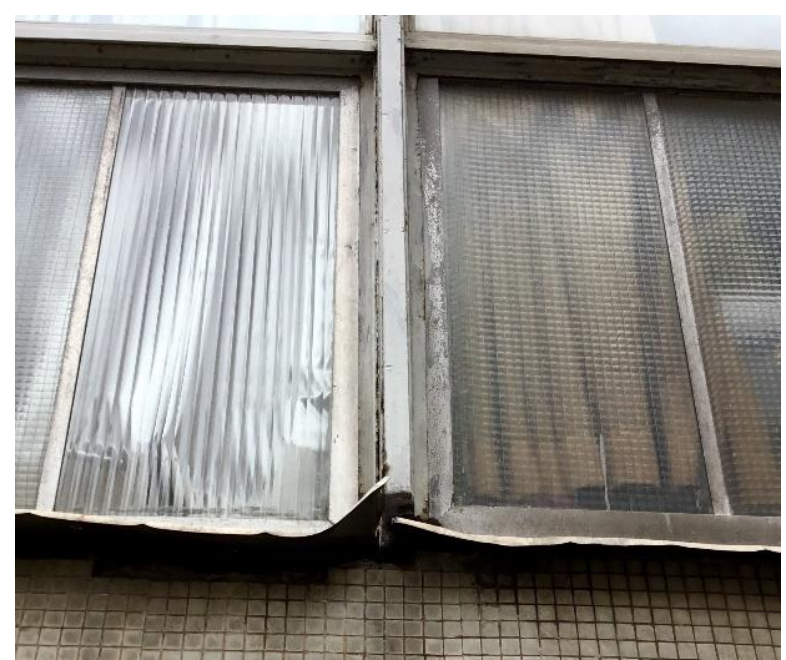




\subsection{5. $\quad$ ALTERAÇÕES NA FACHADA POSTERIOR}

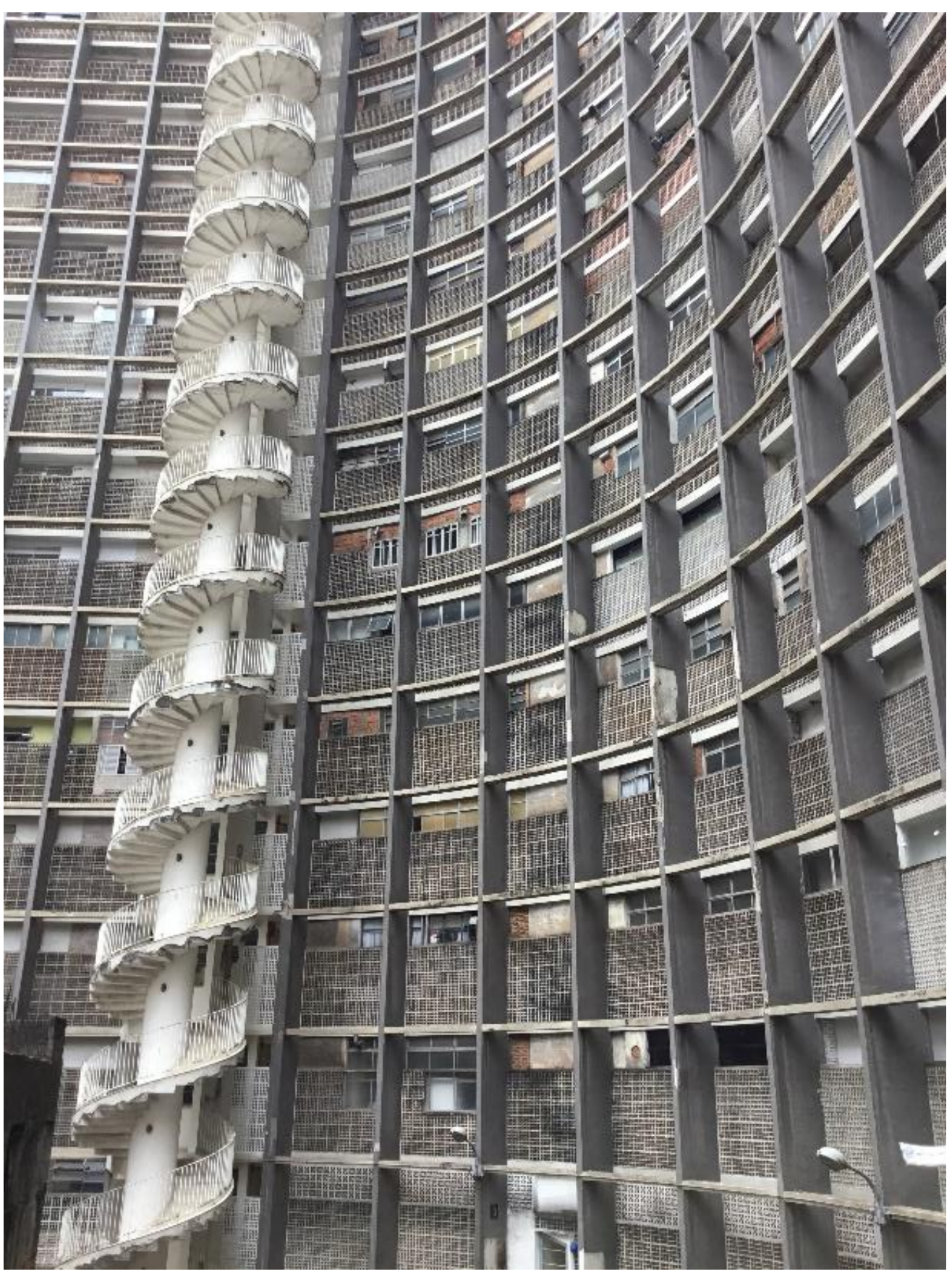

Figura 28 - Alterações na Fachada Posterior Fonte: Acervo da autora.

De todas as alterações realizadas no Copan, as mais impactantes são aquelas promovidas indiscriminadamente, pelos moradores ao longo de suas 5 décadas de ocupação. 


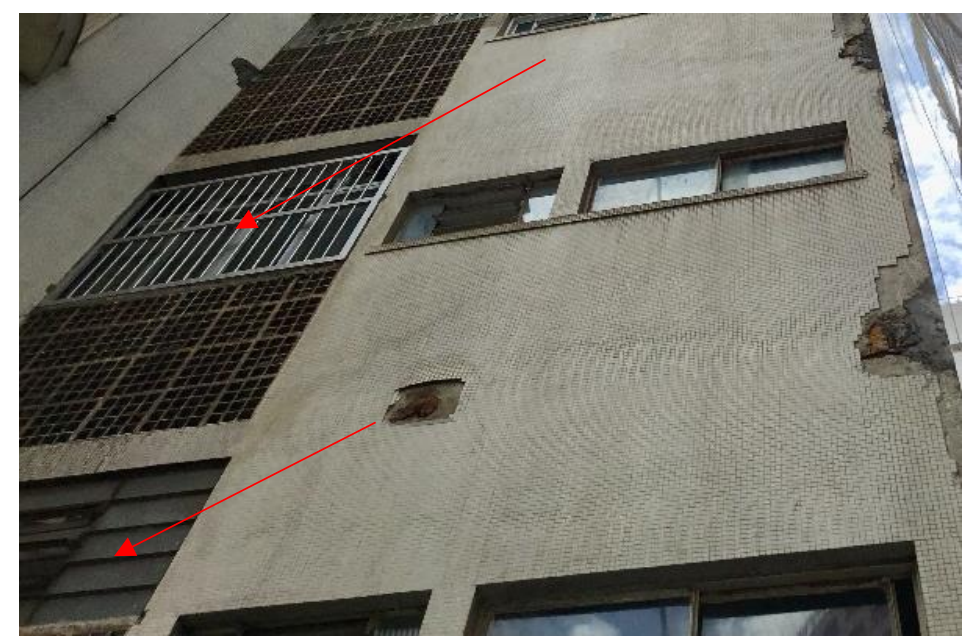

Figura 29 - Alterações na Fachada Posterior Fonte: Acervo da autora.

A fachada mais afetada é a posterior. Ao mesmo tempo a mais complexa e a menos reconhecida tanto pelos moradores quanto pela sociedade.

Há uma lógica arquitetônica que organiza, por meio de uma linguagem de continuidade, os ambientes provenientes das diferentes tipologias de apartamentos. Os elementos vazados vão até $2,10 \mathrm{~m}$ do piso acabado e os ambientes atrás deles são recuados, ficando ocultos na fachada.

Os caixilhos que estão no mesmo plano encontram-se na área revestida de pastilha e estão dispostos acima ou abaixo da linha dos 2,10m criando um alinhamento que organiza a distribuição dos elementos na fachada.
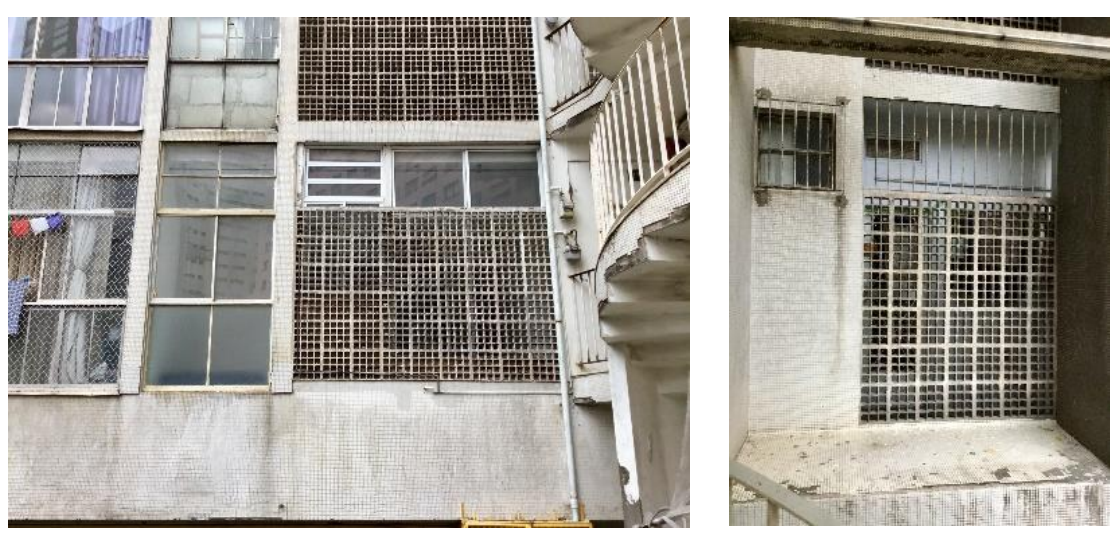

Figura 30 e 31- Alinhamento dos Caixilhos Fonte: Acervo da autora

Ao promoverem modificações sem uma análise prévia, comprometeram a lógica arquitetônica da fachada posterior. 


\subsection{AVALIAÇÃO DO SIGNIFICADO CULTURAL}

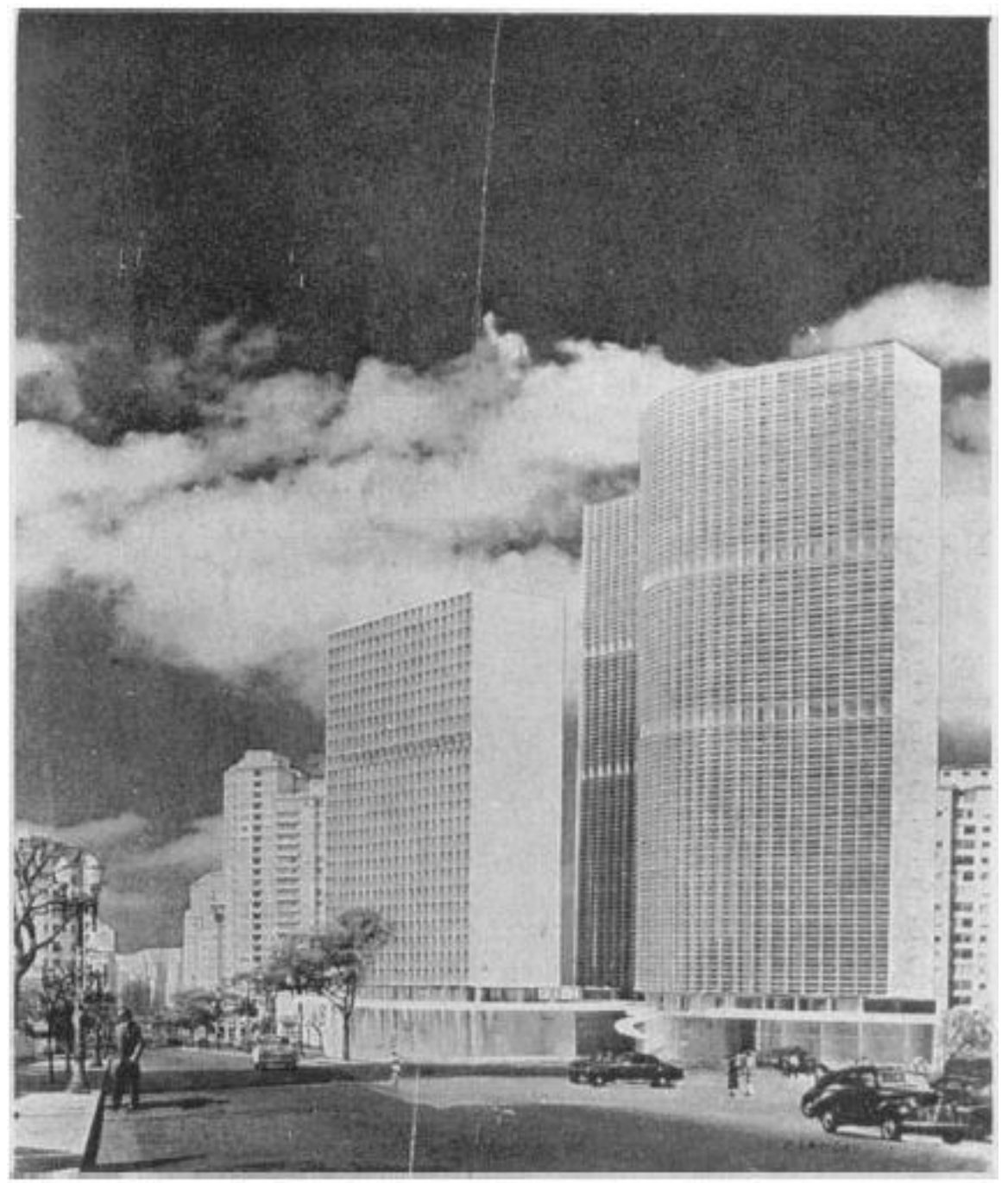

Figura 32 - Fotomontagem do Complexo Hoteleiro - 1952

Fonte: Acervo do Condomínio Copan.

O método utilizado para avaliar a significância cultural das fachadas do Copan, se baseia em uma compreensão dos aspectos estéticos, criados pelo arquiteto Oscar Niemeyer, históricos e sociais, que foram analisados pela ótica das evidências físicas e documentais.

\section{O arquiteto e o Copan}

O arquiteto carioca Oscar Ribeiro de Almeida Niemeyer Soares Filho tinha 44 anos na ocasião em que iniciou o projeto do Copan. Já havia participado de projetos importantes, como o Ministério da Educação e Saúde, 
no Rio de Janeiro (1936), o Pavilhão do Brasil na Feira Mundial de Nova York (1938), a sede da ONU em Nova York de (1947). E realizado projetos de sua autoria como o Conjunto da Pampulha (1939) e o conjunto arquitetônico do Parque do Ibirapuera em São Paulo (1951), realizado em comemoração ao IV centenário da cidade (FUNDAÇÃO OSCAR NIEMEYER, s/d).

Em São Paulo, Niemeyer já havia realizado alguns projetos para BNI, como os edifícios Califórnia, Triângulo, Montreal e Eifel (LEAL, 2003), quando fora chamado por Roxo Loureiro para projetar o Copan, cujo estudo inicial havia sido realizado por escritório americano (LEMOS, 2014).

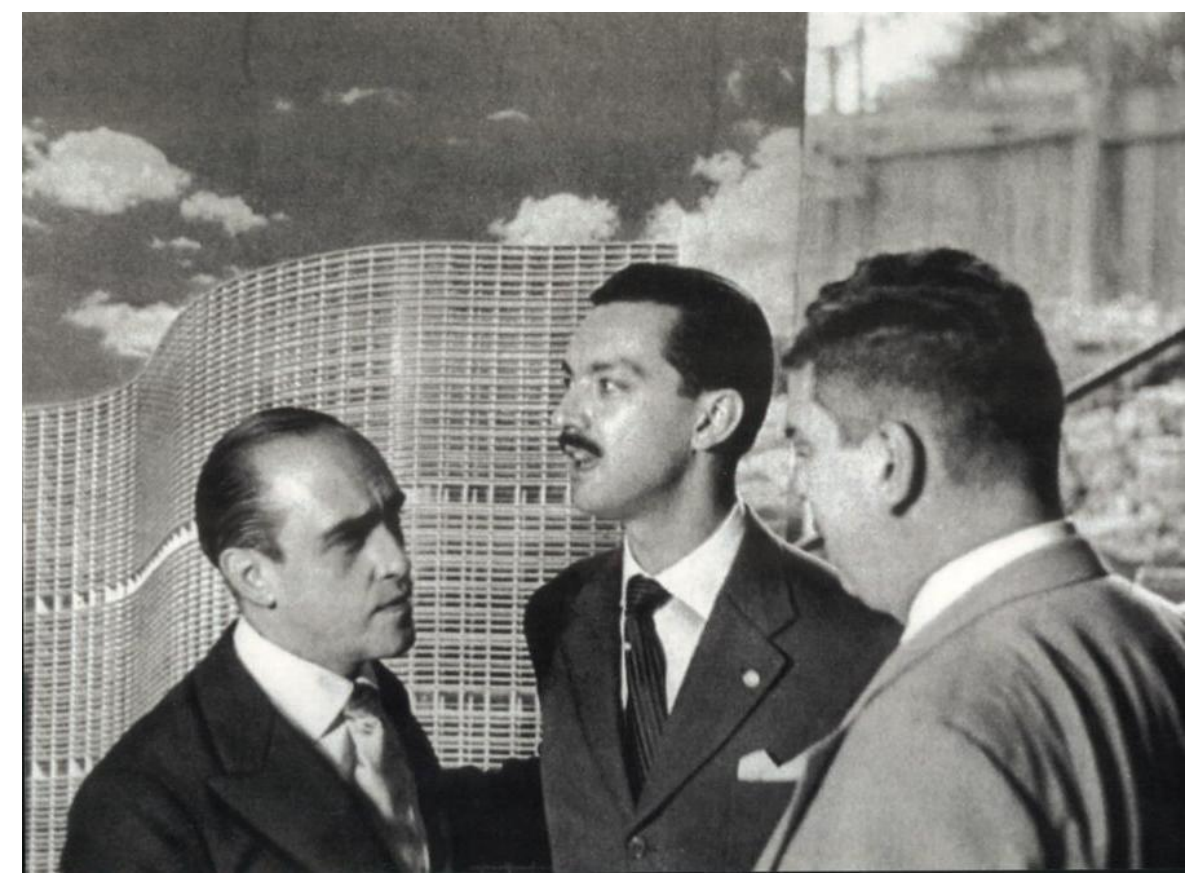

Figura 33 - Niemeyer Durante o Lançamento do Empreendimento Fonte: Acervo do Condomínio Copan.

O terreno de forma irregular foi aproveitado pelos projetistas americanos por meio da distribuição de três lâminas dispostas em ziguezague. Mas no projeto de Niemeyer os ângulos retos foram substituídos por curvas suaves que conferiram ao Copan sua emblemática forma de "S".

Com escritório no Rio de Janeiro e notório medo de aviões, as viagens por terra a São Paulo eram demoradas e penosas, então para poder dar continuidade e agilizar o projeto de prefeitura do Copan, Niemeyer abriu 
um escritório satélite em São Paulo, chefiado pelo arquiteto Carlos Lemos, que assinava os referidos projetos por procuração.

No primeiro projeto apresentado à Prefeitura de São Paulo, o complexo contemplava o edifício Copan e um edifício destinado ao hotel. Sendo o residencial projetado por Niemeyer e o hoteleiro por empresa americana. Ambos teriam terraços interligados por uma passarela. A galeria comercial do térreo, com o piso inclinado, foi projetada para acompanhar o desnível do terreno, entre a Rua Araújo e a Rua Vila Normanda. Já a rampa helicoidal que ficaria próximo à entrada principal daria acesso ao terraço jardim acima da galeria comercial.

A construção teve início no segundo semestre de 1952 e após o Bradesco assumir em 1957 começaram algumas alterações significativas, como: a retirada do teatro; o fechamento do terraço; a redução do cinema e o aumento no número de apartamentos, em função das modificações nos Blocos E e F.

Em entrevista concedida no dia 22 de janeiro de 2018, com termo de consentimento livre esclarecido em anexo, o arquiteto Carlos Lemos falou de algumas soluções projetuais, desenvolvidas por Niemeyer no projeto inicial, suas posteriores transformações ao longo da construção e suas implicações no conceito do edifício.

"As colunas dos 32 andares dos apartamentos terminam na laje de transição, que permitiu dividir toda a carga entre pilares equidistantes. Oscar imaginou esse espaço como se fosse uma área comum, jardim [...] mandou até fazer uma rampa, rampa aberta para quem estivesse passando na rua ir lá para conhecer e a função desse andar, além de distribuir as colunas, são pilotis, no fundo tinha algumas pequenas lojas e aquele espaço imenso de estar público, onde iria ter cafés, confeitaria e uma grande floricultura [...] e bilheterias do cinema e do teatro. $O$ desnivel entre o terreno da rua Araújo, que se prolonga e desce a Ipiranga até a rua Vila Normanda é de 10 metros. Então esse terraço público tinha uma cota só. Ele começava em cima das sobrelojas da Araújo que seguia formando um espaço imenso embaixo, até chegar na Vila Normanda. Essa área embaixo nunca chegou a ser estudada, 
quer dizer, foi estudada, mas não se levou para a frente. Nesse ínterim o Bradesco compra a CNI e não tem o que fazer com essa tal área em cima, foi percebido que esse espaço seria uma dor de cabeça para todo mundo, justamente por que o teatro não foi construído. [...] $O$ teatro também - muito chato, não faz! Aí começou a chatear o Oscar, que falou: "daqui a pouco não vão fazer o prédio!". O cinema eu mudei os acessos pondo-os no térreo. Daí o que aconteceu foi que o Bradesco vendeu para a Telefônica o piloti elevado, futuro jardim. Com essa operação ficou definido um grande lugar que seria ocupado pelo teatro, não só dele, mas também surgido em cima das sobrelojas dessa região da galeria. Essa nova área, acima das sobrelojas ficou vazia por 45 anos. Quem comprou, teve que comprar uma das lojas para conseguir acesso através da sobreloja."

O relato do coautor do projeto mostra que as solicitações de alteração projetual durante a construção, interferiram no projeto original, criando espaços ociosos que nunca foram resolvidos, modicando expressivamente o que havia sido concebido pelo arquiteto.

\section{Uma obra de arquitetura do Movimento Moderno em comemoração ao IV Centenário de São Paulo}

O Edifício Copan tal como conhecido é apenas uma parte do grande complexo que contemplaria hotel, edifício residencial e área destina ao lazer, idealizado para comemorar o IV Centenário da cidade, fomentar o turismo e a economia local. Sua grandiosidade reflete o pensamento de uma época e sua forma sinuosa, que marca a paisagem surgiu como resposta à irregularidade do terreno, aproveitando ao máximo o potencial construtivo permitido na época de sua concepção. 


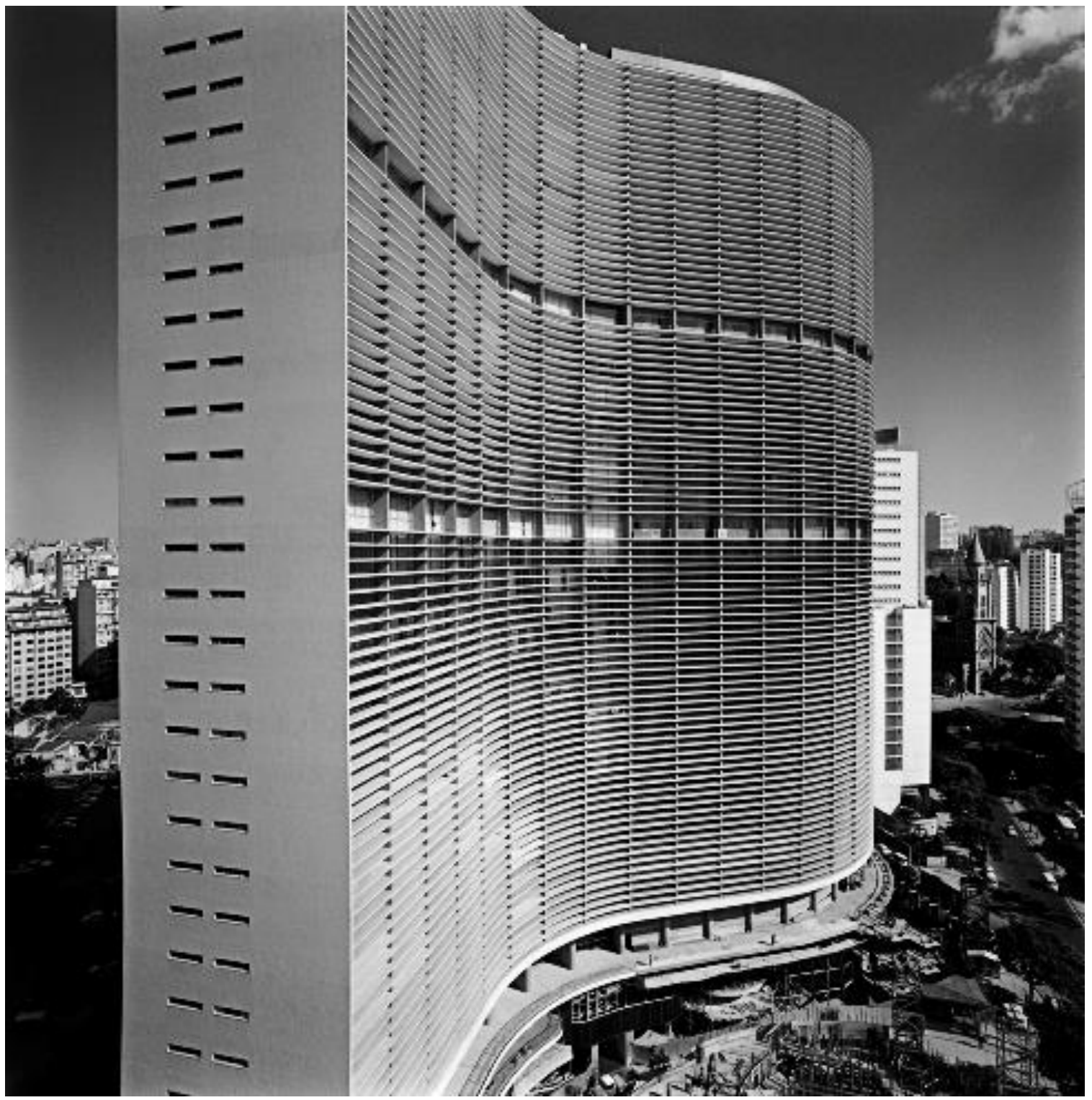

Figura 34 - Edifício Copan

Fonte: Acervo do IMS.

\section{Concepção formal}

Seu aspecto formal é enfatizado por alguns autores como Queiroz (2012) ao dizer que "[...] resulta da adaptação de um gesto integral e unitário a um contexto descontínuo. O tecido da cidade, apesar de configurar um limite, não representa um obstáculo para o desenho da forma que, por oposição, enfatiza a continuidade de um movimento único, porém inserido em um ambiente fragmentado." Por Xavier (2017) ao reafirmar que a forma curva tem relação com o perímetro do terreno e as linhas horizontais de seus brises são as características mais marcantes do Copan. E por Leal (2003) ao postular que 
"[...] sua conformação horizontal contínua amplia verticalmente a forma ondulada da planta e qualifica todo o volume com um tratamento de textura na fachada [...]".

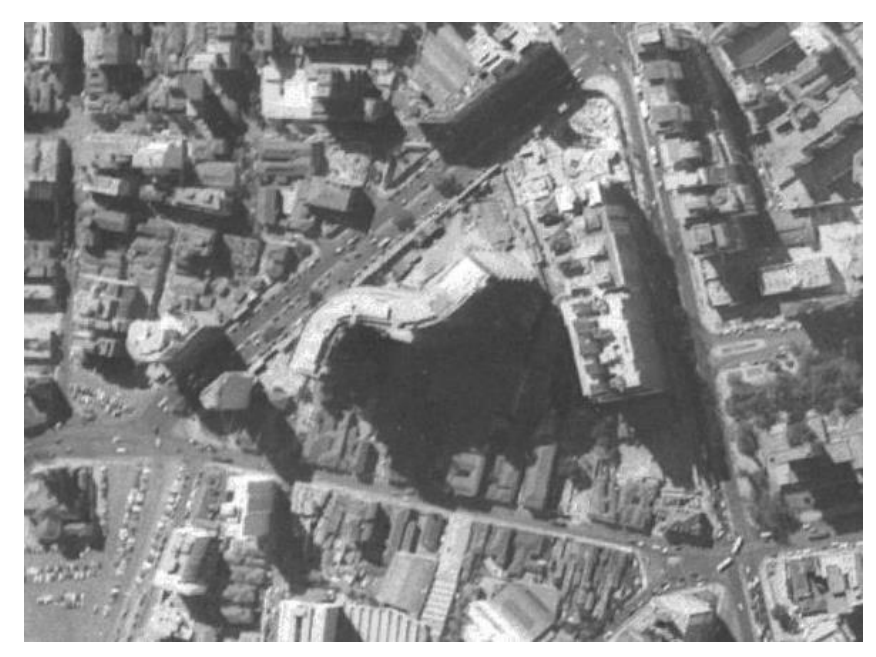

Figura 35 - Foto aérea do Copan de 1958

Fonte: Geoportal Memória

Paulista.

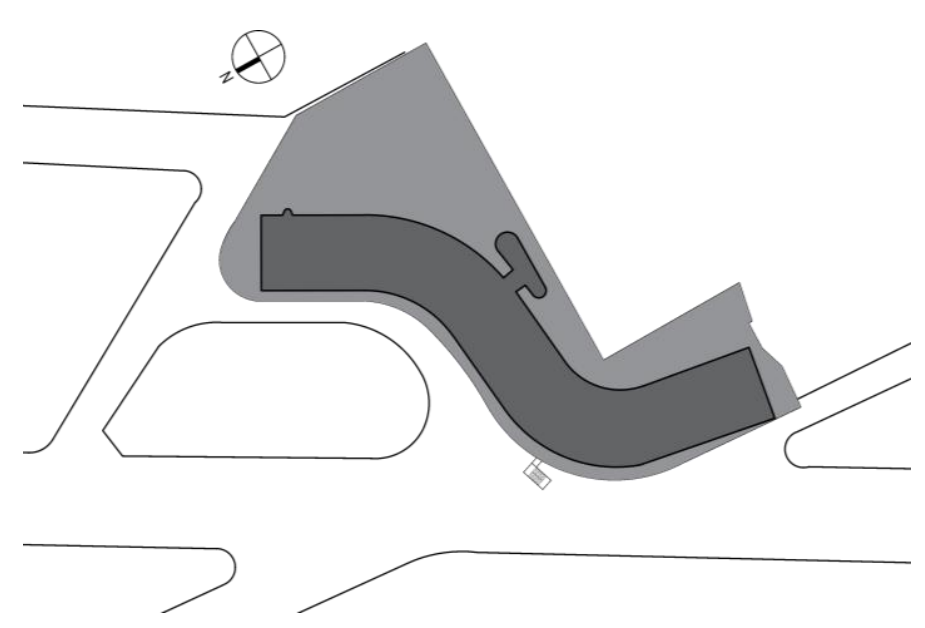

Figura 36 - Implantação Esquemática do Copan Fonte: Elaboração da Autora.

\section{Forma versus estrutura}

A forma resulta do terreno e foi a solução estrutural funcionalista, inspirada em Le Courbusier, que permitiu a estrutura permanecer aparente na face externa, independente do edifício propriamente dito, deixando livre as fachadas e dando liberdade para elaboração das plantas das diferentes tipologias de apartamentos, conforme relata Lemos (2014), coautor do projeto.

As cargas dos pilares dos andares são distribuídas na viga de transição, de onde saem os pilotis, conforme observado no corte transversal (figura 37). 


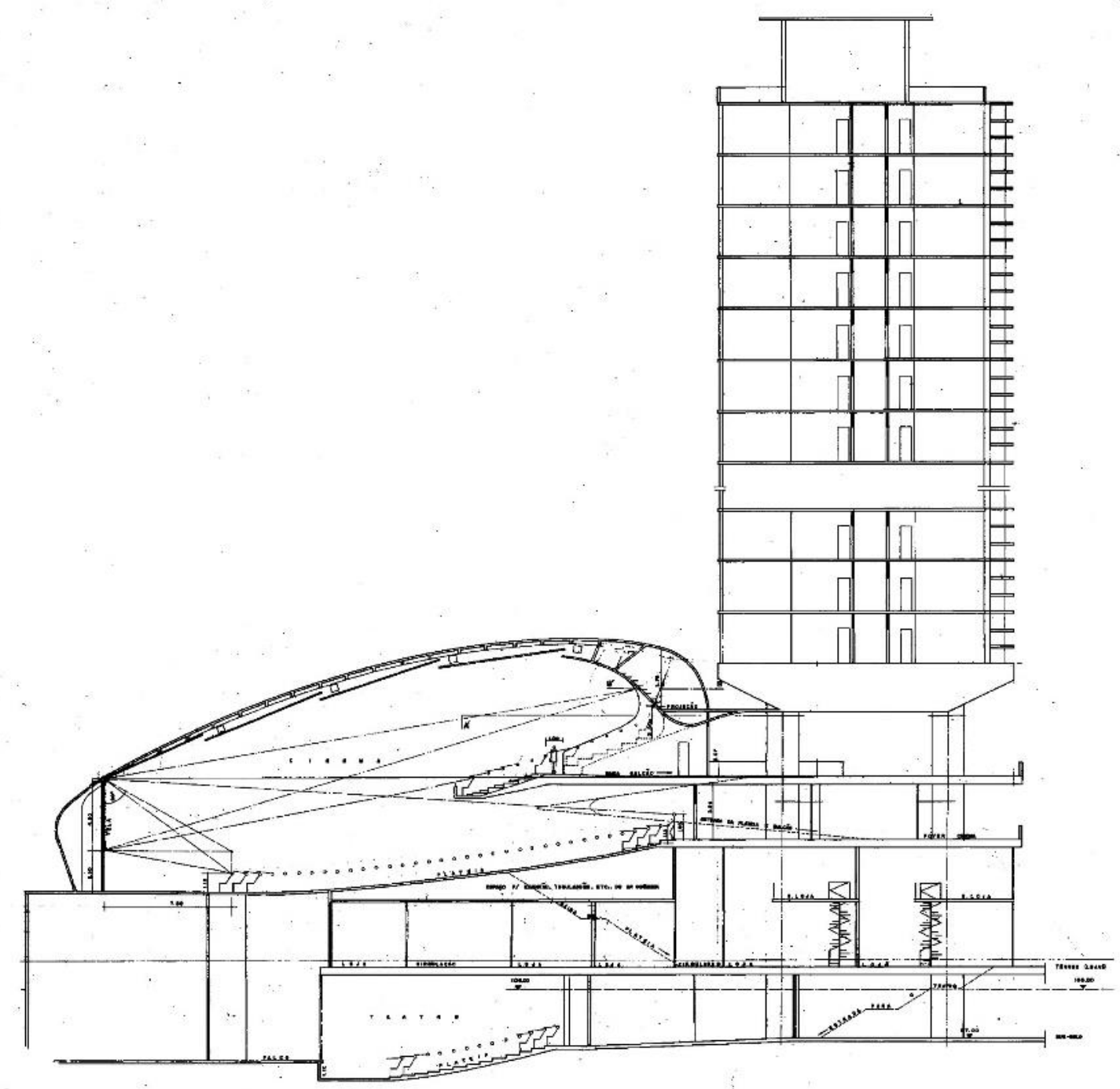

Figura 37 - Corte Transversal

Fonte: Acervo do Arquivo Histórico Municipal.

\section{O terraço que nunca foi jardim}

O projeto contemplava um piso chamado "terraço", - uma área de jardim elevado - disposto logo abaixo da viga de transição, ocupando todo o terreno e coberto apenas pela projeção do "S". Esse terraço seria conectado ao piso similar do hotel por meio de uma passarela, conforme pode ser observado na planta do $1^{\circ}$ projeto de Niemeyer (figura 38).

Essa solução arquitetônica levava para um nível elevado o que geralmente acontecia no rés do chão, o térreo livre da arquitetura do Movimento Moderno. Todavia, no decorrer da construção essa parte foi 
modificada, contragosto do autor, coberta com laje e vendida como área para escritório (LEMOS, 2014).

No projeto inicial de Niemeyer o terraço seria acessado internamente por rampas e escadas rolantes e externamente por uma rampa helicoidal (figura 39), que posteriormente deu lugar à escada projetada por Carlos Lemos, que se encontra construída no local (figura 40).

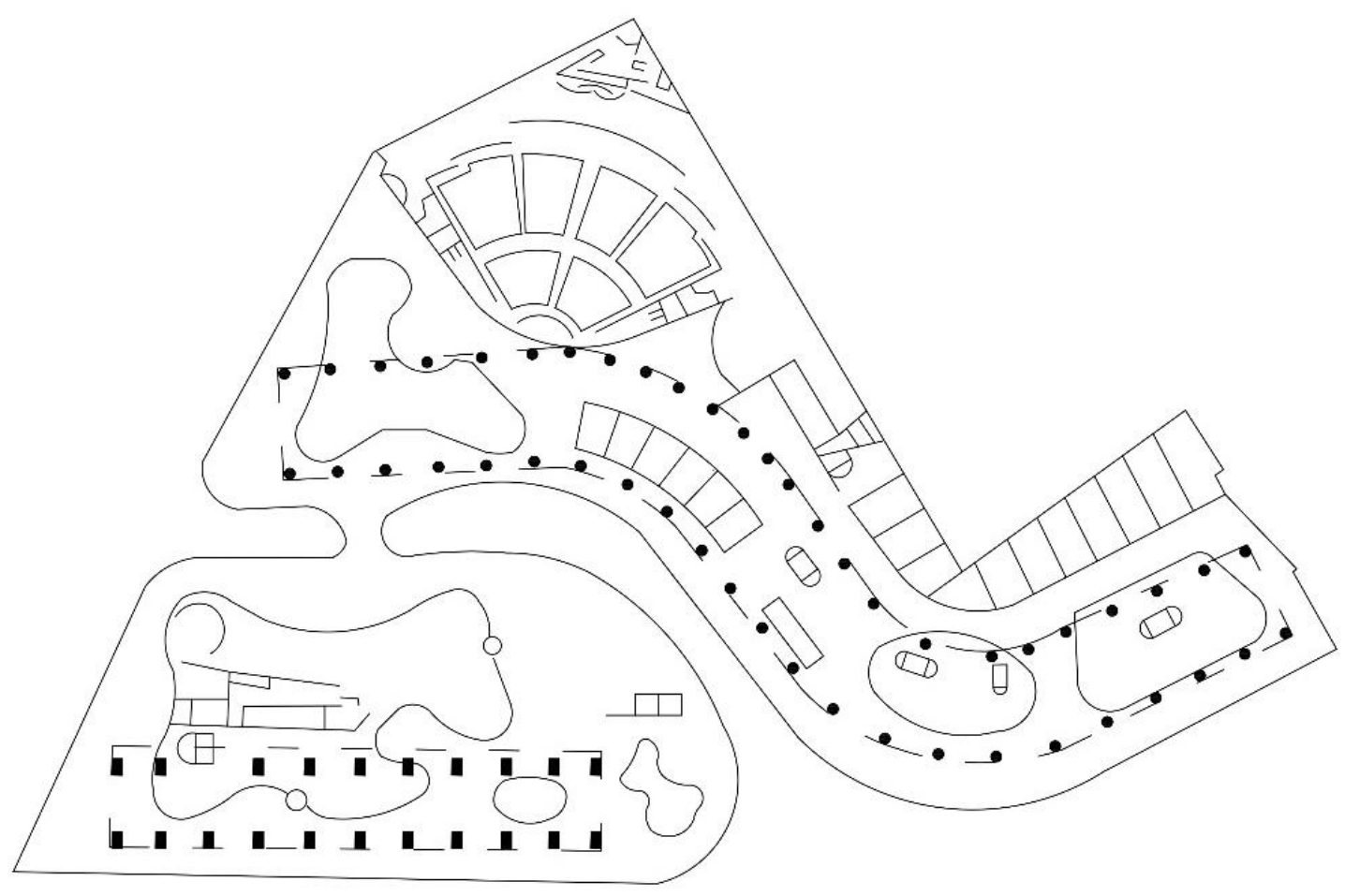

Figura 38 - Planta do $1^{\circ}$ Projeto de Niemeyer para o Copan com o Hotel Fonte: Acervo da Prefeitura de São Paulo (1952) redesenhado por Daniella Freitas do Valle. 


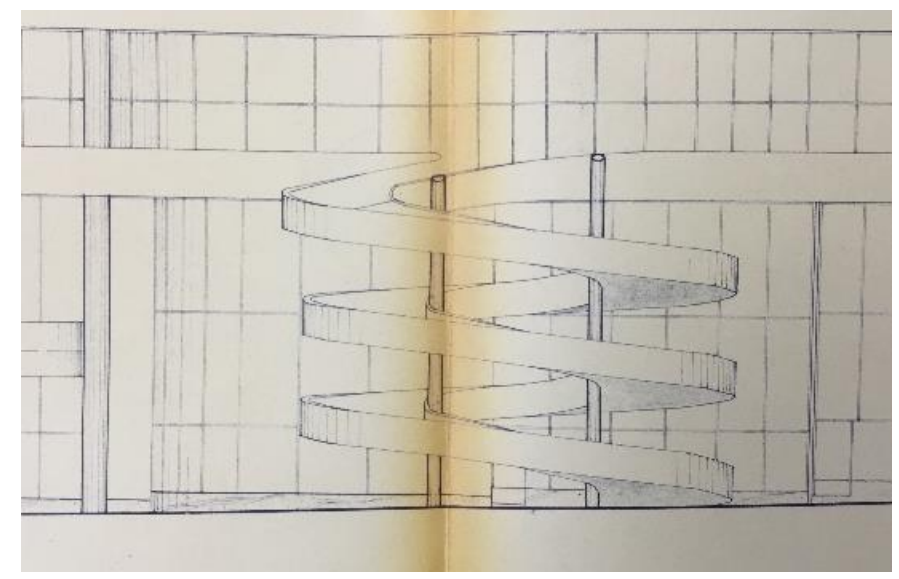

Figura 39 - Rampa

Helicoidal de Acesso

ao Terraço - não

executada

Fonte: Acervo do

Arquivo Histórico

Municipal.

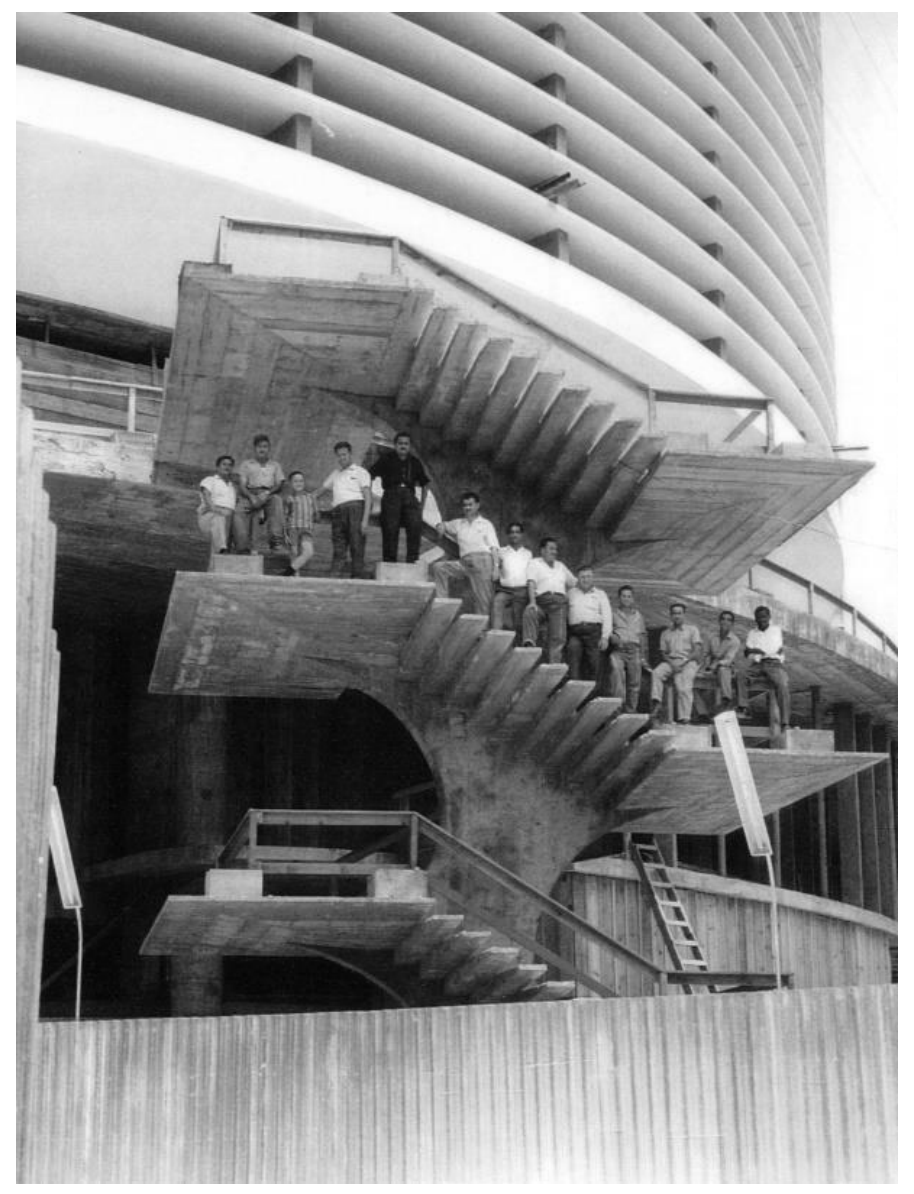

Figura 40 - Escada de acesso ao terraço

Fonte: Acervo do

Condomínio Copan

\section{Os elementos e componentes das fachadas - avaliação de elementos individuais}

Os materiais e componentes originais do Copan são testemunhos de uma época, de uma indústria e de uma linha de produção específicas, algumas que já foram descontinuadas. 
As pastilhas de porcelana brancas e cinza revestem suas enormes fachadas.

Os caixilhos metálicos do piso ao teto, pintados de branco vedam os ambientes voltados para a fachada principal e os apartamentos do Bloco B com face para a fachada posterior.

Os elementos vazados tipo "cobogó" fazem o fechamento dos apartamentos dos Blocos C ao F e parte do Bloco A na fachada posterior.

Caixilhos metálicos nas medidas $0,50 \times 2,80 \mathrm{~m}$ com pintura branca e vidros tipo aramado, dividem dois ambientes distintos (cozinha e banheiro) do Bloco F na fachada sudoeste. Produto da alteração projetual na última fase do projeto. $\mathrm{Na}$ fachada noroeste dois caixilhos nas medidas $0,50 \times 2,80 \mathrm{~m}$ com pintura branca e vidro transparente, atendem um banheiro e um dormitório no Bloco A.

Lambris de madeira estão presentes no embasamento e na galeria do térreo.

Caixilhos metálicos com pintura na cor cinza e os guarda-corpos metálicos do foyer e do terraço são os elementos metálicos do embasamento. compõem o embasamento. Assim como

Guarda-corpos metálicos na cor branca estão locados nas escadas helicoidais de emergência dos Blocos A, D e F.

Guarda-corpos metálicos pintados na cor cinza contornam a cobertura. 

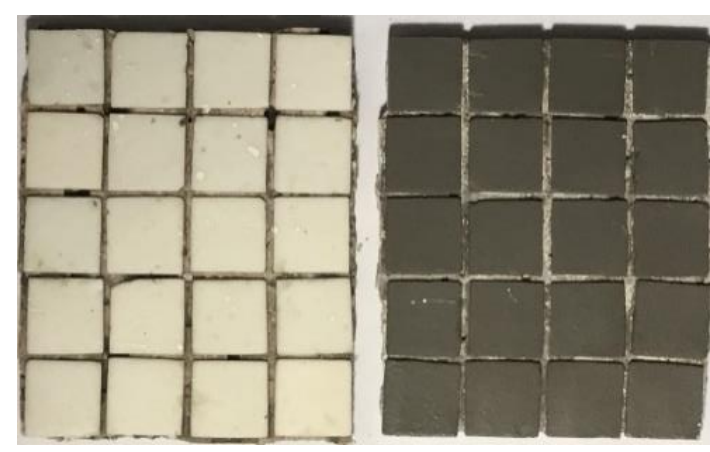

Figura 41 - Pastilhas de Porcelana

Fonte: Acervo da autora.

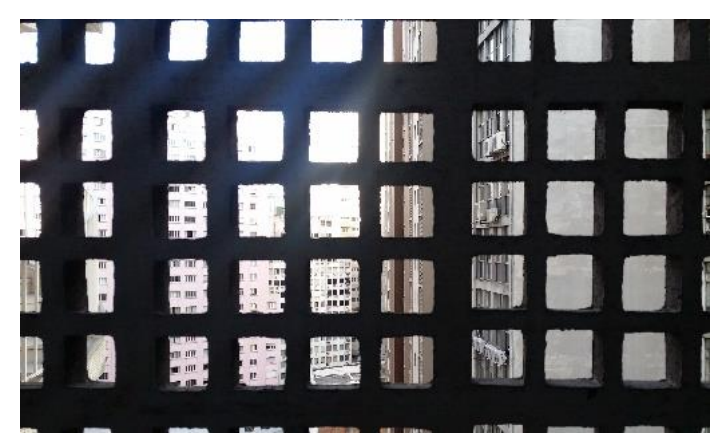

Figura 43 - Elemento Vazado - Cobogó Fonte: Acervo da autora.

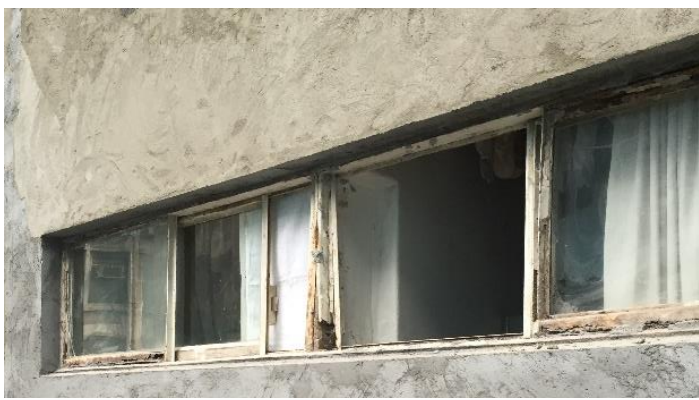

Figura 45 - Caixilho da Fachada Sudoeste Fonte: Acervo de Marianna Tonini.

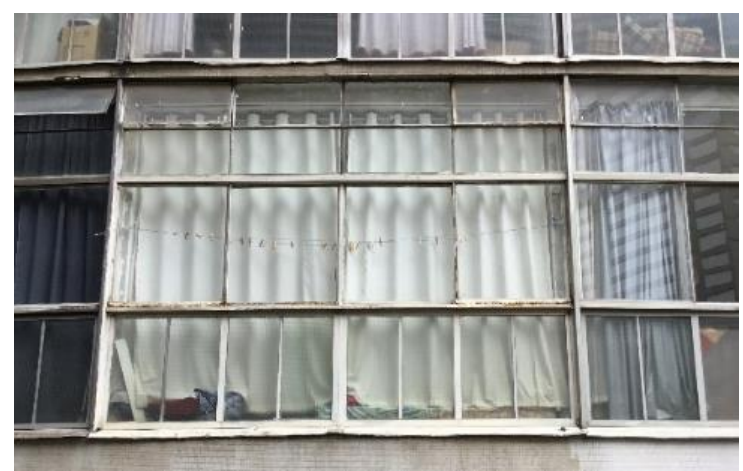

Figura 42 - Caixilhos metálicos do piso ao teto Fonte: Acervo da autora.

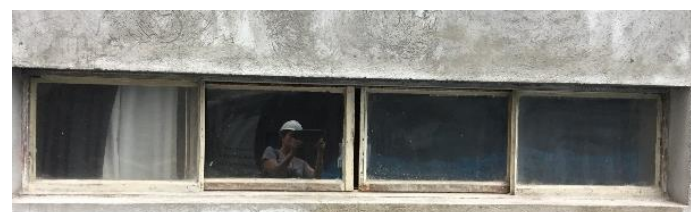

Figura 44 - Caixilho da Fachada Noroeste Fonte: Acervo da autora.

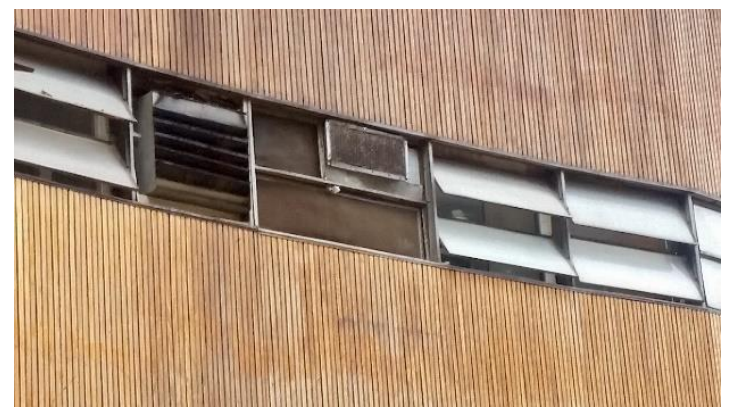

Figura 46 - Lambri de Madeira e Caixilho Metálico

Fonte: Acervo da autora. 


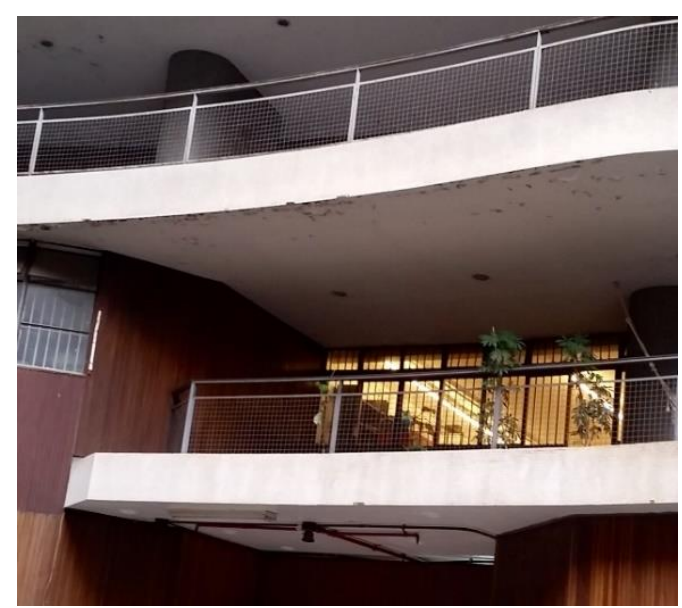

Figura 47 - Guarda-corpo Metálico com tela Fonte: Acervo da autora.

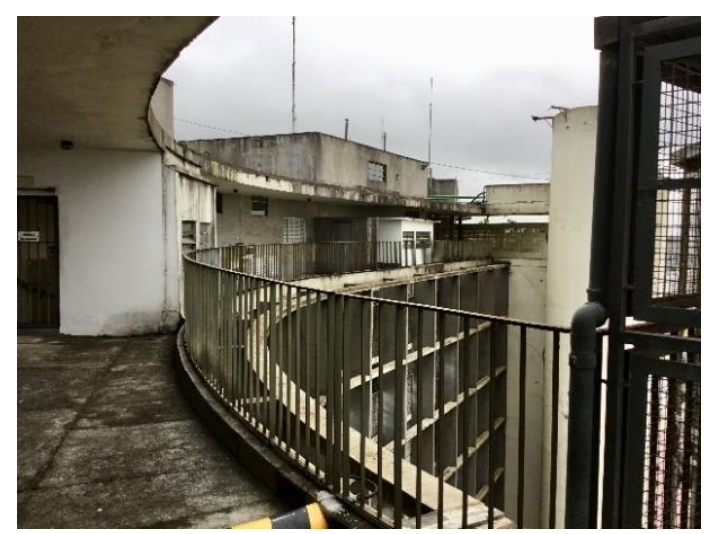

Figura 49 - Guarda-corpo Metálico da Cobertura

Fonte: Acervo da autora.

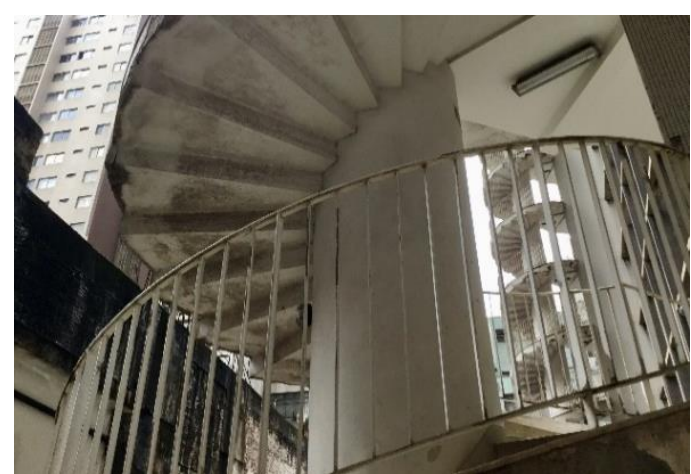

Figura 48 - Guarda-corpo das Escadas Helicoidais

Fonte: Acervo da autora.

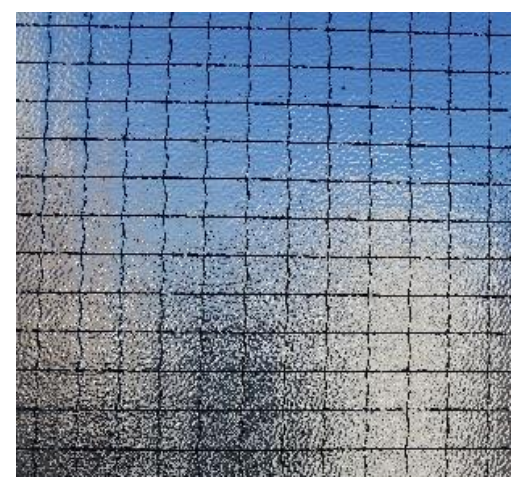

Figura 50 - Vidro aramado Fonte: Acervo da autora.

\section{A apropriação simbólica do Copan}

O Copan começou a figurar na mídia mesmo antes de sair do papel. Foi idealizado para ser um marco na paisagem urbana e com frequência aparece na mídia escrita ou televisiva para aludir à cidade que o abriga.

O Copan se transformou em ponto de encontro, de referência, de visitação. Se para aludir à cidade que o abriga.

O Copan se transformou em ponto de encontro, de referência, de visitação. Se tornou um cartão postal da cidade.

As pessoas atribuem valor ao Copan pela sua grandiosidade, pela forma, pela integração com o tecido urbano, pela arquitetura, pelo arquiteto que o projetou e pela sociedade época no qual foi concebido. O valor é 
atribuído pelo conjunto e isso é refletido nas publicações midiáticas, na literatura e nas artes.

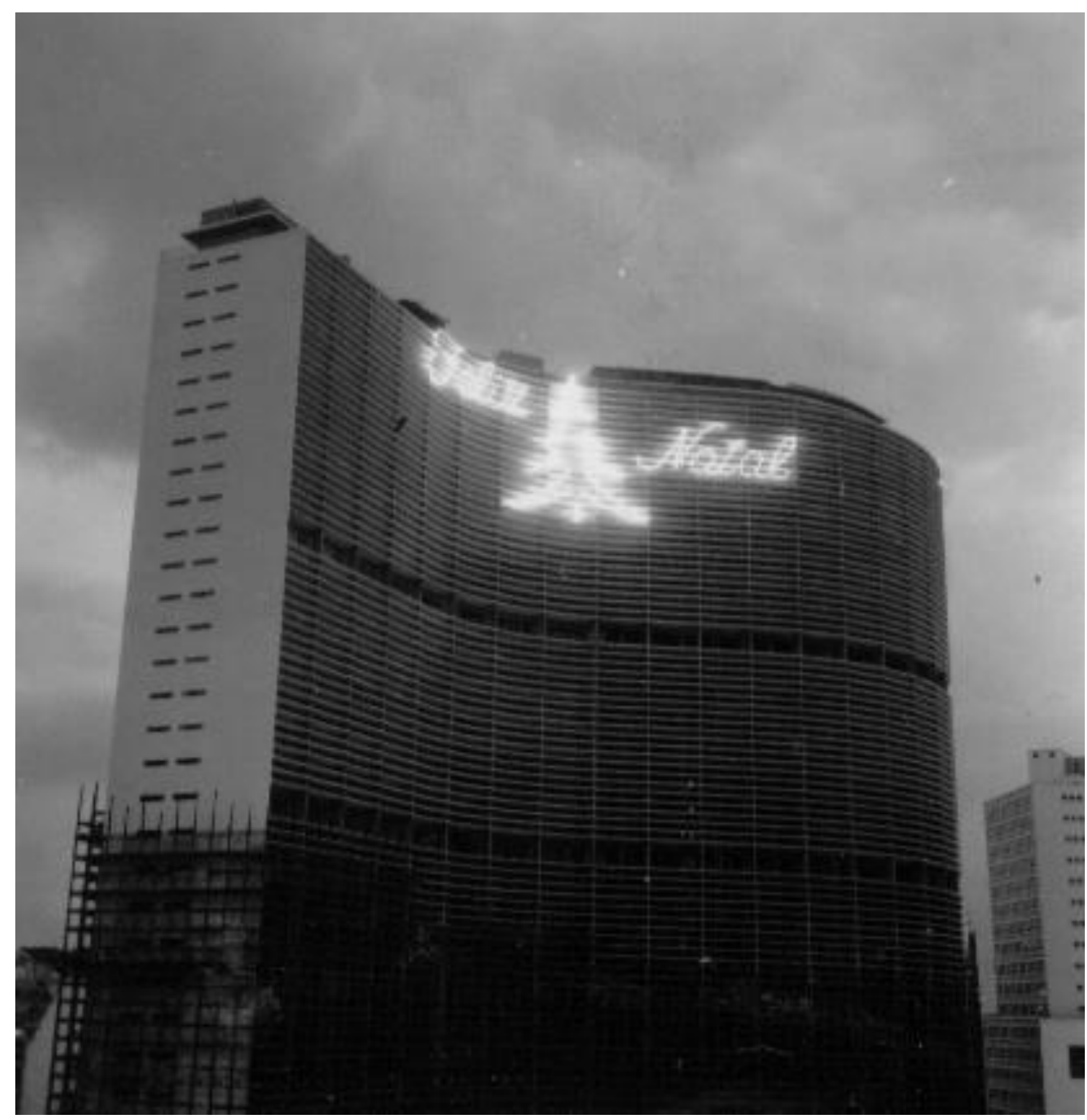

Figura 51 - Letreiro Festivo Durante a Construção em 1961 Fonte: Acervo do Condomínio Copan. 


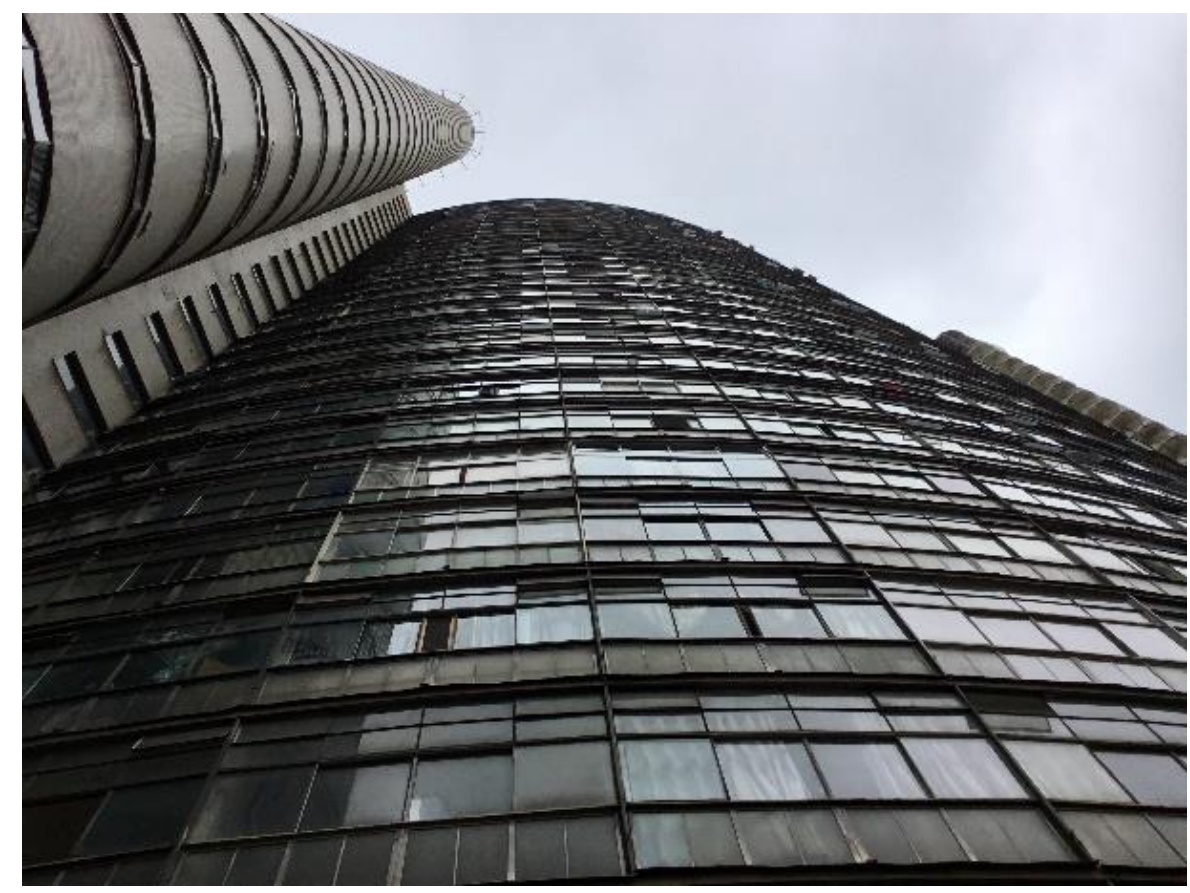

Figura 52 - Fachada Posterior - Bloco B Fonte: Acervo da autora.

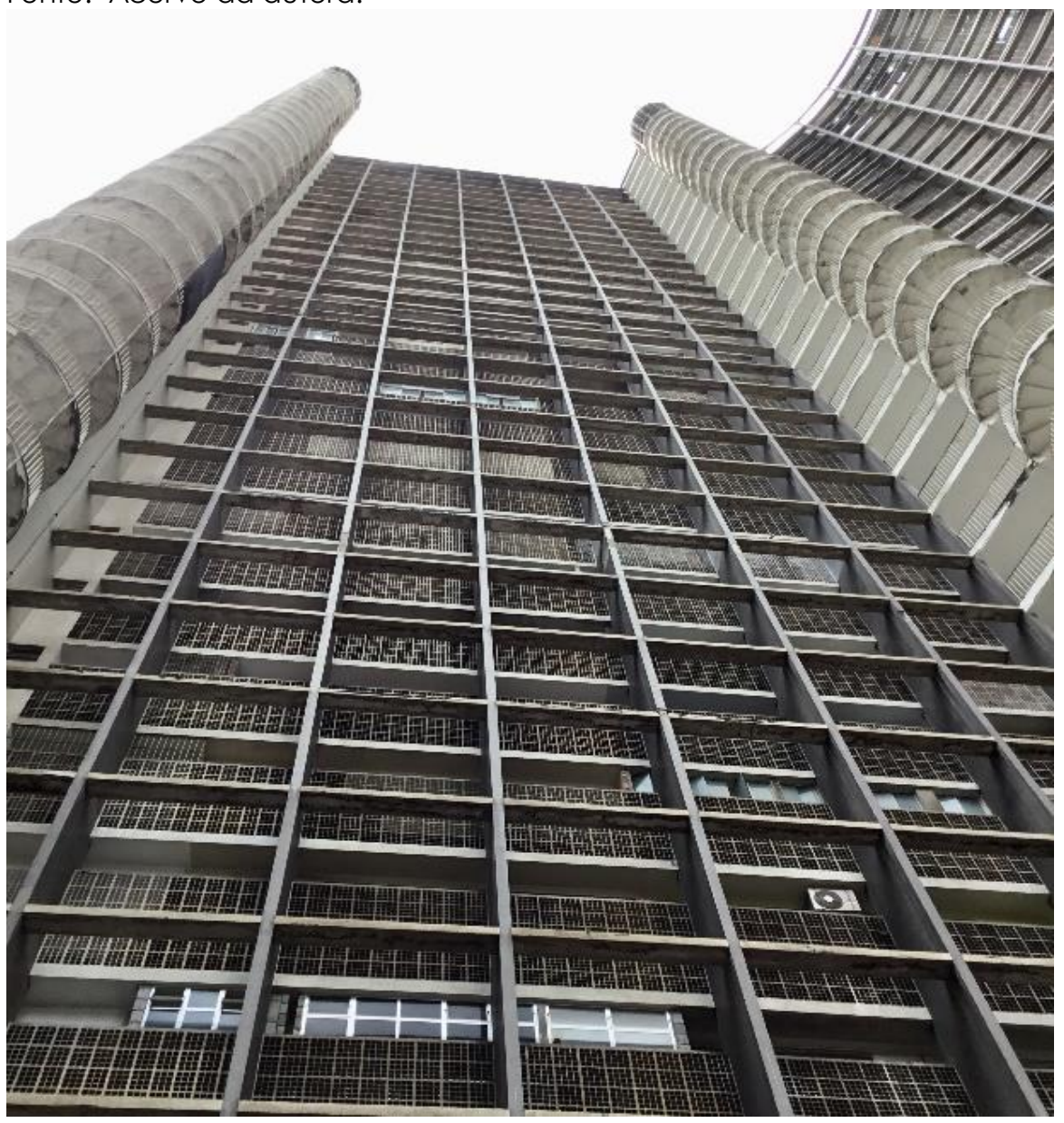

Figura 53- Fachada Posterior - Blocos D e E

Fonte: Acervo da autora. 


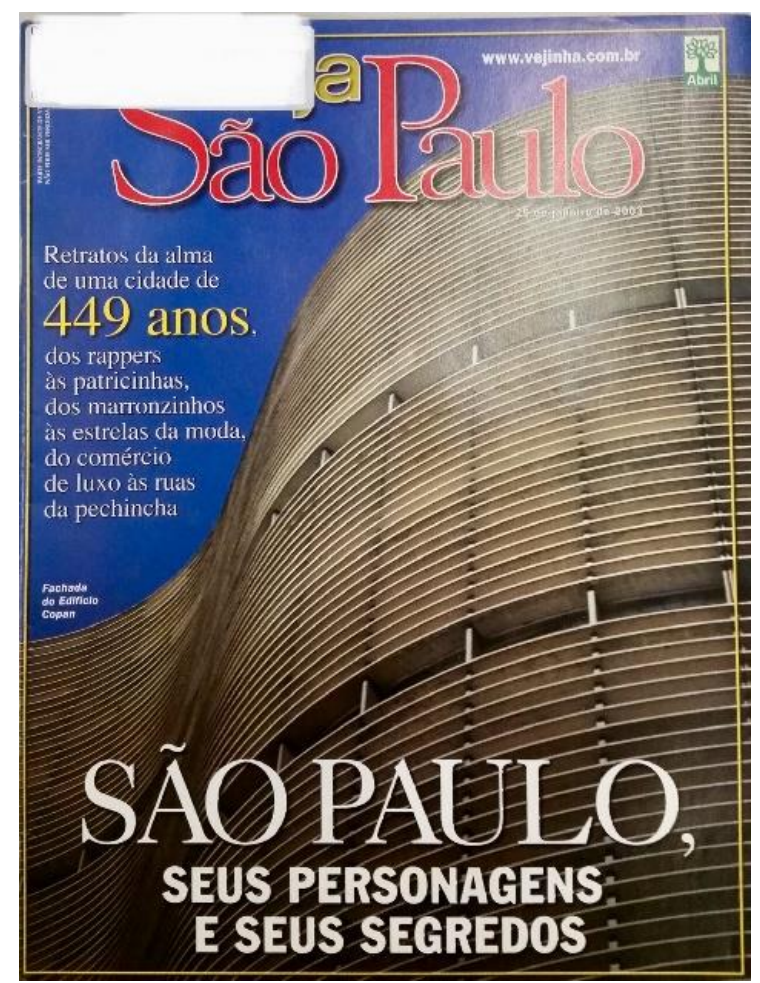

Figura 54 - Copan llustrando Matéria sobre São Paulo

Fonte: Revista Veja, 2003.

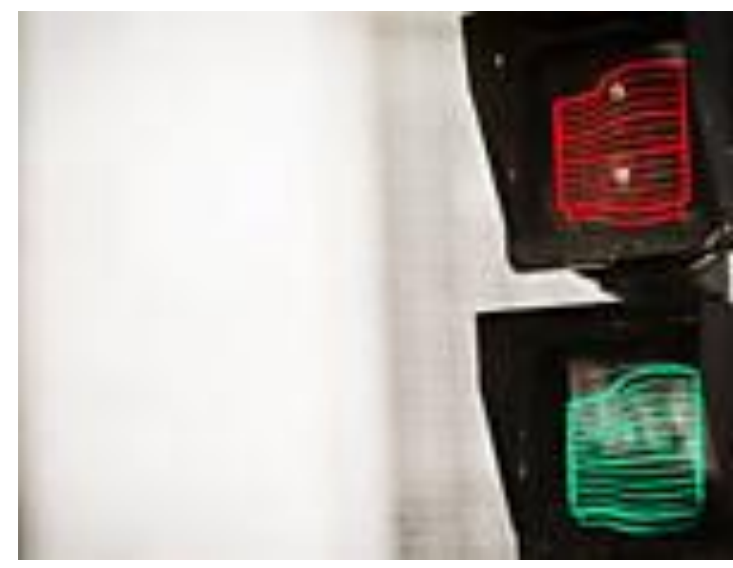

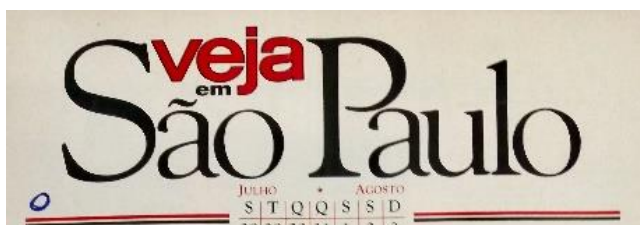

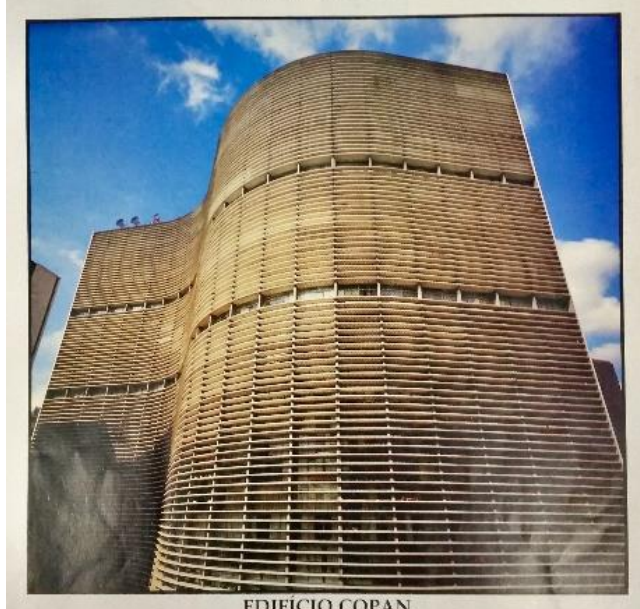

AVIDA NO

\section{CARTÃOPOSTAL DA CIDADE}

Figura 55 - Matéria sobre o Copan Fonte: Revista Veja, 1986.

Figura 56 - Semáforo com Pictograma do Copan Fonte: Folha Uol.

\section{O Reconhecimento oficial}

Após décadas de reconhecimento pela sociedade o CONPRESP Conselho Municipal de Preservação do Patrimônio Histórico, Cultural e Ambiental da Cidade de São Paulo, tombou em 2012 as características arquitetônicas externas e comuns do Edifício Copan e outros edifícios modernos, que constituem um conjunto urbano com unidade histórica, arquitetônica e paisagística. 


\section{DECLARAÇÃO DE SIGNIFICANCIA}

O CONPRESP tombou o Copan em 2012 por meio da Resolução $n^{\circ}$ 33/92, considerando seus valores históricos, arquitetônico e paisagístico, essa visão oficial reflete o olhar da sociedade e os valores por ela atribuídos.

O Edifício Copan se impõe na paisagem paulistana como ícone desta cidade. Sua forma sinuosa impressiona e encanta os que o avistam, sua grandiosidade reflete a sociedade que o concebeu. As diversas tipologias de apartamentos e classes sociais que o habitam, o transformam em uma verdadeira cidade vertical. A galeria comercial no térreo é o ponto de encontro tanto dos moradores quanto dos passantes e, nela se desenrolam relações à moda interiorana, onde as pessoas se conhecem e param tranquilamente para conversar umas com as outras, enquanto turistas observam encantados a obra do grande mestre, fazendo desse espaço uma verdadeira praça de convivência. Paradoxalmente o gigante adquire a escala de uma pequena comunidade e, esses vínculos que nele se desenrolam, não ocorrem em edifícios menores nas proximidades, e conferem ao Copan uma significância excepcional, não apenas no que concerne à arquitetura, mas enquanto palco para as relações sociais.

Alguns aspectos conferem ao Copan uma significância excepcional, são elas:

- A arquitetura ousada e a estrutura funcionalista conferiram ao edifício o status de ícone da arquitetura brasileira do século 20, que apesar das inúmeras transformações projetuais ao longo dos seus 20 anos de construção, conseguiu se impor como marco arquitetônico e cultural;

- A importância do autor do projeto, o premiado arquiteto Oscar Niemeyer reconhecido mundialmente;

- Os poucos projetos de Niemeyer para o mercado imobiliário, tornando o Copan um dos poucos exemplares de edifício voltado para moradia; 
- A implantação no terreno, que permitiu se integrar com o entorno;

- A condição de testemunho técnico construtivo de uma época ao conservar a autenticidade de seus elementos e componentes; 


\subsection{NÍVEIS DE SIGNIFICÂNCIA}

Enquanto a declaração de significância ajuda no entendimento geral do significado do Edifício Copan, a avaliação dos níveis de significância justifica a flexibilidade da abordagem. Pois quanto maior a significância, mais cuidadosa deverá ser qualquer tomada de decisão.

As definições dos níveis de significância foram inspiradas na $4^{\circ}$ Edição do Plano de Conservação do Sydney Opera House elaborado por Alan Croker (CROKER, 2017).

Baseado na avaliação de significado cultural e na declaração de significância, foi possível elencar os elementos e componentes materiais, que suportam os valores culturais atribuídos ao Copan pela sociedade. $\mathrm{Na}$ sequência é apresentada uma lista com seus respectivos níveis de importância e que serviram de parâmetros para o desenvolvimento de políticas de conservação.

\begin{tabular}{|c|c|c|}
\hline Hierarquia & Significância & Definição \\
\hline A & Excepcional & Elementos essenciais para o significado do Copan \\
\hline B & Alta & $\begin{array}{l}\text { Desempenham um papel importante, mas não } \\
\text { crucial na importância do Copan. }\end{array}$ \\
\hline C & Moderada & São suportes para elementos de maior significância. \\
\hline D & Baixa & $\begin{array}{l}\text { Desempenham menor papel no significado do } \\
\text { Copan e podem ter sido comprometidos por } \\
\text { alterações posteriores. }\end{array}$ \\
\hline int & Intrusivo & $\begin{array}{l}\text { São elementos que obscurece, impede ou diminui } \\
\text { o significado de um elemento e seus componentes. }\end{array}$ \\
\hline
\end{tabular}




\section{Configuração geral}

- Aspectos formais e composição volumétrica

A (cheios e vazios), texturas e cores, acessos e implantação

\section{Embasamento}

- Aspectos formais, composição volumétrica,

A texturas e cores

- Lambris de madeira

B

- Caixilhos

B

- Vidros

D

- Guarda-corpos

B

- Pastilhas

B

- Fechamento do terraço

int

- Escadas externa de acesso ao terraço

A

\section{Fachada Principal}

- Aspectos formais, composição volumétrica,

A texturas e cores

- Brises

A

- Pastilhas

B 
- Caixilhos

B

- Vidros

D

- Elementos metálicos de ancoragem dos brises

D

\section{Fachada Sudoeste}

- Aspectos formais, composição volumétrica,

A texturas e cores

- Pastilhas

B

- Caixilhos

B

- Vidros

D

\section{Fachada Noroeste}

- Aspectos formais, composição volumétrica,

A texturas e cores

- Pastilhas

B

- Caixilhos

B

- Vidros

D

\section{Fachada Posterior}

- Aspectos formais, composição volumétrica,

A texturas e cores

- Pastilhas 
- Caixilhos

B

- Vidros

D

- Elemento vazado (cobogó)

C

- Complementos durante o uso e requisições

int externas

\section{Escadas helicoidais de emergências}

- Aspectos formais, composição volumétrica, texturas e cores

- Pastilhas

B

- Guarda-corpo

C

- Complemento metálico

int

\section{Cobertura}

- Aspectos formais, composição volumétrica,

A texturas e cores

- Pastilhas

B

- Caixilhos

B

- Vidros

D

- Guarda-corpo

C

- Antenas

int 


\section{POLÍTICAS DE CONSERVAÇÃO}

O objetivo das políticas de conservação é fornecer um guia para - desenvolvimento e os cuidados necessários para reter e reforçar a significância cultural das fachadas do Copan. Levando em consideração os recursos disponíveis, os usos viáveis, as condições físicas do lugar, os requisitos externos e governamentais e a antecipação de oportunidades e ameaças. Dentro do princípio de que é melhor conservar do que restaurar, ou seja, devese adotar ações para minimizar a deterioração a fim de manter os elementos e componentes originais, preservando a autenticidade do conjunto e retardando a necessidade de restauro. E somente quando não houver possibilidade de recuperação deverá ser realizada a substituição, mas sempre respeitando as características originais idealizadas por Niemeyer.

\subsection{CONFIGURAÇÃO GERAL}

As características arquitetônicas, a volumetria, a textura, as cores, as relações de cheios e vazios, os gabaritos e a escala proposta por Niemeyer devem ser respeitados, a fim de garantir a autenticidade do conjunto e seus valores históricos, estéticos, sociais e culturais. São os itens identificados com nível excepcional e são essenciais para a significância do Copan.

\section{Política 1- Retenção ou revelação de significância}

Todas as intervenções realizadas nas fachadas do Copan devem considerar os níveis de significância estabelecidos anteriormente, a fim de reter ou revelar seu significado.

\section{Política 2- Recursos do Copan e usos viáveis}

Todas as políticas apresentadas deverão considerar os recursos disponíveis e a viabilidade, ou não, de certos usos analisando e buscando o equilíbrio entre as solicitações e a viabilidade, de modo a não permitir que a significância cultural colocada em risco. 


\section{Política 3- Requisitos externos}

O atendimento às determinações legais e governamentais devem ser abordadas sob um viés analítico crítico de modo a minimizar eventuais impactos nas características arquitetônicas do Copan.

\section{Política 4- Escada de acesso ao terraço}

A escada de acesso ao piso concebido como terraço, atualmente utilizado por escritórios, deve ser mantida de acordo com suas configurações originais. Inspeções rotineiras para averiguar as condições estruturais do concreto armado devem ser realizadas e o concreto aparente deve ser tratado com produtos específicos, sempre mantendo a aparência original projetada pelo coautor do Copan, o arquiteto Carlos Lemos.

\subsection{EMBASAMENTO}

O embasamento do Copan compreende a galeria comercial do térreo, a sobreloja, o foyer e o piso do terraço que foi transformado e vendido como escritórios. Os materiais e componentes encontrados são, em sua maioria do nível B. Eles devem ser preservados, de modo a manter a autenticidade e o testemunho construtivo de uma época.

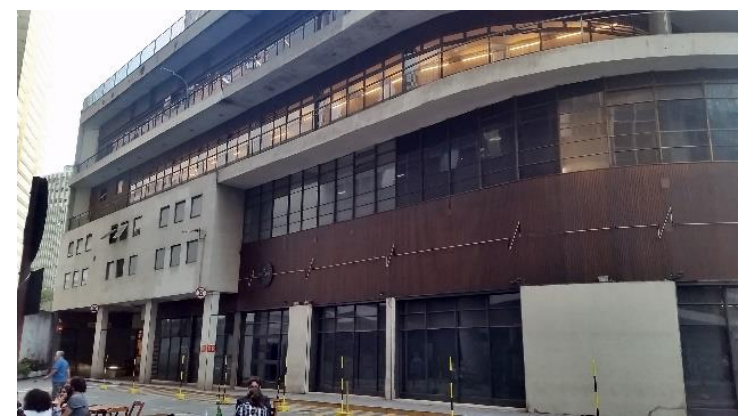

Figura 57 - Embasamento - Vila Normanda Fonte: Acervo da autora.

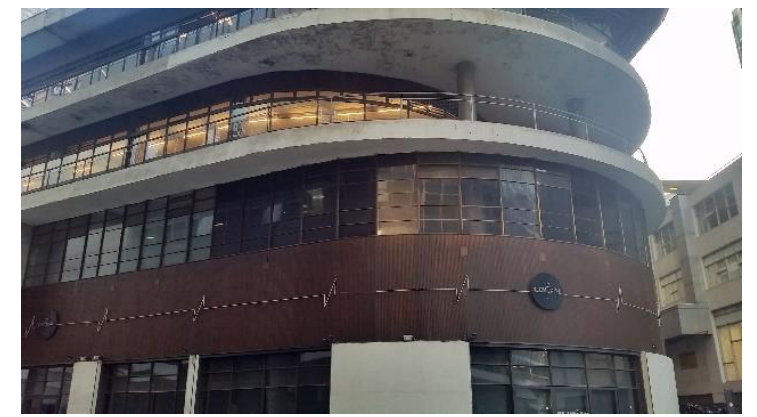

Figura 58 - Embasamento - Vila Normanda com Rua Unaí Fonte: Acervo da autora. 


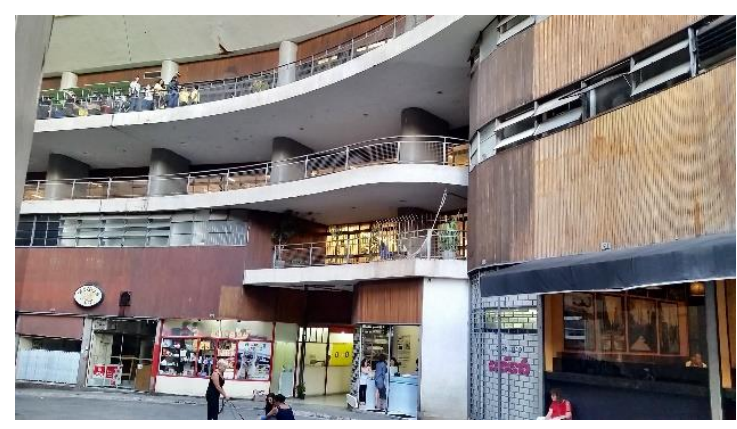

Figura 59 - Embasamento - Rua Unaí Fonte: Acervo da autora.

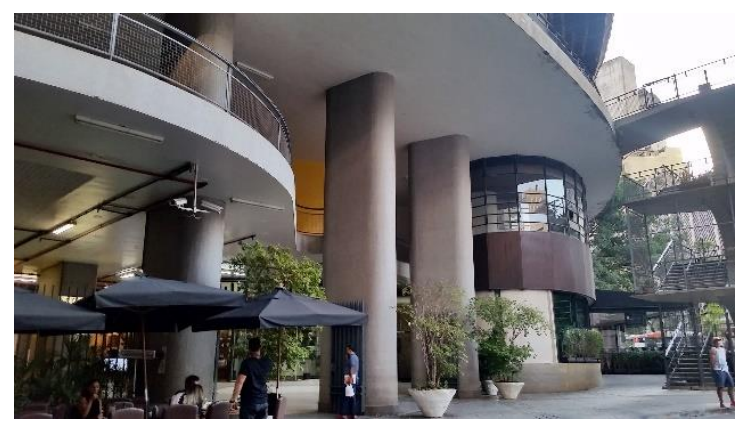

Figura 61 - Embasamento - Rua Unaí Fonte: Acervo da autora.

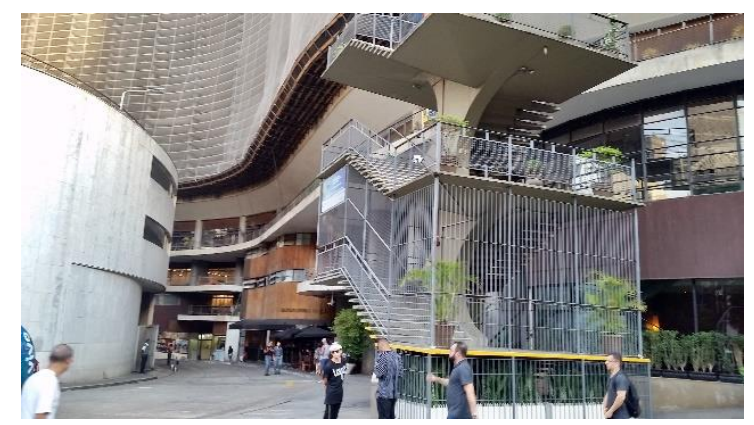

Figura 60 - Embasamento - Rua Unaí com Av. Ipiranga

Fonte: Acervo da autora.

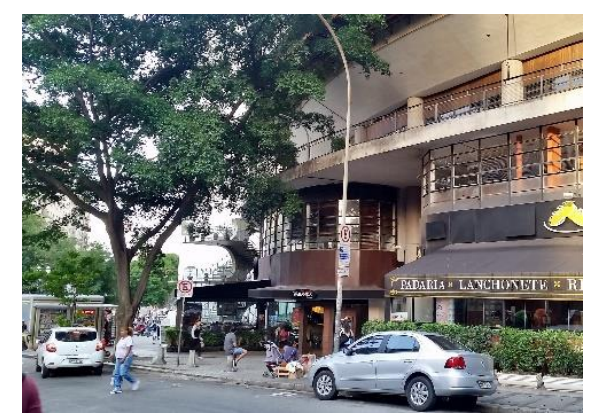

Figura 62 - Embasamento - Rua Araújo Fonte: Acervo da autora.

\section{Política 5- Lambris de madeira}

A madeira original deve ser protegida periodicamente por meio da aplicação de stains, a fim de evitar a necessidade de substituição, mas quando esta for necessária, a madeira a ser introduzida deve apresentar coloração, textura e acabamento superficial similar à original. As dimensões e os detalhes dos encaixes devem respeitar, sempre, o original.

\section{Política 6- Caixilhos metálicos do embasamento}

Sempre que possivel os caixilhos originais devem ser mantidos e a interface caixilho/lambri de madeira deve ser preservada, conforme idealizado por Niemeyer.

Os caixilhos devem passar por manutenção preventiva, recebendo tratamento necessário para resistir às intempéries ao longo dos anos. A cor e o 
acabamento da tinta devem ser o mais fiel possível aos originais e, na necessidade de substituição do vidro, é imprescindível que este mantenha as mesmas características encontradas no conjunto. Caso não seja possível encontrar no mercado vidro com as mesmas características é necessária a substituição total, a fim de evitar reflexos diferentes, que possam destoar na fachada.

\section{Política 7- Guarda-corpo em tela}

Os guarda-corpos em tela estão dispostos no piso do Foyer e no terraço. Devem passar por manutenção preventiva periódica, para o tratamento necessário para resistir às intempéries. A cor e o acabamento da tinta devem ser o mais fiel possível aos originais. Havendo necessidade de substituição é imprescindível que este mantenha as mesmas características encontradas no conjunto original.

A venda do piso do terraço para escritórios, a execução de uma laje para a sua cobertura e o fechamento com caixilhos metálicos e lambris de madeira, são considerados elementos intrusivos, pois não foram previstos na concepção do projeto e essa alteração durante a obra, modifica o partido arquitetônico do Copan. Todavia, ele agora faz parte integrante do Copan, pois foi executado antes da inauguração e deve ser respeitado e tratado com os mesmos cuidados adotados para as outras partes. 


\subsection{FACHADAS}

As fachadas do Copan conferem ao edifício o status de marco arquitetônico da cidade. Cada qual com sua característica e, a mais conhecida e emblemática é a principal - a dos brises.

\section{Política 8- Condição física das fachadas}

Ao longo dos anos as fachadas sofreram grande degradação, diminuindo e, às vezes, até perdendo por completo seu desempenho, sendo necessária ações de restauração e até reconstrução. Os elementos originais devem ser preservados, sempre que possivel. Mas quando já houve perda do material e não for mais possivel recuperá-lo, a substituição e/ou recomposição do material original deve ser por material similar, obedecendo as mesmas propriedades, formato, cor e textura. A fim de preservar ao máximo as características arquitetônicas originais concebidas por Niemeyer.

\section{Política 9- Brises}

Os Brises estão na categoria A de nível de importância. São arquitetônica e socialmente reconhecidos. É imprescindivel ações de manutenção preventiva, inspeções e orientações aos usuários sobre cuidados específicos, como por exemplo, limpeza e uso.

\section{Política 10- Caixilhos}

Os caixilhos das fachadas posterior, sudoeste e noroeste estão bastante danificados por conta das intempéries e ausência de manutenção. Deve-se avaliar a possibilidade de restauração dos originais, mas na impossibilidade devido ao avançado estágio de degradação, estes podem ser substituídos, desde que obedecendo as características físicas dos originais, como cor, formato, textura, dimensões dos montante, panos fixos e móveis, etc. O mesmo vale para os vidros, onde na necessidade de substituição devem obedecer às normas vigentes e o padrão estético original estabelecido. 
A fachada posterior sofreu inúmeras alterações ao longo dos anos, o que em algumas partes, comprometeu a lógica arquitetônica.

Havendo possibilidade, a configuração original deve ser reestabelecida. Mas caso não haja esta possibilidade, alterações indiscriminadas devem ser impedidas, como exemplo, a inclusão de elementos intrusivos, a demolição de elemento vazado e/ou seu fechamento com execução de alvenaria, modificações nos caixilhos ou quaisquer alterações que modifiquem as características arquitetônicas da fachada posterior.

Uma análise detalhada para identificar todas as alterações realizadas, e um estudo de viabilidade técnica e financeira deve ocorrer para definir as ações a serem adotadas.

\section{Política 11 - Fechamento da fachada posterior}

Os elementos vazados (cobogós) devem permanecer com altura máxima de $2,10 \mathrm{~m}$, conforme o original. Assim como as dimensões geométricas, material, cor e textura.

\section{Política 12- Pastilhas}

Após décadas com avançado estágio de degradação houve uma perda significativa das pastilhas que revestem as fachadas do Copan, inviabilizando a restauração e recolocação das pastilhas originais.

Nos locais onde não houve perda significativa, sendo possível elas devem ser mantidas, mas na impossibilidade de preservá-las, estas devem ser substituídas por pastilhas que obedeçam a cor e o formato dos originais.

As fachadas sudoeste e noroeste estão passando por um processo de reconstrução. Foram amplamente investigadas e por meio do conhecimento tanto dos materiais e componentes novos a serem empregados quanto dos originais a serem mantidos, foi possível desenvolver um Manual de Uso, Operação e Manutenção, com ações bem definidas de manutenção, inspeção e registro. O mesmo procedimento deverá ser adotado para as outras 
fachadas, a fim de estabelecer critérios para as ações de manutenção preventiva, que possam estender a vida útil e preservar o desempenho do subsistema.

\subsection{PRESTAÇÃO DE SERVIÇOS E RETENÇÃO DAS CARACTERÍSTICAS}

O edifício em uso requer atualizações dos sistemas e quando estes interferem nas fachadas, como sistemas de proteção contra descargas atmosféricas, sistemas de ancoragem para manutenção ou iluminação, devem ser analisados, compatibilizados e organizados, com atenção aos detalhes, para interferir o mínimo possível na configuração geral do Copan.

\subsection{CUIDADOS COM A CONSTRUÇÃO}

As ações adequadas de manutenção, conservação, restauração, consolidação, remoção de acréscimos intrusivos e prejudiciais configuram-se como ações protetivas, a fim de resguardar as características e as significâncias do edifício.

Os cuidados de limpeza e manutenção preventiva são essenciais para retardar a degradação e com isso a necessidade de ações mais invasivas como manutenção corretiva, restauro ou até mesmo a reconstrução. Ações estas, que embora sejam realizadas para preservar o patrimônio, quando não executada com rigor técnico pode colocar em risco a autenticidade do bem a ser preservado.

\section{Política 13- Manutenção}

O Copan deve ter um programa de manutenção preventiva baseado no conhecimento completo das características externas do edifício e seus materiais, com inspeções regulares e registros das ocorrências, como o Manual de Uso, Operação e Manutenção para as fachadas sudoeste e noroeste. 


\section{Política 14- Equipe de manutenção}

Apenas pessoas qualificas e experientes devem ser empregadas para realização das ações de manutenção.

\section{Política 15- Supervisão da manutenção}

A supervisão das ações de manutenção deve ser feita por profissional treinado, com conhecimento deste Plano de Conservação e do Manual de Uso, Operação e Manutenção para as fachadas sudoeste e noroeste. E ao final de cada ação um relatório, com fotos deve ser desenvolvido e armazenado, a fim de formar um registro das intervenções.

\subsection{CONTROLE DE MUDANÇA}

As modificações, muitas vezes, são necessárias para atender as demandas dos usuários, e são inerentes ao mundo em constante transformação. Todavia, é importante que se tenha um controle do desenvolvimento, orientando as mudanças que são viáveis e compatíveis com a retenção de significância.

Há que se ter em mente que quanto mais alto o nível de significância, menor a tolerância em relação às mudanças.

As mudanças devem ser analisadas sob a luz da necessidade de conservação da autenticidade, integridade, valores, qualidade do edifício e seus elementos, articulados com a tolerância para modificações e oportunidades. 


\section{Política 16- Abordagem cautelosa para mudanças}

De acordo com a Carta de Burral deve-se "mudar tanto quanto necessário, mas tão pouco quanto possível". A análise deve sempre começar pela consideração da intervenção mínima e, somente se necessário as opções de maiores mudanças devem ser consideradas.

\section{Política 17- Itens intrusivos}

Os itens intrusivos devem ser analisados e se não desempenharem papel importante no uso do edifício, devem ser retirados sempre que possível, ou ao menos, ter seu impacto minimizado.

\subsection{GESTÃO}

A gestão da conservação do Copan enquanto patrimônio arquitetônico é de responsabilidade da administração do condomínio, com um conselho formado por especialistas, a fim de assegurar a realização da manutenção adequada visando reduzir a deterioração e os riscos de incêndio, vandalismo e roubo, documentando as intervenções realizadas e os motivos de tais ações como forma de registro para decisões futuras, além de revisão periódica das políticas propostas.

\footnotetext{
1 A Carta de Burra é um documento base que fornece diretrizes e recomendações de conservação e gestão de locais de significado cultural. Desenvolvida pelo ICOMOS (International Council on Monument and Sites) é referência no campo da preservação do patrimônio.
} 


\section{CONSIDERAÇÕES FINAIS}

Após anos sem ações de manutenção as fachadas do Copan sofreram um intenso processo de degradação. Entretanto, desde 2012 a administração do condomínio vem tentando restaurar suas fachadas, iniciado por um intenso levantamento técnico de suas condições físicas, seguido de um projeto executivo de revestimento de fachada e na sequência o início das obras para reconstrução das fachadas sudoeste e noroeste, que se encontram paralisadas desde o final de 2016.

Diante da complexidade e da dimensão de suas fachadas, verificou-se a necessidade de desenvolvimento de Plano de Conservação, específico para esse subsistema, a fim de nortear futuras ações de intervenção.

Por meio do levantamento das características das fachadas foi possível reunir informações específicas sobre elementos e componentes a serem preservados. E a avaliação do significado cultural possibilitou o entendimento do que é significativo para a sociedade e que precisa ser preservado para as gerações futuras, como testemunho de uma época passada.

O levantamento realizado permitiu construir formalmente, por meio do processo de síntese das informações adquiridas, as políticas de conservação. Estas políticas tem um caráter flexível e variam de acordo com requisitos externos, recursos disponíveis e solicitações dos usuários. Isso não significa que as políticas devam ser alteradas para atender a qualquer solicitação, mas, que se deve considerar as possibilidades de mudanças por meio de análise crítica e visão holística. O Plano de Conservação apresenta os níveis de significância, o que deve ser preservado e quais as tolerâncias às mudanças. Entretanto, ele deve estar associado a um programa de manutenção preventiva, desenvolvido a partir de um amplo conhecimento acerca dos materiais e componentes empregados, a fim de programar ações de manutenção necessárias para retardar a degradação e a perda de desempenho dos subsistemas do edifício. 


\section{6. REFERÊNCIAS}

CROKER, Alan. Respecting the Vision Sydney Opera House and its Site - A Conservation Management Plan. 4.ed. Sydney: Sydney Opera House Trust, 2003. Disponível em:< https://www.sydneyoperahouse.com/content/dam/pdfs/conservationmanagement-plan/SOH_CMP_Interactive_1.pdf >. Acesso em: 17 nov. 2017.

ICOMOS. The Burra Charter - The Australia ICOMOS Charter for Places of Cultural Significance, 2013. Disponível em: < http://portal.iphan.gov.br/uploads/ckfinder/arquivos/The-Burra-Charter-2013Adopted-31_10_2013.pdf >. Acesso em: 17 abr. 2017.

FUNDAÇÃO OSCAR NIEMEYER. Disponível em:< http://www.niemeyer.org.br/>. Acesso em: 05 fev.2019.

LEAL, Daniela V. Oscar Niemeyer e o mercado imobiliário de São Paulo na década de 1950: o escritório satélite sob direção do arquiteto Carlos Lemos e os edifícios encomendados pelo Banco Nacional Imobiliário. Campinas, 2003. Dissertação de mestrado. Instituto de Filosofia e Ciências Humanas, Universidade Estadual de Campinas.

LEMOS, Carlos A. C. A história do Edifício Copan. Trilogia do Copan; vol.1. São Paulo: Imprensa Oficial do Estado de São Paulo, 2014.

KERR, James S. Conservation Plan - A guide to the preparation of conservation plans for places of European cultural significance. 7.ed. Sydney: New South Wales Government - Department of the Environment and Heritage, 2013.

A Plan for the Conservation of the Sydney Opera House and its Site. 3.ed. Sydney: Sydney Opera House Trust, 2003. Disponível em:< http://www.environment.gov.au/system/files/pages/59ca36d1-4581-4d7d83d7-04b124d801bl/files/soh-conservationplan.pdf>. Acesso em: 17 nov. 2017. 
Niemeyer no centro de São Paulo. Arquitextos, São Paulo, ano 13, n. 151.08, Vitruvius, dez. 2012. Disponível em:

<http://www.vitruvius.com.br/revistas/read/arquitextos/13.151/4632>. Acesso em: 3 jan. 2018.

XAVIER, A., LEMOS, C. A., CORONA, E. Arquitetura Moderna Paulistana. 2.ed. São Paulo: Pini, 2017. 
7.

\section{Anexo I - Termo de Consentimento Livre e} Esclarecido

\section{IERMO DE CONSENTIMENTO LIVRE E ESCLARECIDO}

Eu Carlos Alberto Cerqueira Lemos concedi uma entrevista, no dia 22 de janeiro de 2018, para o estudo que tem como pesquisadora responsável a aluna de mestrado Valeria Aparecida Costa Bonfim, do programa de pós-graduação da Faculdade Arquitetura e Urbanismo da Universidade de São Paulo, $n^{\circ}$. USP 5522078, que pode ser contatada pelo e-mail valeriabonfim@usp.br e pelo telefone (11)98886-7047. Tenho ciência de que o estudo visa registrar os relatos acerca das decisões projetuais e da construção do Edifício Copan. Minha participação consistiu em conceder uma entrevista que foi gravada e transcrita. Entendo que esse estudo possui finalidade de pesquisa acadêmica, que os dados obtidos não serão divulgados, a não ser com prévia autorização. A aluna providenciou uma cópia da transcrição da entrevista para meu conhecimento. Além disso, sei que posso abandonar minha participação na pesquisa quando quiser e que não receberei nenhum pagamento por esta participação.

São Paulo, 29 de março de 2018.

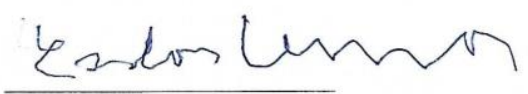

Arq. Prof. Dr. Carlos Alberto Cerqueira Lemos

(Entrevistado)

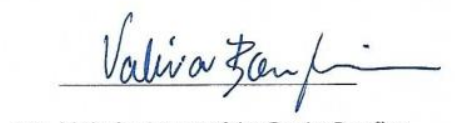

Arq. Valeria Aparecida Costa Bonfim

(Pesquisadora) 


\section{EDIFÍCIO COPAN}

\section{MANUAL DE USO, OPERAÇÃO E MANUTENÇÃO \\ Fachadas Sudoeste e Noroeste}

(Apêndice B)

Versão 1

2019 
Este Manual de Uso, Operação e Manutenção é parte integrante da Dissertação de Mestrado intitulada: A conservação da arquitetura moderna: as fachadas do Edifício Copan, apresentada à Faculdade de Arquitetura e Urbanismo da Universidade de São Paulo.

Autora: Valéria A. C. Bonfim

Orientadora: $\operatorname{Prof}^{a}$. $\mathrm{Dr}^{\mathrm{a}}$. Fabiana Lopes de Oliveira 


\section{SUMÁRIO}

1. INTRODUÇÃO 1

1.1. ORIENTAÇÕES PARA UTILIZAÇÃO DO MANUAL 5

1.1.2. DA INSPEÇÃO 5

1.1.3. DA MANUTENÇÃO 5

1.1.4. DO ARQUIVAMENTO DAS FICHAS 6

1.2. TERMOSEDEFINIÇÕES

2. MEMORIAL DESCRITIVO DO EDIFÍCIO COPAN 12

2.1. DADOS DO EDIFÍCIO 25

3. CARACTERIZAÇÃO DO SUSBISTEMA DE REVESTIMENTO EXTERNO 26

3.1. REVESTIMENTO DE ARGAMASSA E ACABAMENTO DECORATIVO 26

$\begin{array}{lll}\text { 3.2. FRISOS } & 31\end{array}$

3.3. JUNTA DE MOVIMENTAÇÃO 33

3.4. MATERIAIS E COMPONENTES UTILIZADOS NA OBRA DE RECUPERAÇÃO DO SUBSISTEMA DE REVESTIMENTO EXTERNO

3.4.1. FUNDO PREPARADOR DE PAREDES 35

3.4.2. ARGAMASSA ADESIVA PARA CHAPISCO 35

3.4.3. ARGAMASSA INDUSTRIALIZADA 36

3.4.4. RESINA ACRÍLICA 36

3.4.5. POLÍMERO ACRÍLICO COM FIBRAS PARA IMPERMEABILIZAÇÃO DE JUNTAS 37

3.4.6. ARGAMASSA COLANTE

3.4.7. ACABAMENTO DECORATIVO (PASTILHA) 37

3.4.8. LIMITADOR DE PROFUNDIDADE 38

$\begin{array}{lll}\text { 3.4.9 SELANTE } & 38\end{array}$

4. PROGRAMA DE MANUTENÇÃO PREVENTIVA 39

4.1. INSPEÇÃO 39

4.2. RELATÓRIO DE INSPEÇÃO 39 
4.3. AÇÕES DE MANUTENÇÃO 40

4.4. REGISTRO 40

4.5. ROTEIRO DE AÇÕES DE MANUTENÇÃO PREVENTIVA 41

5. FICHAS 50

6. RELAÇÃO DE FORNECEDORES E PROJETISTAS - RECUPERAÇÃO 62

7. REFERÊNCIAS 64

8. ATUALIZAÇÕES E REVISÕES DO MANUAL DE MANUTENÇÃO 66

9. ANEXOS - AMPLIAÇÕES FACHADAS 67 


\section{INTRODUÇÃO}

A manutenção é essencial para preservar o desempenho do edifício e seus subsistemas, prolongando sua vida útil e ajudando a minorar sua deterioração ao longo dos anos. Para isso se faz necessário ter um programa de manutenção, com inspeções programadas e ações preventivas, que estão descritas neste manual, que deve ser consultado antes da realização de qualquer atividade nas fachadas. A periodicidade das inspeções e das ações de manutenção preventiva devem ser observadas e executadas de acordo com o roteiro de ações de manutenção preventiva (item 4.5).

Embora exista um projeto executivo para o revestimento de fachada do Edifício Copan, apenas as fachadas sudoeste (SO) e noroeste (NO) estão sendo recuperadas e, por esse motivo, o presente manual trata especificamente das fachadas que estão em processo de recuperação.

Este manual tem o objetivo de orientar as ações de manutenção nas fachadas sudoeste e noroeste do Edifício Copan, concentrando as informações necessárias para o entendimento do subsistema de revestimento externo das fachadas, para a identificação de manifestações patológicas e das ações preventivas de manutenção, com vistas à preservação do seu desempenho.

Neste manual são apresentadas:

- $\quad$ as definições dos termos utilizados no Manual de Uso, Operação e Manutenção;

- o memorial descritivo com os dados do edifício;

- $\quad$ os materiais e componentes utilizados;

- a caracterização do subsistema de revestimento externo;

- um programa de manutenção com um roteiro de ações de manutenção preventiva; 
- fichas de inspeção, fichas de manutenção e modelos de relatórios;

- relação de fornecedores e projetistas;

- referências;

- fichas de atualizações do manual.

O presente manual foi idealizado para ser utilizado pelo condomínio e com o objetivo de facilitar seu uso e concentrar as informações técnicas pertinentes às fachadas foi criada uma Caixa para o Programa de Manutenção das Fachadas Sudoeste e Noroeste do Edifício Copan, que é composta por dois fichários, um CD de anexos e o Plano de Conservação.

Fichário 1 - Manual de Uso, Operação e Manutenção - Fachadas Sudoeste e Noroeste do Edifício Copan; descreve o subsistema de revestimento externo, os materiais e componentes, a periodicidade e as ações necessárias para manutenção. Deve ser consultado antes de qualquer ação de manutenção e/ou intervenção nas fachadas sudoeste e noroeste.

Fichário 2 - Registro de Manutenção - Fachadas Sudoeste e Noroeste do Edifício Copan; nele são armazenadas as fichas de inspeção, as fichas de manutenção e os relatórios das ações realizadas, que ao longo do tempo formam um banco de dados, possibilitando a rastreabilidade tanto das atividades executadas quanto das eventuais manifestações patológicas recorrentes. Esse fichário deverá ser utilizado para consulta dos serviços realizados e para o arquivamento das fichas e relatórios de toda ação de manutenção executada.

CD de anexos; com documentos referentes às fachadas do Edifício Copan, são eles:

- Lista de documentos do projeto executivo de revestimento de fachada;

- Memorial descritivo do projeto executivo de revestimento de fachada; 
- Fichas técnicas dos materiais e componentes utilizados nas fachadas sudoeste (SO) e noroeste (NO);

- Relatório técnico Falcão Baver;

- Parecer técnico Arco;

- Relatório do Ensaio de Avaliação de Dureza Superficial do Concreto Endurecido;

- Relatório do Ensaio de Reconstituição do Traço de Argamassa de emboço original;

- Relatório do Ensaio de Reconstituição de Traço de Argamassa de reboco original.

- Relatório do Ensaio de Reconstituição de Traço de Argamassa de assentamento original das pastilhas.

Plano de Conservação apresenta uma caracterização de todas as fachadas do edifício, analisa as mudanças que ocorreram ao longo dos anos, identifica o significado cultural, faz a declaração de significância e apresenta às políticas de conservação, mostrando o que deve ser conservado. O plano é um instrumento abrangente, essencial para ajudar na retenção do significado do patrimônio e deve atuar em conjunto com o manual que é o instrumento que diz o como conservar.

As inspeções e as ações de manutenção deverão ser realizadas por empresa especializada/profissional habilitado, mas é recomendável que o condomínio tenha em sua equipe de manutenção predial um profissional capacitado, com conhecimento do teor deste manual, para que possa identificar os problemas nas fachadas relatados pelos condôminos (como exemplos, queda de pastilha, infiltração etc.), bem como acompanhar a empresa contratada e orientá-la acerca da existência e da necessidade de consulta deste manual, como também o preenchimento das fichas e dos relatórios garantindo o registro das atividades. 
Por se tratar de atividades em altura, o condomínio deverá contratar empresas especializadas, que obedeçam às recomendações da Norma Regulamentadora No35 - Trabalho em altura, a Norma Regulamentadora $N^{0} 18$ - Condições e Meios de Trabalho na Indústria da Construção Civil, e a NBR16489/2017 - Sistema e equipamento de proteção individual para trabalho em altura - Recomendações e orientações, para assegurar as condições de trabalho e segurança do profissional e das pessoas em solo. Deve-se atender às referências normativas para adoção de sistemas de ancoragem, uma vez que o edifício não conta com pontos específicos para tal finalidade fixados de forma permanente em sua estrutura, sendo necessária a adoção de outros métodos para ancoragem, como contrapeso para os equipamentos (cadeirinhas, balancins etc.) e os EPIs (equipamento de segurança individual), como cinto de segurança, trava-quedas, talabarte etc., a serem utilizados pelos profissionais envolvidos nas inspeções e ações de manutenção nas fachadas. 


\subsection{ORIENTAÇÕES PARA UTILIZAÇÃO DO MANUAL}

Este manual deve ser consultado antes da realização de qualquer atividade nas fachadas. A periodicidade das inspeções e das ações de manutenção preventiva devem ser observadas e executadas de acordo com o roteiro de ações de manutenção preventiva (item 4.5).

\subsubsection{DA INSPEÇÃO}

Para a realização das inspeções deverá ser utilizada e devidamente preenchida a Ficha de Inspeção (FI), que consta no item 5, específica para cada fachada, pois ela contém um check-list do que deve ser observado e devidamente preenchido.

Após a inspeção deverá ser gerado um Relatório de Inspeção (RI) por profissional habilitado indicando a necessidade ou não de ações de manutenção corretiva em função do que foi observado na inspeção.

\subsubsection{DA MANUTENÇÃO}

Para qualquer ação de manutenção deverá ser utilizada e preenchida a Ficha de Manutenção (FM) - específica para cada fachada -, que se encontra no item 5.

A manutenção é dividida em duas categorias - a preventiva e a corretiva:

A manutenção preventiva deverá seguir o roteiro de ações de manutenção preventiva (item 4.5).

A manutenção corretiva será realizada em função das manifestações patológicas observadas durante a inspeção e do relatório gerado por profissional habilitado. Para tal ação de manutenção é necessário estabelecer um diagnóstico preciso e identificar as causas para, posteriormente, propor soluções adequadas para o tratamento. Essas ações devem ser realizadas por empresa especializada e sob a supervisão de um profissional habilitado. 


\subsubsection{DO ARQUIVAMENTO DAS FICHAS}

Após a realização das inspeções e ações de manutenção as fichas e os relatórios gerados deverão ser arquivados no Fichário 2 - Registro de Manutenção, que se encontra na Caixa para o Programa de Manutenção das Fachadas Sudoeste e Noroeste do Edifício Copan. O preenchimento da ficha de registro e o arquivamento dos documentos é de responsabilidade do condomínio.

As Fichas de Inspeção (FI), as Fichas de Manutenção (FM) e OS Relatórios de Inspeção (RI) deverão permanecer na Caixa para o Programa de Manutenção das Fachadas Sudoeste e Noroeste do Edifício Copan por no mínimo 5 anos após a realização do último serviço, com vistas a facilitar a rastreabilidade das ações realizadas. Após esse período poderão ser transferidas para o arquivo morto da administração do condomínio. Todavia, a ficha de registro com a identificação de todas as fichas e relatórios deverá permanecer no Fichário 2 - Registro de Inspeção e uma cópia desta deverá ser arquivada com o restante do registro no arquivo morto do condomínio. $\mathrm{Na}$ ocasião da digitalização desses documentos um backup deverá ser realizado em CD, DVD, Pen-drive ou outro meio de armazenamento fora da rede do condomínio, preferencialmente em múltiplas plataformas e com a devida indicação de sua localização.

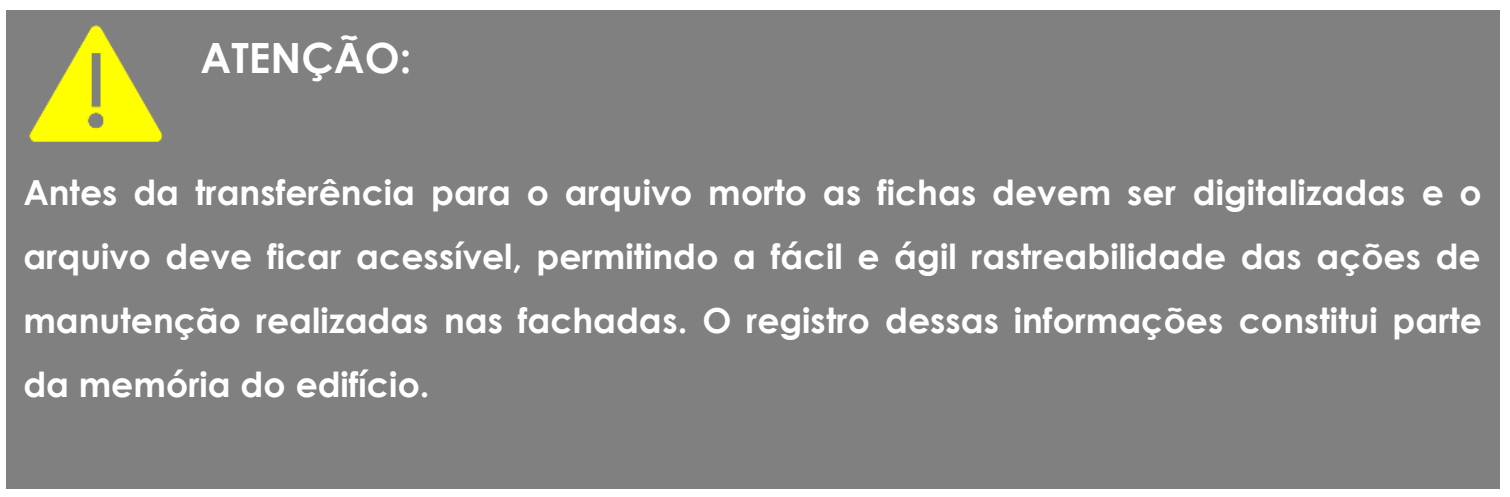




\subsection{TERMOS E DEFINIÇÕES}

Neste manual serão utilizados os seguintes termos e definições:

Acabamento decorativo

Agente de degradação

Ancoragem

\begin{abstract}
Componente
\end{abstract}
Degradação

Desempenho
Material para acabamento aplicado sobre 0 revestimento de argamassa [7]. Neste manual esse termo refere-se às pastilhas.

Tudo que age sobre um subsistema diminuindo seu desempenho [1].

Dispositivo ou local para fixação segura de equipamentos ou sistemas de trabalho em altura [2].

Unidade que faz parte de um determinado subsistema do edifício, com forma definida, atendendo a funções específicas, por exemplo, pastilha [1].

Diminuição do desempenho em função de um ou mais agentes de degradação [1].

Comportamento em uso de um edifício e seus subsistemas [1].

Descolamento É caracterizado pela perda de aderência do acabamento decorativo com 0 revestimento de argamassa. Ocorre com maior frequência nos primeiros e nos últimos andares [13].

Pode ser verificado ao apresentar "som cavo", quando da percussão com martelo de borracha e o "estufamento" das placas de revestimento decorativo. 
Desplacamento

Durabilidade

Elemento

Empresa especializada manutenção local
É caracterizado pela queda do revestimento de argamassa ou do acabamento decorativo. Geralmente ocorre após o descolamento [15].

Capacidade do edifício e seus subsistemas em desempenhar suas funções ao longo do tempo, sob condições de uso e manutenção especificadas no Manual de Uso, Operação e Manutenção [1].

É parte de um subsistema com função específica, composto por um conjunto de componentes, por exemplo: revestimento em pastilha [1].

Organização ou profissional liberal com qualificação e competência técnica específica para exercer determinada função [3].

Trabalhadores que realizam serviços locais, que tenham recebido orientação e possuam conhecimento de prevenção de riscos e acidentes [3].

Falha É um problema decorrente do processo construtivo, do projeto ou da incompatibilidade entre o que foi especificado em projeto e a execução [15].

Friso É uma faixa contínua na argamassa de revestimento, posicionada na interface alvenaria/ fundo de viga. Tem $1,5 \mathrm{~cm}$ de profundidade e $2,0 \mathrm{~cm}$ de espessura. É fechado com selante e não contém limitador de profundidade. 
Inspeção Ato ou efeito de inspecionar, examinar, vistoriar.

Junta de Projetada para aliviar as tensões de deformação da movimentação base e do acabamento decorativo. Estão posicionadas horizontalmente no fundo da viga da cobertura e verticalmente delimitando as faces em 3 panos. Tem de altura $2,0 \mathrm{~cm}$ e de espessura toda a profundidade do emboço, que é demarcada com um limitador de profundidade para garantir dimensão do selante.

Lacuna Espaço vazio, falta ou falha no revestimento cerâmico, nos rejuntes, nas juntas ou nos frisos, decorrentes de perfurações, remoções ou degradação.

Limitador de Material compressível posicionado dentro da junta de profundidade movimentação antes da aplicação do selante. Uma de ou corpo de suas funções é a de garantir a geometria adequada do apoio selante [4].

Manifestações Problemas resultantes de um mecanismo de patológicas degradação.

Manual de uso, Documento que apresenta as informações necessárias operaçãoe para orientar as atividades de conservação, uso e manutenção manutenção da edificação e/ou suas partes [5].

Manutenção É o conjunto de atividades realizadas a fim de conservar ou recuperar a capacidade funcional do edifício e/ou de seus subsistemas, visando atender às necessidades e segurança dos seus usuários [5].

Manutenção Caracterizada por serviços cuja realização seja programada com antecedência, priorizando as 
preventiva solicitações dos usuários, estimativas da durabilidade esperada dos subsistemas, elementos ou componentes das edificações em uso e relatórios de verificações periódicas sobre o seu estado de degradação [3].

Manutenção corretiva

Ponto de ancoragem

Profissional habilitado

Revestimento de argamassa

Revestimento em duas camadas

Revestimento em camada única
Caracterizada por intervenções imediatas, visando garantir a continuidade de uso dos subsistemas, elementos ou componentes dos edifícios, evitando danos aos usuários e ao patrimônio [3].

Parte integrante de um sistema de ancoragem no qual o EPI - equipamento de proteção individual (cinto de segurança, talabarte, trava-quedas etc.) é conectado $[2]$.

Trabalhador previamente qualificado e com registro em conselho de classe.

É o cobrimento de uma superfície com uma ou mais camadas de argamassa sobrepostas [7]. No caso do Copan, o revestimento de argamassa original era composto por duas camadas: emboço e reboco, aplicados sobre alvenaria ou estrutura de concreto armado.

É constituído de mais de dois tipos de argamassa: de emboço e de reboco, excetuando o chapisco, aplicadas sobre a base [7].

É constituído de um único tipo de argamassa, excetuando o chapisco, aplicada sobre a base [7]. 
Selante Material com propriedades elásticas usado para preenchimento das juntas de movimentação e dos frisos, inibindo a passagem de sólidos e líquidos e, ao mesmo tempo, permitindo a movimentação conforme previsto em projeto [4].

Sistema É um conjunto de elementos e componentes destinados a atender uma macrofunção.

Subsistema Conjunto de partes que se inter-relacionam formando um sistema maior.

Subsistema de revestimento externo

Vida útil Apesar da NBR 13529/2013 usar o termo "sistema", neste manual será adotado o termo "subsistema" para designar o conjunto formado por revestimento de argamassa e acabamento decorativo (pastilhas) que compõem as fachadas sudoeste e noroeste do Edifício Copan [7].

Período no qual o edifício e seus subsistemas prestam as atividades para as quais foram projetados e construídos, com atendimento aos níveis de desempenho previstos em norma, considerando a periodicidade e a correta execução dos processos de manutenção especificados no Manual de Uso, Operação e Manutenção [1]. 


\section{MEMORIAL DESCRITIVO DO EDIFÍCIO COPAN}

O memorial descritivo tem por objetivo apresentar as características técnicas e arquitetônicas do Edifício Copan e do subsistema de revestimento externo das fachadas sudoeste (SO) e noroeste (NO).

O Edifício Copan está implantado em terreno na Avenida Ipiranga, com a face sudoeste voltada para Rua Araújo e a face noroeste para rua particular, conhecida como Vila Normanda, conta com 2 subsolos, galeria comercial no térreo (figura 1), por onde se dá o acesso ao edifício e sobreloja. É composto por 4 corpos justapostos (denominados 1, 2, 3 e 4), separados entre si por juntas de dilatação. Ao longo de seus 4 corpos estão distribuídos 6 blocos (denominados A, B, C, D, E e F), nos quais estão distribuídos os 1.160 apartamentos residenciais ao longo de seus 32 andares (figura 2).

Suas fachadas são revestidas com pastilhas nas cores branca e cinza medindo $2 \times 2 \mathrm{~cm}$. A fachada principal é composta por 4 brises por andar (figura 3) e caixilhos metálicos do piso ao teto, excetuando o $15^{\circ}$ e $\circ 23^{\circ}$ andar, que tem apenas 2 brises alinhados com as lajes. Os brises são revestidos na face superior com pastilhas brancas, na parte inferior com pintura na mesma cor. Os pilares que marcam as linhas verticais são revestidos com pastilhas cinza. A fachada posterior é composta de caixilhos metálicos, cobogó (elemento vazado) e revestimento em pastilhas brancas e cinza (figura 4). E as fachadas sudoeste (figura 5) e noroeste (figura 6) são compostas por caixilhos metálicos e revestidas com pastilhas de porcelana na cor branca. 

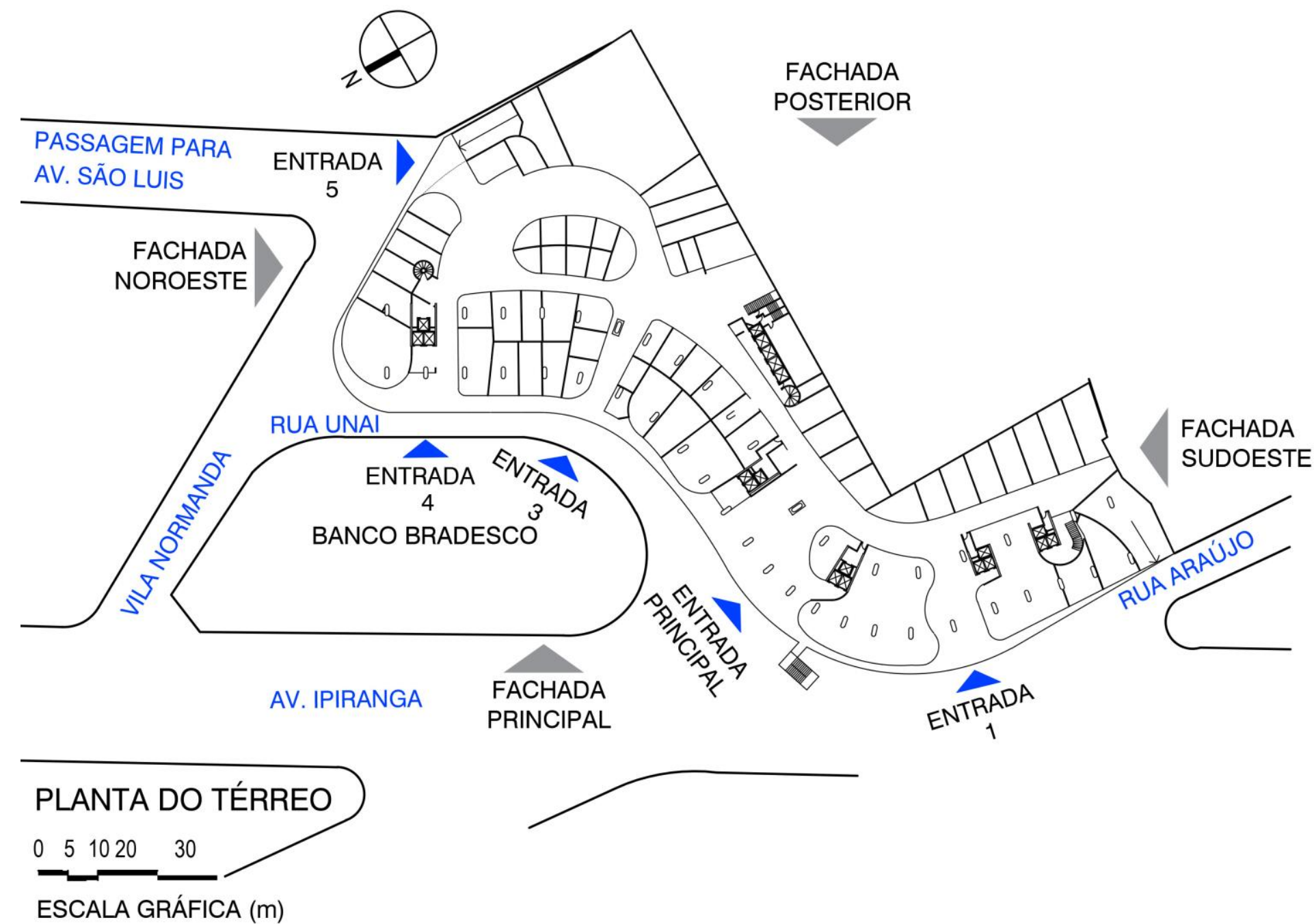

Figura 1 - Planta do Térreo

Fonte: Acervo do Condomínio, adaptado pela autora. 


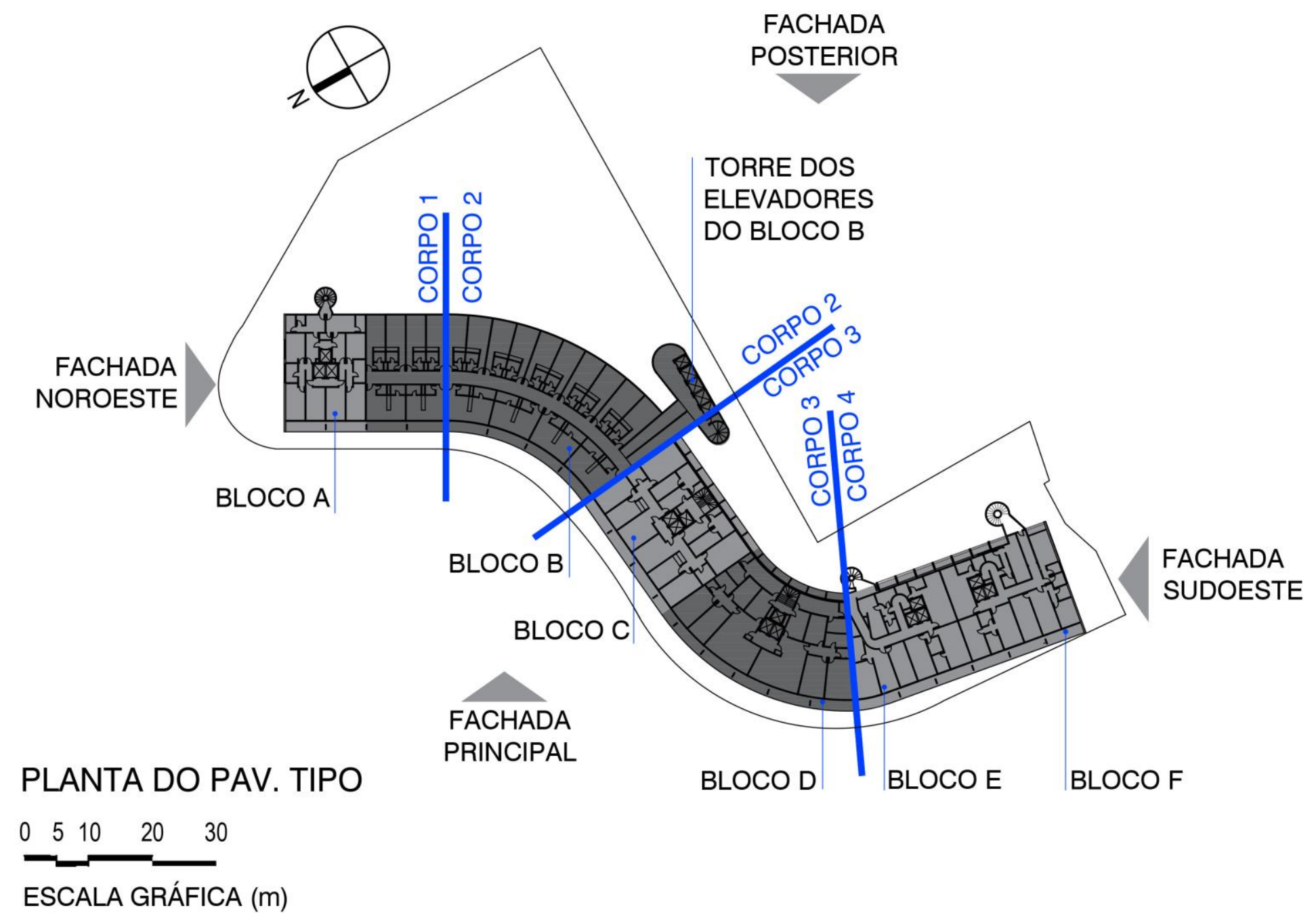

Figura 2 - Planta do Pavimento Tipo

Fonte: Acervo do Condomínio), adaptado pela autora. 


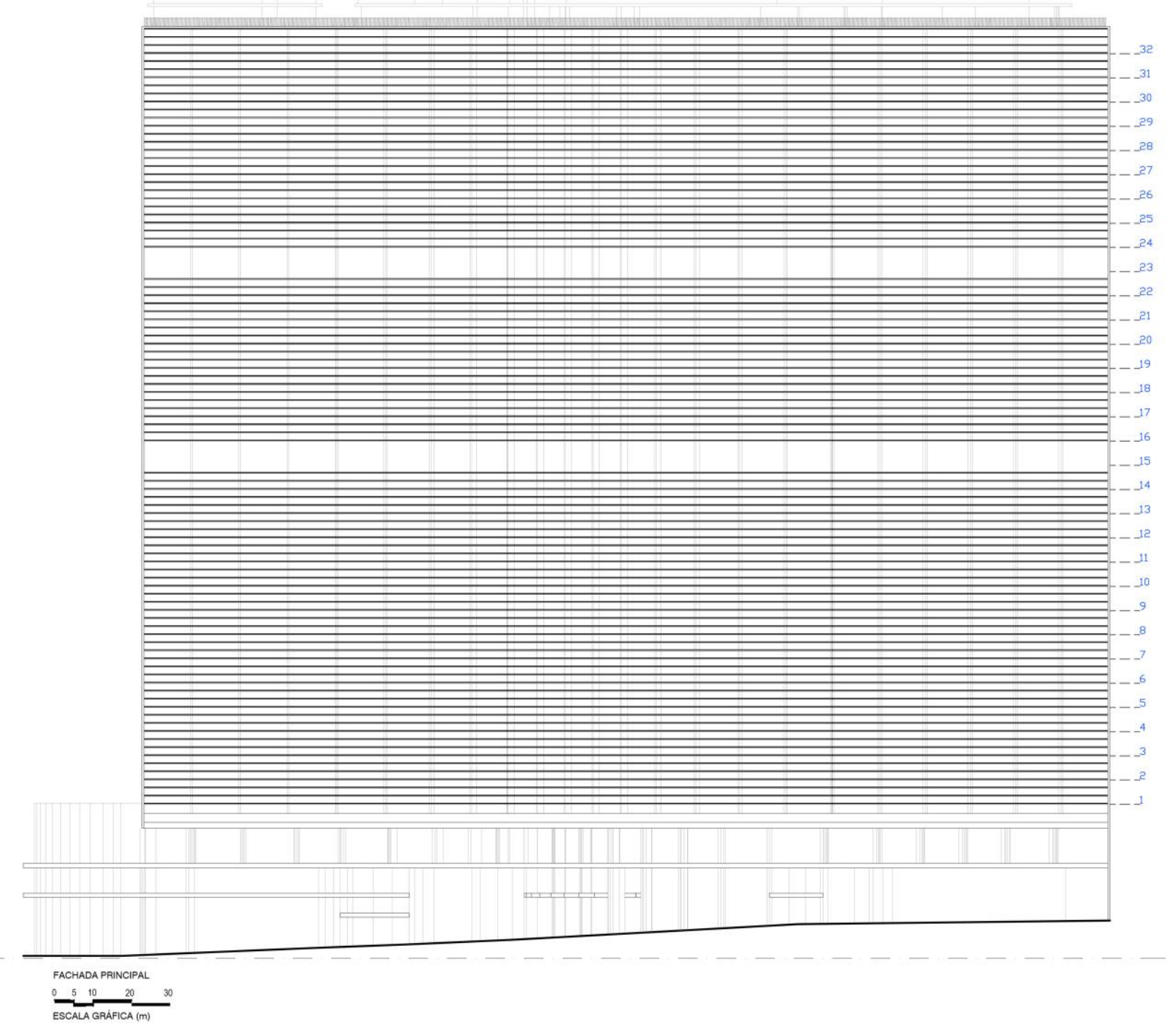

Figura 3 - Elevação da Fachada Principal

Fonte: Elaboração da autora. 


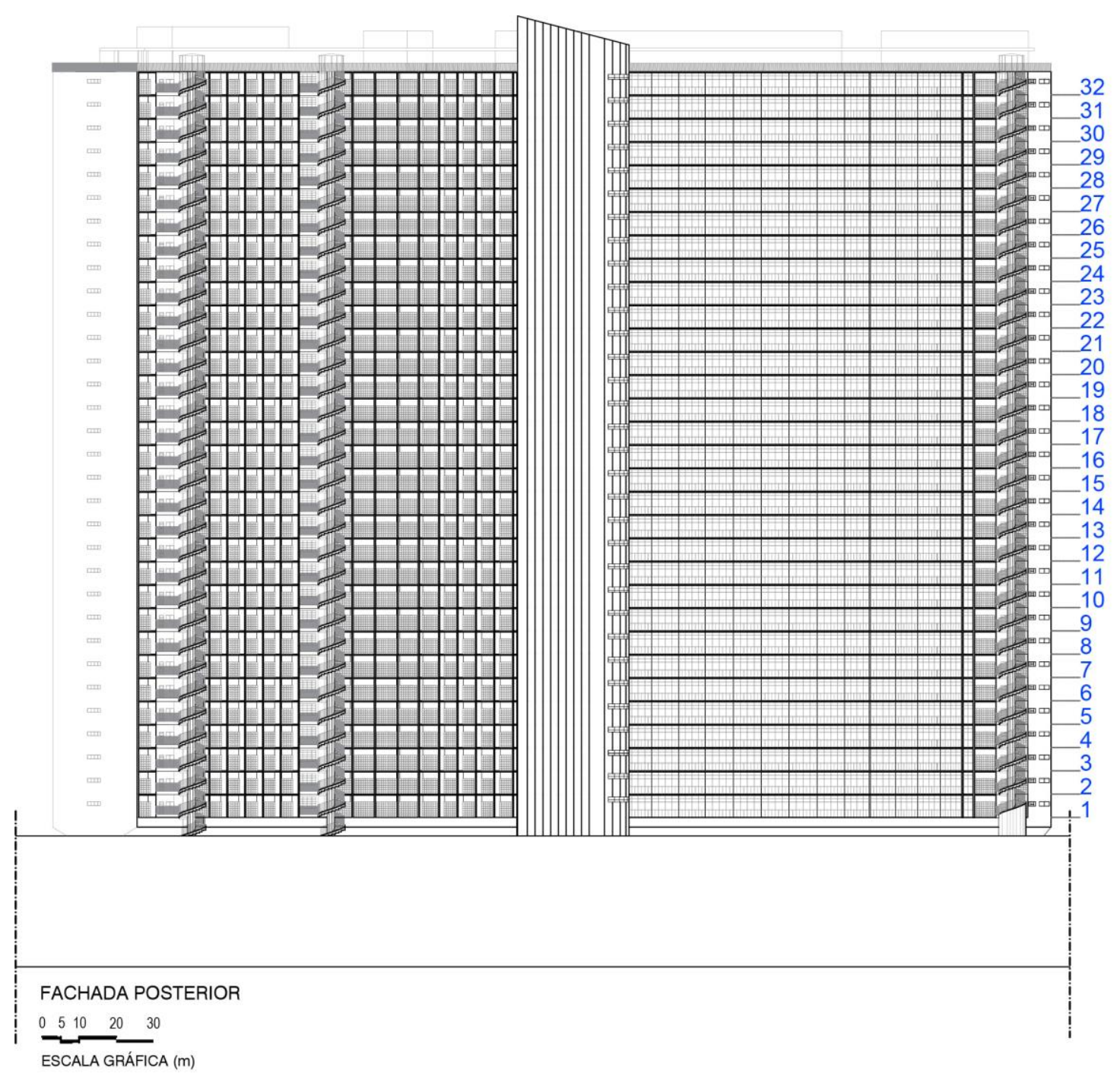

Figura 4 - Elevação da Fachada Posterior Fonte: Elaboração da autora. 


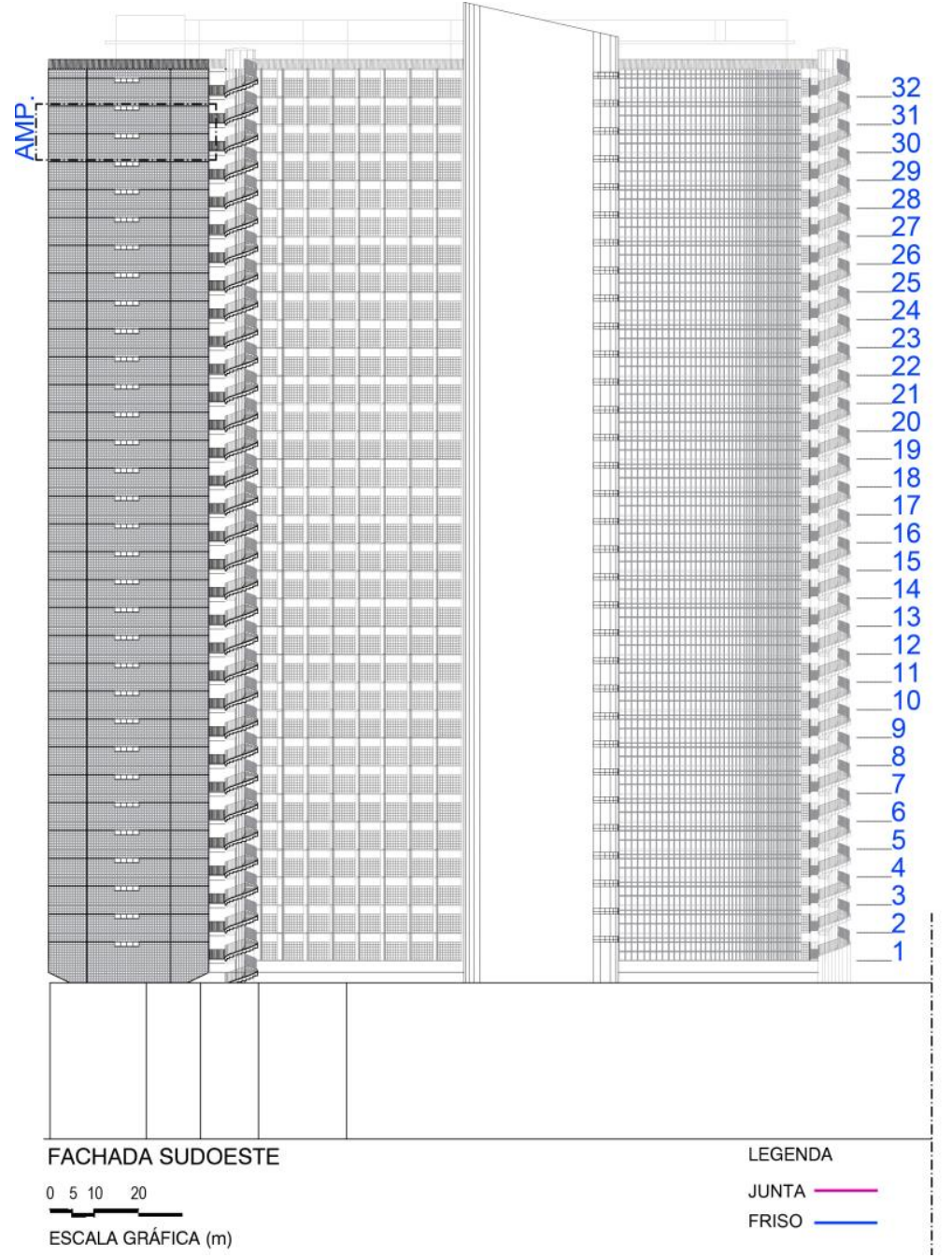

Figura 5 - Fachada Sudoeste

Fonte: Elaboração da autora.

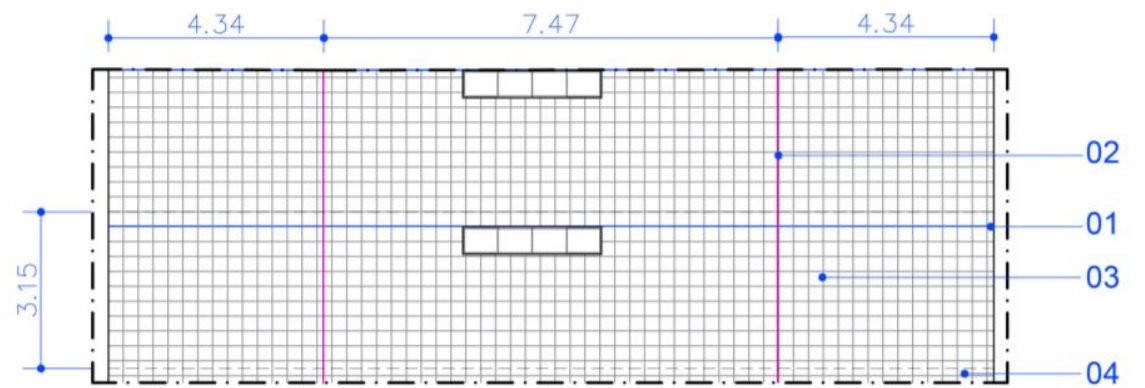

AMPLIAÇÃO

S/ ESCALA

01. Friso/ 02. Junta/ 03. Acabamento decorativo/ 04. Viga

Figura 6 - Elevação e Ampliação Fachada Sudoeste

Fonte: Elaboração da autora. 


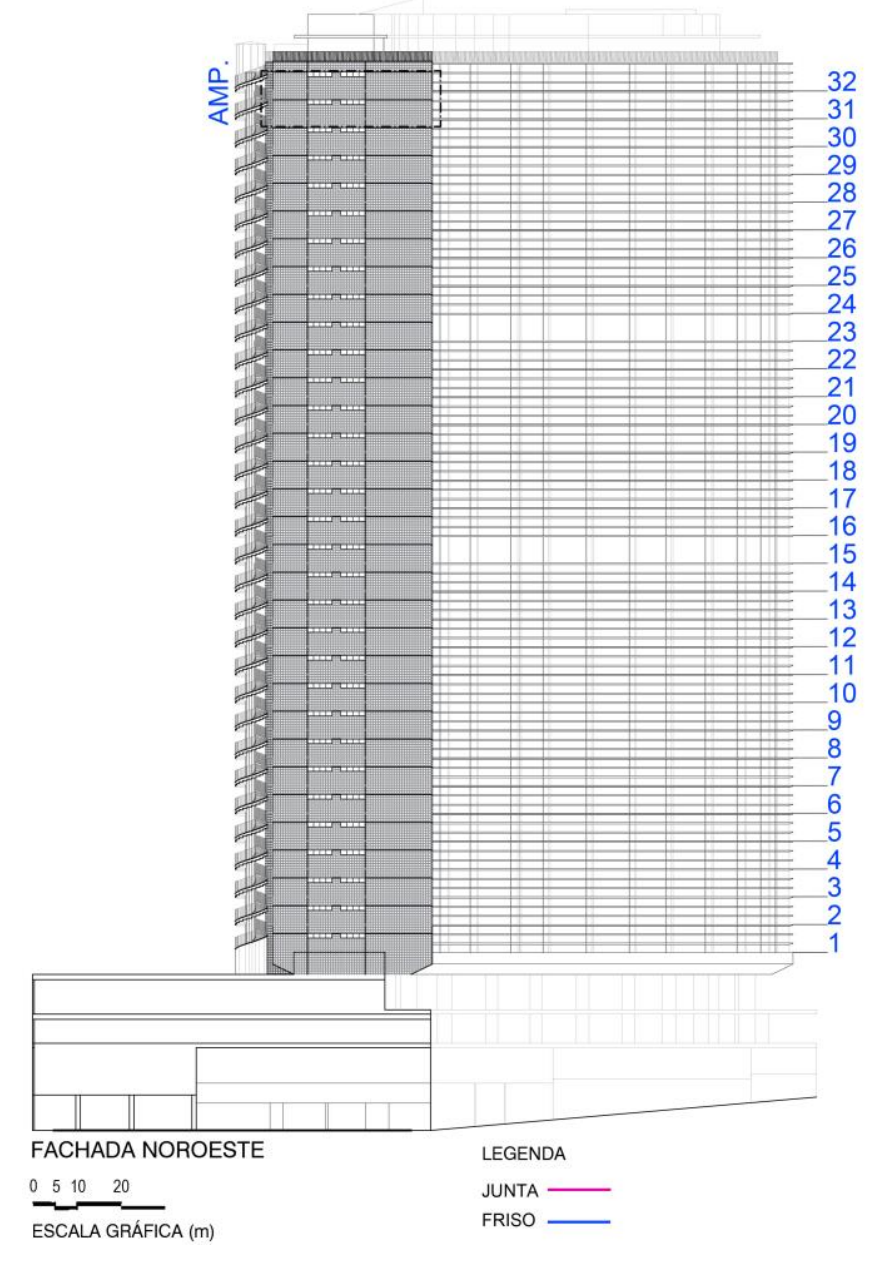

Figura 7 - Elevação da Fachada Noroeste

Fonte: Elaboração da autora

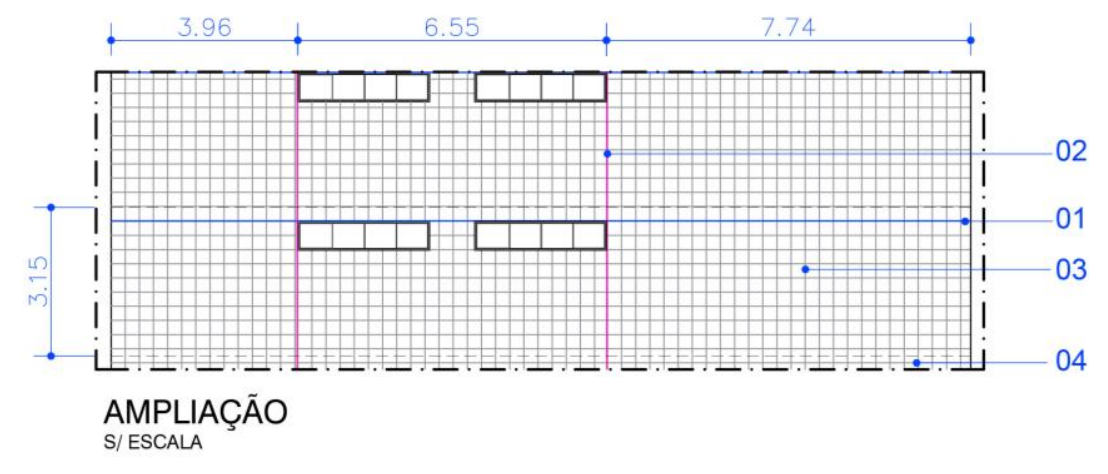

01. Friso/ 02. Junta/03. Revestimento cerâmico/ 04. Viga

Figura 8 - Ampliação Fachada Noroeste

Fonte: Elaboração da autora 


\subsection{DADOS DO EDIFÍCIO}

\begin{tabular}{|c|c|}
\hline Nome & Edifício Copan \\
\hline Localização & Av. Ipiranga, $n^{\circ} 200$, Centro - São Paulo/ SP \\
\hline Projeto de arquitetura & Arq. Oscar Niemeyer e Arq. Carlos Lemos \\
\hline Início da Construção & 1952 \\
\hline Término da construção & 1971 \\
\hline Construtoras & $\mathrm{CNI} / \mathrm{BRADESCO}$ \\
\hline Terreno & $10.572,80 \mathrm{~m}^{2}$ \\
\hline $2^{\circ}$ Subsolo & $6.072,90 \mathrm{~m}^{2}$ \\
\hline $1^{\circ}$ Subsolo & $4.581,00 \mathrm{~m}^{2}$ \\
\hline Térreo & $5.771,90 \mathrm{~m}^{2}$ \\
\hline Sobreloja & $1.709,76 \mathrm{~m}^{2}$ \\
\hline Foyer & $2.832,00 \mathrm{~m}^{2}$ \\
\hline Terraço & $5.771,90 \mathrm{~m}^{2}$ \\
\hline $\begin{array}{l}\text { Blocos residenciais com } \\
32 \text { pavimentos }\end{array}$ & $86.560,00 \mathrm{~m}^{2}$ \\
\hline Cobertura do Terraço & $436,00 \mathrm{~m}^{2}$ \\
\hline Área construída & $115.040,46 \mathrm{~m}^{2}$ \\
\hline Altura & $117 m$ do acesso da Rua Vila Normanda até a cobertura \\
\hline Fachada frontal & 92 brises com $21.344 \mathrm{~m}^{2}$ de revestimento de pastilha \\
\hline Fachada sudoeste & $1.895,90 \mathrm{~m}^{2}$ \\
\hline Fachada noroeste & $1.895,90 \mathrm{~m}^{2}$ \\
\hline Fachada posterior & $\begin{array}{l}\text { Com cobogó, caixilhos metálicos e revestimento de } \\
\text { pastilha nas cores branca e cinza }\end{array}$ \\
\hline Tombamento & Resolução $n^{\circ} 19$ de 18/12/2012 do CONPRESP \\
\hline $\begin{array}{l}\text { Classe de agressividade } \\
\text { ambiental }\end{array}$ & Moderada, de acordo com a NBR 12655/2015 \\
\hline
\end{tabular}




\section{CARACTERIZAÇÃO DO SUSBISTEMA DE REVESTIMENTO EXTERNO}

\subsection{REVESTIMENTO DE ARGAMASSA E ACABAMENTO DECORATIVO}

O Edifício Copan foi construído com estrutura de concreto armado e lajes nervuradas. As vedações externas das fachadas sudoeste e noroeste são de tijolos maciços cerâmicos e seu subsistema original de revestimento externo é composto de duas camadas: uma de emboço com cimento, cal e areia, conforme aponta o ensaio de reconstituição de traço de argamassa [8], e uma camada de reboco constituída, também, de cimento, cal e areia, de acordo com o ensaio de reconstituição de traço de argamassa de reboco [9], sobre a qual foram assentadas as pastilhas originais de porcelana, com argamassa de cimento branco, cal e areia.

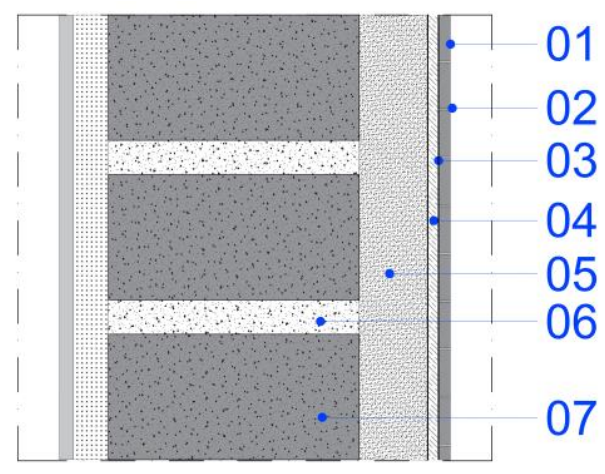

01. Revestimento decorativo/ 02. Rejunte) / 03. Argamassa de assentamento do revestimento decorativo (original)/ 04. Argamassa de reboco (original)/ 05. Argamassa de emboço (original)/ 06. Argamassa de assentamento dos tijolos/ 07. Tijolos maciços cerâmicos.

Figura 9 - Detalhe Esquemático do Subsistema de Revestimento Original Fonte: Elaboração da autora.

Do revestimento original de duas camadas foi removido o reboco e o emboço, que não apresentavam boas condições de aderência e as partes com aderência satisfatória foram mantidas. Nos locais onde as duas camadas 
não estavam aderidas, apresentando "som cavo", ambas foram retiradas, ficando apenas a base de alvenaria e/ou estrutura de concreto armado.

O revestimento de argamassa original que apresentava boas condições de aderência recebeu tratamento superficial com produto aglomerante para a fixação das partículas soltas.

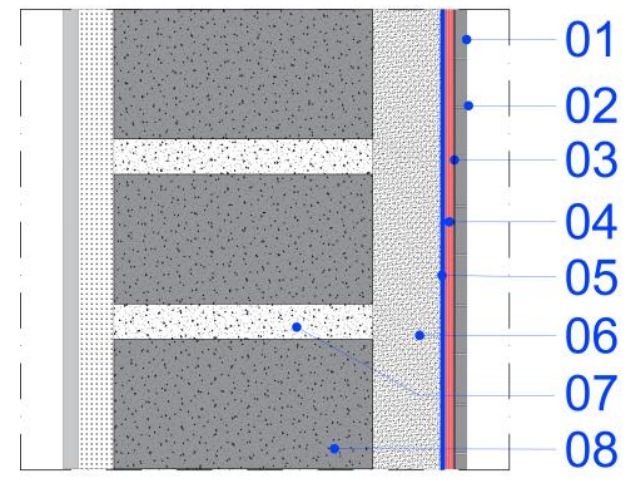

01. Revestimento decorativo (novo)/ 02. Rejunte (novo)/ 03. Argamassa de assentamento do revestimento decorativo (novo)/ 04. Argamassa industrializada (nova)/ 05. Camada de produto aglomerante aplicada no emboço original/ 06. Argamassa de emboço (original)/ 07. Argamassa de assentamento dos tijolos / 08. Tijolos maciços cerâmicos.

Figura 10 - Detalhe Esquemático do Emboço Original com Tratamento Superficial Fonte: Elaboração da autora.

Nos locais onde o revestimento original de duas camadas (emboço e reboco) precisou ser removido, foi realizado um novo revestimento de camada única com argamassa industrializada.

A nova camada única de revestimento é constituída de argamassa adesiva para chapisco industrializado e argamassa industrializada aditivada com $15 \%$ de resina acrílica, sendo a primeira utilizada para o preenchimento de lacunas de pequenas proporções no revestimento de argamassa original e sobre a estrutura de concreto, ao passo que a segunda foi utilizada na recomposição de áreas maiores sobre o emboço remanescente e sobre a alvenaria. 


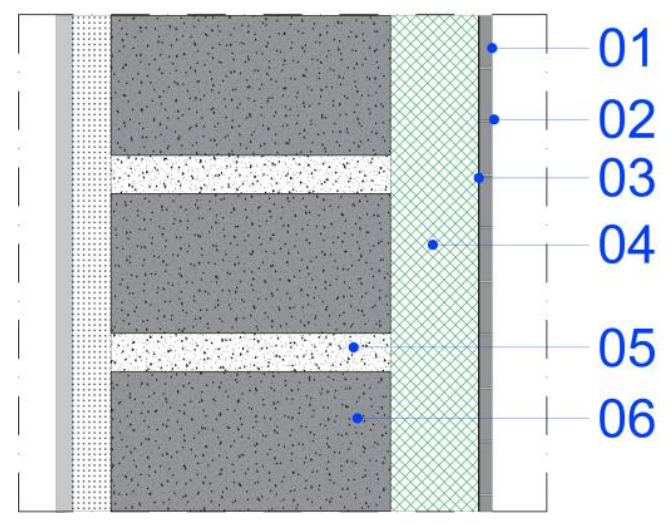

01. Revestimento decorativo (novo)/ 02. Rejunte (novo)/ 03. Argamassa de assentamento do revestimento decorativo (novo)/ 04. Camada única de argamassa industrializada (nova)/ 05. Argamassa de assentamento dos tijolos / 06. Tijolos maciços cerâmicos.

Figura 11 - Detalhe Esquemático da Camada Única de Argamassa Industrializada Fonte: Elaboração da autora.

Para o assentamento do acabamento decorativo (pastilhas nas medidas $2 \times 2 \mathrm{~cm}$ na cor branca) foi indicada a argamassa colante ACIII bicomponente 


\section{MATERIAIS E COMPONENTES}

O emboço remanescente do revestimento original de duas camadas é composto de cimento, cal e areia, conforme apontou o ensaio de reconstituição de traço de argamassa [8], ao qual foi aplicado fundo preparador (Suvinil Fundo Preparador) para aumento da resistência à aderência.

A nova camada única de revestimento é constituída de chapisco industrializado (Chapisco Colante Quartzolit) e argamassa industrializada (2202 Matrix Revestimento Fachada) aditivada com resina acrílica (Baucryl Ecoveda).

Para o assentamento das pastilhas foi utilizada argamassa colante (Bautech Rapcola 2 horas). O rejunte das pastilhas não foi especificado em projeto. 


\section{CUIDADOS DE USO E DURANTE A MANUTENÇÃO}

Ao realizar a fixação de redes de proteção, manutenção e/ou substituição de caixilhos ou qualquer furo no acabamento decorativo (pastilhas), este deverá ser selado, a fim de evitar infiltrações que possam levar à degradação do subsistema de revestimento externo.

Durante a limpeza não utilizar produtos abrasivos, escovas de cerdas duras, esponja ou palha de aço, ferramentas pontiagudas, ácidos ou produtos corrosivos, pois podem danificar os materiais e componentes das fachadas.

\section{NORMAS TÉCNICAS}

ABNT/NBR 7200:1998 - Execução de revestimento de paredes e tetos de argamassas inorgânicas - Procedimento

ABNT/NBR 13529:2013 - Revestimento de paredes e tetos de argamassas inorgânicas - Terminologia

ABNT/NBR 13749:2013 - Revestimentos de paredes e tetos de argamassas inorgânicas - Especificações

ABNT/NBR 13755:2017 - Revestimentos cerâmicos de fachadas e paredes externas com utilização de argamassa colante - Projeto, execução, inspeção e aceitação - Procedimento

ABNT/NBR 13816:1997 - Placas cerâmicas para revestimento - Terminologia

ABNT/NBR 13817:1997- Placas cerâmicas para revestimento - Classificação

ABNT/NBR 13818:1997- Placas cerâmicas para revestimento - Especificação e método de ensaios

ABNT/NBR 15575:2013 - Edificações habitacionais - Desempenho Parte 4: Requisitos para os sistemas de vedações verticais internas e externas - SVVIE 


\subsection{FRISOS}

A delimitação dos panos de revestimento é feita por juntas e frisos. Os frisos estão dispostos horizontalmente no alinhamento inferior das vigas dos pavimentos (figura 10).

Os frisos são faixas contínuas com $1,5 \mathrm{~cm}$ de profundidade e $2 \mathrm{~cm}$ de altura, vedados com selante base acrílica ou poliuretano. Tem como função delimitar os panos de revestimento, aliviando as tensões provocadas pela movimentação do edifício e evitando fissuras e danos subsequentes ao subsistema de revestimento externo.

\section{MATERIAIS E COMPONENTES}

O friso é impermeabilizado com resina acrílica (Quimicryl Baucryl Ecolastic) e fechado com selante acrílico ou poliuretano.

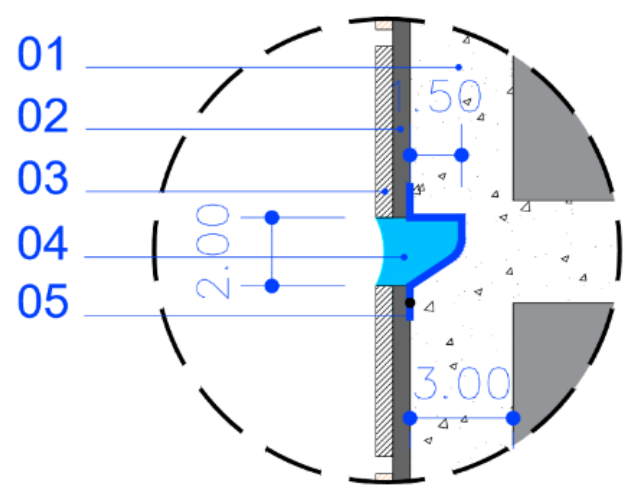

01. Argamassa de emboço/ 02. Argamassa de assentamento das pastilhas/ 03. Pastilhas/ 04. Selante/ 05. Resina acrílica

Figura 12 - Detalhe Esquemático do Friso sem escala (unidade de medida cm) Fonte: ARCO, 2015.

\section{CUIDADOS DURANTE A MANUTENÇÃO}

Durante a limpeza não utilizar produtos abrasivos, escovas de cerdas duras, esponja ou palha de aço duras, ferramentas pontiagudas, ácidos ou produtos corrosivos, que podem comprometer a integridade e $\mathrm{O}$ desempenho do friso. 


\section{NORMAS TÉCNICAS}

ABNT/NBR 13755:2013 - Revestimentos cerâmicos de fachadas e paredes externas com utilização de argamassa colante - Projeto, execução, inspeção e aceitação - Procedimento

ABNT/NBR 15575:2013 - Edificações habitacionais - Desempenho Parte 1: Requisitos gerais 


\subsection{JUNTA DE MOVIMENTAÇÃO}

As juntas de movimentação horizontais são dispostas na base das vigas da cobertura e verticalmente na empena do edifício.

Na fachada noroeste as juntas verticais estão na interface empena de concreto/alvenaria faceando as extremidades externas dos caixilhos em ambos os lados, conforme figura 11.

Já na fachada sudoeste as juntas verticais estão dispostas em panos regulares nas extremidades, faceando os caixilhos por um único lado.

As juntas têm de profundidade toda a espessura do emboço, chegando até a estrutura, e 2cm de altura.

Com o objetivo de garantir a estanqueidade, na eventualidade de falha do selante, há um reforço que consiste em aplicação de uma membrana acrílica, composta de resina acrílica e cimento na proporção de 1:1 em toda a profundidade do sulco, avançando em uma faixa de $10 \mathrm{~cm}$ para cima e para baixo em toda a sua extensão.

Sobre a membrana acrílica há o limitador de profundidade, que tem a função de garantir a espessura do selante acrílico ou poliuretano.

\section{MATERIAIS E COMPONENTES}

As juntas são impermeabilizadas com membrana acrílica composta de uma mistura na proporção 1:1 resina acrílica (Quimicryl Baucryl Vedafriso) e cimento, membrana de poliéster, limitador de profundidade com $\varnothing 2,5 \mathrm{~cm}$ e selante acrílico ou poliuretano. 


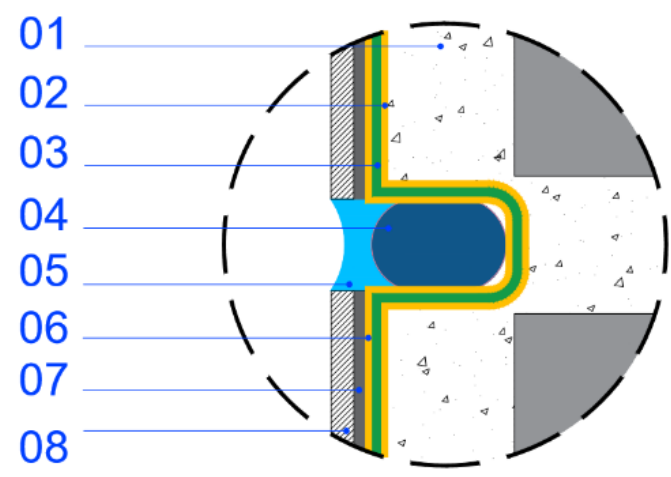

01. Argamassa de emboço/ 02. Membrana acrílica/ 03. Véu de poliéster/ 04. Limitador de profundidade/ 05. Selante/ 06. Membrana acrílica/07. Argamassa de assentamento de pastilhas/08. Pastilha

Figura 13 - Detalhe Esquemático da Junta Fonte: ARCO, 2015.

\section{CUIDADOS DURANTE A MANUTENÇÃO}

Durante a limpeza não utilizar produtos abrasivos, escovas de cerdas duras, esponja ou palha de aço, ferramentas pontiagudas, ácidos ou produtos corrosivos, que podem comprometer a integridade e o desempenho da junta.

\section{NORMAS TÉCNICAS}

ABNT/NBR 13755:2013 - Revestimentos cerâmicos de fachadas e paredes externas com utilização de argamassa colante - Projeto, execução, inspeção e aceitação - Procedimento

ABNT/NBR 15575:2013 - Edificações habitacionais - Desempenho Parte 1: Requisitos gerais 


\subsection{MATERIAIS E COMPONENTES UTILIZADOS NA OBRA DE}

\section{RECUPERAÇÃO DO SUBSISTEMA DE REVESTIMENTO EXTERNO}

O projeto executivo do revestimento de fachada [10] especificou os materiais utilizados na recuperação das fachadas sudoeste e noroeste.

\subsubsection{FUNDO PREPARADOR DE PAREDES}

\begin{tabular}{|l|l|}
\hline Nome do produto & Suvinil Fundo Preparador \\
\hline Fabricante & BASF S.A. \\
\hline Função & $\begin{array}{l}\text { Aglutinar partículas soltas e melhorar a resistência } \\
\text { de aderência da argamassa colante e pastilhas }\end{array}$ \\
\hline Composição & $\begin{array}{l}\text { Resina à base de dispersão aquosa de copolímero } \\
\text { e aditivos especiais }\end{array}$ \\
\hline
\end{tabular}

\subsubsection{ARGAMASSA ADESIVA PARA CHAPISCO}

\begin{tabular}{|l|l|}
\hline Nome do produto & $\begin{array}{l}\text { Chapisco Colante Quartzolit } \\
\text { Fabricante }\end{array}$ \\
\hline Produtos Industriais e para Construção Ltda. \\
\hline Função & $\begin{array}{l}\text { Criar ponte de aderência para o revestimento de } \\
\text { argamassa }\end{array}$ \\
\hline Composição & $\begin{array}{l}\text { Cimento, polímeros e agregados minerais e } \\
\text { aditivos especiais }\end{array}$ \\
\hline
\end{tabular}




\subsubsection{ARGAMASSA INDUSTRIALIZADA}

\begin{tabular}{|l|l|}
\hline Nome do produto & 2202 Matrix Revestimento Fachada \\
\hline Fabricante & $\begin{array}{l}\text { Votorantim Cimentos } \\
\text { Função }\end{array}$ \\
\hline Compostimento de paredes em áreas externas \\
\hline minerais e aditivos químicos
\end{tabular}

\subsubsection{RESINA ACRÍLICA}

\begin{tabular}{|l|l|}
\hline Nome do produto & Ecoveda \\
\hline Fabricante & Baucryl \\
\hline Função & $\begin{array}{l}\text { Impermeabilizante para áreas sujeitas a } \\
\text { movimentações moderadas e com proteção } \\
\text { mecânica }\end{array}$ \\
\hline Composição & $\begin{array}{l}\text { Elastômeros, polímeros e aditivos especiais e } \\
\text { antifúngicos }\end{array}$ \\
\hline
\end{tabular}




\subsubsection{POLÍMERO ACRÍLICO COM FIBRAS PARA IMPERMEABILIZAÇÃO DE JUNTAS}

\begin{tabular}{|l|l|}
\hline Nome do produto & Baucryl Ecolastic \\
\hline Fabricante & Quimicryl S.A. \\
\hline Função & $\begin{array}{l}\text { Impermeabilizar juntas e frisos do revestimento } \\
\text { cerâmico nas fachadas. }\end{array}$ \\
\hline Composição & Emulsão acrílica com fibras \\
\hline
\end{tabular}

\subsubsection{ARGAMASSA COLANTE}

\begin{tabular}{|l|l|}
\hline Nome do produto & Bautech Rapcola 2 horas \\
\hline Fabricante & Bautech do Brasil \\
\hline Função & Assentamento de pastilhas nas fachadas \\
\hline Composição & $\begin{array}{l}\text { Argamassa bicomponente com alto teor de } \\
\text { polímeros }\end{array}$ \\
\hline
\end{tabular}

\subsubsection{ACABAMENTO DECORATIVO (PASTILHA)}

\begin{tabular}{|l|l|}
\hline Nome do produło & Não especificado em projeto \\
\hline Fabricante & Não especificado em projeto \\
\hline Função & Revestir as fachadas \\
\hline Composição & Não especificado em projeto \\
\hline
\end{tabular}




\subsubsection{LIMITADOR DE PROFUNDIDADE}

\begin{tabular}{|l|l|}
\hline Nome do produto & Não especificado em projeto \\
\hline Fabricante & Não especificado em projeto \\
\hline Função & $\begin{array}{l}\text { Limitar a profundidade da junta para a aplicação } \\
\text { do selante }\end{array}$ \\
\hline Composição & Polietileno expandido \\
\hline Dimensões & $\varnothing 2,5 \mathrm{~cm}$ \\
\hline
\end{tabular}

\subsubsection{SELANTE}

\begin{tabular}{|l|l|}
\hline Nome do produto & Não especificado em projeto \\
\hline Fabricante & Não especificado em projeto \\
\hline Função & $\begin{array}{l}\text { Preencher as juntas e impedir a passagem de } \\
\text { líquidos ou sólidos }\end{array}$ \\
\hline Composição & Silicone ou poliuretano \\
\hline
\end{tabular}

\section{ATENÇÃO:}

Observar na ficha técnica do selante a vida útil do material que será utilizado, pois influenciará na periodicidade de sua substituição nas juntas e nos frisos. 


\section{PROGRAMA DE MANUTENÇÃO PREVENTIVA}

As ações de manutenção preventiva visam manter o desempenho do sistema prolongando sua vida útil, retardando a degradação e a necessidade de grandes e onerosas ações de manutenção corretiva e/ou de restauro.

O programa de manutenção preventiva compreende uma rotina de procedimentos sistematizados e se iniciam pela inspeção, que deverá ser realizada de acordo com a periodicidade descrita no roteiro de ações de manutenção preventiva (item 4.5.).

\subsection{INSPEÇÃO}

A inspeção das condições físicas das fachadas deverá ser realizada por profissional habilitado, por se tratar de trabalho em altura. Este profissional deverá seguir o check-list da Ficha de Inspeção (FI) e realizar o preenchimento in loco de todos os campos.

No item 5 deste manual encontra-se a Ficha de Inspeção (FI) para a fachada sudoeste (FISO) e a ficha da fachada noroeste (FINO), ambas com suas respectivas elevações, para que seja possível marcação gráfica aproximada das manifestações patológicas verificadas.

\subsection{RELATÓRIO DE INSPEÇÃO}

De posse da Ficha de Inspeção (FI) devidamente preenchida, uma empresa especializada/profissional habilitado deverá fazer uma análise dos dados coletados na inspeção e apresentar um Relatório de Inspeção (RI) apontando os tipos de ações de manutenção necessária para cada item inspecionado, podendo ser: 


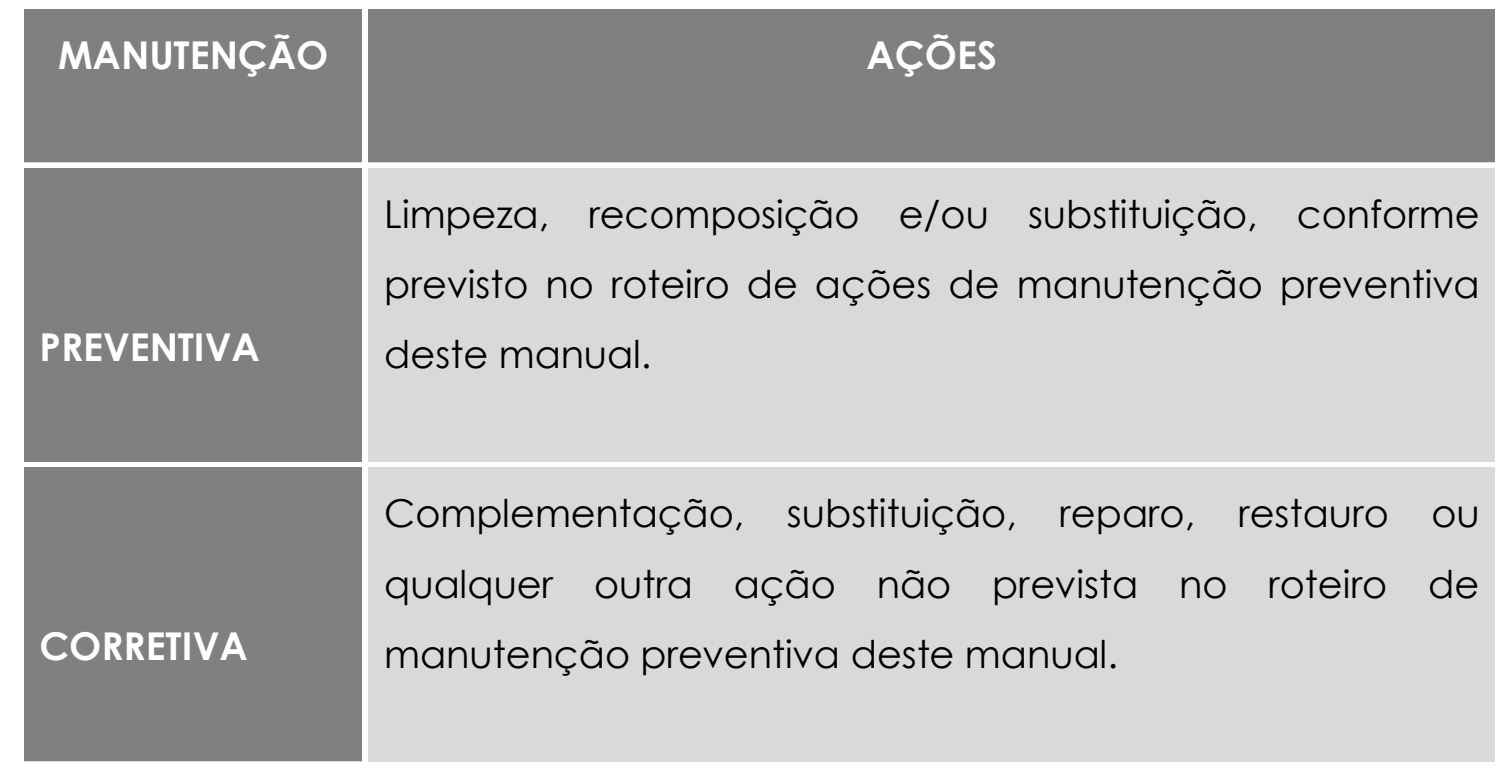

\subsection{AÇÕES DE MANUTENÇÃO}

A partir do relatório de inspeção deverão ser realizadas as ações de manutenção apontadas com base nos dados coletados in loco e de acordo com as orientações deste manual.

Após a execução de cada ação de manutenção as fichas de manutenção (FMSO) e (FMNO), também encontradas no item 5, deverão ser preenchidas, registrando as atividades, os locais e os responsáveis pelo serviço, formando um histórico das ocorrências nas fachadas.

\subsection{REGISTRO}

Ao término das ações de inspeção e manutenção, com as respectivas fichas preenchidas pelo profissional responsável pela atividade, o condomínio deverá preencher a Ficha de Registro (FR), que deverá ser armazenada no Fichário 2 - Registro de Manutenção, para possibilitar a rastreabilidade das ações realizadas. 


\subsection{ROTEIRO DE AÇÕES DE MANUTENÇÃO PREVENTIVA}

Por meio do roteiro de inspeções e ações de manutenção é possível fazer uma programação das atividades de caráter preventivo, que serão realizadas de acordo com a degradação natural de cada elemento e componente das fachadas sudoeste e noroeste.

Este roteiro contempla as ações de inspeção e manutenção preventiva para:

- o revestimento de argamassa e acabamento decorativo (sendo que para o revestimento de argamassa de duas camadas original - e camada única - novo - é contemplada apenas a verificação da aderência do acabamento decorativo, uma vez que esta camada se encontra revestida);

\section{- os rejuntes;}

- os selantes dos frisos e juntas.

A periodicidade das ações está embasada nas seguintes referências normativas:

- ABNT/NBR 15575:2013 - Edificações habitacionais - Desempenho Parte 4: Requisitos para os sistemas de vedações verticais internas e externas - SVVIE

- ABNT/NBR 5674:2012 - Manutenção de edificações - Requisitos para o sistema de gestão da manutenção 


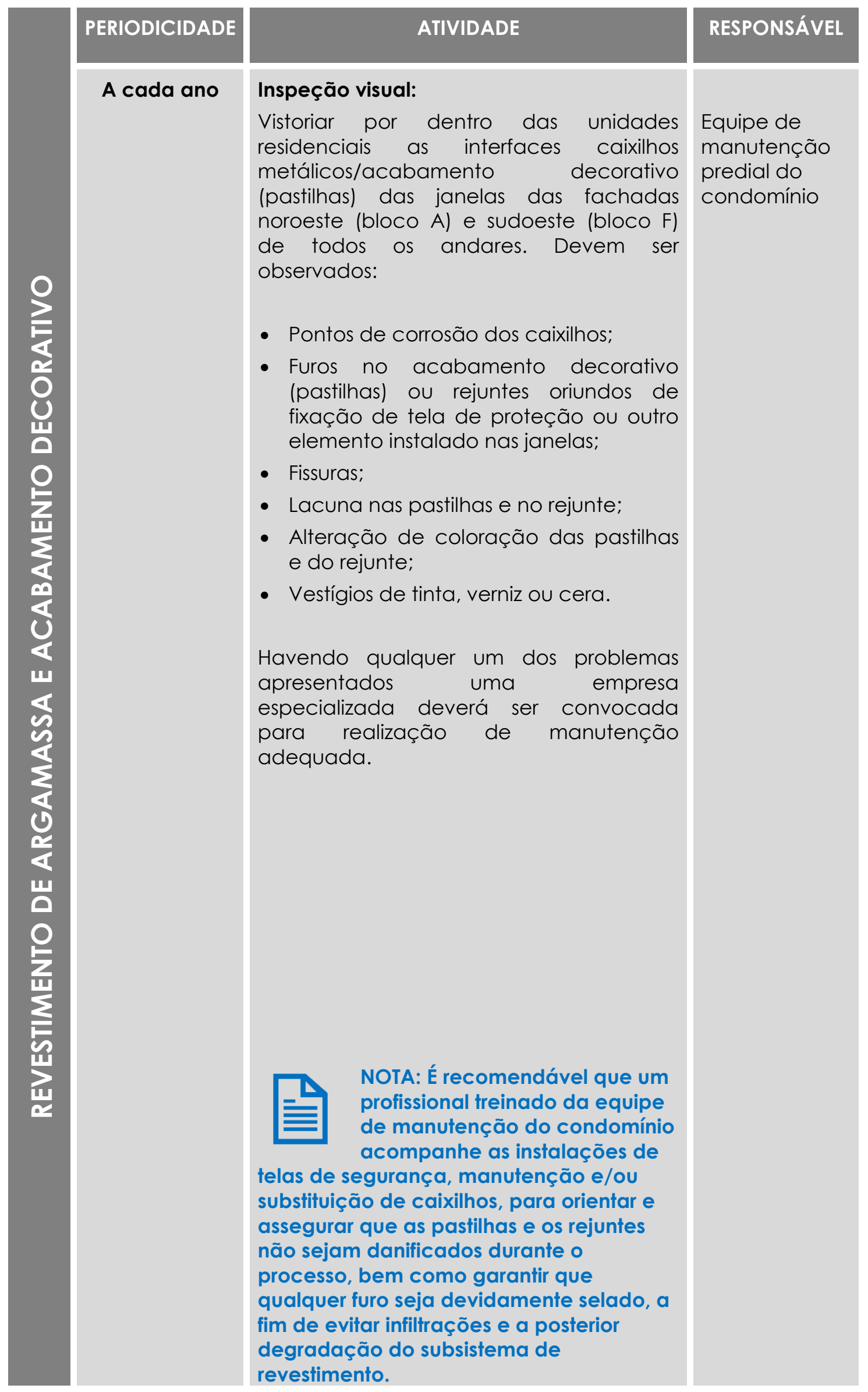




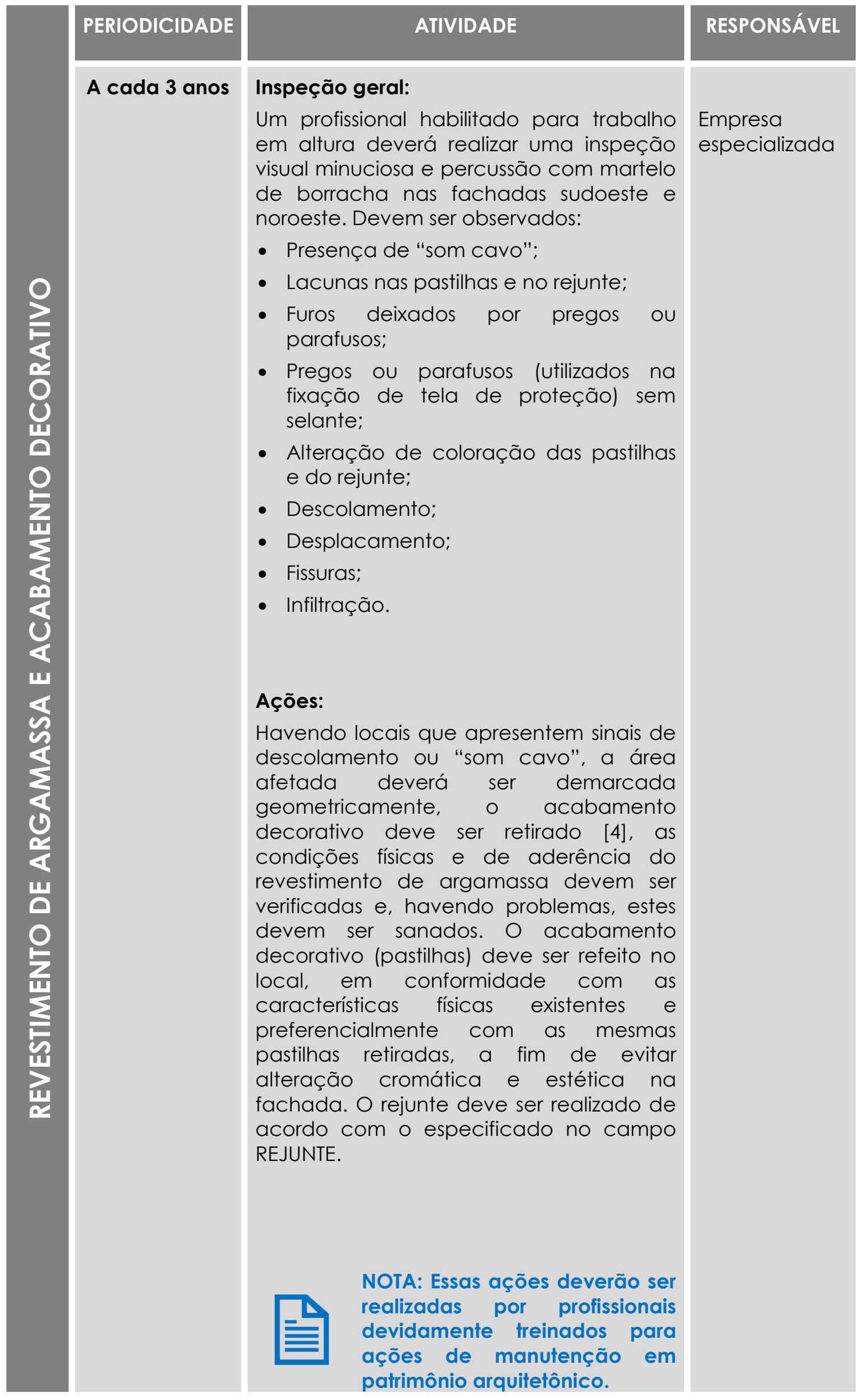




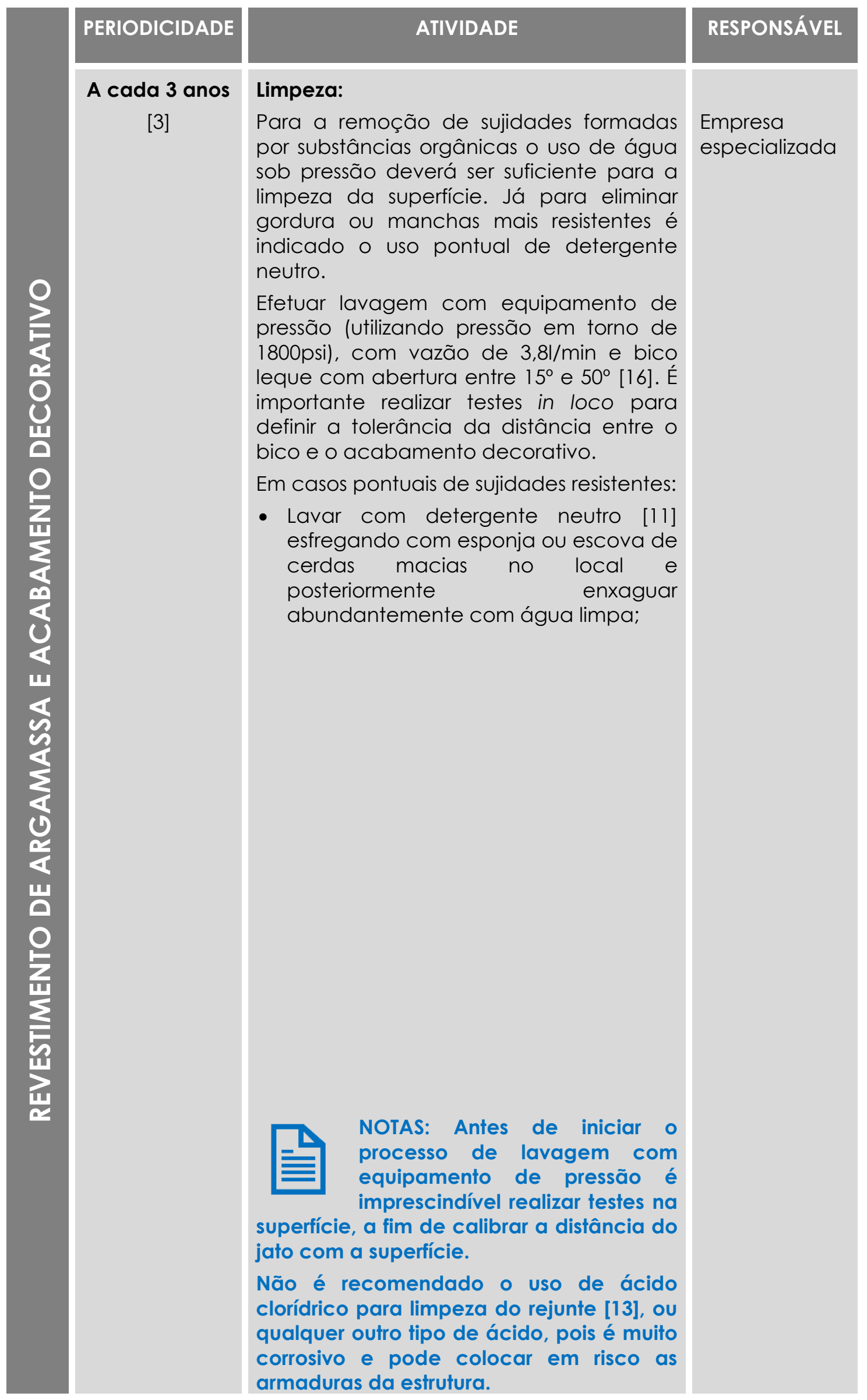




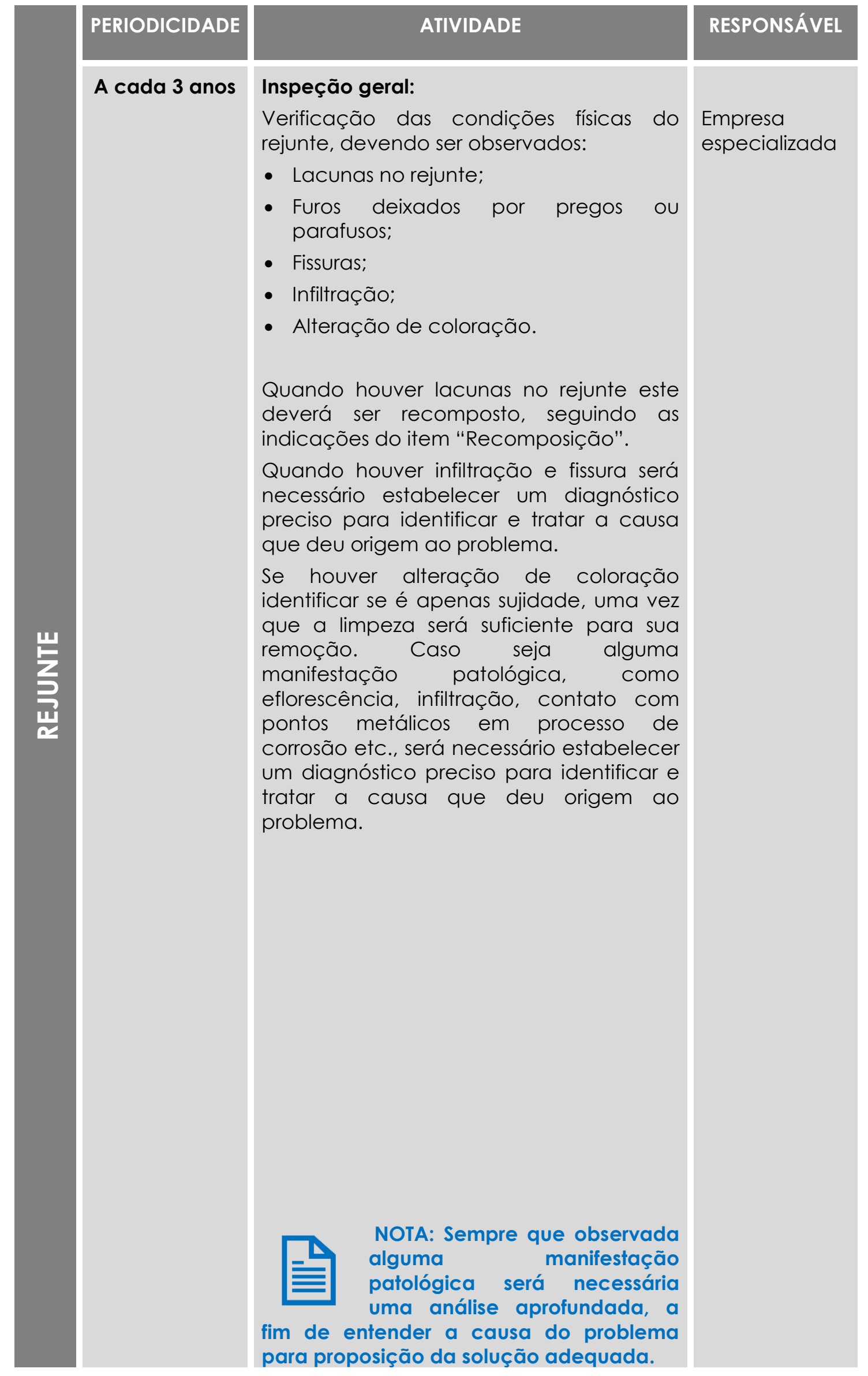




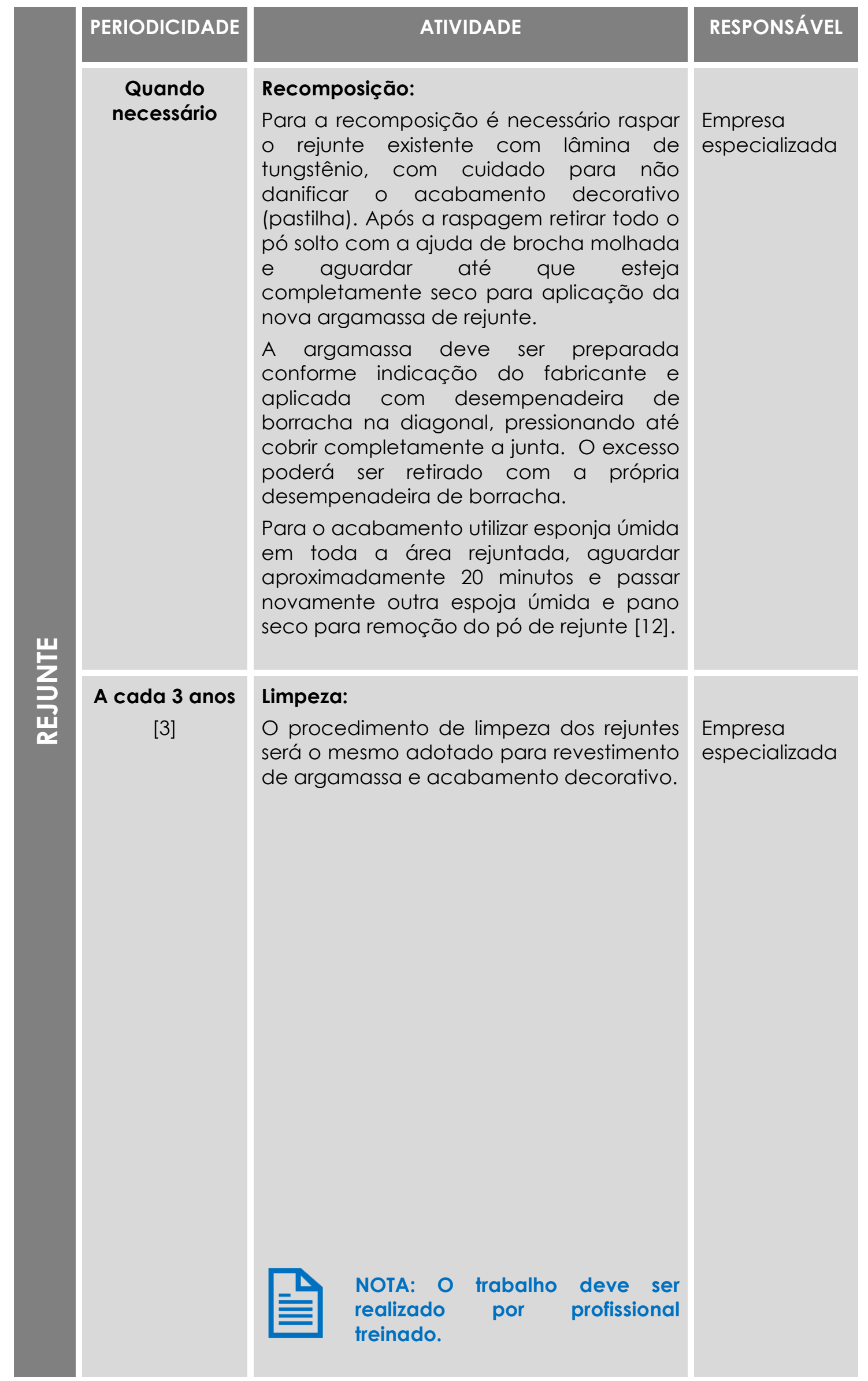




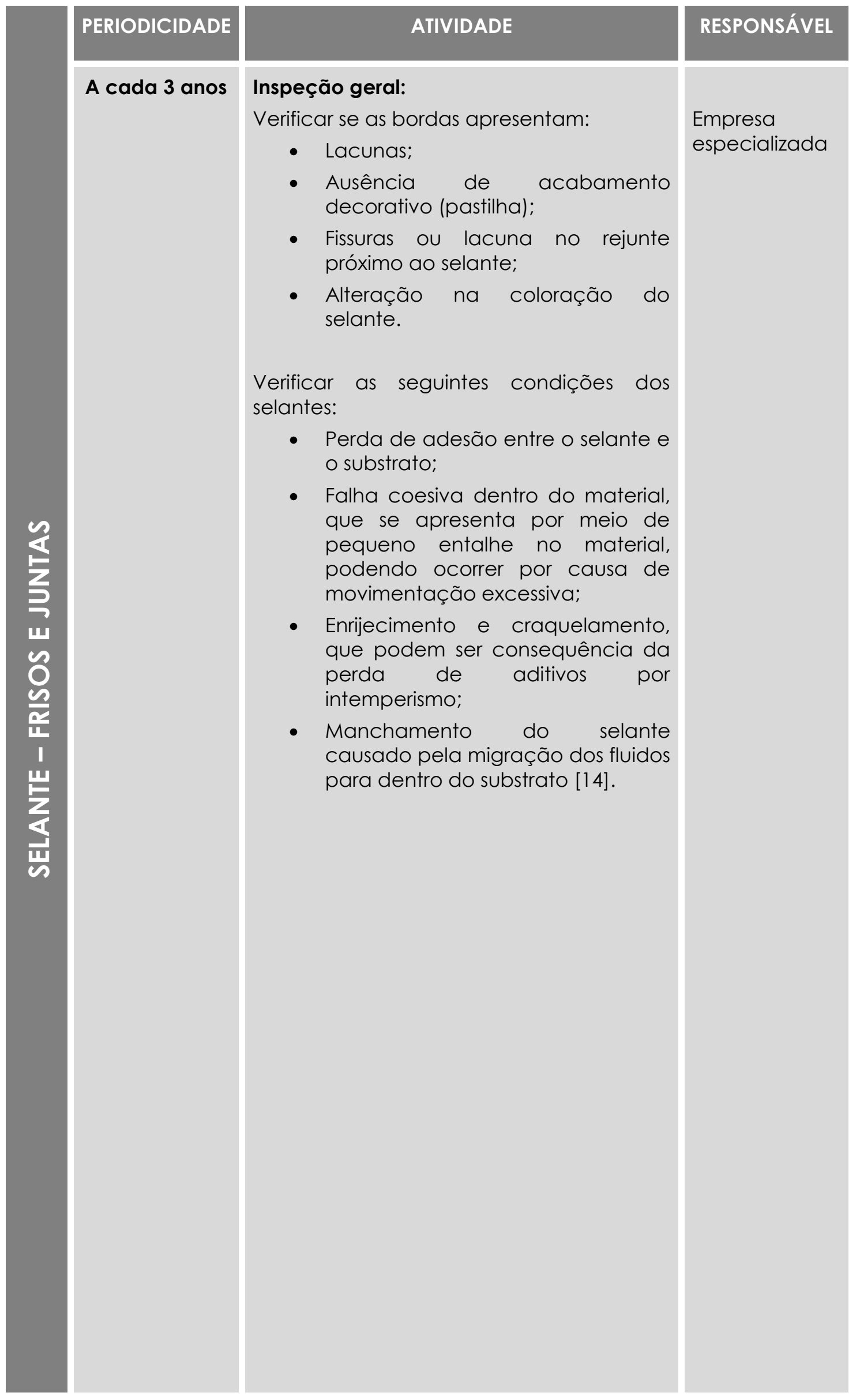




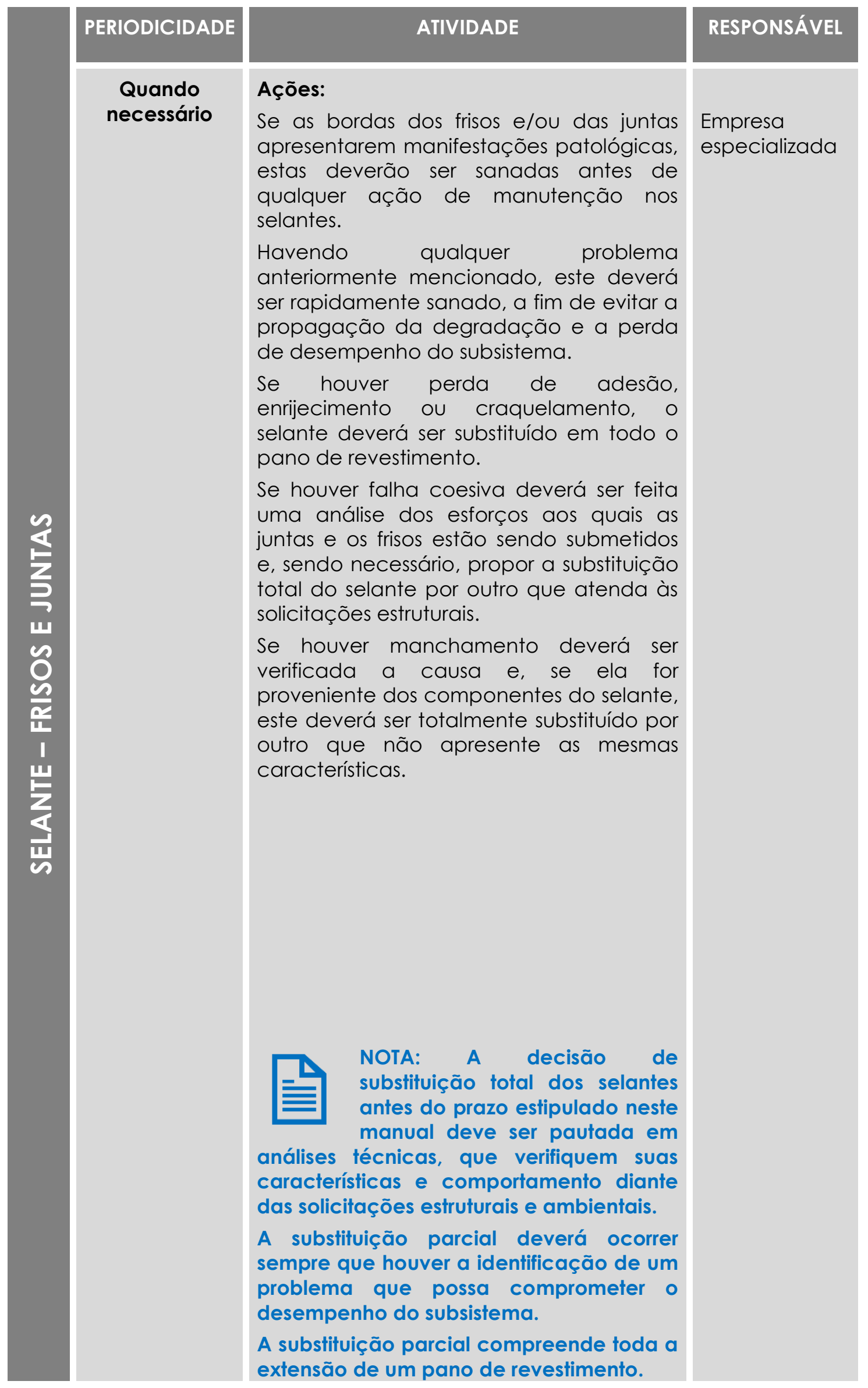




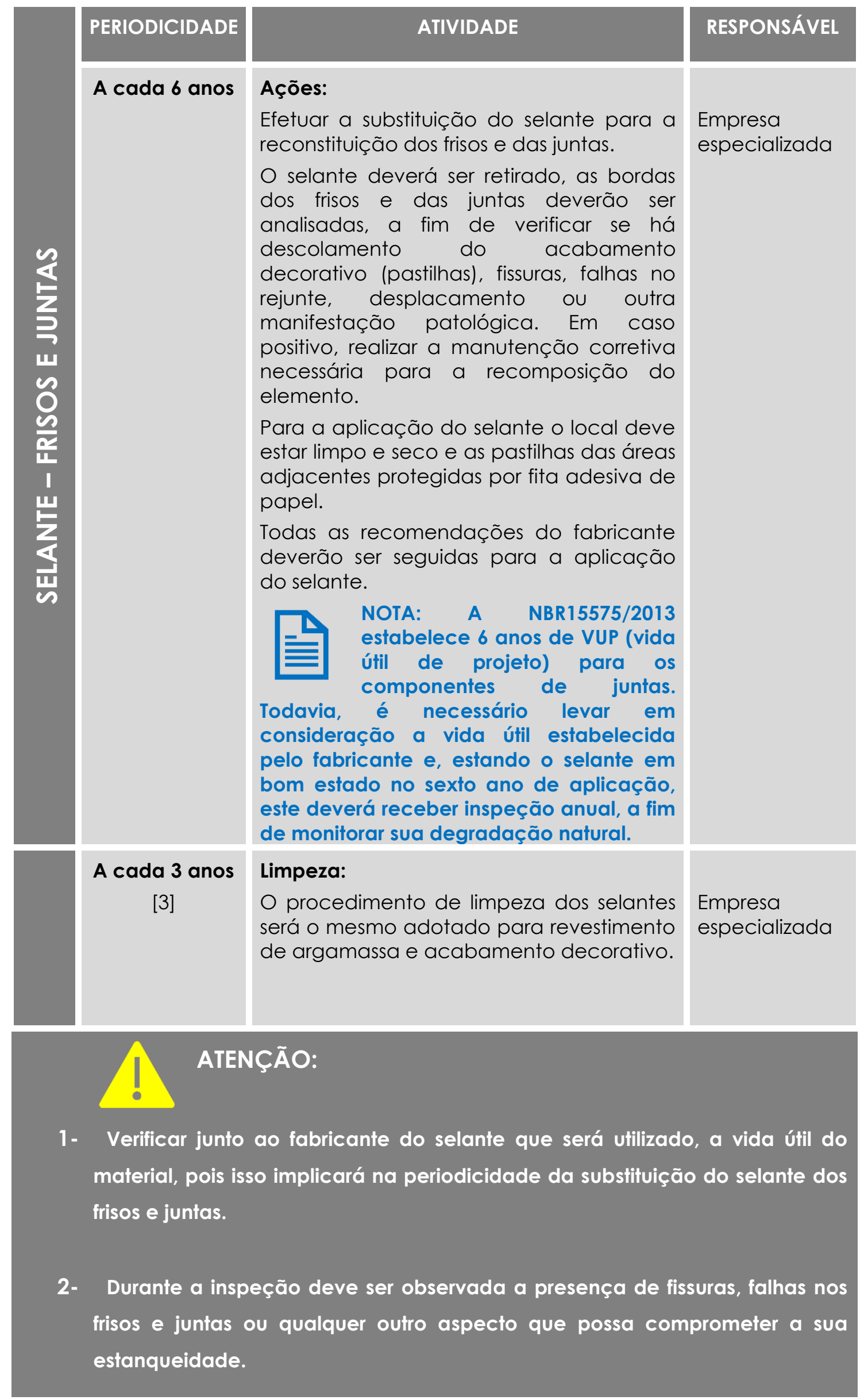




\section{FICHAS}

O controle e o registro da manutenção das fachadas sudoeste (SO) e noroeste (NO) ocorre por meio das fichas (FI).

Para primeira etapa de manutenção, que consiste na inspeção, há uma Ficha de Inspeção (FI) para cada fachada - FISO (ficha de inspeção fachada sudoeste) e FINO (ficha de inspeção fachada noroeste). Essas fichas apresentam um check-list do que deve ser verificado durante a vistoria.

Após a inspeção deve ser gerado um Relatório de Inspeção (RI), elaborado por empresa especializada/profissional habilitado com base no levantamento obtido na inspeção, que apontará as ações de manutenção necessárias de acordo com as recomendações do manual.

Ao término da execução das ações de manutenção a Ficha de Manutenção (FM) para cada fachada - FMSO (ficha de manutenção fachada sudoeste) e FMNO (ficha de manutenção fachada noroeste) deve ser devidamente preenchida, apontando os tipos de ações realizadas, os materiais utilizados, as datas e os profissionais responsáveis.

Ao fim do processo de manutenção o condomínio deverá preencher a Ficha Registros (FR) que se encontra no Fichário 2 - Registro de Manutenção - Fachadas Sudoeste e Noroeste do Edifício Copan, a fim de criar um histórico das manutenções e ocorrências nas fachadas. 


\begin{tabular}{|c|c|c|c|}
\hline \multicolumn{4}{|c|}{ CONDOMÍNIO EDIFÍCIO COPAN } \\
\hline FICHA DE INSPEÇÃO & FISO N & $\begin{array}{l}\text { SUBSISTEMA: } \\
\text { REVESTIMENTO } \\
\text { EXTERNO }\end{array}$ & \begin{tabular}{|l} 
FOLHA \\
$\mathbf{1 / 2}$
\end{tabular} \\
\hline \multicolumn{2}{|l|}{ VISTORIANTE: } & \multirow{3}{*}{\multicolumn{2}{|c|}{ FACHADA SUDOESTE }} \\
\hline \multicolumn{2}{|c|}{ EMPRESA/ RESPONSÁVEL: } & & \\
\hline \multicolumn{2}{|l|}{ DATA DA INSPEÇÃO: } & & \\
\hline
\end{tabular}

\begin{tabular}{|c|c|c|c|}
\hline ITEM & ASPECTO & SIM & OBSERVAÇŌES/ LOCALIZAÇĀO \\
\hline 1. & $\begin{array}{l}\text { REVESTIMENTO DE ARGAMASSA E } \\
\text { ACABAMENTO DECORATIVO }\end{array}$ & & \\
\hline 1.1. & Som cavo & & \\
\hline 1.2. & Descolamento & & \\
\hline 1.3. & Desplacamento & & \\
\hline 1.4. & Lacuna & & \\
\hline 1.5. & Fissura & & \\
\hline 1.6. & Infiltração & & \\
\hline 1.7. & Alteração na coloração & & \\
\hline 1.8. & $\begin{array}{l}\text { Pontos de corrosão (caixilhos } \\
\text { metálicos, parafusos etc.) }\end{array}$ & & \\
\hline 1.9. & Vestígio de tintas e vernizes & & \\
\hline 1.10. & $\begin{array}{l}\text { Furos (da retirada de telas de } \\
\text { proteção) }\end{array}$ & & \\
\hline 1.11. & $\begin{array}{l}\text { Pregos/ Parafusos (para fixação de } \\
\text { telas de proteção sem selante) }\end{array}$ & & \\
\hline 1.12. & Outros & & \\
\hline 2. & REJUNTE & & \\
\hline 2.1. & Lacuna & & \\
\hline 2.2. & Fissura & & \\
\hline 2.3. & Infiltração & & \\
\hline 2.4. & Alteração na coloração & & \\
\hline 2.5 . & $\begin{array}{l}\text { Furos (da retirada de telas de } \\
\text { proteção) }\end{array}$ & & \\
\hline 2.6. & $\begin{array}{l}\text { Pregos/ Parafusos (para fixação de } \\
\text { telas de proteção sem selante) }\end{array}$ & & \\
\hline 2.7. & Outros & & \\
\hline 3. & SELANTES & & \\
\hline 3.1. & Lacuna & & \\
\hline 3.2. & Fissura & & \\
\hline 3.3. & Alteração na coloração & & \\
\hline 3.4. & Perda de adesão & & \\
\hline 3.5. & Falha coesiva (pequeno entalhe) & & \\
\hline 3.6. & Enrijecimento/ craquelamento & & \\
\hline 3.7. & Outros & & \\
\hline
\end{tabular}




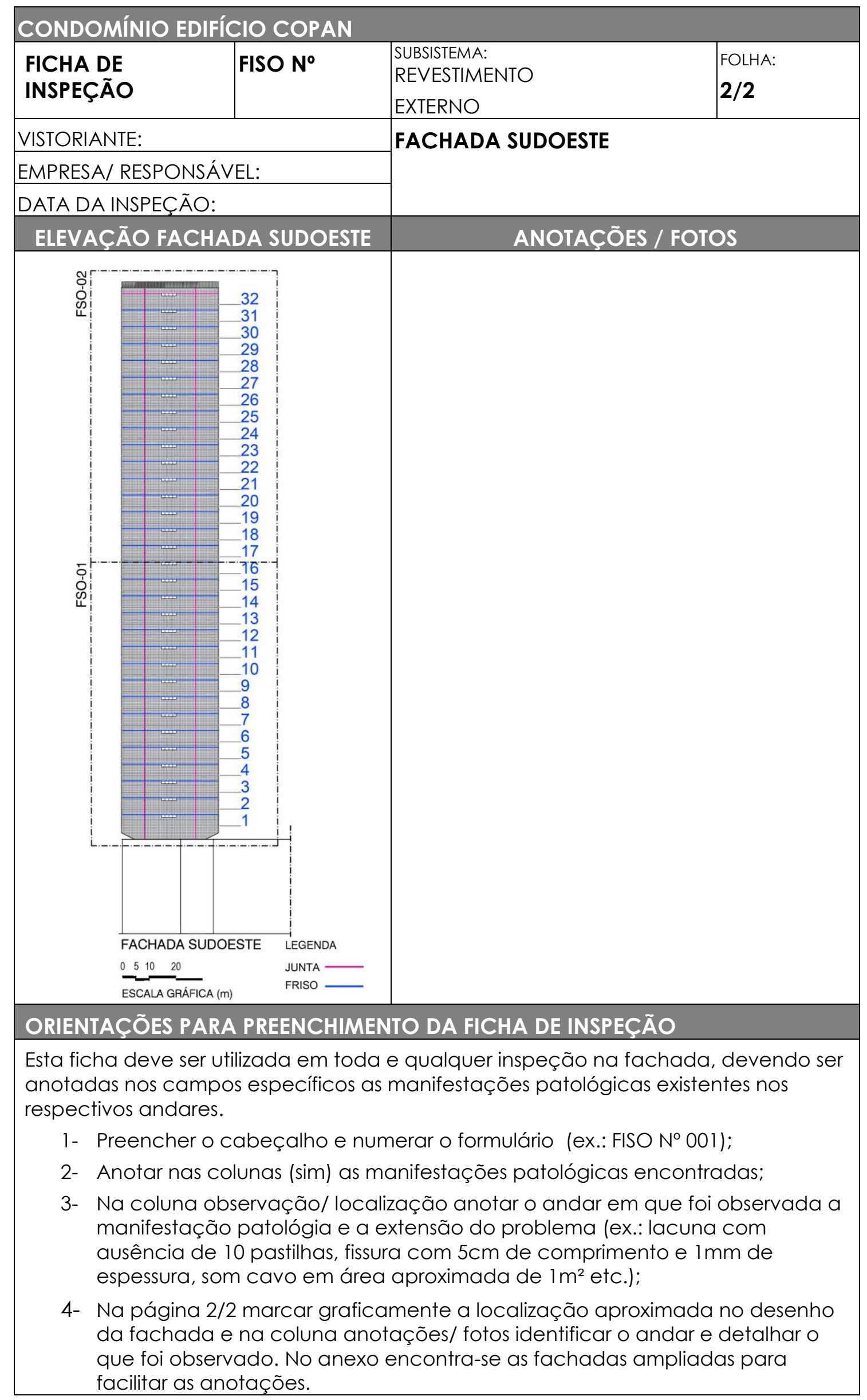




\begin{tabular}{|c|c|c|c|}
\hline \multicolumn{4}{|c|}{ CONDOMÍNIO EDIFÍCIO COPAN } \\
\hline FICHA DE INSPEÇÃO & FINO No & $\begin{array}{l}\text { SUBSISTEMA: } \\
\text { REVESTIMENTO } \\
\text { EXTERNO }\end{array}$ & $\begin{array}{l}\text { FOLHA: } \\
\mathbf{1 / 2}\end{array}$ \\
\hline \multicolumn{2}{|l|}{ VISTORIANTE: } & \multirow{3}{*}{\multicolumn{2}{|c|}{ FACHADA NOROESTE }} \\
\hline \multicolumn{2}{|c|}{ EMPRESA/ RESPONSÁVEL: } & & \\
\hline \multicolumn{2}{|l|}{ DATA DA INSPEÇÃO: } & & \\
\hline
\end{tabular}

\begin{tabular}{|c|c|c|c|}
\hline ITEM & ASPECTO & SIM & OBSERVAÇŌES/ LOCALIZAÇÃO \\
\hline 11. & $\begin{array}{l}\text { REVESTIMENTO DE ARGAMASSA E } \\
\text { ACABAMENTO DECORATIVO }\end{array}$ & & \\
\hline 11.1. & Som cavo & & \\
\hline 1.2. & Descolamento & & \\
\hline 1.3. & Desplacamento & & \\
\hline 1.4. & Lacuna & & \\
\hline 1.5. & Fissura & & \\
\hline 1.6. & Infiltração & & \\
\hline 1.7. & Alteração na coloração & & \\
\hline 1.8. & $\begin{array}{l}\text { Pontos de corrosão (caixilhos } \\
\text { metálicos, parafusos etc.) }\end{array}$ & & \\
\hline 1.9. & Vestígio de tintas e vernizes & & \\
\hline 1.10. & $\begin{array}{l}\text { Furos (da retirada de telas de } \\
\text { proteção) }\end{array}$ & & \\
\hline 1.11. & $\begin{array}{l}\text { Pregos/ Parafusos (para fixação de } \\
\text { telas de proteção sem selante) }\end{array}$ & & \\
\hline 1.12. & Outros & & \\
\hline 2. & REJUNTE & & \\
\hline 2.1. & Lacuna & & \\
\hline 2.2. & Fissura & & \\
\hline 2.3. & Infiltração & & \\
\hline 2.4 . & Alteração na coloração & & \\
\hline 2.5 . & $\begin{array}{l}\text { Furos (da retirada de telas de } \\
\text { proteção) }\end{array}$ & & \\
\hline 2.6. & $\begin{array}{l}\text { Pregos/ Parafusos (para fixação de } \\
\text { telas de proteção sem selante) }\end{array}$ & & \\
\hline 2.7. & Outros & & \\
\hline 3. & SELANTES & & \\
\hline 3.1. & Lacuna & & \\
\hline 3.2. & Fissura & & \\
\hline 3.3. & Alteração na coloração & & \\
\hline 3.4. & Perda de adesão & & \\
\hline 3.5. & Falha coesiva (pequeno entalhe) & & \\
\hline 3.6. & Enrijecimento/ craquelamento & & \\
\hline 3.7. & Outros & & \\
\hline
\end{tabular}




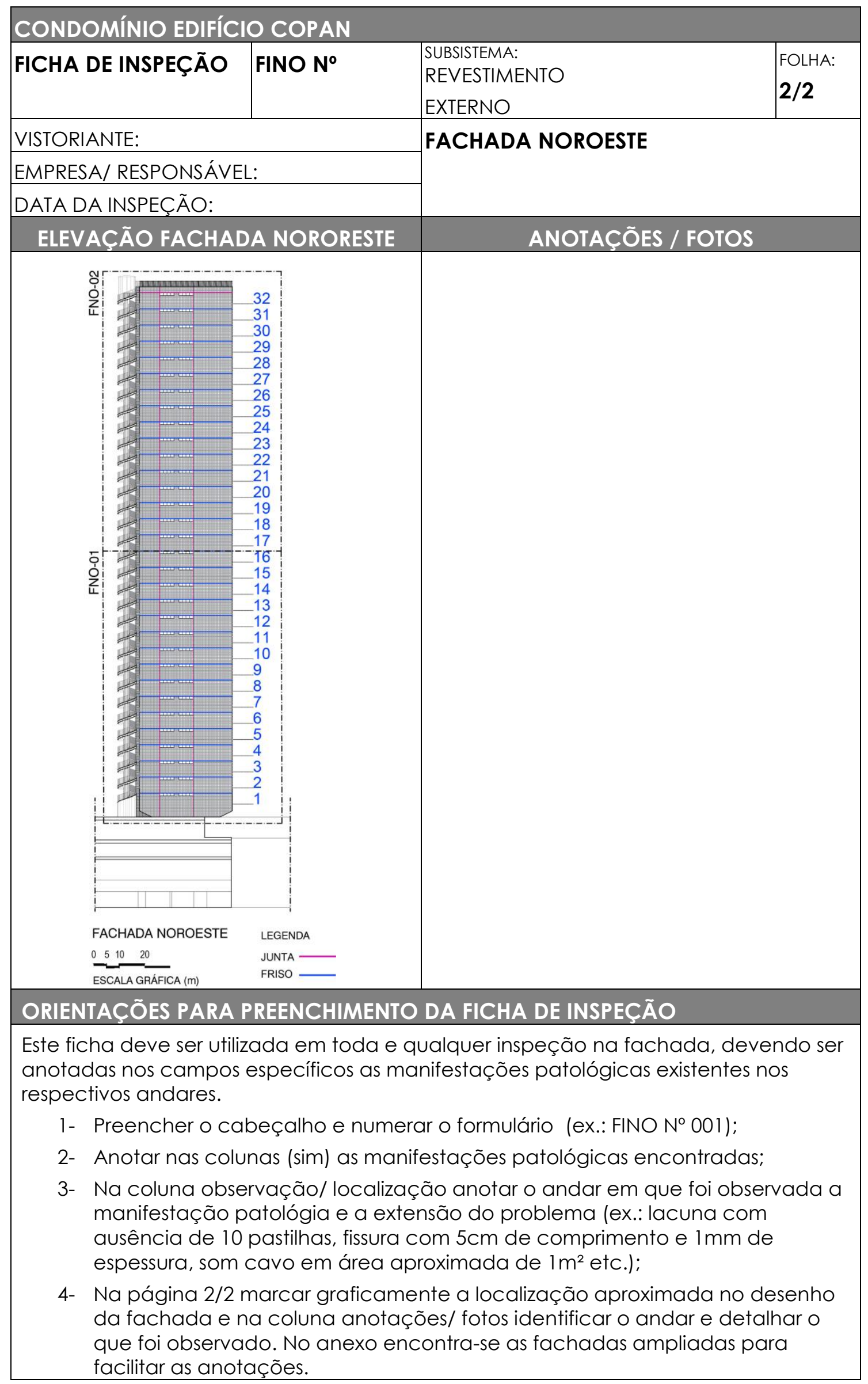




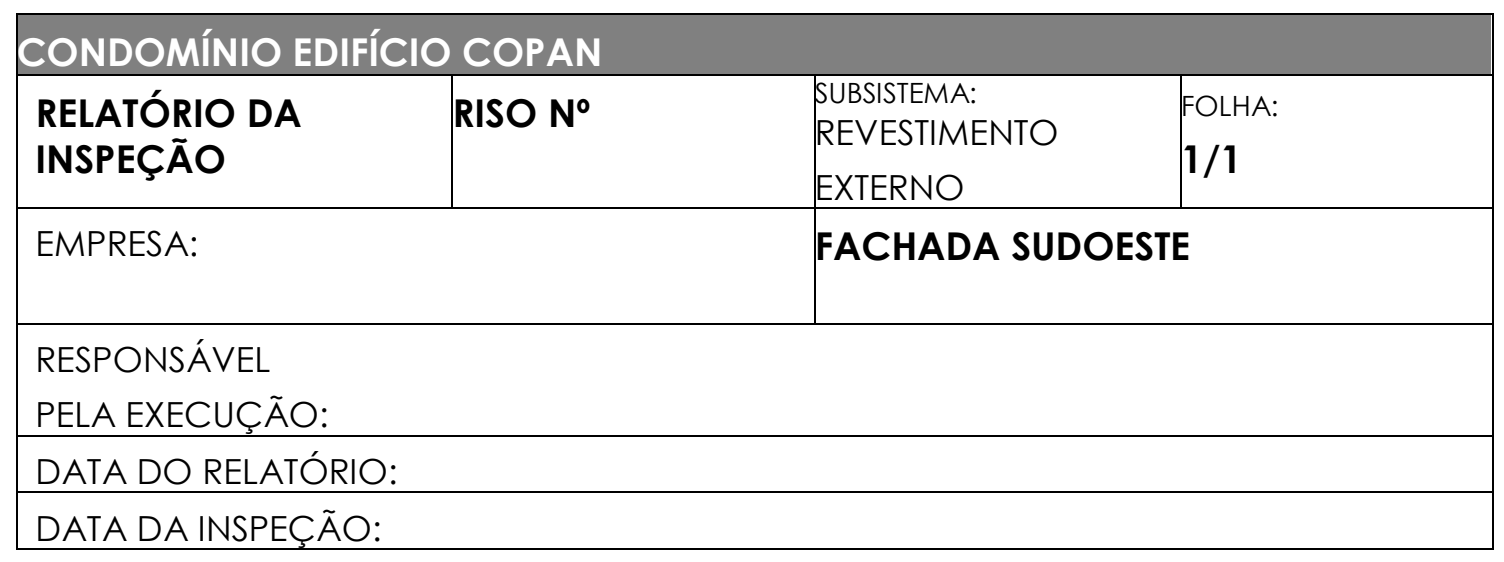

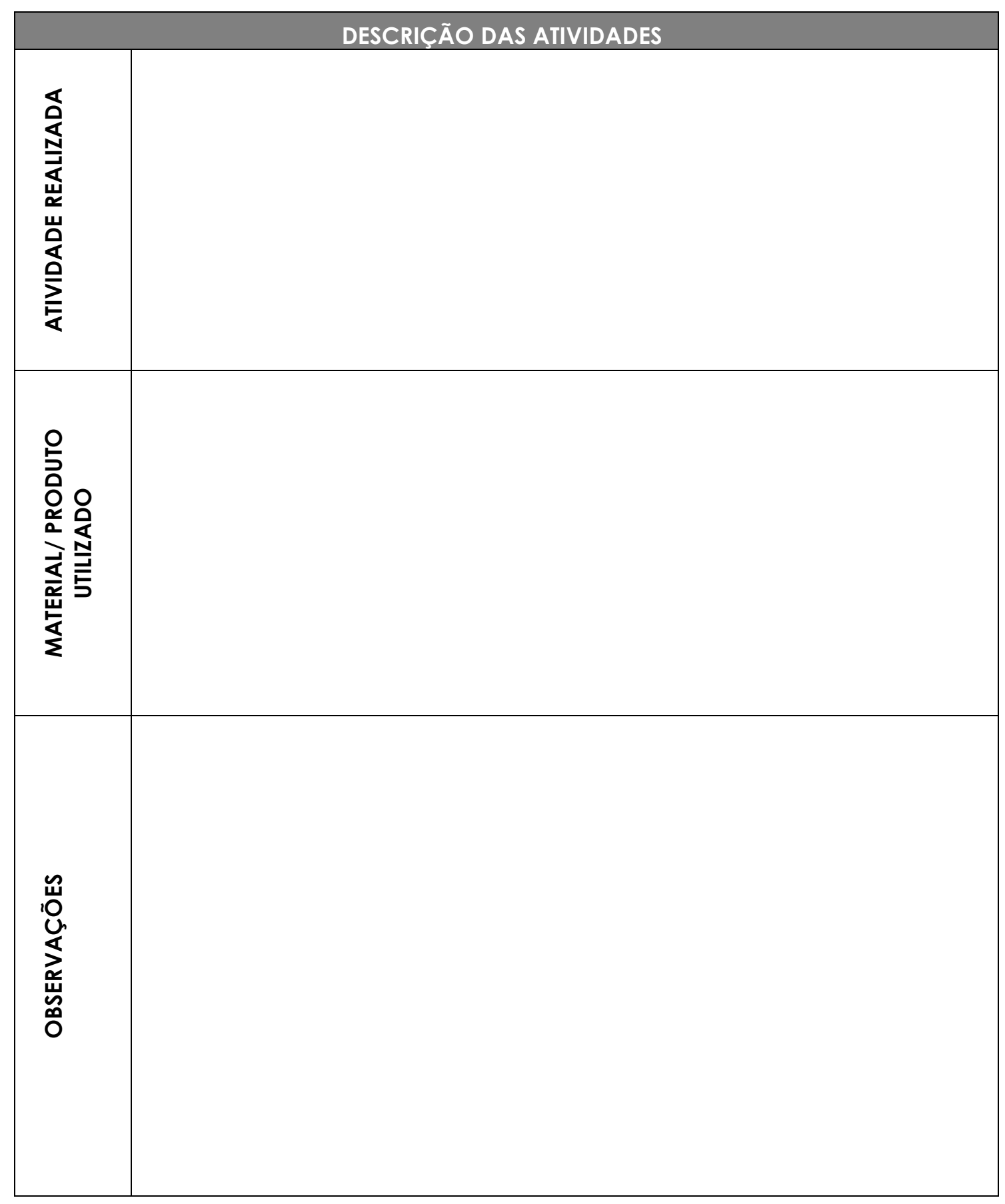




\begin{tabular}{|c|c|c|c|}
\hline \multicolumn{4}{|c|}{ CONDOMÍNIO EDIFÍCIO COPAN } \\
\hline $\begin{array}{l}\text { RELATÓRIO DA } \\
\text { INSPEÇÃO }\end{array}$ & RINO No & \begin{tabular}{|l} 
SUBSISTEMA: \\
REVESTIMENTO \\
EXTERNO \\
\end{tabular} & $\begin{array}{l}\text { FOLHA: } \\
\mathbf{1} / \mathbf{1}\end{array}$ \\
\hline \multicolumn{2}{|l|}{ EMPRESA: } & \multicolumn{2}{|c|}{ FACHADA NOROESTE } \\
\hline \multicolumn{4}{|l|}{ RESPONSÁVEL } \\
\hline \multicolumn{4}{|c|}{ DATA DO RELATÓRIO: } \\
\hline \multicolumn{4}{|c|}{ DATA DA INSPEÇÃO: } \\
\hline
\end{tabular}

\begin{tabular}{|c|c|}
\hline & DESCRIÇĀO DAS ATIVIDADES \\
\hline 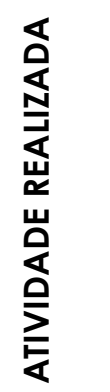 & \\
\hline 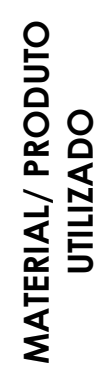 & \\
\hline 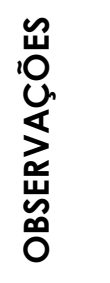 & \\
\hline
\end{tabular}




\begin{tabular}{|l|l|l|}
\hline \multicolumn{2}{|l|}{ CONDOMÍNIO EDIFÍCIO COPAN } & $\begin{array}{l}\text { SUBSISTEMA: } \\
\text { REVESTIMENTO } \\
\text { EXTERNO }\end{array}$ \\
\hline FICHA DE MANUTENÇÃO & FMSO No & $\mathbf{1 / 2}$ \\
\hline EMPRESA: & FACHADA SUDOESTE & \\
\hline RESPONSÁVEL \\
PELA EXECUÇÃO: & $\begin{array}{l}\text { MANUTENÇÃO } \\
\text { PREVENTIVA }\end{array}$ & \\
\hline DATA DE INÍCIO: & $\begin{array}{l}\text { MANUTENÇÃO } \\
\text { CORRETIVA }\end{array}$ & \\
\hline DATA DE TÉRMINO: & & \\
\hline
\end{tabular}

Assinalar o tipo de ação realizada: MANUTENÇÃO PREVENTIVA OU MANUTENÇÃO CORRETIVA

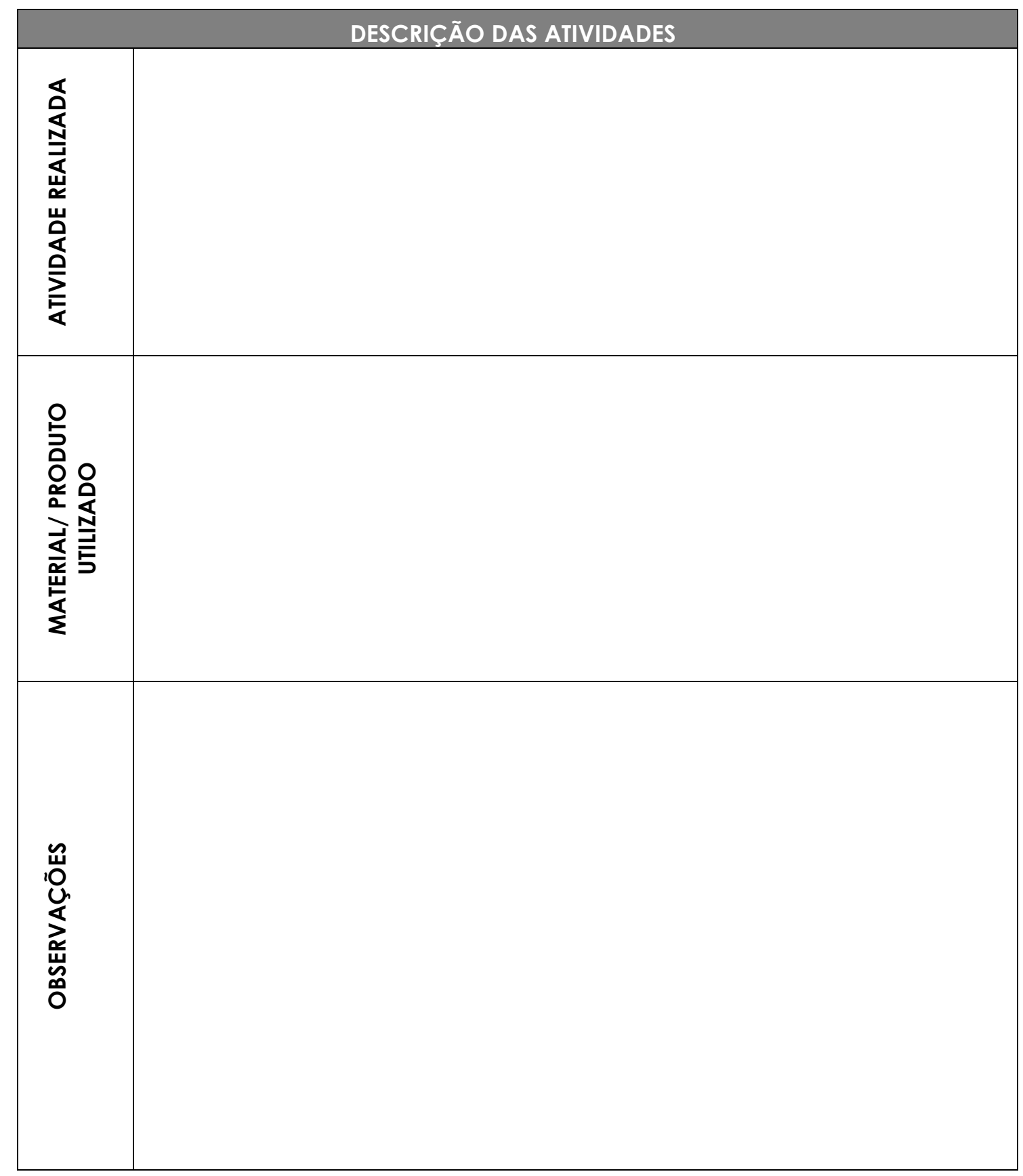




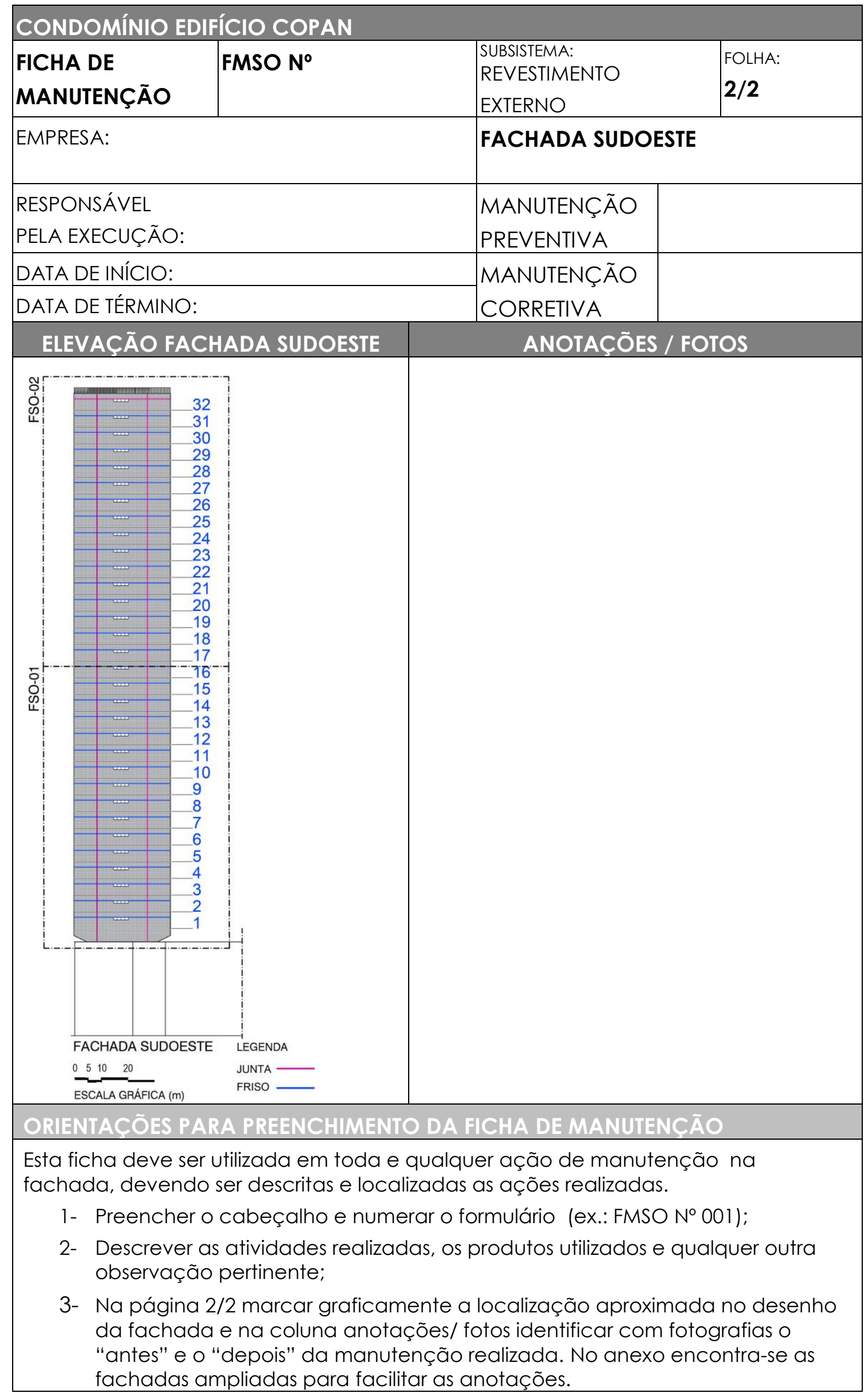




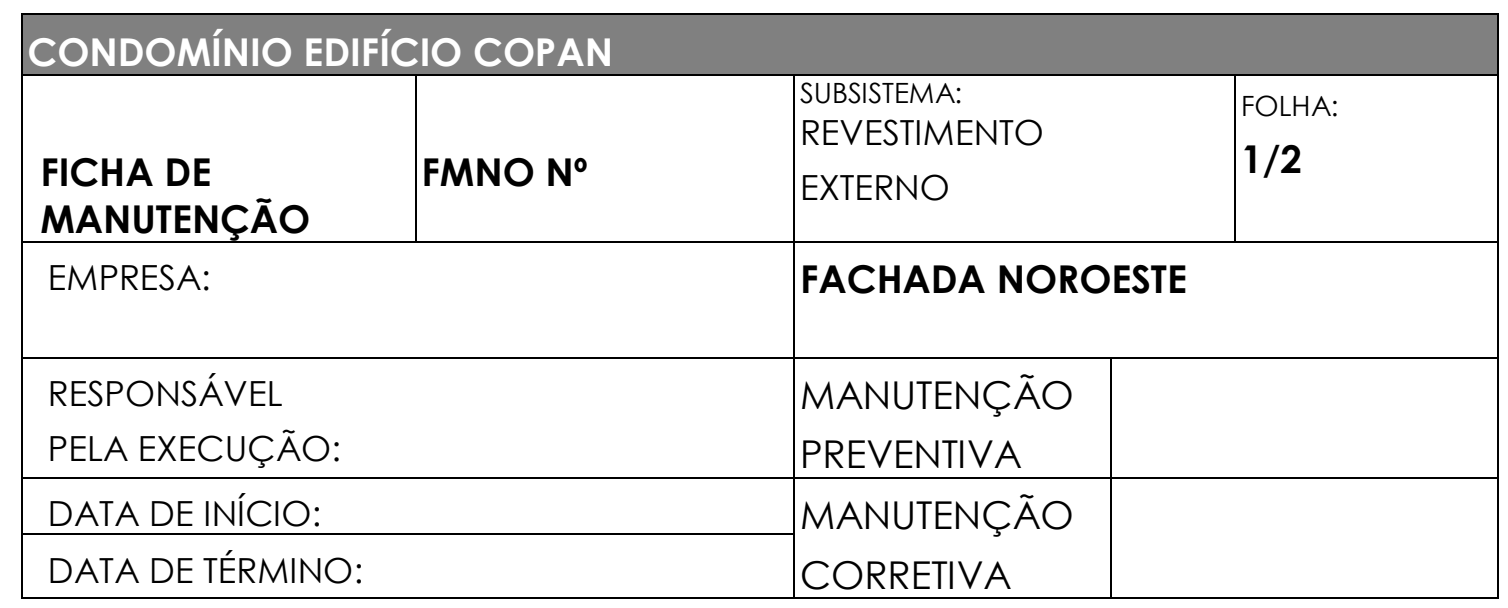

$\checkmark$ Assinalar o tipo de ação realizada: MANUTENÇÃO PREVENTIVA OU MANUTENÇÃO CORRETIVA

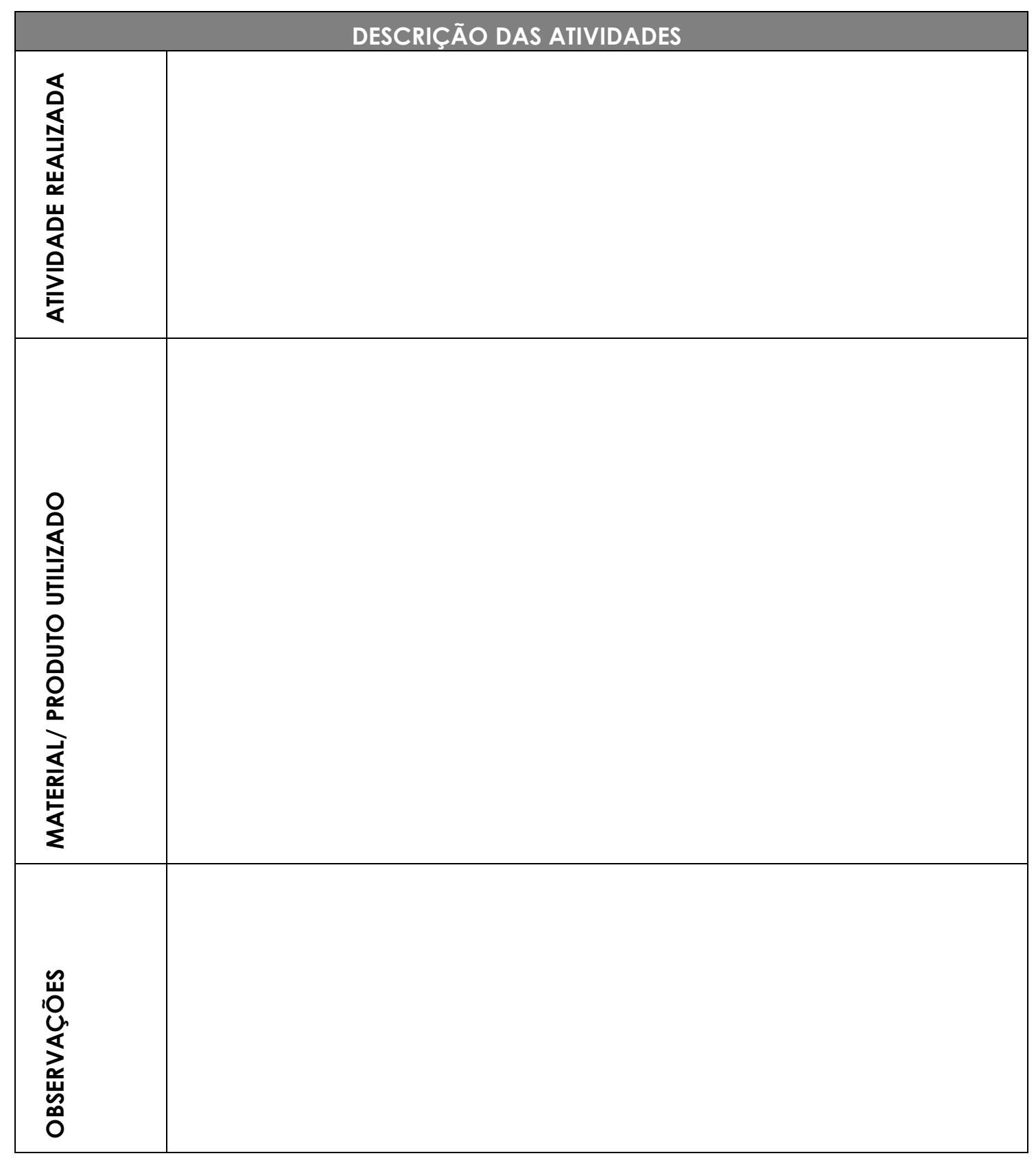




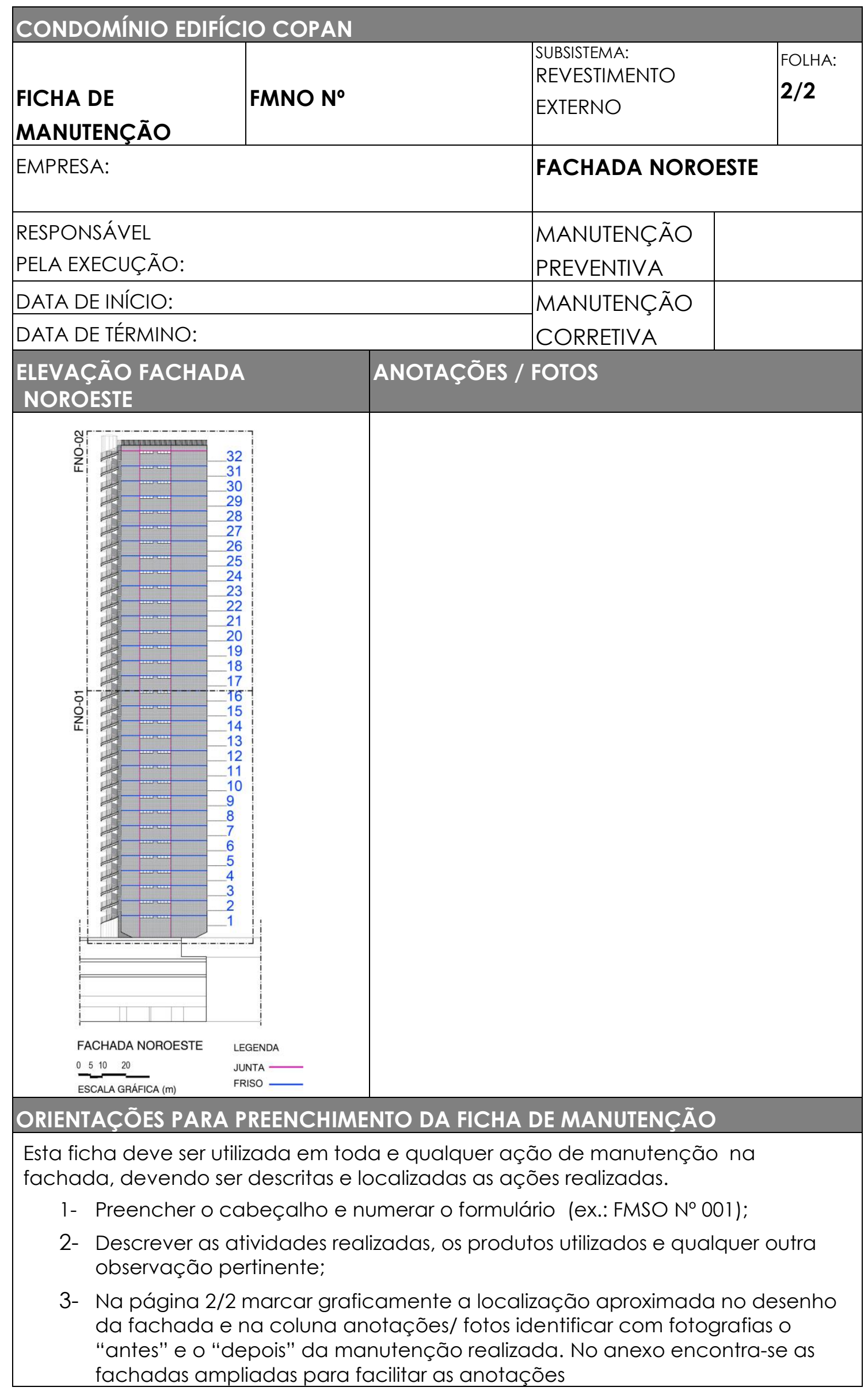




\section{CONDOMÍNIO EDIFÍCIO COPAN}

\section{FICHA DE REGISTRO}

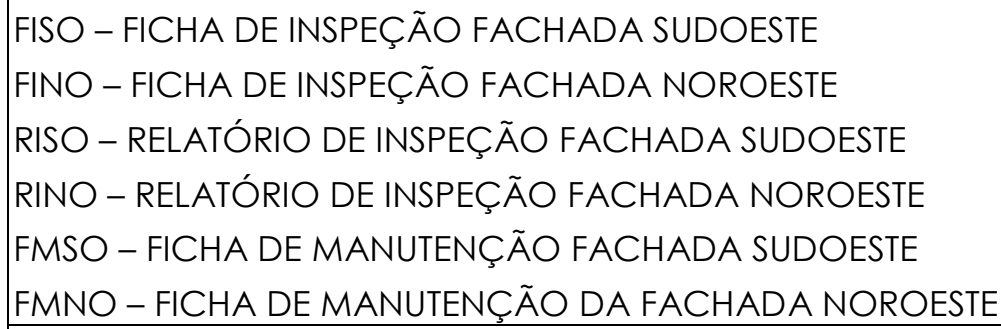

\begin{tabular}{|c|c|c|c|c|c|}
\hline $\begin{array}{c}\text { FACHADA } \\
\text { (FICHA) }\end{array}$ & $\begin{array}{l}N^{\circ} \text { DA } \\
\text { FICHA }\end{array}$ & $\begin{array}{l}\text { DATA DA } \\
\text { ATIVIDADE }\end{array}$ & $\begin{array}{l}\text { RESPONSÁVEL } \\
\text { PELA } \\
\text { ATIVIDADE } \\
\end{array}$ & $\begin{array}{c}\text { RESPONSÁVEL } \\
\text { PELO } \\
\text { ARQUIVAMENTO }\end{array}$ & $\begin{array}{c}\text { DATA DO } \\
\text { ARQUIVAMENTO }\end{array}$ \\
\hline & & & & & \\
\hline & & & & & \\
\hline & & & & & \\
\hline & & & & & \\
\hline & & & & & \\
\hline & & & & & \\
\hline & & & & & \\
\hline & & & & & \\
\hline & & & & & \\
\hline & & & & & \\
\hline & & & & & \\
\hline & & & & & \\
\hline & & & & & \\
\hline & & & & & \\
\hline & & & & & \\
\hline & & & & & \\
\hline & & & & & \\
\hline & & & & & \\
\hline & & & & & \\
\hline & & & & & \\
\hline & & & & & \\
\hline & & & & & \\
\hline & & & & & \\
\hline & & & & & \\
\hline & & & & & \\
\hline
\end{tabular}




\section{RELAÇÃO DE FORNECEDORES E PROJETISTAS - RECUPERAÇÃO}

Contatos dos projetistas e fornecedores envolvidos no processo de recuperação das fachadas sudoeste e noroeste do Edifício Copan.

Projeto de
Revestimento de
fachadas
10/2018

Execução da obra

de restauro

$10 / 2018$
Empresa: ARCO - Assessoria em Racionalização Construtiva S/C Ltda.

Responsável: Eng. Luiz Sérgio Franco e Arq. Carolina Murata

Telefone: (11) 5188-3800

E-mail: contato@arco.eng.br
Fundo preparador

de parede

$10 / 2018$

Argamassa

adesiva para

chapisco

$10 / 2018$

Empresa: FAE - Fachada, Arquitetura e Engenharia

Responsável: Luiz Antônio Agnelli

Telefone: (11) 3213-5049 / (11) 2631-6419

E-mail: fae@faesiscon.com.br

Referência: Suvinil Fundo Preparador

Empresa: BASF S.A.

Telefone: (11) 4346-5901

E-mail: atendimentocomercial@basf.com

Referência: Chapisco Colante Quartzolit

Empresa: Saint-Gobain do Brasil

Produtos Industriais e para Construção Ltda.

Telefone: (1 1)2196-8000

Referência: 2202 Matrix Revestimento Fachada

Empresa: Votorantim Cimentos

Telefone: 08007019898

E-mail: sac@vcimentos.com.br

Empresa: Baucryl S/A

Telefone: (11) 4615-1070

$10 / 2018$

E-mail: atendimento@quimicryl.com.br 


Polímero
acrílico com filbras
para
impermeabilização
de juntas
$10 / 2018$

\section{Argamassa colante}

$10 / 2018$
Empresa: Baucryl S/A

Telefone: (11) 4615-1070

E-mail: atendimento@quimicryl.com.br
Empresa: Bautech do Brasil

Telefone: 0800-778-0877

E-mail: vendas@bautechbrasil.com.br 


\section{REFERÊNCIAS}

[1] ASSOCIAÇÃO BRASILEIA DE NORMAS TÉCNICAS. NBR 15575: Edificações Habitacionais - Desempenho. Partes 1-6. Rio de Janeiro: ABNT, 2013.

[2] .NBR 16489: Sistemas e equipamentos de proteção individual para trabalhos em altura - Recomendações e orientações para seleção, uso e manutenção. Rio de Janeiro: ABNT, 2017.

[3] _. _.NBR 5674: Manutenção de Edifícios - Requisitos Para o Sistema de Gestão da Manutenção. Rio de Janeiro: ABNT, 2012.

[4] __.NBR 13755: Revestimentos cerâmicos de fachadas e paredes externas com utilização de argamassa colante - Projeto, execução, inspeção e aceitação Procedimento. Rio de Janeiro: ABNT, 2017.

[5] .NBR 14037: Diretrizes para elaboração de manuais de uso, operação e manutenção das edificações - Requisitos para elaboração e apresentação dos conteúdos. Rio de Janeiro: ABNT, 2014.

[6] GRANATO. José Eduardo. Patologia das Construções. Disponível em: <http://irapuama.dominiotemporario.com/doc/Patologiadasconstrucoes2002.pdf>. Acesso em: 5 jul. 2018.

[7] ASSOCIAÇÃO BRASILEIRA DE NORMAS TÉCNICAS. NBR 13529: Revestimento de paredes e tetos de argamassas inorgânicas - Terminologia. Rio de Janeiro: ABNT, 2013.

[8] Relatório Técnico elaborado pela empresa "Falcão Baver - Centro Tecnológico de Controle da Qualidade", emitido em 30 de janeiro de 2014. Acervo do Edifício Copan.

[9] Relatório de Ensaio de Reconstituição de Traço de Argamassa de emboço, realizado pela empresa "Falcão Baver - Centro Tecnológico de Controle da Qualidade", emitido em 7 de junho de 2018. Acervo particular do Edifício Copan.

[10] Projeto Executivo e Revestimento de Fachada para o Edifício Copan, desenvolvidos pela empresa "ARCO Assessoria em Racionalização Construtiva". Desenhos emitidos inicialmente em 13 de janeiro de 2015 e com última revisão em 10 de maio de 2016. Acervo particular do Edifício Copan.

[1 1] MENEGAZZO, Ana Paula. (coord.) Manual Setorial Orientativo para Atendimento à Norma de Desempenho ABNT NBR 15575: 2013. ANFACER, 2016. Disponível em: <http://manualdesempenho.anfacer.org.br/>. Acesso em: 28 maio 2018.

[12] Portal da Mineração. Votorantim Cimentos dá dicas de restauração de revestimento cerâmico. Disponível em: $<$ http://portaldamineracao.com.br/votorantim-cimentos-da-dicas-de-restauracaode-revestimento-ceramico/>. Acesso em: 2 jul. 2018. 
[13] SABBATINI, F. H.; BARROS, M. M. S. B. Produção de revestimentos cerâmicos para paredes de vedação em alvenaria: diretrizes básicas. 2001. Revisão do relatório técnico, SABBATINI, F. H.; BARROS, M. M. S. B. Recomendações para a produção de revestimentos cerâmicos para paredes de vedação e em alvenaria - Escola Politécnica da USP, Departamento de Engenharia de Construção Civil, R6-06/90 EP/ENCOL-6, São Paulo, 1990.

[14] RIBEIRO, Fabiana, A. Especificação de Juntas de Movimentação em Revestimento Cerâmico em Fachadas de Edifícios: Levantamento do Estado da Arte. Dissertação de Mestrado. São Paulo, 2006. Escola Politécnica da Universidade de São Paulo.

[15] ANTUNES, Giselle Reis. Estudo de Manifestações Patológicas em Revestimentos de Fachada em Brasília - Sistematização da Incidência de Casos. Braślia, 2010. Dissertação de Mestrado. Faculdade de Tecnologia da Universidade de Brasília.

[16] RESENDE, Maurício Marques. Manutenção Preventiva de Revestimento de Fachada de Edifícios: Limpeza de Revestimentos Cerâmicos. São Paulo, 2004. Dissertação de Mestrado. Escola Politécnica da Universidade de São Paulo. 


\section{ATUALIZAÇÕES E REVISÕES DO MANUAL DE MANUTENÇÃO}

Para que as recomendações do presente manual de manutenção se mantenham válidas é necessário que o documento seja revisto a cada 4 anos e atualizado de acordo com as alterações que surgirem nas fachadas do Edifício Copan.

As alterações, complementações, inclusões e/o remoções de informações devem ser registradas e assinadas pelo responsável, a fim de manter um histórico da evolução do documento.

\begin{tabular}{|c|c|c|c|c|}
\hline $\mathbf{N}^{\circ}$ & $\begin{array}{l}\text { Data de } \\
\text { revisão }\end{array}$ & $\begin{array}{l}\text { Descrição das } \\
\text { revisōes }\end{array}$ & $\begin{array}{c}\text { Páginas ałualizadas } \\
\text { ou removidas }\end{array}$ & $\begin{array}{l}\text { Assinatura do } \\
\text { responsável }\end{array}$ \\
\hline \multicolumn{5}{|l|}{1} \\
\hline \multicolumn{5}{|l|}{2} \\
\hline \multicolumn{5}{|l|}{3} \\
\hline \multicolumn{5}{|l|}{4} \\
\hline \multicolumn{5}{|l|}{5} \\
\hline \multicolumn{5}{|l|}{6} \\
\hline \multicolumn{5}{|l|}{7} \\
\hline \multicolumn{5}{|l|}{8} \\
\hline \multicolumn{5}{|l|}{9} \\
\hline \multicolumn{5}{|l|}{10} \\
\hline \multicolumn{5}{|l|}{11} \\
\hline \multicolumn{5}{|l|}{12} \\
\hline \multicolumn{5}{|l|}{13} \\
\hline \multicolumn{5}{|l|}{14} \\
\hline \multicolumn{5}{|l|}{15} \\
\hline \multicolumn{5}{|l|}{16} \\
\hline \multicolumn{5}{|l|}{17} \\
\hline \multicolumn{5}{|l|}{18} \\
\hline \multicolumn{5}{|l|}{19} \\
\hline \multicolumn{5}{|l|}{20} \\
\hline 21 & & & & \\
\hline
\end{tabular}


9. ANEXOS- AMPLIAÇÕES FACHADAS 


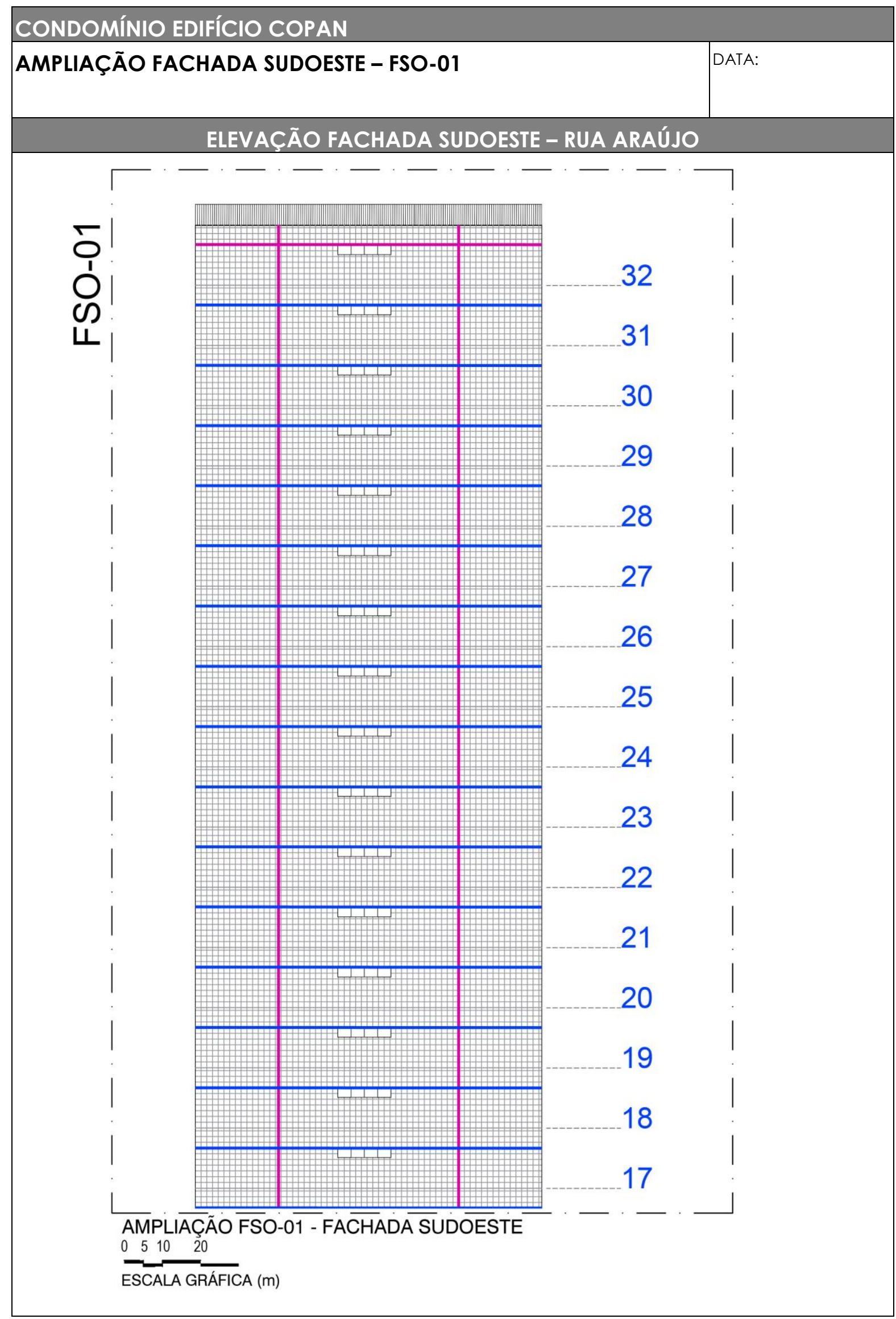




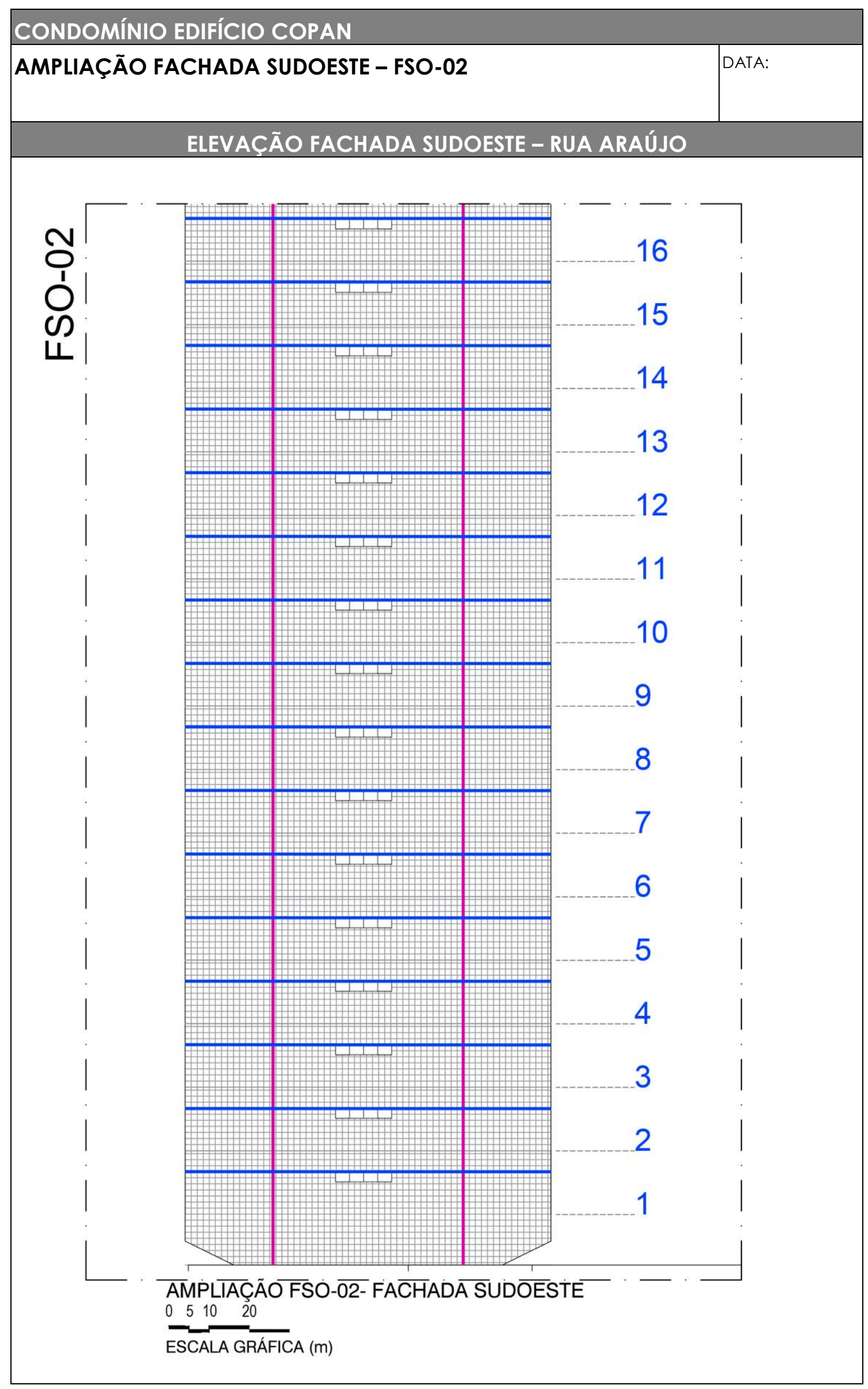




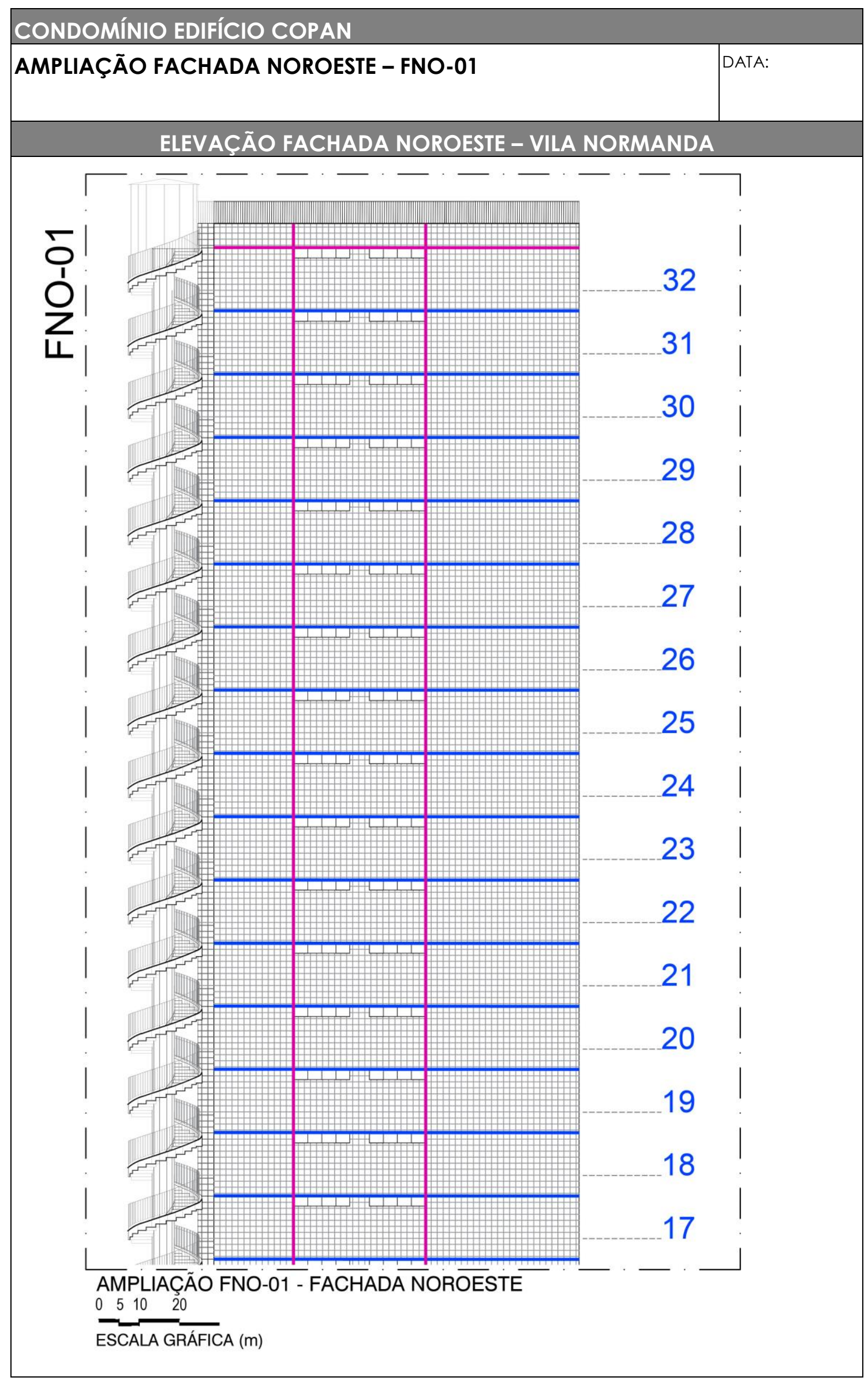




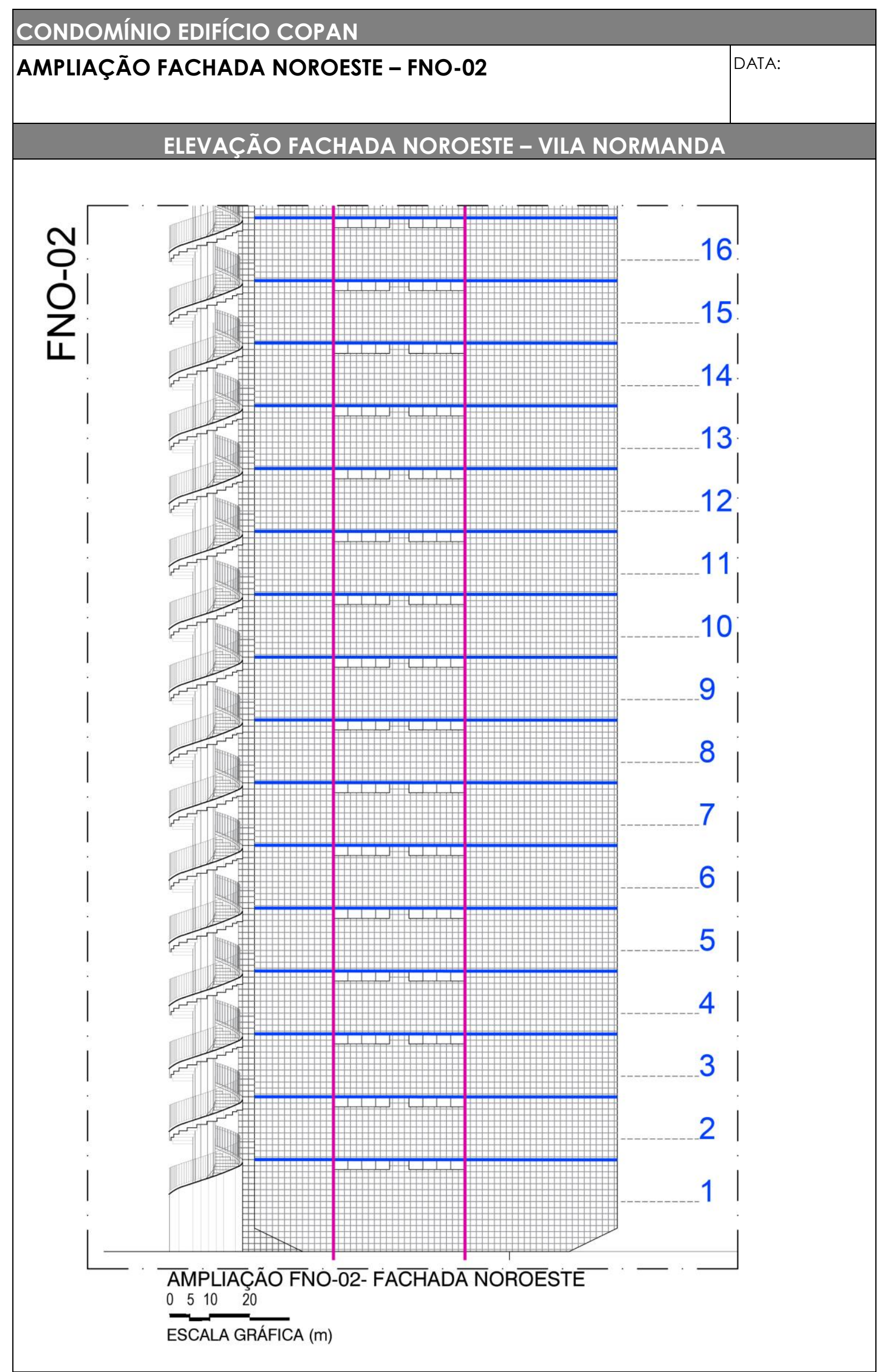

